\title{
Archaeological Investigations Along the Leona River Watershed, Uvalde County, Texas
}

Paul D. Lukowski

Follow this and additional works at: https://scholarworks.sfasu.edu/ita

Part of the American Material Culture Commons, Archaeological Anthropology Commons, Environmental Studies Commons, Other American Studies Commons, Other Arts and Humanities Commons, Other History of Art, Architecture, and Archaeology Commons, and the United States History Commons

Tell us how this article helped you.

This Article is brought to you for free and open access by the Center for Regional Heritage Research at SFA ScholarWorks. It has been accepted for inclusion in Index of Texas Archaeology: Open Access Gray Literature from the Lone Star State by an authorized editor of SFA ScholarWorks. For more information, please contact cdsscholarworks@sfasu.edu. 


\section{Archaeological Investigations Along the Leona River Watershed, Uvalde County,}

Texas

\section{Creative Commons License}

(c) (1) (8)

This work is licensed under a Creative Commons Attribution-NonCommercial 4.0 International License 


\title{
ARCHAEOLOGICAL INVESTIGATIONS ALONG THE LEONA RIVER WATERSHED, UVALDE COUNTY, TEXAS
}

\author{
Paul D. Lukowski
}

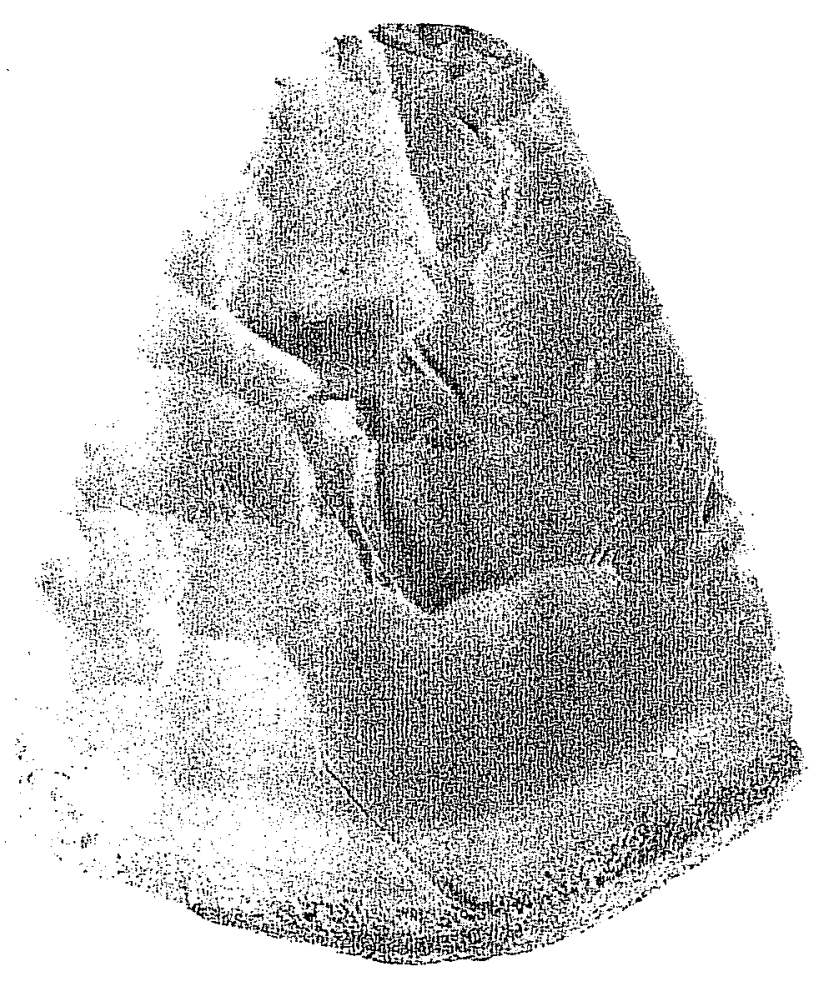

Center for Archaeological Research The University of Texas at San Antonio Archaeological Survey Report, No. 132 1987 



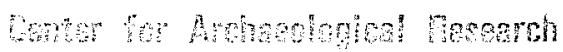

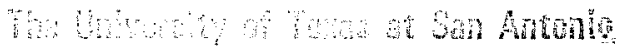

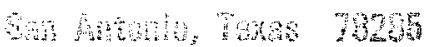




\section{ARCHAEOLOGICAL INVESTIGATIONS ALONG THE LEONA RIVER WATERSHED, UVALDE COUNTY, TEXAS}

Paul D. Lukowski

Report funded by the National Park Service, Interagency Archeological Services under contract C53009(80). Dr. Thomas R. Hester, Principal Investigator

Center for Archaeological Research The University of Texas at San Antonio ${ }^{\circledR}$ Archaeological Survey Report, No. 132 


\section{FOREWORD}

Papa used to make bricks out of the clay on the Leona River... where he was getting the dirt... must have been an Indian burial ground, there were so many bones, cooking utensils, and trinkets. Papa brought the bones to town [Uvalde] to have them examined. He thought they were Indian bones because of the pinkish hue... there surely were a lot of them. ...

Eliza Haygood, ca. 1890

The quote above, taken from Florence Fenley's 01dtimers of Southwest Texas (Uvalde, 1957), relates an early archaeological discovery from the Leona River drainage in Uvalde County, south-central Texas. Some of Fenley's other interviews also record several disastrous floods on the Leona, especially in 1894. These two aspects of pioneer life on the Leona River came together again in the 1970s and 1980s when the Soil Conservation Service of the United States Department of Agriculture began to plan the construction of floodwater retarding structures in the Leona River watershed. While aimed at controlling flooding that had so affected the area in the past, the construction of the dams would al so have an impact on the traces of ancient Indian habitation along the river. Thus, the National Park Service contracted with our research center in 1980 in order to properly study the archaeology before the Soil Conservation Service projects were begun.

Earlier work in the Leona watershed by Grant D. Hall had established that four sites needed intensive study: three were prehistoric occupations ( 41 UV 45, 41 UV 47, and 41 UV 48), and one was an extensive chert quarry area (41 UV 43). Because of the 7 imited nature of previous archaeological research in this part of south-central Texas, research goals had to insure that a maximum amount of data was collected, and that these data were obtained with relevant problem orientations. Site function, the span and frequency of occupations, the utilization of local resources, and the function of specific intrasite features, such as burned rock middens, were among the objectives that guided the field and laboratory analyses.

As a result, the work undertaken by project director, Paul Lukowski and his colleagues, and the report published here constitutes a major contribution to the archaeology of this region. It not only preserves an important data base for the Leona River watershed in Uvalde County, but will also serve as a key reference for ongoing and future studies in adjacent areas on the Edwards Plateau and the South Texas coastal plain.

Thomas R. Hester

Principal Investigator

February 12, 1987 


\section{ABSTRACT}

The investigations of four prehistoric sites in southwest-central Texas allow for research hypotheses relevant to regional questions, particularly the study of cultural changes between the Archaic and Late Prehistoric periods. The sites considered within this report are three campsites, two evidencing significant Late Prehistoric components, the other with primarily Archaic components, and a chert cobble quarry.

The contract mitigation efforts provided surface and subsurface samples that allowed a descriptive and spatially detailed summary of the materials recovered. This data base, which includes information on tool assemblages, 1 ithic reduction technologies, faunal, floral, and invertebrate resources along with a series of radiocarbon dates is the basis for various intersite and intrasite analyses.

The analyses demonstrate cultural changes between the Archaic and Late Prehistoric time periods. Noted are (1) differences in the site structure and utilization of midden and nonmidden activity areas; (2) significant alteration of the tool assemblages; and (3) changes in the lithic reduction sequences related to modification of the tool assemblages. At Archaic base camps, nonmidden site areas are the locus of numerous hearths where most of the tool and debitage generating activities took place. At Late Prehistoric camps, the middens appear to be spatially restricted feature/activity areas where the majority of all camp activity was concentrated. Technological changes from a biface reducing emphasis during the Archaic to an emphasis on flake tool production during the Late Prehistoric are demonstrated through the comparison of tool assemblages and debitage.

Although interpretation was hampered by the problem of differential preservation, the floral and faunal remains recovered suggest that there is little evidence for significant environmental change over time. It is suggested that prehistoric environmental conditions varied little from recent times. However, the biotic communities associated with the Edwards Plateau region and the South Texas Plains are perhaps important factors affecting the prehistoric systems operating in the area. While the two regions offer potentially significant different resources, those resources within each of the regions are distributed such that only a small area surrounding base camps located along drainages offers a nearly complete range of subsistence needs, thus limiting the necessity of numerous task specific sites.

KEYWORDS: Late Prehistoric, Leona River, Uvalde County, watershed, prehistoric archaeology, chronology, lithic technologies, settlement patterns, test excavations 
FOREWORD (Dr. Thomas R. Hester)

ABSTRACT

LIST OF FIGURES

LIST OF TABLES

ACKNOWLEDGMENTS

INTRODUCTION

Description of the Study

Impacted Areas

Project Implementation and Curation

RESEARCH GOALS AND STRATEGIES

IAS-D Goals

Theoretical Base of Study

ENVIRONMENTAL BACKGROUND

ARCHAEOLOGICAL BACKGROUND

DATA RECOVERY AND ANALYTICAL METHODS

$i$

$x$

$x i i$

xiv

1

SITE 41 UV 43

Site Description

Surface Collection

Distribution of the Surface Artifacts

Excavation Areas

Summary

SITE 41 UV 45

Site Description

Surface Collection

Distribution of Surface Artifacts

Summary of Surface Collection

Excavation Areas

Midden Soils.

Terrace Areas

Features

Feature 1

Feature 2

Feature 3

Feature 4

Feature 5

Feature 6

Material Distributions

Artifact Distributions

Arrow Points

Dart Points

Overal1 Retouch Bifaces

Bifacially Retouched Flakes

Bifacial Intergrades

other Bifaces

Unifaces

Modified Flakes and Chips

Cores

Ground Stone

Ceramics

Historic Materials 
Debitage ........................ . . 61

Flake Platforms ....................... . . . 65

Burned Rock ........................... . . . . 68

Plant and Animal Remains..................... . . . 70

Faunal Remains.......................... . . . . . . . 70

Freshwater Mussel Shells . . . . . . . . . . . . . . 71

Snails... . . . . . . . . . . . . . . . . . . . 71

Wood Species Identification . . . . . . . . . . . . . 76

Radiocarbon Dates . . . . . . . . . . . . . . . . . 80

$\mathrm{TX}-4432$. . . . . . . . . . . . . . . . . . . . . . . . . . 80

$\mathrm{TX}-4434$. . . . . . . . . . . . . . . . . . . . . 81

TX-4433 . . . . . . . . . . . . . . . . . . . . . . . . . . 81

Summary and Discussion .................... . 82

Chronology . . . . . . . . . . . . . . . . . . . 82

Site Nature and Extent . . . . . . . . . . . . . . . . 83

Subsistence . . . . . . . . . . . . . . . . . . . 84

SITE 41 UV 47 . . . . . . . . . . . . . . . . . . . . . . . . 85

Site Description ...................... . . 85

Surface Collection . . . . . . . . . . . . . . . . . . 88

Surface Lithic Concentrations . . . . . . . . . . . . . . . 89

Distribution of Surface Artifacts . . . . . . . . . . . . . . 92

Summary of Surface Collection . . . . . . . . . . . . . . 96

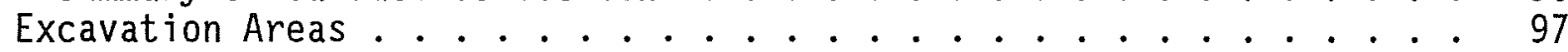

Area A. . . . . . . . . . . . . . . . . . . 98

Area B............................ . 100

Area C............................ . 101

Area D. . . . . . . . . . . . . . . . . . . . 103

Features .............................. 104

Feature 2 . . . . . . . . . . . . . . . . . . 104

Feature 3 . . . . . . . . . . . . . . . . . . . . . . . 104

Feature 4 . . . . . . . . . . . . . . . . . . 106

Material Distributions . . . . . . . . . . . . . . . 107

Artifact Distributions . . . . . . . . . . . . . . . 107

Arrow Points . . . . . . . . . . . . . . . . . . . 107

Dart Points ........................ 109

Overal1 Retouch Bifaces ................... . 110

Bifacially Retouched Flakes .................. . 111

Bifacial Intergrades ..................... . 112

Other Bifaces ........................ 113

Unifaces . . . . . . . . . . . . . . . . . . . . 114

Modified Flakes . . . . . . . . . . . . . . . . 114

Cores . . . . . . . . . . . . . . . . . . . . . . . 115

Other Lithics . . . . . . . . . . . . . . . . . . 116

Ceramics . . . . . . . . . . . . . . . . . . . . 116

Historic Materials . . . . . . . . . . . . . . . . 117

Debitage . . . . . . . . . . . . . . . . . . . . 117

Flake Platforms . . . . . . . . . . . . . . . 124

Burned Rock . . . . . . . . . . . . . . . . . . . . 126

Plant and Animal Remains...................... . . 129

Faunal Remains. . . . . . . . . . . . . . . . . . . . . . 129

Freshwater Mussel Shell . . . . . . . . . . . . . . . . 130

Snail Shells... . . . . . . . . . . . . . . . . . . . 131

Wood Species Identifications . . . . . . . . . . . . . . . . 134 
Radiocarbon Dates . . . . . . . . . . . . . . 137

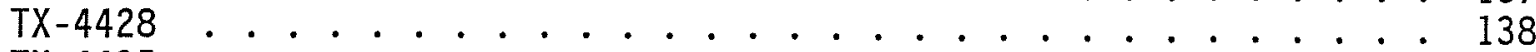

$\mathrm{TX}-4435$. . . . . . . . . . . . . . . . . . 138

Summary and Discussion.................. 139

Chronology .................... . . . 139

Site Nature and Extent .................. 140

Subsistence ................... . . 142

SITE 41 UV $48 \ldots \ldots \ldots \ldots$

Site Description ... . . . . . . . . . . . . . 143

Surface Collection . . . . . . . . . . . . . . . . . 143

Area Summaries...................... 151

Excavation Areas . . . . . . . . . . . . . . . . . 153

Area A...................... . . 153

Area B....................... 155

Area C...................... 155

Area D....................... 159

Summary ...................... 159

Features . . . . . . . . . . . . . . . . . . . . 159

Feature 1 . . . . . . . . . . . . . . . 159

Feature 2 . . . . . . . . . . . . . . . 161

Feature 3 . . . . . . . . . . . . . . 163

Material Distributions . . . . . . . . . . . . . . . 164

Artifact Distributions . . . . . . . . . . . . . . 164

Arrow Points . . . . . . . . . . . . . . . . . 164

Dart Points . . . . . . . . . . . . . . . . 165

Overal1 Retouch Bifaces ................. 169

Bifacially Retouched Flakes . . . . . . . . . . . . . . 171

Bifacial Intergrades . . . . . . . . . . . . . . . . 174

Other Bifaces . . . . . . . . . . . . . . . . . . . 176

Unifaces . . . . . . . . . . . . . . . . . . . 178

Cores ...................... . . 179

Modified Flakes .................... . 180

Other Lithics . . . . . . . . . . . . . . . . . . . . . . 182

Fired Clay ...................... . 182

Historic Materials . . . . . . . . . . . . . . . . . . 182

Debitage . . . . . . . . . . . . . . . . 182

Flake Platforms .................. . . 185

Burned Rock . . . . . . . . . . . . . . . . . . 188

Plant and Animal Remains . . . . . . . . . . . . . . . . . . 188

Faunal Remains . . . . . . . . . . . . . . . . . . . . 188

Area A...................... . . . 193

Area B..................... . . 195

Area C . . . . . . . . . . . . . . . . . 195

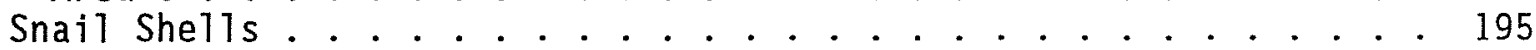

Freshwater Mussel She11 . . . . . . . . . . . . . . . 199

Wood Species Identifications . . . . . . . . . . . . . . 199

Radiocarbon Dates . . . . . . . . . . . . . . . 202

TX-4429.................... 203

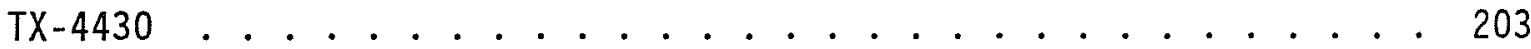

$\mathrm{TX}-4431$. . . . . . . . . . . . . . . . 204

Summary of Radiocarbon Dates . . . . . . . . . . . . 204

Summary ....................... 204

Chronology .................. 204 
Site Nature and Extent ............... . 205

Subsistence Strategies . . . . . . . . . . . . . . 205

ARTIFACTS RECOVERED ................... 206

Arrow Points . . . . . . . . . . . . . . . . . 206

Edwards . . . . . . . . . . . . . . . 206

Perdiz . . . . . . . . . . . . . . . . . . . 208

Perdiz morgan .. . . . . . . . . . . . . . . . . . 208

Perdiz whitney, Short Blade . . . . . . . . . . . . 208

Perdiz whitney, Long Blade . . . . . . . . . . . . . . 208

Perdiz, Pointed Stem ................. . 209

Perdiz, Short Stem .................. . 209

Perdiz Preforms . . . . . . . . . . . . . . . 209

Miscellaneous Perdiz.................. 211

Scallorn . . . . . . . . . . . . . . . . . 211

Scallorn coryel1 . . . . . . . . . . . . . . . . 211

Scallorn eddy .................... 211

Scallorn sattler .................. 212

Miscellaneous Scallorn . . . . . . . . . . . . . 212

Scallorn-1ike Fragments . . . . . . . . . . . . . . . . 212

Sabinal .................. . . 213

Corner-Notched Preforms ................ 213

Basal-Notched Preforms ................ . . 213

Crude Contracting Stemmed Preforms .............. 213

Single-Notched Preforms ................ . 215

Miscellaneous Arrow Points . . . . . . . . . . . . . . 215

Arrow Point Blade Fragments .............. . 215

Dart Points . . . . . . . . . . . . . . . . 215

Bulverde . . . . . . . . . . . . . . . . 216

Castroville ................. . . 216

Early Corner Notched . . . . . . . . . . . . . . . 216

Edgewood ...................... 218

Ensor Variety 1 . . . . . . . . . . . . . . . . 218

Ensor Variety 2 . . . . . . . . . . . . . . . . . 218

Fairland ...................... . . 218

Frio . . . . . . . . . . . . . . . . . 218

Gower ....................... 220

Kinney ...................... . . 220

La Jita ..................... . . 220

Langtry . . .................... 222

Marcos . . . . . . . . . . . . . . . . . . 222

Marshall . . . . . . . . . . . . . . . . . 222

Matamoros .. . . . . . . . . . . . . . . . 222

Montel1 .. . . . . . . . . . . . . . . . . . 224

Nolan . . . . . . . . . . . . . . . . . . . 224

Pedernales ........................ . . 224

Uvalde . . . . . . . . . . . . . . . . . . . 224

Zavala ..................... . . 226

Miscellaneous Dart Points . . . . . . . . . . . . . . 226

Form 1..................... 226

Form 2..................... 226

Form 3.................... . . 226

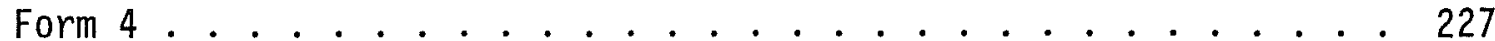

Form 5...................... . . 227 
Form 6 . . . . . . . . . . . . . . . 227

Form 7 . . . . . . . . . . . . . . . . . . . 227

Form 8 . . . . . . . . . . . . . . . . . . . 227

Form 9...................... . . . 228

Form 10 . . . . . . . . . . . . . . . . . 228

Form 11 . . . . . . . . . . . . . . . . . 228

Unidentifiable Dart Point Fragments . . . . . . . . . . . 228

Overal1 Retouch Bifaces . . . . . . . . . . . . . . . . 229

Distally Beveled Tools . . . . . . . . . . . . . . . . . . 229

Clear Fork Tools . . . . . . . . . . . . . . . . . . . 229

Guadalupe Tool . . . . . . . . . . . . . . . . 229

Miscellaneous Forms . . . . . . . . . . . . . . . . 229

Butted Bifaces ...................... . 231

Large, Pointed Ovates ................. . 231

Large Triangulars . . . . . . . . . . . . . . . 231

Convex Base ...................... . 231

Straight Base .................. . . 234

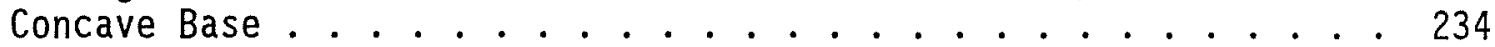

Large Individual Forms . . . . . . . . . . . . . . . . 234

Form 1...................... . . 234

Form 2 . . . . . . . . . . . . . . . . . . 234

Form 3...................... . . 235

Form 4 . . . . . . . . . . . . . . . . . . 235

Form 5..................... . . 235

Form 6..................... . . 235

Form 7 . . . . . . . . . . . . . . . . 235

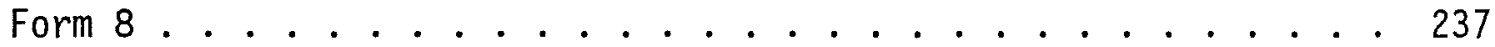

Form 9..................... . . . 237

Rounded Fragments ................... 237

Large Miscellaneous Fragments . . . . . . . . . . . . . . 237

Sma11, Pointed Ovates ................. . 237

Smal1 Triangulars ................. . 240

Sma11 Miscel1aneous Forms ............... . . 240

Bifacially Retouched Flakes ................... . 241

Large, Pointed Ovates ................... . 241

Large Ovates . . . . . . . . . . . . . . . . . . . . . . 241

Large Triangulars . . . . . . . . . . . . . . . . 241

Large Fragments ..... . . . . . . . . . . . . . . . . . 244

Sma11, Pointed Ovates ................... . 244

Stemmed .. . . . . . . . . . . . . . . . . . . 244

Sma11 Triangulars ................. . . 244

Sma11 Fragments ................... . 246

Concave Base. . . . . . . . . . . . . . . . . . . . 246

Amorphous . . . . . . . . . . . . . . . . . 246

Bifacial Intergrades . . . . . . . . . . . . . . . 247

Ovates .................... . . . 247

Pointed Ovates ..................... . . 247

Triangulars ................... . . 247

Asymmetrical ................... . . 250

Fragments . . . . . . . . . . . . . . . 250

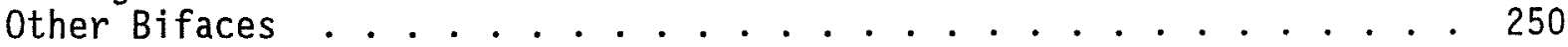

Pointed Fragments . . . . . . . . . . . . . . . . 250

Midsections and Lateral Fragments . . . . . . . . . . . 250 
Miscellaneous Fragments ................ 251

Unifaces .................. . . 251

End Scrapers on Blades ................. . 251

End and One Side................... 253

End and Two Sides .................. 253

Circumferential ................. 253

Two Sides .................... . . 253

One Side...................... 253

Concave Edge.................... 254

Gravers ...................... 254

Miscellaneous .................... . . 254

Modified Flakes and Chips ................. 254

Cores ..................... 256

Unidirectional Prepared Platform . . . . . . . . . . . 256

Multidirectional, Horizontal Platform . . . . . . . . . 256

Multidirectional, oblique Platform . . . . . . . . . . 258

Bifacial .................. 258

Core Tools ..................... . . 258

Natural Platform . . . . . . . . . . . . . . 259

Nuclei.................... . 259

Fragments .................... . . 259

Debitage . . . . . . . . . . . . . . . . 260

Flakes . . . . . . . . . . . . . . . . 260

Primary Flakes ................... . 260

Secondary Flakes . . . . . . . . . . . . . . . 260

Interior Flakes ................. 260

Chips ..................... 261

Corticate Chips ................... 261

Partially Corticate Chips . . . . . . . . . . . . . 261

Decorticate Chips .................. 261

Burned Nonflaked Chert . . . . . . . . . . . . . . . 261

Chunks ...................... 261

other Lithics . . . . . . . . . . . . . . . . . 261

Hammerstones . . . . . . . . . . . . . . . . 261

Ground Stone.................... . 262

Handstones . . . . . . . . . . . . . . . . 262

Grinding Slabs................. . . 264

Smoothed Stone................... 265

Fired Clay. . . . . . . . . . . . . . . . . . 265

Ceramics.................. 265

Leon Plain, Variety 1................ 266

Leon Plain, Variety 2 .............. 266

Leon Plain, Variety 3 ............... . . 268

Leon Plain, Variety 4 . . . . . . . . . . . . . . . 268

Leon Plain, Variety 5 ............... . . 269

Impressed Clay Specimen . . . . . . . . . . . . . 269

Modified Bone ..................... . . 269

Bone Awls . . . . . . . . . . . . . . . . . . 270

Ulna Tools ..................... . . . 270

Historic Artifacts . . . . . . . . . . . . . . . . 270

Ceramics . . . . . . . . . . . . . . . . 272

Glass . . . . . . . . . . . . . . . . 272

Clear Glass .................... 272 
Brown Glass . . . . . . . . . . . . . . . . . 272

Purple Glass......................... . . 272

Green Glass . . . . . . . . . . . . . . . . . . . . 272

Aquamarine Glass... . . . . . . . . . . . . . . . . 274

Mussel Shell Button ....................... . 274

Metal Artifacts . . . . . . . . . . . . . . . . . . 274

Wood Screw .. . . . . . . . . . . . . . . . . . . 274

Fence Staples ......................... . 274

Shotgun Shell Casing..................... . 274

Rimfire Cartridge Casing . . . . . . . . . . . . . . . 274

Rolled Metal . . . . . . . . . . . . . . . . . . . 275

Kettle Handle . . . . . . . . . . . . . . . . . . . 275

DISCUSSION AND PROJECT SUMMARY . . . . . . . . . . . . . . . . . . . . . . 275

Intersite Comparisons . . . . . . . . . . . . . . . . . 275

Chronology ......................... . 275

Tool Assemblages . . . . . . . . . . . . . . . 276

Debitage......................... . 279

Midden Features . . . . . . . . . . . . . . . . . . . 282

Intersite Distributions . . . . . . . . . . . . . . . 284

Intersite Comparison of Middens . . . . . . . . . . . . . . . 285

Summary of Midden Features . . . . . . . . . . . . . . . . . 286

Subsistence and Environment . . . . . . . . . . . . . . . . . . 287

Faunal Remains....................... . 287

Snail and Mussel Shel1. . . . . . . . . . . . . . . . . 288

Wood Charcoal Species Identifications . . . . . . . . . . . 289

Environmental and Subsistence Summary . . . . . . . . . . . . . 290

Settlement Patterns ....................... . . . 291

Site Type Diversity . . . . . . . . . . . . . . . . . 291

Physiographic Considerations . . . . . . . . . . . . . 293

Cultural Change ......................... 294

Mitigation Summary ......................... . . . 296

Future Research ........................ . 297

REFERENCES CITED............................... . . . . . 297

APPENDIX I. SOIL TEST DATA . . . . . . . . . . . . . . . . . . . . . . . 308

APPENDIX II. PROVENIENCE OF ARTIFACTS AND DEBITAGE BY SITE . . . . . . . 316 


\section{LIST OF FIGURES}

1. Project Areas within Uvalde County, Texas . . . . . . . . . . . 2

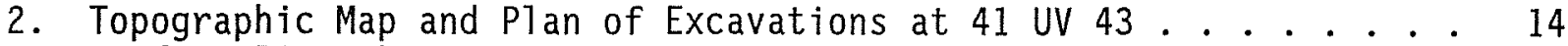

3. Surface Distribution of Debitage from the Random Sample Units at 41 UV 43

4. Distribution of Dart Points, Overall Retouch Bifaces, Bifacially

Retouched Flakes, Other Bifaces, Unifaces, Modified Flakes, and

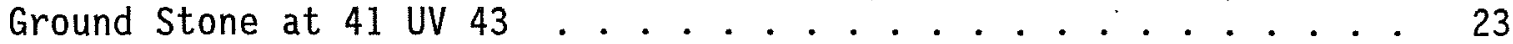

5. Distribution of Bifacial Intergrades at 41 UV $43 \ldots . . . . .25$

6. Unidirectional Cores and Core Fragments at 41 UV $43 \ldots . . . . .28$

7. Distribution of Horizontal and 0blique Platform Cores at 41 UV 43.29

8. Distribution of Natural Platform and Bifacial Cores, Core Nuclei, and Core Tools at 41 UV 43

9. Soil Profile from 41 UV 43, Unit 952-25

10. Topographic Map and Plan of Excavations at 41 UV $45 . . . . . .39$

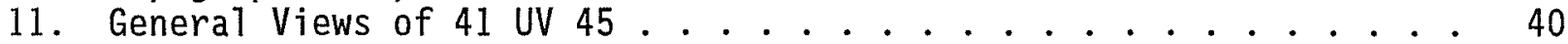

12. Distribution of Surface Artifacts at 41 UV 45 ........... 43

13. Trench Profiles from the Midden Areas at 41 UV 45 . . . . . . . . . 46

14. Profiles from Terrace Area Units at 41 UV 45 . . . . . . . . . . . 50

15. Profiles from Terrace Area Trenches at 41 UV 45 . . . . . . . . . 51

16. Features 1, 2, 4, 5, and 6 at 41 UV $45 \ldots \ldots 52$

17. Vertical Distribution of Debitage at 41 UV $45 \ldots . . . . . . . .62$

18. Topographic Map and Plan of Excavations at 41 UV 47 ....... 86

19. General Views of 41 UV 47 . . . . . . . . . . . . . . . . . . . 87

20. Surface Distributions of Debitage and Projectile Points at

41 UV 47 ...................... 91

21. Distributions of Bifaces, Unifaces, Cores, Hammerstones, and

Ground Stone at 41 UV 47 . . . . . . . . . . . . . . 94

22. Excavation Area A Profiles at 41 UV 47 . . . . . . . . . . . . . 99

23. Excavation Areas B, C, and D Profiles at 41 UV 47 . . . . . . . . 102

24. Features 2, 3, and 4 at 41 UV 47 ........... 105

25. Horizontal Distribution of Debitage and Burned Rock within

Area $A$ at 41 UV 47 ................. 119

26. Comparison of Excavated Flakes and Chips by Area at 41 UV 47 . . . 123

27. Topographic Map and Plan of Excavations at 41 UV 48 . . . . . . . 144

28. Surface Distribution of Debitage and Projectile Points at 41 UV 48 . . . . . . . . . . . . . . . . . . . 148

29. Surface Distribution of Bifaces, Unifaces, Cores, and Other

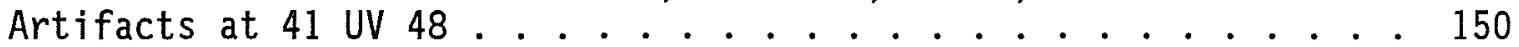

30. Soil Profiles for Area A at 41 UV 48 ............... . 154

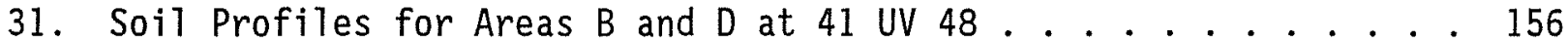

32. Soil Profiles in Areas $A$ and $C$ at 41 UV 48 . . . . . . . . . . . 157

33. Soil Profile for Area $C$ at 41 UV 48 . . . . . . . . . . . . . 158

34. Features 1, 2, and 3 at 41 UV 48 ............. 160

35. Vertical Distribution of Arrow Points at 41 UV $48 \ldots . . . . . .166$

36. Horizontal Distribution of Arrow Points at 41 UV 48 ...... . . . 167

37. Vertical Distribution of Overal1 Retouch Bifaces in Area A at 41 UV 48

38. Vertical Distribution of Bifacially Retouched Flakes in Area A at 41 UV 48 . . . . . . . . . . . . . . . . . . . 172

39. Vertical Distribution of Bifacial Intergrades in Area $A$ at 41 UV 48 
40. Vertical Distribution of Other Bifaces in Area A at 41 UV 48 . . . 177

41. Vertical Distribution of Cores in Area A at 41 UV 48 . . . . . . . 181

42. Comparison of Excavated Flakes and Chips by Area at 41 UV 48 . . . 184

43. Arrow Points . . . . . . . . . . . . . . . . . . 207

44. Arrow Points . . . . . . . . . . . . . . . . . 210

45. Arrow Points . . . . . . . . . . . . . . . . 214

46. Dart Points . . . . . . . . . . . . . . . . . 217

47. Dart Points ... . . . . . . . . . . . . . . . 219

48. Dart Points ... . . . . . . . . . . . . . . 221

49. Dart Points . . . . . . . . . . . . . . . . 223

50. Dart Points . . . . . . . . . . . . . . . . . 225

51. Distally Beveled Tools .................. . 230

52. Overall Retouch Bifaces .................... 232

53. Overall Retouch Bifaces ................... 233

54. Overall Retouch Bifaces ................... 236

55. Overall Retouch Bifaces................... 238

56. Overall Retouch Bifaces .. . . . . . . . . . . . . . . 239

57. Bifacially Retouched Flakes . . . . . . . . . . . . . . 242

58. Bifacially Retouched Flakes . . . . . . . . . . . . . . . . 243

59. Bifacially Retouched Flakes . . . . . . . . . . . . . . . 245

60. Bifacial Intergrades .. . . . . . . . . . . . . 248

61. Bifacial Intergrades ................. . 249

62. Unifaces ..................... . . 252

63. Unifaces ...................... 255

64. Cores ..................... . . 257

65. Hammerstones and Ground Stone . . . . . . . . . . . . . . 263

66. Leon Plain Ceramics and Impressed Clay . . . . . . . . . . . . 267

67. Modified Bone ... . . . . . . . . . . . . . . . . . 271

68. Historic Artifacts . . . . . . . . . . . . . . . 273 


\section{LIST OF TABLES}

1. Field Work Scheduling Statistics . . . . . . . . . . . . . 4

2. Chronological Sequence for the Leona River Watershed Project . . . 11

3. Artifact Types from Random and Nonrandom Surface Collection at 41 UV 43

4. Summary of Debitage from Random and Nonrandom Surface Collection at 41 UV 43

5. Distribution of the Debitage Densities from the Surface Collection at 41 UV 43 .................... . . . 20

6. Summary of Platformed Flake Types from Random Surface Collection at 41 UV 43

7. Distribution of Bifacial Intergrades at 41 uv $43 \ldots$

8. Distribution of Cores at 41 UV $43 \ldots . . . . . . . . . .31$

9. Provenience of Excavated Debitage from 41 UV $43 \ldots . . . . . . . .34$

10. Flake Platform Types from Excavations at 41 UV $43 . . . . . . . .36$

11. Random and Nonrandom Surface-Collected Artifacts Recovered at 41 UV 45

12. Summary of the Artifact Distributions at 41 iv $45 \ldots \ldots 56$

13. Distribution of Debitage by Unit at 41 UV 45 . . . . . . . . . . . 64

14. Summary of Platformed Flakes from 41 UV 45 . . . . . . . . . . . 67

15. Summary of Excavated Burned Rock at 41 UV 45 ........... 69

16. Distribution of Unmodified Bone at 41 UV $45 \ldots . . . . . . . .970$

17. Distribution of Snail Shells from 41 UV 45 ........... . 72

18. Summary of Snail She11 by Unit at 41 UV 45 . . . . . . . . . . . 75

19. Wood Species Identifications for 41 UV 45 . . . . . . . . . . . 77

20. Radiocarbon Dates from 41 UV 45 . . . . . . . . . . . . . 81

21. Random Sample Collection Unit Statistics for 41 UV $47 . . . . . . .990$

22. Random and Nonrandom Artifacts Surface Collected from 41 UV 47 . . 90

23. Arrow Point Distribution at 41 UV $47 \ldots . . . . . . . . .107$

24. Vertical Distribution of Arrow Points in Area A at 41 UV 47 . . . . 109

25. Dart Point Distribution at 41 UV 47 ............ 110

26. Overal1 Retouch Biface Distribution at 41 UV 47 ......... 111

27. Bifacially Retouched Flake Distribution at 41 UV 47 . . . . . . . 112

28. Bifacial Intergrade Distribution at 41 UV 47 . . . . . . . . 113

29. Other Biface Distribution at 41 UV 47 . . . . . . . . . . . 114

30. Uniface Distribution at 41 UV 47 . . . . . . . . . . . . . . . 114

31. Modified Flake Distribution at 41 UV 47 ............ 115

32. Core Distribution at 41 UV 47 ............... 115

33. Debitage Distributions by Area and Level at 41 UV 47 . . . . . . . 120

34. Intrasite Distribution of Debitage from 41 UV 47 . . . . . . . . . 122

35. Summary of Flake Platform Types from 41 UV 47 . . . . . . . . . . 125

36. Summary of Excavated Burned Rock at 41 UV 47 . . . . . . . . . . . 128

37. Faunal Remains from 41 UV 47 . . . . . . . . . . . . . . . . 130

38. Provenience of Mussel She11 from 41 UV 47 . . . . . . . . . . . . 131

39. Intrasite Distribution of Snail Shel1s at 41 UV 47 . . . . . . . . 133

40. Wood Species Identifications from 41 UV 47 . . . . . . . . . . 135

41. Summary of Wood Species by Area for 41 UV 47 . . . . . . . . . . . 136

42. Radiocarbon Dates from 41 UV 47 . . . . . . . . . . . . . . . 138

43. Relative Sample Size of Site Areas for 41 UV 48 . . . . . . . . . . 147

44. Comparison of Nonrandom and Random Surface Collection at 41 UV 48 . 147

45. Debitage Density Summary by Area at 41 UV 48 . . . . . . . . . . . 149

46. Intrasite Distribution of Artifact Categories, 41 UV 48 . . . . . 151 
47. Identified Faunal Elements from Feature 2 at 41 UV $48 \ldots 162$

48. Arrow Point Distribution at 41 UV 48 . . . . . . . . . . . . 164

49. Dart Point Distribution at 41 UV 48 . . . . . . . . . . . . . 165

50. Chronological Sequence of Dart Points from 41 UV 48 . . . . . . 168

51. Overal1 Retouch Bifaces at 41 UV 48 .............. 169

52. Distribution of Bifacially Retouched Fiakes at 41 UV 48 . . . . 173

53. Distribution of Bifacial Intergrades at 41 UV 48 . . . . . . . . 174

54. Other Biface Distribution at 41 UV 48 . . . . . . . . . . . . . 176

55. Distribution of Unifaces at 41 UV 48 . . . . . . . . . . . . 178

56. Distribution of Cores at 41 UV 48 .............. . . 179

57. Summary of Debitage Categories by Area from the Excavations at 41 UV 48 ..................... 185

58. Summary of Platform Categories by Area from the Excavations at 41 UV 48 ................... 187

59. Burned Rock Data at 41 UV 48 . . . . . . . . . . . . . . 189

60. Faunal Remains from 41 UV 48 . . . . . . . . . . . . . 190

61. Age Distribution of Identified Cottontail Rabbit, Jackrabbit, and Deer Elements at 41 UV 48 . . . . . . . . . . . . . . . . 191

62. Identified Elements of Cottontail Rabbit, Jackrabbit, and White-Tailed Deer at 41 UV 48 ............. . 192

63. Summary of the Unidentified and Burned Bone in Area A at 41 UV 48 . 194

64. Snail She11 Provenience at 41 UV 48 . . . . . . . . . . . 196

65. Vertical Distribution of Snail She11s in Area A at 41 UV 48 . . . . 199

66. Mussel Shell Remains by Area from 41 UV 48 . . . . . . . . . . . . 200

67. Wood Species Identifications by Weight (Grams) at 41 UV 48 . . . . 201

68. Wood Species Identifications by Leve1 at 41 UV 48 . . . . . . . . 201

69. Radiocarbon Dates from 41 UV 48 . . . . . . . . . . . . . 203

70. Hammerstones, Provenience and Dimensions .... . . . . . . . 262

71. Handstones, Provenience and Metric Data . . . . . . . . . . . 264

72. Intersite Distribution of Selected Artifact Groups Within the Leona River Watershed Project Area in Percentages . . . . . . . . . 278

73. Intersite Distribution of Debitage Within the Leona River Watershed Project Area . . . . . . . . . . . . . . . . . 280

74. Intersite Summary of Flake Platform Types Within the Leona River Watershed Project Area . . . . . . . . . . . . . . 281

75. Summary Comparison of Midden and Nonmidden Excavations at 41 UV 45, 41 UV 47, and 41 UV 48 in Percentages . . . . . . . . 283

76. Collection and Testing Summary for Processed Soil Samples from the Project Area . . . . . . . . . . . . . . . 309

77. Summary of Soil Test Results, Phosphate Ranges . . . . . . . . 311

78. Results of Soil Tests from the Project Area. . . . . . . . . . . 312

79. Provenience Data for Arrow Points . . . . . . . . . . . . . 317

80. Provenience Data for Dart Points . . . . . . . . . . . . . . . . 320

81. Provenience Data for Bifaces . . . . . . . . . . . . . . . 323

82. Provenience Data for Unifaces, Modified Flakes, Ground Stones, Hammerstones, Prehistoric Ceramics, and Historic Artifacts . . . 327

83. Provenience Data for Debitage . . . . . . . . . . . . 330 


\section{ACKNOWLEDGMENTS}

I am indebted to Dr. Thomas R. Hester, director, and Jack Eaton, associate director, Center for Archaeological Research, The University of Texas at San Antonio. Dr. Hester served as principal investigator of the project; both fully supported my efforts from the research proposal to the final draft.

Dr. William B. Butler, Mr. Donald Fiero, and Mr. Jack R. Rudy of the National Park Service are acknowledged for their continued interest in the progress of the project. Mike Brown and Bob Price of the Soil Conservation Service, Uvalde, Texas, also helped during the field work.

Sharon Quirk edited the report, and Carol Graves helped edit, write, and organize the research proposal. Mary Lou Ellis, secretary for the Center, was helpful in many ways throughout the project. Mrs. Ellis and Ann Young typed early versions of the report and the final draft. Chuck Haight helped type early versions of the draft.

Consultants Dr. Donald R. Lewis (chemical analysis), Donna Lannie (wood species identifications), and Robert F. Scott IV (faunal remains) contributed significantly to this report. John Poindexter of the Office of Media Resources at UTSA is thanked for his photographic work. Bruce and Cathy Ellis did the layout work for the photographs and helped with the other illustrations. Augustine Frkuska, Jr., drew some of the illustrations.

Field crew members were Tom Miller, Cecil Peel, Sylvia Bento, Maggie Mehrtens, Mike Ferguson, and Mary Standifer. Kenneth M. Brown, Janet Stock, Stephen L. Black, and Daniel R. Potter, CAR-UTSA staff, helped us greatly for a brief period of time. The laboratory work was facilitated by the efforts of Al McGraw, laboratory supervisor, and Beverly Ewald and Joan Sherwood. Mike Woerner conducted the soils tests at the CAR-UTSA facilities. Special thanks to Grant D. Hall and Anne Fox at the CAR-UTSA laboratory for their continued personal interest in the project.

Jim Willingham and Frank Speir, landowners of the sites, were generous in allowing us access to their properties; they shared with us information on the sites investigated and other sites on their land that helped out greatly. other local residents who shared their interest in the regional prehistory included Lytle H. Blankenship (Texas A\&M Agricultural Experiment Station), George Nelson, and Pete Curan. 


\section{INTRODUCTION}

The archaeological mitigation of four sites (41 UV 43, 41 UV 45, 41 UV 47 , and 41 UV 48) located in the Leona River watershed, Uvalde County, Texas, was conducted in response to a request by the United States government acting through and by the Heritage Conservation and Recreation Service, Interagency Archeological Services-Denver (IAS-D), now known as the United States Department of the Interior, National Park Service, Rocky Mountain Regional Office, Denver (NPS-D). Contracting officer for the IAS-D was Jack R. Rudy; Dr. William Butler was the contracting officer's technical representative. The Center for Archaeological Research (CAR), The University of Texas at San Antonio (UTSA), was awarded the contract (C53009[80]) by IAS-D in September 1980. Dr. Thomas R. Hester, director of the CAR, was principal investigator, and Jack D. Eaton, associate director, served as co-principal investigator. Project archaeologist was Paul D. Lukowski, and A. Joachim McGraw was assistant director for Taboratory analysis. Both Lukowski and McGraw are research associates at the CAR-UTSA.

The mitigation of the four sites was requested by the IAS-D as a direct result of an archaeological survey conducted by Hal1 (1974) with limited testing in the Leona River watershed in the construction areas for the proposed floodwater retarding structures planned by the USDA Soil Conservation Service (SCS). As a result of Hal1's survey, the four sites documented in this report were determined to be eligible for nomination to the National Register of Historic Places. Mitigation of the four sites was undertaken to provide a surface and subsurface assessment of each prior to adverse construction-related alterations. The work was performed in accordance with the Scope-of-Work provided by the IAS-D under the authority of the Archeological and Historic Preservation Act of 1974 (Public Law 93 291). Funding for the project was provided primarily by the IAS-D; additional funding was provided by the SCS under their obligations under Pub7ic Law 93-291.

\section{DESCRIPTION OF THE STUDY}

\section{$\underline{\text { Impacted Areas }}$}

The Leona River watershed is located in the central portion of Uvalde County, Texas (Fig. 1). The region is considered to be part of the south-centrai Texas area, a cultural and geographical area within which the sites were studied (Hester 1980a). The four site locations within Uvalde County are shown in Figure 1. Sites 41 UV 47 and 41 UV 48 are on the edge of the Leona River, and sites 41 UV 43 and 41 UV 45 are on major tributaries of the Leona River.

Varying degrees of impact are expected at the four sites. At 41 UV 47 , earth-borrowing activities are planned for the eastern portion of the site, where a Late Prehistoric burned rock midden feature has been recorded (see discussion of Area B in section 41 UV 47). Currently, other borrow areas may be used, but a final decision has not been made yet (Bob Price, SCS, personal communication). Should earth-borrowing activities take place at 41 UV 47, the major portions of the eastern section of the site would be completely 


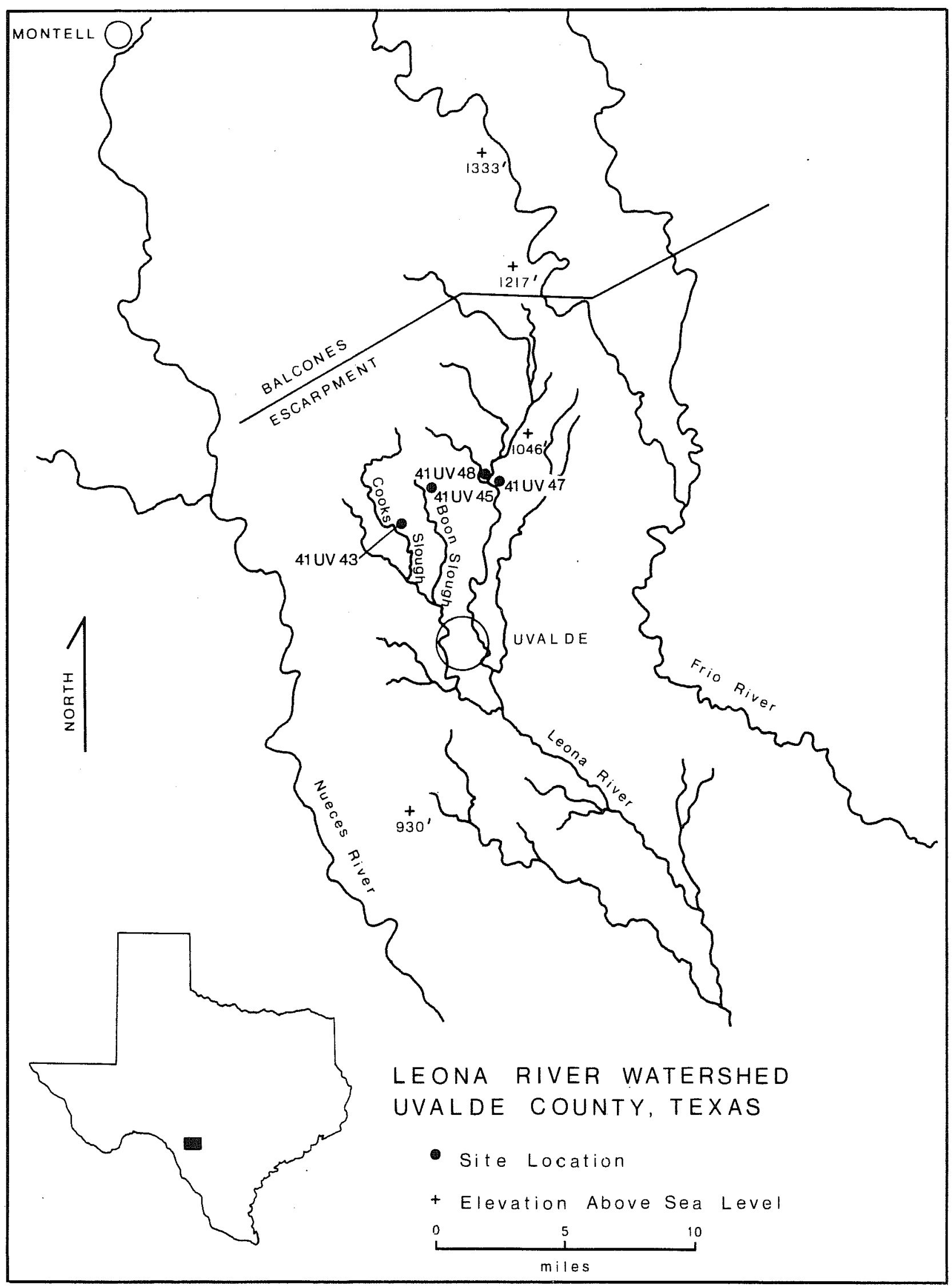

Figure 1. Project Areas within Uvalde County, Texas. 
destroyed. The remaining area of site 41 UV 47 is expected to fall below the proposed floodpool elevation line and hence would be periodically inundated after dam construction is completed. Some additional impact might also occur during the construction phase, when heavy mechanical equipment is operating in the area, but it is uncertain how much damage could be expected.

Site 41 UV 43 is also in an area where one of the proposed floodwater retarding structures will cause some of the most serious negative impact on the cultural resources within the site. Portions of 41 UV 43 are well within the borrow areas and maximum floodpool elevation lines. Because the site is primarily a surficial manifestation, it will remain easily accessible to permanent alterations of its prehistoric resources.

The remaining sites (41 UV 45 and 41 UV 48) wi11 suffer 1esser overall impact, which is expected to be caused by the location of the sites within the proposed maximum floodpool elevation zones. This negative impact will increase erosional and/or depositional occurrences on the surface features at the sites. However, other consequences of a periodic flooding at any of the sites are difficult to assess, e.g., effects of preservation on organic material (Lynott 1979).

\section{Project Implementation and Curation}

A11 field work was carried out between January 21 and May 28, 1981. Field work was aimed at conforming to the contract specifications outlined in the Scope-of-Work presented in RFP $W 530052$ by the IAS-D and the research proposal originally submitted to the IAS-D. Major goals of the mitigation were documentation and assessment of the cultural resources of each of the four sites prior to the construction phase of the floodwater retarding structures. The body of this report describes and summarizes the findings made during the field work and subsequent analyses of the data gathered during the project.

A total of 82 working days and 423 person days was expended during the field work portion of the project. A total of 340 person days was allotted for the laboratory (100 days) and analysis (240 days) portion of the project. Table 1 shows a categorized breakdown of the field time expenditures. Factors affecting the average total working days were dependent upon weather, logistics, and variable crew size.

A11 materials collected from the three sites (4I UV 45, 41 UV 47, and 41 UV 48) on Mr. Jim Willingham's property have been returned to his possession after analysis, at his request and as part of the contract specification. Materials collected from 41 UV 43 will be permanently stored at the CAR-UTSA. A71 project notes, photographs, and records pertaining to the investigation will be filed for further use at the CAR-UTSA. 
TABLE 1. FIELD WORK SCHEDULING STATISTICS

\begin{tabular}{lccc}
\hline Site & $\begin{array}{c}\text { Working } \\
\text { Days* }\end{array}$ & $\begin{array}{c}\text { Person } \\
\text { Days** }\end{array}$ & $\begin{array}{c}\text { Percentage of Field } \\
\text { Time at Site }\end{array}$ \\
\hline 41 UV 43 & 14 & 69 & 16 \\
41 UV 45 & 16 & 95 & 22 \\
41 UV 47 & 25 & 113 & 35 \\
41 UV 48 & 27 & 146 & 100 \\
\hline TOTAL & 82 & 423 & 27 \\
\hline
\end{tabular}

* Contract estimate for a project total of 70 working days.

** Contract estimate for a total of 420 person days.

\section{RESEARCH GOALS AND STRATEGIES}

Research orientation was in part directed by the concerns of the IAS-D (now NPS-D), who funded the mitigation of the four sites under consideration, and by the CAR's longstanding interest in regional archaeological problems. The IAS-D goals were outlined in the Scope of Work contained in RFP W530052 and are briefly reviewed here. The research proposal submitted by the CAR-UTSA in response to the Scope of Work is also reviewed.

\section{IAS-D GOALS}

The IAS-D decided that mitigation, in the form of excavation, be conducted to alleviate the anticipated adverse impact of four specific sites in the vicinity of three proposed floodwater retarding structures to be built by the USDA Soil Conservation Service (SCS). Although all four sites were to be affected, mitigation efforts were primarily directed at the three suspected prehistoric campsites: 41 UV 45, 41 UV 47, 41 UV 48. The other site 41 UV 43, a lithic quarry, was not to be considered until work at the previously mentioned campsites was completed.

A series of research topics was outlined by the IAS-D to be considered the minimum necessary to accomplish the mitigation effort. The research topics set forth by the IAS-D were as follows: (1) identification of the site function; (2) span and frequency of site occupation; (3) a history of the natural environment and an assessment of the available resource exploitation potential within the area; (4) a further definition of the cultural/ historical sequence which would contribute to the understanding of the Uvalde area; (5) a description of the hunting technology; and (6) a further definition of prehistoric (and historic) adaptation, both regionally and 
1ocal1y. The data collected during the course of the project were expected to provide information to be used to identify or clarify aspects of each of the above topics.

\section{Theoretical Base of Study}

The specific topics noted previously were reviewed and integrated into the research proposal submitted by the CAR-UTSA to the IAS-D in response to the RFP W530052. The limited data from the area, mainly from Hall's (1974) survey and other, unpublished data made available by area collectors and researchers were reviewed to obtain an initial assessment of the four sites. This research indicated that three of the sites ( 41 UV 45, 41 UV 47, 41 UV 48) could be multicomponent campsites (probably base camps), representing various periods of the Archaic and Late. Prehistoric. Burned rock concentrations, possibly buried burned rock middens, were either suspected or recorded at the three campsites. However, the extent and the nature of the subsurface deposits (both on and off any of the midden features) were essentially unknown. Hall's (1974) two test pits at 41 UV 47 provided the only data on the subsurface nature of any of the campsites studied. The other site, 41 UV 43, was described as a prehistoric quarry area characterized by chert cobbles eroding out of the soil. Hal1's (1974) initial evaluation of 41 UV 43 was that the site was deflated, with 1ittle or no subsurface context. This assumption, however, had not been tested.

In developing a research strategy, it was necessary that more specific knowledge of each site be gathered prior to excavation. A plan for the overall assessment of each site was organized as part of a multistage field work strategy that would provide for some degree of preliminary site evaluation during the course of field work. The multistage approach utilized controlled surface collections, shovel testing, and backhoe trenching prior to a final stage of more extensive excavations; the preceding field work being used to guide the later.

The research design focused on four basic research problems. The research problems were stated in such a manner so that they might remain realistically approachable with the kinds of data that would be initially collected in the field, knowing that the assessment process could alter this design as new data came to light. These four research problems are inclusive of the various topics outlined by the IAS-D.

The four research goals were as follows: (1) the identification of site chronologies; (2) the determination of the nature and extent of the cultural deposits; (3) the development towards the understanding of settlement patterns, resource utilization, and adaptive strategies expressed at each of the sites; and (4) an investigation of the nature of burned rock midden accumulations within the study area. The four research goals were based on the known composition of each site (aware of just how tenuous the knowledge was). Too 7ittle was known of each site to focus exclusively on any specific research objective, but pursuit of the research goals was expected to generate a pool of data that could be used to understand more about each site in particular and also the prehistory of the south Texas region. 
By the end of the project, it was clear that the quarry site (41 UV 43) was a surface manifestation, but surprisingly, two of the open campsites were found to be predominantly Late Prehistoric component sites. Site 41 UV 45 was a multicomponent Archaic site with some minor Late Prehistoric deposits. The temporal differences between the campsites resulted in a research orientation towards the comparison and contrasting of Late Prehistoric and Archaic components.

\section{ENVIRONMENTAL BACKGROUND}

Uvalde County is about equally divided into two distinct physiographic regions, each associated with variations in the surface geology, topography, and plant and animal distributions. The northern half of the county lies within the uplifted Edwards Plateau region of Texas, while the southern half of the county is part of the South Texas Plains region (Gould 1975; Stevens and Richmond 1976). The two regions meet at the Balcones Escarpment, which occurs as a series of sharp changes in elevation along the Balcones Fault Zone. Major rivers that drain through the county, al1 running in a southeasterly to southerly trending direction, are the West Nueces River, the Leona River, and Blanco Creek. Topographical variations in the Edwards Plateau region include steep hills, ridges, and deep valleys, some approximately 500 feet deep. The elevations within the Edwards Plateau region range from about 2000 to 1100 feet above mean sea level. Soits in the plateau area tend to be dark, stoney calcareous clays and clay loams. Topographic features of the South Texas Plains region are relatively level, consisting of gently rolling hills and broad stream valleys. Elevations in the southern part of the county range from 1000 to 700 feet above mean sea level; soils tend to be deep, dark, clayey and sandy loams (Stevens and Richmond 1976). All of the archaeological sites described in this report lie approximately six miles south of the Balcones Escarpment, which place them in the northern margins of the South Texas Plains region.

The surface geology of Uvalde County is characterized by Cretaceous limestone in the Edwards Plateau region, and Tertiary and Quaternary deposits in the South Texas Plains region and along the major river channels. Cretaceous 7 imestone within the south belongs to the Comanche and Gulf Series (Barnes 1974; Stevens and Richmond 1976). All of the sites in this report occur in fluviate terrace deposits of the Quaternary, although Cretaceous limestone hills border some of the sites. The fluviate deposits in the study area are the Leona formation of the Pleistocene and the Uvalde Gravel formation of the Pliocene. The Uvalde gravels provided an important source of stream-borne chert gravels and cobbles utilized in prehistory. Eocene deposits of sandstones and shales occur mainly in the southern and southeastern part of the county. Igneous plugs or silTs such as the Blue, Inge, Black, and Ingram Mountains occur in the southern half of the county (Stevens and Richmond 1976). The dark basaltic rock from these igneous hills was used as raw material for ground stone tools at some of the sites in this report; the closest of these hills lies $4 \mathrm{~km}$ away from site 41 UV 47 .

Two of the seven biotic provinces described by Blair (1950) occur within Uvalde County: the Balconian Biotic Province and the Tamaulipan Biotic Province. The Balconian Biotic Province extends northward from the Balcones 
Escarpment encompassing the Edwards Plateau physiographic region. The Tamaulipan Biotic Province approximates the South Texas Plains physiographic region, and occurs within the southern half of Uvalde County (Gould 1975; Stevens and Richmond 1976). The Balconian Biotic Province is, in essence, a very broad ecotonal transitional area between the more arid Chihuahuan Biotic Province in the western part of Texas and the more mesic eastern woodlands of the Austroriparian Biotic Province in eastern Texas (B1air 1950). The 1ocal microenvironmental conditions, which may tend to be xeric or mesic, allow for the interdigitation of eastern and western Texas plant and animal species within the ecotonal regional of the Balconian Biotic Province. The Tamaulipan Biotic Province is best characterized as thorny brushlands (Blair 1950).

Within the Balconian Biotic Province, juniper, Texas oak, and shinnery oak are the predominant woody vegetation, although stream valleys may support large elms, oaks, hackberries, and pecan trees (B1air 1950; Gould 1975). In a very few of the eastern valleys of Uvalde County, cypress trees grow (Hester 1971). In the western part of Uvalde County, xeric plants characteristic of the Chihuahuan Biotic Province, such as lechugilla and sotol, occur as far east as Monte11 rockshelter (B1air 1950; Hester 1977b).

In the southern part of the county, the Tamaulipan Biotic Province is characterized by thorny brushlands. Mesquite, acacia, mimosa, guajillo, whitebrush, prickly pear, and cholla are all common. Stream valleys support oak forests and other Targer trees (Blair 1950; Gould 1975).

Several authors have noted that the current landscape, especially within the South Texas Plains region, has developed as a result of land use patterns since historic times. Gould (1975) has suggested that originally the vegetation in the South Texas Plains region was comprised of bunch grasses in an oak and mesquite savanna. Shrubs and trees have invaded or replaced the climax vegetation due to grazing and ranching practices, causing dramatic increases in mesquite, live oak, post oak, Opuntia sp., and Acacia sp. Fisher (1975), in a more general study, notes that while the range of mesquite has remained nearly the same, overall coverage has increased since the 1850s. Fisher (ibid.) attributes the increase in mesquite to control of range fires, grazing, extended droughts, and current 7 and use patterns. In the central and south Texas area, Inglis (1964) has reported early observations by travelers in the area that suggest the spreading of thorny brush in the region is recent. Although the vegetational patterns in the South Texas Plains region has probably significantly changed, there is no reason to suspect that the important food resources such as acorns, persimmon fruits, hackberry fruits, pecans, prickly pear, and many weeds and grasses were not available in the prehistoric.

Wildlife within the Balconian and Tamaulipan Biotic Provinces is diverse and overlapping. Within the Balconian biota, Blair (1950) notes 57 kinds of mammals, 36 snakes, 16 lizards, a land turtle, and a few frog species. The Tamaulipan biota has a similar diversity of animal species. In Uvalde County, white-tailed deer, cottontail rabbit, jackrabbit, turkey, squirrels, and coyote are common. Blair (1950) notes that jackrabbit (an important prehistoric food resource) is more common in the Tamaulipan Biotic Province than in the Balconian Biotic Province. Although bison is no longer present 
in the area, Dillehay (1974) has used data from Texas archaeological sites to suggest that the animal was periodically available as a food resource. Inglis (1964) has documented early historic observations on the quantities of both bison and antelope in the region. The significance of deer as a food item in this area is consistently revealed in the recovery of deer bones at excavated prehistoric campsites and is emphasized by the documentation of deer antlers associated with both Archaic and Late Prehistoric burials (Johnson 1978; Prewitt 1974; Hall 1981; Lukowski 1987).

Climatic conditions for Uvalde County are those of subtropical, hot, humid summers, and mild, dry winters. The maximum mean for the summer month of July is $96^{\circ} \mathrm{F}$, while the maximum average low during January is $37^{\circ} \mathrm{F}$. The first fall freeze generally occurs in mid-November, and the last freeze of the spring generally occurs in mid-March. An average of 41 days have temperatures over $99^{\circ} \mathrm{F}$ between May and September; freezing temperatures can be expected on the average of about 26 times a year (Stevens and Richmond 1976).

Rainfall averages for Uvalde County approach 24 inches a year, but this amount varies greatly from year-to-year and also from month-to-month. Notably, almost $70 \%$ of the yearly precipitation falls between May and October; usually in the form of thundershowers. Most of this rain occurs during the late spring and the early summer, a secondary peak in rainfall occurs in September with the beginning of fall cold fronts. Tropical disturbances in the Gulf of Mexico occasionally contribute to heavy rains during the early fall (Stevens and Richmond 1976).

The mild winters usually have less rain, and although it may occasionally snow (about twice a year), the snow may melt as it falls. Sudden cold snaps in the winter, usually only lasting a few days, may drop the temperature sharply in only a few hours. The low winter rainfall is due to arctic air masses that cut off the usual supply of moisture from the Gulf coast.

Information on the paleoenvironment of the area is sketchy at best. Bryant and Shafer (1977) have proposed a model for a continual drying trend in most areas of Texas, based upon the analysis of pollen from bogs in east Texas and dry cave deposits in the lower Pecos River area. Attempts at pollen recovery from open prehistoric campsites in central Texas have proven to be of 1 ittle success (Dering 1978:223-228; Ha11, Black, and Graves 1982:472). Pollen at these open sites is apparently not well preserved. Bryant and Riskind (1980) have outlined the paucity of useful information currently available to suggest definite paleoenvironmental patterns in the nearby area of northeastern Mexico. The number of variables such as temperature, evaporation, moisture, and edaphic factors clouds interpretations; but Bryant and Riskind (1980) suggest that during the last 30,000 years significant changes in the vegetational patterns have occurred. Dering (1982) suggests the possibility that the present boundaries of the Balconian biota may have extended much farther south in the past, based upon the recovery of juniper wood charcoal specimens from the Choke Canyon Reservoir area, dated between 390-270 B.C.

Studies of faunal remains in northeastern Mexico by Lundelius (1980) also tend to suggest a drying or warming trend after the Pleistocene; this trend being concurrent with a greater seasonality in the climate. Minor 
fluctuations of moister periods are considered likely within the drying trend. Dillehay's (1974) study of bison intrusions and retreats from some areas of Texas may also be linked to relatively significant climatic variation during the prehistoric sequence.

Another 7 ine of research into paleoenvironmental reconstructions showing some promise is that of phytolith analysis. Based upon a study of one site in south Texas, near Victoria, Texas, Robinson (1979) has implied some climatic fluctuations during the last 8000 years. More recent work by Robinson (1982) at three sites in the Choke Canyon Reservoir area of south Texas suggests changes in the environment over the last 5000 years that includes at least two mesic episodes corresponding with glacial expansions.

\section{ARCHAEOLOGICAL BACKGROUND}

Uvalde County lies in an area of Texas where three traditionally recognized cultural areas tend to merge. Two of these cultural areas, the central Texas and the south Texas areas, are in part closely related to the physiographic regions of the Edwards Plateau and the South Texas Plains. The two cultural areas associated with these physiographic regions tend to be commonly expressed in the archaeological manifestations found within the county. Traits common to the lower Pecos River area, the third cultural area, are usually located slightly to the west of Uvalde County, but are occasionally found within it. Recent archaeological overviews including Uvalde County place the study area on the southwest margins of the central Texas area (Prewitt 1981), or in the south-central Texas area (Hester 1981).

Chronological sequences in the prehistory of Texas depend heavily upon historical typologies incorporating stylistic changes in projectile point types. Central Texas diagnostics such as stemmed and/or notched Travis, Pedernales, Frio, and Fairland projectile points are common in the project study area; but the typically stemless projectiles associated with the South Texas Plains cultures (Catan, Abasolo, Desmuke, Refugio) are also present, although less common. The lower Pecos River culture area traits and diagnostics such as Shumla and Langtry projectile points, painted pebbles, and pictographs occur relatively infrequently within Uvalde County.

The basic chronological framework for the central Texas area appears in the publication of Suhm, Krieger, and Jelks (1954) and in Suhm and Jelks (1962). Refinements of the Archaic sequence were later reported by Johnson, Suhm, and Tunnel1 (1962) and by Sorrow, Shafer, and Ross (1967). Syntheses of PaleoIndian and Archaic substages include reviews of the Paleo-Indian period by Hester (1977a) and the Early Archaic period (then termed Pre-Archaic) by Sollberger and Hester (1972). Important publications focusing on the Late Archaic and Late Prehistoric periods are reported by Shafer (1977), Hester and Hill (1975), and Montgomery (1978). Bibliographies for the area are by Campbe11 (1960) and Hester (1974). More recent publications on prehistoric central Texas increasingly focus on definitions of social and economic systems (Weir 1976; Prewitt 1981); as is also the case in publications focusing on southern Texas (Hester 1980a, 1980b, 1981). 
The chronological outline for the study area shown in Table 2 is a reflection of the studies previously discussed. The earliest recognized period for Uvalde County is the Paleo-Indian. Early Paleo-Indian (Clovis and Folsom diagnostics) ends ca. 8000 B.P., and is followed by the Late Paleo-Indian (Circleville phase), which is characterized by lanceolate forms such as Golondrina, Angostura, Plainview, and Meserve projectile points, ending as late as 7000 B.P. The Early Archaic period is marked by the appearance of corner-notched projectile point forms. Martindale, Uvalde, Gower, Early Triangular, and Early Corner Notched points are considered diagnostic of this period which lasts from 5000 to 7000 B.P. The Middle Archaic is characterized by the appearance of burned rock middens. Two subdivisions of this period, the Clear Fork (4000 to 5000 B.P.) and the Round Rock (2600 to 4000 B.P.) are recognized. Slender, rectangular stemmed projectile points, such as Travis and Nolan commonly found in the lower levels of burned rock middens, are diagnostic of the Clear Fork phase. The subsequent Round Rock phase is commoniy recognized by an increase in the number of burned rock midden sites throughout central Texas, and the dominant diagnostic projectile point form is the Pedernales. Minor dart point forms such as Kinney, Bulverde, and Langtry also appear during the Round Rock phase. The Late Archaic period is divided into two phases, the San Marcos phase (1800 to 2600 B.P.) and the Twin Sisters phase (1300 to 1800 B.P.). Corner- and sidenotched points, such as Marcos, Monte11, Castroville (San Marcos phase), Ensor, Frio, and Fairland (Twin Sisters phase) appear in the upper levels of burned rock middens and in open campsites. The introduction of the bow and arrow marks the end of the Archaic period and the initiation of the Late Prehistoric period. Two phases of the Late Prehistoric commoniy acknowledged are the Austin phase (600 to 1600 B.P.) and the Toyah phase (200 to 600 B.P.). Associated with the Austin phase is the Scallorn arrow point form (a variant form; Sabinal also occurs within this phase), and the Edwards type may be a distinctive early Austin phase form. Recent evidence also suggests that ceramics may have been introduced at this time (BTack and McGraw 1985). The last phase of the Late Prehistoric is the Toyah phase, and is characterized by the common occurrence of Perdiz arrow points and Leon Plain bone-tempered ceramics (Suhm and Jelks 1962). The prehistoric sequence in south and central Texas is followed by a brief historic aboriginal period of cultural upheaval and desemination.

Paleo-Indian sites recorded within Uvalde County are not numerous. The earliest projectile point form recorded from the county is Clovis, described by Hester (1970). At the Kincaid rockshelter Folsom points and Pleistocene fauna have been reported by local collectors and from excavations conducted by the Texas Memorial Museum during the early 1950s (Sellards 1952). Late Paleo-Indian artifacts from Uvalde County include a variety of point types, primarily Plainview, Golondrina, and Angostura. Late Paleo-Indian components occur at Montel1 rockshelter (Hester 1977b) and Kincaid rockshelter. One Late Paleo-Indian projectile point recovered from Montell rockshelter, made of obsidian, has been traced to a location in Queretaro, Mexico, about 600 miles away (Hester, Asaro, and Stross 1982).

The Archaic period is represented in Uvalde County by a number of sites that contain multiple, and more rarely single components, of the Early, Middle, and Late Archaic periods. Some of the Early Archaic components within the county and in surrounding counties have been discussed by Sollberger and 
TABLE 2. CHRONOLOGICAL SEQUENCE FOR THE LEONA RIVER WATERSHED PROJECT

\begin{tabular}{|c|c|c|c|c|}
\hline Date & & Period & Phase & Diagnostics \\
\hline $0-200$ & 1 & Historic & 1 & Guerrero points, metal points \\
\hline $200-600$ & 1 & \multirow{2}{*}{ Late Prehistoric } & Toyah & Perdiz, ceramics \\
\hline $600-1600$ & 1 & & I Austin & I Scallorn, Sabinal, Edwards \\
\hline $1300-1800$ & 1 & \multirow{2}{*}{ Late Archaic } & I Twin Sisters & I Ensor, Frio, Fairland \\
\hline $1800-2600$ & l & & I San Marcos & Marcos, Monte11, Castroville \\
\hline $2600-4000$ & 1 & \multirow{2}{*}{ Middle Archaic } & I Round Rock & Pedernales, Bulverde, Kinney \\
\hline $4000-5000$ & 1 & & I Clear Fork & I Nolan, Travis, La Jita \\
\hline $5000-7000$ & 1 & Early Archaic & I San Geronimo & Uvalde, Gower, Early Triangular \\
\hline $7000-8000$ & 1 & Late Paleo-Indian & I Circleville & Golondrina, Angostura, Plainview \\
\hline $8000-?$ & 1 & Early Paleo-Indian & 1 & I Clovis, Folsom \\
\hline
\end{tabular}


Hester (1972) in an overview of the "Pre-Archaic" (Early Archaic in this report). The Early Archaic component best known from Uvalde County is from the excavations at the La Jita site (Hester 1971). Middle Archaic occupations account for a large proportion of the prehistoric sites in Uvalde county. The burned rock middens characteristically associated with the Middle Archaic period are common in the county, although very few have been intensively studied. The well-known Middle Archaic sites from Uvalde County include the Gildhart site (Jackson 1938), the Luce site (Hester 1970), the La Jita site (Hester 1971), and the Anthon site (Weir and Doran 1980). Late Archaic components are also common in the county, but the excavated sites of this period are multicomponent, such as La Jita (Hester 1971) and the Anthon site (Weir and Doran 1980).

Late Prehistoric sites are present throughout Uvalde County, although as is the case with the Archaic sites, few are well documented. Two extensively excavated Late Prehistoric components are known from the La Jita site (Hester 1971) and the Anthon site (Weir and Doran 1980). Huskey (1935) excavated unusual Late Prehistoric burned rock middens in northern Uvalde County similar to features at sites in this report (41 UV 47 and 41 UV 48 ). Mitchell (1978) relied heavily upon sites located in Uvalde County to propose a tentative new Late Prehistoric phase he named the Turtle Creek phase.

Historical archaeological studies within the county have been conducted at the U.S. military site of Fort Inge (Nelson 1981). Work by Tunnell and Newcomb (1969) and a review by Cook (1981) of the Spanish colonial period at Mission San Lorenzo de la Cruz includes brief references to Mission Nuestra Señora de la Candelaria.

Campbell and Campbell (1981) have published an extensive overview summarizing what is known of Coahuilteco, Tonkawa, and other historic Indian groups in south Texas. The Lipan Apache and the Comanche tribes were present in south and central Texas during the final phases of the Historic period, and are probably represented in the archaeological record by the few metal projectile points recorded from Uvalde County and other nearby counties (Mitche11 1974; Hester 1981).

Other archaeological work in Uvalde County has documented a variety of prehistoric sites. Wesolowsky (n.d.) has briefly analyzed human bones representing several individuals from the Garrison site, a rockshelter in northwestern Uvalde County. Benfer and Benfer (1981) reported findings at a disturbed shaft cave burial site in the same area as the Garrison site. Pictograph sites, indicative of a lower Pecos River cultural influence in the Uvalde area, have been reported by Hester (1977b). Painted pebbles, more commonly found in the lower Pecos River area, were reported from Montell rockshelter (Evans 1947). Hester, Asaro, and Stross (1982) have reported on a central Mexico, Classic period style obsidian projectile point. Other investigations by Graves (ms.), Hall (1974), and Patterson (1982) provide additional information from the county. 


\section{DATA RECOVERY AND ANALYTICAL METHODS}

A brief period of time was used at the beginning of each investigation to walk over the site and to make an initial assessment of the overall density and size of the site. This allowed a gross estimate of the site size so that an appropriate grid system could be developed. After the initial walk over, permanent datums were placed at all of the sites. The datums for the sites consisted of iron rods set in concrete for three of the sites; at 41 UV 45 , however, the datum (an iron rod) was not set in concrete. Siting, or alignment points were then established using a transit along at least one axis of each grid. Grid system orientation was generally determined by the nature of the site, usually along the maximum dimensions of the cultural material or paralleling an adjacent drainage. Stakes were driven into the ground along one major axis of the site (in 10 - or 30-m intervals) to determine the size of the grid system and to be used as reference points for later recording activities.

After establishing site controls, a site map showing a grid plan of all of the $10-\mathrm{m}^{2}$ units was drawn, and these units were assigned sequential numbers. Using the grid plan, a 10\% random sample, drawn from a book of random numbers, was selected, and these units were marked on the grid plan. A controlled surface collection of the site was conducted using the plan and the provenience controls established. A series of two teams conducted the surface collection; one using a surveyors compass (or transit) to stake out at least two corners on the targeted unit, the other team responsible for the actual collection of the unit and the recording of the materials removed from each 10-m² unit. Provenience of the cultural materials was measured to within a $2-\mathrm{m}^{2}$ subunit of each $10 \mathrm{~m}^{2}$, thus providing the maximum resolution for data recovery from the surface. An inventory was maintained for each collected unit using standardized mimeographed CAR-UTSA inventory forms. Provenience designations would generally consist of the number of the $10-\mathrm{m}^{2}$ unit, followed by a dash which preceded the $2-\mathrm{m}^{2}$ subunit designation (between 1 and 25). This designation system was also used to provenience excavation units in later stages of field work.

After surface collection activities were completed for each site, and the overall Tithic densities and tool types for each collection unit were coded onto a site plan, the first stage of subsurface investigations was initiated. This stage consisted of placing test pits and backhoe trenches at locations selected on the basis of observations recorded during the surface collection of each site. Areas of high lithic concentrations or other cultural manifestations were selectively explored by test pits, backhoe trenches, or a combination of both. Test pits measured either $50 \mathrm{~cm}^{2}$ or $1 \mathrm{~m}^{2}$ and were excavated in $10 \mathrm{~cm}, 20 \mathrm{~cm}$, or $25 \mathrm{~cm}$ arbitrary levels. All of the fill removed from the test pits was passed through 1/4-inch wire mesh screen, and standard unit-level notes were kept. Backhoe trenches were systematically used to determine the nature and extent of subsubsurface deposits within terrace soils and burned rock middens within the sites. Based upon the results of these testing operations, larger sized excavation units, usually $2 \mathrm{~m}^{2}$ in size were placed within those areas of each site that appeared to offer the best chance at providing data relevant to the research goals. These excavation units were dug in 10- or 20-cm unit-7evels, and all fill was screened through either $1 / 4-i n c h$ or $1 / 8$-inch (whenever smal1 faunal remains 


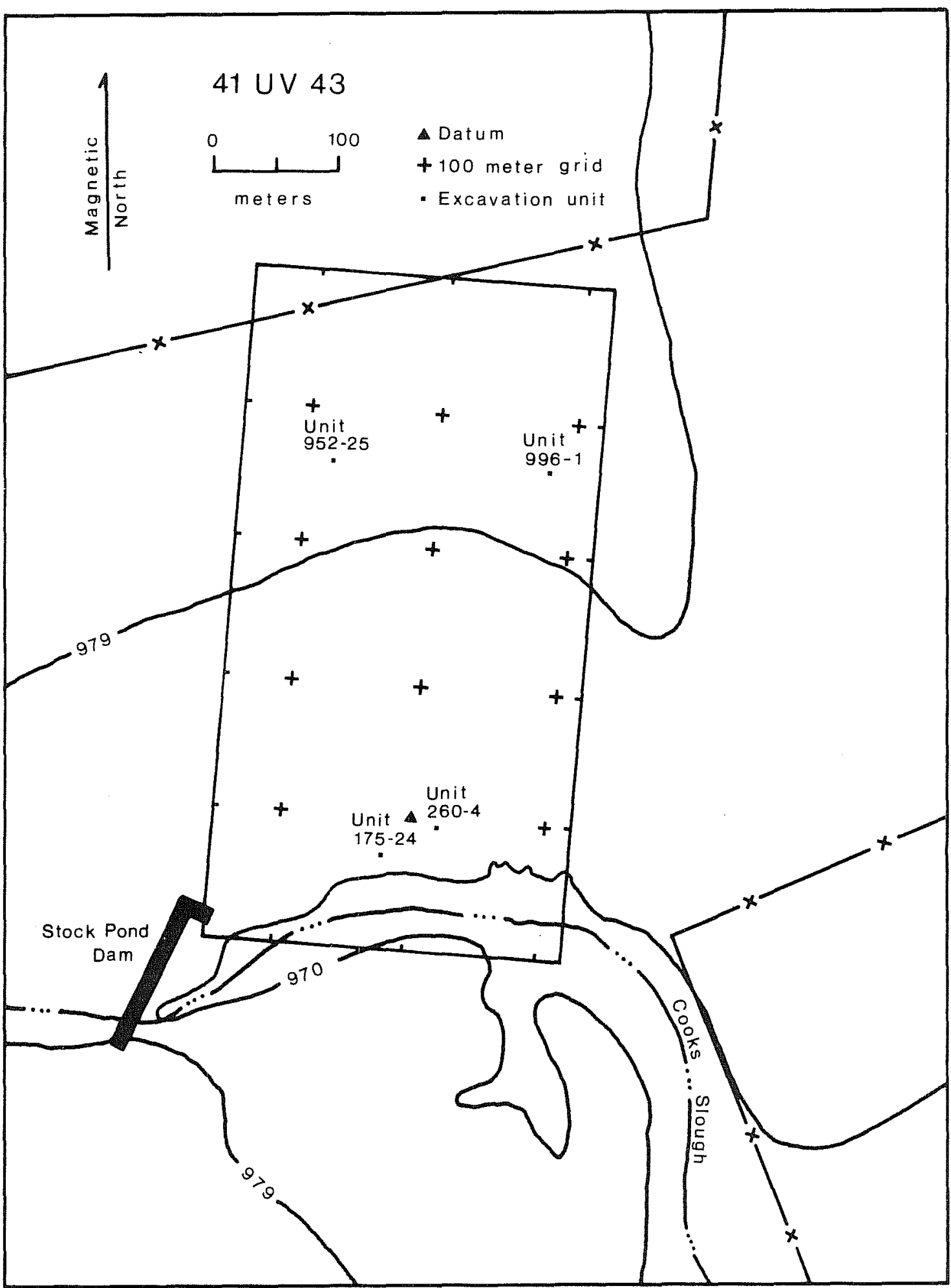

Figure 2. Topographic Map and Plan of Excavations at 41 UV 43. Contours are in feet (MSL). 
were present) screens. Shovels were used to excavate the units except when it was necessary to use trowels for exposing features. Notes were written for each site using standardized CAR-UTSA recording forms. Photographs and sketch plans or profiles were used to supplement written documentation. Prior to leaving the project area, constant volume soil columns and feature matrix samples were collected from different areas of each site for later laboratory analysis.

As required by landowner stipulations, a 11 whole or nearly complete artifacts (such as projectile points) were photographed and inventoried daily in order to facilitate the return of Mr. Willingham's artifacts. Artifacts collected during field work were cleaned by appropriate methods, then all excavated materials were assigned lot numbers. Surface-collected specimens retained their unit-subunit designations in place of lot number assignments. Crossfiles on a standardized 3-x 5-inch card were created for all of the materials collected. Each surface unit and excavation unit was itemized. Tabulation of lithic debitage, tools, and other collected materials by provenience was completed. Chemical analysis of soils was carried out in the CAR-UTSA laboratory. Other special samples and materials (faunal remains, wood charcoal species identification samples, radiocarbon samples, and phytolith samples) were prepared and forwarded to the appropriate consultants or laboratories for analysis.

\section{SITE 41 UV 43}

\section{SITE DESCRIPTION}

Site 41 UV 43 lies approximately $8.5 \mathrm{~km}$ north-northwest of Uvalde, Texas, and is just north of State Route 55. The site is situated on the north bank of Cooks Slough, extending northward from the terrace edge approximately $500 \mathrm{~m}$ to the edge of an open, cultivated field (Fig. 2). There is an earthen dam across Cooks Slough at the southwestern margins of the site. The north-south axis of the site extends from universal transmetric coordinates $418,670 \mathrm{E}$ $3238,260 \mathrm{~N}$ to $418,900 \mathrm{E} 3238,780 \mathrm{~N}$. The grid system imposed on the site measures $500 \mathrm{~m} \times 270 \mathrm{~m}$, with a total site area of $135,000 \mathrm{~m}^{2}$. Elevations within the site range from approximately $295.5 \mathrm{~m}$ (969 feet) $\mathrm{ms} 1$ to $300 \mathrm{~m}$ (983 feet) msl, a variation of over $4.5 \mathrm{~m}$ (14 feet).

The local topography is gently sloping to the south towards Cooks Slough, an intermittent drainage that currently carries only occasional runoff waters. The edge of the slough in some areas is difficult to detect, and at best is defined by a short, gentle slope. Soils at the site include Montell clay, $07 \mathrm{mos}$ soils, and Valco clay loams (Stevens and Richmond 1976), and are characteristical1y dark brown to brown with a lot of gravel. Bedrock limestone outcrops in the southeastern area of the site, and caliche occurs on or very near the surface in the northwestern area of the site. Buried gravel beds up to a meter thick have been exposed in erosional cuts near the earthen dam.

The vegetation on the site generally stands as small mottes of persimmon, mesquite, and oaks; areas between this brush consist largely of weeds and grasses. Vegetation noted in the site area includes Texas persimmon, mormon 
tea, blackbrush, sotol, prickly pear, barrel cactus, mesquite, oaks, weeds, and grasses. Along the slough edge there are large oaks and a dense undergrowth of brush obscuring ground visibility.

\section{SURFACE COLLECTION}

The surface collection methods at 41 UV 43 consisted principally of a simple random sample from the site; this was supplemented by nonrandom collections later in the investigations. Since the site was previously identified as a surface manifestation with littie or no buried deposits by Hall (1974), the primary objective of the field work was controlled surface collections. This section describes the overall results of the surface collection at 41 UV 43 and presents a summary of the surface lithic distribution, focusing on the characteristics of the debitage.

A11 of the $10-\mathrm{m}^{2}$ units within the site were consecutively numbered beginning in the southwest corner of the site, and a $10 \%$ simple random sample of the 1350 units was drawn. After 130 units had been selected from a table of random numbers, they were plotted on a plan map of the site, and the actual surface collection was begun. During the course of staking out the individual units to be collected, 11 of these units were deleted from the sample. Four of the deleted units (Units 1270, 1298, 1325, and 1329) were located in the northwest corner of the site, and outside of the fenced rangeland pasture property in a cultivated field. Five other deleted units (Units 11, 23, 46, 52, and 108) on the southern margin of the site were located on the edge of cooks Slough. Of the two other units deleted from the sample, one was highly disturbed during construction of a stock pond dam (Unit 28), and the other (Unit 648) was in an area of unusual1y dense brush cover. At times brush cover hampered ground visibility within the units, but for the most part this was confined to $1 \mathrm{imited}$ areas inside each $10 \mathrm{~m}^{2}$. Comments on the visibility within the collection units were noted on the field forms used for preliminary site inventories that were completed as each unit was inspected.

In addition to the random sample of units at the site, a controlled surface collection was made of six contiguous units within a small concentration of chert cobbles and debitage and of one additional nonrandom unit from the southern half of the site. These seven units (Units 44, 947, 948, 949, 950, 951, and 952) were collected in order to increase the sample size from this concentration and provide comparable materials from that locality. occasionally other artifacts, primarily cores and bifacial intergrades, were collected from units not included within the random sample. All the artifacts collected are summarized in Table 3 , and the debitage is summarized in Table 4.

The random sample is used to characterize the overa11 nature and distribution of cultural materials collected at the site. In a most general sense, it can be noted that the degree of lithic density within the site varied with the amount of available raw materials (cobbles). Two distinct areas of the site revealed concentrations of 1 ithic debitage. The larger concentration of debitage occurred in the south-central portion of the site, an area which measured approximate 1 y $220 \times 100 \mathrm{~m}$ in size. Outside the two areas of 7ithic 
Site 41 UV $43 \quad 17$

TABLE 3. ARTIFACT TYPES FROM RANDOM AND NONRANDOM SURFACE COLLECTION AT $4 I$ UV 43

\begin{tabular}{lrrr}
\hline \multicolumn{1}{c}{ Artifact Grouping } & $\begin{array}{c}\text { Random } \\
\text { Collection }\end{array}$ & $\begin{array}{c}\text { Nonrandom } \\
\text { Collection }\end{array}$ & Total \\
\hline Dart points & $2(0.7)$ & & $2(0.6)$ \\
Overail retouch bifaces & $2(0.7)$ & $1(2)$ & $3(0.9)$ \\
Bifacially retouched flakes & $2(0.7)$ & $21(40)$ & $2(0.6)$ \\
Bifacial intergrades & $37(14)$ & $2(4)$ & $3(0.9)$ \\
Other bifaces & $1(0.4)$ & $8(15)$ & $16(5)$ \\
Unifaces & $8(3)$ & $3(6)$ & $7(2)$ \\
Modified flakes & $4(1)$ & $16(31)$ & $234(72)$ \\
Cores & $218(80)$ & $1(2)$ & $1(0.3)$ \\
Ground stone & & $52(100)$ & $326(100.3)$ \\
\hline & $274(100.5)$ & $52(3)$ & \\
\hline
\end{tabular}

Note: Parentheses indicate percentage.

TABLE 4. SUMMARY OF DEBITAGE FROM RANDOM AND NONRANDOM SURFACE COLLECTION AT 41 UV 43

\begin{tabular}{lrl}
\hline \multicolumn{1}{c}{ Type } & $\begin{array}{c}\text { Random } \\
\text { Collection }\end{array}$ & $\begin{array}{c}\text { Nonrandom } \\
\text { Collection }\end{array}$ \\
\hline Primary flakes & $131(3.5)$ & $14(3)$ \\
Secondary flakes & $1187(31.5)$ & $71(16)$ \\
Interior flakes & $181(5)$ & $13(3)$ \\
Corticate chips & $76(2)$ & $11(2)$ \\
Partially corticate chips & $559(15)$ & $13(3)$ \\
Decorticate chips & $152(4)$ & $59(13)$ \\
Burned nonflaked chert & $457(12)$ & $208(47)$ \\
Chunks & $1029(27)$ & $445(100)$ \\
\hline
\end{tabular}

Note: Parentheses indicate percentage of overal1 collection. 
concentrations, 1 ithic density was very $10 w$, genera11y under 20 debitage specimens per $10-\mathrm{m}^{2}$ unit.

The distribution of all debitage (flakes, chips, burned chert, and chunks) collected from the random sample collection is shown in Figure 3 . Four debitage density intervals are shown on Figure 3: 0-20 specimens, 21-40 specimens, 41-60 specimens, and more than 60 specimens per $10 \mathrm{~m}^{2}$. There were 19 units collected that contained more than 60 specimens per $10 \mathrm{~m}^{2}$; the actual counts of debitage specimens within these 19 units ranged from 61 to 201 specimens and averaged approximately 110 items per unit. Eleven of these units had more than 10 specimens. A11 of the 19 units (1ess than $16 \%$ of the units examined) were located within the southern concentration, and their combined inventory totaled over 55\% of the site's surface debitage collection.

Most of the units collected during the random sampling were within the lowest debitage density interval (0-20 specimens). Table 5 shows the breakdown in percentages for each of the density intervals. The average number of debitage specimens for the site was 32 items per $10 \mathrm{~m}^{2}$; ranging from a minimum of no items to a maximum of 201 items. To briefly summarize the overall distribution of debitage within the site, Figure 3 shows that large areas of the site contained relatively low lithic densities, concentrations of chipping debris occurred in two localities on the site, and these localities tended to also contain relatively higher amounts of unmodified, natural chert cobbles.

Researchers in south and central Texas have observed distinct characteristics of flaking debris at quarry sites in the region; most commonly a relatively higher percentage of primary and secondary flakes (Kelly and Hester 1975), an increase in the number of single-faceted platform flakes (McGraw and Valdez 1978), and/or an absence of bifacial thinning flakes (Patterson 1975; Hester 1978a). These general indicators of quarry sites are, to some degree, present at 41 UV 43, and are detailed later.

The subdivisions of lithic debitage recognized at 41 UV 43 are presented in Table 5. Three types of flakes are present: primary, secondary, and interior. Chips are subdivided into corticate, partially corticate, and decorticate. Additionally, there are two other subdivisions of 1 ithic debitage, burned nonflaked chert and chunks. Platformed flakes comprise $40 \%$ of the debitage collection. Considering only platformed $f 1 a k e s, 9 \%$ are primary flakes, $79 \%$ are secondary flakes, and $12 \%$ are interior flakes. These percentages are similar to the figures compiled by Kelly and Hester (1975) at three lithic workshops in Comal County, Texas, where the percentage of primary and secondary flakes ranged from $55 \%$ to $75 \%$. Assad (1978), also working in Comal County, recorded that $80 \%$ of the platformed flakes from her controlled surface collection were either primary or secondary flakes.

Chips comprise about $21 \%$ of the total surface-collected debitage from 41 UV 43. As was the case with platformed flakes, the incidence of cortexretaining specimens is very high; $10 \%$ of al1 the chips are corticate, $71 \%$ are partially corticate, and 19\% are decorticate specimens. Burned nonflaked chert specimens total about $12 \%$ of the overall debitage collection, while chunks total $27 \%$ of the collection. 


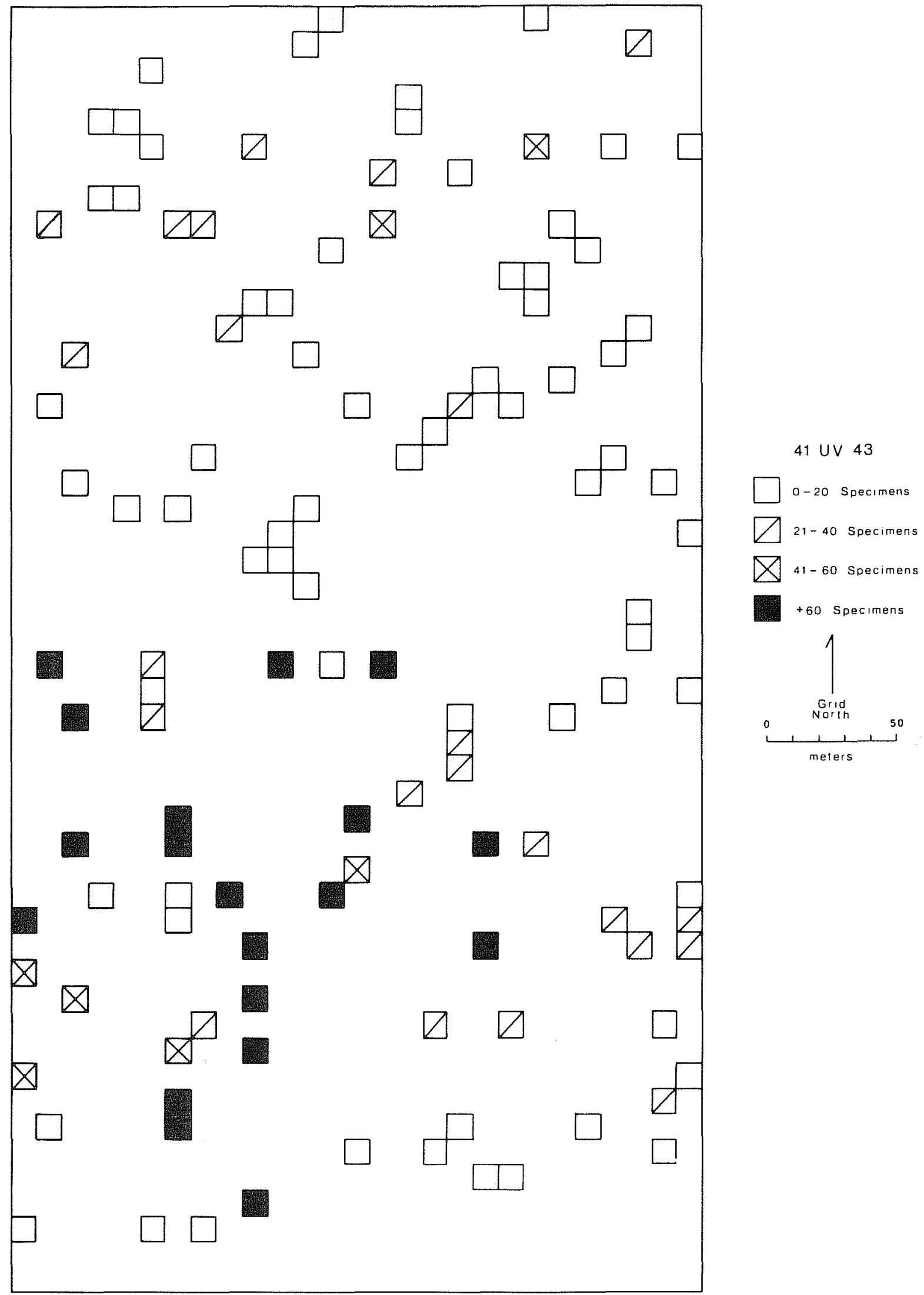

Figure 3. Surface Distribution of Debitage from the Random Sample Units at 41 UY 43. 
TABLE 5. DISTRIBUTION OF THE DEBITAGE DENSITIES FROM THE SURFACE COLLECTION AT 41 UV 43

Debitage Interval Number of Units Percentage of Units

$\begin{array}{rrr}0-20 & 68 & 57 \\ 21-40 & 24 & 20 \\ 41-60 & 8 & 7 \\ +60 & 19 & 16\end{array}$

Total

119

100

Flake platform types represented at the site are summarized in Table 6. These flake platforms have been placed into two larger subgroupings, core reduction flakes and biface reduction flakes, based upon the studies of other researchers working in south and central Texas (Hester 1978a; Montgomery 1978; Thoms, Montgomery, and Portnoy 1981; Ha11, Black, and Graves 1982). Core reduction flakes are represented in this report by the following types: cortex platforms, single facet platforms, large multiple facet platforms, and other platforms. Cortex platforms comprise a substantial proportion of the collection, representing about $32 \%$ of the sample. Large multiple facet platforms (11\% of the collection) and other platforms (2\%) comprise a smaller portion of the core reduction flakes, but together still are more frequent than the biface reduction flakes. The total collection of biface reduction flakes is only $9 \%$ of the site collection; small multiple facet platforms are most common in this category, and 1 ipped flakes total less than $0.002 \%$ of the total collection. The distribution of flake types and the fact that cores are the most numerous artifact form recovered at the site would certainly appear to suggest an emphasis on a primary reduction technology (Table 6); however, the presence of numerous bifacial intergrades at the site indicates that there was some effort expended at the site to produce roughed out bifaces for what has been termed a core-tool industry (Hester 1978a:27). The bifacial intergrades found at the site could indicate increasing numbers of biface reduction flakes as they were further reduced, but in this stage (an intergrade between a core and a biface) they would not have been expected to produce large numbers of 1 ipped or small multiple facet platform flakes. The near absence of overall retouch bifaces (often called thin or finished bifaces) at the site probably helps to explain the low frequency of biface reduction flakes. It seems likely that bifacial intergrades were exported from 41 UV 43 for the final reduction stages, and so the high frequency of core reduction flakes should not necessarily be a direct indicator of a core reduction technology. Undoubtedly, the initial preparatory stages for biface reduction, whether from a flake blank or cobble, will result in platform types found in a core reduction technology. It is interesting, however, that dart points, overall retouch bifaces, bifacially retouched flakes, and bifacial intergrades total $17 \%$ of the artifact collection from the random- 
TABLE 6. SUMMARY OF PLATFORMED FLAKE TYPES FROM RANDOM SURFACE COLLECTION AT 41 UV 43

Core Reduction Flakes

Cortex Platform

Primary Flakes

Secondary Flakes

84

Total

389

473

Single Facet Platform

Primary Flakes

42

Secondary Flakes

542

Interior Flakes

104

Total

688

Large Multiple Facet Platform

Secondary Flakes

132

Interior Flakes

Total

$\frac{32}{164}$

Other Platforms

Primary Flakes

Secondary Flakes

Interior Flakes

Total

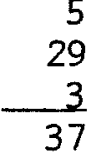

Total Core Reduction Flakes

Biface Reduction Flakes

Sma11 Multiple Facet Platform Secondary Flakes

Interior

Total

Lipped Flakes

Secondary Flakes

Interior Flakes

Total

$\begin{array}{r}0 \\ 2 \\ \hline 2\end{array}$

Total Biface Reduction Flakes 
sampled units, which is lower than the overall percentage of biface reduction flakes from the surface collection (9\%). Cores, the most frequent artifact collected at the site, total $80 \%$ of the random-recovered artifacts; core reduction platforms are present on $91 \%$ of the collected flakes. The frequency of cores and core reduction flakes, like bifaces and biface reduction flakes, very roughly approximate each other, which may suggest that this correlation of specific waste products (platformed flakes) with specific artifact types can be used as a general indicator of the lithic technologies expressed at sites.

\section{Distribution of the Surface Artifacts}

Materials from the $10 \%$ random sample and other controlled collections are included in the discussion of the overall distribution of the artifacts recovered from surface collection activities at 41 UV 43 (Fig. 4 ). The horizontal distribution of the different artifact groups suggest that there were at least two concentrations of quarry activities within the site; however, within these concentrations there did not appear to be any indications of individual workshops. That is, no intraconcentration patternings were apparent.

The two most common artifact forms recovered from 41 UV 43 were cores and bifacial intergrades. These two groupings combined total almost $90 \%$ of the artifacts collected from the site. Cores are by far the most common artifact with 234 (72\%) collected; 58 bifacial intergrades comprise about $18 \%$ of the artifacts collected. Other artifact groupings from the site include two dart points, three overall retouch bifaces (one is a Guadalupe tool), two bifacially retouched flakes, three other bifaces, 16 unifaces, seven modified flakes, and a single ground stone specimen. The distribution of the less frequently occurring artifacts is reviewed first, then bifacial intergrades and core distributions are presented.

Two dart points (one classified as a Form 11 miscellaneous dart point and the other as an unidentifiable dart point fragment) were found on the surface, one within the southern concentration and the other in the northern concentration. Neither of the two projectile points could be placed within existing historical typologies recognized within the region. It is felt that they are Archaic in origin and may be manufacturing failures or discarded preforms. Two of the overall retouch bifaces, classified as 1 arge miscellaneous fragments, were found in fairly close proximity to each of the dart points collected. The other overall retouch biface is a Guadalupe tool which was collected from the southeast margins of the southern concentration. Guadalupe tools are considered diagnostic of the Early Archaic (San Geronimo phase); the presence of this tool at the quarry provides the only time diagnostic artifact recovered from the site. The paucity of well-finished forms like dart points and overall retouch bifaces suggests that final phase reduction sequences were very rarely carried out at the quarry.

The two bifacially retouched flakes from the site were both found on the margins of the southern lithic concentration. Both were amorphous-shaped specimens. The small number of bifacially retouched flakes suggests that the initial stage of shaping flake blanks was not practiced at the quarry. Even 


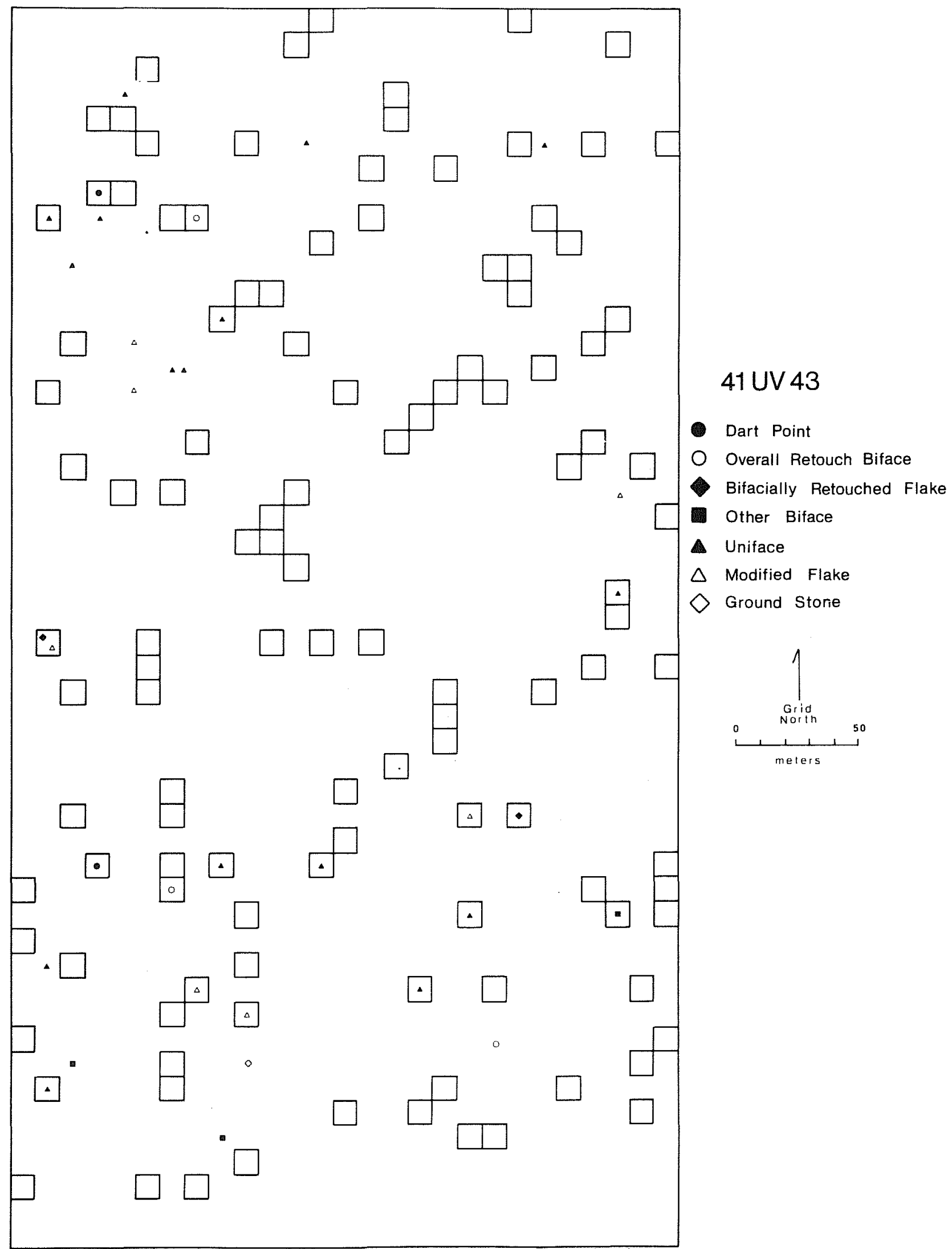

Figure 4. Distribution of Dart Points, Overall Retouch Bifaces, Bifacially Retouched Flakes, Other Bifaces, Unifaces, Modified Flakes, and Ground Stone at 41 UV 43. 
the inclusion of the somewhat more common miscellaneous unifacial types, which might conceivably have been partially shaped flake blanks, do not occur in high enough numbers to suppose that the reduction of flake blanks was frequent.

Other bifaces total three specimens: a pointed fragment, a midsection, and a miscellaneous fragment. These three specimens were located on the south margins of the southern concentration.

Unifaces were one of the more common of the artifacts collected from the site; a total of 16 specimens was collected. The unifaces are described as an end scraper on a blade, three specimens retouched on one side, two specimens retouched on two sides, one specimen retouched on the end and two sides, and the remaining nine unifaces are classified as miscellaneous specimens. Six unifaces were collected in the southern lithic concentration, five miscellaneous specimens and one specimen retouched on one side; no apparent spatial patterning of unifaces was noted in the concentration. The northern 7 ithic concentration contained nine unifaces. Four unifaces are classified as miscellaneous specimens, and the remaining five unifaces are an end scraper on a blade, a specimen retouched on one end and two sides, two specimens retouched on two sides, and a specimen retouched on one side. One additional uniface, a miscellaneous form, was recovered outside the two concentrations; it was from the northeast of the southern concentration. The relatively high number of unifaces may suggest some activities at the site other than quarrying. Kelly and Hester (1975), Assad (1978), and Brown et a1. (1977) have noted similarly unusual numbers of unifaces and trimmed flakes at quarry sites in Comal County, Texas. Kelly and Hester (1975) have suggested that these artifacts may be related to woodworking tasks performed at the sites.

Seven modified flakes were found at the site: five partially corticate specimens, one single facet platform interior flake, and one miscellaneous (other) platform secondary flake. Four of the modified flakes were from the southern lithic concentration, two were from the northern concentration, and one was away from both concentrations.

The only ground stone specimen found at the site was from the southern margins of the southern lithic concentration. No other artifacts were found in the immediate area around the grinding slab fragment. Its presence on the site is puzzling, as very few other artifacts from the site indicate the quarry was used as a campsite. The fact that about $90 \%$ of all the artifacts from the site were directly attributable to quarry operations emphasizes the primary site activity; the remaining $10 \%$ of the artifacts, especially the two dart points, the Guadalupe tool, and the ground stone suggests that there may have been other site functions, such as a temporary campsite, hunting area, or gathering locale. The following paragraphs will focus on the distribution of bifacial intergrades and cores, the two artifact groups that reflect the quarry operations at the site.

A total of 58 bifacial intergrades was surface collected at the site (Fig. 5). The bifacial intergrades were divided into five subgroupings: 20 ovate specimens, 15 asymmetrical specimens, 14 pointed ovate specimens, seven fragments, and two triangular specimens. The majority (67\%) of bifacial 


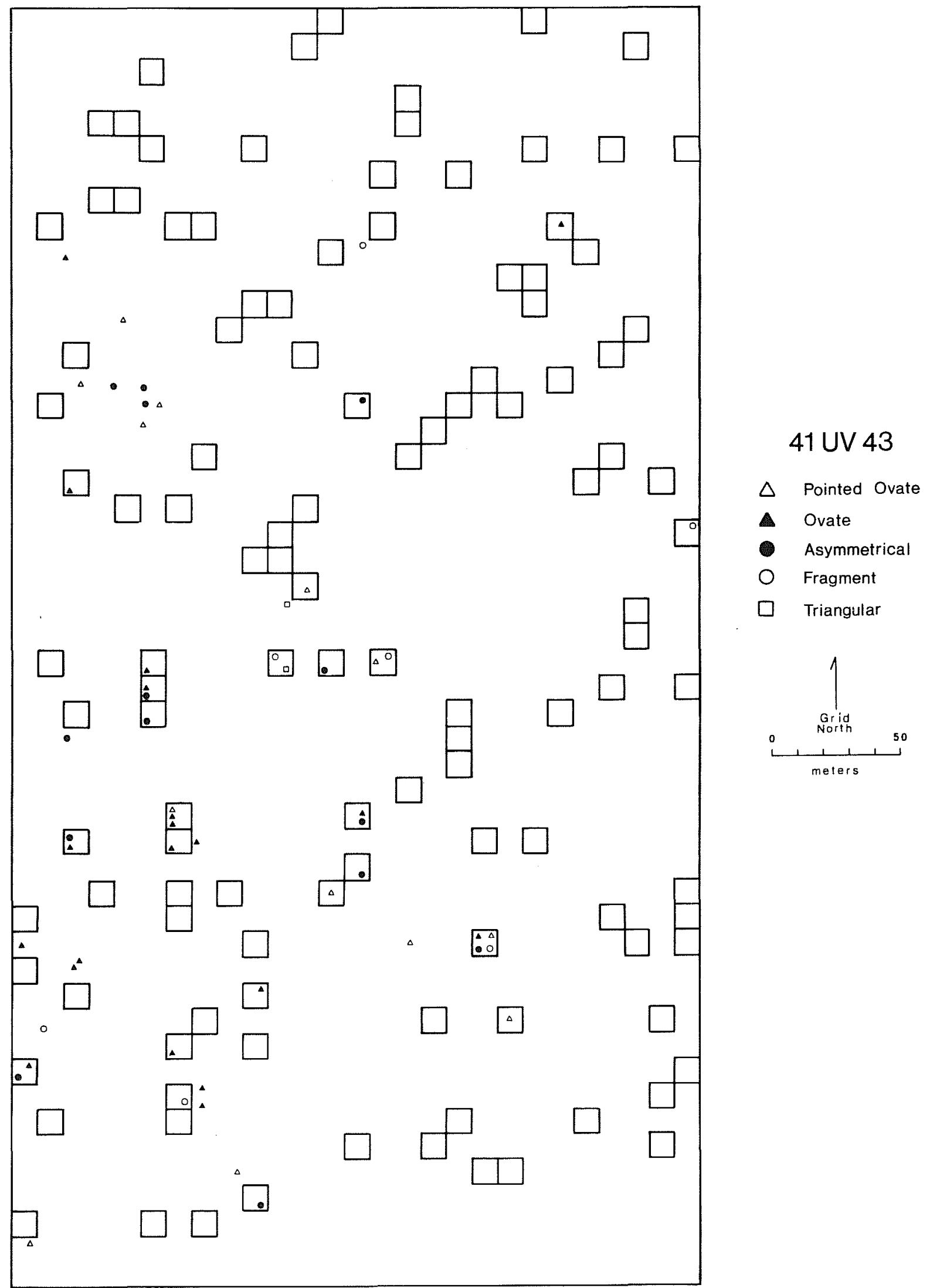

Figure 5. Distribution of Bifacial Intergrades at 41 UV 43. 
intergrades were recovered from the southern concentration within the site; the northern concentration contained $10 \%$, and $22 \%$ were recovered outside of the two artifact concentrations. The distribution of the bifacial intergrades, by the above-mentioned intersite areas is summarized in Table 7.

Eighty-five percent of the ovate bifacial intergrades were recovered from the southern concentration. Only three specimens were collected from outside the southern concentration, two were located in areas peripheral to, and one within the northern concentration. The high percentage of ovate specimens within the southern concentration is the most distinct horizontal clustering of all the bifacial intergrades. The relative frequency and spatial distribution of the specimens suggest that the ovate forms may be associated with a single component, but the temporal parameters cannot be defined.

Ten asymmetrical bifacial intergrade specimens were from the southern concentration, and five specimens were located outside of the two artifact concentrations. Asymmetrical specimens within the southern artifact concentration with the most common in the northern half of that concentration, and the occurrence of four specimens south of the northern concentration may suggest some horizontal patterning of the asymmetrical specimens in the west-central section of the site, but these appear spread over a relatively large area, and do not form a clear horizontal grouping.

The 14 pointed ovate specimens represent one of the larger subgroupings of bifacial intergrades. They were widely scattered throughout the site: six specimens were from the southern concentration, four specimens were from the northern concentration, and the remaining four were from outside the two major artifact concentrations.

Bifacial intergrade fragments were found within the southern concentration (five specimens), the northern concentration (one specimen), and outside of the two concentrations (one specimen). The fragments occurred infrequently,

TABLE 7. DISTRIBUTION OF BIFACIAL INTERGRADES AT 41 UV 43

$\begin{array}{cccr}\begin{array}{c}\text { Concentration } \\ \text { Southern }\end{array} & \text { Northern } & \text { Other } & \text { Total } \\ 17 & 1 & 2 & 20 \\ 10 & & 5 & 15 \\ 6 & 4 & 4 & 14 \\ 5 & 1 & 1 & 7 \\ 1 & & 1 & 2\end{array}$

Total

39

6

13

58 
totaling only $12 \%$ of the bifacial intergrade collection. The low frequency of fragments seems unusual; it may suggest a low incidence of failures at the site.

Triangular bifacial intergrades were the least common form at the site. The two specimens collected were located within $30 \mathrm{~m}$ of each other, one on the north edge of the southern concentration, the other just north of the southern concentration boundary line.

Cores were the most common artifact type recovered from 41 UV 43; a total of 234 specimens was collected. The cores are divided into eight subdivisions: unidirectional, prepared platform cores (55 specimens); multidirectional, horizontal platform cores (46 specimens); core fragments (39 specimens); multidirectional, oblique platform cores (31 specimens); natural platform cores (27 specimens); bifacial cores (26 specimens); core tools (seven specimens); and core nuclei (three specimens). Of the 234 specimens, $75 \%$ were from within the southern artifact concentration, $7 \%$ were from the northern concentration, and $18 \%$ were collected from areas outside the artifact concentrations. The distribution of the various core subdivisions by the above-mentioned site proveniences is summarized in Table 8.

Unidirectional, prepared platform cores were more common in the southern $(31 \%)$ than in the northern concentration $(24 \%)$ or than in other areas of the site (Fig. 6). The presence of unidirectional, prepared platform cores within both artifact concentrations suggests that flake production was a significant goal of the quarry activities at the site.

of the 39 core fragments recovered, 31 were from the southern concentration, four specimens each were from the northern concentration and other areas of the site. Core fragments were the second most common type from the northern concentration, totaling $25 \%$. Core fragments were relatively less common within the southern concentration (18\% of all cores within the cluster) and the other areas of the site $(10 \%$ of a 11 cores outside the northern and southern concentrations). Generally, core fragments were widely distributed throughout the site, and distinct patternings, beyond the relatively higher percentage noted within the northern concentration, were not apparent.

Multidirectional, horizontal platform cores were most common in the southern concentration (36 specimens) and in other areas of the site (seven specimens) than in the northern concentration area (three specimens, Fig. 7). Only 18\% of a 11 the cores from within the northern concentration area were multidirectional, horizontal platform cores.

Natural platform cores were recovered in the southern concentration (19 specimens) and in areas peripheral to that concentration (eight specimens). No natural platform cores were recovered from the northern concentration (Fig. 8).

Bifacial cores were present in all areas of the site, but most common in the southern concentration (16 specimens) and in other areas of the site (eight specimens). Two bifacial cores were recovered from the northern concentration (Fig. 8). 


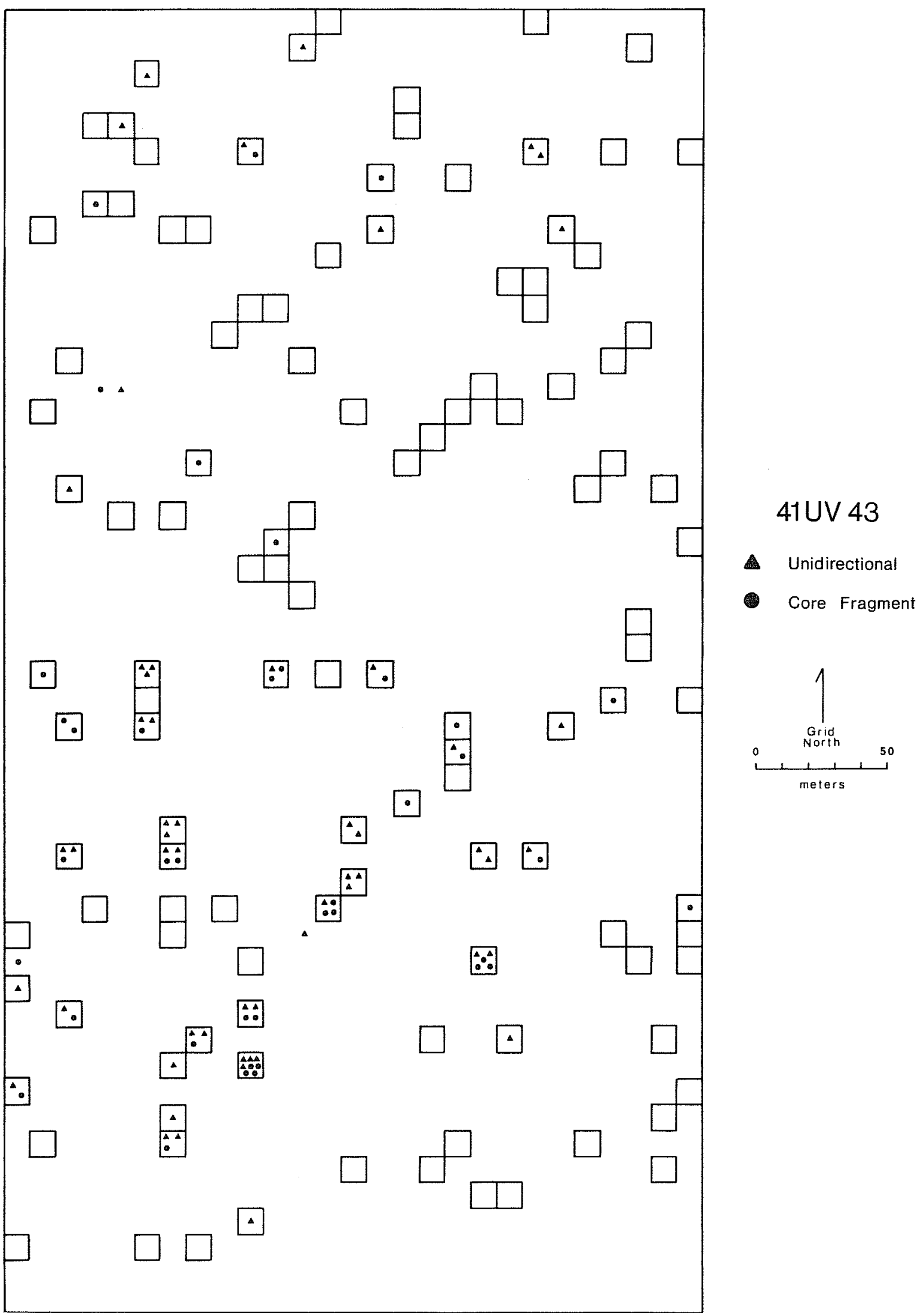

Figure 6. Unidirectional Cores and Core Fragments at 41 uV 43. 


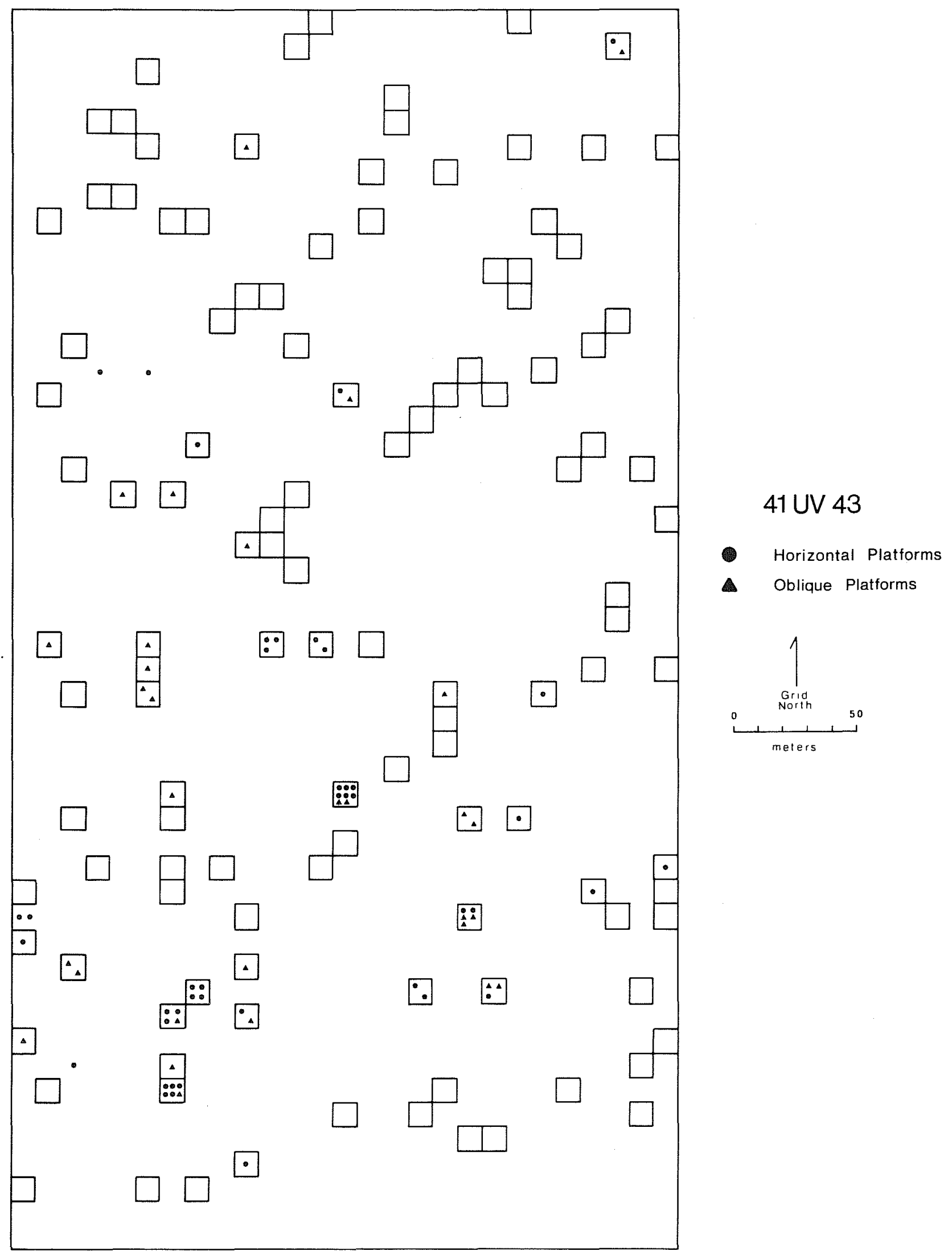

Figure 7. Distribution of Horizontal and Oblique Platform Cores at 41 UV 43. 


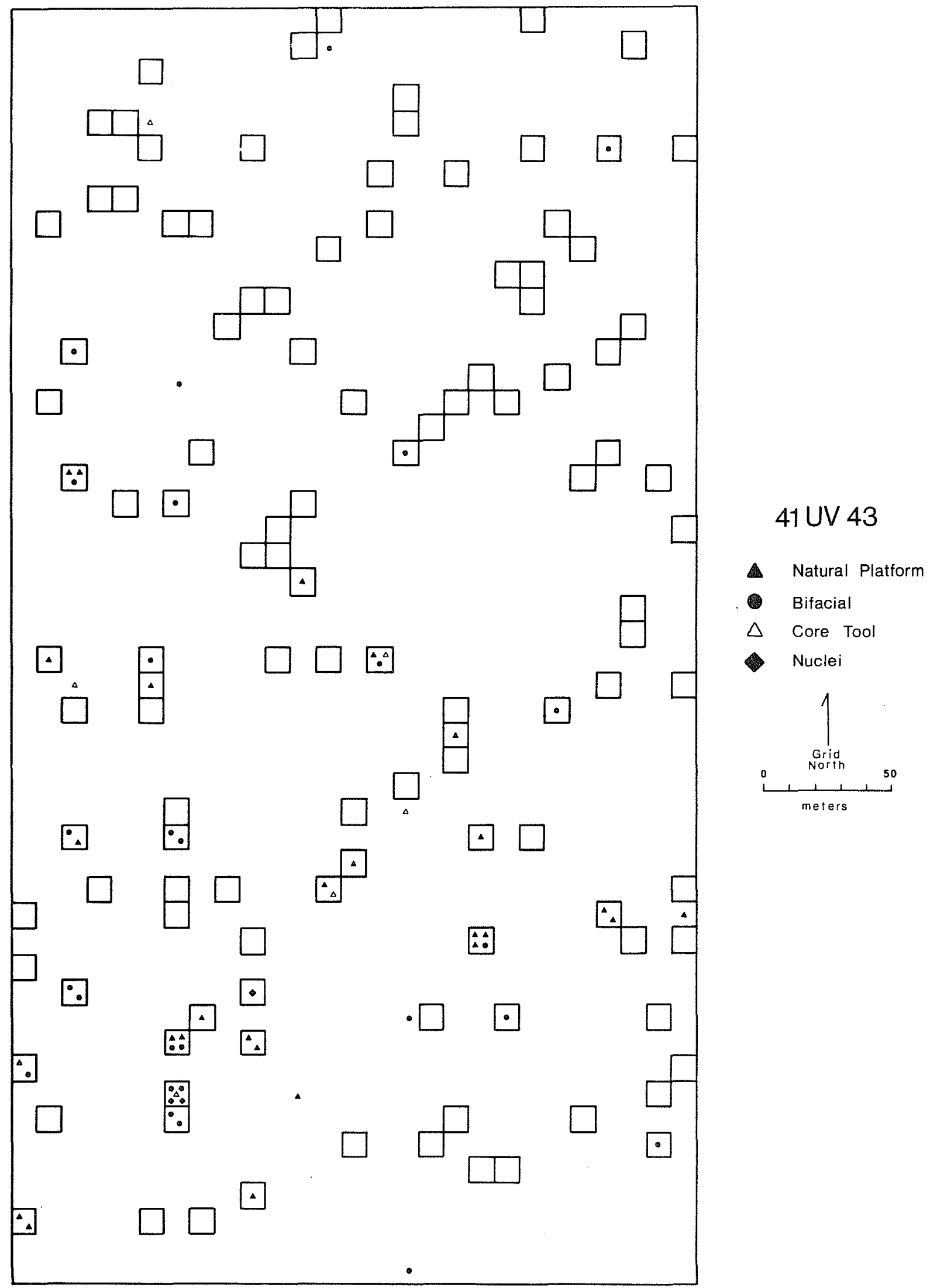

Figure 8. Distribution of Natural Platform and Bifacial Cores, Core Nuclei, and Core Tools at 41 UV 43. 
TABLE 8. DISTRIBUTION OF CORES AT 41 UV 43

\begin{tabular}{|c|c|c|c|c|}
\hline & $\begin{array}{c}\text { Southern } \\
\text { Concentration }\end{array}$ & $\begin{array}{c}\text { Northern } \\
\text { Concentration }\end{array}$ & $\begin{array}{l}\text { Other } \\
\text { Areas }\end{array}$ & Total \\
\hline $\begin{array}{l}\text { Unidirectional, prepared } \\
\text { platforms } \\
\text { Multidirectional, } \\
\text { horizontal platforms } \\
\text { Core fragments } \\
\text { Multidirectional, } \\
\text { oblique platforms } \\
\text { Natural platforms } \\
\text { Bifacial cores } \\
\text { Core tools } \\
\text { Core nuclei }\end{array}$ & $\begin{array}{r}36 \\
31 \\
\\
23 \\
19 \\
16 \\
5 \\
3\end{array}$ & $\begin{array}{l}1 \\
2 \\
1\end{array}$ & $\begin{array}{l}7 \\
4 \\
7 \\
8 \\
8 \\
1\end{array}$ & $\begin{array}{r}46 \\
39 \\
31 \\
27 \\
26 \\
7 \\
3\end{array}$ \\
\hline Total & 176 & 16 & 42 & 234 \\
\hline
\end{tabular}

Core tools (seven specimens) and core nuclei (three specimens) were infrequent at the site, totaling only $3 \%$ and $1 \%$, respectively, of the total core collection. Five of the seven core tools were collected from within the southern concentration; and a single specimen each was collected from the northern concentration and in other areas of the site (Fig. 8). The three core nuclei specimens were al1 collected from the southern concentration. The relatively small number of core tools and core nuclei may indicate that use of the site was short term, and specifically oriented to quarry operations; the lack of core tools ("choppers") suggests activities commonly associated with these tools were infrequent, and the few core nuclei recovered indicate cores were seldom significantly reduced while at the quarry. As relative size of cores implies amount of reduction, it is interesting to note that overa11, cores at 41 UV 43 are larger than their counterparts at 41 UV 45, 41 UV 47, and 41 UV 48 . While $90 \%$ of the cores at 41 UV 43 are between $4 \mathrm{~cm}$ and $12 \mathrm{~cm}$ in diameter, $96 \%$ of the cores from the three other sites investigated during the project are between $1 \mathrm{~cm}$ and $8 \mathrm{~cm}$ in size. Further, in intersite comparisons of cores, $99 \%$ of all the cores at 41 UV 43 retain some cortex, while at the three other sites discussed in this report $82 \%$ of a 17 the cores retain some cortex. It is suggested that the differences in the above percentages reflect a tendency for cores at 41 UV 43 to be reduced less completely than at the other sites in the project area.

\section{EXCAVATION AREAS}

Four units were excavated during the course of field investigations at 41 UV 43. The number of units excavated was limited due to time restraints 
and by current and previous (Hall 1974) field observations on the deflated nature of the site. Placement of the units was directed towards investigating a range of subsurface deposits within the site. In all, a little less than $1 \mathrm{~m}^{3}$ of soil was hand excavated at the site. Although the number of units excavated was 1 imited, it is felt that the efforts were sufficient to substantiate the assessment of the site as primarily a surface manifestation. The placement of the four excavation units is shown in the topographic map of the site (Fig. 2). Each of the excavation units are individually summarized, and the 123 debitage items recovered from the excavations are shown in Table 9.

Unit 260-4, located in the south-central area of the site, was excavated as a $1-\mathrm{m}^{2}$ unit in one level to a final depth of $20 \mathrm{~cm}$. The matrix within the unit was a very dark brown, massive clay containing some small chert gravels. A total of 20 debitage specimens was the only cultural items recovered from the unit. Snail shells were present, but infrequent.

Unit 175-24 was also located in the south-central area of the site, west of Unit 260-4. Excavation in the $1-\mathrm{m}^{2}$ unit was terminated at $20 \mathrm{~cm}$ below the surface. The first $8 \mathrm{~cm}$ excavated were recorded as very stoney, containing numerous chert pebbles and gravels. Soil matrix throughout the unit consisted of a very dark brown, massive clay. Forty-seven debitage specimens and a few land snail shells were recovered from the unit.

Unit 952-25 was located in the northeastern area of the site, near the southern margins of a large surface concentration of cores, bifacial intergrades, and debitage. The $1-\mathrm{m}^{2}$ unit was excavated in two levels to a final depth of $40 \mathrm{~cm}$ below the surface. Within the first level the soil consisted of a dark brown, massive clay. Chert gravels were common throughout the level, particularly near the surface, and decreased in quantity with depth (Fig. 9). Forty-two debitage items were recovered from the unit-level. The second level excavated $(20$ to $40 \mathrm{~cm})$ had a soil composition essentially undifferentiated from Level 1, with the exception that the chert gravels were absent. Cultural remains decreased in density in Level 2, totaling 14 debitage specimens, a dramatic decrease when compared to the 42 items recovered from Level 1.

Unit 996-1 was located in the northeastern area of the site. The unit was $50 \mathrm{~cm}^{2}$ in size, and was excavated to a final depth of $26 \mathrm{~cm}$. The soil within the unit was a brown clay loam containing a few chert cobbles and numerous caliche pebbles. Excavations were terminated when bedrock 1 imestone was encountered. No cultural remains were recovered from the unit.

Flakes comprise $19 \%$ of the total artifact collection from the excavation units. About $9 \%$ are primary flakes, $65 \%$ are secondary flakes, and $26 \%$ are interior flakes. The large amount of secondary flakes is not surprising, and in general reflects the figures for flakes from the surface collection at the site. Chips total $30 \%$ of all the excavated debitage specimens.

Within the chips category, corticate specimens comprise $5.4 \%$ of al1 the chips, partially corticate specimens represent $59.5 \%$ of a 11 the chips, and $35 \%$ are decorticate chips. The relative frequencies of the chips is similar to the frequencies of excavated flakes; in both cases, secondary flakes and 


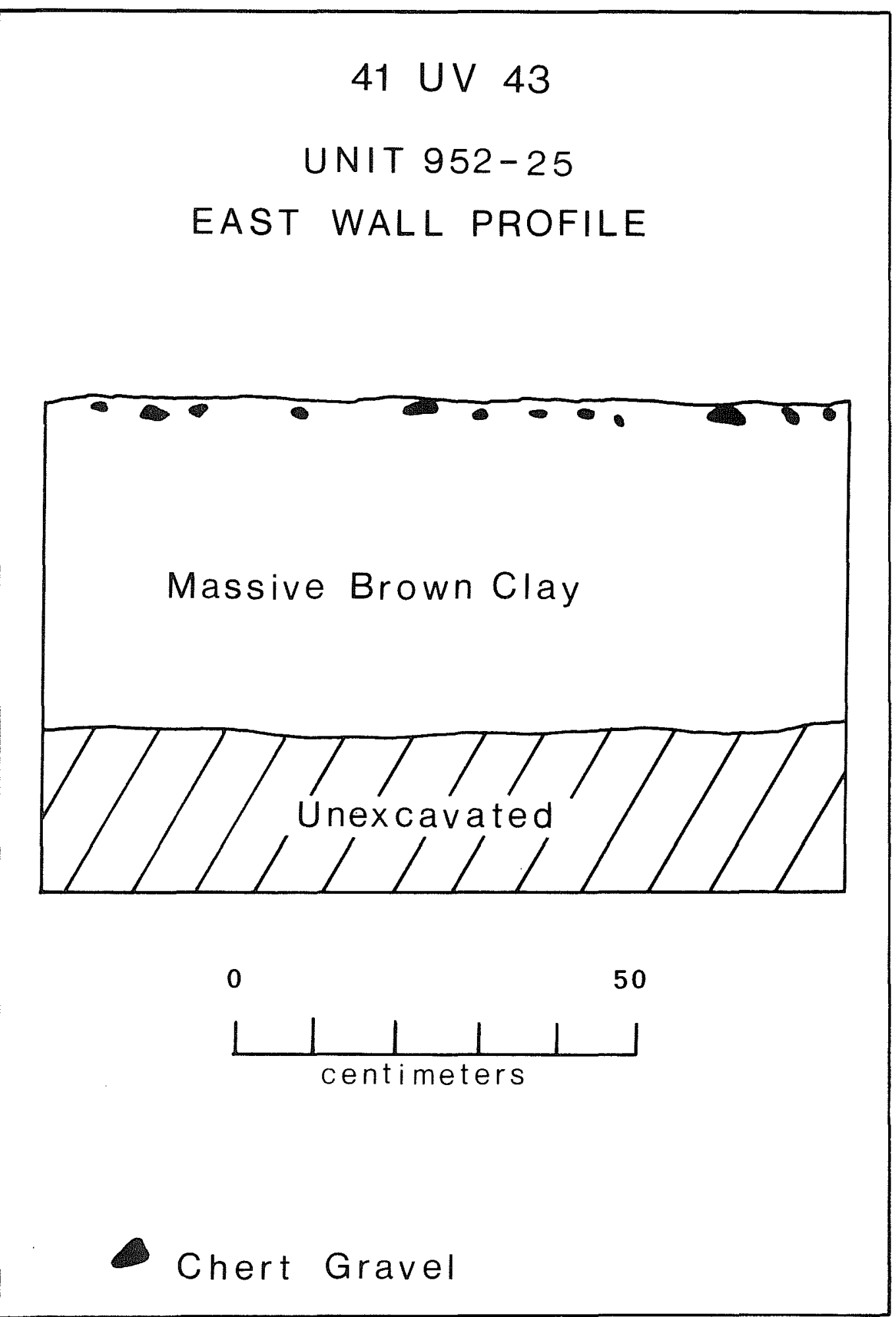

Figure 9. Soil Profile from 41 uv 43, Unit 952-25. 
TABLE 9. PROVENIENCE OF EXCAVATED DEBITAGE FROM 41 UV 43

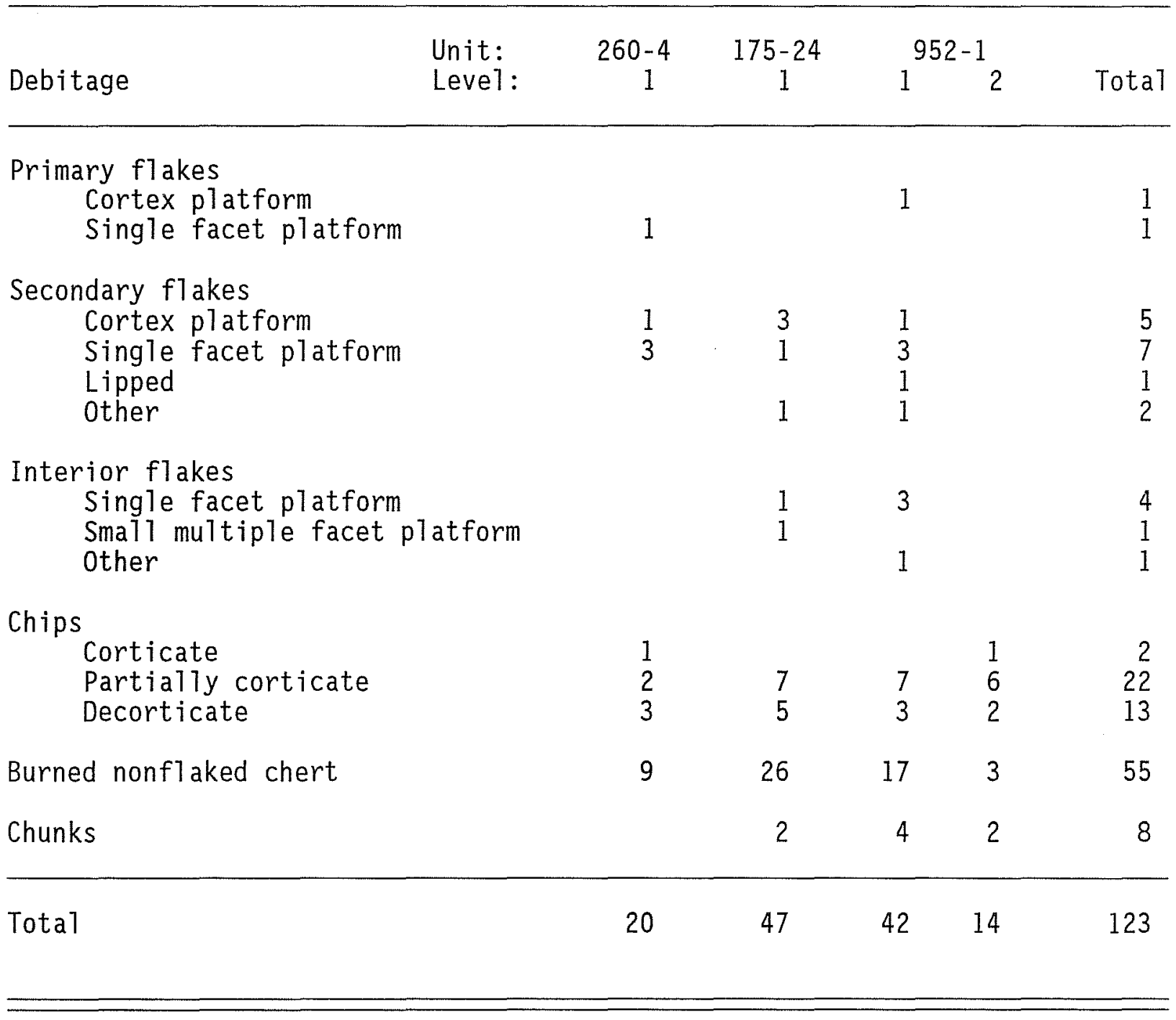

partially corticate chips are much more common than any other type. Burned chert specimens total nearly $45 \%$ of the excavated debitage, a surprisingly high figure, as burned rock, such as hearthstones, were not recorded at the site in surface or subsurface contexts, and heat-treated chert was not recorded at the site. Chunks tota $6.5 \%$ of the excavated specimens.

In some aspects the excavated sample of debitage reflects the debitage frequencies found on the surface of the site. In the surface and subsurface collections, secondary flakes and partially corticate chips represent a substantial proportion of a 11 the flakes and chips. Interior flakes and decorticate flakes were the second most common subcategories of their respective groupings in both surface and subsurface collections, followed by primary flakes and corticate chips. The surface and subsurface collections differed in that $\mathrm{flakes}$ comprise $9 \%$ and chips $21 \%$ of the overa 11 surface 
debitage collected, while the excavated sample totals $19 \%$ and $30 \%$ for flakes and chips, respectively. The unusually high frequency of burned chert within the subsurface sample (45\%) was much greater than the frequency of burned chert on the surface (12\%).

A total of $23 \mathrm{platformed} \mathrm{flakes} \mathrm{was} \mathrm{recovered} \mathrm{from} \mathrm{the} \mathrm{excavation} \mathrm{units.} \mathrm{The}$ platformed flakes are briefly discussed here, and are summarized in Table 10. Platformed flakes were divided into six types based upon striking platform attributes, and the six types were further divided into one of two categories, core reduction flakes or biface reduction flakes. Based upon research by others in the region (Hester 1978a; Montgomery 1978; Ha11, Black, and Graves 1982), this report considers the platform types of cortex, single facet, and large multiple facet flakes to represent debitage derived from a core reduction technology; lipped and small multiple facet platform flakes are thought to result from a biface reduction technology.

At 41 UV 43, the majority of $f 1$ akes are core reduction $f 1$ akes. On 1 y $9 \%$ of the excavated flakes were found to be biface reduction flakes; there is only one specimen each of 1 ipped and small multiple facet flakes. Core reduction flakes total $91 \%$ of the collection. These core reduction flakes are dominated by single facet platform flakes ( $52 \%$ of the total collection), followed by cortex platform flakes (26\% of the total collection), and other flakes (a residual platform category totaling 13\% of the collection). The relative percentages of core and biface reduction flakes in the excavated sample mirror those in the surface collection. The types of platforms in the two collections differ somewhat, with Tipped flakes representing 7 ess than $1 \%$ of the total surface collection and more than $4 \%$ of the excavated sample, and large multiple facet platform flakes do not occur in the excavated sample but total $11 \%$ of the surface collection. These differences in surface and subsurface contexts are likely due to the small excavated sample; however, in a most general sense, it can be suggested that the subsurface flakes recovered reflect the strong dominance of a core reduction technology characterized in the larger surface collection.

\section{SUMMARY}

Surface collections at 41 UV 43 provide the basis for the majority of information from the site; the excavations revealed very shallow deposits, and suggest that the site may be deflated or lie on a geologically stable surface. The surface collection activities at the site included random and nonrandom sampling techniques. Analysis of the surface-collected materials revealed debitage and artifact concentrations within the site area. These areas were identified as a northern and southern concentration of cultural remains dominated by 1 ithic debitage, cores, and bifacial intergrades resulting from prehistoric activities at a chert cobble quarry. The recovery of other artifact types, including dart points, overall retouch bifaces, bifacially retouched flakes, other bifaces, unifaces, modified flakes, and ground stone, were present in small quantities at the site. These artifacts suggest that some activities other than quarry operations took place at the site, but were likely ancillary to lithic procurement goals. 
TABLE 10. FLAKE PLATFORM TYPES FROM EXCAVATIONS AT 41 UV 43

\section{Core Reduction Flakes}

Cortex Platform

Primary

Secondary

1

Total

Single Facet Platform

Primary

Secondary

Interior

$\frac{1}{7}$

4

Total

12

Other Platforms

Secondary

Interior

2

1

Total

3

Total Core Reduction Flakes

Biface Reduction Flakes

Small Multiple Facet Platform

Interior

1

Total

1

Lipped Flakes

Secondary

1

Total

1

Total Biface Reduction Flakes

2

Grand Total

23 
Cores were the most common artifact type at the site, totaling $72 \%$ of the collection. Unidirectional, single platform cores and multidirectional, horizontal platform cores are the most common core types; core tools and core nuclei are the least common types. Bifacial intergrades total $18 \%$ of the collection, and the most common forms are ovate, asymmetrical, and pointed ovate. Bifacial intergrade fragments and triangular forms were present only in very small quantities. The remaining artifact types recovered total $10 \%$ of the overall collection. Of these, unifaces and modified flakes are the most common types; dart points (two specimens), overall retouch bifaces (three specimens), and bifacially retouched flakes (two specimens), were very infrequent at the site.

The two dart points and an overall retouch biface type, a Guadalupe tool, were the only diagnostic artifacts recovered; all are chronological markers for the Archaic period. The two dart points could not be identified within existing historical typologies, making their placement within a phase of the long Archaic sequence not possible. The Guadalupe tool, however, is diagnostic of the Early Archaic period, 6000 B.C. to 3500 B.C. (Ha11, Black, and Graves 1982:340). A single uniface from the site, an end scraper, is of a type frequently found in association with Late Prehistoric artifacts and may suggest that the site was used during the period between A.D. 700 and A.D. 1650; however, Ha11, Black, and Graves (1982:360) have documented an example of an end scraper in association with an Archaic deposit. Site 41 UV 43 is difficult to date because of the lack of sufficient numbers of chronological diagnostic types. The above-noted artifacts cannot confidently be applied in dating the site, but it is suggested that use of the site began as early as 6000 B.C., and continued from the Archaic period into the Late Prehistoric.

Artifacts from the site indicate that the primary task was 1 ithic procurement. Bifacial intergrades and cores comprise $90 \%$ of the artifact collection, strongly suggesting that initial reduction of 1 ithic raw materials was the major activity performed at the site. The overall size of the cores and the percentage that retained some cortex when compared with cores from the other three sites studied within the project area, suggest that cores were only minimally worked at 41 UV 43 . At 41 UV $43,90 \%$ of the cores are between $4 \mathrm{~cm}$ and $12 \mathrm{~cm}$ in size, and core nuclei (exhausted cores) total only $1 \%$ of the collection; $96 \%$ of the cores from the other three sites are between $1 \mathrm{~cm}$ and $8 \mathrm{~cm}$ in size, and $32 \%$ of these cores are nuclei. Only $1 \%$ of the cores at 41 UV 43 are decorticate; $18 \%$ of the cores at the other three sites studied are decorticate.

The lack of significant numbers of artifact forms commonly associated with open campsites in the area such as dart points, overall retouch bifaces, bifacially retouched flakes, other bifaces, unifaces, modified flakes, ground stone, and burned rock suggests that 41 UV 43 was infrequently used as a campsite. The use of the area as a campsite was probably restricted to short term, sporadic visitations throughout the prehistoric sequence. It would seem plausible to suggest that visits to the site were fortuitously made in route between destinations, or specific, planned visits from nearby campsites (1ike nearby 41 UV 45) were made to recover initial core, biface, and flake blanks which could be transported back to base camps for final reduction. 


\section{SITE 41 UV 45}

\section{SITE DESCRIPTION}

Site 41 UV 45 is the smallest site investigated during the course of the project. The universal transmetric coordinates for the site datum are $420,680 \mathrm{E}$ and $3,240,540 \mathrm{~N}$. The site area, as measured by the grid system established is $150 \times 150 \mathrm{~m}^{2}$. Grid north was aligned to run parallel with Boon Slough, which forms the western boundary of the site. Grid north for the site was oriented $6^{\circ}$ east of magnetic north (Fig. 10).

Cultural materials were most visible along the east bank of Boon Slough and a telephone line access road that passes through the site before intersecting Boon Slough (Fig. 11,a,b). Surface materials in these areas consisted primarily of chert debitage and burned rocks. A burned rock midden has been exposed by a shallow draw that enters the slough in the northwestern portion of the site. The surface visibility was obscured by brushy vegetation. Site topography is relatively flat, with a slight rise in the northern half of the site as the land begins to rise upward, exposing a 1 imestone outcropping. Excavations revealed that cultural material deposits were located on top of the 1 imestone base wherever encountered within the site area. The southern portion of the site is represented by Tobosa Clay soils, a vertisol, characteristically a dark grayish brown color that 1ightens in hue with increasing depth. Soils on the opposite side of Boon Slough are similar to the rocky limestone soils on the rise to the north.

The vegetation includes large oak trees along the slough's edge and whitebrush, mesquite, persimmon, juniper, and prickly pear on the site. Ground visibility was hampered by grasses, forbs, and scrub brush.

\section{SURFACE COLLECTION}

In order to provide information on the nature of the characteristics of the cultural materials exposed at the site, and as an aid to field evaluations for identifying possible areas that could be focused on for subsurface testing, a $10 \%$ random sample surface collection was conducted. The surface collection was expected to reveal distributional patterns within the site relative to the surface density and intrasite activity areas. The field activities during the surface collection, the data collected, and the implications of the collection are discussed.

After an initial walk over the site, an estimation of the probable maximum dimensions was made, and a control grid was designed to encompass the estimated boundaries. The final grid enclosed a square area measuring $150 \mathrm{~m}$ to a side. Once the grid axes were staked out, a measured grid plan was drawn, subdividing the site into 225 surface collection units measuring $10 \mathrm{~m}^{2}$ each. Beginning with the first unit in the far northwestern corner of the site, and moving grid east on all rows of units, consecutive numbers were assigned to each of the units. The southwest corner of each unit was selected as the datum corner. Internal provenience control with these units was 1 imited to $2-\mathrm{m}^{2}$ subunits. The use of the subunit provenience controls was maintained throughout the course of the field work and laboratory 


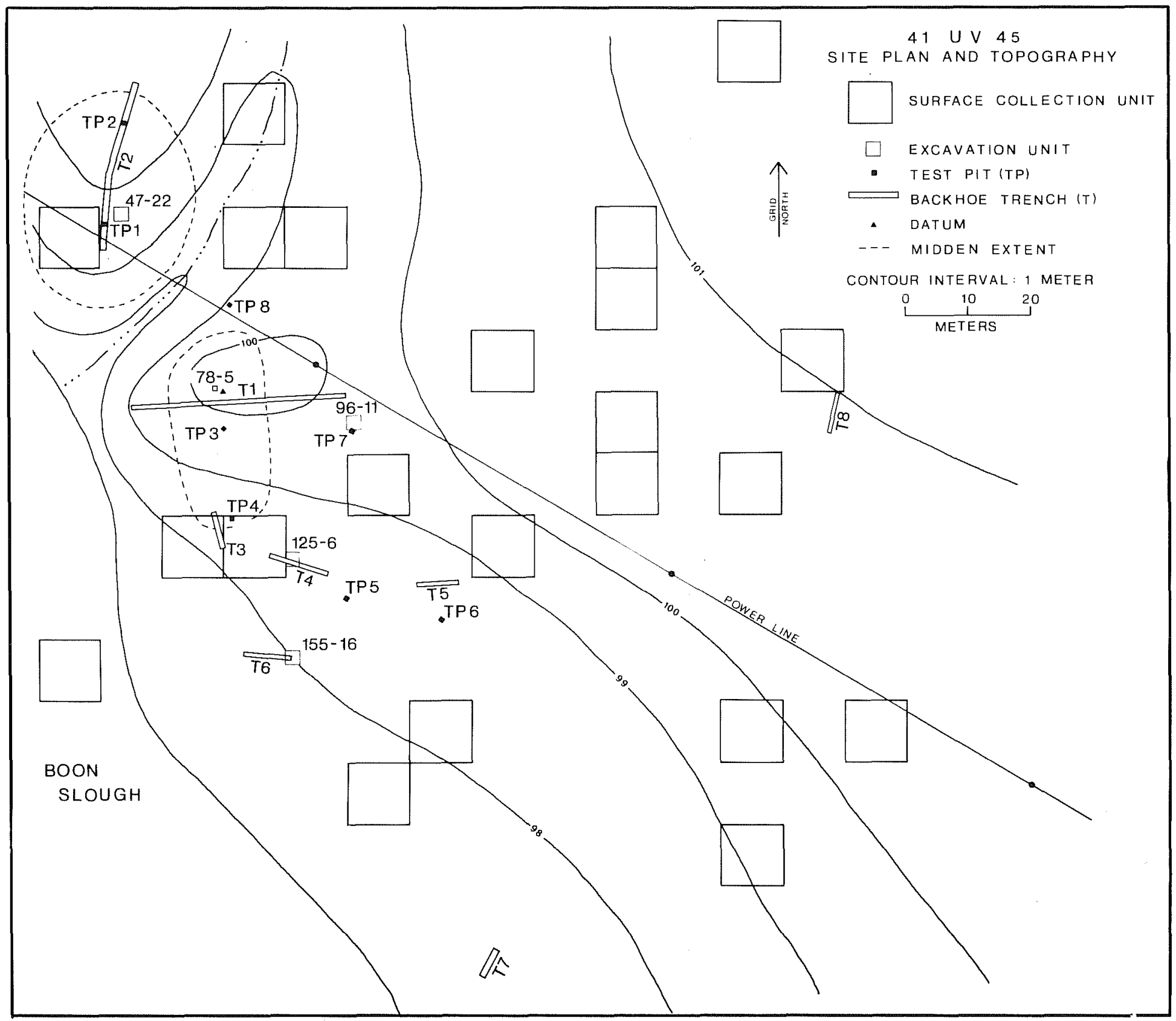

Figure 10. Topographic Map and Plan of Excavations at 41 UV 45. 


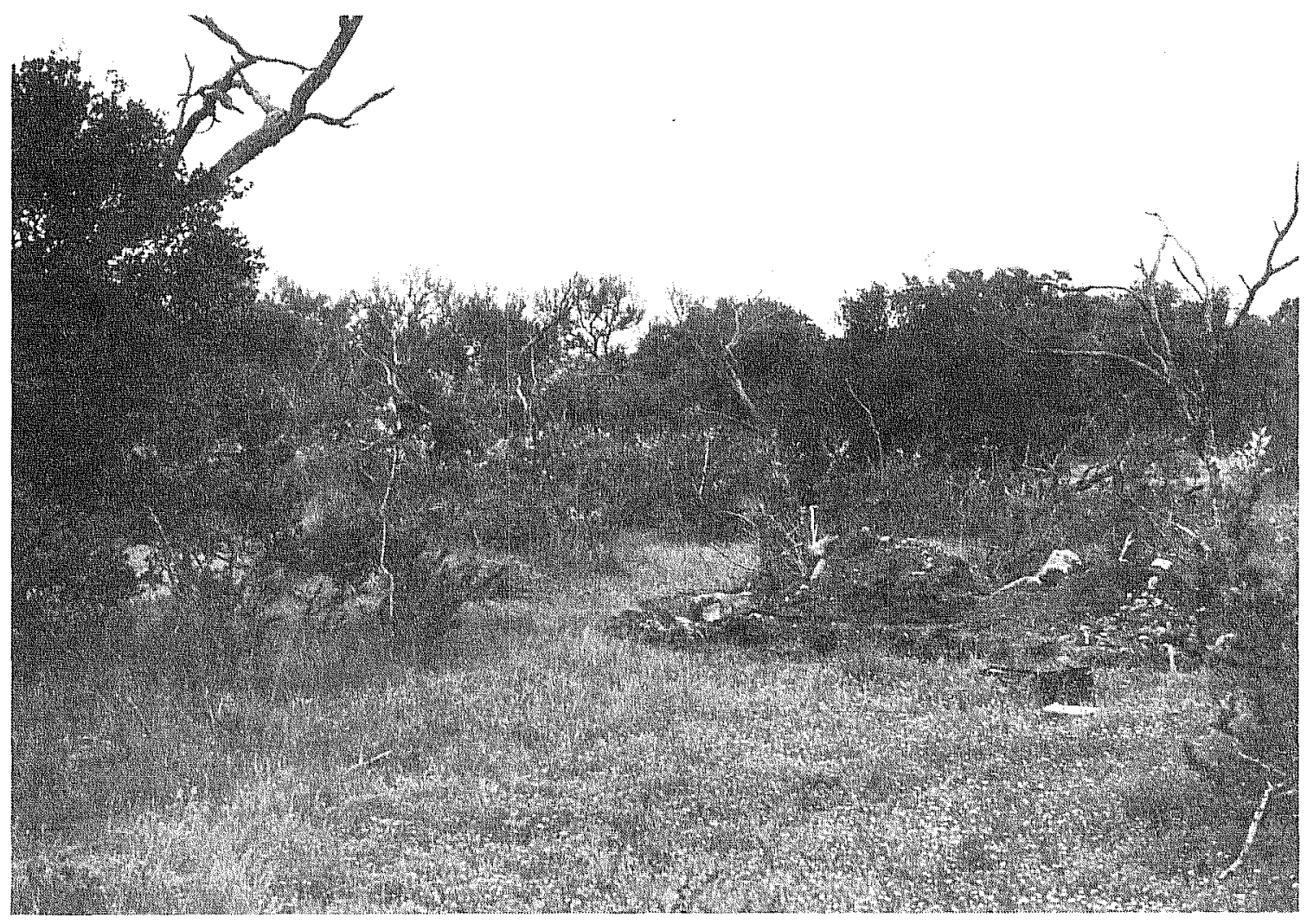

a

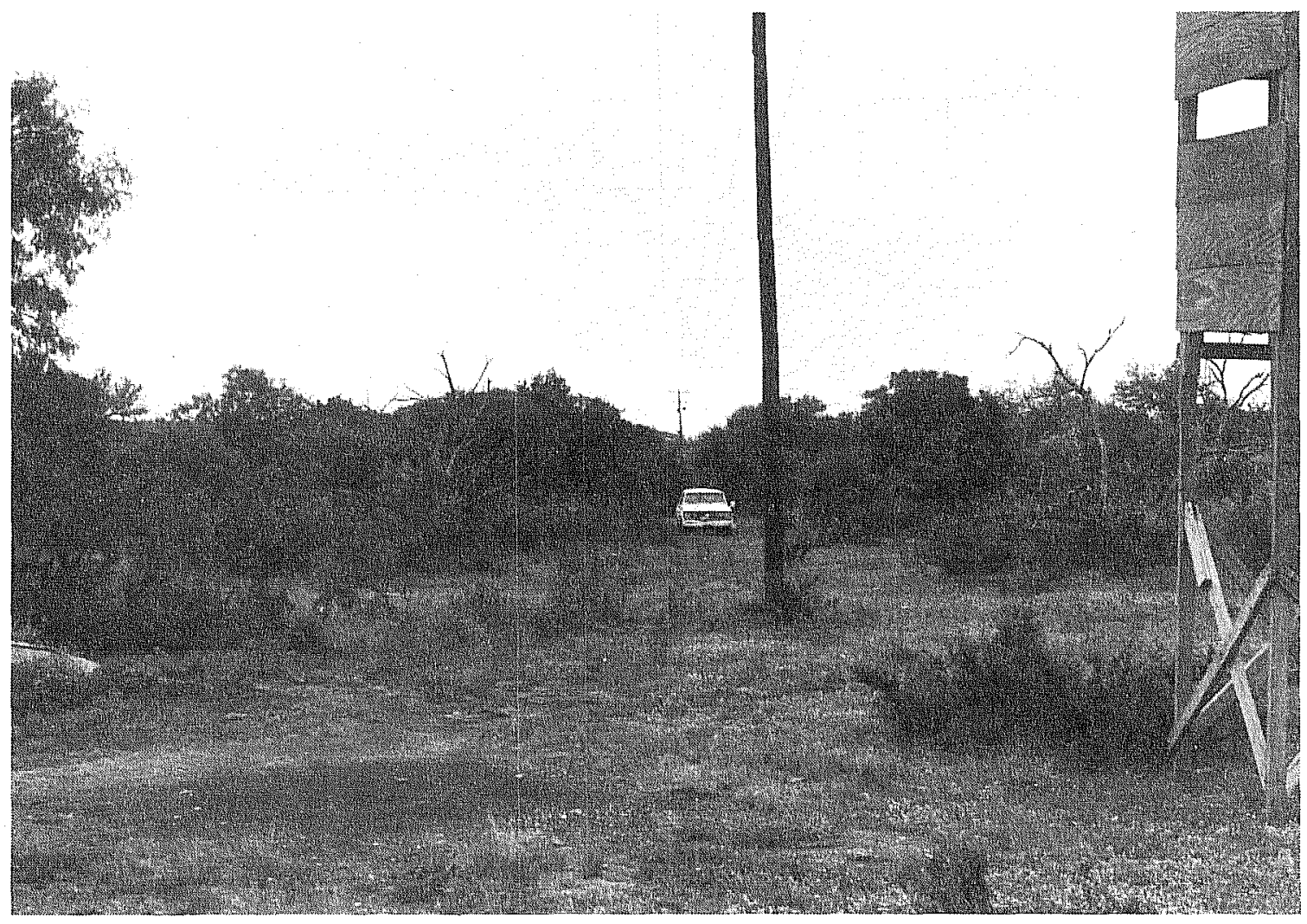

b

Figure 11. General Views of 41 UV 45. a, looking south towards site; b. looking west down telephone 1 ines towards Boon's Slough. 
processing, but this analysis will consider only the 1 arger $10-\mathrm{m}^{2}$ unit proveniences.

A total of 22 of the 225 units within the site was selected for surface collection using a table of random numbers. All of the random sample units but one contained some cultural materials. The single exception was Unit 151, which was located just within Boon Slough and was not collected. In addition to the random sample surface collection, a nonrandom surface collection was made of artifacts discovered outside of the designated 22 units. The nonrandom finds were provenienced when found. A total of 111 artifacts was recovered from the surface. Table 11 compares the relative distribution between the random and nonrandom collections. A total of 38 artifacts was collected outside of the random sample units compared to a total of 73 specimens from within the random sample units. The nonrandom sample comprises $34 \%$ of a 11 the surface artifacts recovered. A11 of the material collected has been used in the distribution study which follows.

\section{Distribution of Surface Artifacts}

The overall distribution of each major artifact grouping surface collected is discussed, emphasizing possible intrasite patterns.

TABLE 11. RANDOM AND NONRANDOM SURFACE-COLLECTED ARTIFACTS RECOVERED AT 41 UV 45

Cultural Materials
Random Percentage

Nonrandom
Count
Arrow points

Dart points

Overall retouch bifaces

Bifacially retouched flakes

Bifaciat intergrades

Other bifaces

Unifaces

Modified flakes

Cores

Ground stone

Ceramics

Historic artifacts
Random

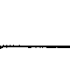

Total

$\begin{array}{rrr} & 100 & 1 \\ 33 & 67 & 12 \\ 75 & 25 & 4 \\ 78 & 22 & 9 \\ 58 & 42 & 12 \\ 82 & 18 & 11 \\ 75 & 25 & 12 \\ 67 & 33 & 3 \\ 91 & 9 & 33 \\ 100 & 100 & 1 \\ & 10 & 3 \\ 90 & & 10\end{array}$

66

34

111 
The overall distribution of the debitage (flakes, chips, burned chert, and chunks) is shown in Figure 12. The total debitage surface inventory within each collected $10-\mathrm{m}^{2}$ unit was sorted into one of five intervals. These groupings are in increments of 10, with the last grouping reserved for unit debitage counts of more than 30. The maximum debitage total for a single unit was 82 specimens (Unit 46). The minimum count from a single sample unit was two specimens (Unit 49). Other sample units with more than 30 debitage specimens are Units 100,115, 123, 124, and 172. The mean debitage count per unit was 27.4 items. In genera1, areas that had high Tithic debitage counts also had high artifact, or tool, recovery rates, but distinct associations of debitage and the various artifact groupings were not noted in the distribution maps. The surface distribution of the debitage indicates that the highest lithic densities occurred on top of the midden area and on top of the deeper terrace deposits close to, but just east and southeast of, the midden.

Only a single arrow point was surface collected from the site, a Perdiz (miscellaneous category) specimen found near the southern edge of the midden deposits (Fig. 12). Dart points were much more common on the surface at the site. A total of 12 specimens was recovered, four of these from the random sample collection, and the remainder from fortuitous finds while working at the site. Three specimens were located on the southern area of the midden deposits, and six specimens were from the areas east and south of the midden. of the 12 dart points collected, only half could be identified as specific Archaic types: Early Corner Notched (Early Archaic), Pedernales, Nolan, and La Jita (all Middle Archaic forms), and two Late Archaic types, Castroville and Monte11. Also one Frio point collected may represent the Terminal, or Transitional Archaic period for the site. No specific horizontal patterning was noted among the different projectile point types collected from the surface, which might suggest spatial differentiation of the various cultural periods represented. However, the relatively large number of Archaic dart points when compared to the single Late Prehistoric arrow point suggests that the major occupations of the site would be expected to date within almost the entire span of the Archaic. Subsequent excavations at the site partially verified this implication, since projectile points identified as from the Middle Archaic to the Late Archaic were most commonly recovered, in contrast to the very smal1 number of Late Prehistoric arrow points.

Four overall retouch bifaces were recovered from the surface. Three of the specimens are large-sized forms; the other is a small triangular form. The larger forms are concave-based specimens from the general surface collection, a Form 9 specimen from the northern midden area, and a rounded fragment from the area east of the southern end of the midden. The specimens were widely scattered over the site, and the small sample size offers no indication of a patterned distribution.

Nine bifacially retouched flakes were recovered from the surface; three are classified as small forms, four are classified as 7 arge, and two are amorphous specimens. Of the nine specimens recovered, only one was found on the midden, a small triangular form. The two amorphous specimens were found on the northern half of the site away from the midden. The remaining six specimens were found on the southern half of the site and are identified as three large, pointed ovate forms; a large fragment; a small triangular form; and a small fragment. The number of bifacially retouched flakes found in the 

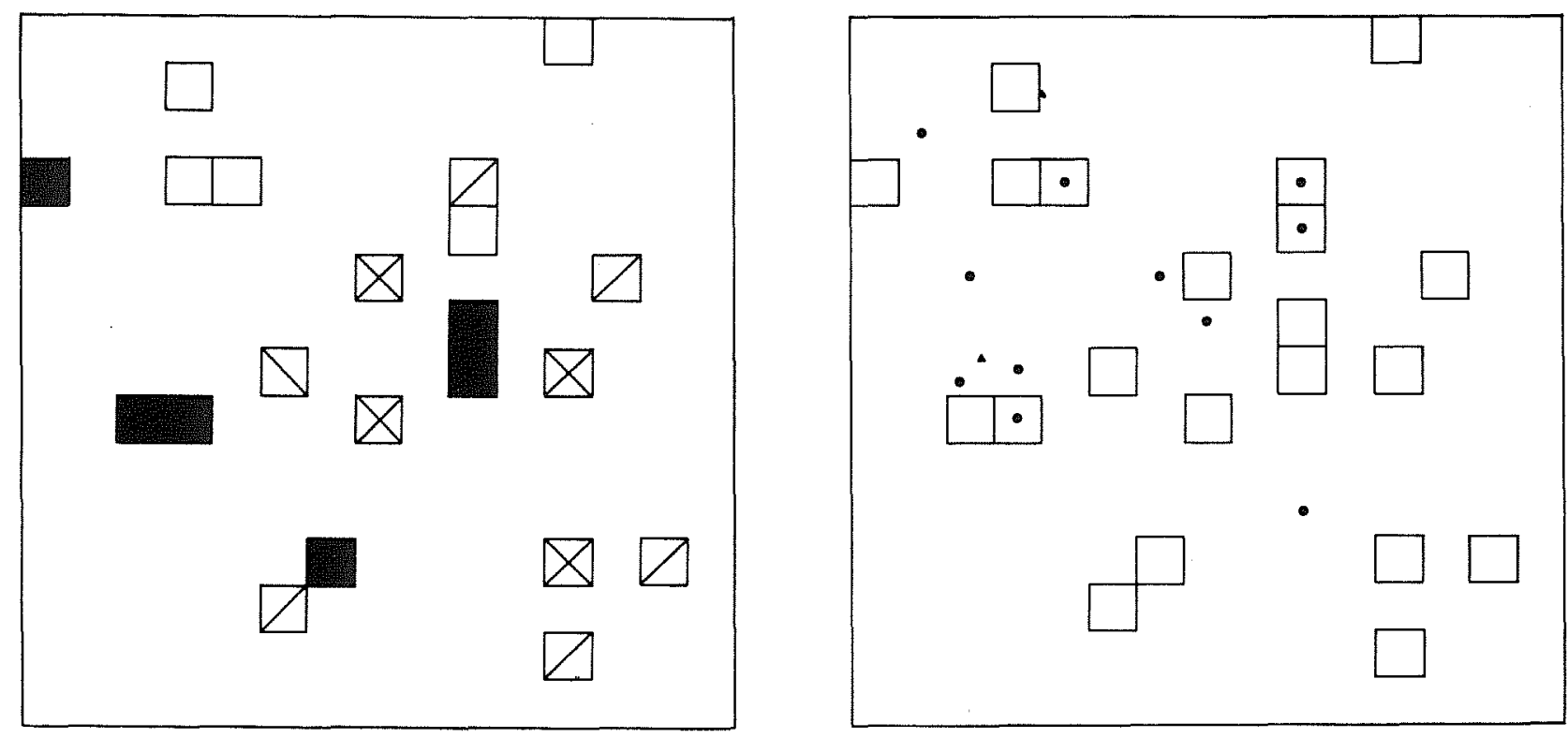

$\square$ 0-10 Specimens

- Arrow Point

\11-20 specimens

- Dart Point

$\triangle$ 21-30 specimens

$31+$ Specimens

41 UV 45
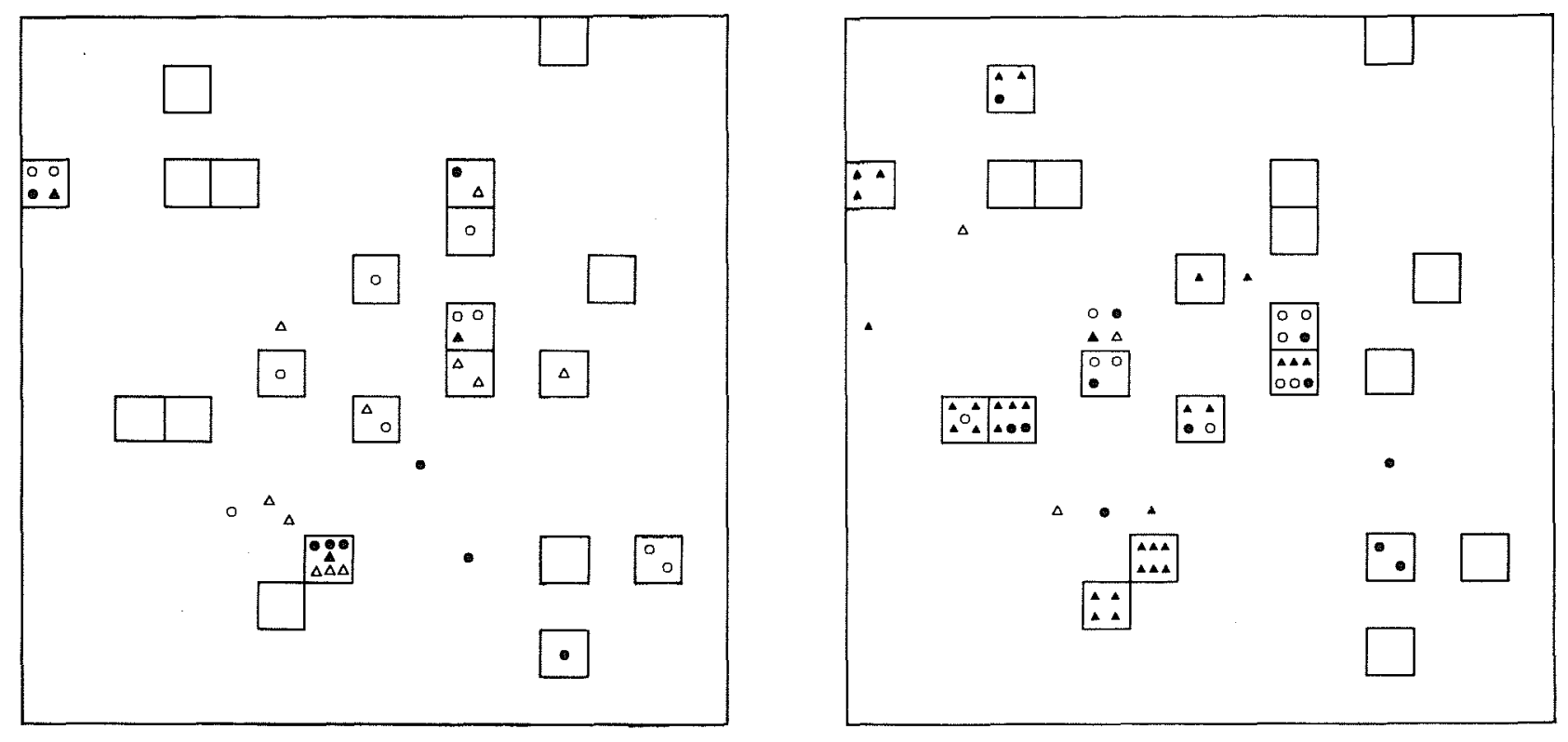

$\triangle$ Overall Retouch Biface

- Bifacially Retouched Flake

- Bifacial Intergrade

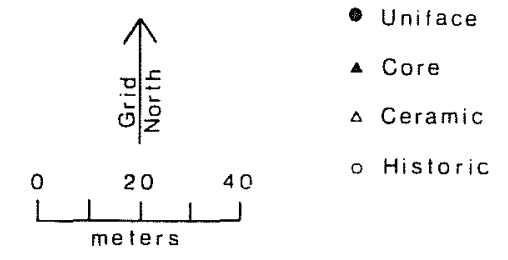

- Other Biface

Figure 12. Distribution of Surface Artifacts at 41 UV 45. 
southeastern area of the site may indicate a possible activity area concentration, but the surface sample is rather small.

The 12 bifacial intergrades collected from the surface are identified as five ovate forms, six pointed ovate forms, and a single fragment. All of the specimens were recovered from the east and southeast of the midden boundaries. This may suggest that most of the activities related to primary bifacial reduction occurred away from the midden area.

Of the 11 other bifaces surface collected, al1 but two came from the areas southeast and east of the midden boundaries. They are identified as four specimens each of pointed and lateral fragments and a single miscellaneous fragment. Only two specimens were recovered on the midden, a pointed fragment and a miscellaneous fragment from Unit 46.

Unifaces were relatively common in the surface collection. of the 12 specimens collected, four are classified as end scrapers, three as side scrapers, and the remaining five specimens are miscellaneous retouched specimens. Most of the specimens occurred east and southeast of the midden area, but the variety of forms in that area was intermixed. Additionally, three modified flakes were collected from the surface, one a decorticate multiple facet platformed flake; the other two are chips without platforms.

Cores were the most common artifact found on the surface, with a total of 33 specimens. Ten are multidirectional, horizontal platform cores; eight are core nuclei; seven are multidirectional, oblique platform cores; four are core tools, and two specimens each are bifacial and unidirectional, prepared platform cores. All varieties of cores occurred together in all areas of the site, with most of the specimens recovered to the east and southeast of the midden area. Three of the four core tools from the surface were from within or very near Unit 172, southeast of the midden area, forming a small clustering similar to the core tool cluster noted at another.site in the project area, 41 UV 47.

In addition to the previously described artifact categories, a single ground stone fragment and three scattered prehistoric ceramic sherds were found on the midden. The sherds appeared scattered around the edge of the midden area, with a single sherd classified as Leon Plain, Variety 1, and the other two sherds classified as Leon Plain, Variety 2.

Ten historic artifacts were collected from the surface, all loosely clustered within the central area of the site. The material includes eight glass fragments, of which six are brown colored, and one specimen each is of clear and purple glass. Other historic artifacts are a single white paste earthenware sherd and an iron kettle horizontal lug handle.

\section{Summary of Surface Collection}

On the basis of surface collections at the site, including a random $10 \%$ sampling strategy for the $22,500 \mathrm{~m}^{2}$ of the site area, the analysis of the overall 1ithic debitage density indicated that most of the debitage could be expected to be found on the midden and on the terrace areas of deeper soil 
deposits east and south of the midden. While the material densities between the midden and adjacent areas off of the midden appear comparable, the area off of the midden is a larger areal manifestation, and there was some indication that site activities between the two areas differed. The implication of differing intrasite activity areas is supported by the distribution of the various artifact categories; most of the artifacts that were collected came from an area east and southeast of the midden. However, a distinct boundary or break in materials between the two areas could not be defined due to the low resolution of the surface collection strategy. Another intrasite characteristic revealed by the random sampling strategy was a tapering off of both debitage and artifact densities in the northern site area where soil deposition was rather shallow.

Distinct intrasite distributions suggestive of specific activity areas could not be defined from the sample data, although it was possible to show that in general, artifacts (i.e., tools and cores) were more common off of the midden. More specifically, the various artifact categories of bifaces, unifaces, and cores were most frequent on the terrace surface south and east of the midden areas. A single artifact category, that of core tools (chopperlike cores), although small in number, appeared clustered together just southeast of the midden, and they represent a situation that is reminiscent of a clustering of core tools on the surface of another site in the project area, 41 UV 47.

Artifacts with temporal implications are limited to some of the projectile points, prehistoric ceramics, and a few historic artifacts. These artifacts suggest the site may have been used during al1 prehistoric cultural periods from the Early Archaic to the Late Prehistoric, and then once again historically.

\section{EXCAVATION AREAS}

The following descriptions of the excavation units, test pits, and trenches are presented to describe various areas within the site, and to characterize the subsurface nature of site deposits. The descriptions will focus on the dichotomy of midden vs. nonmidden (terrace) contexts within the site. The difference between the midden and terrace area excavations are best noted in the soil profiles of Trench 3 (Fig. 13). Excavation plans showing the placement of the units discussed are shown in Figure 10.

\section{Midden Soils}

Two excavation units (Units 47-22 and 78-5) were placed through the midden soils, in addition to four test pits. Unit 47-22 measured $2 \mathrm{~m}^{2}$ and was excavated in arbitrary $20 \mathrm{~cm}$ levels. The first four levels were completely excavated, but the last level was cut in size by half, and only the western half of the unit was excavated. Unit 78-5 measured $1 \mathrm{~m}^{2}$ and was excavated in $20 \mathrm{~cm}$ Tevels to a maximum depth of $140 \mathrm{~cm}$. Test Pits $1,2,3$, and 4 each measured $50 \mathrm{~cm}^{2}$ and were excavated in either $20 \mathrm{~cm}$ or $25 \mathrm{~cm}$ levels. Test Pit 1 was excavated in $25 \mathrm{~cm}$ levels to a depth of $65 \mathrm{~cm}$, Test Pit 2 was excavated in $25 \mathrm{~cm}$ levels to a depth of $70 \mathrm{~cm}$, and Test Pit 3 was excavated 


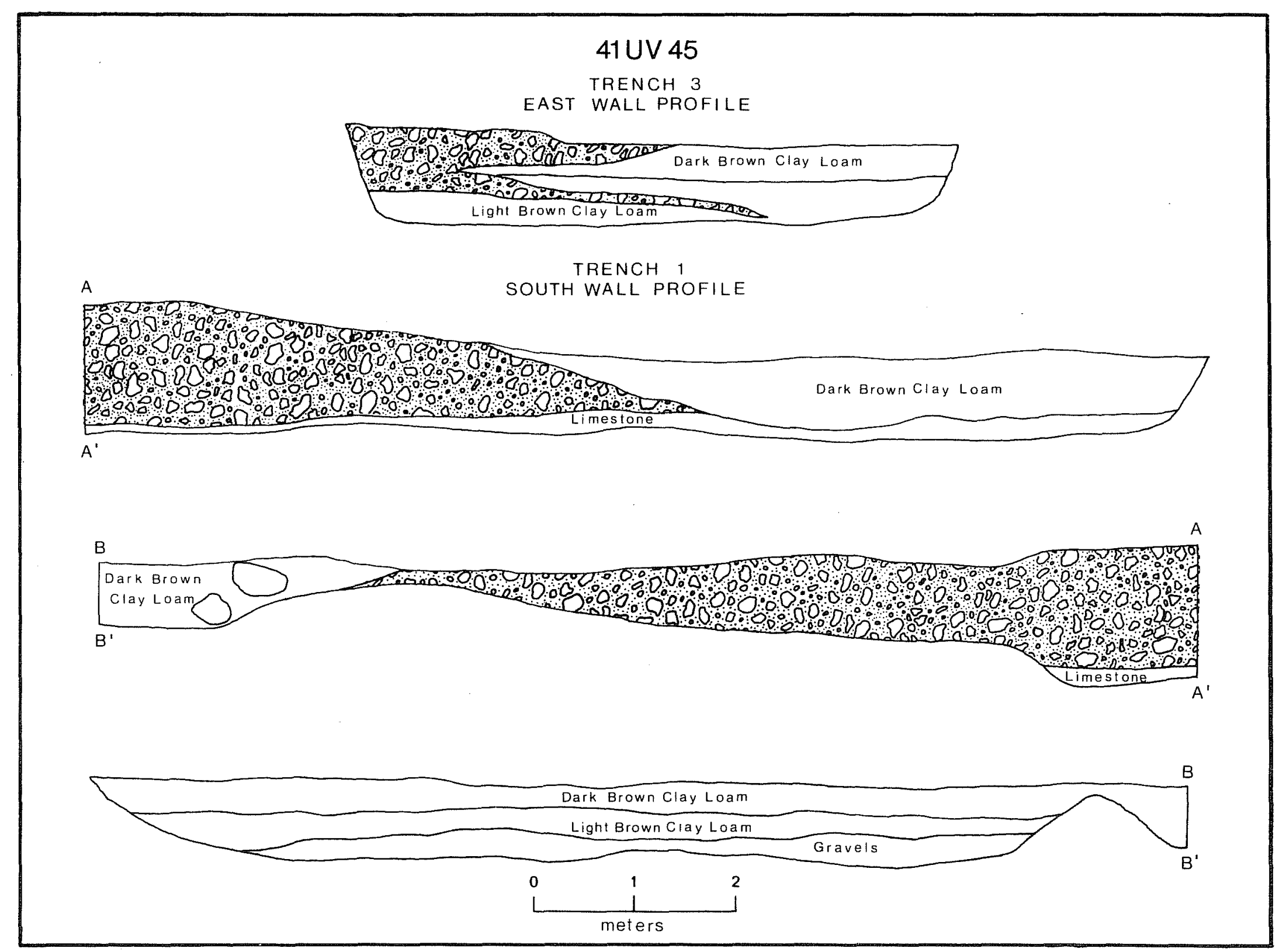

Figure 13. Trench Profiles from the Midden Areas at 41 UV 45. 
in $20 \mathrm{~cm}$ levels to a depth of $80 \mathrm{~cm}$. Three backhoe trenches were cut across the midden areas in order to determine the horizontal extent of the midden. Backhoe Trench 1 was approximately $34 \mathrm{~m}$ long and varied in depth from about $70-100 \mathrm{~cm}$. Backhoe Trench 2 was $26 \mathrm{~m}$ 1ong and varied from about $50-80 \mathrm{~cm}$ in depth. Backhoe Trench 3 was about $7 \mathrm{~m}$ long and averaged $80 \mathrm{~cm}$ in depth. Al1 the trenches were approximately $50 \mathrm{~cm}$ wide.

An estimated $31.39 \mathrm{~m}^{3}$ of $\mathrm{fil1}$ were removed in conjunction with the midden area excavations. Five cubic meters of fill were removed from Units 47-22 and 78-5, $0.69 \mathrm{~m}^{3}$ were removed from the four test pits, and $25.7 \mathrm{~m}^{3}$ were removed from the three backhoe trenches. The surface area exposed during excavations was $39.5 \mathrm{~m}^{2} ; 6 \mathrm{~m}^{2}$ from the hand excavations, and $33.5 \mathrm{~m}^{3}$ from the backhoe operations.

Representative soil profiles of the midden deposits are shown in Figure 13. The midden areas covered an areal extent of approximately $25 \times 40 \mathrm{~m}$ in the northern part of the site, and an area approximately $15 \times 33 \mathrm{~m}$ in the southern part of the site. Because of a gully cut between the two areas it remains uncertain if the two areas represent distinct, separate features. The soil profiles from both of the areas indicate little dissimilarity between the northern and southern areas.

Midden area profiles generally show that the midden deposits extended vertically from the surface down to a solid limestone bedrock base, or to the top of a sterile caliche gravel zone. The maximum depth recorded for the midden features was about $140 \mathrm{~cm}$, but the deposits most common $7 y$ averaged between 80-100 cm in depth. The midden in the southern area consisted mainly of angular, fist-sized burned rocks. Between the burned rocks, the soil was a clay loam that varied in color from 7 ight gray to dark gray. There was some indication in the soil profile of Backhoe Trench 3 of at least two episodes of midden accumulation. Approximately the lower half of the midden, resting on sterile caliche gravels, had been built up and then abandoned for some period of time while the outer edges of the midden deposits were buried under brown clay loam terrace deposits. During a later stage of midden accumulation, burned rock was deposited on top of the earlier midden near the thickest deposits, and spread out onto the terrace deposits that had covered the outer edges of the lower concentration of rocks. While excavating, there was some indication that the lower levels of the midden (those associated with the first sequence of deposition) contained less organic content than the upper levels, which tended to have a more "greasy" texture. Cultural material was scarce in both deposits.

The profiles from the northern midden area (Unit 47-22 and Backhoe Trench 2) were similar to those from the southern area. Black, rich organic clay loam soils with numerous burned rocks comprised the midden zone, and occurred from the surface to a solid 1 imestone bedrock base, although chunks of unburned 1 imestone became quite common in the 1 ower $20 \mathrm{~cm}$ of the deposits.

\section{Terrace Areas}

Units 96-11, 125-6, and 155-16 were excavated in the terrace areas surrounding the midden features. The units were selected in order to further 
investigate specific features identified during the backhoe and test pit phases of investigation. Prior to the opening of the three excavation units, four test pits and five backhoe trenches were placed in selected areas of the site.

Unit 96-11 measured $2 \mathrm{~m}^{2}$. The first level excavated was an arbitrary $20 \mathrm{~cm}$ level; the second level was excavated to a depth of $34 \mathrm{~cm}$ below the surface and exposed Feature 5. After recording Feature 5, the west half of the unit was excavated as a $16 \mathrm{~cm}$ level (Level 3) to a depth of $50 \mathrm{~cm}$ below the surface, and then Level 4 was excavated to a depth of $70 \mathrm{~cm}$ below the ground surface.

Unit 125-6 measured $2 \mathrm{~m}^{2}$ and was partially transected by Backhoe Trench 4. Because of Backhoe Trench 4, the excavated area of the unit was of a somewhat irregular shape. The approximate north $1.2 \mathrm{~m}$ of Unit 125-6, the area north of Backhoe Trench 4, was excavated. The top $35 \mathrm{~cm}$ of soil was removed as overburden with a backhoe, and then the remaining fill was hand excavated from 35-40 cm as the first screened level. Thereafter, the remaining west half of the unit was excavated in arbitrary $20 \mathrm{~cm}$ unit-levels, to a final depth of $100 \mathrm{~cm}$.

Unit 155-16 measured $2 \mathrm{~m}^{2}$ and was excavated in order to expose a buried feature noted in the east end of Backhoe Trench 6 . Consequently some of the fill from the unit had been removed prior to hand excavation. The southwest quadrant of Unit 155-16 was designated a control quad and excavated from the surface to a final depth of $80 \mathrm{~cm}$ in arbitrary $10 \mathrm{~cm}$ unit-levels. The remaining quadrants of Unit 155-16, where portions of the fill had been removed by backhoe operations, were excavated in the following sequence: prior to excavating Level 1 approximately the first $20 \mathrm{~cm}$ of $\mathrm{fil} 1$ were removed as overburden; Leve1 1 (21-40 cm) was followed by Level $2(40-50 \mathrm{~cm})$ which exposed Feature 4; then Level $3(50-60 \mathrm{~cm})$ was excavated from the north half of the unit.

Test Pits 5, 6, and 7 measured $50 \mathrm{~cm}^{2}$. Test Pit 5 was excavated in two arbitrary $20 \mathrm{~cm}$ levels to a depth of $40 \mathrm{~cm}$ below the surface, Test Pit 6 was excavated in two arbitrary $25 \mathrm{~cm}$ levels to a depth of $50 \mathrm{~cm}$, and Test Pit 7 was excavated in three arbitrary $25 \mathrm{~cm}$ levels to a total depth of $75 \mathrm{~cm}$ below the surface. Test Pit 8 measured $1 \mathrm{~m}^{2}$ and was excavated to a bedrock base varying from 18 to $26 \mathrm{~cm}$ below the surface, and averaging $22 \mathrm{~cm}$ in depth.

Five backhoe trenches (Backhoe Trenches 4-8) were excavated through the terrace deposits. Backhoe Trench 4 was $10 \mathrm{~m}$ long and averaged approximately $70 \mathrm{~cm}$ in depth. Backhoe Trench 5 was $6 \mathrm{~m}$ long and had a maximum depth of $115 \mathrm{~cm}$. Backhoe Trench 6 was $8 \mathrm{~m}$ long and was excavated to an average depth of $70 \mathrm{~cm}$. Backhoe Trench 7 averaged approximately $80 \mathrm{~cm}$ in depth and was $4 \mathrm{~m}$ long. Backhoe Trench 8 was approximately $6.5 \mathrm{~m}$ long and averaged $65 \mathrm{~cm}$ in depth. All trenches were dug with an 18-inch bucket (approximately $50 \mathrm{~cm}$ wide).

An estimated $20.25 \mathrm{~m}^{3}$ of $\mathrm{fill}$ were removed from the terrace deposits, $6.15 \mathrm{~m}^{3}$ from the excavation units, $0.63 \mathrm{~m}^{3}$ from the test pits, and $13.46 \mathrm{~m}^{3}$ from the five backhoe trenches. The total surface area exposed was $26.9 \mathrm{~m}^{2}$ from the hand excavations and $14.75 \mathrm{~m}^{2}$ from the backhoe trenches. 
Representative soil profiles from the terrace area are shown in Figures 14 and 15. Figure 14 shows the profiles drawn for Units 96-11, 125-6, and 15516. Figure 15 shows profiles from Backhoe Trenches 4, 5, 7, and 8 . The soi1 profiles varied from trench to trench, and from unit to unit, but a general sequence of soil zones is present throughout the site.

The first of the soil zones, the A-horizon, occurs from the surface to a depth between 20-35 cm below the surface, characteristically a dark gray brown or dark brown clay loam. The second soil zone is the B-horizon and occurs from a smooth, gradual boundary with the A-horizon to a depth of approximately 45-65 cm below the surface. This zone is usually $25-35 \mathrm{~cm}$ thick. The soil color tends to be lighter in hue, but this is not always the case, varying from dark brown to brown in color. The B-horizon is usually a more compact clay loam than the A-horizon, and calcareous pebbles may occasionally occur within it. Both of the upper soil zones contain occasional flakes or burned 1 imestone cobbles. The last soil zone is considered a culturally sterile zone within the site. It usually begins between $60-70 \mathrm{~cm}$ below the surface, and is identified by a lighter colored, usually yellowish brown, clay loam with increasing amounts of gravels and calcareous inclusions and a decrease in cultural materials. This zone extends to the bedrock surface, which may occur on the surface in the extreme northern areas of the site, or may be deeper than a meter in the southern areas of the site.

\section{FEATURES}

Six features were recorded at site 41 UV 45 , and a 17 except one feature (Feature 6) were original1y discovered during the test pit and trenching phases of field work. All features were located in the terrace deposits of the site away from the midden areas, and each represents burned rock clusters or were identifiable as hearths. Those features designated as burned rock clusters of indeterminate function are Features 1-3. Features 4-6 are interpreted as cooking hearths. The following presents a description of each feature.

\section{Feature 1}

Feature 1 was a dense burned rock accumulation of fired 1 imestone rocks clustered in a roughly oval to circular plan (Fig. 16,a). The feature was partialiy exposed in Test Pit 8. The horizontal extent of the exposed portion of the feature measured $83 \times 67 \mathrm{~cm}$, although the actual dimensions must remain undefined as portions of the feature extended into the north and west walls of the test unit. Depth of the feature rocks ranged from surface to bedrock, recorded between $18-26 \mathrm{~cm}$ below the surface.

The feature was comprised of approximately 151 burned rocks, varying in size from a few centimeters to about $10 \mathrm{~cm}$ in diameter. The total weight of the burned rocks removed from the surface was $28.1 \mathrm{~kg}$. The soil matrix within the feature was undifferentiated from that of the surrounding soil, a dark brown clay loam with occasional charcoal chunks. 


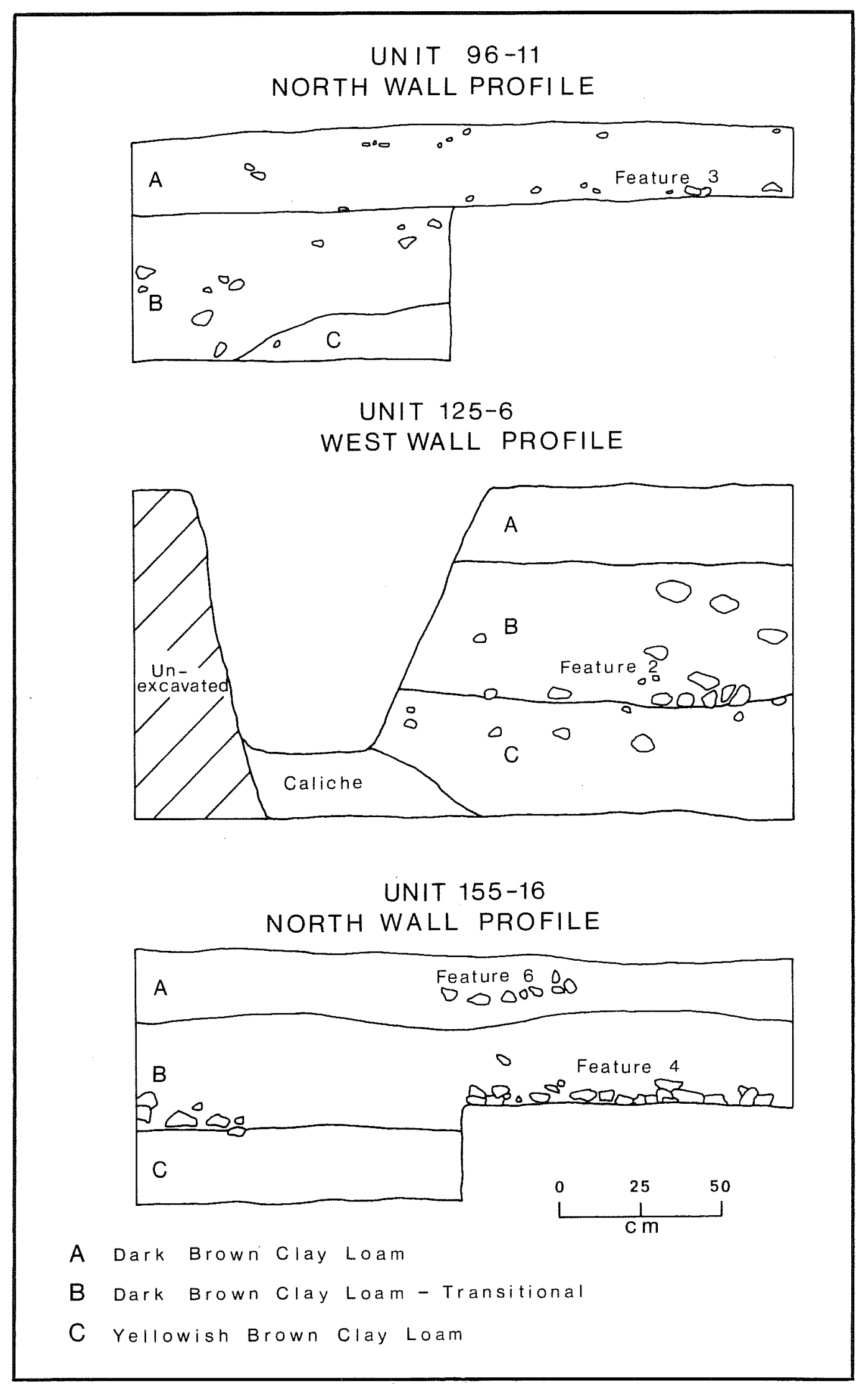

Figure 14. Profiles from Terrace Area Units at 41 UV 45. 
TRENCH 4 SOUTH WALL

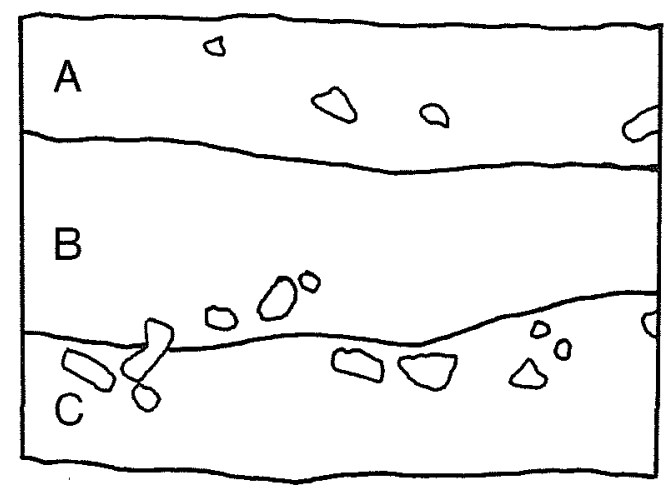

TRENCH 5 SOUTH WALL

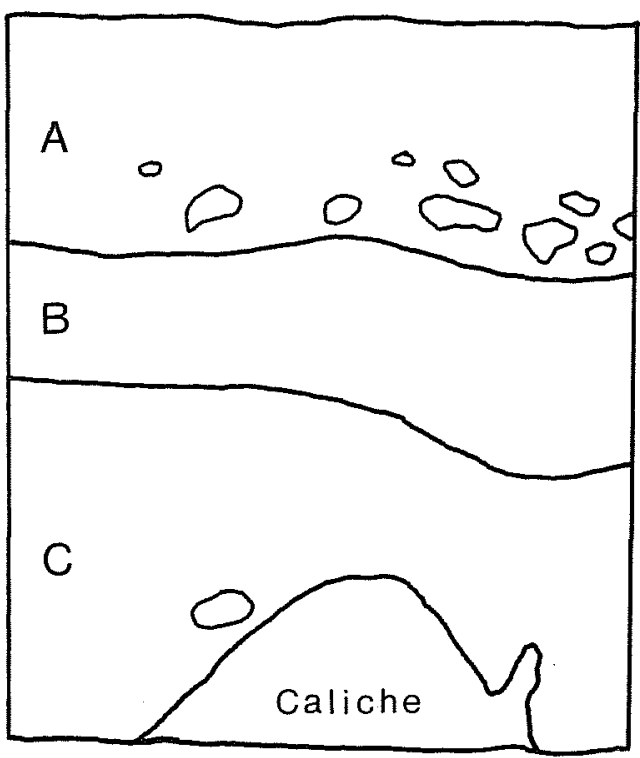

TRENCH 7

WEST WALL

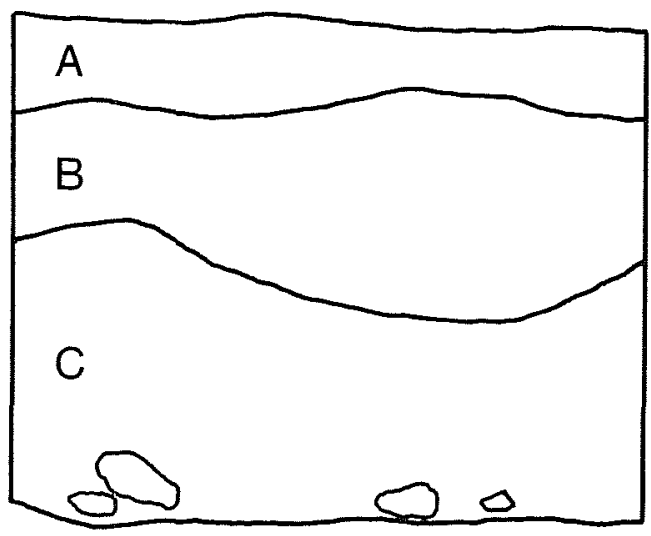

TRENCH 8 EAST WALL

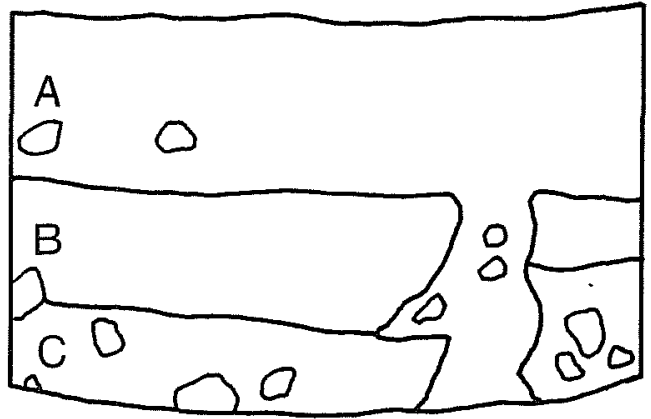

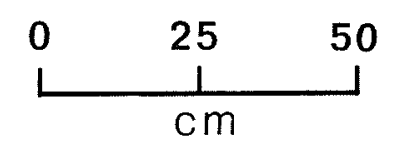
A Dark Brown Clay Loam
B Dark Brown Clay Loam - Transitional
C Yellowish Brown Clay Loam

Figure 15. Profiles from Terrace Area Trenches at 41 UV 45. 


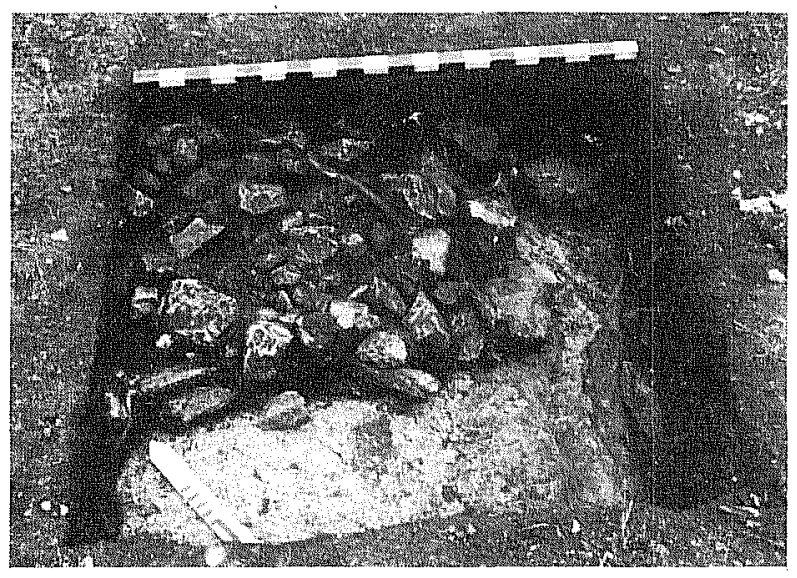

a

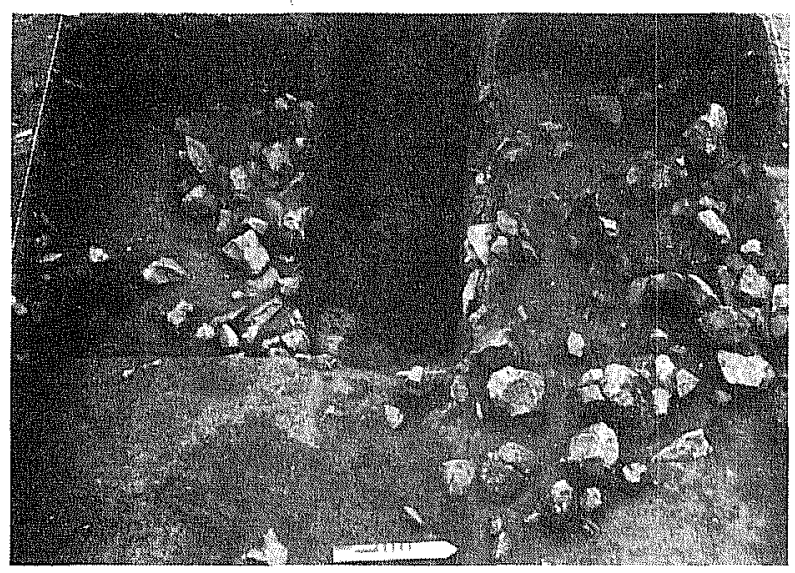

C

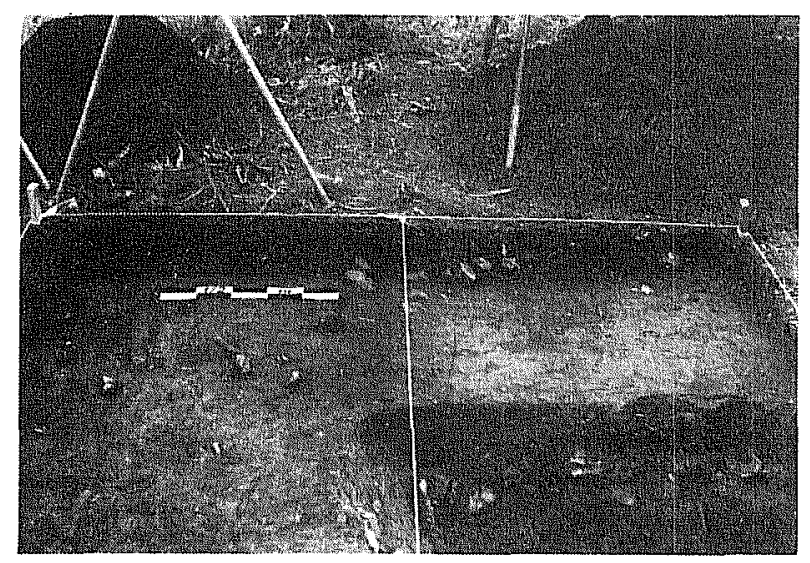

e

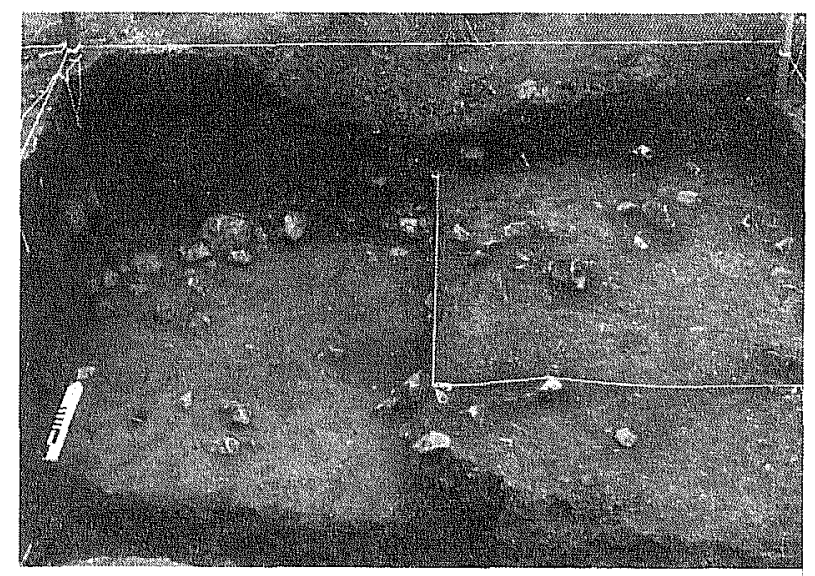

b

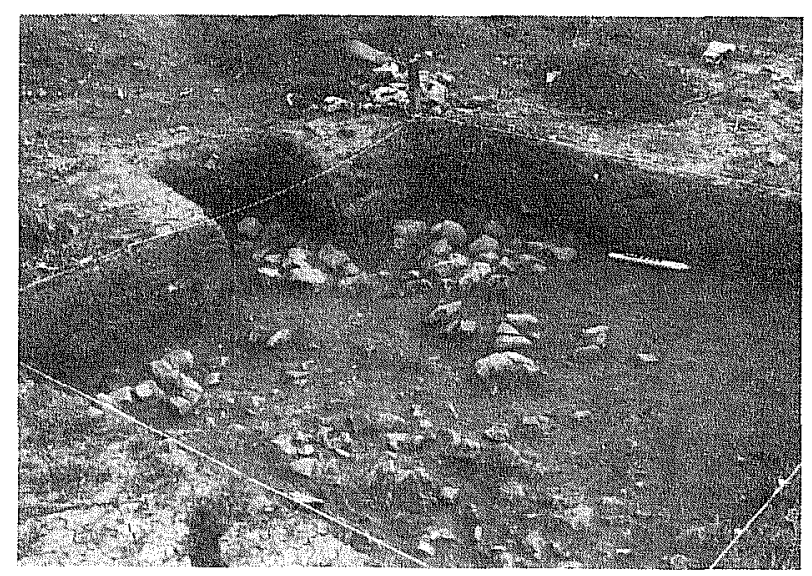

d

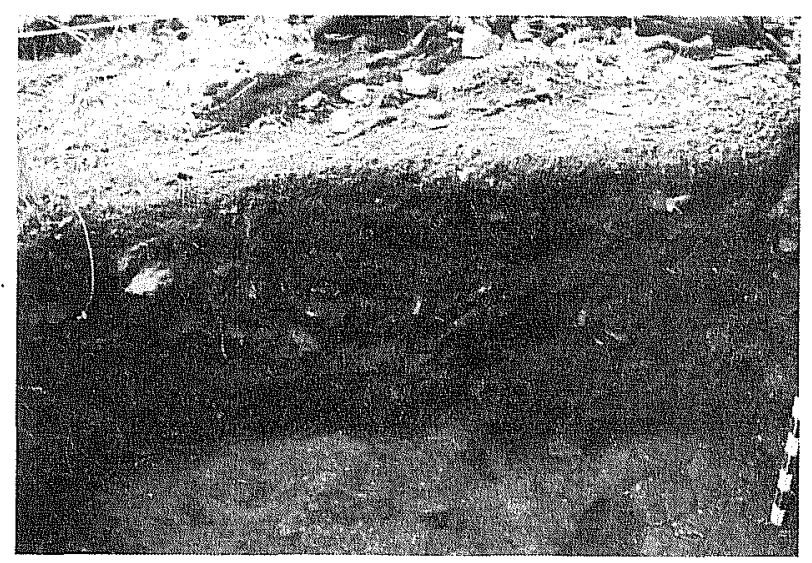

f

Figure 16. Features 1, 2, 4, 5, and 6 at 41 UV 45. a, Feature 1, looking northeast; b. Feature 2, looking west; $c$, Feature 4, upper levels looking west; d, Feature 4, lower levels exposed; e, Feature 5, looking south; f, Feature 6, looking south. 
Cultural materials associated with Feature 1 included a single Matamoros projectile point, an amorphous bifacially retouched flake, and 399 debitage specimens, most (70\%) of which were decorticate chips. Additionally, a single Rabdotus sp. snail shell and 18 Helicina shells were recorded.

Feature 1 rested directly on top of a solid 1 imestone bedrock base, very close to the surface; areas of the bedrock showed evidence of burning through discoloration of the limestone. The interpretation of Feature 1 must remain indefinite, although it may represent the remains of a hearth feature or possibly "spil1" or rock roll from nearby midden areas.

\section{Feature 2}

Feature 2 was identified originally in the north wall of Backhoe Trench 4 and was Tater exposed in Unit 125-6 within Level $3(40-60 \mathrm{~cm}$; Fig. 16,b). It was defined as a loosely clustered burned 1 imestone accumulation. The feature 1 imits extended into the north, west, and east wall of Unit 125-6, with the exposed portion of the feature measuring one meter east to west and $128 \mathrm{~cm}$ north to south. The recorded depths of the burned rocks within the feature varied from $52-63 \mathrm{~cm}$ below the surface.

Feature 2 was comprised of about 195 individual rocks, with a total weight of $53 \mathrm{~kg}$. The rocks varied in size from a few centimeters to as 1 arge as $20 \mathrm{~cm}$ in diameter. The rocks were not tightly packed together, and the soil matrix from both inside and outside the feature boundaries was a brown clay loam. Stratigraphically, the feature was just above a soil change from a brown clay loam to a yellowish brown clay loam.

Cultural materials associated with the feature included a Pedernales dart point, $61 \mathrm{~cm}$ below the surface; a large, triangular concave base overa 11 retouch biface, $55 \mathrm{~cm}$ below the surface; three other bifaces (a pointed fragment, a midsection, and a miscellaneous fragment); a core nuclei; and 460 debitage specimens. Other materials recovered within Feature 2 were 38 Rabdotus sp. snail shells, five Polygyra sp. shells, traces of freshwater mussel she11, and occasional wood charcoal flecks.

Feature 2 may represent the remains of a scattered hearth, but as no definite outline could be defined, the interpretation as a hearth is speculative.

\section{Feature 3}

Feature 3 was a small scatter of burned rocks exposed in the west end of Backhoe Trench 4. The feature was not completely excavated so dimensions are approximate; profile measurements indicate a minimum size of approximately $1.2 \mathrm{~m}$ in length. Vertically, the feature occurred between $38-72 \mathrm{~cm}$ below the ground surface, and averaged about $50 \mathrm{~cm}$ in depth. Size of the individua 1 stones varied from about 5-10 cm in diameter. Stratigraphically, the feature occurred at the top of the lowest recorded soil zone in Backhoe Trench 4, a calcareous, yellowish brown clay loam containing occasional gravels. A matrix sample taken from Feature 3 recovered 12 debitage specimens and a single Rabdotus sp. snail she17. The feature is thought to be the scattered 
remains of a hearth, or possibly midden debris from the nearby burned rock midden feature exposed in Backhoe Trench 3.

\section{Feature 4}

Feature 4 was initially exposed in the east end of Backhoe Trench 6, and was later exposed in excavation Unit 155-16. The feature was a circular burned rock hearth approximately $1.7 \mathrm{~m}$ in diameter. Vertically, the feature occurred between 28-52 cm below the ground surface, primarily concentrated near the $52 \mathrm{~cm}$ level. Most of the feature was exposed in hand excavations; only a relatively small proportion was removed during backhoe trenching.

The feature consisted of 304 burned 1 imestone rocks ranging in size from a few centimeters to as 1 arge as $20 \mathrm{~cm}$ in diameter. The total weight of the burned rock was $128.9 \mathrm{~kg}$. The burned rock in the upper levels of the feature appeared to be more scattered than the tightly clustered rocks at the lower levels, where the circular outline of the hearth became apparent (Fig. 16,c,d). The feature matrix was a brown clay loam and was indistinguishable from the soil surrounding the feature. Stratigraphically, the feature was just above a soil zone transition from the brown clay loam to a more compacted, slightly lighter hue brown clay loam.

In the southeast quadrant of Unit 155-16, Level 5 (associated with Feature 4), the debitage total was 229 specimens, notably the highest debitage count recorded from that quadrant, suggesting an increase in cultural activity within Level 5. Artifacts from Level 5 are identified as a Marsha11 dart point and a pointed other biface fragment. Two dart points, a Castroville and a Langtry, were recovered from below the feature. Snail shells were scarce in Level 5; three Rabdotus sp., one Polygyra, and one Helicina comprise all of the snails retrieved. Feature 4 is interpreted as a Late Archaic hearth based upon the recovery of a Marshall dart point.

\section{Feature 5}

Feature 5 was a flat, circular hearth exposed in the southwest corner of Unit 96-11 (Fig. 16,e). The feature was first 10cated in Test Pit 7 . The horizontal extent of the exposed feature was $1.20 \times 0.95 \mathrm{~m}$. The overall size of the hearth is estimated to be approximately $1.6 \mathrm{~m}$ in diameter. Vertically, the feature occurred from $29-36 \mathrm{~cm}$ below the ground surface.

Feature 5 consisted of angular, fist-sized burned rocks that formed a distinct cluster. While the plan was clearly ovate to circular, there was no specific patterning or placement apparent for any of the individual rocks, although the rocks on the outer edges of the hearth were more tightly grouped than the rocks towards the center of the feature. In a11, a total of 104 rocks was removed from the feature, weighing a total of $34.9 \mathrm{~kg}$. Scattered burned rock was common away from the feature and may represent other, scattered hearths, but no distinct concentrations were noted. The soil within the feature was the same as that of the surrounding areas, a brown clay loam, with a few small gravels. 
Cultural materials associated with Feature 5 are identified as two bifacial intergrades (a pointed ovate form and a miscellaneous fragment) and four other bifaces (two pointed fragments and two midsections) from Level 2 (20$34 \mathrm{~cm})$. Additionally, a Kinney dart point was recovered from the soil column sample at a depth of 32-42 cm below the ground surface. Notably, debitage counts for the unit were at their highest in the levels directly above and below the feature. Based upon the presence of the Kinney dart point, the feature is assigned to the Middle Archaic occupations at the site.

\section{Feature 6}

Feature 6 was defined as a small cluster of burned rocks associated with a stained area of soil near the south wall of Unit 155-16 (Fig. 16,f). The feature occurred in association with Levels $2(10-20 \mathrm{~cm})$ and $3(20-30 \mathrm{~cm})$ of the southeast quadrant control unit within Unit 155-16. The exposed feature 1 imits were recorded as $55-68 \mathrm{~cm}$, with the long axis running north to south.

The burned rocks appeared between $20-30 \mathrm{~cm}$ below the ground surface and were best represented in cross section in the south wall of the unit. The cross section showed 13 burned rocks in a distinct cluster parallel to the ground surface, and contained within the uppermost soil zone of the unit profile. The zone was a dark grayish brown clay loam containing scattered bits of wood charcoa1. The stained area of soil associated with the burned rock appeared, after investigation, to have been made by a charred tree stump and is not considered a cultural manifestation.

Cultural materials associated with the feature are identified as two other bifaces and a core nuclei from Level $3(20-30 \mathrm{~cm})$ of the southeast quadrant. From Leve] 1 (20-40 cm) of the remaining quadrants, an overall retouch biface (1arge triangular form with a straight base), a bifacial intergrade fragment, and two other bifaces were recovered. A light increase in the overall debitage count was noted in Level $3(20-30 \mathrm{~cm})$ of the southeast quadrant.

\section{MATERIAL DISTRIBUTIONS}

The overall distribution of cultural materials recovered from site 41 UV 45 is discussed. While the surface-collected artifacts are included in this discussion, it should be noted that they have been separately discussed earlier in this section and are not considered in great detail here. The material distributions are subdivided into three categories: artifacts, debitage, and burned rocks. Comments on the material distributions consider the site area as a whole, and the distributional differences between the midden area and the terrace deposits are also considered.

\section{Artifact Distributions}

The artifacts considered for the overall distributional study at 41 UV 45 are arrow points, dart points, overall retouch bifaces, bifacially retouched flakes, bifacial intergrades, and other biface forms, unifaces, modified flakes and chips, cores, ground stone, ceramics, and historic materials. 
Each of these artifact groups is considered briefly by a review of the surface distribution, and then by the context of the excavated material, focusing on the differences in midden and nonmidden distributions. A brief summary of the various artifact groupings is shown in Table 12.

\section{Arrow Points}

Six recovered projectile points are classified as arrow points. The Edwards, Perdiz, and Scallorn types are represented. One specimen was surface collected, a Perdiz (a miscellaneous form), from the area just southeast of the midden. All of the remaining arrow points were recovered in the northern midden area from Unit 47-22. From Level 1 a Scallorn corye11, a Scallorn eddy, and an arrow point blade fragment were recovered. From Level 2, one Perdiz preform and from Level 3, one Edwards type were recovered. The concentration of arrow points in the northern midden area indicated that most, if not a11, of the Late Prehistoric subsurface deposits would be expected to be confined to this area of the site. The small number of arrow points recovered ruled out conclusive vertical distributional studies, but it is interesting to note that the two Scallorn types overlie the Edwards type; the presence of the Perdiz preform between the two earlier arrow point types would suggest that some mixing of the soil deposits has taken place. The distribution and variety of these Late Prehistoric artifacts suggest that all three local cultural phases (Toyah, Austin, and Turtle Creek) occur in a somewhat mixed context within a single area of the site.

TABLE 12. SUMMARY OF THE ARTIFACT DISTRIBUTIONS AT 41 UV 45

Cultural Materials

Surface

Collection

Excavated

$\begin{array}{cc}\text { Midden } & \text { Terrace } \\ \text { Area } & \text { Area }\end{array}$

Total

Arrow points

Dart points

Overa11 retouch bifaces

Bifacially retouched flakes

Bifacial intergrades

Other bifaces

Unifaces

Modified flakes

Cores

Ground stone

Ceramics

Historic artifacts

$\begin{array}{rr}1 & 5 \\ 12 & 13 \\ 4 & 7 \\ 9 & 10 \\ 12 & 19 \\ 11 & 32 \\ 12 & 5 \\ 3 & 6 \\ 33 & 18 \\ 1 & 1 \\ 3 & 1 \\ 10 & 1\end{array}$

1

$\begin{array}{lll}1 & 2 & 13\end{array}$ 


\section{Dart Points}

A total of 34 dart points was recovered from the site; 12 specimens from the surface, and 22 specimens from the excavations. Of the 12 surface finds, seven are of known types: Early Corner Notched (an Early Archaic form), Nolan, La Jita, and Pedernales (Middle Archaic forms), Castroville and Montell (Late Archaic forms), and Frio (a Transitional Archaic form). Surface specimens not chronologically placed are four unidentifiable fragments and miscellaneous Form 9. The 22 excavated dart points were approximately equally distributed inside and outside of midden contexts, with totals of 13 and 9, respectively. Dart points from the midden area are one Ensor Variety 1, one Ensor Variety 2, three Frio types, one Kinney, one Marcos, one Pedernales, one miscellaneous Form 5, and three unidentified fragments. Most of these dart points were found within Unit 47-22, except the following: the Frio and the Pedernales came from Backhoe Trench 2, the Kinney from Backhoe Trench 1 , and the miscellaneous Form 5 from Test Pit 3. Stratigraphically, the identifiable types from Unit 47-22, are as follows: Level 1, Ensor Variety 2; Level 2, one Marshal1; Level 3, one Ensor Variety 1, two Frio types, and one Marcos. All of the dart point types identified in the first three levels of Unit 47-22 could be assigned to the Late Archaic or Transitional Archaic, but these were also mixed with chronologically later arrow point types, revealing a considerably mixed cultural stratigraphy. Of note, and possibly suggesting a difference in the material content of the southern midden area, no projectile points were recovered from Unit 78-5.

In the terrace deposits, the following dart point types are identified: Castroville, Ensor Variety 1, Kinney (two) Langtry, Marshall (two), Matamoros, Pedernales, and an unidentifiable fragment. of the seven identifiable types, most can be assigned to the Middle Archaic (Pedernales, Langtry, and Kinney). Of the three remaining dart points, two are assigned a Late Archaic age (Castroville and Marshall), and one is classified as a Late Transitional Archaic (the Ensor). The Ensor was from Level 1 of Unit 96-11, and the Marshal1 and Castrovil1e were from Levels 5 and 6 of Unit 155-16, respectively. The two Kinney dart points were found in Backhoe Trench 4 and Leve 13 of Unit 96-11; the Langtry was from Level 7 of Unit 155-16, and the Pedernales was from Level 3 of Unit 125-6. Although the seven identifiable dart points do not provide a very large sample, the distribution seems to indicate that terrace area units excavated to investigate the subsurface features exposed by backhoe operations are most commonly associated with Late Archaic and Middle Archaic types. The single Transitional Archaic type, the Ensor, found outside of the midden excavations, was well above the recorded feature associated with Unit 96-11. This distribution contrasts with the predominance of Transitional Archaic types and Late Prehistoric arrow points recorded from the northern midden area of the site.

\section{Overal1 Retouch Bifaces}

A total of 16 overall retouch bifaces was recovered from the site; four specimens were surface finds, seven were excavated from the midden areas, and five came from the terrace area excavations. The surface-collected specimens are three Targe bifaces (a concave-based specimen, a Large Individual Form 9, 
and a rounded fragment) and a single small triangular form. Specimens from the midden area excavations are a rounded and a miscellaneous fragment, both from Unit 47-22, and five specimens from Backhoe Trenches 1, 2, and 3 . A gouge and a fragment (classified as miscellaneous) are the specimens from Backhoe Trench 1; the two specimens from Backhoe Trench 2 are a fist axe and a Large Individual Form 6; the single specimen found in Backhoe Trench 3 is a large straight base form. The overal1 retouch bifaces from the excavated terrace deposits are a triangular, concave-based specimen from Level 3 of Unit 96-11; a miscellaneous fragment from Level 2 of Unit 125-6; a triangular, convex-based specimen from Level 3 of Unit 125-6; a Clear Fork tool from Leve1 4, Unit 125-6; and a triangular, straight-based specimen from Level 1 of Unit 155-16.

The distribution of the overall retouch bifaces, like that of the dart points, seems to indicate that the specimens were about equally distributed between midden and terrace contexts. Of interest is the rarity of small forms (only one from the site), which may represent a specific Late Prehistoric tool form, judging from the relatively high frequency of smal1 triangular forms at 41 UV 47 and 41 UV 48.

\section{Bifacially Retouched Flakes}

A total of 21 bifacially retouched flakes was recovered from the site, nine specimens from the surface, 10 from excavations in the midden area, and two from the terrace excavations. The surface-collected specimens were located primarily along the southern half of the site away from the midden area. The surface finds consist of two small triangular forms, a small miscellaneous fragment, three 7 arge pointed ovate forms, a large fragment, and two amorphous specimens. The following specimens were recovered from the midden excavations: three large fragments and two amorphous specimens were recovered from Unit 47-22; three amorphous specimens (one at each provenience) were found in Unit 78-5, Test Pit 1, and Backhoe Trench 1; and one large triangular was found in Unit 78-5 and a large fragment from Backhoe Trench 2. The two bifaces from the terrace excavations were both amorphous specimens, one recovered from Test Pit 8 and the other from Unit 155-16. Most of the bifacially retouched flakes appear to be concentrated in the northern midden area excavations, but the high frequency of large fragments and amorphous specimens throughout the site may suggest that bifacially flaked tools were not emphasized at the site.

\section{Bifacial Intergrades}

There was a total of 38 bifacial intergrades recovered from 41 UV 45 . Of these, 12 were found during surface collections, 19 were excavated from the midden area, and the remaining seven were from the terrace deposits. The surface finds are six pointed ovate forms, five ovate forms, and a single fragment. The surface finds were located to the east and southeast of the midden area. Most of the excavated specimens were from the midden area; four are ovate forms, one is a pointed ovate form, one is a triangular form, nine are asymmetrical forms, and four are fragments. Approximately half of the bifacial intergrades from the midden excavations were recovered from the 
three backhoe trenches. The seven specimens recovered from the terrace excavations are a single pointed ovate form, an ovate form, a triangular form, and four fragments. The unusually high concentration of bifacial intergrades in the excavated midden contexts would suggest that perhaps the primary stages of biface production were concentrated in the midden areas.

\section{Other Bifaces}

Other biface specimens were the single most common bifacial form at the site, with 60 specimens recorded. Of the 60 specimens, 11 were surface finds, 32 were from the midden excavations, and 17 were from the terrace area. Most of the surface finds (nine) were located off of the midden area, with the following forms recovered: four pointed fragments, four lateral fragments, and a miscellaneous fragment. A pointed fragment and a miscellaneous fragment were surface-collected specimens from the midden area. Of the 49 excavated other bifaces, most were from midden contexts. There were 19 specimens from Unit 47-22 alone: 10 pointed fragments, seven lateral fragments, and two miscellaneous fragments. One miscellaneous and two pointed fragments were recovered from Unit 78-5. One pointed fragment was removed from the backdirt of Unit 47-22, another from Test Pit 4 . The remaining specimens from the midden excavations were found in Backhoe Trenches 1, 2, and 3. The following forms were recovered: three pointed fragments, four lateral fragments, and a single miscellaneous fragment. In the terrace area excavations the following forms were recovered: two pointed and two lateral fragments from Unit 96-11; two pointed, a 1ateral, and a miscellaneous fragment from Unit 125-6; and three pointed, a lateral, and two miscellaneous fragments from Unit 155-16. There was also a lateral fragment recovered from Test Pit 5, a pointed fragment from Backhoe Trench 8 , and a lateral fragment from Backhoe Trench 6 . The relative distribution of the other bifaces is similar to that of the previously discussed bifacial categories in that a11 appear to be most common in the midden deposits, and specifically within Unit 47-22 in the northern midden area excavations.

\section{Unifaces}

of the 18 unifaces recovered from the site, three-quarters of the specimens were surface finds, and six specimens were excavated. Of the surface collected specimens, four are classified as end scrapers, two are retouched on one side, one is retouched on two sides, and the remaining five specimens are miscellaneous forms. Most of the specimens were found off of the midden areas. Five of the unifaces were recovered from the midden area excavations and are identified as two specimens retouched on one side, a concave edged specimen (possibly a spokeshave), a graver, and a miscellaneous form. The graver and one of the side retouched unifaces were from Unit 47-22, the other side retouched uniface and possible spokeshave were from Backhoe Trench 2, and the miscellaneous specimen was from Unit 78-5. The only uniface excavated from the terrace deposits was a miscellaneous form from Unit 15516. The small number of unifaces recovered, including the four end scrapers, which are often associated (but not always) with Late Prehistoric occupations (Ha11, Black, and Graves 1982), suggests that unifacial tools were not a major part of the Archaic tool kit inventory of the site. 


\section{Modified Flakes and Chips}

Eleven modified flakes and chips were recovered at 41 UV 45 , three from the surface, six from the midden area excavations, and two from the terrace excavations. The surface-collected specimens are a decorticate multiple facet platform flake, a decorticate chip, and a corticate chip. The six specimens excavated from the midden areas are a corticate single facet platform flake from Backhoe Trench 1, a decorticate chip from Level 2 of Unit 47-22, and two decorticate chips and a corticate indeterminate platform flake from Leve 14 of Unit 47-22. The two specimens excavated from the terrace deposits are a corticate indeterminate platform flake from Level 1 of Unit 125-6 and a decorticate chip from Level 2 of Unit 155-16. Like the unifacial artifacts, modified flakes and chips comprise only a very small proportion of the overall artifact inventory at the site.

\section{Cores}

Of the 55 core specimens recovered, 33 were surface finds, 18 were excavated from the midden areas, and only four were recovered from the terrace excavations. The cores are classified as follows: 16 multidirectional, horizontal platform cores; 14 multidirectional, oblique platform cores; 13 nuclei; six core tools; and three specimens each of unidirectional platform cores and bifacial cores. The surface finds are 10 multidirectional, horizontal platform cores; seven multidirectional, oblique platform cores; four core tools; two unidirectional, prepared platform cores; two bifacial cores; and eight nuclei. Surface cores occurred throughout the site, and there was some indication that three of the core tools formed a distinct activity area just southeast of the midden area. Of the specimens recovered from the midden area excavations, seven are multidirectional, oblique platform cores; six are multidirectional, horizontal platform cores; three are nuclei; and one specimen each of a bifacial and a unidirectional, prepared platform core. Most of the midden area excavated cores came from Unit 47-22 (eight specimens) or from Backhoe Trench 2 (five specimens). Specimens recovered from Unit 47-22 are two multidirectional, oblique platform cores and a nuclei from Leve1 1; two multidirectional, oblique platform cores, a multidirectional, horizontal platform core, and a nuclei from Level 3; and a unidirectional, prepared platform core from Level 4 . The five specimens from Backhoe Trench 2 are two specimens each of the multidirectional, oblique platform core and multidirectional, horizontal platform core, and one bifacial core. Other cores associated with the midden area excavations are classified as a multidirectional, oblique platform core from Level 2 of Unit 78-5; a multidirectional, horizontal platform core from Level 3 of Unit 78-5; a multidirectional, horizontal platform core from Level 3 of Test Pit 3; a multidirectional, horizontal platform core from Unit 47-22 backdirt; and a core nuclei from Trench 1.

Two core tools and two nuclei were recovered from the terrace excavations. The core tools were recovered from Level 1 of Unit 96-11 and Backhoe Trench 7. The two nuclei were found in Level 2 of Unit 125-6 and Leve 3 of Unit 155-16. 
Notably, most of the excavated cores came from the northern portions of the midden area, as did many of the other artifact categories. Core tools were limited to the terrace areas, while unidirectional and bifacial cores occurred only in the midden deposits.

\section{Ground Stone}

Onty two ground stone grinding slab fragments were found at the site; one on the surface in the northern midden area, and the other from Level 4 of Unit 47-22.

\section{Ceramics}

of the four prehistoric sherds recovered, three were surface finds (two sherds of Leon Plain, Variety 2 and a single Leon Plain, Variety 1 sherd). The single excavated prehistoric sherd (Leon Plain, Variety 2) was recovered from Level 1 of Unit 47-22.

\section{Historic Materials}

Of the 13 historic artifacts recovered, 10 were surface finds, and three were excavated. The surface finds are eight glass fragments (six brown, one purple, one clear), a white paste earthenware sherd, and an iron kettle lug handle. All of the surface finds were loosely clustered in the central area of the site. The three excavated historic artifacts are a shell button from Level 1 of Unit 47-22, an aquamarine glass fragment from Backhoe Trench 4, and a rolled metal fragment from Level 1 of Test Pit 5.

\section{Debitage}

The intrasite distribution patterns of debitage (flakes, chips, burned nonflaked chert, and chunks) are discussed, focusing primarily on the relationship of midden area vs. terrace area contexts. The results of the flake platform studies are summarized in order to discuss the lithic technologies expressed at the site. A total of 7848 items was classified as debitage. Because of the variable size of the individual units and levels at the site, the intrasite comparisons are based upon the estimated counts per cubic meter for each unit-level, which was calculated by dividing the raw unit-level debitage inventories by the estimated volume of fill removed from each unitlevel. The following comparisons and discussions will utilize only the material recovered from the southeast quadrant of Unit 155-16, which was excavated as a $1-x 1-\mathrm{m}$ control unit in arbitrary $10 \mathrm{~cm}$ levels, and will exclude the debitage removed from the test pits and backhoe trenches.

Vertical distributional summaries are discussed from the individual units, and then are characterized by site context (midden vs. terrace areas). Figure 17 compares the relative vertical distribution of the estimated counts per cubic meter of the five excavation units at the site. Additionally, 

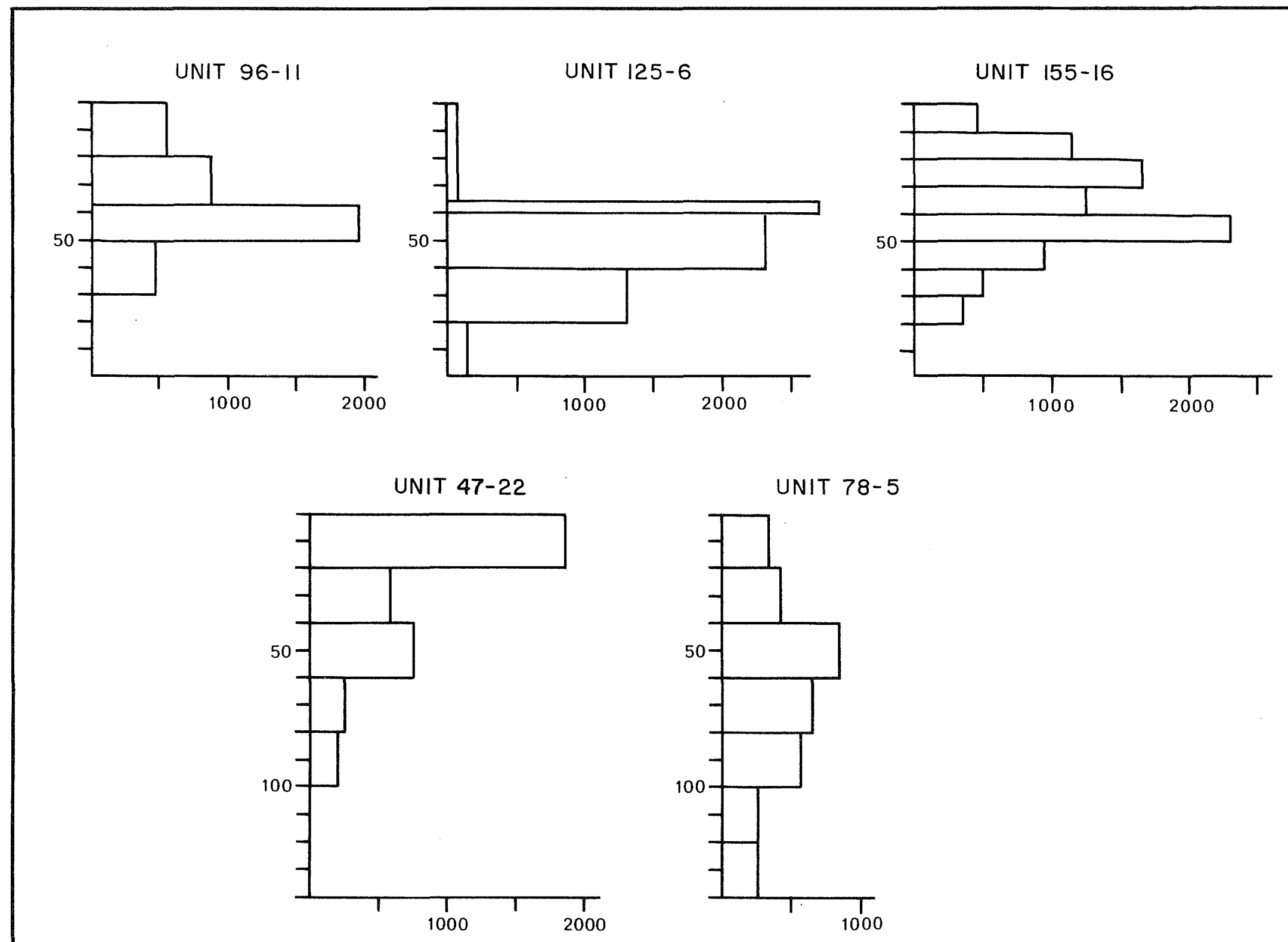

Figure 17. Vertical Distribution of Debitage at 41 UV 45 . Vertical axis represents depth below ground surface in centimeters. Horizontal axis represents debitage count per cubic meter excavated in a level. 
Table 13 shows the relative distribution of the various debitage groupings within the units.

Figure 17 reveals two trends in the overall debitage distribution within the site: first, there are consistent indications of a major concentration of debitage occurring between approximately 40 to $60 \mathrm{~cm}$ below the ground surface; second, there is a relatively distinct difference in the overall quantities of debitage inside and outside of the midden areas. Considering the major concentration of lithics between 40 and $60 \mathrm{~cm}$ it can be seen that the distribution of debitage peaks in Level $3(34-50 \mathrm{~cm})$ of Unit 96-11 with a total of 1591 specimens, then drops off greatly. In Unit 125-6, the peak occurrence of debitage occurs in Leve1 $2(35-40 \mathrm{~cm})$ with 2271 specimens, but is closely followed by Level $3(40-60 \mathrm{~cm})$ with 1917 specimens per cubic meter. In Unit 155-16, the peak occurrence of 7 ithics was in Level 5 (40$50 \mathrm{~cm}$ ) with 2290 specimens, the highest number from the excavation units. In Unit 47-22 (a midden area unit), the highest debitage counts were from Leve 1 1 $(0-20 \mathrm{~cm})$ with 1303 specimens and in Level $3(40-60 \mathrm{~cm})$ with 1591 specimens. In Unit 78-5, excavated through the deepest midden deposits at the site, the vertical distribution clearly shows that most of the flakes were from Level $3(40-60 \mathrm{~cm})$ where 830 debitage specimens per cubic meter occurred. The consistent occurrence of high debitage estimates per cubic meter between 40-63 $\mathrm{cm}$ below the surface suggests a site-wide occupational phenomena. As several of the features occur at approximately the same level (Feature 2 at 52-63 cm, Feature 3 at $38-72 \mathrm{~cm}$, and Feature 4 at $28-52 \mathrm{~cm}$ ), this may be taken as further indication of a site-wide increase in activity at this level. Notably the diagnostic artifacts associated with these debitage increases are primarily Late and MiddTe Archaic forms.

Comparisons between the midden and terrace areas show that the vertical distribution of debitage in the two areas, while essentially consistent in the locations of peak counts and unimodal graphs, varies in the amount of relative quantities. Within the three terrace area units at site 41 UV 45, debitage counts vary from 1591 to 2290 specimens, while the midden area debitage counts from the excavation units vary from 830 to 1303 specimens. Notably, Leve1 $1(0-20 \mathrm{~cm})$ of Unit 47-22, with 1303 debitage specimens, is associated with a Late Prehistoric occupation, probably postdating A.D. 1440 (see TX-4432), while Level 3 of the same unit with 1591 debitage specimens is more likely associated with Late Archaic occupations at the site (and with the trend of site-wide intensive occupation between $40-60 \mathrm{~cm}$ below the surface). If the maximum debitage estimates per cubic meter for the Archaic occupations in the terrace area range from 1591 to 2290 specimens, and the maximum estimates for the Archaic occupations within the midden areas range from 759 to 830 specimens, a ratio of over 2 to 1 is suggested for the terrace area. This distributional pattern is reminiscent of Hester's (1971) findings at the La Jita site, where most of the Archaic occupations were concentrated in the terrace deposits away from the middens.

Table 13 shows the counts of various debitage categories per cubic meter, a figure obtained by dividing the total unit inventory for any grouping by the total volume of fill removed from the unit. The figures in Table 13 indicate most of the debitage categories, specifically primary flakes, secondary flakes, corticate chips, partially corticate chips, decorticate chips, and chunks, were relatively equally distributed throughout the site, although 
TABLE 13. DISTRIBUTION OF DEBITAGE BY UNIT AT 41 UV 45

\begin{tabular}{|c|c|c|c|c|c|}
\hline \multirow[b]{2}{*}{ Debitage } & \multicolumn{2}{|c|}{ Midden } & \multicolumn{3}{|c|}{ Terrace } \\
\hline & $\begin{array}{l}\text { Unit } \\
47-22\end{array}$ & $\begin{array}{l}\text { Unit } \\
78-5\end{array}$ & $\begin{array}{l}\text { Unit } \\
96-11\end{array}$ & $\begin{array}{l}\text { Unit } \\
125-6\end{array}$ & $\begin{array}{c}\text { Unit } \\
155-16 \\
\text { (SE Quad) }\end{array}$ \\
\hline $\begin{array}{l}\text { Primary flakes } \\
\text { Secondary flakes } \\
\text { Interior flakes } \\
\text { Corticate chips } \\
\text { Partially corticate }\end{array}$ & $\begin{aligned} 2 & (1) \\
58 & (9) \\
136 & (20) \\
8 & (1)\end{aligned}$ & $\begin{aligned} 46 & (10) \\
134 & (29) \\
3 & (1)\end{aligned}$ & $\begin{aligned} 58 & (8) \\
255 & (35) \\
3 & (1)\end{aligned}$ & $\begin{aligned} 3 & (1) \\
222 & (39)\end{aligned}$ & $\begin{aligned} 24 & (2) \\
289 & (27) \\
13 & (1)\end{aligned}$ \\
\hline $\begin{array}{l}\text { chips } \\
\text { Decorticate chips } \\
\text { Burned chert } \\
\text { Chunks }\end{array}$ & $\begin{aligned} 41 & (6) \\
292 & (43) \\
137 & (20) \\
2 & (1)\end{aligned}$ & $\begin{aligned} 31 & (7) \\
115 & (25) \\
137 & (29) \\
1 & (1)\end{aligned}$ & $\begin{aligned} 32 & (4) \\
312 & (43) \\
65 & (9) \\
5 & (1)\end{aligned}$ & $\begin{aligned} 35 & (6) \\
246 & (43) \\
64 & (11) \\
2 & (1)\end{aligned}$ & $\begin{aligned} 68 & (6) \\
561 & (52) \\
120 & (11) \\
4 & (1)\end{aligned}$ \\
\hline Total & $676(99)$ & 467 (101) & $730(100)$ & $572(100)$ & 1079 (99) \\
\hline
\end{tabular}

Note: Percentages are indicated by parentheses.

* Estimates obtained by dividing total unit count by total volume excavated. The percentages are not used in text.

some degree of variation between the units does occur. Very few primary flakes, corticate chips, and chunks were recovered from the site, the maximum being eight corticate chips per cubic meter from any particular area of the site. Secondary flakes and partially corticate chips were more numerous at the site, with secondary flake counts per cubic meter varying between 24 in Unit 155-16 to as high as 58 in Units 47-22 and 96-11, and partially corticate chips varied between 31 in Unit 78-5 to 68 in Unit 155-16. Neither the secondary flakes nor the partially corticate chips appear to dominate in either the terrace or midden area excavation units. The number of decorticate chips varies widely as shown in Table 13, ranging from 115 specimens in Unit 78-5 to as high as 561 specimens in Unit 155-16. There does not appear to be any tendency for decorticate chips to be more common in either the midden or the terrace units of the site.

Two subcategories of debitage shown on Table 13 exhibit some tendency to be more common in either the midden or terrace area of the site. Interior flakes were recovered in relatively low numbers (134 and 136) from the midden areas of the site and in relatively high numbers $(222,225$, and 289 ) from the terrace deposits. The other subcategory of debitage that shows a tendency to be differentially distributed between the midden and terrace area excavations 
is that of burned chert. Burned chert is more numerous in the midden area in comparison to the terrace area excavations. For both Units 47-22 and 78-5 in the midden areas, 137 specimens were recovered; in the terrace area, counts for Units 96-11 and 125-6 were 65 and 64, respectively, and for Unit 155-16, the count was 65 specimens.

The two locational differences in the distribution of burned chert and interior flakes may have some bearing on the intrasite activity patterns. Interior flakes are more numerous away from the midden areas, and as noted in the flake platform analysis of the debitage at 41 UV 45, most of these interior flakes are small, multiple facet, and platformed, which expresses a strong bifacial reduction technology within the site. These two findings, that of an off-midden predominance of interior flakes and a biface reduction technology, may suggest that the terrace areas were a commonly preferred section of the site for bifacial tool production.

In regards to the dominance of burned chert within the midden deposits, it should be noted that the distribution expressed at 41 UV 45 is quite different from what Hester (1971) has reported from his analysis at the nearby La Jita site. Hester found that slightly more burned chert was recovered from the terrace deposits at La Jita than was recovered from the various midden features excavated. Hester hypothesized from this evidence, along with data showing an overall lower debitage density within the middens, that the middens may have accumulated as hearthstone rubble dumps away from the primary activity areas. The data from 41 UV 45 does not duplicate Hester's results totally. While there was evidence that debitage densities were lower within the midden levels associated with Archaic occupations, the predominance of burned chert within the middens may possibly suggest that the middens can be associated with an increase in fire-related activities and thus serve as a specialized locus of activity within the site. If the middens are indeed associated with increased burning activities, then their function(s) at this site may better be explained as a possible processing oven (cf. Weir 1976) rather than as hearthstone rubble dumps.

\section{Flake Platforms}

In the following analysis, 2504 platformed flakes are considered; the figure represents all of the platformed flakes collected (raw material counts) except for the southwest, northwest, and northeast quadrants of Unit 155-16 and the backhoe trench material. Six platform types are used in the study: cortex platforms, single facet platforms, large multiple facet platforms, small multiple facet platforms, lipped flakes, and other platforms (a residual category). The various platform types are grouped into one of two larger categories which represented possible lithic reduction technologies. The two assumed lithic reduction technologies, based upon the work by other researchers in the area (Hester 1978; Montgomery 1978; Ha11, Black, and Graves 1982), are those of either a core reduction or a biface reduction emphasis. The biface reduction technology is represented by all of the small multiple facet platformed flakes and the lipped flakes. The core reduction technology at the site is assumed to be represented by primarily the single facet platform flakes, but also includes cortex platform, large multiple facet platform, and other flakes. A summary of the counts and relative 
percentages of each of the platformed flake types by context (midden. area vs. terrace area) is presented in Table 14.

Considering the site as a whole, Table 14 shows that approximately $38 \%$ of the platformed flakes are representative of the core reduction technology, and the remaining $62 \%$ of the flakes are $\mathrm{placed}$ into the biface reduction technology. Within the grouping of core reduction flakes, it was found that the majority of the specimens are single facet platforms, approximately $63 \%$ of al1 the core reduction flakes. The relative percentages of the other core reduction flake types are 22\%, large multiple platform flakes; $14 \%$, cortex platform flakes; and less than 1\%, other platforms. Considering the overall collection of biface reduction flakes, by far the small multiple facet platform flakes dominate the collection, representing $98 \%$ of the biface reduction flakes; 1 ipped flakes comprise on $7 y 2 \%$ of the grouping.

Dividing the platformed flakes into primary, secondary, and interior flakes reveals that the number of biface reduction flakes tends to increase as the decortication process increases. Of the eight primary flakes, five have single facet platforms, and three have cortex platforms. of the 535 secondary flakes (21\% of the total platform flake collection), $33 \%$ have small multiple facet platforms, $31 \%$ have single facet platforms, $24 \%$ have cortex platforms, $10 \%$ have large multiple facet platforms, approximately $1 \%$ are lipped flakes, and less the 1\% are other platforms. Interior flakes recovered total 1961; the various platform types and percentages are as follows: $70 \%$, small multiple platform flakes; $21 \%$, single facet platform flakes; $8 \%$, large multiple facet platform flakes; $1 \%$, 1 ipped flakes; $1 \%$, other platform types. Of note, all of the cortex flakes are classified as core reduction technology flakes, and on 1 y $30 \%$ of the interior flakes are classified as core reduction flakes.

of the total 2504 platform flakes, 940 , or $38 \%$ of the collection are core reduction $f 1$ akes, and 1564 , or $62 \%$ are considered biface reduction flakes. These figures contrast rather sharply with the results of similar flake platform studies for two other occupation sites considered in this report, the predominantly Late Prehistoric component sites 41 UV 47 and 41 UV 48 . At these two Late Prehistoric sites approximately $60 \%$ of a 11 the platformed flakes were found to be representative of a core reduction technology, while on 7 y $30 \%$ were considered as derived from a biface reduction technology. In other words, the relative percentages between the two Late Prehistoric sites and the predominantly Archaic component 41 UV 45, are nearly reversed in the amounts of the two considered lithic reduction technologies. While there is no doubt both 1 ithic reduction technologies existed at al1 three sites, it appears that a biface reduction technology dominated at the Archaic site, and core reduction technologies dominated at the two Late Prehistoric occupation sites.

of particular interest is the intrasite distribution of the two represented lithic reduction technologies. It would appear as if biface and core reduction technologies were close to being equaliy represented throughout the excavated midden deposits; with the relative percentages being $42 \%$ core reduction flakes vs. $58 \%$ biface reduction flakes from the larger excavation Units 47-22 and 78-5 and 53\% core reduction flakes vs. $47 \%$ biface reduction flakes for the four smaller test pits. In the terrace area excavations, both 
TABLE 14. SUMMARY OF PLATFORMED FLAKES FROM 41 UV 45

\begin{tabular}{|c|c|c|c|c|c|c|c|}
\hline & \multicolumn{6}{|c|}{ Site Areas } & \multirow[b]{2}{*}{$\begin{array}{l}\text { Grand } \\
\text { Total }\end{array}$} \\
\hline & Unit & $\begin{array}{l}\text { Test } \\
\text { Pit }\end{array}$ & Total & Unit & $\begin{array}{l}\text { Test } \\
\text { Pit }\end{array}$ & Total & \\
\hline \multicolumn{8}{|l|}{ CORE REDUCTION FLAKES } \\
\hline $\begin{array}{l}\text { Cortex Platform } \\
\text { Primary Flakes } \\
\text { Secondary Flakes. }\end{array}$ & $\begin{array}{r}3 \\
62\end{array}$ & $\overline{6}$ & $\begin{array}{r}3 \\
68\end{array}$ & $\begin{array}{r}0 \\
62\end{array}$ & - & $\overline{62}$ & $\begin{array}{r}3 \\
130\end{array}$ \\
\hline Total & 65 & 6 & 71 & 62 & - & 62 & $133(5)$ \\
\hline $\begin{array}{l}\text { Single Facet Platform } \\
\text { Primary Flakes } \\
\text { Secondary Flakes } \\
\text { Interlor Flakes }\end{array}$ & $\begin{array}{r}4 \\
89 \\
155\end{array}$ & $\begin{array}{l}- \\
12 \\
26\end{array}$ & $\begin{array}{r}4 \\
101 \\
181\end{array}$ & $\begin{array}{r}1 \\
63 \\
232\end{array}$ & $\begin{array}{l}- \\
2 \\
8\end{array}$ & $\begin{array}{r}1 \\
65 \\
240\end{array}$ & $\begin{array}{r}5 \\
166 \\
421\end{array}$ \\
\hline Total & 248 & 38 & 286 & 296 & 10 & 306 & $592(24)$ \\
\hline $\begin{array}{l}\text { Large Multiple Facet Platform } \\
\text { Secondary Flakes } \\
\text { Intertor Flakes }\end{array}$ & $\begin{array}{l}22 \\
68\end{array}$ & $\begin{array}{l}4 \\
8\end{array}$ & $\begin{array}{l}26 \\
76\end{array}$ & $\begin{array}{l}26 \\
74\end{array}$ & $\begin{array}{l}1 \\
6\end{array}$ & $\begin{array}{l}27 \\
80\end{array}$ & $\begin{array}{r}53 \\
156\end{array}$ \\
\hline Total & 90 & 12 & 102 & 100 & 7 & 107 & $209(8)$ \\
\hline $\begin{array}{l}\text { Other Platforms } \\
\text { Primary Flakes } \\
\text { Secondary Flakes } \\
\text { Intertor Flakes }\end{array}$ & $\begin{array}{l}0 \\
1 \\
2\end{array}$ & $\begin{array}{l}0 \\
0 \\
0\end{array}$ & $\begin{array}{l}0 \\
1 \\
2\end{array}$ & $\begin{array}{l}0 \\
1 \\
2\end{array}$ & $\begin{array}{l}0 \\
0 \\
0\end{array}$ & $\begin{array}{l}0 \\
1 \\
2\end{array}$ & $\begin{array}{l}0 \\
2 \\
4\end{array}$ \\
\hline Tota1 & 3 & - & 3 & 3 & - & 3 & $6(>I)$ \\
\hline Total Core Reduction Flakes & 406 & 56 & 462 & 461 & 17 & 478 & $940(38)$ \\
\hline \multicolumn{8}{|l|}{ BIFACE REDUCTION FLAKES } \\
\hline $\begin{array}{l}\text { Small Multiple Facet Platform } \\
\text { Secondary Flakes } \\
\text { Interior Flakes }\end{array}$ & $\begin{array}{r}95 \\
442\end{array}$ & $\begin{array}{l}13 \\
31\end{array}$ & $\begin{array}{l}108 \\
473\end{array}$ & $\begin{array}{r}66 \\
857\end{array}$ & $\begin{array}{r}4 \\
27\end{array}$ & $\begin{array}{r}70 \\
884\end{array}$ & $\begin{array}{r}178 \\
1357\end{array}$ \\
\hline Total & 537 & 44 & 581 & 923 & 31 & 954 & $1535(61)$ \\
\hline $\begin{array}{l}\text { Lipped Flakes } \\
\text { Secondary Flakes } \\
\text { Interior Flakes }\end{array}$ & $\begin{array}{r}3 \\
10\end{array}$ & $\begin{array}{l}1 \\
5\end{array}$ & $\begin{array}{r}4 \\
15\end{array}$ & $\begin{array}{l}1 \\
5\end{array}$ & $\begin{array}{l}1 \\
3\end{array}$ & $\begin{array}{l}2 \\
8\end{array}$ & $\begin{array}{r}6 \\
23\end{array}$ \\
\hline Total & 13 & 6 & 19 & 6 & 4 & 10 & $29(1)$ \\
\hline Total Biface Reduction Flakes & 550 & 50 & 600 & 929 & 35 & 964 & $1564(62)$ \\
\hline
\end{tabular}

Note: Parentheses indicate percentage. 
the 1 arger excavation units and the smaller test pits showed $67 \%$ of the platformed flakes were of the biface reduction technology, and $33 \%$ of the platformed flakes were of the core reduction technology. This intrasite distribution suggests that the biface reduction technology was more common in the terrace areas away from the midden. It may be that there was some preferential use of nonmidden areas of the site as activity areas for biface production over the midden areas. An alternative explanation is that the concentration of excavated Late Prehistoric and Late Archaic (Twin Sisters phase) components in the northern midden area reflects a biasing for the overrepresentation of a core reduction technology which was more clearly expressed at the two Late Prehistoric sites 41 UV 47 and 41 UV 48.

\section{Burned Rock}

Burned rock from the site was recorded for all units and test pits by counting the number of fist-sized or larger stones. Additionally, the weight of all the burned rock was recorded for the unit-levels. After these data were recorded, the burned rock was discarded in the field. The burned rocks generally consisted of fist-sized or larger, angularly fractured, gray limestone specimens, but the size range varied considerably from about $3 \mathrm{~cm}$ to $20 \mathrm{~cm}$ in size. The actual counts by unit-levels are presented in Table 15. Table 15 also shows estimated counts or weights per cubic meter for the different unit-levels; these figures were obtained by dividing the actual count or weight by the volume of fill removed from the unit-levels.

Table 15 shows that the burned rock counts were relatively consistent within the individual units and test pits excavated through the midden deposits, and "peaks" of maximum counts can be seen occurring in the second or third levels (ca. 20-60 cm below the ground surface). Actual counts ranged from 0 to 150 in the test pits, and from 22 to 2119 in the excavation units. The average estimated counts per cubic meter for the unit and test pits, however, showed a much more restricted range of variation within the midden, from 1255 to 1873.3 burned rocks per cubic meter over six different units and test pits. The recorded weight for Units 47-22 and 78-5 varied from 4.7 to a maximum of $424.3 \mathrm{~kg}$ per unit-level, with estimated average weight per cubic meter $294.8 \mathrm{~kg}$ in Unit 47-22 and $369.0 \mathrm{~kg}$ for Unit 78-5. The counts and weights per cubic meter within the midden area suggest a rather uniform burned rock composition throughout the extent of the midden areas.

Looking at the terrace area figures in Table 15 shows a much wider range of variation, with counts varying from 0 to 160 burned rocks in the unit and test pit levels. The counts per cubic meter also varied considerably, from 0 to 288.1. Counts for the recorded features varied from 112 specimens in Feature 1 to a maximum of 304 in Feature 4. The weights per cubic meter for Units 96-11, 125-6, and 155-16 also varied considerably, from $14.1 \mathrm{~kg}$ in Unit 155-16 to $144.7 \mathrm{~kg}$ in Unit 96-11. In summary, burned rock frequencies were very high and relatively consistent throughout the midden deposits at the site, and tended to be quite variable and relatively low within the terrace deposits. 
TABLE 15. SUMMARY OF EXCAVATED BURNED ROCK AT 41 UV 45

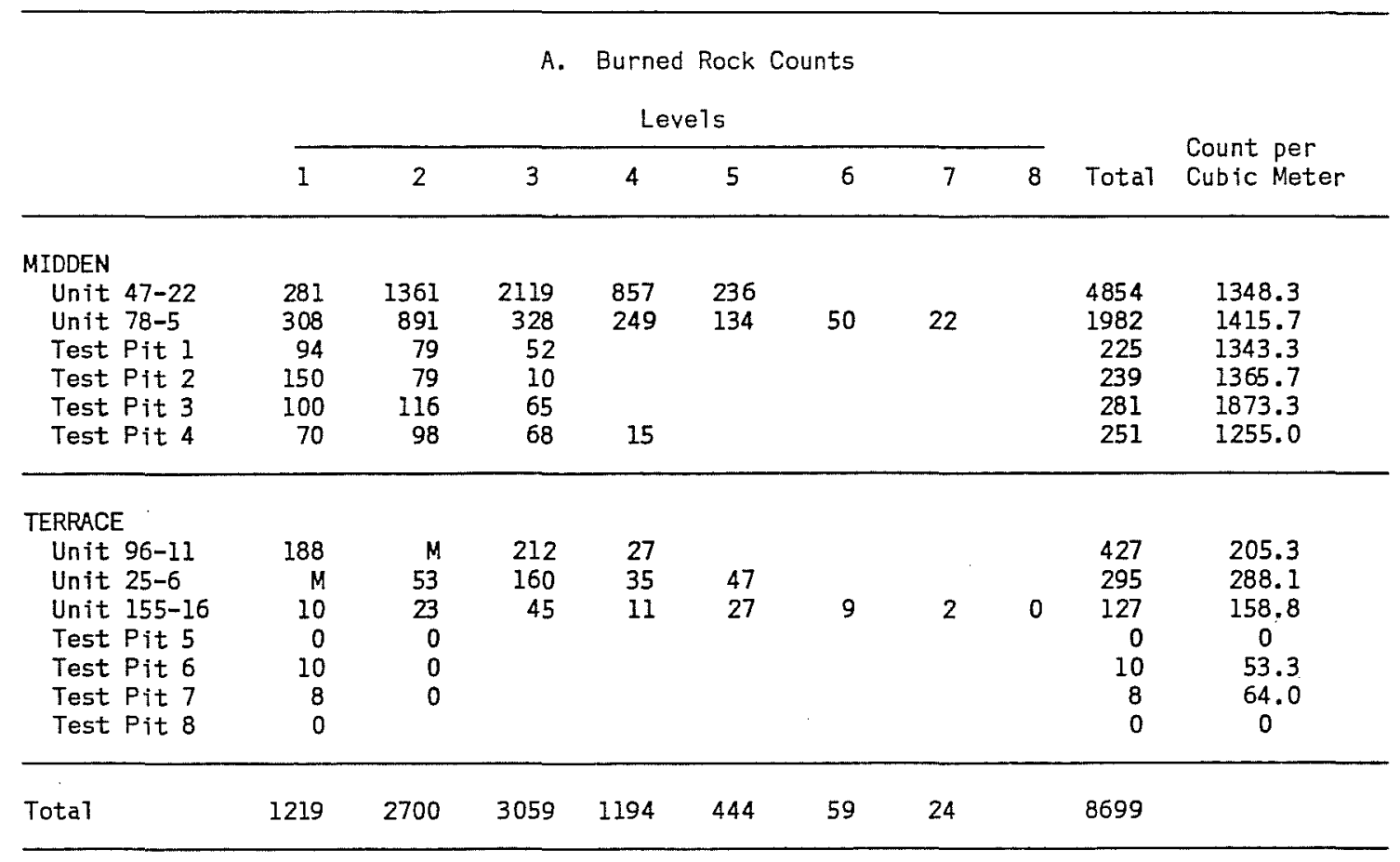

B. Burned Rock Weights in Kilograms

\begin{tabular}{|c|c|c|c|c|c|c|c|c|c|}
\hline \multicolumn{8}{|c|}{ Levels } & \multirow[b]{2}{*}{ Total } & \multirow{2}{*}{$\begin{array}{l}\text { Weight per } \\
\text { Cubic Meter }\end{array}$} \\
\hline$I$ & 2 & 3 & 4 & 5 & 6 & 7 & 8 & & \\
\hline
\end{tabular}

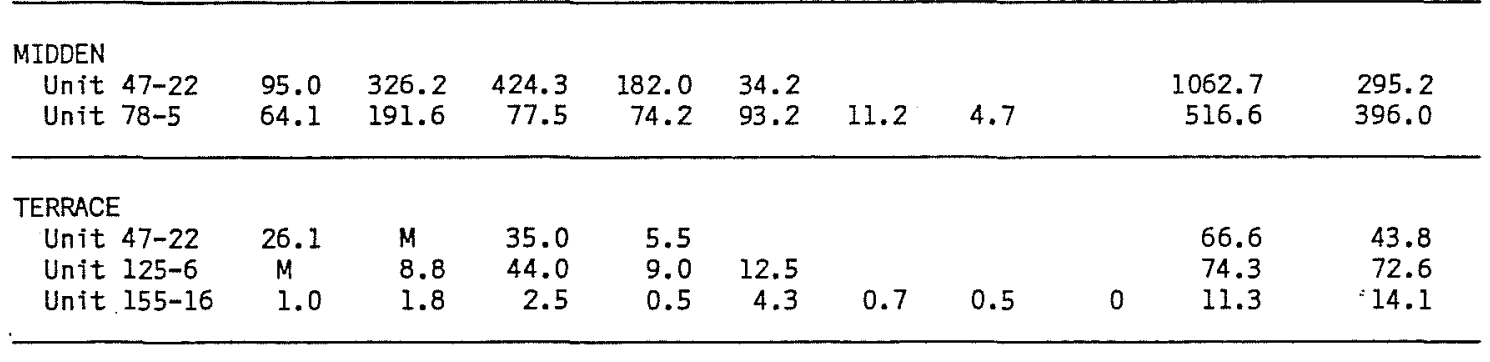

$M=$ Data is missing 


\section{PLANT AND ANIMAL REMAINS}

The following summarizes the faunal, snail, mussel, and wood species identifications recorded for 41 UV 45 . Each grouping is discussed separately.

\section{Faunal Remains}

A total of 182 specimens of unmodified bone was recovered from 41 UV 45 . The provenience for the faunal remains recovered from the site is provided in Table 16. The majority of the faunal remains, (86\%; 157 specimens) were recovered from Unit 47-22. Of the remaining specimens, a71 but two were found within the midden deposits; six were from Unit 78-5, and 17 were from Test Pit 1. The two specimens recovered from the terrace area excavations were identified as a fish bone fragment from the upper portion of the exposed profile of Backhoe Trench 4. The single identifiable bone from within the midden area was from Level 2 of Test Pit 1; the specimen was identified as from cottontail rabbit. In addition to the three identified unmodified bone specimens, two modified bone specimens were recorded: a deer ulna tool from Leve1 4 of Unit 47-22, and an aw1 section recovered from Backhoe Trench 2.

As Table 16 shows, most of the remaining faunal material was recovered from Levels 3 and 4 of Unit 47-22, about $71 \%$ of the total collection from the site. Only $6 \%$ of the unmodified bone was burned; al1 11 specimens were recovered from Unit 47-22.

Although the number of faunal remains from the site was small, most were concentrated in the northern midden area, represented by the relatively large

TABLE 16. DISTRIBUTION OF UNMODIFIED BONE AT 41 UV 45

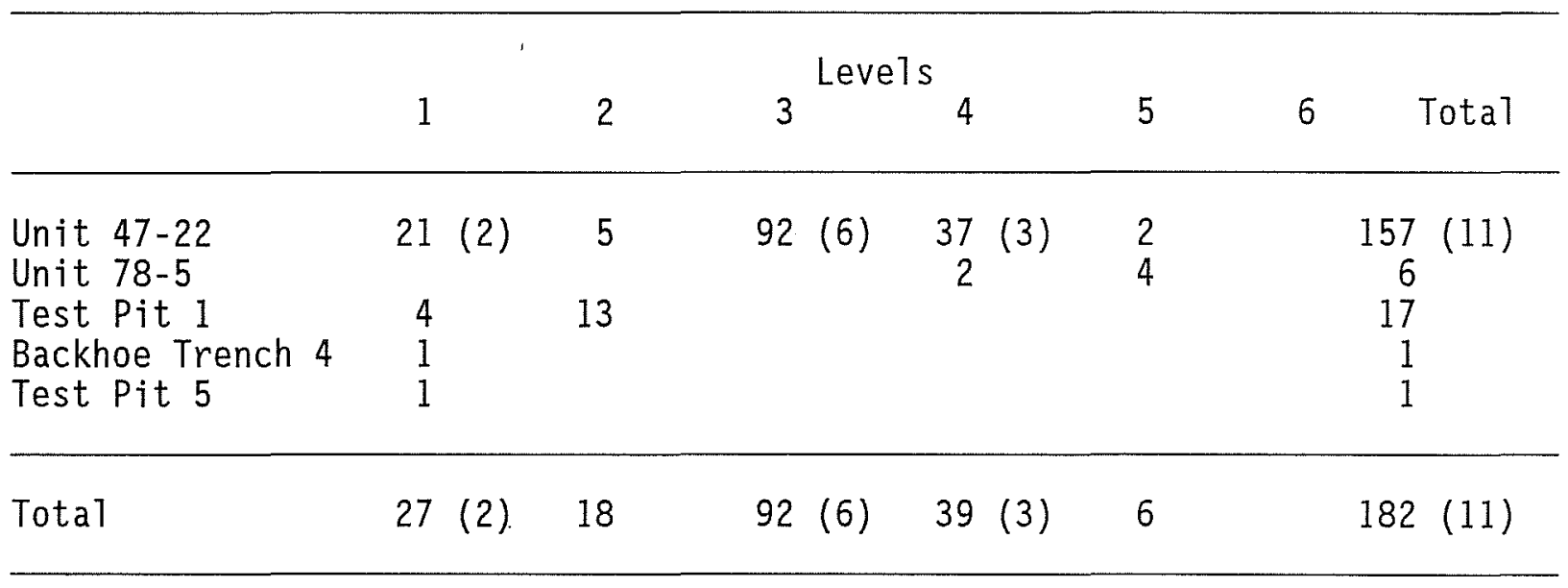

Note: Numbers in parentheses are burned bone. 
recovery rate from Unit 47-22. It may be that this area of the site served as an animal processing or discard area during the Late Archaic (Twin Sisters phase) and/or Late Prehistoric periods.

\section{Freshwater Musse1 She11s}

Mussel shel1 remains, unionids, were present only in trace amounts from the site. Within the midden area excavations, a few small fragments of mussel shel1 were recovered from the following proveniences: Levels 3 and 4 of Unit 47-22, Level 6 of Unit 78-5, and Level 2 of Test Pit 2. Within the terrace deposits, mussel she11 fragments were recovered from the following unitleve1s: Levels 2 and 4 of Unit 96-11, Level 3 of Unit 125-6 (some of the fragments from this level were burned), and Levels 1-3 of Unit 155-16. The scarcity of freshwater mussel shell remains at the site is not really surprising, as most other organic material that may have been expected at the site is also scarce, but the presence of mussel shells at the site can be used to infer at least a minor food resource.

\section{$\underline{\text { Snai1s }}$}

Snail shells were collected from all hand excavations, and the analys is describes their horizontal distribution within the site. While the $1 / 4$-inch mesh screens used during the course of excavations may have allowed some of the smaller sized specimens to be lost within the sample, those that were recovered are briefly discussed. Provenience data for the various species are presented in Table 17.

In order to make meaningful comparisons between the different excavation units and test pits, counts per cubic meter were calculated for each unit and test pit by dividing the actual counts for each species by the volume of excavated fill from each unit. The results of these calculations are summarized in Table 18. The summary shows a difference in the number of Rabdotus sp. found in the northern and southern midden excavation areas. In the southern midden excavation area, which includes Unit 78-5, Test Pit 3, and Test Pit 4, the number of Rabdotus sp. ranges from 118 specimens in Unit 78-5 to a maximum of 153 specimens in Test Pit 3 . These figures contrast sharply with the totals for the northern midden area excavations (Unit 47-22, Test Pit 1, and Test Pit 2), which are much 10 wer, with a minimum of 46 in Test Pit 2 to a maximum of 55 in Test Pit 1 . The horizontal distinction within the midden areas suggests there may be some differences in the northern and the southern areas. Notably, the counts for the northern midden area excavations (from 46 to 55 specimens per cubic meter) are very similar to the counts from the terrace area excavations. Rabdotus sp. from the terrace excavations varies from five specimens in Test Pits 6 and 8 to a maximum of 60 specimens in Unit 96-11; the average for the terrace excavations is 50 specimens per cubic meter.

Helicina sp. varied considerable within the site, but was overall the second most common snail species represented at the site. Helicina sp. ranged from a minimum of 11 specimens per cubic meter in Test Pit 2 to a maximum of 43 specimens per cubic meter in Test Pit 1 within the midden area excavations. 
TABLE 17. DISTRIBUTION OF SNAIL SHELLS FROM 41 UV 45

\begin{tabular}{|c|c|c|c|c|c|}
\hline Unit/Leve1 & Rabdotus & Polygyra & Helicina & Other & $\begin{array}{l}\text { Leve } 1 \\
\text { Total }\end{array}$ \\
\hline \multicolumn{6}{|l|}{ Unit $47-22$} \\
\hline Level 1 & 12 & & 54 & & 66 \\
\hline Level 2 & 24 & & 25 & & 49 \\
\hline Level 3 & 92 & 1 & 9 & & 102 \\
\hline Level 4 & 47 & & 2 & & 49 \\
\hline Level 5 & 5 & & 1 & & 6 \\
\hline Unit Totals & 180 & 1 & 91 & & 272 \\
\hline \multicolumn{6}{|l|}{ Unit 78-5 } \\
\hline Level 1 & 1 & 1 & 12 & & 14 \\
\hline Level 2 & 15 & & 6 & & 21 \\
\hline Leve1 3 & 40 & 1 & 2 & & 43 \\
\hline Level 4 & 52 & & 5 & & 57 \\
\hline Leve] 5 & 21 & 2 & 2 & & 25 \\
\hline Level 6 & 18 & & & & 18 \\
\hline Level 7 & 18 & & 6 & & 24 \\
\hline Unit Totals & 165 & 4 & 33 & & 202 \\
\hline \multicolumn{6}{|l|}{ Test Pit 1} \\
\hline Leve1 1 & 8 & 1 & 6 & & 15 \\
\hline Level 2 & & & & & \\
\hline Leve1 3 & 1 & & 1 & & 2 \\
\hline Unit Totals & 9 & 1 & 7 & & 17 \\
\hline \multicolumn{6}{|l|}{ Test Pit 2} \\
\hline Level 1 & 2 & & & & 2 \\
\hline Level 2 & 4 & & 2 & & 6 \\
\hline Level 3 & 2 & & & & 2 \\
\hline Unit Totals & 8 & & 2 & & 10 \\
\hline \multicolumn{6}{|l|}{ Test Pit 3} \\
\hline Level 1 & 6 & & & & 6 \\
\hline Level 2 & 14 & & 2 & & 16 \\
\hline Level 3 & 3 & & & & 3 \\
\hline Unit Totals & 23 & & 2 & & 25 \\
\hline
\end{tabular}


TABLE 17. (continued)

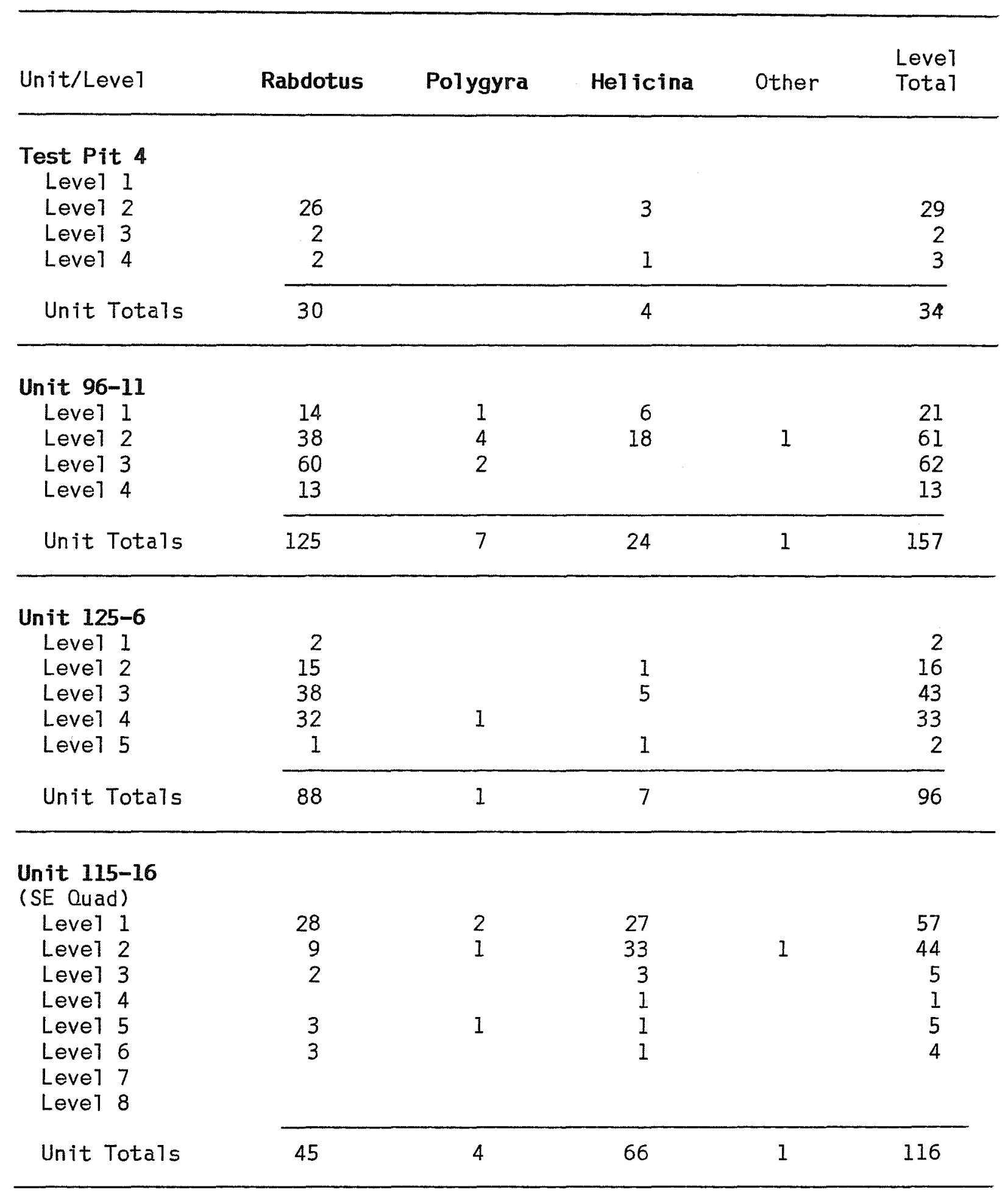


TABLE 17. (continued)

\begin{tabular}{|c|c|c|c|c|c|}
\hline Unit/Leve1 & Rabdotus & Polygyra & Helicina & Other & $\begin{array}{l}\text { Leve } \\
\text { Total }\end{array}$ \\
\hline \multicolumn{6}{|l|}{$\begin{array}{l}\text { Unit } 115-16 \\
\text { (SW, NW, NE) }\end{array}$} \\
\hline Level 1 & 11 & 3 & 14 & & 28 \\
\hline Leve1 2 & 8 & 6 & 3 & & 17 \\
\hline Leve1 3 & 10 & 1 & 1 & & 12 \\
\hline Unit Totals & 29 & 10 & 18 & & 57 \\
\hline \\
\hline $\begin{array}{ll}\text { Leve1 } 1 \\
\text { Leve1 } & 2\end{array}$ & 3 & & 2 & & 5 \\
\hline Unit Totals & 3 & & 2 & & 5 \\
\hline \multirow{2}{*}{\multicolumn{6}{|c|}{$\begin{array}{l}\text { Test Pit } 6 \\
\text { Level } 1\end{array}$}} \\
\hline & 1 & & 1 & & 2 \\
\hline $\begin{array}{l}\text { Level } 2 \\
\text { Level } 3\end{array}$ & & 1 & & & 1 \\
\hline Unit Totals & 1 & 1 & 1 & & 3 \\
\hline \multicolumn{6}{|l|}{ Test Pit 7} \\
\hline Level 1 & 4 & 1 & 2 & & 7 \\
\hline Leve1 2 & 2 & & 3 & & 5 \\
\hline Unit Totals & 6 & 1 & 5 & & 12 \\
\hline \multicolumn{6}{|l|}{ Test Pit 8} \\
\hline Level 1 & 1 & & 18 & & 19 \\
\hline Unit Totals & 1 & & 18 & & 19 \\
\hline
\end{tabular}


TABLE 18. SUMMARY OF SNAIL SHELL BY UNIT AT 41 UV 45

\begin{tabular}{|c|c|c|c|c|c|c|c|c|c|c|c|c|c|}
\hline \multirow[b]{2}{*}{ She11 } & \multirow[b]{2}{*}{$\begin{array}{l}\text { Unit } \\
47-22\end{array}$} & \multirow[b]{2}{*}{$\begin{array}{l}\text { Unit } \\
78-5\end{array}$} & \multicolumn{3}{|c|}{ Midden } & \multirow[b]{2}{*}{$\begin{array}{l}\text { Test } \\
\text { Pit } 4\end{array}$} & \multirow{2}{*}{$\begin{array}{l} \\
\text { Unit } \\
96-11\end{array}$} & \multirow[b]{2}{*}{$\begin{array}{l}\text { Unit } \\
125-6\end{array}$} & \multicolumn{2}{|c|}{ Terrace } & \multirow[b]{2}{*}{$\begin{array}{l}\text { Test } \\
\text { Pit } 6\end{array}$} & \multirow[b]{2}{*}{$\begin{array}{l}\text { Test } \\
\text { Pit } 7\end{array}$} & \multirow[b]{2}{*}{$\begin{array}{l}\text { Test } \\
\text { Pit } 8\end{array}$} \\
\hline & & & $\begin{array}{l}\text { Test } \\
\text { Pit } 1\end{array}$ & $\begin{array}{l}\text { Test } \\
\text { Pit } 2\end{array}$ & $\begin{array}{l}\text { Test } \\
\text { Pit } 3\end{array}$ & & & & $\begin{array}{l}\text { Unit } \\
155-16\end{array}$ & $\begin{array}{l}\text { Test } \\
\text { Pit } 5\end{array}$ & & & \\
\hline Rabdotus & 50 & 118 & 55 & 46 & 153 & 150 & 60 & 48 & 56 & 30 & 5 & 32 & 5 \\
\hline Polygyra & 0.3 & 3 & 6 & & & & 3 & 0.5 & 5 & & 5 & 5 & \\
\hline Hel icina & 25 & 24 & 43 & 11 & 13 & 20 & 12 & 4 & 83 & 20 & 5 & 27 & 82 \\
\hline Succinia & & & & & & & 0.5 & & & & & & \\
\hline Hel isoma & & & & & & & 1 & & 1 & & & & \\
\hline Tota1 & 75.3 & 145 & 104 & 57 & 166 & 170 & 75.5 & 52.5 & 145 & 50 & 15 & 64 & 87 \\
\hline
\end{tabular}

Note: Figures show estimated counts per cubic meter excavated. 
The overall average number of Helicina sp. per cubic meter within the midden excavations was 24 specimens. In the terrace area excavations, Helicina sp. counts ranged from five specimens per cubic meter in Test Pit 6 to 83 specimens in Unit 155-16. The average estimated total for Helicina sp. per cubic meter in the terrace deposits was 23 specimens, nearly the same total as for the midden area excavations.

Polygyra sp. occurred infrequently throughout the site, totaling only about $2 \%$ of the total snail collection. Estimated counts per cubic meter for the midden area excavations and terrace area excavations were one and three specimens, respectively. The remaining two snail species recorded for the site, Succinia sp. and Helisoma sp. were represented by single specimens each. The Succinia sp. was recovered from Level 2 of Unit 96-11, and the Hel isoma sp. was recovered from Level 2 in the southeast quadrant of Unit 155-16.

The vertical distribution of snails at the site offers little distinct data. Within the midden area excavations, Rabdotus sp. showed a rather steady tendency to "peak" in the middle levels of the two excavated units, with maximum estimated counts per cubic meter of 115 specimens in Level 3 of Unit 47-22 and 260 specimens in Level 4 of Unit 78-5. In the test pits excavated through the midden deposits, Rabdotus sp. were always the most common in Level $2(20-40 \mathrm{~cm}$ or $25-50 \mathrm{~cm}$ below the ground surface). Helicina sp., in general, tended to co-vary with the Rabdotus sp. throughout the levels within the test pits; however, in Units 47-22 and 78-5, Helicina sp. was found to be most common in the first level of both units and then steadily decreased in number with depth.

In summary, there was some indication at the site that Rabdotus sp. exhibited the only significant differentially distributed snail species within the site, being most common in the southern midden excavation area, and rather equally distributed between the northern midden area excavations and the terrace area excavations, but in much smaller numbers than were recorded for the southern midden area excavations. An unusually high number of Helicina sp. recorded within Unit 155-16 was not found to be associated with any significant cultural manifestation. Although little can be said of the vertical distribution of snails within the site, there was a general tendency for them to "peak" in the range of 20 to $60 \mathrm{~cm}$ below the ground surface. Finally, Rabdotus sp. and Helicina sp. were most common throughout the site, representing 69 and $27 \%$, respectively, of the whole sample. Polygyra sp., Succinia sp., and Helisoma sp. were present in small amounts at the site.

\section{Wood Species Identification}

A total of $16.58 \mathrm{~g}$ of wood charcoal from the site was sent to consultant Donna Lannie of Mesquite, Texas, for species identification. Her identifications are utilized to summarize the intrasite distributions expressed at 41 UV 45. Of the $16.58 \mathrm{~g}$ sent for identification, $15.93 \mathrm{~g}$ were examined; the remaining $0.65 \mathrm{~g}$, passed through a $3.35-\mathrm{mm}$ screen, were excluded from the sample due to the small size of the individual specimens. The results of Lannie's analysis are summarized for the site in Table 19. 
TABLE 19. WOOD SPECIES IDENTIFICATIONS FOR 41 UV 45

a. Identifications by Weight

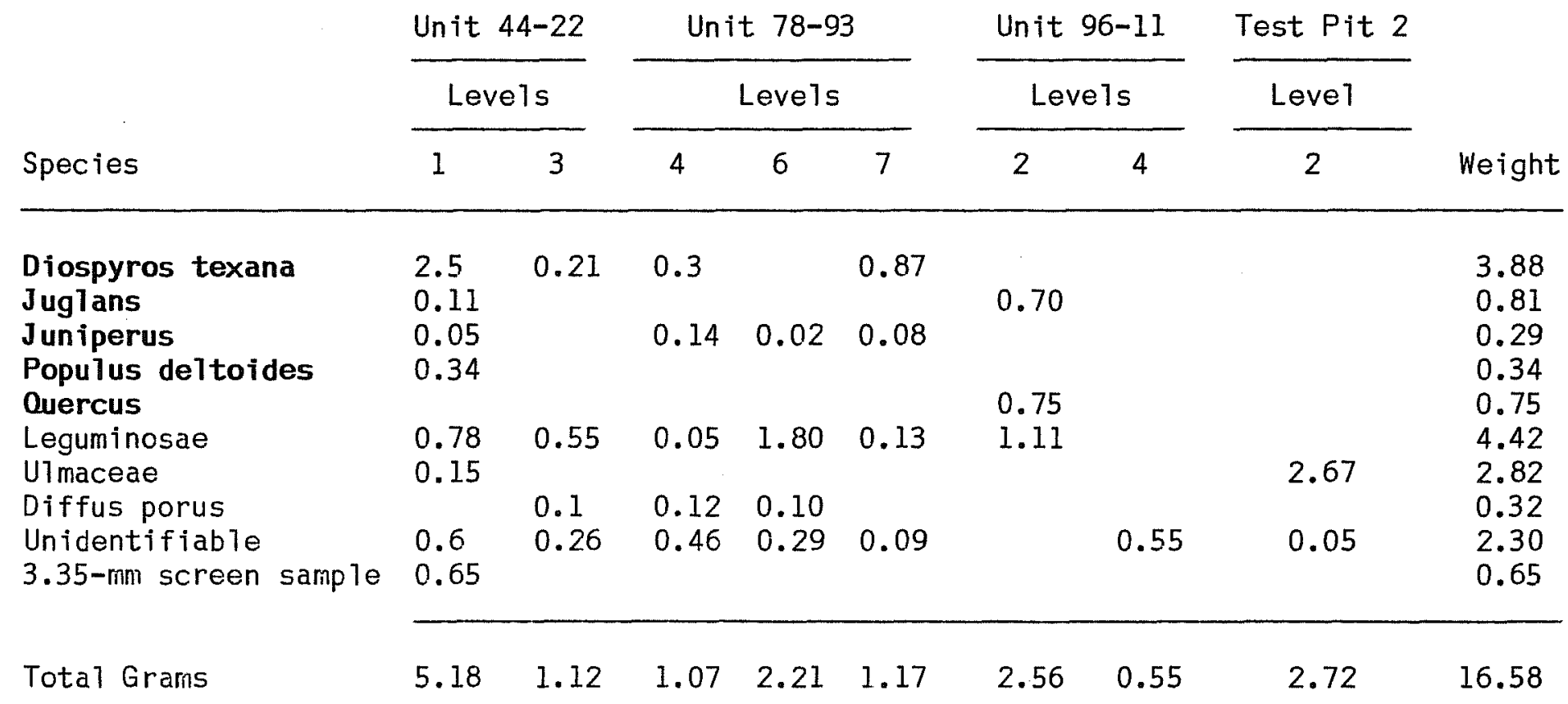


b. Comparison of Relative Percentages by Site Context

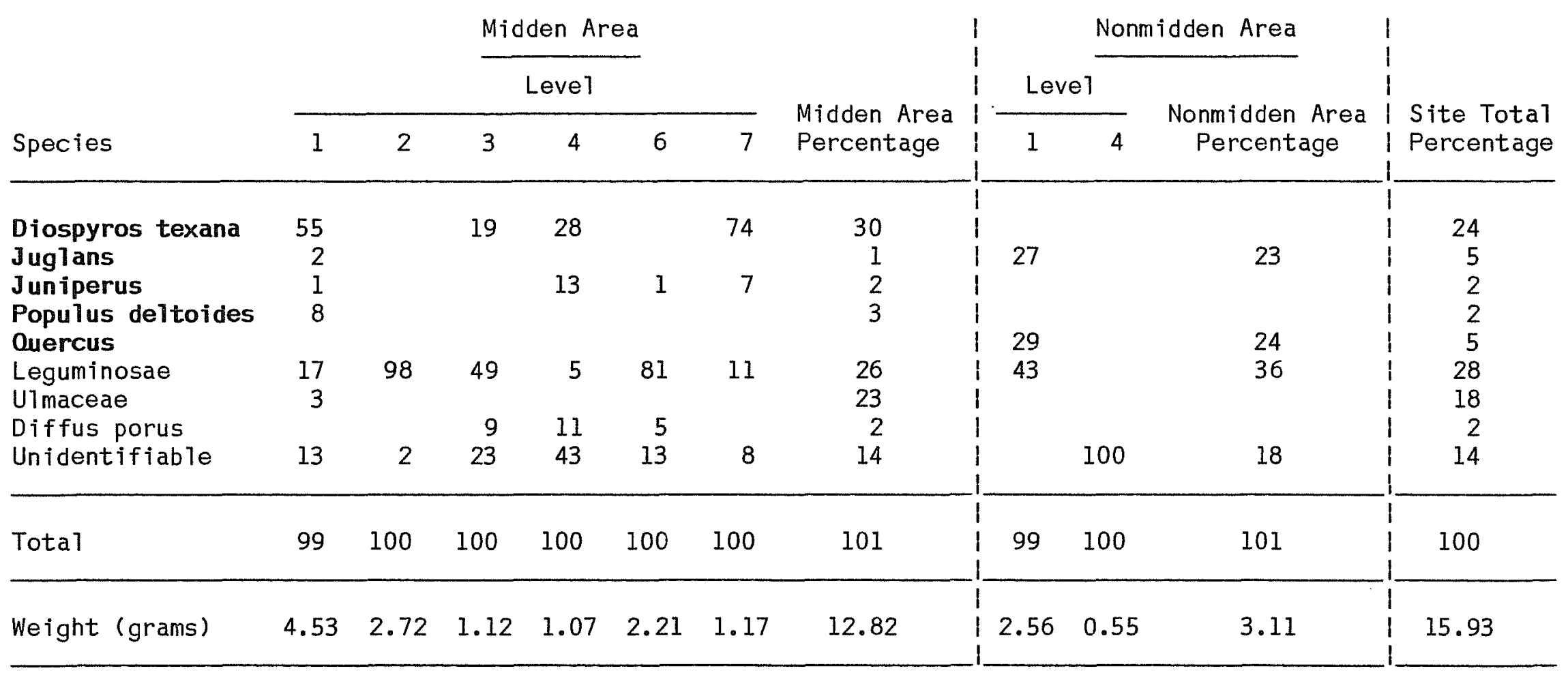


Eight categories other than unidentifiable were identified. These categories, in order of frequency were: Leguminosae, including Acacia spp., Prosopis spp. (mesquite), Gleditsia tricanthos L. (common honeylocust), and Cercis canadensis L. (red bud) with $4.42 \mathrm{~g}$ ident ified; Diospyros texana (Texas persimmon) with $3.88 \mathrm{~g}$ identified; Ulmaceae, including U1mus (elm) and Celtis (hackberry) with $2.82 \mathrm{~g}$ identified; Juglans spp. (walnut) with $0.81 \mathrm{~g}$ identified; Quercus spp. (oak) with $0.75 \mathrm{~g}$ identified; Populus deltoides (cottonwood) with $0.34 \mathrm{~g}$ identified; diffus-porus wood, primarily woods from Acer, Platanus occidentalis, Populus deltoides, and Salix, with $0.32 \mathrm{~g}$ identified; and Juniperus spp. (juniper) with $0.29 \mathrm{~g}$ identified. In all, $13.63 \mathrm{~g}$ were $\mathrm{placed}$ into one of these categories, the remaining $2.3 \mathrm{~g}$ were unidentifiable.

Texas persimmon and legumes were the most commonly identified plants from the site, comprising approximately $24 \%$ and $28 \%$ of the total weight submitted for analysis. Ulmaceae was also relatively common, comprising approximately $18 \%$ of the total collection. The remaining wood charcoal identifications, including walnut, cottonwood, oak, juniper, and diffus-porus woods each comprised $5 \%$ or less of the total weight of identified charcoal specimens. A11 of the specimens that were identified at the site are in the area at present, if not in the immediate area of the site, and so suggest little indication of environmental change over time.

In summary, the intrasite distributional patterns of the identified wood species are utilized, in that the described patterns may reflect both sampling and/or preservation biases; specimens were collected usually during the course of screening, and charcoat specimens outside of the midden areas were relatively uncommon. Most of the wood charcoal specimens, $13.47 \mathrm{~g}$ or $81 \%$ of the total weight of the collection, were recovered from the midden area excavations; only $3.11 \mathrm{~g}$ of wood charcoal submitted for identification came from the terrace deposits, and this was all from Levels 2 and 4 of Unit 96-11. From the midden areas, al1 wood charcoal categories except oak were identified, and Texas persimmon, juniper, and legumes were the only categories found in both the northern and southern midden areas. Walnut, cottonwood, and Ulmaceae were identified in the northern midden area in addition to those categories already noted. Outside of the midden areas, in Unit 96-11, walnut, oak, and legumes were identified.

To summarize, Quercus spp. was found only within the terrace deposits, Leguminosae occurred both in midden and terrace deposits, Diospyros texana and Juniperus spp. were recorded from midden contexts only, Populus deltoides and UTmaceae occurred in only the northern midden area excavations, and Juglans spp. was identified from the north midden area and terrace deposits. The relative abundance of both Diospyros texana and UTmaceae in the midden area excavations, while totally absent from the terrace deposits, stands out and may suggest some possibilities of a difference in the intrasite utilization of these woods, but a larger sample, especially from the terrace deposits, is needed to study the question.

While little suggestion of environmental change over time, or intrasite variations can be postulated from the available sample, some of the wood charcoal identified at the site may be used to suggest possible food resources. In particular, Juglans spp. and Quercus spp. are nut producers, 
Diospyros texana has an edible fruit, and some of the Leguminosae and UTmaceae have seeds that could have been used as a food source. Importantly, the presence of ground stone implements at the site suggests plant processing was a part of the site function.

\section{RADIOCARBON DATES}

Three wood charcoal samples from site 41 UV 45 were submitted to the Radiocarbon Laboratory at the Balcones Research Center, Austin, Texas, for assay. The three samples were chosen in hopes of providing absolute dates from specific contexts within the site relevant to determining overall site chronology. The results of the assays are shown in Table 20; both the uncorrected B.P. date and the MASCA corrected dates (Ralph, Michael, and Han 1973) are provided. Two of the samples, TX-4432 and TX-4434 were collected from different levels of Unit 47-22.

Sample number TX-4432 was taken from Level $2(20-40 \mathrm{~cm})$ of Unit 47-22 and was associated with a Perdiz arrow point preform and a Marshall dart point. The date expected from the sample was one corresponding to the Late Archaic Twin Sisters phase (A.D. 200-700); thus reflecting what was hypothesized as the later portion of the predominantly Archaic midden accumulations. Similarly, TX-4434 was taken from Level $4(60-80 \mathrm{~cm})$ of Unit $47-22$, and it was expected to date sometime during the Late Archaic (650 B.C. to A.D. 200). The sample was associated with the lower levels of an unstratified midden resting on a solid limestone bedrock base. As is discussed later, both assays provided dates much later than expected. The third sample, TX-4433, was taken from Level 3 (30-50 cm) of Unit 96-11. The sample was associated with an overall increase in debitage, a Kinney projectile point, and more generally with Feature 5. A Middle Archaic date (2000 B.C. to 650 B.C.) was expected from the sample. Although TX-4433 was the earliest date reported for the site, the assay was much younger than expected. A brief summary for each of the samples follows.

$\underline{T X-4432}(410 \pm 50$ B.P.)

The sample consisted of wood charcoal collected from throughout Level 2 of Unit 47-22. The unit-level contained a Late Prehistoric, Toyah phase Perdiz arrow point preform and a Marshall dart point. Other artifacts from this level are identified as four bifacial intergrades, one ovate and three asymmetrical forms, and an other biface miscellaneous fragment. Three arrow points and two dart points were recovered from the unit-level immediately following Level 2. Because of the location below a number of Late Prehistoric arrow points and above Late Archaic or later dart points, a date between A.D. 200 and A.D. 700 (the generally acknowledged dates for the Late Archaic in central Texas) was expected. The later date suggests the level should be assigned to the Late Prehistoric period. 
TABLE 20. RADIOCARBON DATES FROM 41 UV 45

\begin{tabular}{llcr}
\hline $\begin{array}{l}\text { Laboratory } \\
\text { Number }\end{array}$ & Provenience & $\begin{array}{c}\text { Uncorrected } \\
\text { Date (B.P.) }\end{array}$ & $\begin{array}{c}\text { MASCA } \\
\text { Date* }\end{array}$ \\
\hline TX-4432 & Unit 47-22, Leve1 2 & $410 \pm 50$ & A.D. 1440 \\
TX-4433 & Unit 96-11, Leve1 3 & $2080 \pm 70$ & $100-10$ B.C. \\
TX-4434 & Unit 47-22, Leve7 4 & $1060 \pm 60$ & A.D. 950 \\
\hline
\end{tabular}

*Ralph, Michael, and Han 1973

$\underline{\mathrm{TX}-4434}(1060 \pm 60$ B.P.)

The sample was collected from throughout Level 4 of Unit 47-22. Although the sample was not directly associated with any diagnostics, there was a number of artifacts collected from the level. The artifacts are identified as an overall retouch rounded biface fragment, a bifacially retouched flake fragment, two bifacial intergrades, three other bifaces, a side retouched uniface, an unidirectional core, and a grinding slab fragment. Dart points from the preceding unit-level are identified as one Ensor, Variety 1, two Frio types, one Marcos, and an unidentifiable fragment. A single Edwards arrow point was also recovered from the preceding level above the charcoal sample. Considering the sample of dart points found above the sample, it was thought that the expected date for this level of the midden deposits would be sometime within the Late Archaic period. However, the assay suggests a date within the Late Prehistoric/Austin phase of central Texas (Prewitt 1981). The late date may indicate that the Archaic period lasted 1onger in this region than in other parts of central Texas. In the Choke Canyon area of southern Texas, a series of radiocarbon dates indicates that the "Late Archaic" may not have began until A.D. 1200 (Ha11, Black, and Graves 1982). Weir (1976) has also suggested that the Late Archaic may overlap the Late Prehistoric in central Texas by as much as 700 years.

\section{$\underline{\text { TX-4433 }}(2080 \pm 70$ B.P. $)$}

The charcoal sample was collected from throughout Level $3(30-50 \mathrm{~cm})$ of Unit 96-11, and was the on 1 y sample submitted from the terrace deposits. The sample provided the earliest date recorded for 41 UV 45 . Associations with the sample included an increased debitage count, one Kinney dart point, an overal1 retouch large triangular concave base biface form, and Feature 5 (29$36 \mathrm{~cm})$. Because of the Kinney dart point, a minor Middle Archaic type (Hester 1971; Weir and Doran 1980), a date of 640-240 B.C. was expected. However, the corrected date of 100-10 B.C. would place the sample from the Late Archaic period. As was the case with another sample from the site $(T X-4434)$, the unusual1y late date may suggest the Middle Archaic lasted 
longer in this region than it did in other parts of central Texas. Hester (1971) reported a date as late as A.D. 100 (TX-692) for the latter part of the Middle Archaic at the La Jita site, and Weir and Doran (1980) reported a date as 1 ate as 260 B.C. (TX-2380) from the Middle Archaic component at the Anthon site.

\section{SUMMARY AND DISCUSSION}

The chronology, nature and extent of deposits, and the subsistence strategies expressed at the site are summarized in the following pages.

\section{Chronology}

A relative chronology for the site is based primarily upon the identification of the various projectile points recovered. In addition, three radiocarbon dates were obtained from different levels within the site, providing a series of absolute dates to supplement the relative chronology. The site contained multicomponents, with periods from the Early Archaic to the Late Prehistoric represented.

The projectile points found on the surface and during the excavations provide the most important evidence to build a site chronology. Overall, Archaic dart points were more common at the site, but a small number of Late Prehistoric artifacts (arrow points and ceramics) were also collected. Forty projectile points were recovered at the site; six specimens are arrow points, and 34 specimens are dart points. Of the 34 dart points, 23 specimens can be used for dating purposes; the identified dart points are 13 Late Archaic specimens (Ensor, Frio, Marcos, Monte11, Castroville, and Marshall types), nine Middle Archaic types (Pedernales, Kinney, La Jita, Langtry, and Nolan), and one Early Archaic specimen (an Early Corner Notched type). Five of the six arrow points are identified as diagnostic of the three phases of the Late Prehistoric: two Perdiz types (Toyah phase), two Scallorn types (Austin phase), and an Edwards (Turtle Creek phase).

The arrow points suggest Late Prehistoric occupations occurred at the site between A.D. 700 and A.D. 1750. A single radiocarbon sample associated with the Late Prehistoric deposits suggests a date of A.D. 1440 (TX-4432). Notably, the sample, and virtually all of the Late Prehistoric cultural material, were concentrated in the northern midden area.

Twelve of the 23 dart points used to date the site were from excavated contexts; of these excavated specimens, most are Late Archaic types, and three are Middle Archaic types. Based upon the relative frequency and contexts of these types, the site is interpreted as primarily a Late Archaic to Middle Archaic component site. Two radiocarbon dates relevant to these Archaic components provide dates of A.D. 950 (TX-4434) and 100-10 B.C. (TX-4433). The later date is associated with a number of Late Archaic dart point types (Ensor, Frio, Marcos) from the northern midden area. The earlier date is associated with a Kinney type. Although this earlier date of 100-10 B.C. is younger than the commonly recognized cut off date for the Middle Archaic of central and south Texas, other radiocarbon dates from the county, 
specifically those from the La Jita site (TX-692) and the Anthon site $(T X-2380)$, may suggest the Middle Archaic lasted longer in this region than in other parts of Texas.

In summary, regional chronologies and radiocarbon dates suggest that 41 UV 45 was a multicomponent site. Primary occupations were Late Archaic and Middle Archaic, dating between A.D. 950 to 100 B.C. A 1 imited Late Prehistoric occupation existed in some areas of the site and is dated at approximately A.D. 1440 .

\section{Site Nature and Extent}

The use of controlled surface collections and mechanical and hand excavations showed natural soil and cultural deposits were represented by burned rock middens and terrace soils over an area approximately $150 \times 150 \mathrm{~m}$. These activities defined the site boundaries and revealed characteristic traits to describe the overall nature of the site area.

Cultural materials were collected from the surface throughout the site area, but appeared to be most common on the middens and terrace areas close to the middens. In areas of the site where bedrock was exposed on the surface or very close to the surface, cultural materials were not frequently found. $A$ $10 \%$ random sample of $10-\mathrm{m}^{2}$ units gridded over the site showed that in the 22 units examined, cultural material was found in a11. A total of 73 artifacts was collected from the sampling, and an average 1ithic debitage density of 27 specimens per unit was recorded. The actual counts per individual unit, however, vary from 2 to 82 debitage specimens. The heaviest debitage and tool densities were recorded in the central area of the site just east of the burned rock middens. Spatial analysis of the cultural materials does not reveal any distinct associations among the various artifact groupings.

The total amount of fill excavated at the site was $51.64 \mathrm{~m}^{3}$, with over $66 \mathrm{~m}^{2}$ of surface area exposed by hand and mechanical excavations. During hand excavations, $12.47 \mathrm{~m}^{3}$ of fill were removed, and the total surface area exposed by this method was $18.15 \mathrm{~m}^{2}$.

The excavations defined the horizontal and vertical extent of the burned rock middens, and revealed the nature of the cultural and natural soil depositions. Two midden areas were present; the southern midden area measured ca. $15 \times 33 \mathrm{~m}$ in size and was a maximum of $140 \mathrm{~cm}$ deep, and the northern midden area measured $25 \times 40 \mathrm{~m}$ and was a maximum of $100 \mathrm{~cm}$ deep. Both midden areas were unstratified, but in the profiles of a trench on the southernmost edge of the southern midden area, at least two periods of burned rock accumulations were evidenced by lenses of rock separated by terrace soils on the edge of the midden.

In the northern midden area, while the midden zone was visually unstratified, the excavations showed at least two major periods of occupation deposition: a Late Archaic occupation containing a number of diagnostics and other artifacts, and a Late Prehistoric occupation also containing numerous artifacts. Comparisons between the northern and southern midden areas indicate both had relatively equally distributed quantities of lithic 
debitage and burned rocks, but differed in the relative amounts of tools, faunal remains, and snail shells.

Excavations in the terrace areas showed a relatively basic, site-wide soil stratigraphy. The basal level, culturally sterile, consisted of a gravelly caliche zone occurring at about 60-70 cm or deeper below the surface in the southern half of the site. In the northern half of the site, the basal caliche zone was replaced by bedrock limestone that outcropped in the northern extremes of the site. These strata were overlaid by a B-horizon of brown clay loam ca. $30 \mathrm{~cm}$ thick and a dark brown A-horizon 40-60 cm thick.

Cultural deposits were present in the upper two soil zones throughout the site, but appeared to be consistently most abundant vertically at about 40 $60 \mathrm{~cm}$ below the surface in association with Late Archaic and Middle Archaic diagnostics. Six burned rock features were exposed in the terrace area excavations, including oval to circular hearths.

Intrasite studies of the cultural material in the midden and terrace areas show that chert debitage was most frequent in the terrace deposits. Examination of the relative distribution of the various subgroupings of debitage indicates most occurred in the same relative proportions within midden and nonmidden contexts but quantitatively less frequent in the midden. There were two exceptions to this trend. Interior flakes were more common in the terrace areas. Most of the interior flakes (90\%) have small multiple facet platforms, suggesting that the off-midden areas served as a preferred locale for final biface production. The other exception was burned chert which was more common in the midden areas, suggesting the possibility that more firerelated activity occurred in this area. Faunal remains, charcoal, and snails were more frequently recovered from the northern midden areas.

\section{Subsistence}

Direct and indirect evidence of site subsistence economies was recovered in the form of $1 \mathrm{jthic}$ and bone tools, and the examination of faunal, invertebrate, and wood charcoal specimens.

Faunal remains were not common at 41 UV 45 , and those recovered were primarily from the northern midden area. Bison, cottontail rabbit, and fish were identified from the site, and all would be excellent food resources. Rabdotus sp. accounted for about $71 \%$ of the snails collected at the site. Snail shells have been recognized as an important food resource in prehistoric times. Mussel shell was not common at the site, but its presence too, indicates it was at least a minor food item in the diet of the site occupants.

Wood charcoal species identifications suggests that a variety of vegetal foods could have been obtained in the vicinity of the site. Nut producing trees such as walnut (Juglans sp.) and oak (Quercus sp.) were identified at the site, along with Texas persimmon (Diospyros texana) which has an edible fruit. Leguminosae and UTmaceae, also recovered at the site, include some species that may have provided edible seeds. 
The recovery of a variety of 1 ithic tools from the site provides some further indication of the subsistence patterns practiced at the site. Clearly, the projectile points indicate that hunting was an important part of the prehistoric economy. Other bifacial tools probably served as cutting and butchering instruments for plants and animals, and the few unifacial tools recovered can be associated with scraping functions. The presence of grinding slab fragments is evidence that plant processing was carried out at the site. A bone awl from the site may be a piercing or weaving tool, and the blunted ulna tool is likely a weaving tool; both would suggest some manufacturing of basketry was part of the site activities. Finally, Late Prehistoric ceramics functioned as cooking and storage vessels.

\section{SITE 41 UV 47}

\section{SITE DESCRIPTION}

Site 41 UV 47 is about $9.98 \mathrm{~km}$ northeast of Uvalde, Texas. The site datum is approximately located at the universal transmetric coordinates $425060 \mathrm{E}$ $3240880 \mathrm{~N}$. The site area, as measured by the grid system, is $130,000 \mathrm{~m}^{2}$. The long axis of the site extends $650 \mathrm{~m}$ grid east to west. The site width measures $200 \mathrm{~m}$ and is oriented on grid north (18 east of magnetic north). Prior to the surface collection, the site area was divided into unequally sized quadrants intersecting at the site datum (Fig. 18). The quadrants are identified as northwest (NW), southwest (SW), southeast (SE), and northeast $(\mathrm{NE})$.

Site 41 UV 47 1ies on the first terrace of the north bank of the Leona River (Fig. 18). A permanent water source, the Eightmile Waterhole, occurs in the riverbed adjacent to the southwestern quadrant. The topography within the site is relatively flat, and the visibility is clear along the long axis of the site. The terrace slopes create a bank about one meter in height at the western end of the site, which becomes increasingly pronounced towards the eastern end of the site, where it approximates three meters in height above the Leona River bed (Fig. 19, a-d).

Vegetation along the waterhole margins consists primarily of elms, large oaks, and 1ush grasses. Away from the water source, thorny brush predominates; acacia, prickly pear, catclaw, yucca, and mesquite were noted. The whole extent of the site was cleared of brush by root plowing within the last 10 years, and today remains relatively clear of the dense brush characteristic of unimproved pastures in the nearby area. Most of the ground cover is comprised of sparse grasses and forbs. Aerial photographs show past brush cover was fairly extensive prior to mechanical clearing.

The site lies within the Balcones Fault Zone, which in its most visible surface manifestation forms the Balcones Escarpment, a topographical feature occurring less than $25 \mathrm{~km}$ north of the site (Barnes 1974). The escarpment is used as a natural dividing point between the uplifted Edwards Plateau and the Gulf coastal regions of Texas. This same escarpment has also been used to separate the traditional cultural areas of south and central Texas (cf. Suhm, Krieger, and Jelks 1954; Prewitt 1981). The soils at the site have been identified as Knippa clay (Stevens and Richmond 1976), a brown clay loam that 


\section{U V 47}

SITE PLAN AND TOPOGRAPHY

DEXCAVATION UNIT

- test PIT ITP)

- BACKHOE TRENCH (T)

$\triangle D A T U M$

- - MIDDEN EXTENT

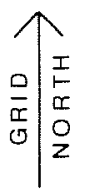

CONTOUR INTERVAL: 4 FEET

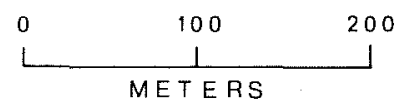

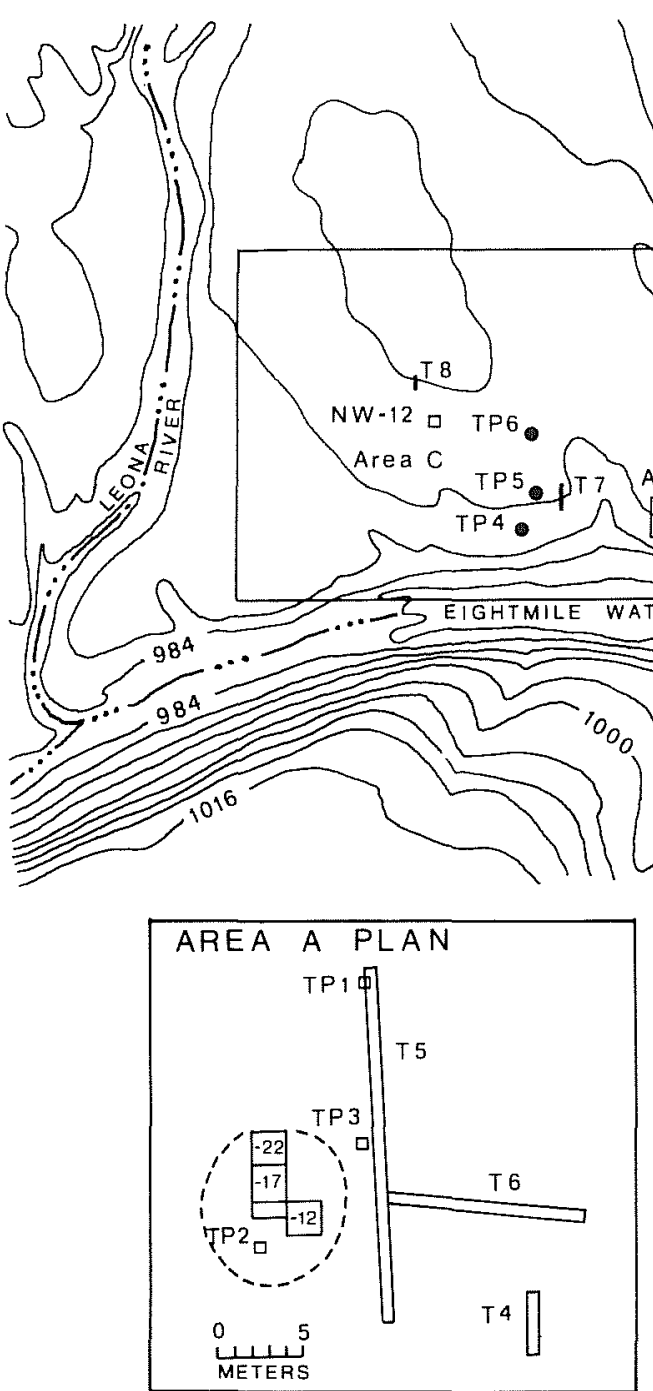
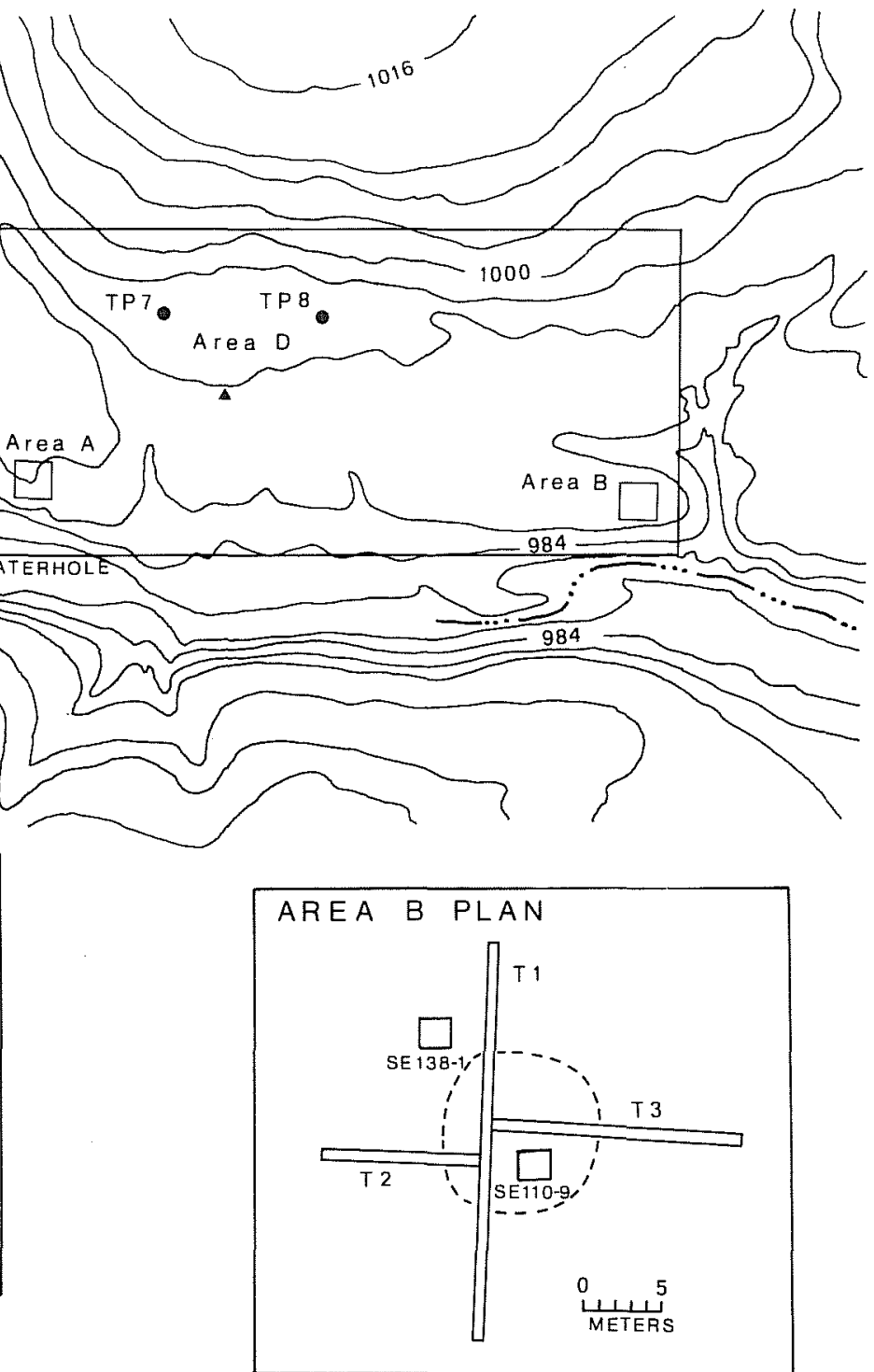

Figure 18. Topographic Map and P1 an of Excavations at 41 UV 47. 


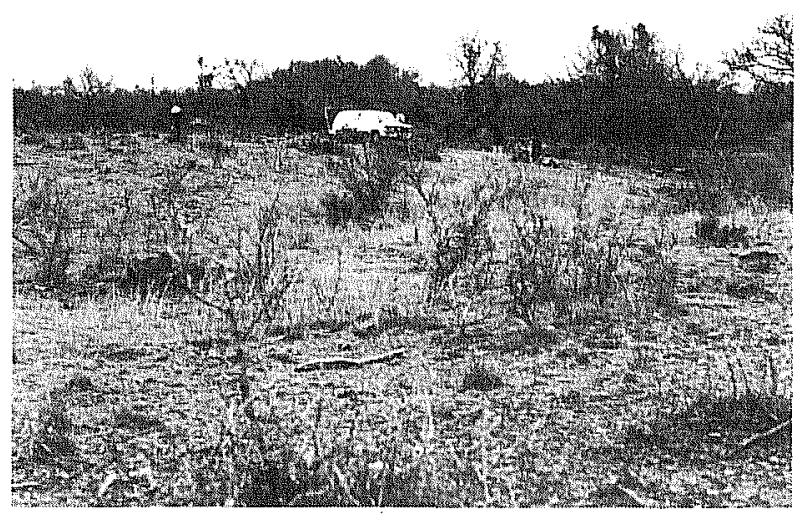

a

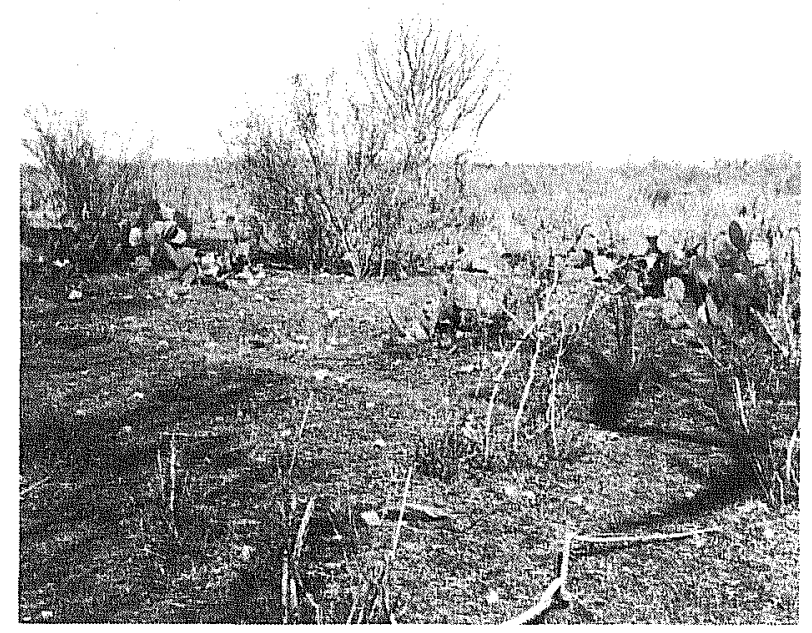

C

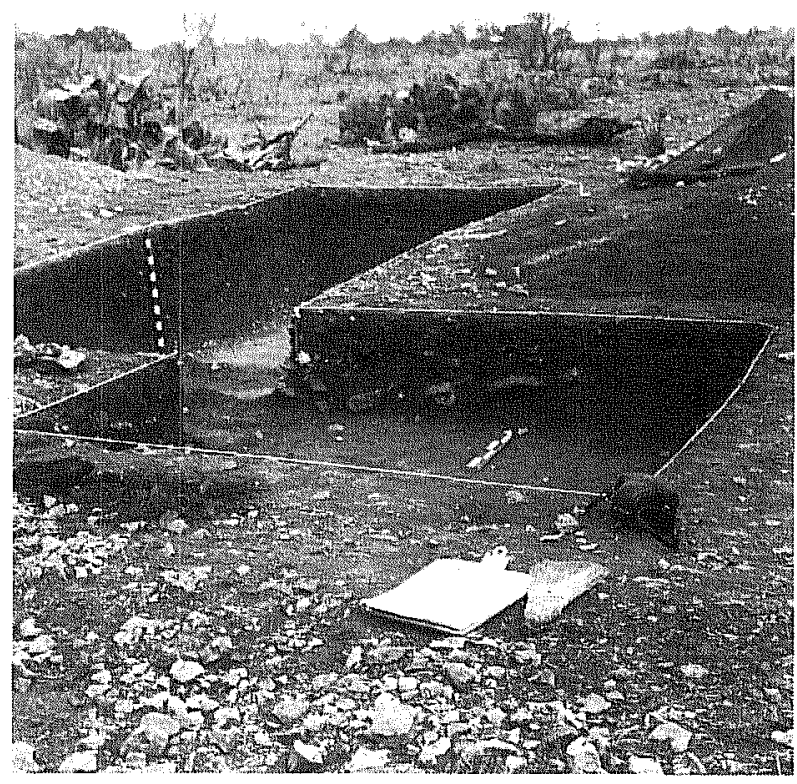

b

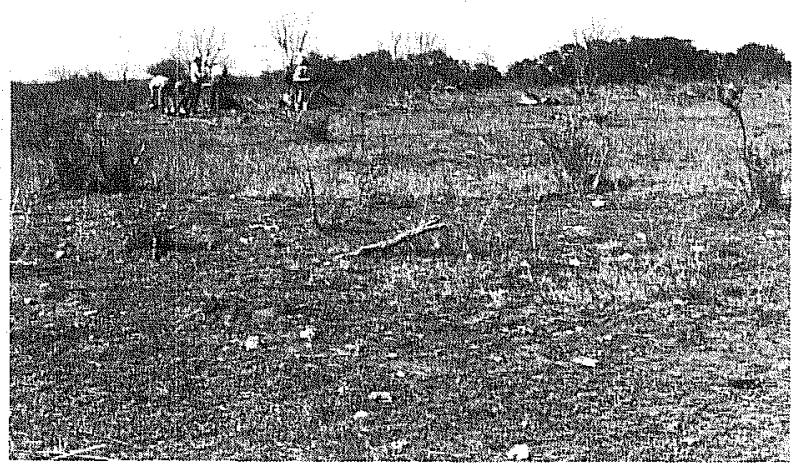

d

Figure 19. General Views of 41 UV 47. a, looking southeast at Area $A$; $b$, Area $A$ excavations looking to the northwest; $c$, looking northwest at Area $B$ prior to excavations; d, looking west towards Area C. 
tends to lighten in hue and become increasingly calcareous with depth. The Knippa clay varies from about 60 to $150 \mathrm{~cm}$ in depth at the site, and overlies the culturally sterile Pliocene gravel deposits of the Uvalde Gravel formation. Buda Limestone outcrops in a low hill immediately north of the site (Barnes 1974).

The site would appear to provide an ideal location for prehistoric occupations. The site lies close to a permanent water source, and raw material resources such as 1 imestone and occasional chert cobbles are readily accessible. Paleo-ecological studies in this report indicate that the natural prehistoric environment was similar to that of the present.

\section{SURFACE COLLECTION}

A $10 \%$ random sample surface collection of the site was carried out to provide information on the surface characteristics of the site, and also to provide a means by which a field evaluation for subsequent subsurface investigations could be established. The distributional patterns noted by the cultural materials recovered during the surface collection were expected to provide information on the density and composition of intrasite areas.

The sample was used to separate large areas of the site by two general observations in the field. The first was based on proximity to the Leona River. The site grid extended from the banks of the river to $200 \mathrm{~m}$ into the terrace area. The southern half of the $200-m$ site width was considered water-proximate, the northern half water distant (Fig. 18). The second observation recognized obvious variations in lithic densities and was also used to isolate, to some degree, the two midden features on the site. This observation roughly divided the site in half across its long axis, east to west. As a result, the site was essentially divided into four quadrants. The quadrants were identified as southwest (SW), northwest (NW), southeast (SE), and northeast (NE), all intersecting at the site datum and aligned on the grid system imposed over the site. Each quadrant was subdivided into $10-m^{2}$ sampling squares that were numbered consecutively west to east, beginning at the southwest corner of each quadrant, thus providing unit identifications (SW76, NE224, SE105, etc.). A simple 10\% random sample for each quadrant was then drawn from a table of random numbers for each quadrant. The cultural material from within each $10-m^{2}$ unit was further provenienced within $2 \mathrm{~m}^{2}$ in case more detailed distributional studies should be considered desirable in the future.

Changes and errors in the sampling process were identified in the laboratory analysis and are noted here. These problems concern the selection and placement of units within some of the quadrants. In the southwest quadrant, there were four units in the Leona River bed (Units SW7, SW21, SW26, and SW63) deleted from consideration in the surface collection. Additionally, four other units, whose number had been randomly drawn, were found to have no field or laboratory records once the field work had been completed. These units were SW102, SW218, SW226, and SW235. Units SW226 and SW235 were overlooked during the transfer of the drawn numbers to a field mapping grid plan. Units SW102 and SW218 were placed on the mapping grid plan used to set up the 
units in the field for surface collection, but the units were apparent1y either never staked out or collected during the course of field work.

In the northeast quadrant, four units (NE212, NE239, NE266, NE269) were field assessed as "off-site" and replaced with four random numbers held in reserve for that purpose (NE34, NE54, NE90, NE113). In the northwest quadrant, one random unit (NW304) had no corresponding laboratory or field data. Table 21 shows the random sample collection statistics without consideration to the units with missing data or to those removed from the sample.

Table 21 shows that approximately a $10 \%$ sample was collected for each quadrant. Only 16 units (1.2\% of the sample) did not contain cultural remains.

In the process of working within the site, a substantial number of artifacts were observed and collected from outside the boundaries of the sample units. of the 229 artifacts collected from the surface of the site (excluding debitage), 66 were nonrandom finds, Table 22 compares the overall totals for each major artifact grouping between the random and nonrandom collections. The nonrandom collections comprise $29 \%$ of the surface finds. All of the surface artifacts were used for the artifact distribution study which follows.

\section{Surface Lithic Concentrations}

The surface distribution of debitage (flakes, chips, burned chert, and chunks) is shown in Figure 20. The distribution map shows the location of al1 the random-selected units inspected, plotted over a topographic map of the site. The surface density of each $10 \mathrm{~m}^{2}$ shown in Figure 20 has been categorized by one of five subdivisions based on the total amount of debitage within each unit. The subdivisions presented in Figure 20 are (1) units with no debitage; (2) units with debitage counts of 1 to 10; (3) units with debitage counts of 11 to 20 ; (4) units with 21 to 30 pieces of debitage; and (5) units with debitage counts of more than 31 . The greatest debitage count from a single sample unit was 321 items (Unit SW165), and seven sample units had debitage counts of 100 or more (Units SW76, SW165, SW215, SW276, SW314, SW349, and NE113). The average estimated debitage density per quadrant was calculated by dividing the total debitage count of each quadrant by the number of examined units in that quadrant. The southwest quadrant contained the highest average debitage density at the site, about 53 items per unit. The northwest and northeast quadrants had relatively equal average debitage counts per unit at approximately 15 and 11 items per unit, respectively. The southeast quadrant had the lowest average debitage density per examined unit, about six flakes per each $10-\mathrm{m}^{2}$ unit.

Four 7 ithic concentrations can be isolated in Figure 20, three of which are relatively small and essentially contained by three sample units; the other concentration covers a much larger area and probably reflects the most heavily utilized portion of the site. The first of the smaller concentrations is located in the far southwestern corner of the site, and contains Units SW75, SW76, and SW77 (Fig. 20). This southwest 7 ithic concentration contained five cores, six bifaces (five of which are bifacial intergrades), a 
TABLE 21. RANDOM SAMPLE COLLECTION UNIT STATISTICS FOR 41 UV 47

\begin{tabular}{ccccc}
\hline Quadrant & $\begin{array}{c}\text { Units } \\
\text { with Lithics }\end{array}$ & $\begin{array}{l}\text { Units with } \\
\text { No Recovery }\end{array}$ & $\begin{array}{l}\text { Total } \\
\text { Sample }\end{array}$ & $\begin{array}{c}\text { Quadrant } \\
\text { Size }\end{array}$ \\
\hline SW & $34(9.2)$ & $2(0.5)$ & $36(9.7)$ & $370(100)$ \\
NW & $34(9.2)$ & $2(0.5)$ & $36(9.7)$ & $370(100)$ \\
SE & $21(7.5)$ & $7(2.5)$ & $28(10)$ & $280(100)$ \\
NE & $23(8.2)$ & $5(1.8)$ & $28(10)$ & $280(100)$ \\
\hline Total & $112(8.6)$ & $16(1.2)$ & $128(9.8)$ & $1300(100)$ \\
\hline
\end{tabular}

Note: Number in parentheses indicates percentages.

TABLE 22. RANDOM AND NONRANDOM ARTIFACTS SURFACE COLLECTED FROM 41 UV 47

\begin{tabular}{|c|c|c|c|}
\hline & \multicolumn{2}{|c|}{ Percentage } & \multirow{2}{*}{$\begin{array}{l}\text { Count } \\
\text { Total }\end{array}$} \\
\hline & Random & Nonrandom & \\
\hline $\begin{array}{l}\text { Arrow points } \\
\text { Dart points } \\
\text { Overall retouch bifaces } \\
\text { Bifacially retouched flakes } \\
\text { Bifacial intergrades } \\
\text { Other bifaces } \\
\text { Unifaces } \\
\text { Modified flakes } \\
\text { Cores } \\
\text { Hammerstones } \\
\text { Ground stone } \\
\text { Ceramics } \\
\text { Historic }\end{array}$ & $\begin{array}{r}69 \\
45 \\
56 \\
44 \\
81 \\
67 \\
72 \\
95 \\
100 \\
\\
50 \\
29 \\
50\end{array}$ & $\begin{array}{r}31 \\
55 \\
44 \\
56 \\
19 \\
33 \\
28 \\
5 \\
100 \\
50 \\
71 \\
50\end{array}$ & $\begin{array}{l}13 \\
29 \\
16 \\
9 \\
32 \\
24 \\
32 \\
20 \\
40 \\
1 \\
4 \\
7 \\
2\end{array}$ \\
\hline \multirow{2}{*}{\multicolumn{3}{|c|}{$\begin{array}{l}\text { Total random surface collection } \\
\text { Total nonrandom surface collection }\end{array}$}} & 163 \\
\hline & & & 66 \\
\hline \multicolumn{3}{|l|}{ Grand Total } & 229 \\
\hline
\end{tabular}



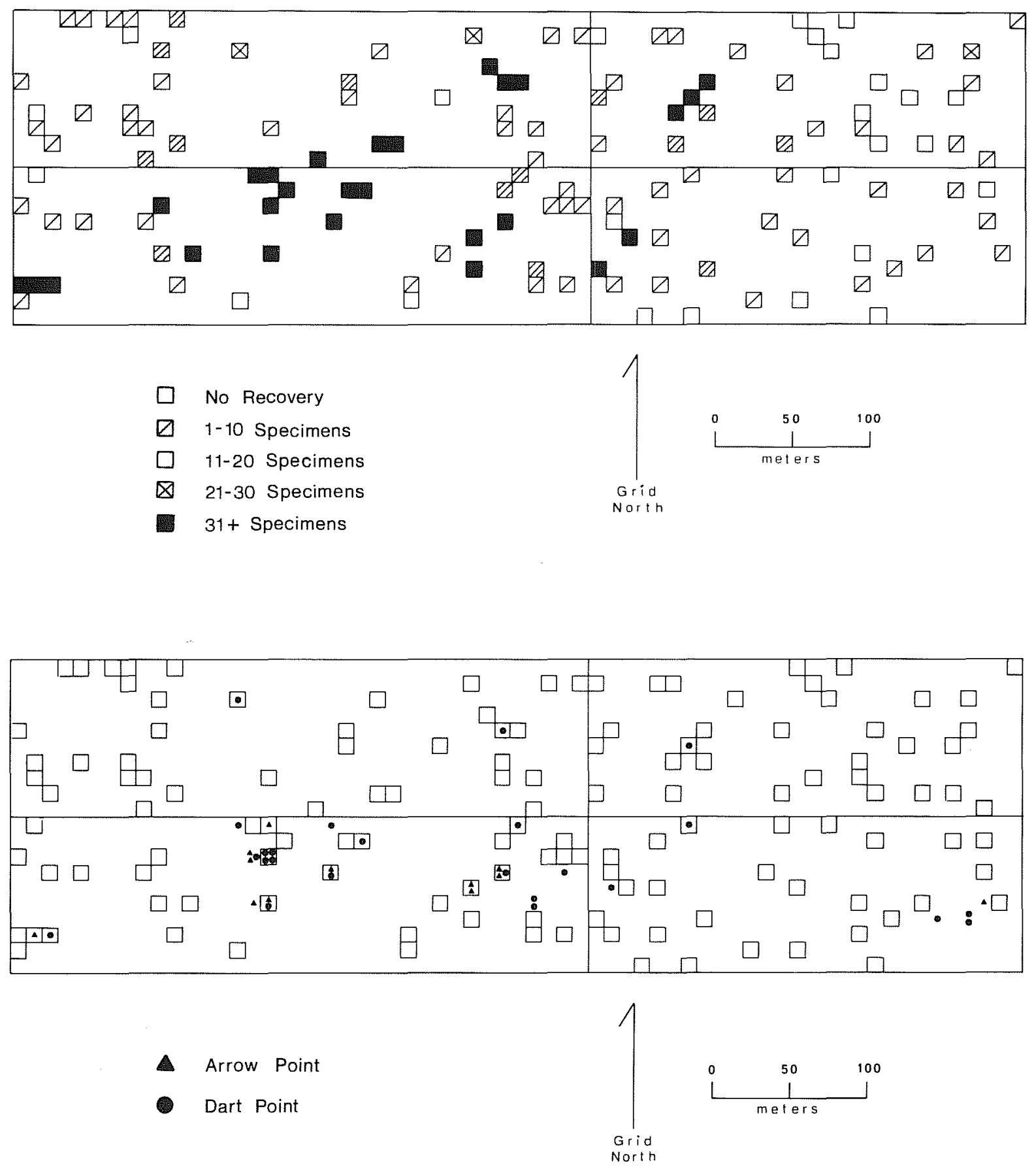

Figure 20. Surface Distributions of Debitage and Projectile Points at 41 UV 47. 
Perdiz arrow point, a Castroville dart point, a uniface, and a modified flake. The high incidence of cores and bifacial intergrades suggests that this is an isolated chert reduction locale within the site. A second cluster of units in the northeastern corner of the northwest quadrant (Units NW217, NW218, and NW253) isolates the second 1ithic concentration. Associated with this debitage concentration were six artifacts: an unidentifiable dart point fragment, two overall retouch bifaces (a large miscellaneous fragment and a large triangular with a concave base), an asymmetrical bifacial intergrade, a core nuclei, and a piece of brown glass. This concentration was subjected to a subsurface test (see Area D in Excavation Areas section, 41 UV 47). The last of the smaller lithic concentrations isolated by the random surface collection is contained by Units NE90, NE119, and NE148 in the west-central area of the northeast quadrant (Fig 20). Few artifacts were associated with this debitage concentration: an unidentifiable dart point fragment, an asymmetrical bifacial intergrade, and a multidirectional core with horizontal flaking scars. There is a dirt road intersecting each of the units defining this concentration, and the road may have exposed more material than would normally occur on the surface. A test pit was placed in this area revealing very minor subsurface manifestations (see Area D in Excavation Areas section, 41 UV 47$)$. The largest $(300 \times 100 \mathrm{~m}) 7$ ithic concentration revealed by the random surface collection was located mainly within the southwest quadrant, along the banks of a permanent pond, the Eightmile Waterhole (Fig. 20). The area is roughly halved into east and west sections by a draw that empties into the Eightmile Waterhole. Within this large concentration lies the bulk of the sample units at the site with debitage densities of over 31 items per $10-\mathrm{m}^{2}$, and the majority of the surface-collected artifacts. Especially notable among the artifacts occurring within this area are arrow points (11 of 13 from the total surface collection), dart points (22 of 27), and unifacial end scrapers (all provenienced specimens). This area was extensively tested for subsurface deposits (see Areas $A$ and $C$ in the Excavation Areas section, 41 UV 47). The relatively large quantities of debitage and artifactual material found on the surface suggest that this area immediately adjacent to the Eightmile Waterhole was the favored locale within the site for prehistoric occupations.

Notably, the random surface collection failed to indicate the presence of a lithic concentration around the midden feature in the far southeastern corner of the site, earlier recorded and tested by Hall (1974). Also, the surface collection did not isolate the Late Prehistoric midden feature adjacent to the Eightmile Waterhole, and designated excavation Area A in this report. Both of these features are visible on the surface and have obviously higher lithic densities associated with them than the immediate surrounding areas. However, both are highly localized concentrations less than $15 \mathrm{~m}$ in size, and their small size was undoubtedly partially responsible for their not being defined as a lithic concentration from the random sample surface collection.

\section{Distribution of Surface Artifacts}

A review the overall distribution of artifacts in each of the four quadrants at the site is presented. The average debitage density of each quadrant is shown in Figure 20. The artifact distributions will be discussed by each major category (arrow points, dart points, bifaces, etc.) with emphasis 
placed on the significance of the intrasite distribution patterns. This approach differs slightly from the previous lithic concentration section just presented, for ease in presentation. The significance of the quadrant distributions will be, in part, associated with the aforementioned 1 ithic concentrations.

Of the 13 surface-collected arrow points, 92\% (12 specimens) came from the southwest quadrant (Fig. 20). All of the Toyah phase diagnostics (Perdiz) also came from this quadrant; one Perdiz came from the midden feature in the far southwestern corner of the site, the remainder from the 7 arge central 1 ithic concentration (Fig. 20). Other arrow points recovered from the southwest quadrant are two Scallorn eddy forms, a Sabinal, a crude contracting stem preform, a miscellaneous arrow point, and two arrow point blade fragments. The single arrow point, a Scallorn-like specimen, outside of the southwest quadrant came from the southeast quadrant, and was closely associated with the midden feature in the far southeastern corner of the site.

Dart points were present in all quadrants, but most common in the southwest (19 of 29 specimens) and the southeast (five specimens) quadrants (Fig. 20). Late Archaic (Twin Sisters phase) forms comprise 53\% of the dart points collected from the southwest quadrant. The Late Archaic (Twin Sisters phase) points from the southwest quadrant are an Ensor Variety 2, four Fairland types, and five Frio types. Late Archaic (San Marcos phase) points are a single specimen each of Castroville and Montell. Probable Middle Archaic forms are four Langtry types (all of that type collected at the site) and a Pedernales point. A miscellaneous dart point Form 3 and an unidentifiable dart point fragment were also recovered from the southwest quadrant. In the southeast quadrant, the five recovered projectile points are a Late Archaic (Twin Sisters phase) Ensor Variety 1, a Middle Archaic Nolan, and two Early Archaic forms, an Early Corner Notched, and a Gower. In the northwest quadrant, two points were recovered, one a Pedernales, the other unidentifiable. A single unidentifiable dart point was recovered from the northeast quadrant. The important aspects of the quadrant distribution of the dart points are (1) the occurrence of all but a single specimen of the Late Archaic forms in the southwest quadrant; and (2) the occurrence of lesser numbers of dart points, most of which are Middle and/or Early Archaic, in the remaining quadrants.

Overall retouch bifaces were present in all quadrants, but most (10 of 16 specimens) came from the southwest quadrant (Fig. 21). Three gouges were surface collected: a Clear Fork tool from the southeast quadrant, one miscellaneous form from the northeast quadrant, and one miscellaneous form from the unprovenienced surface collections. Small overall retouch bifaces are identified as two small triangulars (southwest and southeast quadrants) and a single pointed ovate specimen from the southwest quadrant. The larger specimens are four rounded fragments from the northeast, southeast, and southwest quadrants; two large miscellaneous forms from the southwest and northwest quadrants; a large triangular with a concave base from the northwest quadrant; and one each of individual Forms 4 and 7 from the southwest quadrant. No significant clustering of overall retouch bifaces, other than their association with lithic debitage increases, was noted. 
94 Leona River Watershed
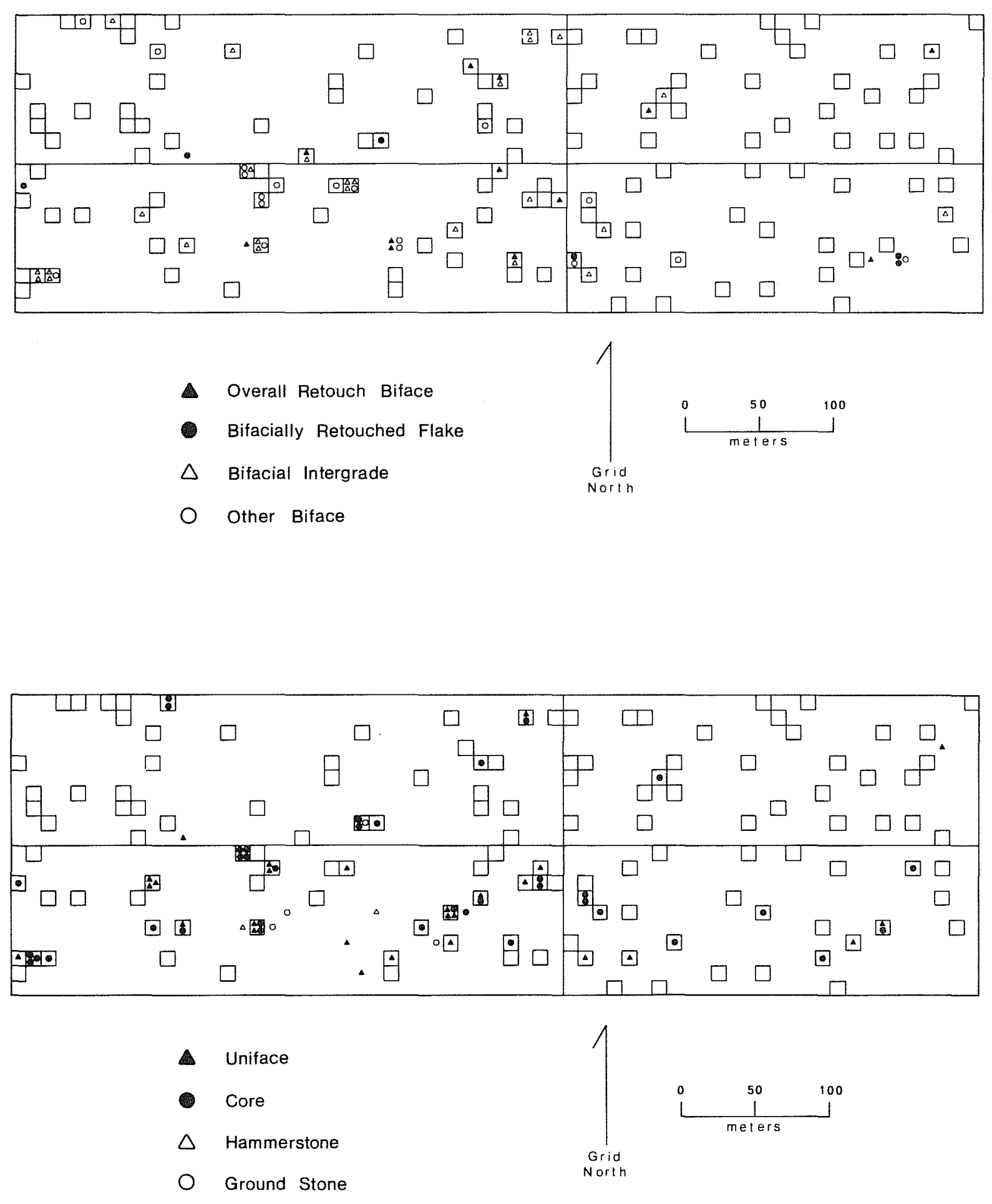

Figure 21. Distributions of Bifaces, Unifaces, Cores, Hammerstones, and Ground Stone at 41 UV 47. 
Bifacially retouched flakes were the least common bifacial form from the surface (Fig. 21). Of a total of nine specimens, six are classified as large retouched flakes including three pointed ovate forms, each from a different quadrant (northwest, southwest, and southeast). Two large fragments came from the southeast quadrant, and one large ovate specimen was from the southwest quadrant. Additionally, there was a small pointed form from the southeast quadrant and two amorphous specimens, one each in the southwest and northwest quadrants. No bifacially retouched specimens were recovered from the northeast quadrant.

Bifacial intergrades, with a total of 32 specimens, were the most common bifacial form recovered from the surface (Fig. 21). As with the previously mentioned bifacial forms most of the intergrades were from the southwest quadrant (53\% of the specimens). All subcategories were found within the southwest quadrant in quantities of at least two or more; the most frequent forms were asymmetrical and fragments (five specimens each). Pointed ovates (two specimens) occurred exclusively in the southwest quadrant. of the ovate bifacial intergrades, three were from the southwest quadrant, two from the northwest quadrant, and one from the southeast quadrant. Two triangular forms were from the southwest quadrant, and one was from the northwest quadrant. Asymmetrical intergrades were found in the southwest, northwest, and northeast quadrants. Fragments occurred in all of the quadrants. There was a suggestion of some clustering of the bifacial intergrades in the far southwestern corner of the site (Fig. 21), where five of the six nonstemmed bifaces recovered were bifacial intergrades.

Other bifaces (tips, midsections, etc.) numbered 24 specimens. Over 62\% came from the southwest quadrant (Fig. 21). Within the southwest quadrant, nine of the 14 specimens with unit-specific proveniences were found in the western half of the large central lithic concentration previously mentioned. This rather vague pattern is emphasized by the scarcity of biface fragments in the eastern area of that same large lithic concentration around the waterhole.

Seventy-two percent (23 of 32 specimens) of the surface-collected unifaces were from the southwest quadrant (Fig. 21). Collected from the southwest quadrant were eight end scrapers (six with unit-specific provenience), end and two-sided forms (four specimens) a circumferential retouched specimen, a two-sided uniface, three one-sided forms, a concave edge form, two gravers, and three miscellaneous forms. Forms occurring only in the southeast quadrant are identified as a one-sided uniface, one two-sided uniface, one concave edge specimen, and one graver. Two unifaces with two sides and one miscellaneous form were recovered from the northwest quadrant. Forms occurring in the northwest quadrant are identified as one miscellaneous form and an end and one-sided uniface. The eight end scrapers represent a distinctive type usually associated with the Late Prehistoric period (Jelks 1962; Hester 1980a:110). Six of these scrapers were provenienced, and there appears to be some indication that the majority (four tools) had a relatively common association in the eastern area of the large central 1ithic concentration adjacent to the Eightmile Waterhole. This may suggest a specific hideworking activity locale within the site.

Modified flakes occurred in all site quadrants, but were most common in the southwest quadrant. There were a total of 19 modified flakes collected from 
the surface, with the following quadrant distributions: southwest, 13; northwest, 2; southeast, 3; and northeast, 1.

Cores were relatively common finds during the surface collection. of a total of 40 cores, 24 were found in the southwest quadrant, seven in the northwest quadrant, eight in the southeast quadrant, and one in the northeast quadrant (Fig. 21). Al1 subcategories of cores occurred in the southwest quadrant, and a 11 except bifacial cores occurred in both the northwest and southeast quadrants. The single specimen from the northeast quadrant was a multidirectional core with horizontal flaking scars. Of note, concerning the intrasite distribution of cores, is the relative concentration of various subcategories of cores in the far southwestern area of the site (suggesting a lithic reduction locale--see comments regarding the presence of bifacial intergrades in the same locale), and the presence of four core tools in the western half of the southeast quadrant (Fig. 21). The core tools seem to be in a provenienced association similar to the one described for the end scrapers. The core tool distribution close to, but distinct from the unifacial end scrapers, may indicate the cores are related in some manner to the hide-working activities previously suggested for the end scraper concentration.

Other lithic artifacts (ground stone and hammerstones) occur on the surface only in the southwest and northwest quadrants (Fig. 21). All are associated with the previously mentioned large debitage concentration near the Eightmile Waterhole.

Ceramics found on the surface tended to be in the northwestern area of the large debitage concentration. Most of the ceramics recovered on the surface came from Unit NW12, which later was partially excavated (see Area $C$ in Excavation Areas section, 41 UV 47).

\section{Summary of Surface Collection}

On the basis of a stratified $10 \%$ random sample of a $130,000-\mathrm{m}^{2}$ grid placed over the site, an analysis of the overall lithic debitage density/distribution of the site revealed four significant debitage concentrations. Three of these concentrations were relatively small, probably reflecting specific activity areas. A fourth and much larger lithic debitage concentration was also defined through the random sample debitage analysis. Each of the four lithic concentrations are briefly summarized.

The first of the smaller lithic concentrations was located in the far southwestern area of the site. The units used to define this concentration are SW38, SW75, SW76, and SW77. The units can be characterized as having an increase in overall debitage counts and an associated increase in the number of certain artifacts, especially bifacial intergrades and cores. The two diagnostic projectile points found in this concentration are a Perdiz arrow point (Late Prehistoric period) and a Castroville dart point (Late Archaic period). It is suggested that the area represents a lithic reduction locale within the site based upon the number of bifacial intergrades and cores associated with it. 
The second small concentration isolated by the random sample analysis was located in the northeastern area of the northwest quadrant (Units NW217, NW218, NW253). The concentration is characterized by an increased debitage count and a small number of artifacts. The artifacts include an unidentifiable dart point fragment, two overall retouch bifaces, a bifacial intergrade, and a core nuclei. A specific activity or function for the area could not be suggested, but this concentration and the following one contained only Archaic dart point forms, possibly indicating that no Late Prehistoric activity was carried out within either of the two concentrations.

The third lithic concentration was located in the west-central area of the northeast quadrant. The collection units considered part of this concentration are NE90, NE119, and NE148. Few artifacts occurred within these units, and it is considered to be, at least in part, an erosional phenomenon, occurring as a result of a dirt road passing through the units.

The final 1ithic debitage concentration revealed by the random surface collection covered a much larger area within the site, approximating $300 \mathrm{x}$ $100 \mathrm{~m}$ in size. This concentration occurs mainly within the eastern half of the southwest quadrant and the far western portion of the southeast quadrant. In addition to containing a number of units with unusually high lithic inventories, the majority of surface-collected artifacts also occurred within this area. Arrow points, Transitional and Late Archaic dart points, unifacial end scrapers, ground stone, and prehistoric ceramics were found to occur exclusively, or nearly so within the concentration. Additionally, three different artifact categories (other bifaces, unifacial end scrapers, and core tools) showed some suggestion of a horizontal patterning within the concentration. Other bifaces tended to occur in the western half of the concentration, while unifacial end scrapers and core tools were most common in the eastern half of the concentration. This concentration is suggested to have been the preferred occupation locale within the site during prehistoric times.

The $10 \%$ random sample provided a means by which an overall assessment of the surface character and extent could be recorded. It allowed, in conjunction with occasional nonrandom collections, intrasite patterns of lithic debitage and artifact distributions to be defined. Notably, the random sample failed to identify the two burned rock midden features visible on the surface of the site, a problem which had to be corrected by other means.

\section{EXCAVATION AREAS}

The excavations carried out at the various locations within site 41 UV 47 are described. Four separate excavation areas, defined as excavation Areas A-D, were investigated in order to obtain information on the character and nature of the subsurface deposits within the site. The area designations were delineated on the basis of earlier testing results reported by Hall (1974), and on the preliminary results of the random sample collection carried out during the course of this project (see surface collection section). The focus of the following area characterizations is on the stratigraphic sequences evidenced in the soil profiles drawn for the various units and 
trenches opened within the site. The location of all excavation units is shown in Figure 18.

\section{Area A}

Area $A$ is defined as those units and trenches excavated in and near the burned rock concentration located on the surface in the southwest quadrant of the site. It includes the 2-m² units, SW173-13, SW173-17, SW173-22, and the single $1-x 2-m^{2}$, SW 173-12. Other excavations in Area $A$ include the following three test pits: SW210-25 (Test Pit 1), SW173-11 (Test Pit 2), and SW173-25 (Test Pit 3). The backhoe trenches within Area A are Backhoe Trenches 4, 5, and 6 . The three test pits were $50-\mathrm{cm}^{2}$ in size, and were each excavated to a depth of $80 \mathrm{~cm}$ in $20-\mathrm{cm}$ levels. The larger excavation units were excavated to varying depths: SW173-12, to $30 \mathrm{~cm}$; SW173-13, to $50 \mathrm{~cm}$; SW173-17, to $110 \mathrm{~cm}$; SW173-22, to $90 \mathrm{~cm}$. Each of these units was excavated in $10-\mathrm{cm}$ levels. The three backhoe trenches measured approximately $3 \mathrm{~m}$ long (Backhoe Trench 4), $21 \mathrm{~m}$ long (Backhoe Trench 5), and $13 \mathrm{~m}$ 1ong (Backhoe Trench 6). Each trench was approximately $50-\mathrm{cm}$ wide (18-inch bucket) and 90 $\mathrm{cm}$ deep. Using the above figures, an estimated volume of $10.6^{3}$ was removed from the excavation units, $0.6 \mathrm{~m}^{3}$ from the test pits, and $16.65 \mathrm{~m}^{3}$ from the backhoe trenches. The surface area exposed, excluding the backhoe trenches, was $14.75 \mathrm{~m}^{2}$.

Area A can best be characterized by the two profiles presented in Figure 22. Figure 22, a shows the profile of the east walls of Units SW173-17 and SW173-22, and clearly indicates a midden deposit. The midden covered a horizontal area with an estimated diameter of about $9 \mathrm{~m}$. It was located in the central region of Area A excavations. Four stratigraphic soil zones can be described for the units excavated through the midden. The soil zones are identified as the midden zone, the transitional zone, Knippa clays, and the gravel zone (Fig. 22). The uppermost deposit is the midden zone, occurring from the surface to a depth of about 30 to $40 \mathrm{~cm}$ below the ground surface, but was noted to occur up to $60 \mathrm{~cm}$ below the surface. The midden zone consists of a dark grayish brown, sometimes ashy texture clay loam interspersed with numerous angular, fist-sized burned limestone rocks. The soil was generally either unconsolidated, or very friable, but difficult to excavate because of the numerous burned 1 imestone rocks. The midden zone contained the majority of the recovered cultural material, including numerous artifacts and debitage, 1 and snail she11s, and mussel shel1 fragments. The stratum was radiocarbon dated at $620 \pm 70$ B.P. (TX-4435, MASCA corrected) via a charcoal sample taken from Feature 3. This radiocarbon date is applicable to the Late Prehistoric artifacts found within the midden zone.

Underlying the midden is the transitional zone, occurring from approximately 40 to $60 \mathrm{~cm}$ below the surface. The transitional zone is characterized by brown Knippa clays mottled with dark grayish brown soils (1ike those of the midden zone). The degree of soil mottling decreases with depth, so that the boundary with the Knippa clay strata is smooth and difficult to pinpoint. The clay soils of the transitional zone are compact and firm, with a blocky structure, and there are a few naturally occurring pebbles in the soil. cultural material diminishes relative to the amounts contained within the midden zone; most notably in the amounts of Tithic debitage and burned rocks. 

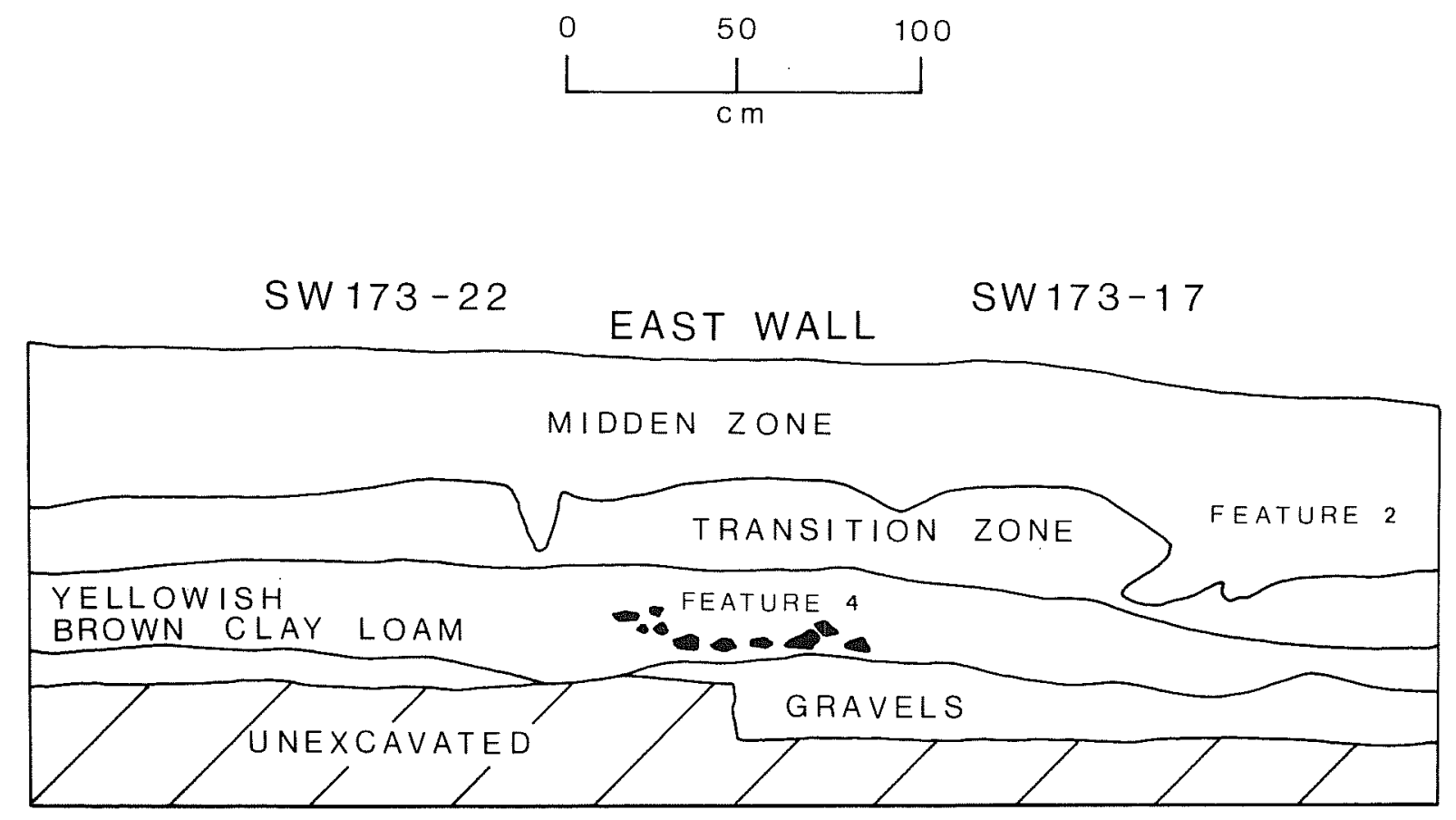

TRENCH 5
EAST WALL
\begin{tabular}{|c|c|}
\hline DARK GRAYISH BROWN & $\begin{array}{c}\text { CLAY } \\
\text { LOAM }\end{array}$ \\
\hline BROWN CLAY LOAM & \\
\hline YELLOWISH & CLAY \\
\hline
\end{tabular}

Figure 22. Excavation Area A Profiles at 41 UV 47. a, Units SW173-17 and SW173-22 east wa11s; b, east wa11 Trench 5. 
The transitional zone may represent the remaining, lower portion of the A-horizon of the Knippa clays remaining relatively unaltered from its natural appearance (Stevens and Richmond 1976).

The Knippa clay strata lies directly below the transitional zone. It is comprised of a very compact clay loam with a hard, friable structure. The zone is generally $1 \mathrm{imited}$ to between 60 to $90 \mathrm{~cm}$ below the ground surface. There were indications of a slight increase in cultural materials within this zone, including dart point forms diagnostic of the Late Archaic period. Feature 4 was contained within the Knippa clay strata.

The gravel zone is the deepest recorded strata within Area A with a distinct upper boundary at about $90 \mathrm{~cm}$ below the ground surface. The gravel zone consists of calcium carbonate materials within a brown clay loam. There was some indication of alternating gravel and soils lenses or beds within the gravel zone. Cultural material recovery dropped off dramatically within the gravel zone.

The soils outside the defined horizontal limits of the midden within Area A are shown in the soil profile for a section of the east wall of Backhoe Trench 5 in Figure 22. There are three separate soil zones shown in the profile, the uppermost is a dark grayish brown clay loam, occurring from the surface to a depth of about 20 to $25 \mathrm{~cm}$. The soil zone contains occasional burned rock, lithic debitage, land snail shells, and mussel shell. The soil is compact and friable. This soil zone probably delimits an occupational zone equivalent to the midden zone previously described for Area, A. Below the dark grayish brown clay is a zone of brown clay loam, occurring at depths up to $60 \mathrm{~cm}$ below the surface. The clay loams of this strata are similar to those of the previously mentioned transitional zone, although the mottled appearance of the transitional zone was not noted in the Backhoe Trench 5 profile. This zone probably reflects a distinct, remaining portion of the Ahorizon of the site's Knippa clays (Stevens and Richmond 1976). The Knippa clay B-horizon is the deepest exposed soil zone in the Backhoe Trench 5 profile. This soil zone is very similar to the Knippa clay strata noted beneath the midden deposits. Of note is the presence of a group of burned limestone rocks in the trench wall, possibly indicating the presence of a hearth similar to Feature 4 and at the same approximate depth as Feature 4. No other such clusters of burned rocks were found anywhere within the site.

\section{$\underline{\text { Area B }}$}

Area B excavation consisted of Units SE110-9 and SE138-1, and Backhoe Trenches 1, 2, and 3. As an analytical unit, the excavations were intended to define the cultural materials associated with a burned rock midden and the surrounding area located in the far southeastern end of the site. Unit SE110-9 is located close to Hall's (1974) Test Pit 2. Both Test Pit 2 and Unit SE110-9 penetrated the burned rock midden. Unit SE138-1 was 1ocated about 10 m northwest of Unit SE110-9 and was placed outside of the midden. Both SE110-9 and SE138-1 were excavated in 2-m² units, to depths of 80 and $60 \mathrm{~cm}$ below the ground surface, respectively. The last two unit-levels of SE110-9 were reduced to areas $1-\mathrm{m}^{2}$ (the southwest quadrant of the unit), and the total estimated volume for units SE110-9 and SE138-1 was $5 \mathrm{~m}^{3}$. Backhoe 
Trenches 1 through 3 measured (in sequential order) 25, 11 , and $16 \mathrm{~m} 1 \mathrm{ong}$. Each was excavated to an approximate depth of $60 \mathrm{~cm}$ below the surface.

In comparison to the other excavation areas of the site, the soil profile within Area $B$ is relatively shallow, although nearby machinery cuts excavated by the Soil Conservation Service (SCS) to test for borrow areas revealed that the gravel deposits in the area extend to depths of a least $2.5 \mathrm{~m}$ below the surface. The deep profile cuts in the SCS test pit were inspected for cultural material and found to be sterile.

The profile of the south wall of Unit SE110-9 shows four strata, the midden zone, a transitional zone, Knippa clay, and the gravels (Fig. 23,a). The uppermost strata, the midden zone, occurs from the ground surface to a maximum depth of $40 \mathrm{~cm}$ below the ground surface, but averages about $30 \mathrm{~cm}$ in depth. The midden consists of closely packed, fist-sized, angular burned limestone rocks and a dark, grayish brown clay loam. The midden soil varies from moderately to loosely compacted and is described as "greasy" in texture. Most of the archaeological remains in the unit came from the midden zone; however, the overall quantity was lower than was the case in the Area A midden levels. A thin transitional zone lies directly beneath the midden, varying from a few to $15 \mathrm{~cm}$ thick. The soil color and texture within the transition zone are the same as that described for the midden zone, the essential difference between the two is a decrease in the burned rock density. The Knippa clay begins to show at about $40 \mathrm{~cm}$ below the surface, and ends abruptly on top of the gravels, at about $60 \mathrm{~cm}$ below the surface. The Knippa clay is a compacted brown clay loam without the obvious organic content of the strata above it. Burned rock is not common in this zone, and other cultural remains also decrease in frequency. The gravel zone extends from some $60 \mathrm{~cm}$ below the ground surface to the bottom of the excavation unit, $80 \mathrm{~cm}$ below the surface.

The soil profile for Unit SE138-1 is characteristic of nonmidden areas within Area B. The profile shows the A- and B-horizons of the Knippa clays in Area B (Fig. 23,b). The A-horizon extends from the surface to approximately 40 to $45 \mathrm{~cm}$ below the surface. The contact between the $A$ - and B-horizon is smooth and gradual. The soil is a dark brown to brown clay loam that increases in compaction and lightens in hue with depth. A radiocarbon sample (TX-4428) dated at $740 \pm 110$ B.P. (MASCA corrected) was taken from the base of the A-horizon in Level 5 of this unit. The date seems acceptable in view of the Late Prehistoric diagnostics found in the two excavated units in Area B. The B-horizon is characterized by increased compaction, increased calcium carbonate pebbles, and a lightening of hue, all beginning at about $45 \mathrm{~cm}$ below the surface, and extending to the bottom of the unit at $60 \mathrm{~cm}$ below the surface.

\section{Area C}

Excavation in Area $C$ consisted of a more widely scattered array of units and trenches than was the case for Areas $A$ and $B$. Excavation units ( $2-m^{2}$ units) in this area are NW12-7, NW12-8, NW12-12, and NW12-13. The three test pit units (a11 50- $\mathrm{cm}^{2}$ units) in this area are SW165-3 (Test Pit 4), SW240-1 (Test Pit 5), and SW350-25 (Test Pit 6). Backhoe Trenches 7 and 8 were the two 


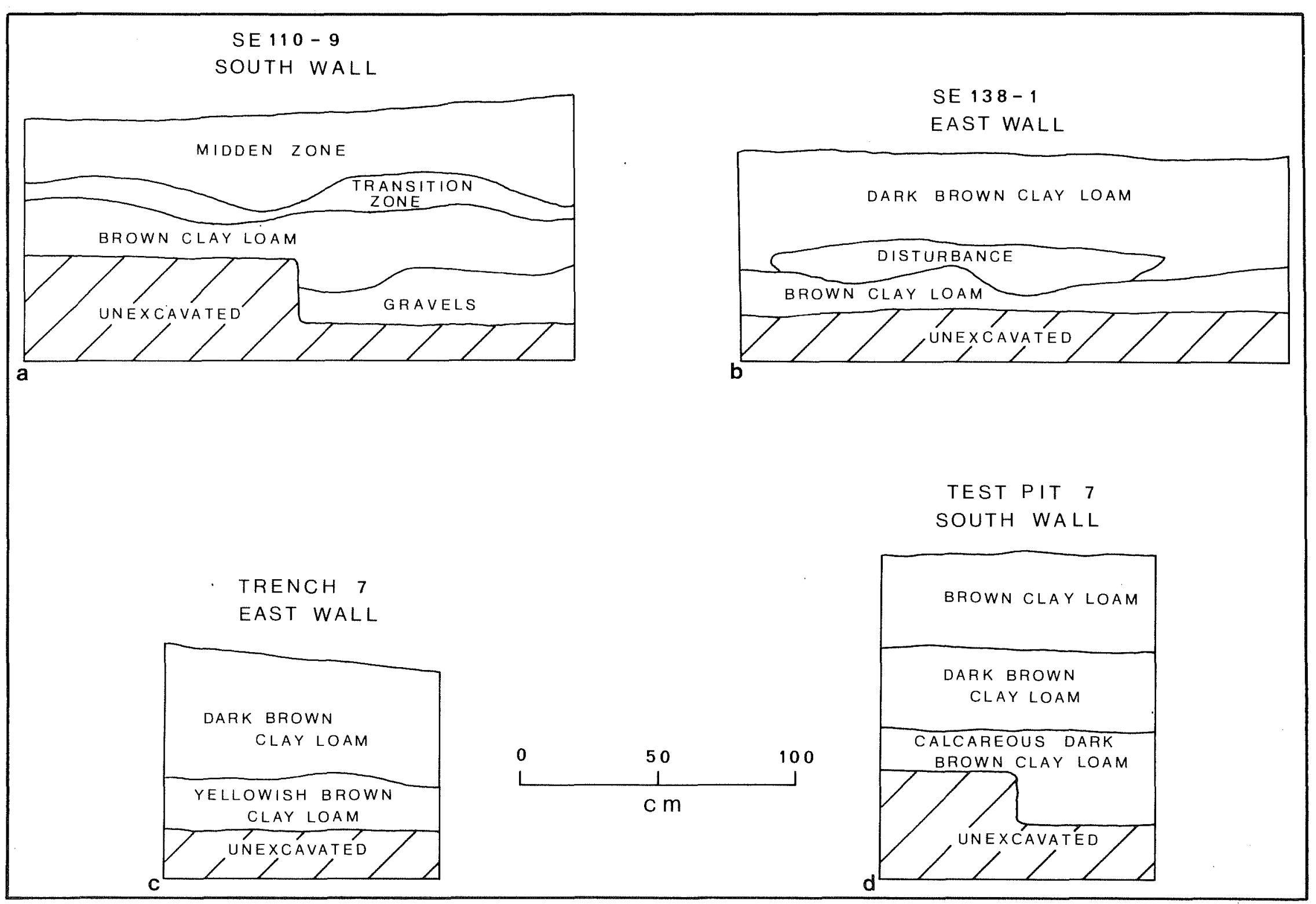

Figure 23. Excavation Areas B, C, and D Profiles at 41 UV 47. a, south wal1 of Unit SEl10-9; b, east wa11 of Unit SE138-1; c, east wal1 of Trench 7; d, south wall of Test Pit 7. 
trenches excavated within Area $C$. The excavation units were excavated in 10-cm increments. On1y Unit NW12-13 was excavated deeper than the first leve1, to Level 2, which encompassed a $1-\mathrm{m}^{2}$ area (the southwestern quadrant of that unit). Test pits were excavated in $20-\mathrm{cm}$ levels. Test Pits 4 and 6 were excavated to a depth of $80 \mathrm{~cm}$; Test Pit 5 was excavated to a depth of $100 \mathrm{~cm}$. Backhoe Trench 7 was approximately $19 \mathrm{~m}$ in length, and Backhoe Trench 8 approximately $9 \mathrm{~m}$ long. Both trenches reached a maximum average depth of $70 \mathrm{~cm}$ and were about $50 \mathrm{~cm}$ wide. An estimated $12.15 \mathrm{~m}^{3}$ of soil was excavated within Area $\mathrm{C} ; 1.95 \mathrm{~m}^{3}$ from the excavation units and test pits, and $9.8 \mathrm{~m}^{3}$ from the backhoe trenches. Excluding the backhoe trenches, a total of $16.75 \mathrm{~m}^{2}$ of surface area was exposed in Area C.

Although the various units assigned to Area $C$ were placed at locations relatively distant to one another (Fig. 18) and the individual excavation profiles vary slightly, they can, as a group be characterized by the profile drawn for Backhoe Trench 7 and shown in Figure 23,c. No middens, hearths, or other burned rock features were recorded for Area C, although the surface collection had indicated that this was an area of a relatively dense lithic scatter. The subsequent excavations revealed that cultural material occurred in varying densities at depths to $100 \mathrm{~cm}$ below the ground surface.

The profile shown in Figure 23, c indicates the first $50 \mathrm{~cm}$ of soil to be a dark brown clay loam identified as the A-horizon of the Knippa clay soils (Stevens and Richmond 1976) characterized by a lightening in hue and an increase in compaction with depth. The Knippa clay B-horizon begins at approximately $50 \mathrm{~cm}$ below the surface and may extend up to one meter below the surface. This B-horizon is characterized by very compact clay loams and an increase in calcium carbonate deposits. The gravel zone begins at a minimum depth of $70 \mathrm{~cm}$, but may occur at even deeper depths in some parts of Area $C$, as was indicated by the absence of a gravel zone in the meter deep Test Pit 5 .

\section{Area D}

Excavation Area $D$ consisted of two test pit excavations in the north-central area of the site (Fig. 23,d). The test pits are NW218-5 (Test Pit 7) and NE118-5 (Test Pit 8). These two units were placed within sma11, localized lithic concentrations revealed by the random sample surface collection. Both test pits revealed very minor subsurface 1 ithic deposits near the surface. Both of the units were $1-\mathrm{m}^{2}$ and excavated in $20 \mathrm{~cm}$ levels to a depth of $80 \mathrm{~cm}$. A final level (80-100 cm below the surface) was excavated in both units, but was 1 imited to a $50-\mathrm{cm}^{2}$ area (one quadrant). The soil profiles for the two units were virtually identical; the profile for NW218-5 (Test Pit 7 ) is shown in Figure 23,d. The uppermost zone consists of a brown clay loam mixed with numerous pea-sized calcareous gravels. The zone is $35 \mathrm{~cm}$ thick, and is identified as a portion of the A-horizon of the Knippaclays. At approximately 35 to $60 \mathrm{~cm}$ below the surface, the gravels are much 1 es s frequent, and the soil becomes increasingly compact; however, there is no soil color change. The area between 35 and $60 \mathrm{~cm}$ probably represents the remaining A-horizon of the Knippa clay. The deepest identified zone in Area $D$ occurs from $60 \mathrm{~cm}$ to at least $100 \mathrm{~cm}$ below the surface, where the excavations were terminated. The soil in this zone increases in clay content 
and compactness, and an increase in calcium carbonate deposits was noted. Large vertical cracks, widest at the floor of the test pit were also noted within this zone. The soil zone probably represents the B-horizon of the Knippa clay in those units.

\section{FEATURES}

Three features were recorded at site 41 UV 47 . Two of the features were identified as hearths having distinct outlines; the other feature was recorded as a burned rock cluster (Fig. 24,a-d). All three of the features occurred within the Area A excavation units, two associated with the midden deposits, the other located well below the midden zone. Originally, the ceramic scatter found on the surface within Unit NW12 was thought to be a feature, and the first number assignment was reserved for it, but during later excavations within this unit it was deemed unnecessary; as a result Feature 1 remains unassigned.

\section{Feature 2}

Feature 2 was an amorphous cluster of approximately 140 burned rocks. It was located in the southwestern quadrant of Unit SW173-22, and portions of it extended into the south and west walls of that unit (Fig. 24,a). The horizontal limits of the exposed feature boundaries measured $110 \times 80 \mathrm{~cm}$, and was recorded at depths between 25 to $38 \mathrm{~cm}$ below the ground surface.

The feature consisted of about 140 burned rocks, individually varying in size from about $10 \mathrm{~cm}$ in diameter to smaller. The soil matrix between the stones was undifferentiated from the soil surrounding the feature, a dark brown clay loam identified in the Area A excavation profiles as the midden zone soils. Since the feature 1 ies very close to the basal levels of the midden, it is suspected that the feature may have occurred naturally, possibly as a result of an uneven floor for the midden. That is, Feature 2 may represent a scatter of midden soil and rocks at a slightly deeper level than noted in other areas within the unit. A profile of the west walls of Area A Units SW173-12, SW173-17, and SW173-22 shows a slight depression in the midden zone in association with Feature 2, but it could not be determined if the depression was constructed or a natural undulation in the strata.

No diagnostic artifacts were directly associated with the feature, but materials recovered from the screened matrix of the feature are identified as 44 debitage specimens, two small unidentifiable bone fragments, and six Rabdotus sp. land snail shells.

\section{Feature 3}

Feature 3 was defined as a crescent-shaped concentration of unusually large burned 1 imestone rocks (Fig. 24,c,d). The feature formed an open-ended, or "halved" circular shape, with the large stones (15 to $30 \mathrm{~cm}$ in length) set in place around the perimeter of the hearth. Smaller burned rocks were scattered over the larger stones and concentrated within the interior of the 


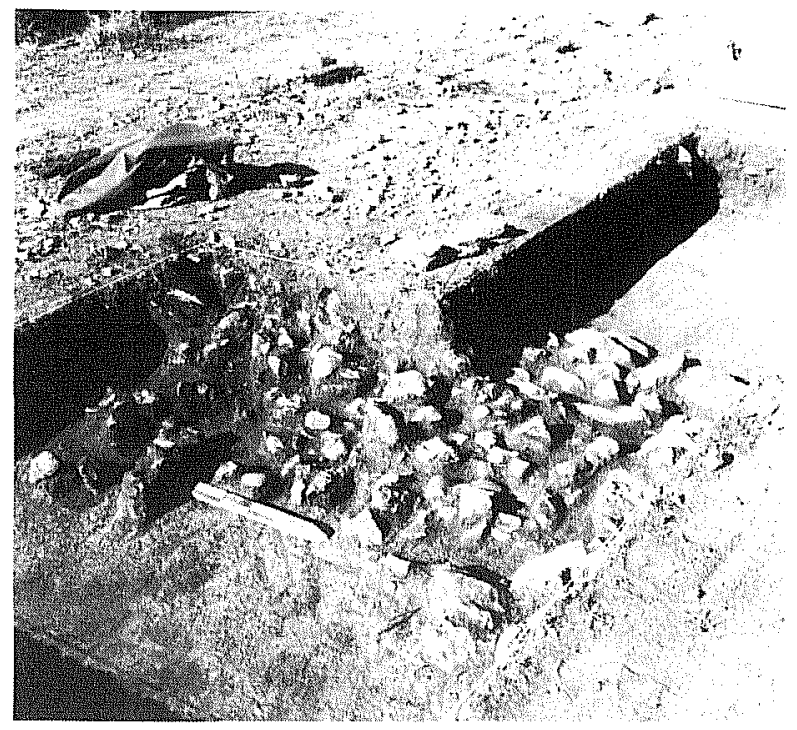

a

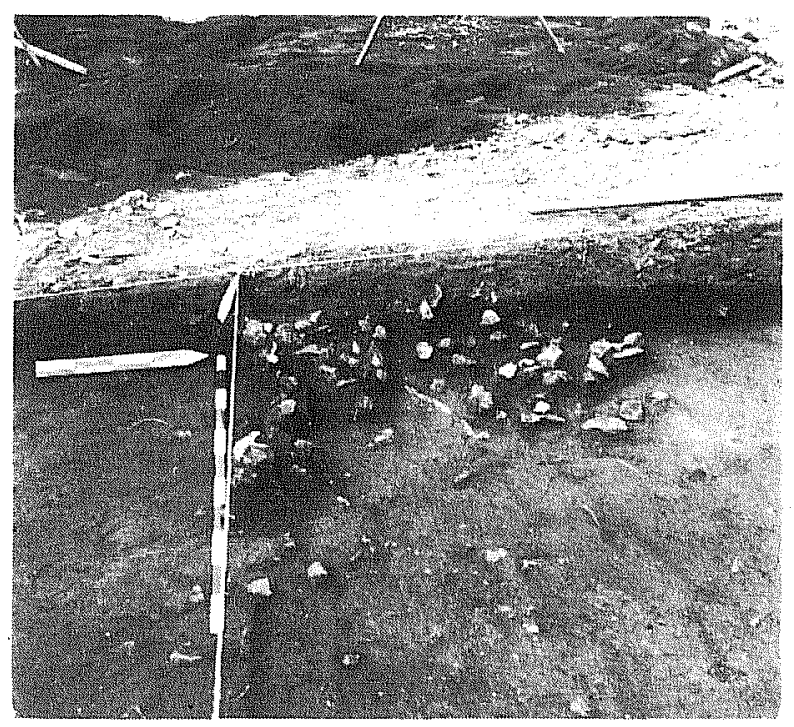

C

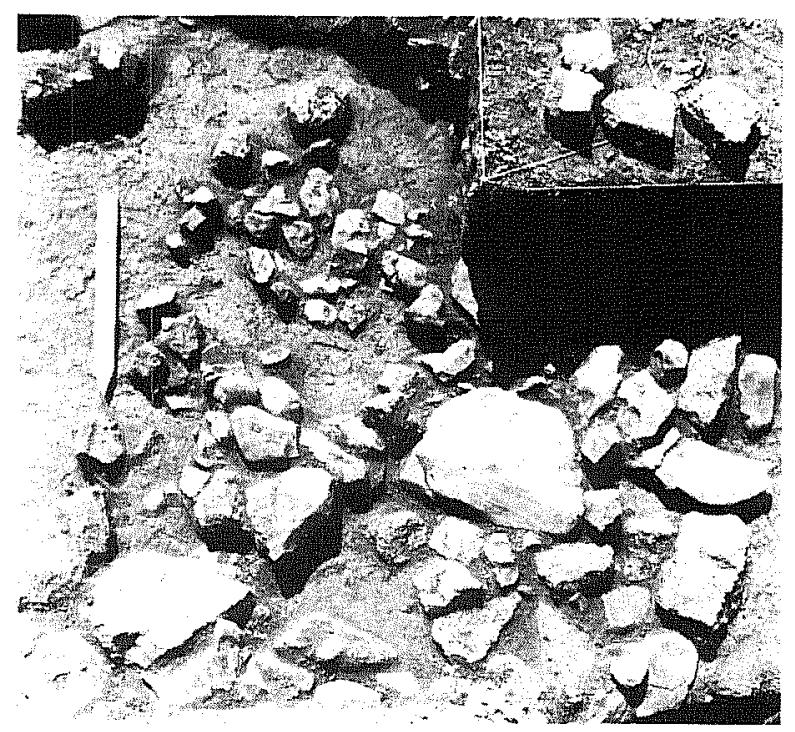

b
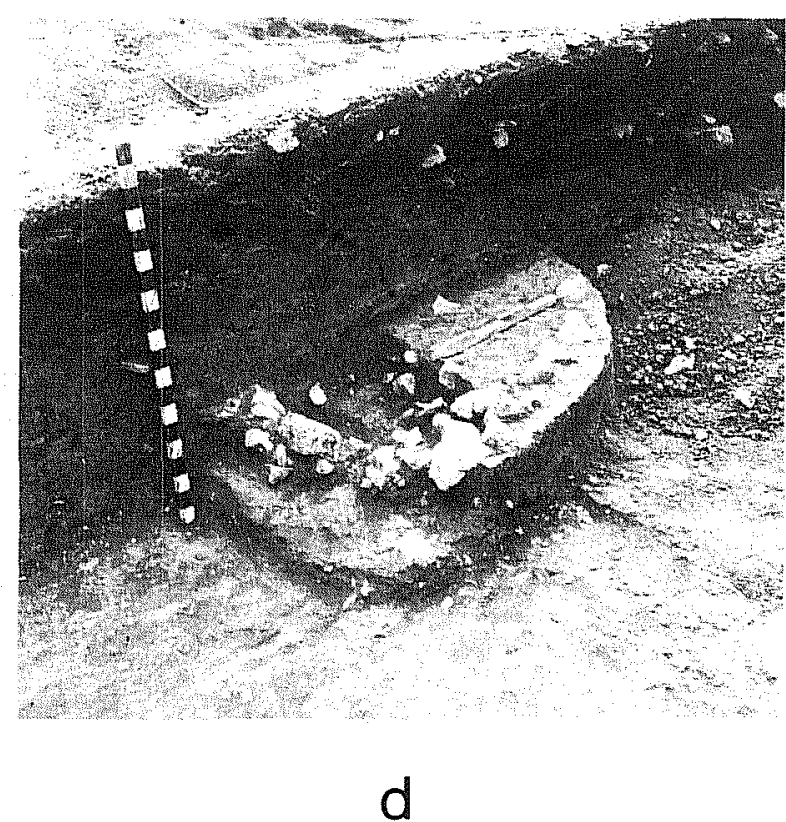

Figure 24. Features 2, 3, and 4 at 41 UV 47. a, Feature 2, 1 ooking west; b, Feature 4, looking southeast; c, Feature 3, plan view; d, Feature 3, looking southwest. 
feature. The feature was shallow and basin-shaped, and the open end of the half circle faced to the southeast.

The exposed portion of the feature was located mainly within Unit SW173-13, and portions of SW173-12, at depths between 35 to $57 \mathrm{~cm}$ below the ground surface. The feature covered a horizontal area measuring approximately $160 \times$ $170 \mathrm{~cm}$ in size. The feature matrix was the same as that of the surrounding midden zone soils. The feature occurred at the basal levels of the midden zone. A charcoal sample taken from Feature 3 was assayed at $620 \pm 70$ B.P. (TX-4435, MASCA corrected), and provides the only date available for the midden zone in excavation Area A. Since the dated charcoal sample came from a distinct feature associated with the basal levels of the midden, the date probably reflects the time period when the midden began to accumulate.

Screened feature matrix contained 135 debitage specimens, 55 of which are burned (41\%). Other recovered materials are mussel shell fragments, two identifiable bone fragments, and 101 land snail shells (98 of which are Rabdotus sp.).

\section{Feature 4}

Feature 4 was identified as a circular, basin-shaped hearth made of burned 1 imestone rocks (Fig. 24,b). An estimated one-half of the feature was exposed by the excavations. The hearth was constructed by placing a single, tightly fitted ring of limestone rocks, averaging 10 to $15 \mathrm{~cm}$ in size, around the perimeter of the feature. Numerous smaller rocks were scattered about within the ring of 1 arger rocks in such a manner as to indicate an earthen basin had been dug out from within the ring. However, no direct evidence of any basin wall was noted when the feature was recorded.

Feature 4 was located within two excavation units: the far northeastern corner of Unit SW173-17 and the far southeastern corner of Unit SW173-22. The exposed portion of the feature covered a horizontal area of $120 \times 65 \mathrm{~cm}$, probably representing the west one-half of a hearth approximately 120 to $140 \mathrm{~cm}$ in diameter. The feature was located at a depth 72 to $99 \mathrm{~cm}$ below the ground surface, within the Knippaclay zone, a zone of compact brown clay loam occurring at least $20 \mathrm{~cm}$ below the midden zone (see Excavation Areas section for 41 UV 47). The feature matrix was the same as that of the surrounding Knippa clay.

Few materials were recovered from the screened feature matrix. There were 17 specimens of debitage (three were burned), a trace of mussel shel1, and 11 land snail shells. Of note, in regards to the relative chronological placement of this feature, is the presence of a number of dart points recovered in two associated units (SW173-17 and SW173-22) below the midden zone. Of nine projectile points found at depths greater than $40 \mathrm{~cm}$ below the surface (the approximate depth of the midden zone), six were dart point forms, suggesting possible Archaic affiliation. Three of the six dart points could be identified as to type (Castroville, Marcos, and Montel1), all diagnostic of the Late Archaic (650 B.C. to A.D. 200) as suggested by Prewitt (1981) for central Texas. 


\section{MATERIAL DISTRIBUTIONS}

The distribution of cultural material remains is presented for site 41 UV 47 by the discussion of artifact, debitage, and burned rock assemblages. The horizontal and vertical patterning within each area of the site and the intrasite distributions are considered for each grouping discussed. Comments on the material is generally limited to consideration of the site area as a whole.

\section{Artifact Distributions}

Arrow points, dart points, overall retouch bifaces, bifacially retouched flakes, bifacial intergrades, other bifaces, unifaces, modified flakes, cores, other lithics, ceramics, and historic materials are individually discussed as artifacts. Only brief mention of the surface artifacts will be included in the following comments, since the surface distribution of these materials has already been reviewed.

\section{Arrow Points}

A total of 62 arrow points was collected at the site. Thirteen of the specimens were surface collected, and 49 were from an excavated context. The distribution of the specimens is shown in Table 23.

The surface distribution of arrow points was almost exclusively limited to the lithic concentrations adjacent to the Eightmile Waterhole, and included Perdiz, Scallorn, and Edwards types. The two specimens found away from the large lithic concentration were a Scallorn from the far southeastern corner of the site, and a Perdiz from the far southwestern corner of the site.

The majority of the arrow points (79\%) were excavated. Arrow points were most common within Area A (38 specimens), but specimens were also recorded in Areas $B$ and $C$. No arrow points were found in the Area D excavations. A summary, by area, of the excavated specimens follows.

TABLE 23. ARROW POINT DISTRIBUTION AT 41 UV 47

\begin{tabular}{|c|c|c|c|c|c|c|c|c|c|}
\hline \multicolumn{4}{|c|}{ Surface Quadrants } & \multirow[b]{2}{*}{ Total } & \multicolumn{4}{|c|}{ Excavation Areas } & \multirow[b]{2}{*}{ Total } \\
\hline SW & NW & SE & NE & & $A$ & B & C & D & \\
\hline 12 & 0 & 1 & 0 & 13 & 38 & 6 & 5 & 0 & 49 \\
\hline
\end{tabular}


Area A contained a variety of arrow point forms 1 imited to Levels $1-4,6$, and 7. Arrow points from the excavation units were most common in Leve 1 (14 specimens) and tended to decrease in amounts thereafter. Table 24 summarizes the vertical distribution of arrow points from the excavation units in Area A. Arrow point preforms, miscellaneous arrow points, and arrow point blade fragments have been grouped together under the category "other arrow points" in Table 24, and two other excavated specimens from SW173-11, Level 1 (a Perdiz pointed stem) and Backhoe Trench 5 (a Scallorn corye11) are not shown in Table 24. Perdiz was the dominant arrow point type (10 specimens), especially Perdiz with pointed stems (five specimens). Notably, only six Perdiz with pointed stems were recovered from all four sites investigated during the project (the sixth specimen is from site 41 UV 48). Other Perdiz forms from Area A are three Perdiz whitney, Iong blade forms; Perdiz whitney, short blade; and a miscellaneous Perdiz. All of the Perdiz arrow points were recovered from Levels 1 and 2 . Scallorn arrow points were the next most common arrow point type (eight specimens), occurring in Levels 1-4, and 6. Three Scallorn specimens were recovered from Level 2; and Levels 1, 3, 4, and 6 contained a single specimen each. The Scallorn forms include two of the coryell variety, two specimens of the eddy variety, a single Scallorn sattler specimen, and three Scallorn-like specimens. The two excavated Sabinal types were confined to Level 4 of Area A. The single Edwards type from Area $A$ was also the deepest recorded typed arrow point; it was recovered from Level 7. Other arrow point forms from Area $A$ include a basal-notched preform, a crude contracting stem form, three single-notched preforms, four miscellaneous arrow point forms, and eight blade fragments. Table 24 shows some indications of a vertical sequence for the typed arrow point forms, with Edwards recorded as the earliest type, followed by Sabinal, Scallorn, then Perdiz.

Six arrow points were recovered from Area B. The forms are Edwards, Scallorn, and an arrow point blade fragment; al1 were recovered from Levels 2-4 of the unit excavated through the midden in Area B (SE110-5). Scallorn types are a coryell variety in Level 2 and a single specimen each of eddy and sattler varieties from Leve1 3. The two Edwards type specimens were found in Levels 3 and 4 . Perdiz is noticeably absent from Area $B$.

Five arrow points were recovered from the Area $C$ excavations: a miscellaneous Perdiz, two Scallorns (coryel1 and eddy varieties) associated with the numerous ceramic sherds from within Level 1 of the NW12 excavation units, a Scallorn-like specimen from SW165-3 (Test Pit 4), and an arrow point blade fragment from SW240-1 (Test Pit 5). All of the specimens from Area C came from the top $20 \mathrm{~cm}$ of the soil deposits. The frequency of arrow points in Area $C$ seems to be relatively lower than that for Areas $A$ and $B$.

In summary, arrow points were recovered from Areas $A, B$, and C. Perdiz was the dominant form from Area $A$ and was confined to Levels 1 and 2 . Additional1y, there was some suggestion of a vertical sequence of arrow points in Area A with Edwards the earliest form, followed by Sabinal, Scallorn, and Perdiz types. Area A contained more arrow point forms than other areas of the site. Scallorn and Edwards were the only typed arrow points from Area $B$, and all of the arrow points in Area $B$ were recovered from within the midden deposits of that excavation area. From Area $C$ were Perdiz and Scallorn types, both forms associated with the remains of prehistoric ceramics. 
TABLE 24. VERTICAL DISTRIBUTION OF ARROW POINTS IN AREA A AT 41 UV 47

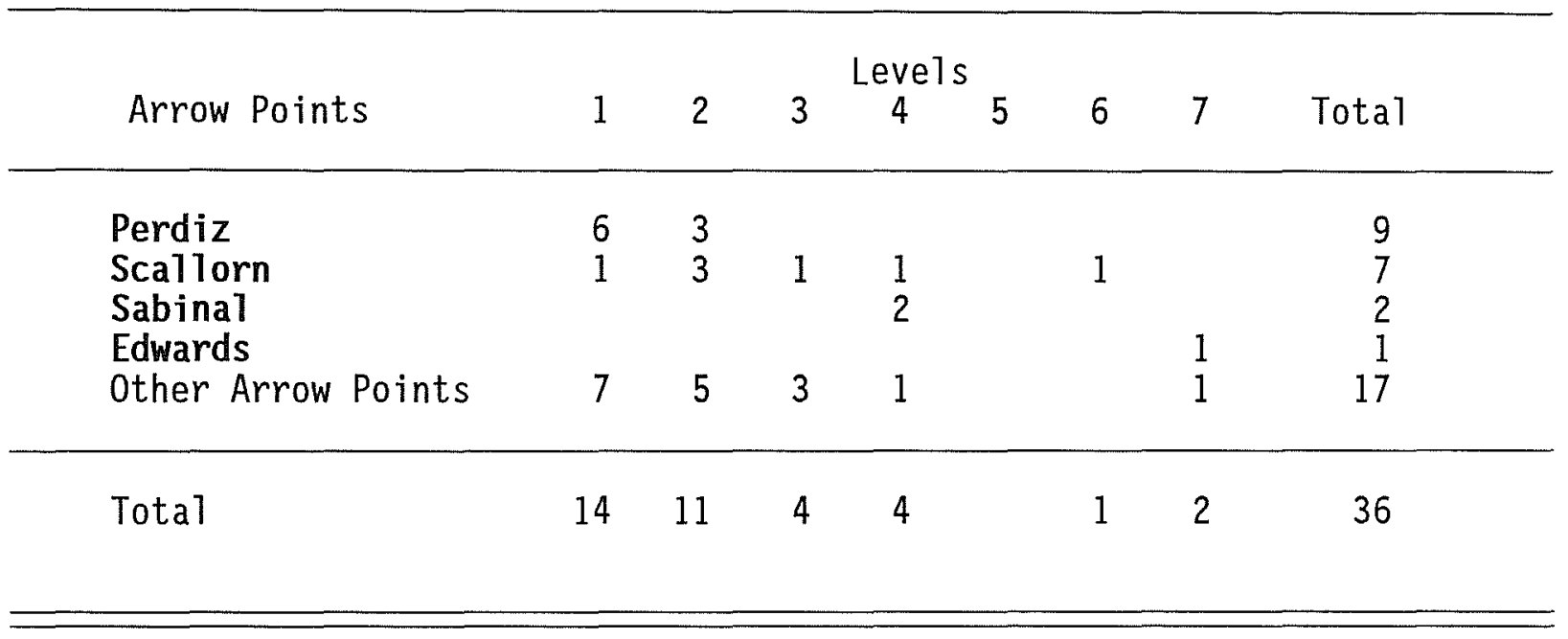

\section{Dart Points}

A total of 41 dart points was recovered from the site. Twenty-nine specimens were surface collected (70\%), most from the southwest quadrant. Of the 12 excavated specimens, 10 are from Area $A$ excavations, and the remaining two specimens are from Areas B and C (Table 25). No dart points were associated with Area D.

The surface distribution of the dart points (Table 25) reveals that most of the specimens were located in the southwest quadrant, and over half of the specimens from that quadrant are identified as Late Archaic Twin Sisters phase forms. The relative frequency of the Twin Sisters phase types within the southwest quadrant was partially matched by a corresponding increase in the percentage of Middle Archaic or earlier forms in the northwest and southeast quadrants (cf. Surface Collection section for 41 UV 47). The recovery of dart point forms on the surface was not matched in the subsurface excavations. Excavations have revealed that Archaic components do indeed exist within the terrace deposits, but at this site the overwhelming percentage of dart points were surface finds, which leads one to suspect that many of the dart points are out of context. It is suspected that the large number of surface-collected dart points were by and 1arge, imported to the site by later populations.

of the 12 excavated dart point specimens, only two came from outside of Area A, an Ensor Variety 1 from Level 4 of SE138-1 in excavation Area B and a Frio from Level 1 of NW12-8 in excavation Area C. The following dart points were recovered from Area $A$ : a single, unidentifiable dart point from Level 1 of SW173-11 (Test Pit 2); in the southwest quadrant, single specimens from Levels 1, 3, and 4 (a Fairland from SW173-12, a Montel1 from SW173-17, and a miscellaneous Form 4 from SW173-22, respectively); a Montell from Level 5 of SW 173-17; a Castroville from Level 6 of SW173-22; a Marcos from Leve 7 of SW 173-17; and three remaining specimens from Levels 5-7 of SW173-22 are unidentifiable. It is worthy of note that the specimen from Level 1 is a 
TABLE 25. DART POINT DISTRIBUTION AT 41 UV 47

\begin{tabular}{|c|c|c|c|c|c|c|c|c|c|}
\hline \multicolumn{4}{|c|}{ Surface Quadrants } & \multirow[b]{2}{*}{ Tota1 } & \multicolumn{4}{|c|}{ Excavation Areas } & \multirow[b]{2}{*}{ Total } \\
\hline SW & NW & SE & NE & & A & B & $C$ & $D$ & \\
\hline 19 & 2 & 5 & 1 & $29 *$ & 10 & 1 & 1 & & 12 \\
\hline
\end{tabular}

*Two specimens are included that are not provenienced.

Late Archaic Twin Sisters form (Fairland), while all of the remaining types identified are classified as Late Archaic San Marcos forms. Also, the depth to which over half of the dart point specimens were provenienced was $50 \mathrm{~cm}$ or more below the ground surface. This depth is below the midden deposits, and it should be noted that only three of the 38 arrow point forms were recovered at depths greater than $50 \mathrm{~cm}$. These data would suggest that a Late Archaic component exists below the midden deposits.

\section{Overal1 Retouch Bifaces}

of the 32 specimens classified as overall retouch bifaces from 41 UV 47, 16 were surface collected, and 16 were from excavated contexts. The distribution is shown in Table 26. Most of the surface-collected specimens were from the southwest quadrant of the site (seven of 16 specimens). Most of the excavated specimens were found in excavation Area $A$ (10 specimens), but specimens also occurred in Areas B, C, and D.

Within excavation Area $A$, six of the overall retouch bifaces are classified as small (40 $\mathrm{mm}$ in length or less), and four specimens are classified as large (over $40 \mathrm{~mm}$ ). The small bifaces were collected in Levels 4 and above, the larger specimens in Level 4 or below. The six small specimens are identified as either triangular forms (three specimens) or miscellaneous forms (three specimens). The small miscellaneous forms occurred in Levels 1 and 2, the triangular forms in Levels 3 and 4 . Although the number of specimens is small for conclusive comparative statements, it is interesting to note that the occurrence of the three small triangular bifaces is within the lower levels of the midden deposit and below the peak occurrence of arrow point forms. This is a situation similar to that of the overall retouch bifaces at 41 UV 48. Of the large forms, there are two triangular forms, a rounded fragment, and an individual Form 4.

Four overall retouch bifaces, a large pointed ovate, two small pointed ovates, and two small miscellaneous specimens were recovered from Area B. A single, small pointed ovate and a small miscellaneous form were recovered from Level 2 of Unit SE110-5, and a large pointed ovate and a small pointed ovate were recovered from LeveTs 3 and 4 of Unit SE138-1, respectively. It 
TABLE 27. BIFACIALLY RETOUCHED FLAKE DISTRIBUTION AT 41 UV 47

\begin{tabular}{|c|c|c|c|c|c|c|c|c|c|}
\hline \multicolumn{4}{|c|}{ Surface Quadrants } & \multirow[b]{2}{*}{ Total } & \multicolumn{4}{|c|}{ Excavation Areas } & \multirow[b]{2}{*}{ Total } \\
\hline SW & NW & SE & $\overline{N E}$ & & $A$ & B & C & $\bar{D}$ & \\
\hline 3 & 2 & 4 & 0 & 9 & 16 & 3 & 1 & 0 & 20 \\
\hline
\end{tabular}

recovered from below Level 4 was a small pointed ovate from Level 6 . Small pointed ovates were the most common form from Area A (four specimens), and small forms were twice as common as large specimens.

The three bifacially retouched flakes recovered from Area B within Levels 5 and 6 of Unit SE138-1 are al1 1arge fragments. The bifacial1y retouched flake recovered from Area C within Level 1 of SW165-3 (Test Pit 4) is a large pointed ovate.

In summary, of the 20 excavated specimens, most were found in Area A. Pointed ovate forms were the most common outline shape (1arge or smal1), followed by fragments, triangulars, amorphous forms, and concave-based specimens.

\section{Bifacial Intergrades}

of the 49 bifacial intergrades collected at 41 UV 47, 32 were surface finds, and 18 specimens were from excavated contexts. The surface finds were most commonly recovered in the southwest and northwest quadrants. The excavated specimens were most commonly recovered in Area $A$, but also occurred in excavation Areas B and C (Table 28).

Within Area A, bifacial intergrades were most common in Levels 1 and 2 (three specimens in each leve1). There were two specimens each in Levels 3 and 4 and a single specimen in Level 4. Asymmetrical forms were the most common subgrouping (seven of eleven specimens); other subgroupings include triangulars (two specimens), a pointed ovate, and a fragment of a bifacial intergrade. Asymmetrical specimens occurred in all the unit-levels containing bifacial intergrades (Levels 1-4 and 9), while the single pointed ovate was found within Level 1, the two triangular specimens were both in Leve1 2, and the fragment was found within Leve1 3.

A11 four of the bifacial intergrades from the Area B excavations were found within the midden or transitional soil zones of Unit SE110-5. They are identified as an asymmetrical form from Level 1 of that unit, and one pointed ovate, one asymmetrical form, and one fragment from within Level 4. The two specimens from excavation Area $C$ are classified as an asymmetrical and a 
TABLE 26. OVERALL RETOUCH BIFACE DISTRIBUTION AT 41 UV 47

\begin{tabular}{|c|c|c|c|c|c|c|c|c|c|c|}
\hline & \multicolumn{4}{|c|}{ Surface Quadrants } & \multirow[b]{2}{*}{ Total } & \multicolumn{4}{|c|}{ Excavation Areas } & \multirow[b]{2}{*}{ Total } \\
\hline & SW & NW & SE & $\mathrm{NE}$ & & $A$ & $B$ & $\mathrm{C}$ & $\bar{D}$ & \\
\hline & 7 & 3 & 2 & 3 & $16^{*}$ & 10 & 4 & 1 & 1 & 16 \\
\hline \multicolumn{11}{|c|}{ *0ne specimen is included that was not provenienced. } \\
\hline
\end{tabular}

should be noted that of the three artifact groupings of overall retouch bifaces, bifacially retouched flakes, and bifacial intergrades, the pointed ovate form was the only identifiable geometric outline within Area B; all other specimens were recorded as fragmentary or indeterminate in outine. Four of the 11 specimens from the above-mentioned artifact groupings had pointed ovate outlines.

Within Areas $C$ and $D$, a single overall retouch biface was recovered from each area. A small triangular form was collected from Backhoe Trench 8 in Area C, and a large miscellaneous form was found within Level 1 of NW218-5 (Test Pit 7).

In summary, 32 overal1 retouch bifaces were recovered at 41 UV 47 . Half of the specimens were surface collected, most of these from the southwest quadrant. Of the excavated specimens, pointed ovate forms were confined to Area $B$, triangular forms to Areas $A$ and $C$, and irregular forms or fragmentary specimens occurred in a 11 excavation areas.

\section{Bifacially Retouched Flakes}

of the 29 bifacially retouched flakes collected from the site, nine specimens were from the surface, and 20 specimens were from an excavated context (Table 27). Of the excavated specimens, 16 were recovered in Area A, three in Area $B$, and one specimen from Area $C$. No bifacially retouched flakes were recovered from Area D.

Within Area A, 15 specimens came from the excavation units, one specimen (a concave-based form) came from Backhoe Trench 5 . Vertically, bifacially retouched flakes came from Levels 2 and 4 (five and four specimens, respective1y), and only one specimen was recovered from below Level 4. Only large specimens were recovered from Leve 1 1: a large pointed ovate, a large triangular, and a large fragment. Level 2 contained a concave-based specimen and four small specimens. The small specimens from Level 2 are a pointed ovate, a triangular, and two fragments. Two small pointed ovates were recovered from Leve1 3. Leve1 4 contained four specimens: a 1 arge pointed ovate, a small triangular, and two amorphous forms. The only specimen 
TABLE 28. BIFACIAL INTERGRADE DISTRIBUTION AT 41 UV 47

\begin{tabular}{|c|c|c|c|c|c|c|c|c|c|}
\hline \multicolumn{4}{|c|}{ Surface Quadrants } & \multirow[b]{2}{*}{ Total } & \multicolumn{4}{|c|}{ Excavation Areas } & \multirow[b]{2}{*}{ Total } \\
\hline SW & NW & SE & NE & & A & $B$ & C & D & \\
\hline 17 & 9 & 2 & 3 & $32^{*}$ & 11 & 4 & 2 & & 17 \\
\hline
\end{tabular}

*0ne specimen was included that was not provenienced.

fragment from the first level of Units NW12-8 and NW12-12, respectively. No bifacial intergrades were found in the Area $D$ excavations.

In summary, most $(65 \%)$ of the bifacial intergrades recovered at 41 UV 47 were surface finds. Of the excavated specimens, the asymmetrical and fragmented specimens occurred in Areas A, B, and C, pointed ovates in Areas $A$ and $B$, and triangulars only in Area $A$. Asymmetrical specimens were the most common subgrouping of bifacial intergrades at the site.

\section{Other Bifaces}

Other bifaces comprise the largest grouping of bifaces at 41 UV 47 . A total of 82 specimens was recovered from the site; 24 were surface collected, most recovered from the eastern half of the southwest quadrant. Of the 58 specimens from an excavated context, 48 were from Area $A$, four were from Area B, five from Area C, and one specimen from Area D (Table 29).

Of the 48 other bifaces recorded from Area A, 65\% (31 specimens) are pointed fragments; $29 \%$ (14 specimens) are midsections or lateral fragments, and three are miscellaneous specimens. The pointed fragments occurred in Levels 1-7 of the excavation units, and one specimen each came from Levels 2 and 4 of SW173-11 (Test Pit 2). Most of the pointed fragments occurred in Levels 1 and 2 (nine specimens in each leve1). The number of pointed fragments decreased greatly after Leve1 2, with the exception of Level 4 (with five specimens). The other levels contained only one or two specimens per level. Midsections or lateral fragments were much less commonly recovered than the pointed fragments, but they did occur in Levels 1-5 and 7 and were most frequent in Level 2 (five specimens). Single examples of miscellaneous specimens occurred in Levels 1-3.

Of the four other bifaces excavated from Area B, three are pointed fragments, one each from Levels 3, 4, and 6 of Unit SE110-9, and the other is a midsection or lateral fragment from Level 3 of Unit SE138-1. Five other bifaces were collected within Area C, are classified as two pointed fragments, two midsections or lateral fragments from Level 1 of the excavation units within the NW12 unit, and a single midsection or lateral 
TABLE 29. OTHER BIFACE DISTRIBUTION AT 41 UV 47

\begin{tabular}{|c|c|c|c|c|c|c|c|c|c|}
\hline \multicolumn{4}{|c|}{ Surface Quadrant } & \multirow[b]{2}{*}{ Total } & \multicolumn{4}{|c|}{ Excavation Area } & \multirow[b]{2}{*}{ Total } \\
\hline SW & NW & SE & NE & & $A$ & B & $C$ & $\bar{D}$ & \\
\hline 15 & 3 & 4 & & $24^{*}$ & 48 & 4 & 5 & 1 & 58 \\
\hline
\end{tabular}

*Two specimens were included that were not provenienced.

fragment from Leve1 1 of SW240-1 (Test Pit 5). The single other biface from Area $D$ is a miscellaneous specimen from Level 4 of NE118-5 (Test Pit 8).

\section{Unifaces}

The unifaces from the site are classified most commonly as miscellaneous forms (nine of 16 specimens). Of the five other subgroups of unifaces (gravers, end scrapers, end and one side, circumferential, and concave edged), the widest variety occurred within Area $A$, and only end scrapers occurred in more than one excavation area. The uniface distribution at 41 UV 47 is shown in Table 30.

\section{Modified Flakes}

Of the 33 specimens classified as modified flakes from 41 UV 47, 20 were surface collected, and 13 were from excavated contexts (Table 31). Similar to the other artifact groups, most of the surface-collected specimens were found in the southwest quadrant, and most of the excavated specimens came from within Area A.

TABLE 30. UNIFACE DISTRIBUTION AT 41 UV 47

\begin{tabular}{|c|c|c|c|c|c|c|c|c|c|}
\hline \multicolumn{4}{|c|}{ Surface Quadrants } & \multirow[b]{2}{*}{ Total } & \multicolumn{4}{|c|}{ Excavation Area } & \multirow[b]{2}{*}{ Total } \\
\hline SW & NW & SE & $\overline{N E}$ & & $A$ & $B$ & $C$ & $\bar{D}$ & \\
\hline 23 & 3 & 4 & 1 & $32^{*}$ & 11 & 2 & 2 & 1 & 16 \\
\hline
\end{tabular}

*0ne specimen is included that was not provenienced. 
TABLE 31. MODIFIED FLAKE DISTRIBUTION AT 41 UV 47

\begin{tabular}{|c|c|c|c|c|c|c|c|c|c|}
\hline \multicolumn{4}{|c|}{ Surface Quadrant } & \multirow[b]{2}{*}{ Total } & \multicolumn{4}{|c|}{ Excavation Area } & \multirow[b]{2}{*}{ Total } \\
\hline SW & NW & SE & NE & & A & $\mathrm{B}$ & C & $\mathrm{D}$ & \\
\hline 14 & 2 & 3 & 1 & 20 & 10 & 1 & 1 & 1 & 13 \\
\hline
\end{tabular}

The 10 excavated specimens from Area $A$ are identified as two decorticate single facet platform flakes from Leve 1 4; one corticate and three decorticate multiple facet platform flakes from Levels 1, 3, and 8; and two corticate and two decorticate chips from Levels 1-3. Within Area B, a single decorticate chip from Level 1 of SE110-5 was the only recorded modified flake in that area. Within Area $C$, the only recorded modified flake is a corticate single facet platform flake from Level 1 of Unit NW12-13. The single modified flake from Area $D$ is a corticate multiple facet platform flake from Leve 2 of NW218-5 (Test Pit 7).

Of the 33 modified flakes, 11 are multiple facet platform flakes, 11 are chips, six are single facet platform flakes, and five flakes have other platforms. Of the 33 flakes, 18 retain some cortex, and 15 are decorticate.

\section{Cores}

There was a total of 56 cores recovered from the site (Table 32). Of these, 40 were surface collected $(70 \%)$, and 16 were from excavated contexts. General1y cores were scattered about on the surface of the site, but there was a locale in the far southwestern corner of the site that contained a relatively high core count; additionally, a core tool concentration was noted adjacent to the Eightmile Waterhole within the eastern half of the site (see 41 UV 47, Surface Collection section).

TABLE 32. CORE DISTRIBUTION AT 41 UV 47

\begin{tabular}{|c|c|c|c|c|c|c|c|c|c|}
\hline \multicolumn{4}{|c|}{ Surface Quadrants } & \multirow[b]{2}{*}{ Total } & \multicolumn{4}{|c|}{ Excavation Areas } & \multirow[b]{2}{*}{ Total } \\
\hline SW & NW & SE & NE & & $A$ & $B$ & C & $D$ & \\
\hline 24 & 7 & 8 & 1 & 40 & 6 & 7 & 2 & 1 & 16 \\
\hline
\end{tabular}


Two core tools and four core nuclei were recovered from excavation Area $A$. The core nuclei occurred in Levels 1, 2, and 4 (two nuclei in Level 4), and two core tools were recovered from Level 1 and Backhoe Trench 6.

The seven cores recovered from Area $B$ are three core nuclei, two multidirectional cores with horizontal striking platforms, a unidirectional core with a prepared platform, and a bifacial core. Two of the cores were collected from the backhoe trenches (one unidirectional core and one multidirectional core). Four of the five cores excavated from the units occurred in Level 1 of Area $B$, and a single specimen was from Level 3.

The two specimens from Area $C$ are a core nuclei from Level 1 of Unit NW12-12, and a multidirectional core with horizontal striking platforms from Level 1 of SW350-25 (Test Pit 6). The single specimen from Area $D$ is a multidirectional core from Level 1 of NE118-25 (Test Pit 8).

Core nuclei were the most common type of core excavated at the site (eight of 16 specimens), followed by four multidirectional cores with horizontal striking platforms, two core tools, a unidirectional core, and a bifacial core.

\section{Other Lithics}

The category of other lithics consists of a hammerstone, two grinding slabs, three handstones, and a smoothed stone. The single hammerstone was surface collected from the southwest quadrant. The two grinding slab fragments were surface collected from the northwest and the southwest quadrants. The single smoothed stone specimen was surface collected from the southwest quadrant. of the three handstones recovered from the site, one was surface collected from the southwest quadrant, and two were excavated from Level 3 of Unit SE110-5 within Area B.

A11 of the surface-collected specimens in this category were associated with the large lithic debitage concentration adjacent to the Eightmile Waterhole (see 41 UV 47, Surface Collection section). The only excavated specimens were from Area B.

\section{Ceramics}

Three possible varieties of Leon Plain ceramics were recorded from the site, represented by 312 sherds. Most of these sherds are associated with the materials excavated from units within Area C. Within the four excavation units opened in NW12, 303 sherds were recovered and are bel ieved to represent the remains of a single vessel, of the Leon Plain, Variety 2 type. Two other sherds of the Variety 2 type were excavated from Area A. Leon Plain, Variety 1 sherds (two sherds) were recovered from the surface of the southwest quadrant and from excavation Area A (two sherds). Leon Plain, Variety 5 sherds occurred only within Level 1 of SW240-1 (Test Pit 5). Ceramic fragments occurred only in Areas $A$ and $C$, within the upper $20 \mathrm{~cm}$ of Area $C$ and the upper $30 \mathrm{~cm}$ of Area $A$. 


\section{Historic Materials}

Historic artifacts were scarce at 41 UV 47 . A total of 13 artifacts was recovered, identified as a white paste earthenware sherd, seven glass specimens, and five metal objects. Two of the finds, a rim fire cartridge casing and a brown bottle glass sherd were from the surface collection (southwest and northwest quadrants, respectively). The excavated historic artifacts are from Areas $A$ and $B$. Three fence staples and a shotgun shel1 casing were recovered from Area A, Levels 1-3 of Unit SW173-13. Collected from the backhoe trenches of Area B were two sherds each of clear, green, and brown glass containers, and a white paste earthenware sherd.

\section{Debitage}

The intrasite distribution of debitage (flakes, chips, burned nonflake chert, and chunks) and the lithic reduction technologies expressed at the site are discussed using the flake platform types. A total of 18,795 items was classified as debitage. Excavation area summaries and intrasite comparisons are restricted to consideration of specific units, so only a part of the debitage is considered in the discussions that follow. Unless otherwise stated, Test Pits 1-6, features, and backhoe trenches have been excluded. The excavation area summaries consider debitage by level, but the intrasite comparisons will be more generalized, and will not consider vertical provenience.

The reader should again note that unit size and level increments are variable within the site. The aforementioned test pits (1-6) were laid out as $50 \mathrm{~cm}^{2}$, while Test Pits 7 and 8 were laid out as $1 \mathrm{~m}^{2}$. A11 test pits were excavated in $20-\mathrm{cm}$ levels. A11 other excavation units were $2 \times 2 \mathrm{~m}^{2}$, excavated in 10-cm levels, with the following exceptions: Unit SW173-12 was a $1 \times 1 \mathrm{~m}^{2}$, Levels 7 and 8 of Unit SE110-5 were reduced to $1 \mathrm{~m}^{2}$ (one quadrant of a $2 \mathrm{~m}^{2}$ ) as was Level 2 of Unit NW12-13. The following discussion will summarize the debitage from each area individually, and will be followed by intrasite comparisons.

A total of 14,184 debitage items was considered within Area A. As shown by Table 33, the overall debitage totals were most frequent in Level 2, although the specific subgrouping of any of the debitage categories may have been more frequent in Level l (specifically secondary flakes and partially corticate chips). While most of the debitage occurred in Levels 1 and 2 (51\% of the Area A collection), a substantial drop in quantity did not occur until after Level 6. Level 6 is at the approximate depth assigned to the bottom of the transitional soil zone within Area A (see Fig. 22). Considering the vertical distribution of the subgrouping of debitage, decorticate chips was the only item to consistently decrease in quantity after it peaked in Level 2 of Area A. Other debitage items experienced a minimum of one other increase in the vertical distribution besides the one recorded for either Level 1 or Leve1 2. Four types of debitage show a secondary peak, or increase, in Level 4 (primary flakes, secondary flakes, interior flakes, and partially corticate chips), three types (secondary flakes, corticate chips, and partially corticate chips) increase in quantity within Level 9, and two types (burned chert and chunks) increase within Level 6. Levels 5, 7, and 8 showed an 
increase in quantity of the following debitage items respectively: corticate chips, secondary flakes, and chunks. Table 33 shows that there are minor variations in counts of specific debitage items, with the possible exception of those items associated with the increase within Level 4 (secondary flakes, interior flakes, and partially corticate chips).

The horizontal distribution of debitage in all levels except Level 1 indicates that debitage items were more frequent as one moved northward within Area A (Fig. 25). Utilizing burned rock counts as an indicator of midden density, it appears that most of the debitage occurred towards the edge of the midden, while burned rock counts increased towards the center of the midden. Test Pits 1 (Unit SW210-25), 2 (Unit SW173-11), and 3 (Unit SW173-25) tend to support this distributional pattern. Test Pit 1, which was located well away from the defined midden boundaries, has a relatively low overall debitage inventory. Of the other two test pits, Test Pit 3 was located on the periphery of the midden and contained the highest debitage inventory, while Test Pit 2, placed within the midden, contained the lowest debitage inventory of the three test pits. The data would suggest most of the activity producing the debitage took place towards the perimeter of the midden, with the least activity in the central part of the midden. However, within as 7 ittle as $10 \mathrm{~m}$ away from the midden the debitage density begins to drop off.

To summarize the debitage distribution of Area A, debitage items were more frequently recovered within Levels 1 and 2 of the midden zone, but the amount did not greatly decrease until after Level 6 , which corresponds to the bottom of the transitional soil zone. The horizontal distribution of debitage tends to be most dense towards the edges of the midden boundaries but then decreases a short distance away from the midden.

Within Area B, a total of 2222 debitage items was recorded within two units (SE110-9 and SE138-1). The vertical distribution of the debitage is summarized in Table 33. Table 33 shows that most of the debitage occurred in Level 3 of Area B. However, as the two units varied considerably in stratigraphy and content, it is worthwhile to consider each separately. Unit SE110-9 was excavated through a midden and contained 1451 debitage items, about twice as much as recovered from Unit SE138-1 (771 specimens). Unit SE138-1 was located about $10 \mathrm{~m}$ northwest of Unit SE110-9 and outside of the midden boundaries. The debitage items from Unit SE110-9 were found to be most frequent within Levels 2 and 3 , levels which approximate the lowest levels of the midden zone (Fig. 26; 41 UV 47, Excavation Areas section). The amounts of recorded debitage decrease sharply below Level 4, as the submidden Knippa clay is reached. Burned nonflaked chert is much more common in Unit SE110-9 than in SE138-1 comprising 83\% (256 of 308 specimens) of the burned chert from Area B. All other debitage items (except a small number of chunks) within SE110-9 never totaled more than $70 \%$ of the area collection. The high percentage of burned chert within the midden would indicate firerelated activities were concentrated within the midden. As will be shown later in the intrasite comparisons, the relatively higher amount of burned nonflake chert (and burned rock) from Area $B$ in comparison to the midden deposits of Area A points to an important difference between the two middens. Unit SE138-1 was excavated into the terrace deposits outside of the midden in Area $B$, and contained a total of 771 debitage items, an amount roughly 

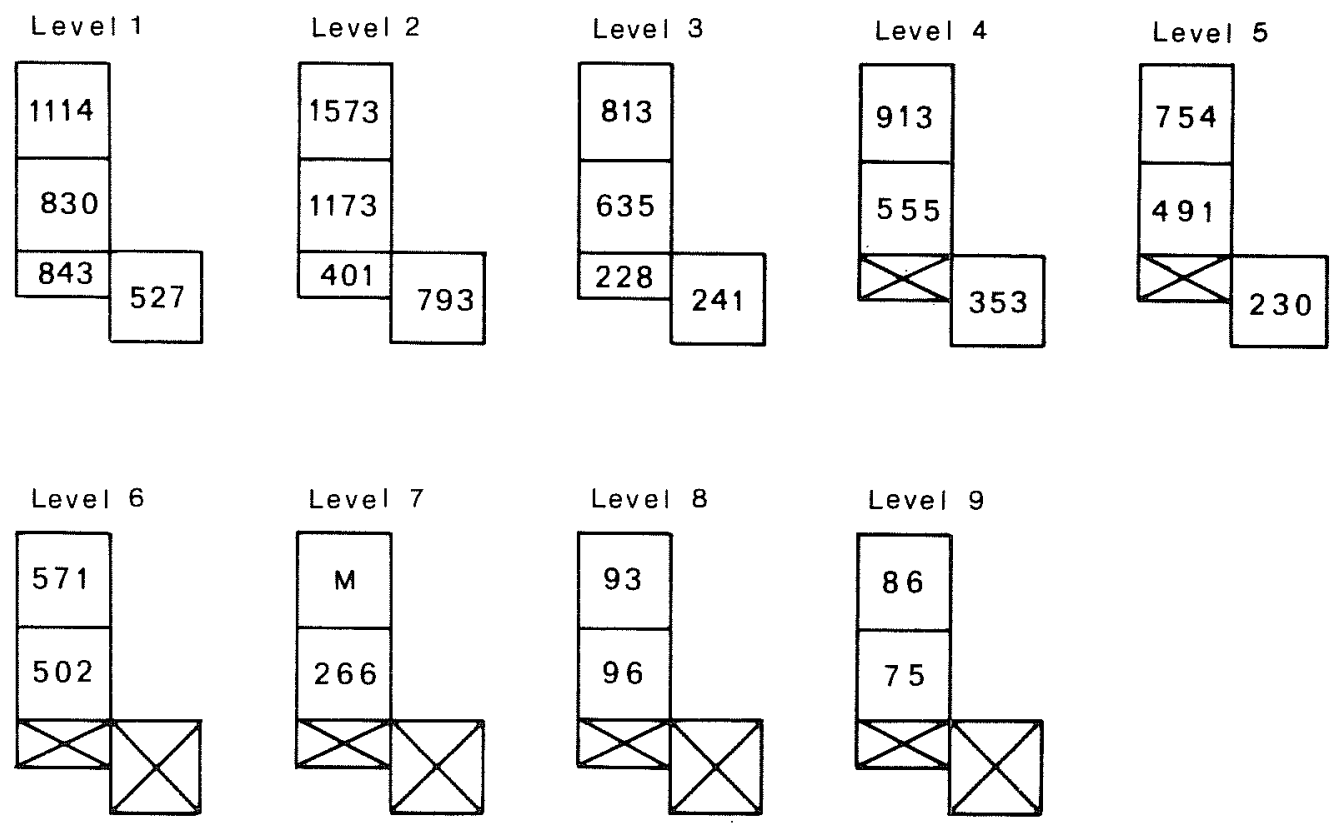

Debitage
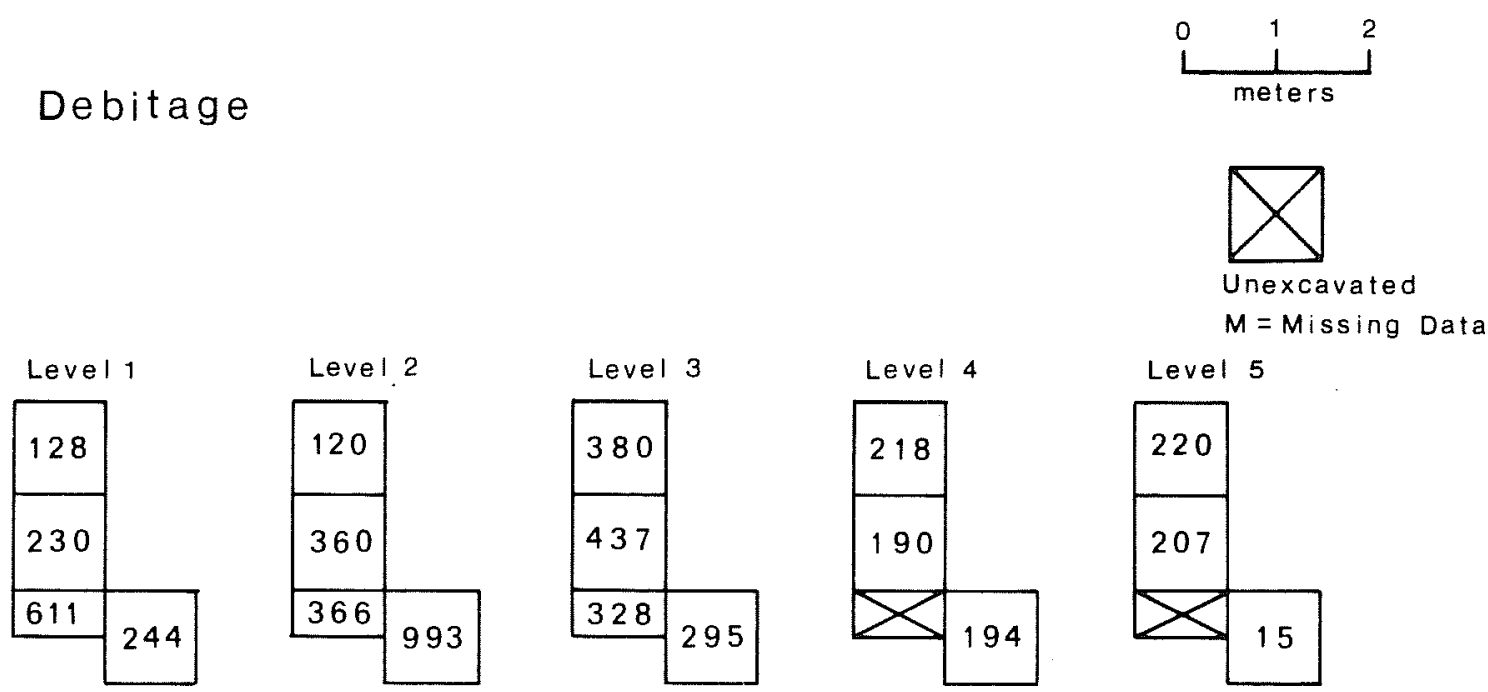

Level 5
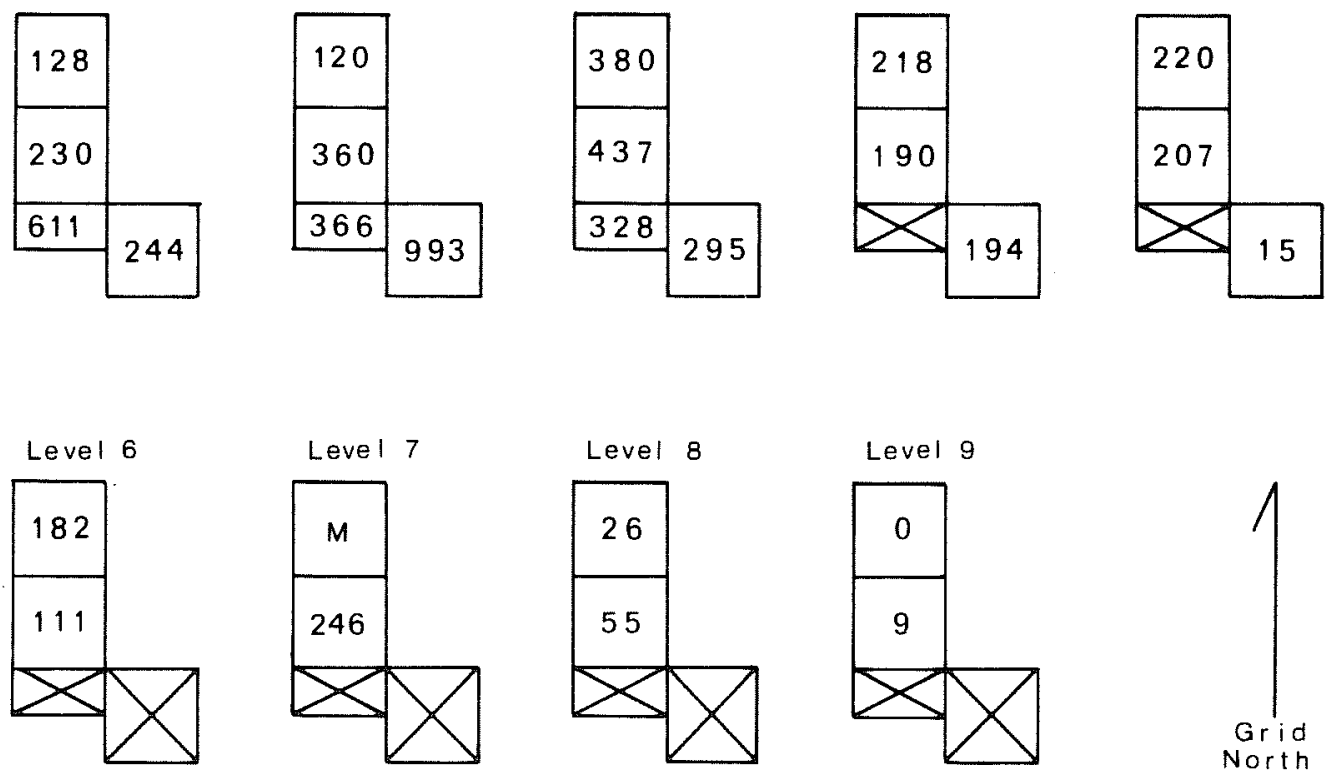

Burned Rock

Figure 25. Horizontal Distribution of Debitage and Burned Rock within Area A at 41 UV 47. 


\begin{tabular}{|c|c|c|c|c|c|c|c|c|c|c|c|c|c|c|c|c|c|c|c|c|c|}
\hline \multirow[b]{2}{*}{ Debitage } & \multicolumn{12}{|c|}{ Area A } & \multicolumn{9}{|c|}{ Area B } \\
\hline & 1 & 2 & 3 & 4 & 5 & 6 & 7 & 8 & 9 & 10 & 11 & Total & 1 & 2 & 3 & 4 & 5 & 6 & 7 & 8 & Total \\
\hline Primary flakes & 3 & 6 & 0 & 4 & 2 & 2 & 0 & 1 & 0 & 2 & 1 & 21 & $\exists$ & 4 & 0 & 2 & 3 & 1 & 0 & 0 & 13 \\
\hline Secondary fi & 164 & 118 & 47 & 130 & 25 & 20 & 26 & $\bar{I}$ & 3 & 1 & 0 & 535 & 14 & 15 & 19 & 44 & 7 & 9 & 1 & 0 & 109 \\
\hline Interior flake & 437 & 501 & 204 & 301 & 146 & 146 & 62 & 40 & 23 & 5 & 1 & 1866 & 33 & 45 & 55 & 82 & 44 & 32 & 0 & 8 & 299 \\
\hline $\begin{array}{l}\text { Corticate chips } \\
\text { Partially corticate }\end{array}$ & 58 & 123 & 71 & 7 & 64 & 43 & 2 & 1 & 13 & 8 & 6 & 396 & 14 & 19 & 12 & 16 & 14 & 11 & 0 & 0 & 86 \\
\hline $\begin{array}{l}\text { chlps } \\
\text { chly cort }\end{array}$ & 306 & 223 & 116 & 150 & 102 & 77 & 14 & 5 & 14 & 2 & 4 & 1013 & 23 & 34 & 73 & 27 & 18 & 11 & 3 & 0 & 189 \\
\hline $\begin{array}{l}\text { Decorticate chips } \\
\text { Burned nonflake }\end{array}$ & 2171 & 2477 & 1325 & 1084 & 1019 & 660 & 142 & 123 & 95 & 30 & 13 & 9139 & 179 & 267 & 305 & 185 & 165 & 69 & 9 & 0 & 1179 \\
\hline $\begin{array}{l}\text { Burned nonflake } \\
\text { chert }\end{array}$ & 152 & 370 & 133 & 127 & 116 & 118 & 19 & 15 & 11 & 7 & 2 & 1070 & 36 & 63 & 107 & 73 & 25 & 4 & 0 & 0 & 308 \\
\hline Chunks & 23 & 66 & 21 & 18 & 1 & 7 & 1 & 3 & 2 & 2 & 0 & 144 & 6 & 18 & 3 & 7 & 3 & 0 & 2 & 0 & 39 \\
\hline Total & 3314 & 3884 & 1917 & 1821 & 1475 & 1073 & 266 & 189 & 161 & 57 & 27 & 14,184 & 308 & 465 & 574 & 436 & 279 & 137 & 15 & 8 & 2222 \\
\hline
\end{tabular}

\begin{tabular}{|c|c|c|c|c|c|c|c|c|c|c|c|c|c|c|c|}
\hline \multirow[b]{2}{*}{ Debitage } & \multicolumn{3}{|c|}{ Area C } & \multicolumn{6}{|c|}{ Test Pit } & \multicolumn{6}{|c|}{ Area D } \\
\hline & 1 & 2 & Total & 1 & 2 & 3 & 4 & 5 & Total & 1 & 2 & 3 & 4 & 5 & Total \\
\hline $\begin{array}{l}\text { Primary flakes } \\
\text { Secondary flakes } \\
\text { Interfor flakes } \\
\text { Corticate chips } \\
\text { Partfally corticate chips } \\
\text { Decorticate chips } \\
\text { Burned nonflake chert } \\
\text { Chunks }\end{array}$ & $\begin{array}{r}3 \\
21 \\
146 \\
11 \\
56 \\
419 \\
47 \\
12\end{array}$ & $\begin{array}{r}0 \\
3 \\
9 \\
0 \\
1 \\
21 \\
1 \\
0\end{array}$ & $\begin{array}{r}3 \\
24 \\
155 \\
11 \\
57 \\
440 \\
48 \\
12\end{array}$ & $\begin{array}{r}0 \\
6 \\
33 \\
5 \\
15 \\
93 \\
19 \\
0\end{array}$ & $\begin{array}{r}0 \\
7 \\
17 \\
4 \\
8 \\
76 \\
6 \\
2\end{array}$ & $\begin{array}{r}0 \\
11 \\
56 \\
3 \\
14 \\
91 \\
21 \\
1\end{array}$ & $\begin{array}{r}0 \\
12 \\
21 \\
0 \\
8 \\
84 \\
0 \\
1\end{array}$ & $\begin{array}{l}0 \\
0 \\
0 \\
0 \\
0 \\
4 \\
0 \\
0\end{array}$ & $\begin{array}{r}0 \\
36 \\
127 \\
13 \\
45 \\
348 \\
46 \\
4\end{array}$ & $\begin{array}{r}0 \\
2 \\
32 \\
8 \\
5 \\
72 \\
11 \\
0\end{array}$ & $\begin{array}{r}0 \\
2 \\
22 \\
1 \\
6 \\
62 \\
0 \\
2\end{array}$ & $\begin{array}{r}0 \\
1 \\
17 \\
4 \\
0 \\
38 \\
2 \\
4\end{array}$ & $\begin{array}{r}0 \\
0 \\
2 \\
0 \\
0 \\
16 \\
2 \\
2\end{array}$ & $\begin{array}{l}0 \\
0 \\
1 \\
1 \\
0 \\
1 \\
0 \\
2\end{array}$ & $\begin{array}{r}0 \\
5 \\
74 \\
14 \\
11 \\
189 \\
15 \\
10\end{array}$ \\
\hline Total & 715 & 35 & 750 & 172 & 120 & 197 & 126 & 4 & 619 & 130 & 95 & 66 & 22 & 5 & 318 \\
\hline
\end{tabular}


one-half of that from the midden unit. Most of the debitage occurred in Levels 4 and 5 of Unit SE138-1. These two Tevels correspond to the lower portion of the defined Knippa clay A-horizon zone. The debitage count dropped considerably once into the B-horizon zone.

To summarize the Area B debitage, there is a noticeable difference in the horizontal distribution of the material, and it would appear that most of the chipping activity took place within the midden. Vertically, debitage was most frequent near either the base of the midden deposits or at the bottom of the Knippa clay A-horizon.

A total of 1369 debitage items was recorded from the excavations in Area C, excluding a very small amount of material from the trenches. Table 33 summarizes the debitage from the excavation units within the 10-m block NW12 and the test pit units. The four units opened up within Unit SW12 were excavated only to the first level, excluding a second level excavated within a quadrant of Unit NW12-13. The block of units contained 750 debitage specimens, of which $50 \%$ (337 specimens) came from Level 1 of Unit NW12-12. of note, just under $50 \%$ of the ceramics recovered from the NW 12 units came from that same unit. The three excavated test pits within Area $C$ contained 619 debitage specimens (Table 33). Approximately 55\% of the debitage was recovered from SW240-1 (Test Pit 5), with the remaining debitage divided into rough7y equal proportions between Units SW165-3 (Test Pit 4) and SW350-25 (Test Pit 6). The vertical distribution of debitage within the test pits shows a bimodal distribution pattern, with most of the material occurring in Levels 1 and 4.

In summary, Area $C$ contained evidences of substantial subsurface deposits to a depth of at least $80 \mathrm{~cm}$ below the surface, over a wide area. These deposits were not associated with midden features.

Within Area D, 318 debitage specimens were recovered from two test pits, NW218-5 (Test Pit 7) and NE118-25 (Test Pit 8). The distribution of debitage by level for the area is shown in Table 33. Debitage was most frequent in Level 1 of both units and tended to decrease in quantity each level thereafter. The overall recovery rate for the site was the lowest within Area D, and it is inferred from the low debitage and artifact recovery rate that the area was the least frequently utilized site area tested within the site.

The intrasite distribution of the debitage excavated from the four site areas is presented in Table 34 . Table 34 shows the debitage items by actual count and approximate percentage within the excavation areas. The relative percentages of the debitage subgroupings remain fairly consistent between areas for most items, with a few exceptions. Interior flakes within Areas $A$ and $B$ are relatively less frequent than is the case for interior flakes from Areas C and D (13\% vs. approximately $22 \%$ of the area specific collections, respectively). A more detailed examination of the relation between flakes and chips is graphically presented in Figure 26 . The histograms in Figure 26 compare the intrasite distribution of flakes and chips and show that the Tower percentages of interior flakes within Areas A and B indicated by Table 33 were met by an increase in secondary flakes in those two areas. Secondary flakes are about twice as common within the total collection of flakes as are partially corticate chips within the total chip collection. One would expect 
TABLE 34. INTRASITE DISTRIBUTION OF DEBITAGE FROM 41 UV 47

\begin{tabular}{|c|c|c|c|c|c|c|c|c|c|c|}
\hline \multirow[b]{2}{*}{ Debitage } & \multicolumn{8}{|c|}{ Excavation Areas } & \multirow{2}{*}{\multicolumn{2}{|c|}{ Total }} \\
\hline & A & & $B$ & & $\mathrm{C}$ & & D & & & \\
\hline $\begin{array}{l}\text { Primary flakes } \\
\text { Secondary flakes } \\
\text { Interior flakes } \\
\text { Corticate chips } \\
\text { Partially corticate chips } \\
\text { Decorticate chips } \\
\text { Burned nonflaked chert } \\
\text { Chunks }\end{array}$ & $\begin{array}{r}21 \\
535 \\
1866 \\
396 \\
1013 \\
9139 \\
1070 \\
144\end{array}$ & $\begin{array}{l}* \\
(4) \\
(13) \\
(3) \\
(7) \\
(64) \\
(8) \\
(1)\end{array}$ & $\begin{array}{r}13 \\
109 \\
299 \\
86 \\
189 \\
1179 \\
308 \\
39\end{array}$ & $\begin{array}{l}(1) \\
(5) \\
(13) \\
(4) \\
(9) \\
(53) \\
(14) \\
(2)\end{array}$ & $\begin{array}{r}3 \\
24 \\
155 \\
11 \\
57 \\
440 \\
48 \\
12\end{array}$ & $\begin{array}{l}* \\
(3) \\
(21) \\
(1) \\
(8) \\
(59) \\
(6) \\
(2)\end{array}$ & $\begin{array}{r}0 \\
5 \\
74 \\
14 \\
11 \\
189 \\
15 \\
10\end{array}$ & $\begin{array}{l}(0) \\
(2) \\
(23) \\
(4) \\
(3) \\
(59) \\
(5) \\
(3)\end{array}$ & $\begin{array}{r}37 \\
673 \\
2394 \\
507 \\
1270 \\
10,947 \\
1441 \\
205\end{array}$ & $\begin{array}{l}* \\
(4) \\
(14) \\
(3) \\
(7) \\
(63) \\
(8) \\
(1)\end{array}$ \\
\hline Total & 14.184 & $(100)$ & 2222 & (101) & 750 & $(100)$ & 318 & $(99)$ & 17,474 & $(100)$ \\
\hline
\end{tabular}

*Less than $1 \%$. 


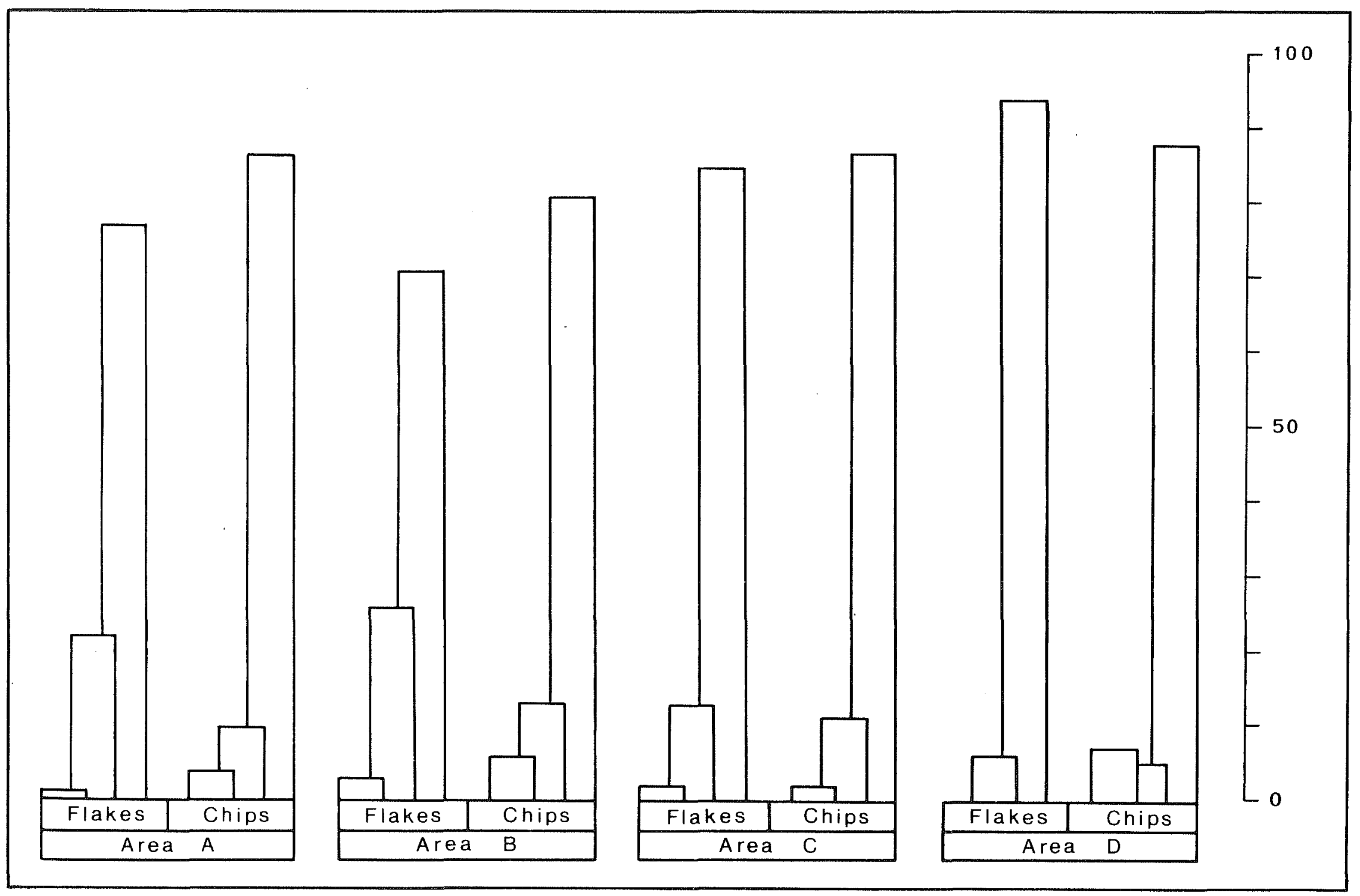

$\infty$
\&
\pm
$\Xi$
\pm
\pm

Figure 26. Comparison of Excavated Flakes and Chips by Area at 41 UV 47. 
a more similar distribution between the flakes and chips when subdivided according to the amount of remaining cortex; a distribution more 1 ikely expressed by the flakes and chips from Areas $C$ and $D$ where the percentages of corresponding flake and chip specimens are approximately equal to each other. A satisfactory explanation for the disproportional relationship within Areas $A$ and $B$ cannot be offered, other than to suggest that secondary flakes were selected for in such a manner that their frequency was increased by intentional curation or by discard.

The intrasite distribution of burned nonflaked material within the debitage collection shows an unusually high percentage within Area B (Table 33). As was noted in the area summaries, most of the burned chert was found in the midden deposits of Area B. Coupled with the higher density of burned limestone rocks and a lower overall debitage recovery rate per unit-level than within Area $A$, the large amount of burned chert within Area B suggests that the two middens on the site vary significantly, with more fire-related activity taking place within Area B.

Overall debitage densities within the site indicate Area A contained the highest average unit-level recovery rate, followed by Areas $B$ and $C$ in roughly equal proportions. The lowest overall debitage recovery was from Area D. Intrasite densities were compared by relative percentages of debitage items within areas.

To summarize, the distribution of the various debitage items is relatively consistent between site areas, although it was shown that secondary flakes were unusually more frequent within Areas $A$ and $B$ of the site. Additionally, burned nonflaked material was more common in Area B than any other area of the site. Overall, the density of debitage within the site varied locally, being most frequent in Area $A$, and least frequent in Area D. Areas $C$ and $D$ have roughly equal debitage densities.

\section{Flake Platforms}

A total of 3104 platformed flakes was considered in the following analysis. This total includes all the platformed flakes, except for those from Test Pits 1-6 and the backhoe trenches. Six platform types are recognized within the collection: cortex platforms, single facet platforms, small multiple facet platforms, large multiple facet platforms, lipped flakes, and other platforms. Utilizing previous work by others in south and central Texas (Hester 1978a; Montgomery 1978; Hall, Black, and Graves 1982), the platform types can be used to infer the presence of certain lithic reduction technologies. In this report, cortex platforms, single facet platforms, and large multiple facet platform flakes are suggested to be representative of a core reduction technology. Other platform flakes, a catch-all category representing less than $1 \%$ of the flake collection, have been arbitrarily included within the group of core reduction flakes. The distribution of core reduction flakes is shown in Table 35. The flakes with small multiple facet platforms and 1 ipped flakes are suggested to represent a biface reduction technology, and are also summarized in Table 35. 
TABLE 35. SUMMARY OF FLAKE PLATFORM TYPES FROM 41 UV 47

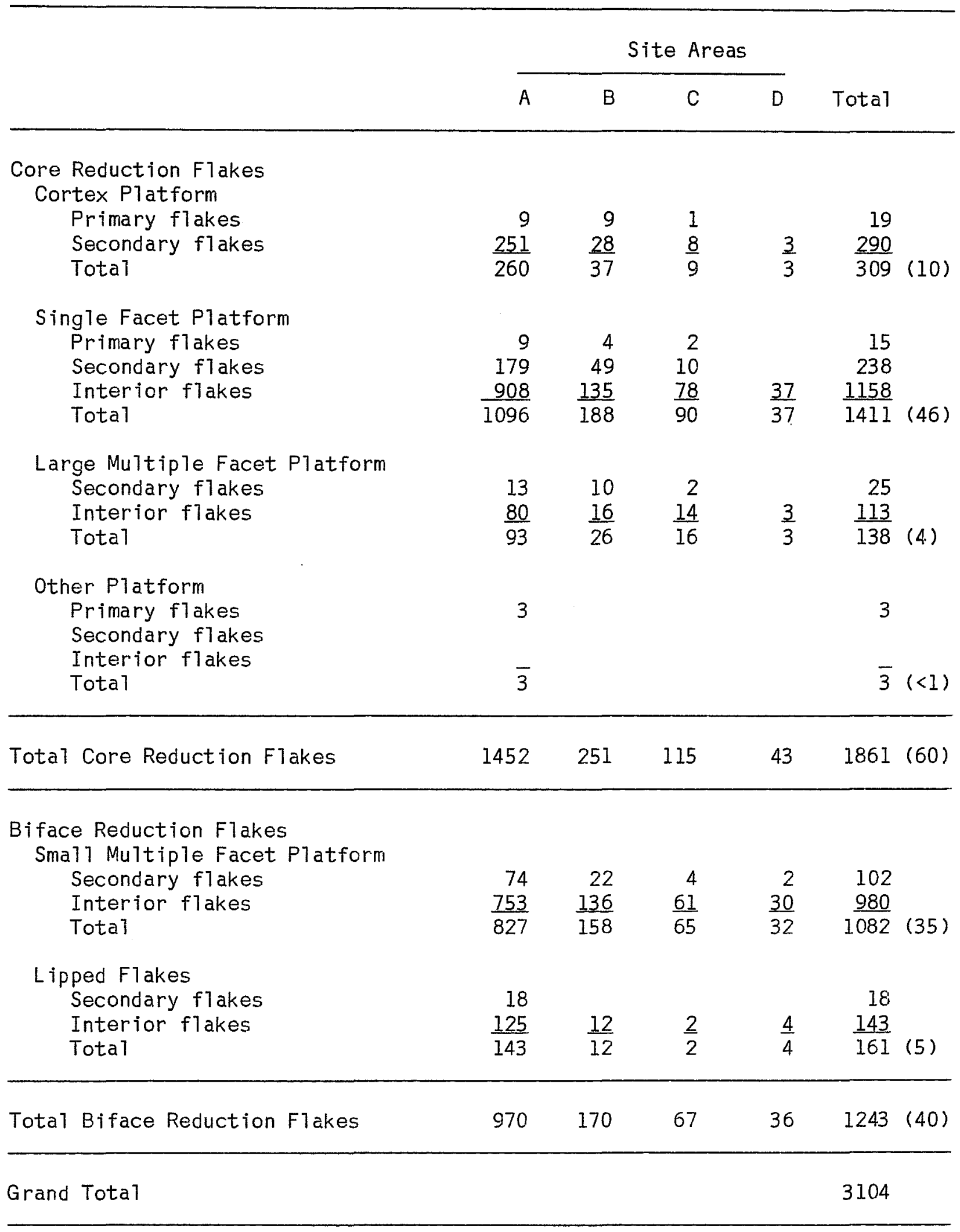

Note: Numbers in parentheses represent percentages. 
Approximately $60 \%$ of the platformed flakes were identified as core reduction flakes, the remaining $40 \%$ fell within the biface reduction $\mathrm{flake}$ group. The majority of the core reduction flakes have single facet platforms (over $75 \%$ of the core reduction flakes), and the majority of the biface reduction flakes have small multiple facet platforms (about $87 \%$ of the biface reduction flakes).

of the primary flakes, cortex platforms and single facet platforms are present in about the same amount; a few specimens classified as other platforms were also recorded. Secondary flakes total 673 specimens, $43 \%$ of which have cortex platforms and $35 \%$ have single facet platforms. Secondary flakes with small multiple facet platforms (15\%), large multiple facet platforms (4\%), and 1 ipped flakes (3\%) were much less common than the previously mentioned platform types. The 2394 interior flakes were dominated by single facet platform flakes (48\%) and small multiple facet platform flakes (41\%). Lipped flakes and large multiple facet platforms were much less common on interior flakes ( $6 \%$ or less each). Thus, over one-half of all the primary, secondary, and interior flakes are classified with the core reduction flake group. This was especially evident with the primary and secondary flakes, as all of the primary flakes and $82 \%$ of the secondary flakes were placed (via platform type) under the core reduction flake group. Interior flakes were more evenly divided between the two flake types, with slightly more than half of the interior flakes classified as core reduction flakes (53\%).

The high number of core reduction flakes implies that core reduction activities were a major component of the lithic technology expressed at the site. Additionally, the high number of one platform type (single facet platform flakes) would point to a specific, preferred core reduction technology (Montgomery 1978). The production of flakes suitable as blank forms for tool production is considered a major emphas is of the core reduction technology, and finds support in the relative frequency of the excavated bifacially retouched flakes in comparison to overall retouch bifaces and bifacial intergrades. Of note, the excavated sample of cores is comprised mostly of core nuclei and multidirectional cores with horizontal striking platforms. Less frequent are prepared platform unidirectional cores, bifacial cores, and core tools. None of the core types occur in enough quantities to suggest a single core type may have been produced as a result of any specific reduction practice.

To summarize, the flake platforms described here indicate that core reduction activities were the predominant reduction technology at the site. The high number of single facet platform flakes may suggest a particular core reduction technique was preferred, possibly to produce flake blanks exemplified by the numerous bifacially retouched flake specimens recorded at the site. However, a specific core form could not be associated with the core reduction technology.

\section{Burned Rock}

Burned rock, virtually all limestone, from 41 UV 47 was quantified by counting the number of specimens within most of the unit-levels excavated. 
Burned rocks were recorded in the field as unit-levels were excavated and then discarded. The rocks recorded were not subject to strict 1 imitations on size or shape, but generally the rocks were angular-shaped specimens, $3 \mathrm{~cm}$ or greater in size. The results of the field tabulations for the various unitlevels are presented in Table 36.

The burned rock counts in Table 36 are used to make some general observations on excavation area distributions and also to make intrasite comparisons. The following summarizes each excavation area individually and considers the intrasite distributional patterns.

Area A contained burned rock counts of over 100 specimens per unit-level in a 11 levels above Level 7 , with a single exception (15 burned rocks in Unit SW173-13, Leve1 5). Generally, most of the burned rock occurred in Levels 1 3 , with peak occurrences in Level 2 or Level 3. Burned rock counts for Levels 1-3 varied from 120 to 993 specimens per unit-level, with an average of 340 burned rocks per unit-level. In contrast, there was an average of only 91 burned rocks per unit-level for Levels 4-11; although the burned rock counts per any specific unit-level varied from 0 to 260 . So, although the burned rock count was variable, a sizable relative density can be noted between the midden and submidden soil zones. As was noted in the debitage distribution discussion, horizontal trends in the distribution of burned rocks can be suggested within Area A (Fig. 25). In the upper levels of Area A (within the first three levels), burned rocks tend to increase in quantity towards the south, indicating that most of the burned rock was concentrated near the center of the defined midden boundaries. Below Level 4, burned rock densities begin to drop off, and for any particular level, burned rocks tend to be more often found in the northernmost units.

Within excavation Area B, burned rocks were unusually dense in Unit SE110-9, which was excavated through a thin midden zone. Generally, the midden zone was defined as occurring in Levels 1-4. The peak occurrence for burned rock counts was 2565 in Level 2, and an average burned rock count of 1087 specimens was calculated for Levels 1-4. Below the midden zone (Levels 5-8), burned rock dropped off dramatically to a maximum of 283 specimens in Leve1 5. Very few burned rocks were recorded within the two lowest levels, which penetrated the gravel zone of that area. Away from the midden area, with in Unit SE138-1, burned rock counts increased from Leve1 1 to Leve1 4, with 189 specimens recorded for Level 1 and 615 in Level 4.

Within excavation Area $C$, burned rock recorded from the four units excavated in Unit NW12 varied from a maximum of 185 to a minimum of 35 for the first level, and would indicate a relatively low burned rock density in comparison to either excavation Area A or Area B. The amount of burned rock recorded from the three test pits within Area $C$ was variable from test pit to test pit. Eighty-six specimens was the maximum recorded count from Level 1 of SW240-1 (Test Pit 5), four was the minimum count from Level 4 of SW165-3 (Test Pit 4).

In excavation Area D, burned rocks were relatively infrequent. The highest count was 175 specimens in Level 1 of NE118-5 (Test Pit 8), but much lower counts were common (Table 36). 
TABLE 36. SUMMARY OF EXCAVATED BURNED ROCK AT 41 UV 47

\begin{tabular}{|c|c|c|c|c|c|c|c|c|c|c|c|c|c|}
\hline Area/Unit & Leve 1: & $: 1$ & 2 & 3 & 4 & 5 & 6 & 7 & 8 & 9 & 10 & 11 & Total \\
\hline $\begin{array}{l}\text { Area A } \\
\text { SW173-12 } \\
\text { SW173-13 } \\
\text { SW173-17 } \\
\text { S173-22 }\end{array}$ & & $\begin{array}{l}611 \\
244 \\
230 \\
128\end{array}$ & $\begin{array}{l}366 \\
993 \\
360 \\
120\end{array}$ & $\begin{array}{l}328 \\
295 \\
437 \\
380\end{array}$ & $\begin{array}{l}194 \\
190 \\
218\end{array}$ & $\begin{array}{r}15 \\
207 \\
220\end{array}$ & $\begin{array}{l}111 \\
182\end{array}$ & $\begin{array}{r}M \\
246\end{array}$ & $\begin{array}{l}55 \\
26\end{array}$ & $\begin{array}{l}9 \\
0\end{array}$ & 21 & $x$ & $\begin{array}{l}1305 \\
1741 \\
1620 \\
1520\end{array}$ \\
\hline Total & & 1213 & 1839 & 1440 & 602 & 442 & 293 & 246 & 81 & 9 & 21 & & 6186 \\
\hline & Level: & $: 1$ & 2 & 3 & 4 & 5 & 6 & 7 & 8 & Total & & & \\
\hline $\begin{array}{l}\text { Area B } \\
\text { SE110-9 } \\
\text { SE138-1 }\end{array}$ & & $\begin{array}{l}629 \\
189\end{array}$ & $\begin{array}{r}2565 \\
267\end{array}$ & $\begin{array}{r}1529 \\
445\end{array}$ & $\begin{array}{l}992 \\
615\end{array}$ & $\begin{array}{l}283 \\
501\end{array}$ & $\begin{array}{l}232 \\
211\end{array}$ & 33 & 1 & $\begin{array}{l}6264 \\
2228\end{array}$ & & & \\
\hline Total & & 818 & 2832 & 1974 & 1607 & 784 & 443 & 33 & 1 & 8492 & & & \\
\hline & Leve1: & $: 1$ & 2 & 3 & 4 & 5 & Total & & & & & & \\
\hline $\begin{array}{l}\text { Area C } \\
\text { NW12-7 } \\
\text { NW12-8 } \\
\text { NW12-12 } \\
\text { NW12-13 } \\
\text { Test Pit } 4 \\
\text { Test Pit } 5 \\
\text { Test Pit } 6\end{array}$ & & $\begin{array}{r}185 \\
M \\
45 \\
35 \\
30 \\
36 \\
18\end{array}$ & $\begin{array}{r}7 \\
43 \\
37 \\
60\end{array}$ & $\begin{array}{r}55 \\
\times \\
19\end{array}$ & $\begin{array}{r}4 \\
\times \\
25\end{array}$ & $x$ & $\begin{array}{r}185 \\
\\
45 \\
42 \\
132 \\
73 \\
122\end{array}$ & & & & & & \\
\hline Total & & 349 & 147 & 74 & 29 & & 599 & & & & & & \\
\hline & Leve1: & 1 & 2 & 3 & 4 & 5 & Total & & & & & & \\
\hline $\begin{array}{l}\text { Area D } \\
\text { Test Pit } 7 \\
\text { Test Pit } 8\end{array}$ & & $\begin{array}{r}20 \\
175\end{array}$ & $\begin{array}{c}M \\
56\end{array}$ & $\begin{array}{r}x \\
11\end{array}$ & $\begin{array}{l}M \\
1\end{array}$ & $\begin{array}{l}M \\
0\end{array}$ & $\begin{array}{r}20 \\
243\end{array}$ & & & & & & \\
\hline Total & & 195 & 56 & 11 & 1 & 0 & 263 & & & & & & \\
\hline
\end{tabular}


At 41 UV 47, burned rock was most common within the midden zones of excavation Areas $A$ and $B$. Of the two middens, the one in Area $B$ showed a higher overall average of burned rocks. Beneath the midden zones and away from the middens the number of burned rocks was characteristically smaller. The distribution of burned rocks on the site suggests fire-related activities took place throughout the site, but was probably concentrated within the middens.

\section{PLANT AND ANIMAL REMAINS}

Vertebrate faunal remains, snail shells, unionids (freshwater mussels), and wood charcoal specimens comprise the plant and animal remains analyzed for 41 UV 47. Each group is discussed separately.

\section{Faunal Remains}

Relatively few faunal remains were recovered from site 41 UV 47 , especially when one considers the numerous faunal remains found at the nearby site, 41 UV 48. Table 37 shows the provenience of all the faunal specimens recovered at 41 UV 47 . Faunal identifications were made by Robert $F$. Scott IV (then of the University of Wyoming). The following paragraphs will briefly summarize the recovered bone from each excavation area.

Excavation Area A contained the majority of the recovered bone at the site. The only three identifiable specimens from the site were found within excavation Area $A$. They are identified as two deer-sized phalanges recovered from Level 5 of Unit SW173-17 and a distal tibia fragment of a mature Sylvilagus auduboni i (cottontail rabbit) from Level 2 of Unit SW173-14 (Test Pit 2). Most of the faunal remains within Area $A$ were unidentifiable bone fragments. Of the 282 unidentifiable specimens, 35 are burned. Excluding 10 bone fragments recovered from the test pits, trenches, and features, 252 of the 272 bone fragments from the Area A excavation units came from Levels $1-3$. The following level distributions are noted for the first three leve1s: 54 specimens in Level 1, 65 specimens in Level 2, and 133 specimens in Level 3. Below Level 3, the total level count does not exceed nine specimens. Within the first three unit-levels, however, the number of bone fragments recovered from any particular unit-level varied considerably, from a total absence of bone to 114 specimens.

Very little bone was recovered within excavation Area B. Of the 19 bone fragments from Area B, 14 were from a single unit-level (Level 9 of Unit SE110-9). The remaining specimens consist of a single burned bone fragment in Level 4 of Unit SE138-1 and four fragments scattered in Levels 1, 3, and 4 of Unit SE110-9 (Table 37).

Bone recovery within Area $C$ was also scarce. Fourteen bone fragments were found within Area $C$, with all but a single specimen coming from Levels 1 and 2 of Unit SW165-3 (Test Pit 4). No faunal remains were recovered from within excavation Area D. 
TABLE 37. FAUNAL REMAINS FROM 41 UV 47

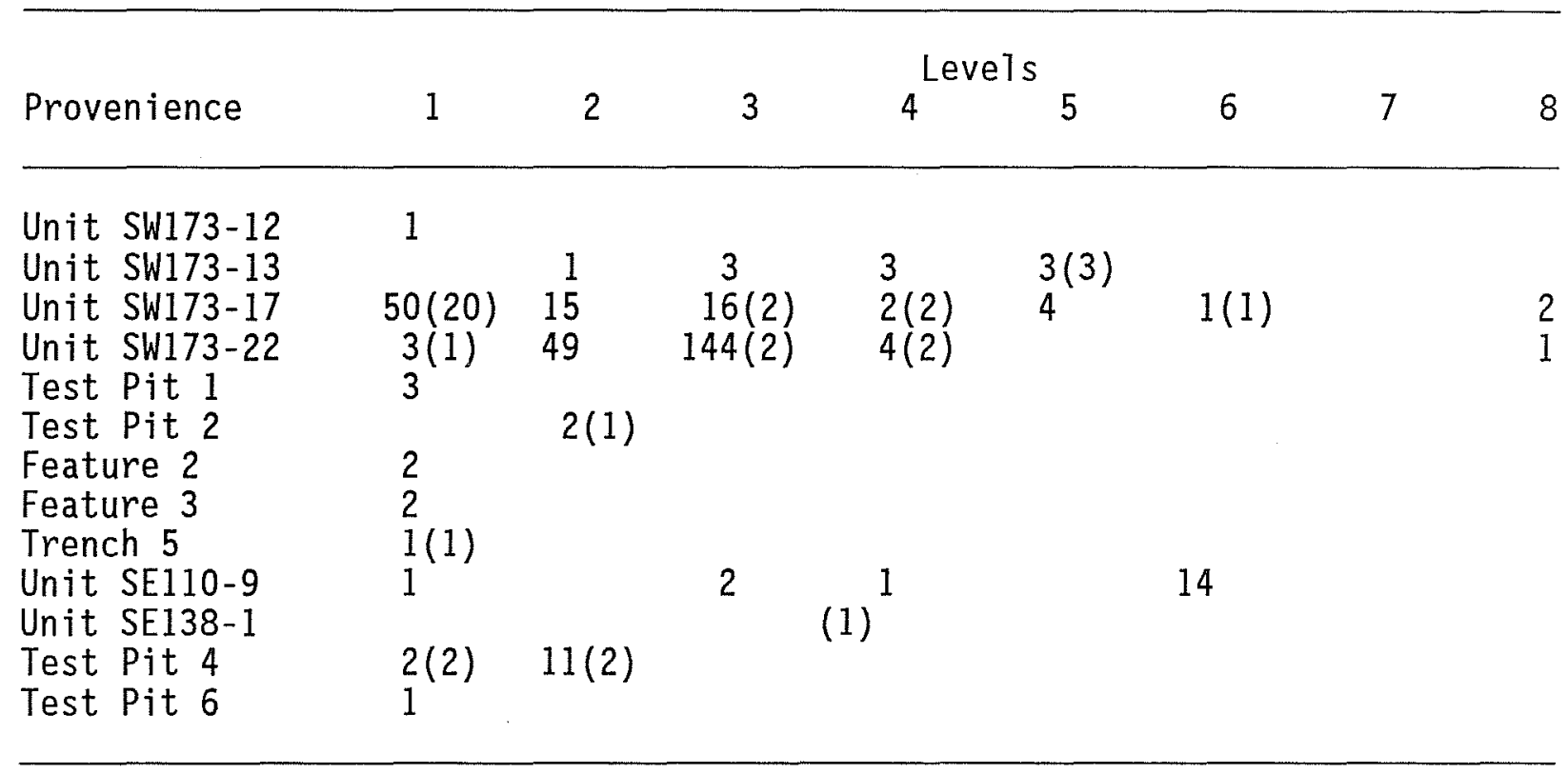

Note: Number in parentheses represents burned specimens.

In summary, faunal remains were relatively infrequent at site 41 UV 47 , especially when compared to the total recovery from nearby site 41 UV 48. Within 41 UV 47, the majority of faunal remains (approximately 90\%) came from the Area A excavations, and these were mostly limited to the midden zone deposits. The few identified specimens from the site are cottontail rabbit and probable deer elements.

\section{Freshwater Mussel She11}

Freshwater mussel shell remains were commonly found within excavation Areas $A, B$, and $C$; none were recovered from Area D. While mussel shell was a relatively common find in any particular unit-level, the remains usually consisted of only trace amounts of shell fragments. Only 14 umbo were recovered at the site. Table 38 summarizes the distribution of mussel she11 remains at 41 UV 47 , and either indicates the number of umbos, or notes the presence of fragmentary shell remains for each level excavated at the site.

A11 of the mussel she11.umbos were recovered in Area A. Additional1y, a11 umbos occurred in or above Level 6. A cursory examination of the shel1 fragments within Area $A$ would indicate that the frequency of mussel shell remains within the midden zone of Area $A$ was relatively higher than the frequency (or bulk) of shell remains from below the midden zone. Generally, there were more and larger shell fragments in the upper levels. 
TABLE 38. PROVENIENCE OF MUSSEL SHELL FROM 41 UV 47

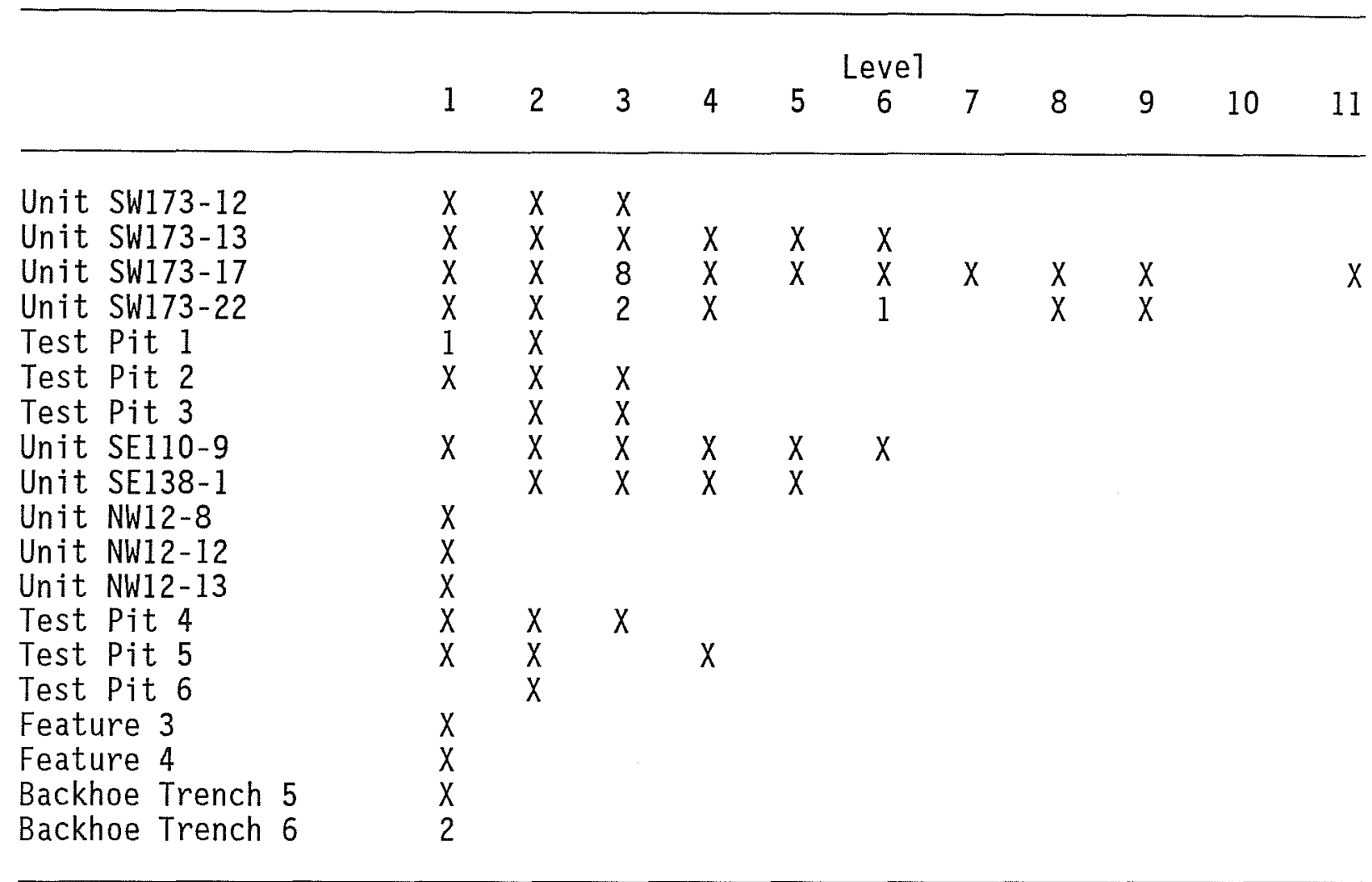

Note: $X=$ She11 present.

Within excavation Areas $B$ and $C$, mussel shell fragments were present in all test pits and excavation units except Unit NW12-7. As noted previous7y, no musse1 she11 remains were recorded for excavation Area D.

The occurrence of mussel she11 in Areas A, B, and C may suggest that unionids were utilized and discarded throughout the areas of major activity at the site. The relatively small amounts of mussel shell present in the deposits further suggest it was a minor food resource, as has been suggested by the findings at other sites in the region (Montgomery 1978; Ha11, Black, and Graves 1982).

\section{Snail She11s}

A11 complete 1 and snails were collected from the screens during the project. Because some of the snail species are relatively small they may be more 1ikely to pass through the $1 / 4$-inch screen, and so bias the collection in favor of large snail species (especially the large Rabdotus sp.). However, 
analysis shows there is some indication of vertically and intrasite variability worthy of note within the site.

Five snail species were identified at 41 UV 47 . Rabdotus sp. was by far the most common 1 and snail on the site, comprising about $88 \%$ of all the snails from the site. Polygyra sp. and Helicina sp. Were present in roughly equal proportions, with Helicina sp. slightly more common of the two; together the two snail species comprise $13 \%$ of the site collection. Other species identified at the site were Helisoma sp., Succinea sp., and a few unidentified snails (grouped together as "other"). The Helisoma sp., Succinea sp. and other snail shells together comprise less than $1 \%$ of the total site collection.

Snails may have provided an important food resource and may provide indications on the paleoenvironment (Gerstle, Kel1y, and Assad 1978; Fox 1979; Hester 1980a; Hall, Black, and Graves 1982). Preferred habitats can be suggested for each of the species represented at the site. Rabdotus sp., Polygyra sp., and Helicina sp. can be characterized as relatively hardy 1 and snail species preferring woodlands or open fields, and more commoniy are found in drier environmental situations than either the Succinea sp. on the Hel isoma sp. Succinea sp. is a land snail that prefers moist wooded areas with a woodland floor cover, and Helisoma sp. is a freshwater snail that prefers fast moving waters.

An analysis of each site area shows few definite patterns in distributions. One pattern observed may suggest Rabdotus sp. was a food resource associated with the midden deposits in excavation Areas $A$ and $B$. In unit-levels excavated through the midden zones, Rabdotus sp., Polygyra sp., and Helicina sp. occur in approximately equal ratios. That is, Rabdotus sp. comprises more than $90 \%$ of the total collection within the midden zones, and Polygyra sp. and Helicina sp. each make up about $3 \%$ to $4 \%$ of the midden zone collection. However, it should be noted that snail shell counts are much more common in the midden zones than in submidden zones, and the overall density of snail shel1s is greater in Area B. In contrast, units excavated through soils containing no midden deposits (in excavation Areas $A$, B, and $D$ ), the ratio of Rabdotus sp., Polygyra sp., and Helicina sp. differs from that of the midden units. In the nonmidden units, Rabdotus sp. comprises only $65 \%$ to $71 \%$ of the collection, a substantial decrease from the more than $90 \%$ figure within the midden units. Within the nonmidden units of excavation Areas B and C, Helicinia and Polygyra sp. comprise $8 \%$ and $20 \%$ of the collection, respectively. In Area D, no Helicina sp. were recorded, but Polygyra sp. comprises $31 \%$ of the excavation area collection. The relatively high percentages of Polygyra sp. and Helicina sp. in the nonmidden units contrast with the lower percentage figures found within the midden units. Additionally, the overall snail density is lower in nonmidden units than in those units excavated through midden zones. As Rabdotus sp. is a relatively large species that has been suggested to be a food resource in south and central Texas (Clark 1969; Hester and Hill 1975; Hall, Black, and Graves 1982), the implication here is that the more frequent occurrence of Rabdotus sp. in association with the midden units is the result of processing the species within the midden areas. 
Thus a horizontal distributional pattern is demonstrated where midden areas are associated with higher overall snail densities, and Rabdotus sp. comprises a larger percentage of the midden areas snail collection than is found in nonmidden areas (Table 39).

The vertical distribution of various snails throughout the site shows a pattern that may suggest environmental changes occurred at the site. Rabdotus sp., Polygyra sp., and Helicina sp. comprise over $99 \%$ of the snail she11 collection, and although their overall numbers tend to decrease with depth, their presence would suggest an environmental setting in the past that was similar to that of the present. However, the freshwater snail Helisoma sp. and the land snail Succinea sp. may be indicators of a moister locale, if not regional conditions, and their vertical distribution patterns hint at the possibility of a less arid situation associated with the premidden deposits at the site. The number of Succinea sp. (six specimens) and Helisoma sp. (20 specimens) is sma71, but it is interesting to note that $77 \%$ (20 specimens) of these two snail species are from contexts of $50 \mathrm{~cm}$ or more below the ground surface.

The vertical distribution of Helisoma sp. Within excavation Area A clearly shows a clustering of this species in the lower levels. In Area A, 13 of the 14 Helisoma sp. specimens were from Levels 5-8, and increased in quantity with depth. Additiona77y, three of the four Succinea sp. in Area A were from Feature 4 ( 71 to $99 \mathrm{~cm}$ below the surface). Thus, in the submidden deposits of Area A, representing a Late Archaic component containing Castroville, Monte11, and Marcos dart points, there is an increase in the two snail species characteristically preferring moister habitats than do other species

TABLE 39. INTRASITE DISTRIBUTION OF SNAIL SHELLS AT 41 UV 47

\begin{tabular}{|c|c|c|c|c|c|c|}
\hline & \multicolumn{2}{|c|}{$\frac{\text { Midden Units }}{\text { Percentage }}$} & \multicolumn{3}{|c|}{ Nonmidden Units } & \multirow[b]{2}{*}{$\begin{array}{l}\text { Percentage } \\
\text { of Collection }\end{array}$} \\
\hline & $\begin{array}{l}\text { Per } \\
\text { Area } \\
\text { A }\end{array}$ & $\begin{array}{c}\text { tage } \\
\text { Area } \\
\text { B }\end{array}$ & $\underset{B}{\text { Area }}$ & $\begin{array}{l}\text { rcenta } \\
\text { Area } \\
\text { C }\end{array}$ & $\begin{array}{c}\text { Area } \\
\text { D }\end{array}$ & \\
\hline $\begin{array}{l}\text { Rabdotus } \\
\text { Polygyra } \\
\text { Hel icina } \\
\text { Hel isoma } \\
\text { Succinea } \\
\text { Others }\end{array}$ & $\begin{array}{r}91 \\
4 \\
4 \\
1 \\
<0.5 \\
<0.5\end{array}$ & $\begin{array}{r}93 \\
3 \\
4 \\
0 \\
<0.5 \\
<0.5\end{array}$ & $\begin{array}{r}71 \\
8 \\
20 \\
<1 \\
0 \\
0\end{array}$ & $\begin{array}{r}71 \\
8 \\
20 \\
1 \\
<0.5 \\
<0.5\end{array}$ & $\begin{array}{r}69 \\
31 \\
0 \\
0 \\
0 \\
0\end{array}$ & $\begin{array}{r}89 \\
5 \\
7 \\
<0.5 \\
<0.5 \\
<0.5\end{array}$ \\
\hline Count Total & 2691 & 1055 & 48 & 507 & 13 & 4684 \\
\hline
\end{tabular}


recorded at the site. However, supporting data from other excavation areas were minimal; only one specimen each of Helisoma sp. and Succinea sp. occurred in Area B, and neither species occurred in Area D. In Area C, four of the five Helisoma sp. recovered came from a depth of 80 to $100 \mathrm{~cm}$ below the ground surface (Level 4 of Test Pit 4). The remaining Helisoma sp. and a single Succinea sp. within Area $C$ were recovered from above $40 \mathrm{~cm}$ below the ground surface.

In summary, the distribution of snail shells at the site offers some indications of a particular resource utilization and environmental change. The high proportions of the land snail Rabdotus sp. within the units penetrating middens in excavation Areas $A$ and $B$ when compared to nonmidden excavation units in Areas $B, C$, and $D$ suggest that the utilization of Rabdotus sp. as a food source was primarily associated with midden areas. Additionally, an indication of at least a locally more moist environmental situation prior to the accumulation of the Late Prehistoric midden deposits is suggested by the presence of a majority of the two snail species Helisoma sp. and Succinea sp. in the lower levels of the site deposits.

\section{Wood Species Identifications}

A total of $330.19 \mathrm{~g}$ of wood charcoal from site 41 UV 47 was submitted for species identification to Donna Lannie of Mesquite, Texas. The result of Lannie's analysis for the site is presented in Table 40. The table shows the total weights in grams of the various woods identified at the site. of the $330.19 \mathrm{~g}$ submitted, $220.54 \mathrm{~g}$ were passed through a $3.35-\mathrm{mm}$ sieve and thus eliminated from further analysis. The remaining $109.65 \mathrm{~g}$ of wood charcoal were examined by lot, with individual specimens from each lot examined until a minimum of 10 identifications were made (or less if the sample contained fewer than 10 specimens).

The identified specimens from the site, in order of relative abundance, are Texas persimmon (Diospyros texana), Leguminosae, Ulmaceae, walnut (Juglans sp.), hickory (Carya sp.), oak (Quercus sp.), juniper (Juniperus sp.), willow (Salix sp.), and diffus-porus specimens. Texas persimmon and Leguminosae were by far the most common plants at the site. Texas persimmon comprises nearly $40 \%$ of the total weight for all the examined collection, and Leguminosae specimens comprise about $21 \%$ of the total weight. Other woods were much less common, with each category totaling $12 \%$ or less of the site collection. All of the plants identified are present in the area today. Considering that the site contains no cultural components preceding the Late Archaic, beginning about 650 B.C. (Prewitt 1981), the occurrence of the aforementioned plants would suggest no significant change in the distribution of the woody plants has taken place in the last 2600 years.

The distribution of the various specimens of wood species is summarized by excavation area in Table 4l, along with the weight for each unit-level collected.

Within excavation Area A, charcoal specimens were available for identification in Levels 2-7 and Level 11; no specimens were submitted for Levels 1 and 8-10. Charcoal was most common in Levels 1-3, then decreased considerabiy in 
TABLE 40. WOOD SPECIES IDENTIFICATIONS FROM 41 UV 47

\begin{tabular}{|c|c|c|c|c|c|c|c|c|c|c|c|c|c|c|}
\hline Units & Level & 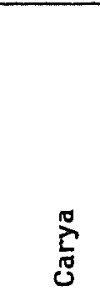 & 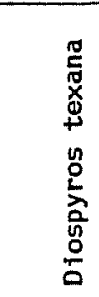 & 亮 & $\begin{array}{l}\frac{n}{5} \\
\frac{10}{5} \\
\frac{5}{5}\end{array}$ & $\begin{array}{l}\frac{n}{2} \\
\frac{2}{0} \\
\frac{2}{E} \\
\frac{5}{5}\end{array}$ & $\begin{array}{l}\text { ñ } \\
\stackrel{u}{0} \\
\stackrel{0}{z}\end{array}$ & $\frac{x}{\pi}$ & 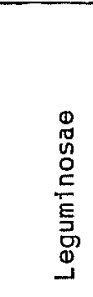 & $\begin{array}{l}\mathbb{0} \\
\mathbb{0} \\
0 \\
0 \\
\tilde{m} \\
5\end{array}$ & 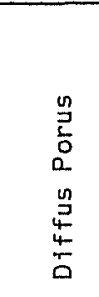 & 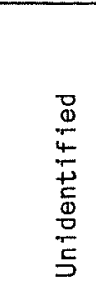 & 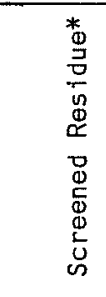 & 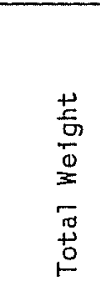 \\
\hline SW173-12 & $\begin{array}{l}2 \\
3\end{array}$ & 0.18 & $\begin{array}{l}0.03 \\
0.60\end{array}$ & & $\begin{array}{l}0.25 \\
0.34\end{array}$ & 0.16 & 0.97 & & $\begin{array}{l}0.79 \\
2.01\end{array}$ & $\begin{array}{l}3.86 \\
1.31\end{array}$ & & $\begin{array}{l}0.34 \\
0.43\end{array}$ & $\begin{array}{l}8.91 \\
6.62\end{array}$ & $\begin{array}{l}14.36 \\
12.44\end{array}$ \\
\hline SW173-13 & $\begin{array}{l}2 \\
3 \\
4\end{array}$ & $\begin{array}{l}0.81 \\
0.29 \\
0.78\end{array}$ & 0.64 & $\begin{array}{l}1.52 \\
0.13 \\
0.77\end{array}$ & $\begin{array}{l}0.36 \\
0.27\end{array}$ & $\begin{array}{l}0.21 \\
0.14\end{array}$ & 0.13 & & $\begin{array}{l}2.57 \\
0.90 \\
0.80\end{array}$ & $\begin{array}{l}0.25 \\
0.40 \\
0.74\end{array}$ & & $\begin{array}{l}0.10 \\
0.43\end{array}$ & $\begin{array}{l}3.61 \\
1.01\end{array}$ & $\begin{array}{l}9.33 \\
2.86 \\
4.67\end{array}$ \\
\hline SW173-17 & $\begin{array}{r}2 \\
3 \\
4 \\
5 \\
6 \\
7 \\
11\end{array}$ & $\begin{array}{l}0.34 \\
1.26 \\
0.19 \\
0.18 \\
0.06\end{array}$ & $\begin{array}{r}13.33 \\
2.07 \\
\\
0.34 \\
1.63 \\
0.05\end{array}$ & $\begin{array}{l}0.41 \\
0.49 \\
0.64 \\
0.55 \\
0.10\end{array}$ & $\begin{array}{l}0.30 \\
0.63 \\
0.29\end{array}$ & 0.25 & $\begin{array}{l}1.20 \\
0.90 \\
0.26 \\
0.34\end{array}$ & 0.05 & $\begin{array}{l}0.59 \\
1.97 \\
1.70 \\
2.09 \\
1.78 \\
0.53 \\
0.92\end{array}$ & $\begin{array}{l}0.45 \\
0.17 \\
0.30\end{array}$ & 0.11 & $\begin{array}{l}0.44 \\
0.47\end{array}$ & $\begin{array}{r}6.15 \\
27.74 \\
29.78 \\
9.52 \\
4.94 \\
0.88 \\
0.35\end{array}$ & $\begin{array}{r}20.51 \\
34.48 \\
34.77 \\
13.63 \\
8.13 \\
3.40 \\
2.13\end{array}$ \\
\hline SW173-22 & $\begin{array}{l}3 \\
4 \\
5 \\
7\end{array}$ & 0.21 & $\begin{array}{r}0.27 \\
22.69 \\
0.08\end{array}$ & $\begin{array}{l}0.27 \\
0.56\end{array}$ & $\begin{array}{l}0.89 \\
0.18\end{array}$ & & & 0.46 & $\begin{array}{l}0.91 \\
0.88 \\
0.34\end{array}$ & $\begin{array}{l}3.10 \\
1.66\end{array}$ & & $\begin{array}{l}0.30 \\
0.18\end{array}$ & $\begin{array}{r}40.79 \\
63.83 \\
9.39\end{array}$ & $\begin{array}{r}45.28 \\
86.52 \\
13.85 \\
1.34\end{array}$ \\
\hline SEl10-9 & $\begin{array}{l}3 \\
5 \\
6\end{array}$ & 0.56 & $\begin{array}{l}0.07 \\
0.26 \\
0.51\end{array}$ & 0.30 & $\begin{array}{l}0.36 \\
0.07\end{array}$ & $\begin{array}{l}0.34 \\
1.11\end{array}$ & 0.39 & & $\begin{array}{l}1.52 \\
0.89 \\
1.64\end{array}$ & $\begin{array}{l}0.14 \\
0.28\end{array}$ & 0.13 & $\begin{array}{l}0.30 \\
0.27 \\
0.45\end{array}$ & $\begin{array}{l}5.17 \\
0.54\end{array}$ & $\begin{array}{l}8.76 \\
3.66 \\
2.88\end{array}$ \\
\hline SE138-1 & 6 & & & & 2.04 & & & & & & & 0.27 & 1.31 & 3.62 \\
\hline NW12-12 & I & & & & & & & & 0.25 & & & 0.60 & & 0.85 \\
\hline NW218-5 & 1 & & & & 2.39 & & & & & 0.42 & & & & 2.81 \\
\hline
\end{tabular}

* Sample, unanalyzed portion which fell through 3.35-mm screen. 


\begin{tabular}{|c|c|c|c|c|c|c|c|c|c|c|c|c|c|}
\hline Area/Leve1 & $\overbrace{0}^{\infty}$ & 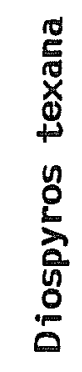 & 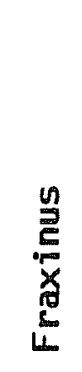 & 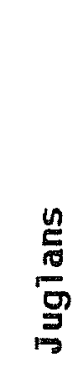 & 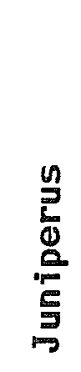 & $\begin{array}{l}\stackrel{n}{0} \\
\frac{0}{0} \\
\stackrel{0}{3}\end{array}$ & $\frac{x}{\sqrt[x]{n}}$ & 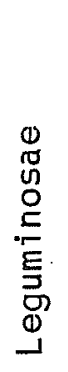 & 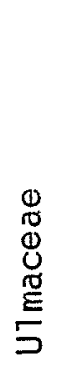 & $\begin{array}{l}n \\
3 \\
2 \\
0 \\
0 \\
0 n \\
3 \\
4 \\
4 \\
0\end{array}$ & 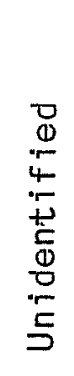 & 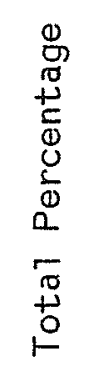 & $\begin{array}{l}\widehat{\sigma} \\
+ \\
\stackrel{5}{\sigma} \\
\stackrel{0}{\Xi} \\
\stackrel{0}{=}\end{array}$ \\
\hline \multicolumn{14}{|l|}{ Area $A$} \\
\hline Leve1 2 & 4 & 52 & 6 & 2 & 1 & & & 15 & 16 & & 3 & 99 & 25.53 \\
\hline Leve1 3 & 4 & 18 & 3 & 5 & 1 & 12 & & 29 & 26 & & 3 & 101 & 19.91 \\
\hline Leve1 4 & 7 & 72 & 4 & & $*$ & 3 & & 8 & 3 & & 3 & 100 & 31.43 \\
\hline Level 5 & 2 & & 11 & 18 & & 3 & 5 & 35 & 23 & & 4 & 101 & 8.57 \\
\hline Leve1 6 & 6 & 11 & 17 & & & 11 & & 56 & & & & 101 & 3.19 \\
\hline Level 7 & & 44 & 15 & 5 & & & 1 & 23 & & & 13 & 101 & 3.86 \\
\hline Leve1 8 & & & & & & & & & & & & & \\
\hline Leve1 9 & & & & & & & & & & & & & \\
\hline Leve1 10 & & & & & & & & & & & & & \\
\hline Level 11 & 3 & 3 & 6 & 16 & 14 & & & 52 & & 6 & & 100 & 1.78 \\
\hline
\end{tabular}

Area B

Level 1

Leve1 2

Level 3

Level 4

Level 5

Leve1 6

$\begin{array}{lllll}16 & 2 & 8 & 10 & 9\end{array}$

$42 \quad 4$

8
89

$\begin{array}{rrrr}8 & 2 & 36 & 13 \\ 10 & 40 & & \end{array}$

$\begin{array}{rrrrrr}29 & & 4 & 7 & 99 & 3.12 \\ 32 & 5 & & 14 & 101 & 5.19\end{array}$

Area $\mathrm{C}$

Level 1

29

$71 \quad 100 \quad 0.85$

Area $D$

Leve 1

85

15

100

2.81

* = 1ess than $1 \%$. 
lower levels. Ash (Fraxinus sp.) and Leguminosae were present in Levels 2-7 and 11. Hickory (Carya sp.), Texas persimmon (Diospyros texana), and walnut (Juglans sp.) occurred in most examined levels of Area A with the following exceptions: Carya sp. was absent from Leve1 7, Diospyros texana was absent from Leve 15 , and Juglans sp. was absent from Levels 4 and 6 . Oak (Quercus sp.) was confined to Levels 3-6, and U1maceae was similarly restricted to Levels 2-5. Juniperus sp. was present in small amounts for Levels 2-4 and 11. Willow (Salix sp.) was the least common plant identified at the site, and only occurred in Levels 5 and 7 of Area A.

Within Area B, charcoal specimens were identified from Unit SW110-9, Levels 3, 5, and 6 and from Level 6 of Unit SE138-1. The total amount of charcoal available for analysis from Area B was much lower than what was available from Area $A$, but nevertheless all of the plants identified in Area A were also found in Area B, with the single exception of willow (Salix). Within the three unit-level samples submitted from Unit SE110-9, Texas persimmon (Diospyros texana) and Leguminosae were present in al1 samples. Walnut (Juglans sp.) and juniper (Juniperus sp.) occurred in Levels 3 and 5. U1maceae was present in Levels 3 and 6 . Hickory (Carya sp.) and ash (Fraxinus sp.) occurred only in Level 3, and oak (Quercus sp.) was identified from Unit SE138-1, Level 5. Walnut (Juglans sp.) was the only plant identified from Unit SE138-1, Leve1 6.

For excavation Areas $C$ and $D$, only three samples were available for identification. Leguminosae was the on 1 y identification for Area C (in Level 1 of Unit NW12-13). In Area D, walnut (Juglans sp.) and UTmaceae were identified from Leve1 I of NW218-5 (Test Pit 7).

In summary, all of the plants identified at the site can be found in the project area today. Of the nine woody plants found at the site, Texas persimmon (Diospyros texana) and Leguminosae dominate the collection. This analysis suggests a paleoenvironmental situation similar to that of the present, possibly for as long as 2600 years ago, based upon the estimated age of the earliest component identified at the site. The presence of some plants like ash (Fraxinus sp.) and willow (Salix sp.), and possibly others such as hickory (Carya sp.), walnut (Juglans sp.), and U1maceae, all most commonly confined to the river margins in the region (BTair 1950), suggests a reliable water source was locally available in the prehistoric past. Finally, some of the plants identified at the site may represent possible food sources. Hickory (Carya sp.), walnut (Juglans sp.), and oak (Quercus sp.) are nut producers that may have been utilized by the site occupants, and Texas persimmon (Diospyros texana) grows an edible fruit. Various species of Leguminosae and U1maceae may have also provided a source of edible seeds. However, the wood species identifications offer only indirect evidence of possible gathering resources, and it should be noted that no seed or nut remains were recorded at the site.

\section{RADIOCARBON DATES}

Two wood charcoal samples from site 41 UV 47 were submitted to The University of Texas at Austin Radiocarbon Laboratory, Balcones Research Center, Austin, Texas, for assay. The two samples were selected in order to provide absolute 
dates from controlled contexts that would hopefully reflect major occupations of the two midden features at the site. The results of the assays are shown in Table 42. Sample TX-4435 was obtained from Feature 3 of excavation Area A. The feature, a hearth, occurred at the basal levels of the midden zone, and so it was expected that the date obtained would reflect the period when the midden accumulation began. The second sample, TX-4428, was taken from Level 5 of Unit SE138-1, in excavation Area B. Although the sample was not in direct association with the midden feature from Area $B$, the vertical distribution of debitage in Unit SE138-9 indicated the major occupation occurred in Level 5. The maximum debitage density within Unit SE110-9 occurred in Level 3, which corresponds to the base of the midden zone. Thus, the association between the two units was established, and the resulting radiocarbon assay was expected to reflect the period when the midden began to accumulate. Both of the radiocarbon dates are further discussed separately.

TABLE 42. RADIOCARBON DATES FROM 41 UV 47

Laboratory

Number
Provenience
B.P. Date

Masca Corrected*
$\mathrm{TX}-4428$

$\mathrm{TX}-4435$
Unit SE138-1, Leve1 5

Unit SW173-13, Feature 3
$800 \pm 110$

$630 \pm 70$
A.D. 1210

A.D. 1330

* RaTph, MichaeT, and Han 1973

\section{$\underline{T X-4428}$}

The sample was comprised of charcoal collected throughout Level 5 of Unit SE138-1. The sample was associated with the "peak" vertical occurrence of debitage, and also with a couple of bifacially retouched flakes. The only diagnostic projectile point from the unit was an Ensor Variety 1 from Level 4. However, within the first four levels of nearby Unit SE110-9, Scallorn and Edwards arrow points were the only projectile points recovered (five specimens in a11). Thus, the presence of the single Ensor point in Level 4 of Unit 138-1 notwithstanding, the radiocarbon date obtained for TX-4428 seems acceptable. The range of A.D. 1110 to A.D. 1320 (MASCA corrected) would place it within the latter half of the Austin phase (A.D. 700-1300).

\section{$\underline{T X-4435}$}

The sample was taken from the in situ hearth recorded as Feature 3, associated with the basal levels of the midden zone within excavation Area A. 
No diagnostics were directly associated with the feature. The assay of A.D. 1260 to A.D. 1400 (MASCA corrected) would place the feature within the earlier half of the Toyah phase (A.D. 1300-1750). An earlier date was expected for this feature, during the Austin phase, as Perdiz arrow points (diagnostic of the Toyah phase) were limited to the upper levels of the midden zone, and expanding stem arrow points (particularly Scallorn and Sabina 1) more typical of the Austin phase were not uncommon in the midden deposits.

In summary, the two dated radiocarbon samples (TX-4428 and TX-4435) indicate an occupational time span of 290 years at the two midden features at the site, from A.D. 1110 to A.D. 1400 . This period spans the latter half of the Austin phase and the earlier half of the Toyah phase. There is some indication of temporal differences between the two middens in either excavation Area A or Area B, but more radiocarbon dates would be necessary to substantiate the differences.

\section{SUMMARY AND DISCUSSION}

The chronology, site nature and extent, and the subsistence strategies indicated by the data collected from 41 UV 47 are reviewed. Each topic is presented separately.

\section{Chronology}

Relative chronologies, based primarily upon projectile point types and supported by radiocarbon dates, were used to define the cultural components at the site. The data indicates that Late Prehistoric components dominated at the site, but there is also evidence of an Archaic component.

The various projectile point types and their relative abundance, provide the basic framework used to define the chronology at the site. Based upon the total number of projectile points recovered at the site, a Late Prehistoric component, represented by arrow points, dominated at the site, with dart points, representative of various Archaic stages, less frequently found. of 103 projectile points identified at the site, 62 are arrow points, and 41 are dart points. Typed forms within the arrow point collection indicate that two Late Prehistoric phases are represented at the site. The latter half of the Late Prehistoric is represented by Perdiz arrow points, diagnostic of the Toyah phase (A.D. 1300-1750), and the first half of the Late Prehistoric is represented by Scallorn arrow points, diagnostic of the Austin phase (A.D. 700-1300). Sabinal may be a local variant of the Scallorn type, and Edwards has been suggested as a diagnostic of the proposed Turtle creek phase, possibly a local antecedent to the Austin phase. Vertical sequences of arrow points at the site indicate that the excavated deposits are mixed to varying degrees, and cannot be used to confidently isolate components verticaliy; however, there was some suggestion that Edwards may have been the earliest Late Prehistoric arrow point at the site, followed by Sabinal, Scallorn, and Perdiz, in that order. 
of the various dart point types recorded at the site, typed specimens of the Early Archaic (Early Corner Notched and Gower), the Middle Archaic (Pedernales, Langtry, and Nolan), the Late Archaic San Marcos phase (Castroville, Marcos, and Monte11), and the Late Archaic Twin Sisters phase (Ensor, Fairland, and Frio) were recorded. However, it should be emphasized that over one-half of the dart points were surface collected. Further, only Late Transitional and Late Archaic projectiles were found in excavated contexts. Based upon stratigraphic associations within excavation Area $A$, a sparse Late Archaic (650 B.C.-A.D. 200) component is the only in situ Archaic manifestation recognized at the site.

Two radiocarbon dates, associated with Late Prehistoric deposits in different excavation areas of the site, provide corrected dates of A.D. 1210 and A.D. 1330. The two dates and their ranges span between A.D. 1110 to A.D. 1400 , a period of 290 years. This dates the Late Prehistoric deposits at the site to the later half of the Austin phase and the earlier half of the Toyah phase. The two radiocarbon dates may suggest a horizontal separation of Austin and Toyah phases within the site. The deposits in excavation Area $B$ may represent an Austin phase component, as it provided the earlier of the two dates. The date is partially supported by the projectile points recorded from the area (Scallorn and Edwards arrow points and a single Ensor dart point). The midden deposits within excavation Area A provided the date that fell within the Toyah phase, and although the type diagnostic, Perdiz, of the Toyah phase dominated within the midden deposits, the presence of chronologically earlier arrow points within the midden (Scallorn and Sabinal) would indicate a multicomponent midden deposit. More radiocarbon dates would be necessary to satisfactorily determine the age of the two midden deposits.

In summary, regional chronologies and radiocarbon dates were used to identify the various components represented at the site. Although diagnostic types of the Early Archaic (5050 B.C. -3050 B.C.) to the Late Prehistoric Toyah phase (A.D. 1300-1750) occurred at the site, in situ components are believed to be no earlier than the Late Archaic (650 B.C.-A.D. 200). Late Prehistoric components, radiocarbon dated to between A.D. 1110 to A.D. 1400, dominated the site deposits.

\section{Site Nature and Extent}

Controlled surface collections and excavations within the site showed that cultural deposits existed throughout the site. The data collected provide a more complete characterization of the nature and extent of the site deposits than was previously available from earlier work at the site (Hall 1974).

The site's surface area covers approximately $130,000 \mathrm{~m}^{2}$. A $10 \%$ random sample of this area, a total of 128 individual collection units $10 \mathrm{~m}^{2}$ in size, showed an average 1 ithic density of about 23 items per unit. However, the debitage density within the 128 sample units varied considerably; there was seven examined units containing no lithics and seven units with 100 or more pieces of debitage (the maximum total for a single unit was 321 specimens). Additionally, 164 artifacts (projectile points, bifaces, unifaces, etc.) were randomly collected, an average of about 1.3 artifacts per unit. Localized lithic concentrations of artifacts and debitage were noted within the site. 
Much of the site's cultural remains were confined within these localized 1 ithic concentrations. The largest 1 ithic concentration covered a surface area roughly $100 \times 300 \mathrm{~m}$ in size and was located adjacent to the Eightmile Waterhole. The concentration contained the most dense lithic scatter within the site and represents the area of greatest prehistoric activity. 0ther, smaller lithic concentrations appear as satellites to the larger cultural concentration. Additionally, two areas within the site were defined as midden concentrations of relatively higher chipped stone and burned rock amounts.

Subsurface tests were primarily directed by the surface distribution of cultural materials. A $41.5-\mathrm{m}^{2}$ area was opened at the site, excluding the areas exposed by backhoe trenching. An estimated $19.85 \mathrm{~m}^{3}$ of earth were removed during the excavations, again excluding soil from the backhoe trenches. The excavations revealed a relatively simple stratigraphic sequence site-wide, characteristically consisting of Knippa clays overlying a gravel bed of the Uvalde Gravel formation, which usually occurred at depths of 60 to $100 \mathrm{~cm}$ below the surface. Culturally rich midden and transitional soil zones occurred in only two excavation areas.

Generally, the gravel bed that the site rests on was considered to be culturally sterile although debitage items, assumed to be introduced from the upper soil zones, were recovered from the gravel layer. The Knippa clay was found to contain cultural remains throughout the site, although in varying amounts on an intrasite basis. While debitage items were found throughout the Knippa clays, the number of artifacts within the clays was relatively low, as was the overall debitage density when compared to recovery rates from the same materials within midden zones.

The two middens at site 41 UV 47 were approximately $10 \mathrm{~m}$ in diameter and relatively thin, about 30 to $50 \mathrm{~cm}$ in depth. Both middens were visible on the surface as burned rock and debitage scatters, but did not appear as mounds elevated from the surrounding soils. The two middens were Late Prehistoric features, and although they showed similarities in size and shape, and both were apparently focal points of cultural activity, the two middens did differ in some significant aspects in their content. In comparing the two middens, it was found that the debitage to burned rock ratio was relatively high within the Area $A$ midden, while the opposite was true for the excavation Area B midden, i.e., the debitage to burned rock ratio was very low. Also an unusually high percentage of the debitage from the midden in Area B was burned chert. Finally, a temporal difference between the two middens was suggested by the absence of any Toyah phase diagnostics within Area B. The data suggest two kinds of Late Prehistoric middens are present at the site; one (in Area A), a concentrated activity locus where chipping activities predominate, the other (Area B) a concentrated cultural locus dominated by fire-related activities.

In summary, while small localized surface concentrations may exist in some areas of the site, most of the cultural materials were found to be limited to the area adjacent to Eightmile Waterhole and the midden features. The midden features were the most intensively used activity areas. 


\section{Subsistence}

Direct and indirect evidence of the subsistence pursuits practiced at the site are available. Direct evidence of probable food sources include faunal remains, and snail and mussel shells. Indirect evidence of subsistence pursuits can be seen in the kinds of tools recovered and from the charred botanical remains at the site.

Faunal remains were not abundant at 41 UV 47 . Of the bone recovered, only three specimens could be identified. Sylvilagus audoboni (cottontail rabbit) and probably deer were identified in the collection. Most of the bone was unidentifiable fragments. Bone scrap was most common in the midden zone of excavation Area A, possibly suggesting that the midden area was a focus for faunal processing activities within the site. The scarcity of faunal remains is suspected to be caused by poor preservation of the materials.

Snail shells were abundant at the site, and their importance as a food resource for aboriginal populations gains increasing support in recent publication (Hester 1980a; Hall, Black, and Graves 1982:470). In comparing midden to nonmidden areas of the site, it was found that Rabdotus sp., the largest of the snail species recorded in the collection, was more common in the midden soils than outside of the midden. Rabdotus sp. comprised about $90 \%$ of the snails in the midden compared to only about 65 to $70 \%$ elsewhere in the site.

Mussel shell remains are another bit of direct evidence of a food resource utilized at the site, and are commonly noted at many sites in south Texas (Hester 1980a). Traces of mussel shel1 remains were present in most unitlevels throughout the site, except for excavation Area D, where the shell was totally absent. Mussel shel1 remains were somewhat more common in the midden soils of excavation Area A than in other areas.

The presence of certain tool types on the site indicates a variety of subsistence activities were associated with the site. The large number of projectile points suggests that hunting was an important subsistence activity. Bifacial tools were probably associated with cutting functions, and would indicate processing of a variety of vegetal and meat products. The presence of unifacial tools is a further indication of processing activities carried out at the site. The unifaces most likely represent a variety of scraping functions for either hard vegetal materials or animal hides. Ceramics at the site would indicate cooking or storage activities. Ground stone slab fragments and handstones evidence the processing of seeds, nuts, or berries.

Botanical remains (charcoal) indicated a variety of nut bearing trees were present locally during the past. Walnuts (Juglans sp.), hickory (Carya sp.), and oak (Quercus sp.) may have supplied important food products. Also the Texas persimmon (Diospyros texana) and the various species of Leguminosae and Ulmaceae may have provided a source of edible seeds or fruits. However, it should be noted that no direct evidence of any seed or nut remains were recorded at the site. 


\section{SITE 41 UV 48}

\section{SITE DESCRIPTION}

Site 41 UV 481 ies approximately $10 \mathrm{~km}$ north-northeast of Uvalde, Texas, located on the western bank of the Leona River, at a point where the river makes a northward trending bend above the Eightmile Waterhole. The north to south axis of the site, starting from the south, extends from UTM coordinates $424590 \mathrm{E} 3240980 \mathrm{~N}$ to $424990 \mathrm{E} 3241480 \mathrm{~N}$. The site area, as measured by the grid system placed over it, covers $147,800 \mathrm{~m}^{2}$. The long axis of the site (north to south) runs $650 \mathrm{~m}$ and is a maximum of $280 \mathrm{~m}$ in width.

Subsequent to the field work, site area subdivisions were delimited based on field notes and laboratory observations (Fig. 27). These area subdivisions (designated Areas A, B, C, and D) were used to aid in intrasite judgments regarding subsurface testing and as units for comparative purposes during the 1 aboratory anatysis.

Area A, located in the southeast end of the site, is the most visible cultural manifestation at the site. A dense burned rock scatter and numerous chert pieces are clearly visible on the ground surface of Area $A$.

Area $B$, grid west of Area $A$, is 10cated on a northward trending ridge that begins in Area $A$. Area $B$ is $42,800 \mathrm{~m}^{2}$ in size, and was judged in the field to be a marginal extension of Area $A$; cultural materials were less common in Area $B$ than they were in Area $A$.

Area $C\left(52,200 \mathrm{~m}^{2}\right)$, the northern end of the site area, is characterized by a wide scatter of 7 ithic chipping debris and burned rock and a burned rock midden feature. While all of the site has undergone brush clearing in the past, Area $C$ is at present used agriculturally, i.e., portions of the site have been planted in permanent grasses and in yearly harvested hays.

Area $D$, in the central part of the site, contains a low swalelike drainage and is at a lower elevation as compared to the other areas of the site. Few cultural materials were recovered from Area D.

\section{SURFACE COLLECTION}

Prior to the initiation of the surface collection, the site area was estimated visually, and a base line was established on the long axis of the site. The base 7 ine was used as grid north for the site (40 east of magnetic north). Stakes were driven in at $10-\mathrm{m}$ intervals along the base line, originating from a site datum set in concrete, until the long axis of the site was established as $660 \mathrm{~m}$ in length. Estimates as to the width of the site were taken by transit shots to either side of the base 7 ine. Once the site boundaries were established, a grid plan was prepared for a site area totaling $147,800 \mathrm{~m}^{2}$. On the grid plan, 1478 surface collection units, measuring $10 \mathrm{~m}^{2}$ in size, were numbered consecutively beginning in the far southeast corner of the site. Unit number assignments moved in a northward direction within the site boundaries, then the process was repeated in the next row of units west. Thus, while Unit 1 is located in the far 


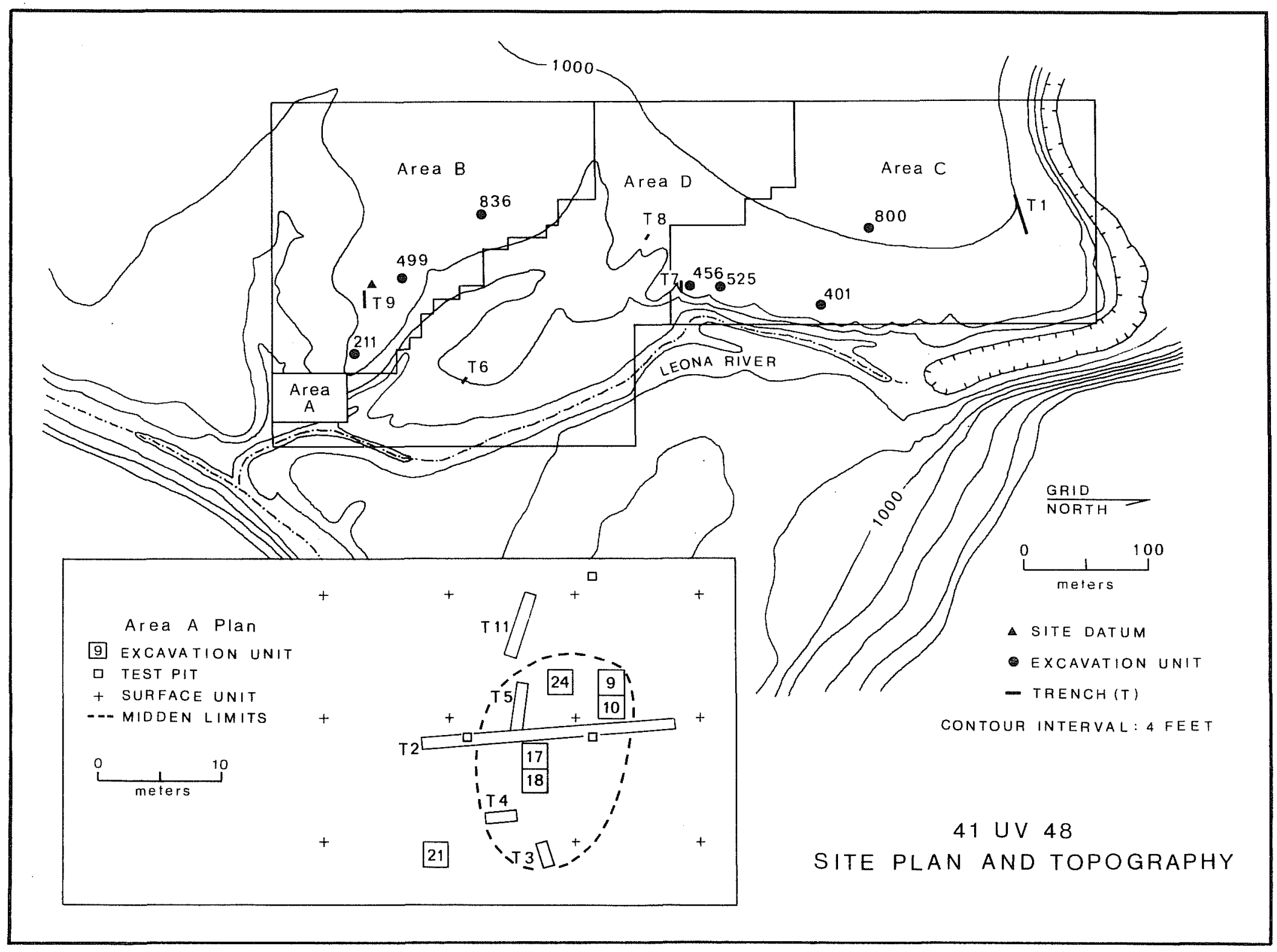

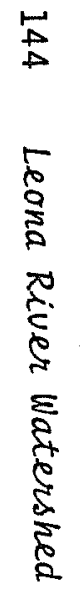

Figure 27. Topographic Map and Plan of Excavations at 41 UV 48. 
southeastern corner of the site, Unit 1478 lies in the far northwestern corner of the site. After the units had been plotted on a plan map, a simple $10 \%$ random sample was drawn from a table of random numbers, and the selected units were marked on the plan. A total of 120 units was surface collected in five days, averaging a set up and collection time of just slightly more than three units per hour.

A total of 20 of the random selected units was arbitrarily removed from consideration in the collection process for various reasons. During the course of surface collecting, two blocks of units measuring $100 \times 70 \mathrm{~m}$ and 70 $x 50 \mathrm{~m}$ in size were arbitrarily removed from the extreme southwestern and northwestern corners of the site, respectively. This decision resulted in the removal of 13 random selected units from the original $10 \%$ sample of units. Additionally, the outer $10 \mathrm{~m}$ from the site boundaries, on all sides except the west, were deemed off-site, resulting in the elimination of another seven of the selected units. Finally, any collection unit which obviously fell outside of the site boundaries or was unsuitable for surface collecting was eliminated from the sample. This includes five units on or beyond the terrace slopes of the Leona River, and two units that were recently disturbed by construction activities. The arbitrary eliminations from the site area totalled 227 units $\left(227,000 \mathrm{~m}^{2}\right)$, including 27 of the random selected units.

A series of field errors also affected the random sample collection. The errors are noted below. Unit 1100 was not collected. Five units were incorrectly placed. The five units (with the actual unit collected enclosed in parentheses) are 297(279), 848(838), 976(975), 1113(1103), and 1433(1434). Chaining errors in two separate areas of the site resulted in a total of 21 units being incorrectly staked on the ground $10 \mathrm{~m}$ due west of their intended locations. The following 7 ists the intended units, along with the actual unit collected.

\begin{tabular}{|c|c|c|c|}
\hline $\begin{array}{l}\text { Sample No. } \\
\text { Drawn }\end{array}$ & $\begin{array}{c}\text { Actual Unit } \\
\text { Collected }\end{array}$ & $\begin{array}{l}\text { Sample No. } \\
\text { Drawn }\end{array}$ & $\begin{array}{l}\text { Actual Unit } \\
\text { Collected }\end{array}$ \\
\hline $\begin{array}{l}128 \\
132 \\
139 \\
140 \\
191 \\
200 \\
220 \\
222 \\
258 \\
260 \\
278\end{array}$ & $\begin{array}{l}157 \\
161 \\
168 \\
169 \\
220 \\
229 \\
249 \\
251 \\
287 \\
289 \\
307\end{array}$ & $\begin{array}{r}279 \\
306 \\
989 \\
1255 \\
1318 \\
1319 \\
1377 \\
1443 \\
1445 \\
1450\end{array}$ & $\begin{array}{r}308 \\
372 \\
1057 \\
1321 \\
1384 \\
1385 \\
1443 \\
10 \mathrm{~m} \text { grid west } \\
10 \mathrm{~m} \text { grid west } \\
10 \mathrm{~m} \text { grid west }\end{array}$ \\
\hline
\end{tabular}


While the stated field errors and boundary alterations need to be noted, their significance in altering the overall value of the gathered data is actually very slight. To summarize, a total of $227,000 \mathrm{~m}^{2}$ was arbitrarily eliminated from the site area. Twenty-eight of the random selected units were, for various reasons, not investigated. Twenty-six units were incorrectly staked out. Of the 1251 surface units remaining within the altered site area, 120 random selected units were investigated, which is a $9.6 \%$ site sampling from the site.

Field observations during the course of investigations indicated that intrasite lithic debitage concentrations existed. In the laboratory distinct intrasite areas were established based upon field observations, resulting in the identification of Areas A, B, C, and D. Each of the site areas maintains an approximate $10 \%$ sampling (Table 43 ).

The results of the random sample surface collection and a sizeable nonrandom collection will be summarized by the individual areas later in this section. The nonrandom collection consists of those artifacts collected from the units not included within the random sample. The artifacts in the nonrandom collection show a marked bias for projectile points, overall retouch bifaces, ground stone, and hammerstones (Table 44). Approximately $35 \%$ of all the recovered artifacts were nonrandom finds. Table 44 shows the percentages of the various artifact group based upon their method of collection.

Figure 28 shows the distribution of debitage at the site. There are two locations within the site that tend to have relatively higher debitage densities than other areas. The first debitage concentration is a single, linear concentration contained within Areas A and B. This concentration is apparently confined to a topographic feature of the site--a low ridge that begins at a point within Area $A$ and extends out in a northwest direction into Area B. The ridge parallels a small drainage to the north. The debitage concentration is estimated to be about $250 \mathrm{~m}$ long and no more than $50 \mathrm{~m}$ wide. There were four collection units within this concentration that contained more than 31 flakes. After noting the debitage counts in these four units, it appears that the 1 ithic scatter was most dense within Area A, Units 90 and 91, and decreases in density as one moves away from the Leona River (Unit 211 contained 163 items, Unit 835 only 53 items). The second debitage concentration, confined to Area $C$, covers a large area. The concentration occurs close to the Leona River in the southern half of Area $C$ and extends well westward onto a very gently sloped hilltop area near the center of Area $C$. This concentration of debitage is more nebulous than the first, but is estimated to be approximately $100 \mathrm{~m}$ or less in diameter (using Unit 800 as the center point). There were six units within the second concentration that contained debitage counts of 31 or more specimens: Unit 400 (32 specimens), Unit 526 (66 specimens), Unit 668 (31 specimens), Unit 800 (100 specimens), Unit 801 (32 specimens), and Unit 1260 (47 specimens). Overall the debitage density is slightly lower than was the case for the first concentration.

Table 45 summarizes the relative distribution of 1ithic densities within the site by areas. Notably, $21 \%$ of the sampled units contained no debitage, and more than $80 \%$ of the nonrecovery units were located in Area D. Units with debitage counts from one to 10 specimens comprise $53 \%$ of the sampled units, 
TABLE 43. RELATIVE SAMPLE SIZE OF SITE AREAS FOR 41 UV 48

\begin{tabular}{|c|c|c|c|c|c|}
\hline & \multicolumn{5}{|c|}{ Site Areas* } \\
\hline & A & B & $c$ & $D$ & Total \\
\hline $\begin{array}{l}\text { Original Grid Area } \\
\text { Eliminated Area } \\
\text { Altered Site Area } \\
\text { Investigated Area } \\
\text { Sampled Percentage }\end{array}$ & $\begin{array}{r}24 \\
4 \\
20 \\
2 \\
10.0\end{array}$ & $\begin{array}{r}434 \\
99 \\
335 \\
30 \\
9.0\end{array}$ & $\begin{array}{r}522 \\
81 \\
441 \\
45 \\
10.2\end{array}$ & $\begin{array}{r}498 \\
43 \\
455 \\
43 \\
9.5\end{array}$ & $\begin{array}{r}1478 \\
227 \\
1251 \\
120 \\
9.6\end{array}$ \\
\hline$* \times 10 \mathrm{~m}^{2}$ & & & & & \\
\hline
\end{tabular}

TABLE 44. COMPARISON OF NONRANDOM AND RANDOM SURFACE COLLECTION AT 41 UV 48

\begin{tabular}{|c|c|c|c|}
\hline \multirow[b]{2}{*}{ Artifact Group } & \multicolumn{2}{|c|}{ Percentages } & \multirow[b]{2}{*}{$\begin{array}{c}\text { Specimen } \\
\text { Total }\end{array}$} \\
\hline & $\begin{array}{l}\text { Random } \\
\text { Collection }\end{array}$ & $\begin{array}{l}\text { Nonrandorn } \\
\text { Collecticn }\end{array}$ & \\
\hline $\begin{array}{l}\text { Arrow points } \\
\text { Dart points } \\
\text { Overal } 1 \text { retouched bifaces } \\
\text { Bifacially retouched flakes } \\
\text { Bifacial intergrades } \\
\text { Other bifaces } \\
\text { Unifaces } \\
\text { Cores } \\
\text { Modified flakes } \\
\text { Ground stone } \\
\text { Hammerstones }\end{array}$ & $\begin{array}{l}31 \\
33 \\
45 \\
82 \\
74 \\
81 \\
88 \\
69 \\
80\end{array}$ & $\begin{array}{l}69 \\
67 \\
55 \\
18 \\
26 \\
19 \\
12 \\
31 \\
20 \\
100 \\
100\end{array}$ & $\begin{array}{r}13 \\
18 \\
11 \\
11 \\
34 \\
37 \\
8 \\
39 \\
5 \\
3 \\
3\end{array}$ \\
\hline Total & & & 182 \\
\hline
\end{tabular}



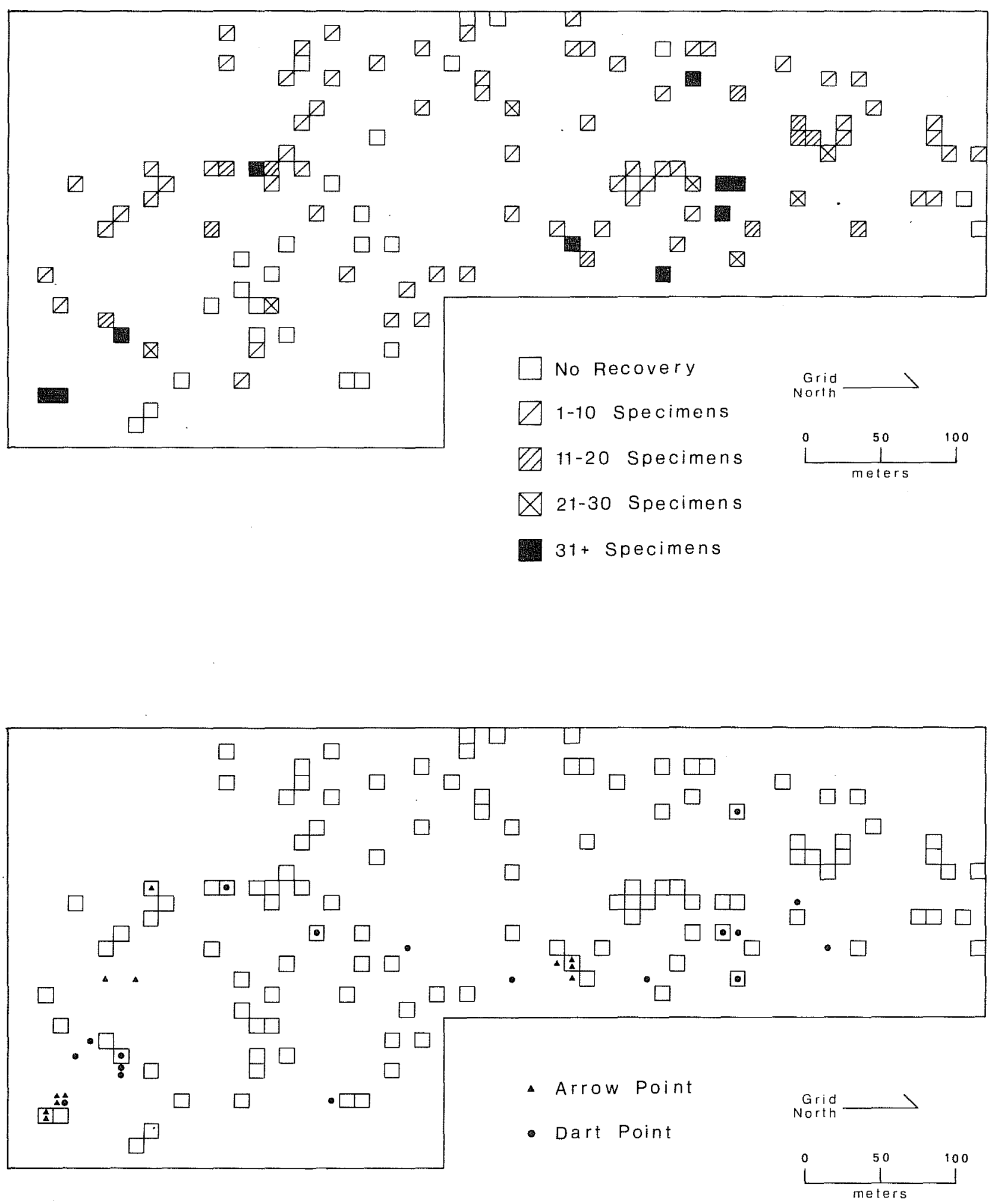

Figure 28. Surface Distribution of Debitage and Projectile Points at 41 UV 48. 
TABLE 45. DEBITAGE DENSITY SUMMARY BY AREA AT 41 UV 48

\begin{tabular}{|c|c|c|c|c|c|c|}
\hline & $\begin{array}{c}\text { No } \\
\text { Recovery } \\
\text { Units }\end{array}$ & $\begin{array}{l}1-10 \\
\text { Specimens } \\
\text { per Unit }\end{array}$ & $\begin{array}{l}11-21 \\
\text { Specimens } \\
\text { per Unit }\end{array}$ & $\begin{array}{l}21-30 \\
\text { Specimens } \\
\text { per Unit }\end{array}$ & $\begin{array}{l}31+ \\
\text { Specimens } \\
\text { per Unit }\end{array}$ & $\begin{array}{l}\text { Total } \\
\text { Units }\end{array}$ \\
\hline $\begin{array}{ll}\text { Area } & \text { A } \\
\text { Area } & \text { B } \\
\text { Area } & \text { C } \\
\text { Area } & D\end{array}$ & $\begin{array}{r}2 \\
3 \\
21\end{array}$ & $\begin{array}{l}21 \\
23 \\
20\end{array}$ & $\begin{array}{l}4 \\
8\end{array}$ & $\begin{array}{l}1 \\
5 \\
2\end{array}$ & $\begin{array}{l}2 \\
2 \\
6\end{array}$ & $\begin{array}{r}2 \\
30 \\
45 \\
43\end{array}$ \\
\hline $\begin{array}{l}\text { Total numb } \\
\text { of Units }\end{array}$ & 26 & 64 & 12 & 8 & 10 & 120 \\
\hline
\end{tabular}

while units with higher debitage counts are much less common, totaling only $30 \%$ of all the sampled units.

Table 46 summarizes the artifact categories by area from the surface collection. The projectile point distribution (Fig. 28) shows that arrow points were most common in Area A. Arrow points in Area $C$ were clustered around or in Unit 526, near the Leona River. No arrow points were found in Area D. Of the diagnostic forms, Perdiz (one specimen) was confined to Area A, Scallorn to Areas A (five specimens) and B (one specimen), and Edwards points (two specimens) were found only in Area C. The dart point distribution differs somewhat, since dart points are most common in Areas $B$ and $C$ of the site. There is some indication of a horizontal distribution reflecting temporal implications for the Archaic point types identified within the site. Within Areas $A$ and $B, a 11$ of the time diagnostic dart points (one each of Fairland, Frio, Pedernales, and Zavala) can be placed within the Middle or Late Archaic, while the identifiable dart points (including one specimen each of Castroville, Gower, La Jita, and Nolan) from Area $C$ are, with the exception of the Castroville, diagnostic of the Middle Archaic or earlier. As for Area D, it is interesting to note that the two typed dart points (Frio and Uvalde) lie closest to the site area containing a majority of dart point types chronologically equivalent to each form.

of the combined bifacial artifact categories (93 specimens), most were from Areas A and B (46\%) or Area C (50\%) as shown by Figure 29, with the few remaining specimens in Area D. Bifaces with overall retouch occurred in a11 areas except Area D. Bifacially retouched flakes occurred in a 11 areas of the site. Bifacial intergrades also occurred in all site areas, but were most common in Area $C$ ( $50 \%$ of all specimens). Of the other bifaces, $1 i k e$ the bifacial intergrades, most occurred in Area C (62\% of the other bifaces), and none were found in Area D. 

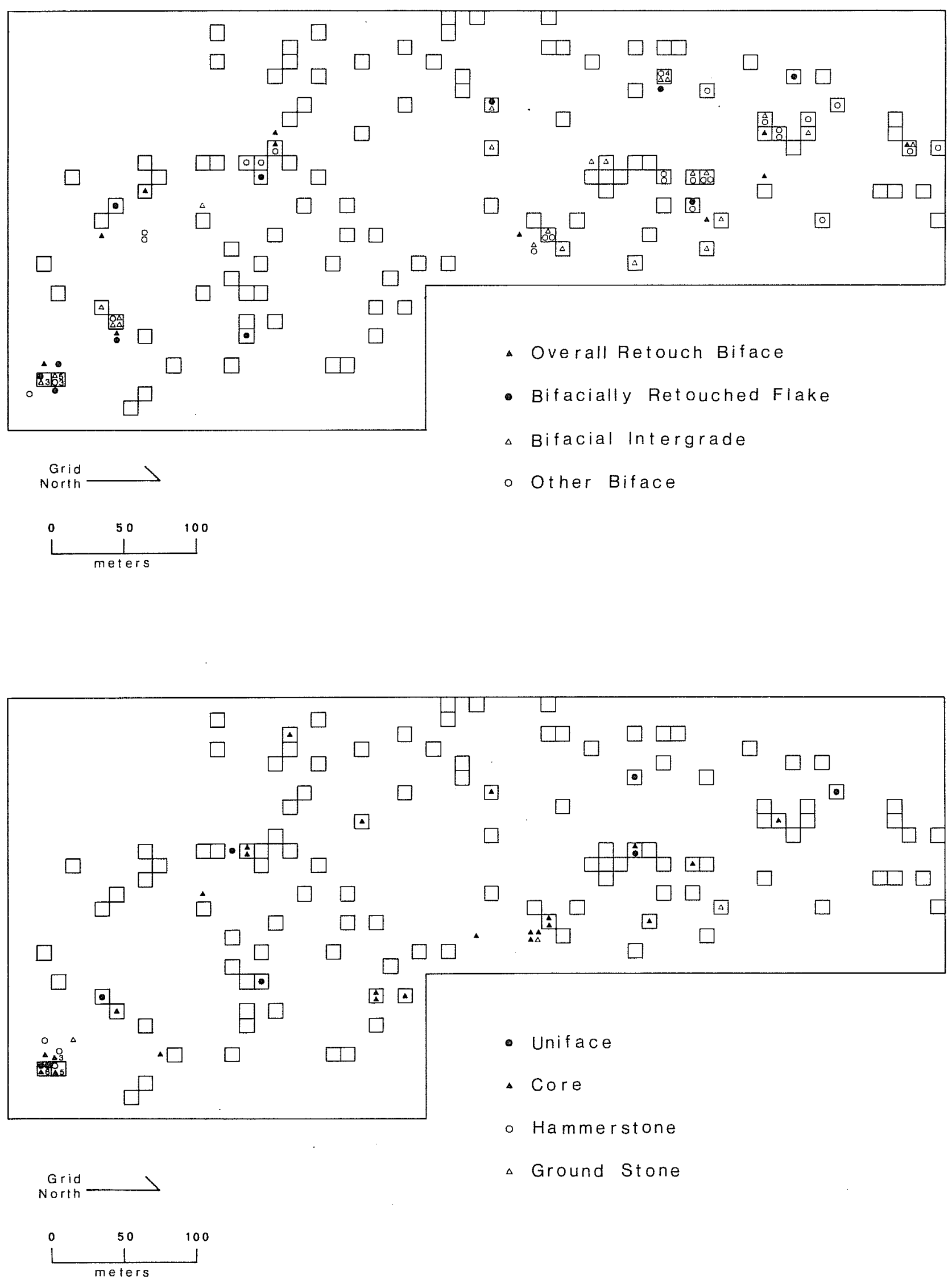

Figure 29. Surface Distribution of Bifaces, Unifaces, Cores, and Other Artifacts at 41 UV 48. 
TABLE 46. INTRASITE DISTRIBUTION OF ARTIFACT CATEGORIES, 41 UV 48

\begin{tabular}{|c|c|c|c|c|c|}
\hline & \multicolumn{3}{|c|}{ Areas } & & \multirow[b]{2}{*}{ Total } \\
\hline & A & B & C & D & \\
\hline $\begin{array}{l}\text { Arrow points } \\
\text { Dart points } \\
\text { Overall retouched bifaces } \\
\text { Bifacially retouched flakes } \\
\text { Bifacial intergrades } \\
\text { Other bifaces } \\
\text { Unifaces } \\
\text { Cores } \\
\text { Modified flakes } \\
\text { Ground stones } \\
\text { Hammerstones }\end{array}$ & $\begin{array}{r}6 \\
1 \\
1 \\
3 \\
9 \\
7 \\
2 \\
17 \\
3 \\
1 \\
3\end{array}$ & $\begin{array}{l}3 \\
6 \\
5 \\
4 \\
5 \\
7 \\
2 \\
5\end{array}$ & $\begin{array}{r}4 \\
8 \\
4 \\
2 \\
17 \\
23 \\
3 \\
10 \\
2 \\
2\end{array}$ & $\begin{array}{l}3 \\
1 \\
2 \\
3 \\
1 \\
7\end{array}$ & $\begin{array}{r}13 \\
18 \\
11 \\
11 \\
34 \\
37 \\
8 \\
39 \\
5 \\
3 \\
3\end{array}$ \\
\hline Total & 53 & 37 & 75 & 17 & 182 \\
\hline
\end{tabular}

Unifaces occurred in small quantities in all areas of the site (Fig 29). Cores also occurred in all areas but were more common (the most common artifact category from the surface; Table 46) than unifaces. In Area A, 17 specimens were collected. Ground stone occurred only in Areas $A$ and $C$, located near the Leona River. Hammerstones occurred only in Area A.

\section{Area Summaries}

The brief characterizations of each of the four site areas (Areas A, B, C, and $D$ ) that follow will summarize the results of the surface collection from 41 UV 48. Three of the site areas contained substantial 1ithic concentrations. In addition, some temporal and distributional variations are indicated within the site.

Area A contained the densest 1ithic debitage concentration at the site. The debitage concentration was associated with a midden feature exposed on the surface of the site. Artifacts were common within the area and comprise $29 \%$ of all the surface-collected artifacts at 41 UV 48 . The most common artifacts recovered within Area $A$ are classified as cores and bifacial intergrades. Other bifaces and arrow points were also common, but not as frequent. Bifacially retouched flakes, hammerstones, unifaces, dart points, overall retouch bifaces, and ground stone occurred in small quantities. The frequency of cores and bifacial intergrades suggests that flake and tool production was a major activity within the area. The presence of ground stone points to plant food processing. The high incidence of arrow points to 
dart points (six to one) would indicate a Late Prehistoric occupation. The identifiable arrow point types are Perdiz and Scallorn; the single dart point is a Zavala.

Within Area B, the overall debitage density was much lower, although there was a linear concentration of debitage that extended out from Area $A$ and through Area B, following a low ridge that extends through the two site areas. Artifacts were also less frequent in Area B. Other bifaces are the most common type (seven specimens); followed by dart points (six specimens), overall retouch bifaces, bifacial intergrades, and cores (five specimens each); bifacially retouched flakes (four specimens); arrow points (three specimens); and unifaces (two specimens). There is some indication of intraarea patterning of the aforementioned artifacts. 0verall retouched bifaces, bifacially retouched flakes, and arrow points tended to be located in the western half of Area B, while dart points and bifacial intergrades tended to be located in the southern half of Area B, near Area A. Of the identifiable dart points, a Pedernales, a Frio, and a Fairland, all are Middle Archaic or later forms. The three arrow points recovered from the area were are Scallorn sattler, a crude contracting stem specimen, and a blade fragment.

Area $C$ was the largest site area. The debitage distribution within the area indicated most of the debitage was concentrated near the edge of the Leona River and on the highest elevations within the area. Other bifaces and bifacial intergrades are the most common artifact forms recovered (23 and 17 specimens, respectively), and together total over half of all the artifacts from Area C.

The remaining artifacts within Area $C$ are cores (10 specimens), dart points (eight specimens), arrow points (four specimens), overall retouch bifaces (four specimens), unifaces (three specimens), bifacially retouched flakes (two specimens), and ground stone (two specimens). Projectile points, cores, and ground stone tended to be found close to the Leona River, while bifaces and unifaces tended to occur farther west of the river. of the projectile points, two arrow points are identified as Edwards, and the identifiable dart points are Castroville, Gower, La Jita, and Nolan.

Area $D$ contained a much lower debitage density than any other area of the site. Over $80 \%$ of the examined collection units containing no debitage were located within Area D (Table 45). Only 16 artifacts were recovered from Area $D$. The artifacts are cores (seven specimens), bifacial intergrades, dart points (three specimens each), bifacially retouched flakes (two specimens), and one uniface. The relatively lower lying elevations within Area $D$ are a likely factor in the sparse debitage and artifact inventories from the area.

In summary, the random sample collection, supplemented by a number of nonrandom collections, allowed for an overall assessment of the site surface within the boundarjes originally defined by Hall (1974). Four site areas were defined based upon field observations of the site's varying 1 ithic scatters and topographic features. An intrasite analysis of the defined site areas suggested that the site contained specific lithic concentrations and associated artifact assemblages useful in understanding the surface nature and extent. 


\section{EXCAVATION AREAS}

As previously stated four distinct site areas were investigated during the surface collection. These four areas were also used during the testing and excavation phase of field work; a description of the kinds and amounts of subsurface work carried out in each area and the soil profiles within the site are detailed.

\section{$\underline{\text { Area A }}$}

Area A excavations were Backhoe Trenches 2-5 and 11; Test Pit Units 91-1, 921 , and 150-5; and excavation Units 61-21,91-17,91-18,120-24,121-9, and 121-10. The total cubic volume excavated was $13.5 \mathrm{~m}$, not including the backhoe trenches. The total surface area exposed was $25.5 \mathrm{~m}^{2}$, again excluding backhoe trenches. The excavations in Area A showed four definable stratigraphic zones, identified as the midden zone, transitional zone, Knippa clay, and gravels (Fig. 30).

Within Area A the midden zone was the uppermost stratum. It occurred throughout the area, but was more pronounced towards the center and tended to become less distinct towards the edges of Area A. The depth of the midden zone varied from approximately $25-50 \mathrm{~cm}$ below the surface, generally averaging 35-40 cm in depth. The soil consists of a loosely compacted, dark grayish brown to gray silty clay loam, and is often noted as ashy, but never greasy in texture. Burned rocks are common throughout the midden zone in varying concentrations, but they tended to be more compact in the area where Backhoe Trenches 2 and 5 connect, although distinct parameters were difficult to define. Cultural material was common within this midden zone. The vast majority of excavated materials came from this zone along with large numbers of land snails (especially Rabdotus sp.), mussel shell fragments, faunal remains, and charcoal. Although the area has been cleared of brush, large rotten mesquite roots and many smaller roots occurred within the midden zone.

Usually, but not always, occurring is a transitional zone bridging the dark gray midden soils and the deeper lying brown Knippa clays (Stevens and Richmond 1976). The transitional zone occurs from 25 to $60 \mathrm{~cm}$ below the ground surface and can be identified by an increasing compaction, or hardness in the soil, and a lighter hue. Often the transitional soils are mottled with brown and gray soils. Roots are present, but not as often as in the midden zone. There is a noticeable decline of cultural materials upon entering the transitional soil zone. Below the transitional zone, and sometimes directly below the midden zone is a brown, highly compacted clay loam that is identified as Knippa clay. White calcium carbonate deposits are common and root disturbances decline. The soil zone occurs from 20-140 cm below the ground surface. The soil zone was, for practical purposes, sterile, and excavations were for the most part terminated at the upper levels of the Knippa clays in Area A.

The Knippa clays rest on top of a gravel zone that is known to occur up to a depth of two meters as was shown in Backhoe Trench 2. The gravels consist of soft masses and pebbles of calcium carbonate. No cultural material was observed in the gravels. 


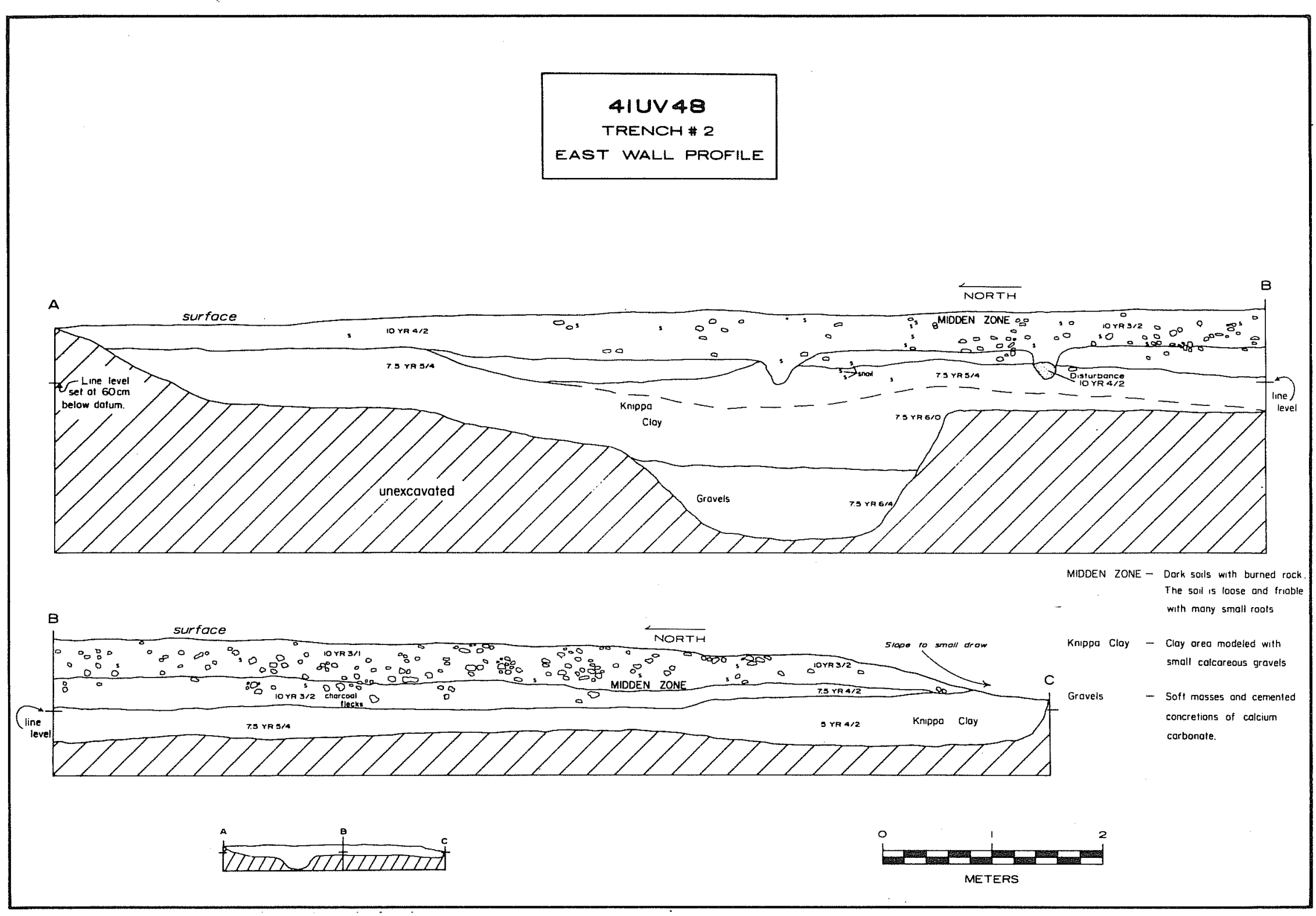


Overal1 the composition of Area A shows some similarities to soils described for site 41 UV 47, Area A, and 1ater, intersite comparisons will show other similarities.

\section{Area B}

Area B excavations include Test Pit Units 211-3, 499-12, 836-6, and Backhoe Trench 9; and excavation Units 207-24, 207-25, 208-4, and 208-5 were opened to investigate Feature 3 . A maximum depth of $80 \mathrm{~cm}$ was reached during the excavations in Area B. The area is characterized by noticeably less prehistoric alteration of the soil profile. Three zones are recognized in the soil profiles, which are defined as the A- and B-horizons of Knippa clay and the underlying gravel zone (Fig. 31). The A- and B-horizons are dark brown to grayish brown soils that tend to become lighter in hue with increasing depth. The A-horizon contained the majority of cultural material (7ithics, burned rock, she11), but in much smaller amounts than in Area $A$. The upper zone is less compacted than the B-horizon and contains more roots. Calcium carbonate deposits occur in both horizons. The upper horizon occurs from the surface to 30-45 cm in depth, while the B-horizon can occur from $30-80 \mathrm{~cm}$ below the surface. Grave1s were encountered onty in Unit 211-11, where they appeared at 45-60 cm below the surface. Vertisol cracks up to $4 \mathrm{~cm}$ wide were encountered in all of the excavation units that entered the B-horizon.

\section{$\underline{\text { Area C }}$}

Area $C$ is spatially the largest and is under more intensive agricultural use than any other area at 41 UV 48 . Portions of Area $C$ are seasonally turned by machinery. Investigations in the area include Test Pit Units 40116, 456-11, 525-5, and 801-1, and Backhoe Trenches 1 and 7 (Fig. 32). The horizontal area opened for excavation was $4 \mathrm{~m}^{2}$ for a total volume of $2.0 \mathrm{~m}^{3}$ (a11 totals exclude backhoe trench excavations).

Profile descriptions for the excavation units indicated a soil column similar to Area B (Fig. 33). A generalized profile for the test pits includes an upper zone, $20-35 \mathrm{~cm}$ thick, dark to medium brown, uncompacted clay $10 \mathrm{am}$, often with a relatively higher gravel and pebble count than at lower levels. The majority of cultural materials (lithics, burned rock, snails, charcoal flecks) occurred within this upper zone. The lower zone, from about 40$110 \mathrm{~cm}$, is a.7ighter, more compacted clay loam. Calcium carbonate deposits also increase relative to the upper soil zone. Cultural material was noticeably absent in the lower soil zone. The lower soil zone can probably be defined as a B-horizon, and the upper zone as an often culturally altered A-horizon.

The midden feature in Area $C$ was made distinct in the profile mainly by the presence of burned rock. Although the soil color was slightly darker in the center of the feature, the gradational color changes towards the edges were difficult to distinguish and use in defining the midden boundary. 
UNIT 211-11

NORTH WALL PROFILE

\begin{tabular}{|c|}
\hline $\begin{array}{l}\text { DARK GRAYISH BROWN } \\
\text { CLAY LOAM }\end{array}$ \\
\hline BROWN CLAY LOAM \\
\hline GRAVELS \\
\hline
\end{tabular}

UNIT 499-12

WEST WALL PROFILE

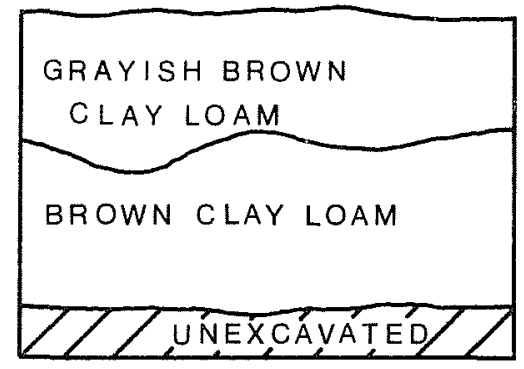

TRENCH 6

NORTH WALL PROFILE

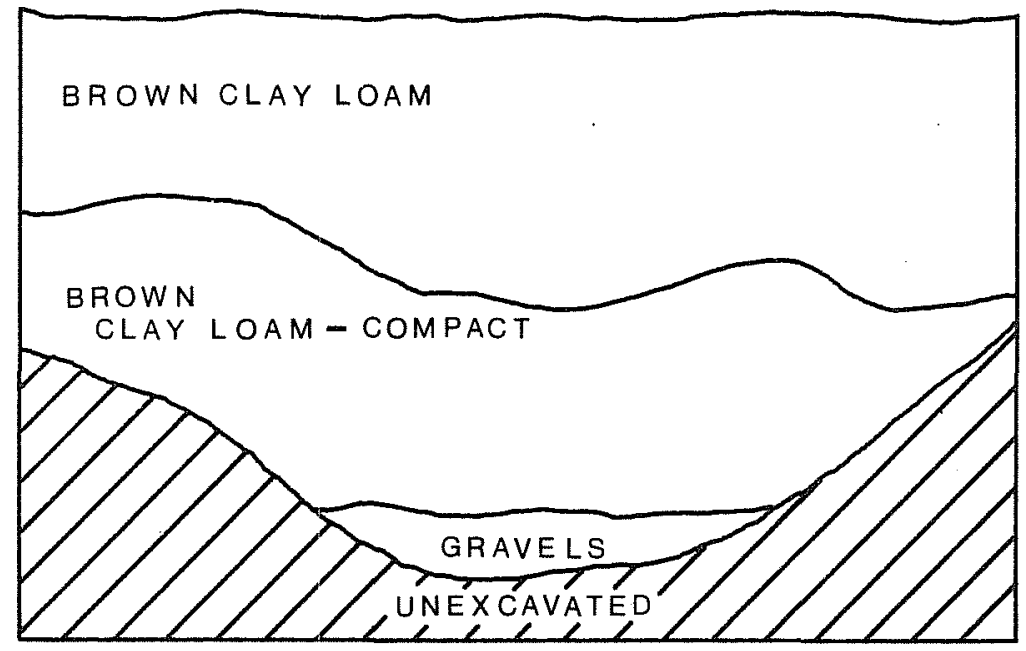

TRENCH 8

NORTH WALL PROFILE
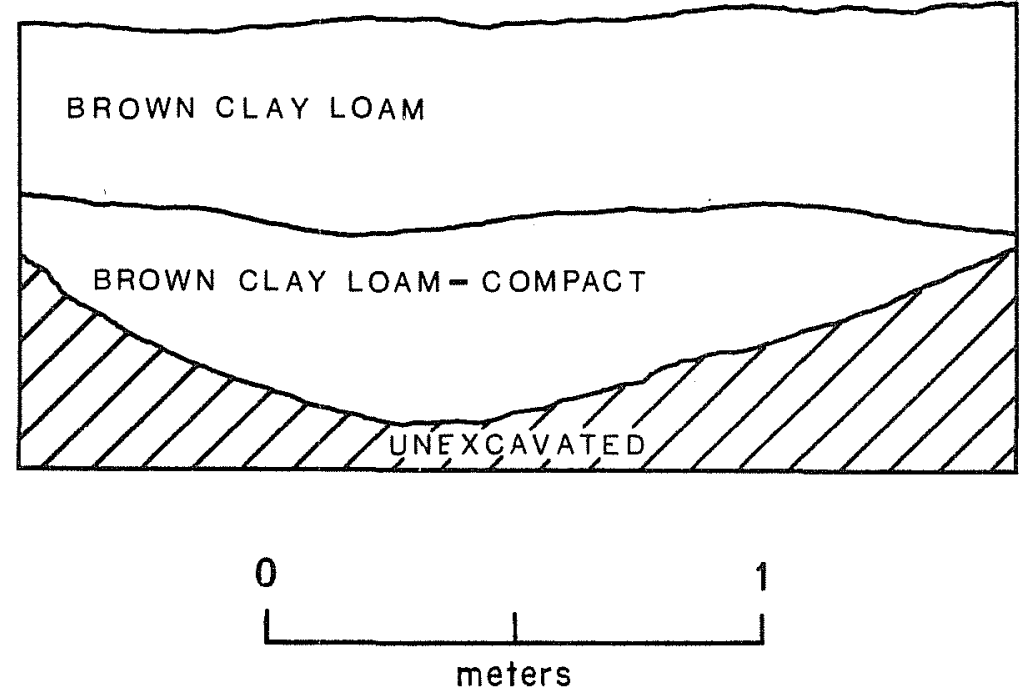

Figure 31. Soil Profiles for Areas B and D at 41 UV 48. 


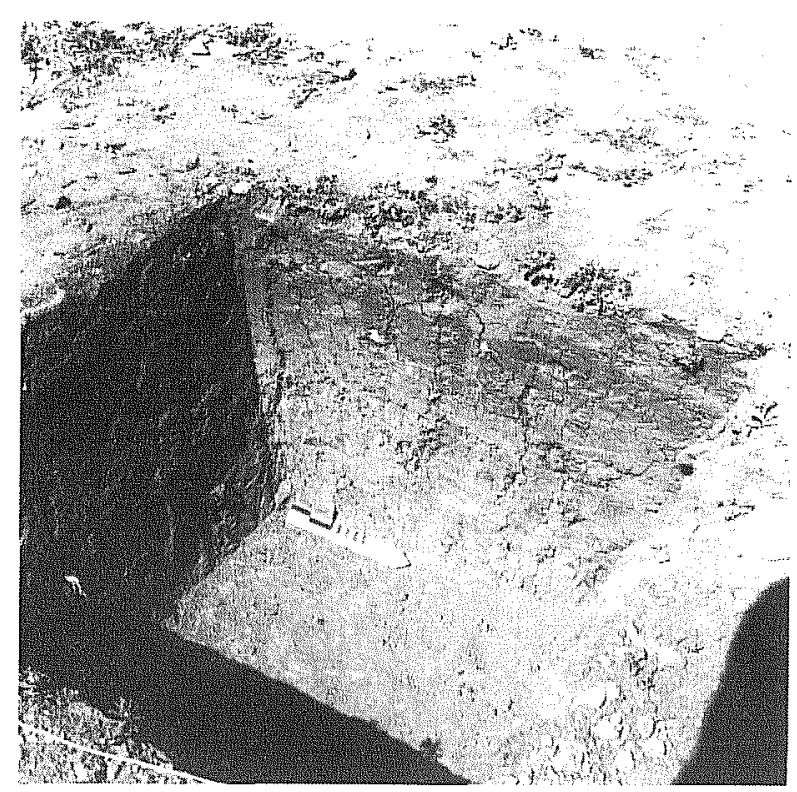

a

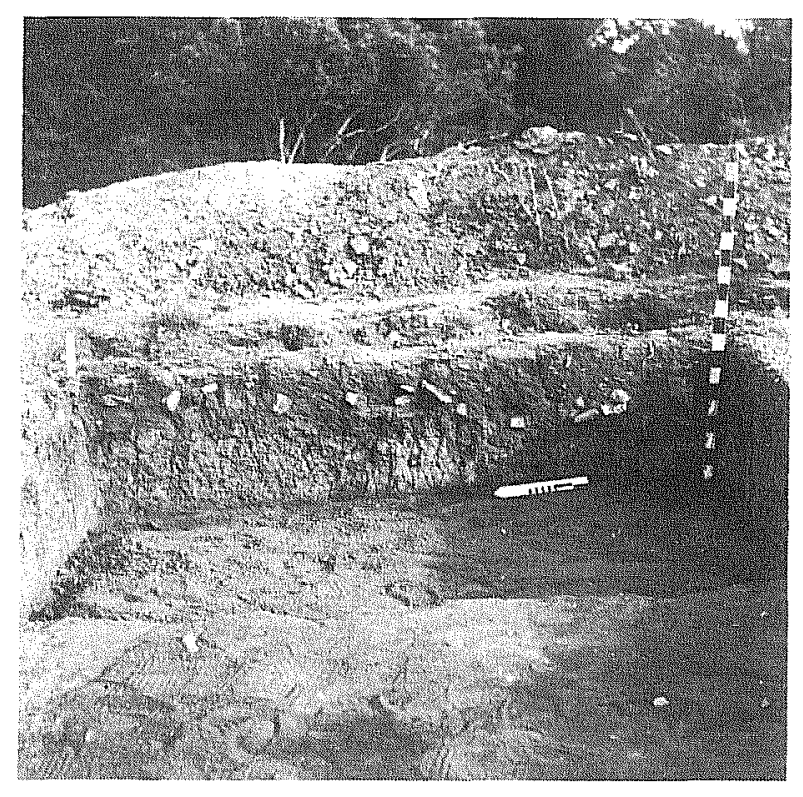

C

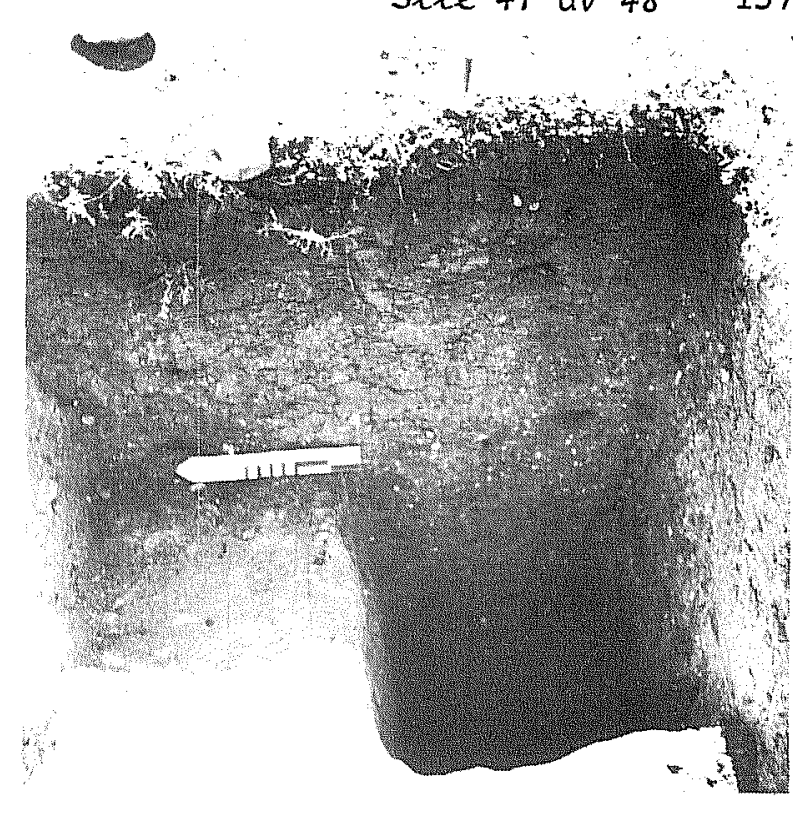

b

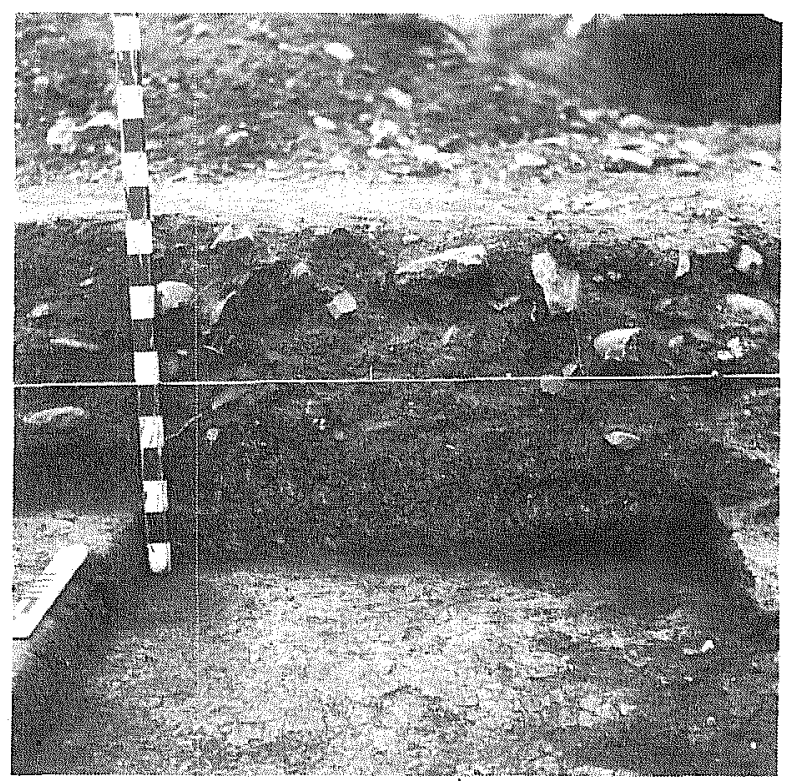

d

Figure 32. Soil Profiles in Areas $A$ and $C$ at 41 UV 48. a, east wal1, Unit 525-5 in Area C; b, west wa 11. Unit 456-11 in Area $C$; $c$, east wa11, Unit 120-10 in Area $A_{;}$d, north wa 17, Unit 91-18 in Area $A$. 


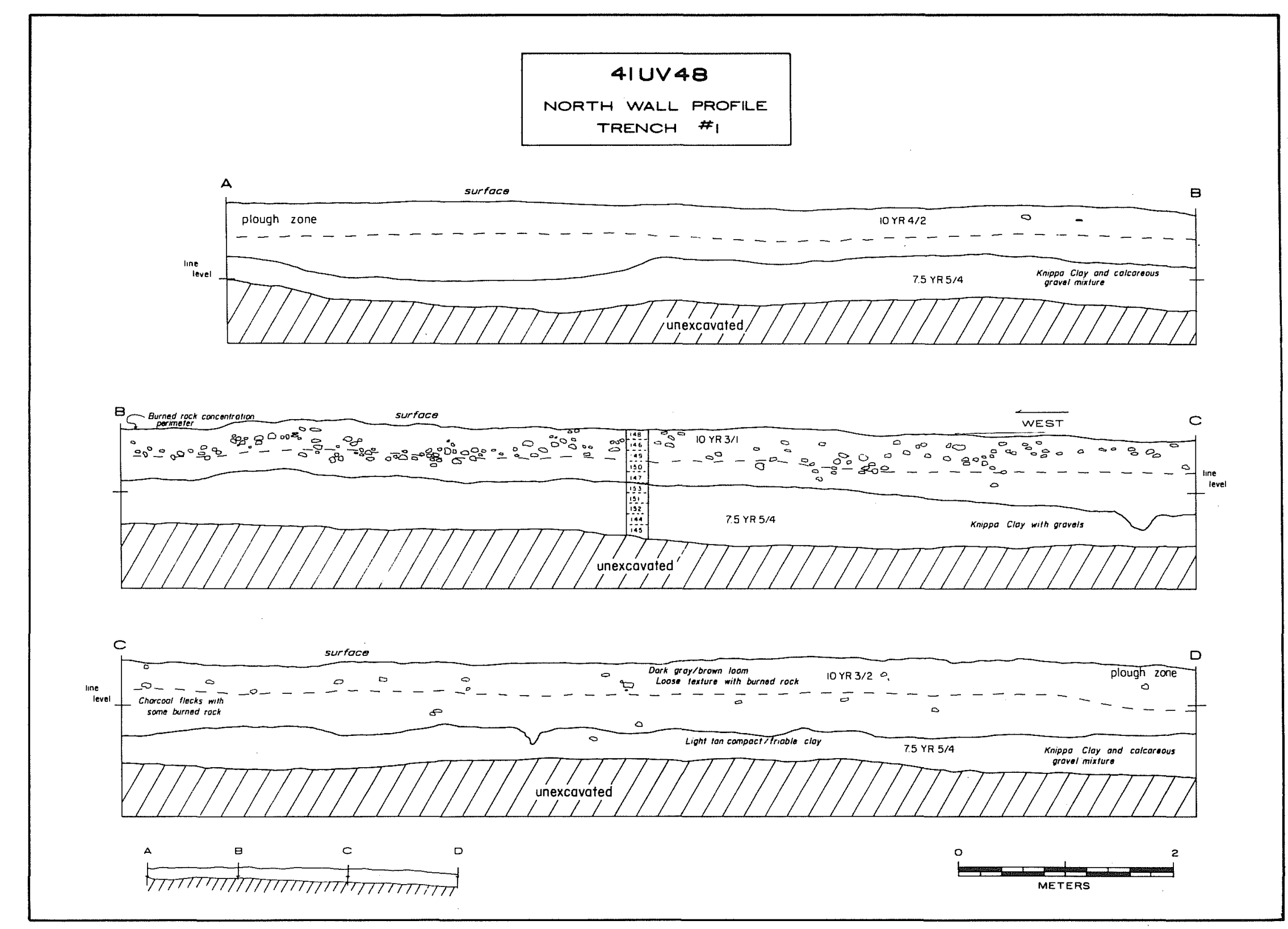

Figure 33. Soil Profile for Area C at 41 UV 48. Midden feature in Trench 1, north wal1. 


\section{$\underline{\text { Area D }}$}

Within Area D, Backhoe Trenches 6 and 8 were excavated. No cultural material was observed in the walls or collected from the backdirt. The soil profiles of the two trenches (Fig. 31) show similarities with both Areas $B$ and $C$ profiles, with the noted exception of absent cultural materials. Both trench profiles show both $A$ and $B$ soil horizons, usually separated by a gradual boundary marked by a lighter hue and increased compaction towards the deeper horizon. In addition, calcium carbonate deposits increase with depth. The $A-B$ horizon boundary occurs at about $40 \mathrm{~cm}$ below the ground surface. The B-horizon is at least $40 \mathrm{~cm}$ thick in Backhoe Trench 6 , but may be deeper in other areas of the site. In the Backhoe Trench 6 profile, a gravel 1 ayer, presumably the basal soil zone, occurs at about $100 \mathrm{~cm}$ below the ground surface. This gravel zone also occurred in Areas $A$ and $B$ of the site, although at varying depths (ca. 140 and $50 \mathrm{~cm}$, respectively).

\section{Summary}

In a general sense, the various site soil profiles show a great deal of continuity across all the designated site areas. The most basic of these similarities includes the presence of a single soil type, Knippa clay, which may show some visible cultural alterations at various locations (especially middens) within the upper portions of the soil column. Usually, visible alterations and significant cultural deposits occur only in the upper 40 to $60 \mathrm{~cm}$, which is roughly correlated to the A-horizon in less disturbed portions of the site. Site-wide there is a tendency for color hue to lighten with depth, and for the soils to become increasingly compact and calcareous within the B-horizon. Although not shown for all site areas, it is likely that the Knippa clays rest on a gravel stratum, which is culturally sterile, and occurs at different depths throughout the site.

\section{FEATURES}

Three features were recorded during the field work at 41 UV 48 . These are a hearth, a burned rock scatter, and a soil anomaly (Fig.34,a-c). The features are briefly described and summarized below.

\section{Feature 1}

Feature 1 was defined by a small hearthlike concentration of burned limestone rocks exposed in Level $3(40-60 \mathrm{~cm})$ of Unit 401-16. The feature size averaged about $60 \mathrm{~cm}$ in diameter, with a vaguely circular configuration. A cross section was not prepared, but it was clearly observable that a basin$7 \mathrm{ike}$ profile could be expected. The feature consisted entirely of bluish gray burned 1 imestone rocks, varying in individual size from about 2 to $15 \mathrm{~cm}$. A total burned rock count of 32 stones was estimated.

The feature fill and the surrounding soil were a 1 ight brown, compact clay loam interspersed with a few calcareous, pea-sized gravels. Feature records indicated that although the soil inside and outside the feature usually 


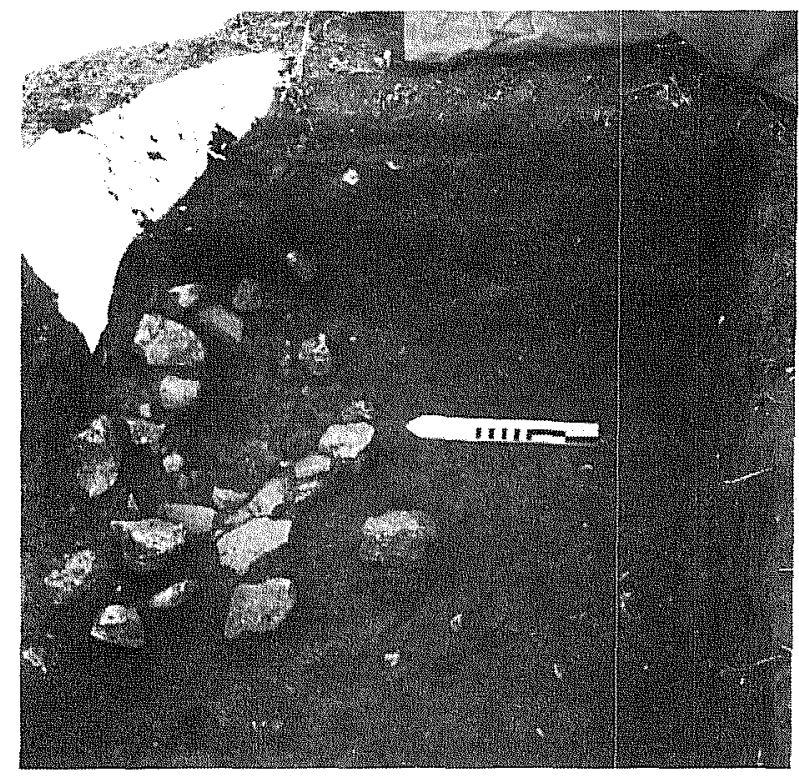

a

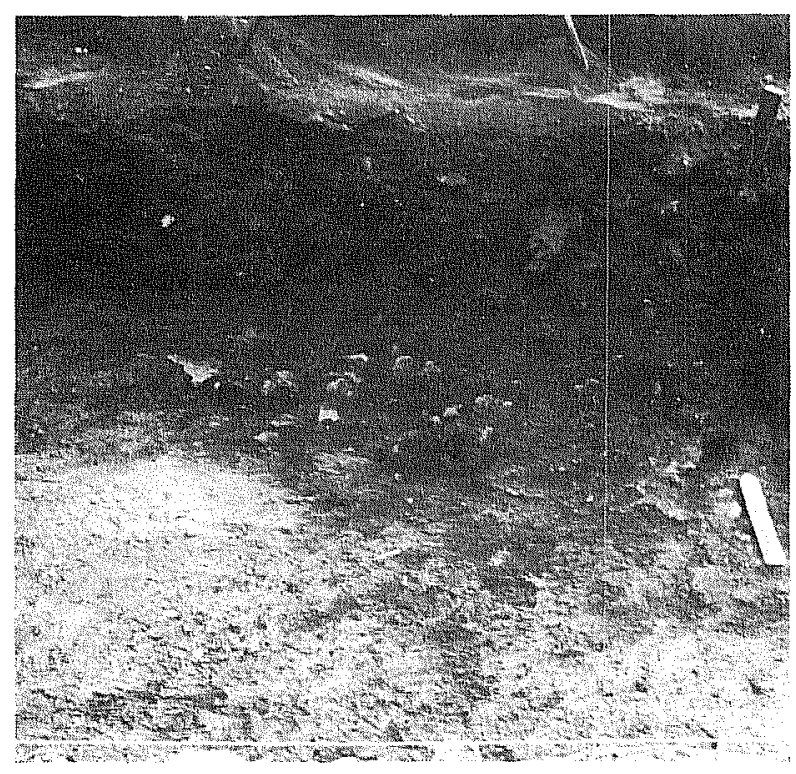

C

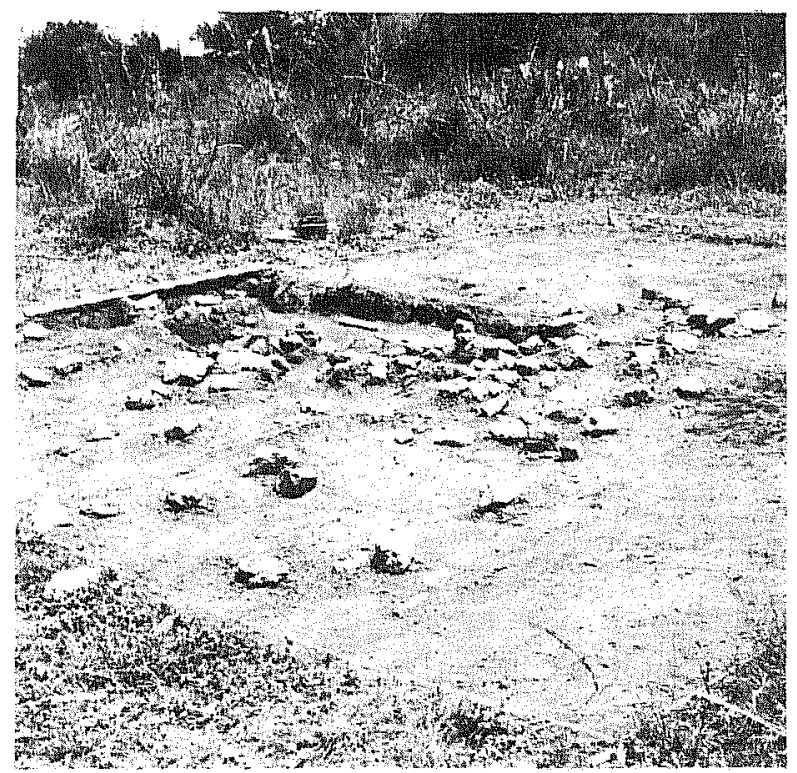

b
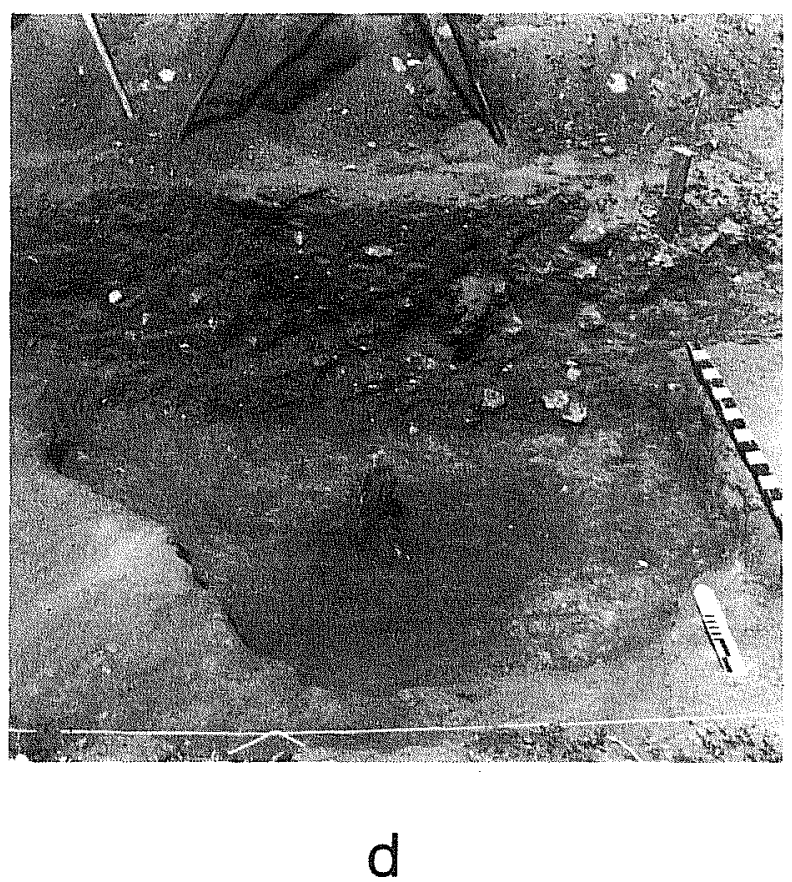

Figure 34. Features 1, 2, and 3 at 41 UV 48. a, Feature 1; b, Feature 2; c, Feature 3 prior to excavation; d. Feature 3 after excavation. 
appeared identical, the soil excavated from between the feature rocks was slightly more compact. Stratigraphically the feature was recorded as well within the B-horizon (previously described for Area $C$ in the Excavation Areas section for site 41 UV 48). The average depth of the feature is estimated to be $55 \mathrm{~cm}$ below the surface, and the $A$ soil horizon boundary occurs at approximately $40 \mathrm{~cm}$.

The stratigraphic placement of Feature 1 in the $B$ soil horizon makes it the only cultural feature at the site believed to have originated in the $B$ soil horizon. In this respect it is similar to Feature 4 at 41 UV 47 and several features at 41 UV 45, both of which show Archaic period origins. Not enough charcoal was recovered from Feature 1 for a radiocarbon date, and only a single overall retouch biface (large triangular biface with a straight base) was recorded from the unit-level associated with the feature. So a more definite chronological placement, other than Archaic, is impossible at this time.

Other cultural material associated with the unit-level and Feature 1 includes a few platformed flakes (nine secondary and 53 interior), chips (seven partially corticate and 100 decorticate), a few burned chert pieces, two mussel shell umbos (Unio sp.), and three species of snails (88\% of which are Rabdotus sp.).

\section{Feature 2}

Feature 2 was defined as a soil anomaly consisting of midden soils that intruded into the submidden soil zones of Area $A$. The feature was recorded in Unit 121-9, Level $6(50-60 \mathrm{~cm})$. Maximum and minimum dimensions of the feature were 190 to $120 \mathrm{~cm}$, with an irregular outline. The vertical extent of the feature was $12 \mathrm{~cm}(50-62 \mathrm{~cm}$ below the surface). However, there were indications that the feature may have had a higher origin point. Unit-level plan drawings for Unit 121-10, Level 4 show a dark midden soil outline in the northwest corner that may have been the easternmost edge of what was 1 ater recorded as Feature 2. If this is the case, the feature may have had a depth of at least $22 \mathrm{~cm}$ (from 40 to $62 \mathrm{~cm}$ below the surface). The origin point (as opposed to the detection point) could not be satisfactorily determined due to the fact that the feature matrix was indistinguishable from the surrounding midden zone soils in levels above $50 \mathrm{~cm}$ below the ground surface for Unit 121-9. The northwest profiles of Units 121-9 and 121-10 provided a clear cross section of the feature showing the Feature 2 fitl to be visually identical to the midden zone soils.

The screened feature matrix contained 245 burned rocks, with a total weight of $39.5 \mathrm{~kg}$. Other materials recovered from the matrix are two Scallorn arrow points, a bifacially retouched flake, six other bifaces, two cores, 46 flakes, 329 chips, 54 burned chunks, over 1190 bone fragments, and snails (a17 but two of the 267 snails were Rabdotus sp.).

The faunal remains were recovered using $1 / 8$-inch screening techniques in addition to standard 1/4-inch mesh screening procedures. Faunal analysis identified at least six species of mammals and two kinds of reptiles 
(Table 47). A more complete discussion of the faunal remains is available later in this section.

Charcoal was common within the feature. A total of $280.0 \mathrm{~g}$ of charcoal was collected in the unit-level containing Feature 2, and a sample of $173.5 \mathrm{~g}$ was submitted for wood species identifications. Of the $16.4 \mathrm{~g}$ identified, the following woods and their corresponding percentages within the feature were recorded: diffus-porus woods (47\%), Fraxinus sp. (18\%), Juglans (16\%), Diospyros texana (10\%), and Quercus sp. (8\%).

It remains in question if this feature is a cultural construction. The high artifact inventories, bone counts, and charcoal amounts, are not uncommon for the midden soils within Area $A$ of the site. The presence of large, rotting mesquite roots within the feature floor and profile may indicate that the feature resulted from foot disturbances in the area. Yet another possible cause for the feature occurrence has been discussed for similar kinds of features in south Texas (see Hester and Hill 1980). Hester and Hil1 (1980) describe some recent pack rat nests as having nest foundations of saucershaped depressions up to four feet in diameter $(\mathrm{ca} .120 \mathrm{~cm})$ and about three inches deep $(\mathrm{ca} .8 \mathrm{~cm})$. The materials within the described nests sometimes contained prehistoric artifacts when occurring near a site (Hester and Hill 1980). They state that if such nests occurred within a site in the prehistoric past, the resulting archaeological remains could be mistaken for a cultural feature. Feature 2 certainly fits Hester and Hill's (1980) description in outline, but the feature may be somewhat deep in comparison to the more recent pack rat nests they describe. It is interesting to note that $75 \%$ of all the pack rat faunal elements identified at 41 UV 48 came from either Feature 2 or the unit-level directly above it (see Faunal Remains section).

TABLE 47. IDENTIFIED FAUNAL ELEMENTS FROM FEATURE 2 AT 41 UV 48

Species

Total Elements

Canis domesticus - dog

Lepus californicus - jackrabbit

Sylvilagus audubonii - cottontail rabbit

Rabbit

Neotoma sp. - pack rat

Sigmodon hispidus - cotton rat

Spermophilus sp. - ground squirrel

Rodent

Lizard

Turtle

Totals 
The function and origin of Feature 2 remains uncertain. The presence of the Scallorn arrow points and the character of the feature (midden soils) point to a Late Prehistoric chronological placement for the feature. The feature dimensions, in conjunction with the number of pack rat skeletal elements associated with it may suggest the feature represents the remains of a pack rat nest.

\section{Feature 3}

Feature 3 was defined by a surface scatter of loosely concentrated burned 1 imestone rocks confined to an area of ca. $3 \mathrm{~m}^{2}$ and contained within Units 204-4,204-5, 205-24, and 205-25. After recording the surface scatter, a portion of the feature was excavated to determine its depth and subsurface nature.

The burned rocks that appeared on the surface were thought to be eroding out of the soil, exposed by a wide and shallow drainage that fed into a nearby arroyo. The average individual rock sizes in the cluster varied from about 2 to $20 \mathrm{~cm}$ in diameter. Burned rock total and weight for the first level of Unit 208-4 and the surface of the remaining units were 161 rocks at $65.4 \mathrm{~kg}$. The total for a 11 the excavated burned rocks for three unit-levels was 149 rocks at $59.2 \mathrm{~kg}$.

No subsurface structure to the feature was noted in the wall profiles of the unit nor was any noted during the excavation. Both the amounts of burned rock and the cultural material appeared to decrease after the first few centimeters below the ground surface. Five bifaces were associated with the feature. These are an unidentified dart point fragment, a triangular intergrade, two pointed fragments, and a single miscellaneous other biface. Sixty-two percent of the debitage excavated from Feature 3 was within Level 1. A small amount of charcoal was present, and a trace of mussel shel1 was recovered from Unit 208-4, Leve1 $2(15-25 \mathrm{~cm})$. Snails were present in all unit-levels, with Polygyra sp. and Helicina sp. specimens less frequent than Rabdotus sp.

The soil matrix within the feature was identical to that of the surrounding soils. The soils were a light brown, friable clay containing a few calcareous gravels and small calcium carbonate deposits. The soil was loose on the surface and interspersed with organic materials, but it quickly became very compact and blocky a few centimeters below the surface and remained that way to the final excavated unit-level at a maximum of $35 \mathrm{~cm}$ below the surface. No staining or color variation was observed within or around the feature. No major root disturbances were visible during the course of excavation, however, one should be cautious in evaluating the feature as it lay on or near the surface of a pasture that has been cleared of brush in the past.

It was originally believed when investigating the feature, that the concentration of burned rock might be the partially disturbed remains of a hearth. In addition, its short distance from the midden feature in Area $A$ further suggested it might be an indication of some kind of activity area located adjacent to the midden. None of the speculations could be borne out by the data collected. The concentration showed no clear internal structure 
suggesting it was a prehistorically constructed feature. Artifact associations with the feature did 1ittle to clarify the feature function or age, and a satisfactory charcoal sample was unavailable for dating. The stratigraphic position of the feature, when considered in light of work in other locations within the site, would suggest that the feature, whether or not cultural, must date from late in the Late Prehistoric period or from the Historic period.

\section{MATERIAL DISTRIBUTIONS}

The distribution data for the cultural materials from the site are summarized. Artifacts, debitage, and burned rock are individually considered. The horizontal distribution of the material is presented in regards to site areas (Areas A, B, C, and D) for each group. Comments on the vertical placement of materials are generally considered by combining the individual unit-levels into more generalized area levels.

\section{Artifact Distributions}

The artifact distributions take into account the arrow points, dart points, overall retouch bifaces, bifacially retouched flakes, bifacial intergrades, other bifaces, unifaces, cores, modified flakes, other lithics, fired clay, and historic materials. Each is separately discussed.

\section{Arrow Points}

As is the case with most of the following artifact groups, arrow points were most common in Area $A$ of the site. Table 48 summarizes the recovered arrow points from the site by area.

TABLE 48. ARROW POINT DISTRIBUTION AT 41 UV 48

\begin{tabular}{lccccc}
\hline & \multicolumn{5}{c}{ Site Area } \\
& A & B & C & D & Total \\
\hline Surface & 6 & 3 & 4 & 0 & 13 \\
Excavated & 108 & 0 & 2 & 0 & 110 \\
\hline Total & 114 & 3 & 6 & 0 & 123 \\
\hline \hline
\end{tabular}


Within Area A, vertical proveniences by level indicated that there was some suggestion of a relative chronological sequence within the midden deposits. Arrow points occurred most frequently in Level 3 of the excavations in Area $A$ (Fig. 35); however, Toyah phase Perdiz arrow points occurred most frequent]y in Leve1 2. Arrow points from the earlier Austin phase include Scallorn, Sabina1, and Edwards types, each of which is most common in Level 3 of Area A. Ideally, the Edwards type, which has been proposed as a diagnostic form of the Turtle Creek phase (Mitchel1 1978), should occur in deeper context than either Sabinal (Jerry Henderson, personal communication) or Scallorn (Hester 1971). Even though, it should be noted that the vertical distributions shown in Figure 35 indicate the materials are mixed to some degree. The horizontal distributions within Area $A$ are shown in Figure 36. Most of the arrow points shown in Fig. 36 are from the westermost units of Area A (Units 120-4 or 121-9) with the exception of the Edwards type, which is most common in Unit 91-17.

No Perdiz points were recovered outside of Area $A$. Edwards points occurred only in Areas $A$ and $C$. Of the three Edwards points from Area $C$, only one came from a controlled excavation (Unit 456-11, Level 2). The only other diagnostic arrow point in Area $C$ was a Scallorn sattler form from Unit 525-5, Leve1 1. No arrow points were excavated from Area B, and the only diagnostic form found on the surface was a Scallorn sattler.

\section{Dart Points}

Table 49 shows the horizontal distribution of dart points by area at 41 V 48. Dart points were most common in the Area $A$ excavations, but surface finds of dart points were more frequent in the other three site areas.

The vertical distributions by level within Area A show that dart points were most frequent in Level 3. Late Archaic forms were the most common forms in Area A ( 17 of 20 diagnostics). Late Archaic Twin Sisters phase forms are Ensor (two specimens), Fairland (three specimens), and Zavala (five

TABLE 49. DART POINT DISTRIBUTION AT 41 UV 48

Site Area

$\begin{array}{lllll}\text { A } & \text { B } & \text { C } & \text { D } & \text { Total }\end{array}$

\begin{tabular}{lrrrrr}
\hline Surface & 1 & 6 & 8 & 3 & 18 \\
Excavated & 26 & 3 & 5 & 0 & 34 \\
\hline Total & 27 & 9 & 13 & 3 & 52
\end{tabular}



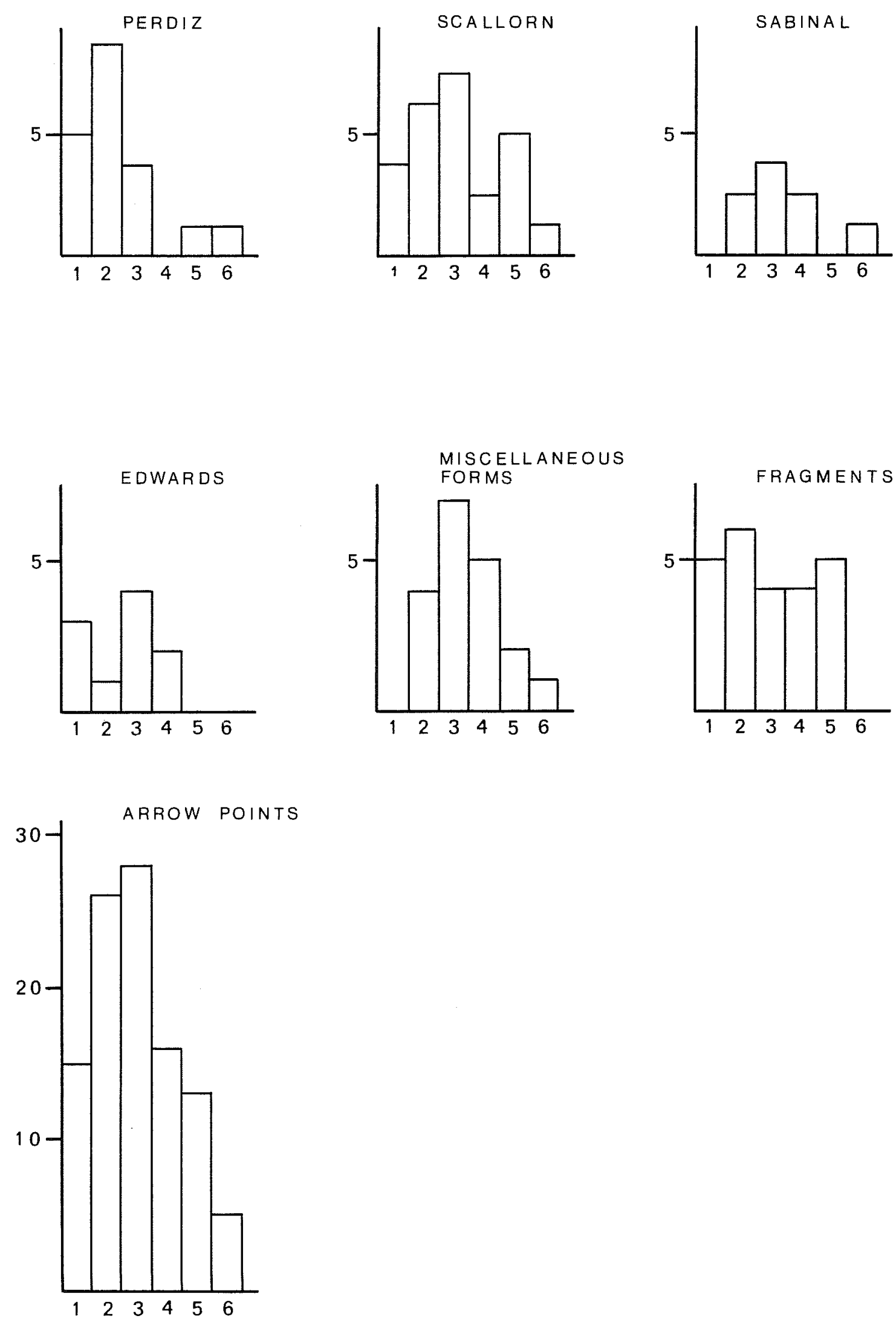

Figure 35. Vertical Distribution of Arrow Points at 41 UV 48. 


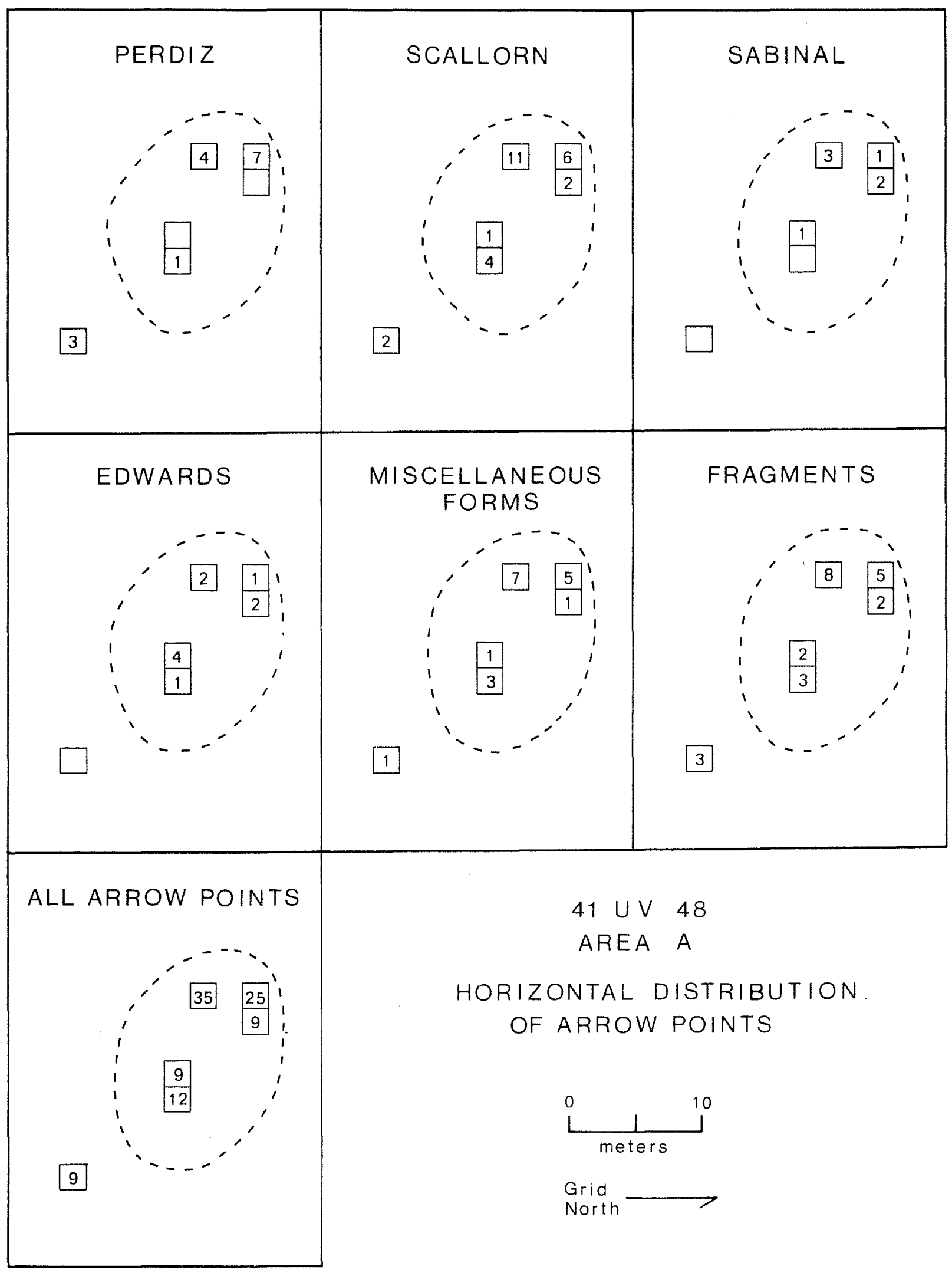

Figure 36. Horizontal Distribution of Arrow Points at 41 UV 48. 
specimens). Late Archaic San Marcos phase forms in Area A are Castroville (one specimen), Edgewood (one specimen), Frio (four specimens), and Marcos (one specimen). The only other diagnostic dart points from Area A were assignable to the Middle Archaic period (a Pedernales and two Bulverdes).

Archaic dart points from Area B are a single specimen each of Bulverde, Castroville, Fairland, Frio, and Pedernales; and four unidentifiable specimens. The three excavated dart points are from the first level of Units 2113 (an unidentifiable fragment), 499-12 (a Castroville), and Backhoe Trench 9 (a Bulverde). Within Area C, dart point forms are Bulverde, Castroville, Edgewood, Gower, La Jita, Nolan, two Pedernales, individual Forms 1 and 8, and three unidentifiable fragments. One of the Pedernales dart points was excavated from the first 7 evel of Unit 525-5, and the remaining four excavated dart points (Bulverde, Edgewood, Pedernales, and an unidentifiable fragment) were recovered from the backdirt of Backhoe Trench 1. No dart points were recovered from a subsurface context within Area D. The three surface-collected points are Frio, Uvalde, and an unidentifiable fragment.

The subsurface recoveries from Areas $A, B$, and $C$ reflect the temporal implications pointed out in the surface collection (see Surface Collection section). That is, dart points from the surface of Areas $A$ and $B$ are all assignable to the Middle Archaic period or later in time (primarily in the form of Late Archaic types). This surface characteristic was strongly supported in the subsurface recoveries as only four of the identifiable, excavated dart points from the combined Areas A and B are Middle Archaic forms (the remaining 17 are Transitional or Late Archaic forms). In Area C, of the four surface dart points, one is a Late Archaic form, two are Middle Archaic forms, and one is an Early Archaic form; the subsurface recoveries included four identifiable dart points, one Late Archaic form, and three Middle Archaic forms. Table 50 summarizes the chronological ordering of the projectile points from the site.

TABLE 50. CHRONOLOGICAL SEQUENCE OF DART POINTS FROM 41 UV 48

\begin{tabular}{|c|c|c|c|c|c|c|}
\hline \multirow{2}{*}{ Archaic Period } & \multirow[b]{2}{*}{ Types } & \multicolumn{5}{|c|}{ Areas } \\
\hline & & A & B & C & $D$ & Total \\
\hline \multicolumn{7}{|l|}{ Transitional } \\
\hline $\begin{array}{l}\text { Twin Sisters phase } \\
\text { Late }\end{array}$ & Ensor, Fairland, Zavala & 10 & 1 & 0 & 0 & 11 \\
\hline San Marcos phase & $\begin{array}{l}\text { Edgewood, Castroville } \\
\text { Frio, Marcos }\end{array}$ & 7 & 2 & 2 & 1 & 12 \\
\hline Middle Archaic & $\begin{array}{l}\text { Bulverde, La Jita, } \\
\text { Nolan, Pedernales }\end{array}$ & 3 & 2 & 5 & 1 & 11 \\
\hline $\begin{array}{l}\text { Early Archaic } \\
\text { No Designation }\end{array}$ & $\begin{array}{l}\text { Gower, Uvalde } \\
\text { Individual forms, } \\
\text { unidentifiable fragments }\end{array}$ & $\begin{array}{l}0 \\
7\end{array}$ & $\begin{array}{l}0 \\
4\end{array}$ & $\begin{array}{l}1 \\
5\end{array}$ & $\begin{array}{l}1 \\
1\end{array}$ & $\begin{array}{r}2 \\
17\end{array}$ \\
\hline
\end{tabular}




\section{Overa11 Retouch Bifaces}

Fifty-three specimens are classified as overall retouch bifaces. They were most common in Area A, possibly because of the more extensive excavations carried out in that area. The distribution of the overall retouch bifaces is shown in Table 51.

The vertical distribution by level for overall retouch bifaces in Area $A$ includes 28 specimens, and is shown in the histograms in Figure 37 . Also shown are those subcategories that occur in quantities of more than one. Sma11 triangulars were the most common form, comprising $54 \%$ of a 11 the overail retouch bifaces from Area $A$. Of the small triangulars, nearly onehalf were recovered in Level 5 (Fig. 37). Horizontally, small triangulars were concentrated in Unit 120-24, Level 5 (five specimens), but were absent in Units 91-17 and 91-18. The remaining forms are sma11 miscellaneous forms (five specimens), and one specimen each of a large miscellaneous form, large rounded fragments (three specimens), large pointed ovates (two specimens), and one specimen each of a large miscellaneous form, large triangular, Form 5, Form 8, and a small pointed ovate. The large forms comprise $28 \%$ of the overall retouch bifaces from Area $A$. This may suggest a specialized tool form of the Late Prehistoric period, emphasizing small overall retouch bifaces (less than $4 \mathrm{~cm}$ in length). Notably, the small triangular form is most frequent two unit-levels below the peak occurrences of Edwards, Scallorn, and Sabinal arrow points (see Fig. 35). Perhaps the form represents an arrow point form without a definable hafting element, or a distinctive knife or preform group.

In Area $B$, the seven collected specimens are two 1arge triangulars with convex bases, one large triangular with a concave base, two 1 arge rounded fragments, and two large miscellaneous forms. Two specimens were excavated from the first level of Area B: the large triangular with a convex base (from Unit 499-12) and a 1arge rounded fragment (from Unit 211-3). A11 of the specimens from Area B are classified as large forms (over $4 \mathrm{~cm}$ in length).

TABLE 51. OVERALL RETOUCH BIFACES AT 41 UV 48

Site Area

$\begin{array}{lllll}\text { A } & \text { B } & C & \text { D } & \text { Total }\end{array}$

Surface

Excavated

$\begin{array}{rrrrr}1 & 5 & 4 & 1 & 11 \\ 31 & 2 & 9 & 0 & 42\end{array}$

Total

32

7

13

1

53 


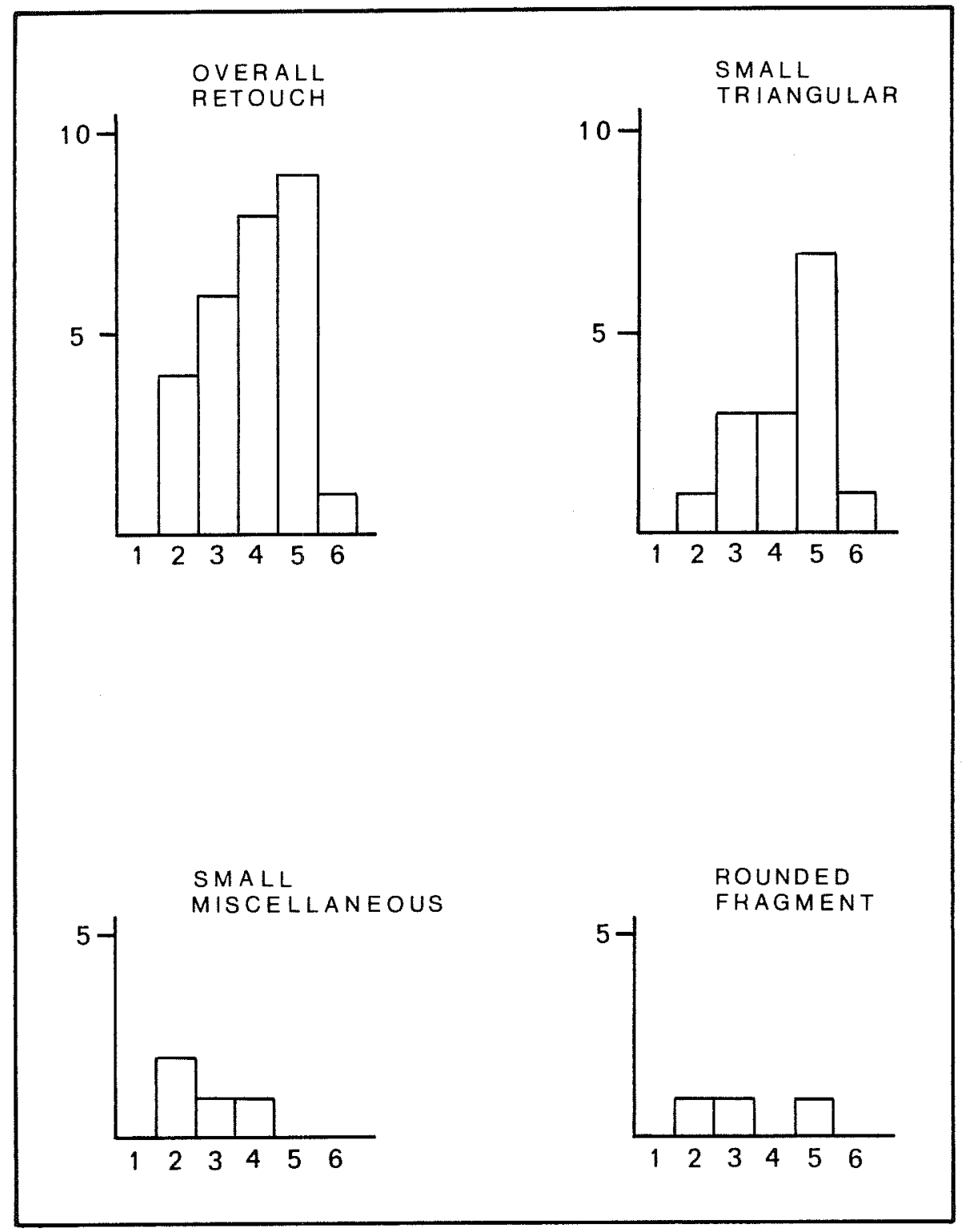

Figure 37. Vertical Distribution of Overal1 Retouch Bifaces in Area $A$ at 41 UV 48. 
The overall retouch bifaces collected from Area $C$ differ from the Area $B$ specimens because small forms are present (23\% of the area collection). The small forms are one triangular and two miscellaneous forms. Large forms are one fist axe, three pointed ovates, one triangular, four rounded fragments, and one Form 1 . Nine of the 13 specimens were from an excavated context. Excavated from Level 2 were one rounded fragment (Unit 456-11) and a smal1 triangular (Unit 525-5). A large triangular with a straight base, which was associated with Feature 1 in Unit 401-16, was excavated from Level 3, Area B. Six specimens were recovered from the backdirt of Backhoe Trench 1: one fist axe, one Form 1, three rounded fragments, and one smal1 miscellaneous form.

Some associations within Area $C$ worthy of note are the quantities of large forms compared to small forms; the association of the fist axe, often considered a tool form of the Archaic (Weir 1976), with the four dart points from Backhoe Trench 1 ; and the association of several arrow points in and near Unit 525-5 with the single small triangular form excavated from that unit.

Large triangulars and 1 arge rounded fragments occurred in Areas $A, B$, and C. Large pointed ovates, small triangulars, and small miscellaneous forms occurred in Areas A and C. Large miscellaneous forms occurred in Areas A and $B$. The remaining forms were found confined to specific site areas: one Form 5, one Form 8, and one smal1 pointed ovate from Area A; one fist axe and one Form 1 from Area C; and a Clear Fork gouge from Area D.

\section{Bifacially Retouched Flakes}

Seventy-one bifacially retouched flakes were recovered at 41 UV 48 . Their distribution by area for the site is shown in Table 52 .

Amorphous specimens are the most common form recovered from the site, comprising about $39 \%$ of a 71 the bifacially retouched flakes. The next most frequent form is large pointed ovates, comprising about 13\% (nine specimens) of the collection, followed by eight sma11 fragments (11\%), seven 1 arge fragments (10\%), five small pointed ovates, five small triangulars, four Targe triangulars, two specimens each of concave based and stemmed forms, and one single large ovate form.

Within Area $A$ there were 53 bifacially retouched specimens, $38 \%$ of which are classified as amorphous forms. The vertical distribution of the amorphous forms and other selected forms is shown in Figure 38. The distribution of the amorphous forms appears to be negatively correlated with the other bifacially retouched flake forms of small and large specimens (Fig. 38). Considering the small specimens (pointed ovates, triangulars, and fragments), they were most frequent within Level 3 of Area A. Large specimens, while occurring in the same quantity as small forms, were most common in Levels 1 and 2, then tend to decreased in frequency in the levels thereafter (Fig. 38). The large specimens are eight pointed ovate forms and four specimens each of the triangular and fragment categories. The two concave based specimens from the site were located in Levels 5 and 6 of Area A, one of which was found within Feature 2. 


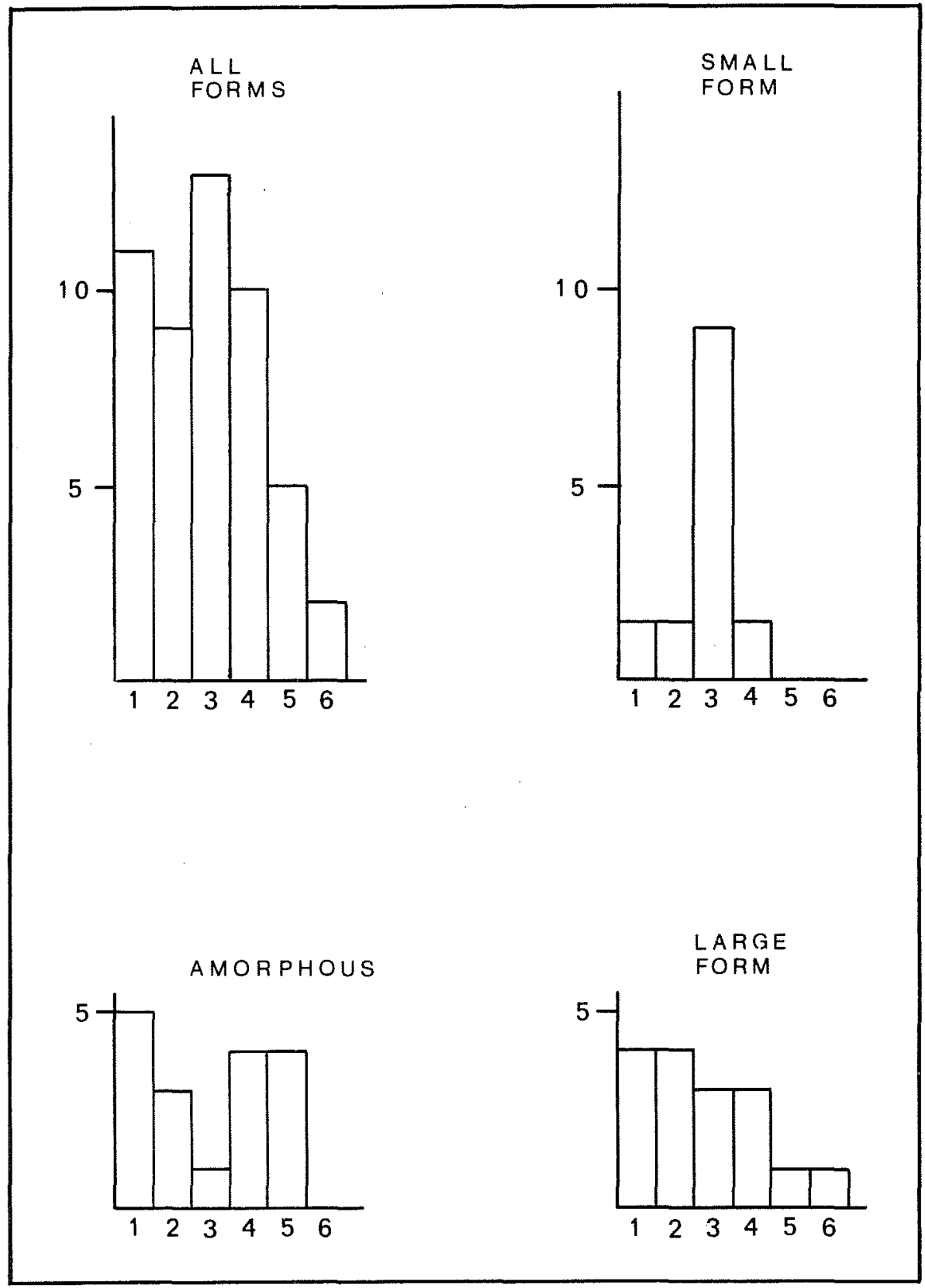

Figure 38. Vertical Distribution of Bifacially Retouched Flakes in Area A at 41 UV 48. 
TABLE 52. DISTRIBUTION OF BIFACIALLY RETOUCHED FLAKES AT 41 UV 48

\begin{tabular}{|c|c|c|c|c|c|}
\hline & \multicolumn{5}{|c|}{ Site Area } \\
\hline & $A$ & $B$ & $\mathrm{C}$ & $D$ & Total \\
\hline $\begin{array}{l}\text { Surface } \\
\text { Excavated }\end{array}$ & $\begin{array}{r}3 \\
50\end{array}$ & $\begin{array}{l}4 \\
6\end{array}$ & $\begin{array}{l}2 \\
3\end{array}$ & $\begin{array}{l}2 \\
0\end{array}$ & $\begin{array}{l}11 \\
59\end{array}$ \\
\hline Total & 53 & 10 & 5 & 2 & 70 \\
\hline
\end{tabular}

The 10 specimens from Area B are three specimens each of 1 arge fragment and amorphous forms, two stemmed specimens, one small pointed ovate, and one small fragment. Six of the bifacially retouched flakes were from excavated contexts. This includes two large fragments from Level 1 of Unit 836-9 and two amorphous specimens from Level 2 of that same unit. The other two excavated specimens (one large and one small fragment) were from Backhoe Trench 9. Stemmed specimens were the only form occurring exclusively in Area $B$ of the site.

Within Area $C$, the bifacially retouched flakes consisted of four amorphous specimens and one large pointed ovate. The only two excavated specimens (amorphous forms) were recovered from Backhoe Trench 1 . The bifacially retouched flakes seem unusually scarce within Area $C$, relative to the number of other kinds of bifacial artifacts recovered.

of the two surface finds within Area D, one is a small fragment, the other a large pointed ovate. No bifacially retouched flakes came from subsurface contexts.

Five forms of bifacially retouched flakes occurred exclusively within a particular site area. Large triangulars, small triangulars, and concave based specimens were confined to Area $A$. Stemmed forms were found only in Area $B$, and one single ovate form was found in Area C. Large fragments and small pointed ovates occurred only in Areas A and B. Large pointed ovates, the most common form other than amorphous specimens, were almost exclusively 1 imited to Area $A$ of the site (one specimen of the nine recovered came from Area D). It was a similar case for small fragments, as most occurred in Area A, but single examples were found in Areas B and D. Amorphous specimens, the most common form of bifacially retouched flakes, were found in al1 three site areas ( $A, B$, and $C$ ). In a 11, the unusually 7 arge number of bifacially retouched flakes within Area $A$ tends to associated them with the Late Prehistoric midden feature, especially in regards to forms with definite geometric outlines (large and small pointed ovates and triangulars). 


\section{Bifacial Intergrades}

There was a total of 63 bifacial intergrades recovered from 41 UV 48 . Their distribution, by area, is shown in Table 53.

Bifacial intergrade fragments were the most common form (20 specimens), followed by asymmetrical forms (18 specimens), triangulars (10 specimens), pointed ovates (eight specimens), and ovates (seven specimens).

A11 forms were present within Area A. Asymmetrical forms were the most common in the Area $A$ excavations, and they tend to increase in frequency with depth (Fig. 39). Triangular forms, in contrast, are most frequent in Level 2 of Area A. The other intergrade forms in Area A (fragments, pointed ovates, and ovates) appear either fairly evenly distributed vertically, or they occurred too infrequently to suggest any trend in patterning.

The six specimens from Area B represent all forms of bifacial intergrades. The single triangular form from Area $B$ was also the only excavated bifacial intergrade specimen (Unit 208-4, Leve1 1). The forms are represented by a single example each, except for asymmetricals (two specimens). The distribution of the bifacial intergrades within Area $B$ indicates a 71 but one specimen occurred close to the eastern border shared with Area A (see Fig. 39).

Area $C$ contained the largest number of surface-collected bifacial intergrades (17 specimens). The surface-collected specimens are identified as nine fragments, four ovate specimens, three pointed ovate forms, and one asymmetrical. Excavated specimens are one triangular from Level 2 of Unit 401-16, and one fragment and one asymmetrical from Backhoe Trench 1. A11 forms were represented within Area C. However, as was the case with Area B, the single triangular form from each of the areas was from a subsurface context.

Within Area D, there were only three specimens found, all from the surface. The three specimens are classified as pointed ovate, triangular, and asymmetrical. There were no subsurface recoveries from Area D.

TABLE 53. DISTRIBUTION OF BIFACIAL INTERGRADES AT 41 UV 48

Site Area

\begin{tabular}{|c|c|c|c|c|c|}
\hline & $A$ & B & $C$ & $D$ & Total \\
\hline $\begin{array}{l}\text { Surface } \\
\text { Excavated }\end{array}$ & $\begin{array}{r}9 \\
25\end{array}$ & $\begin{array}{l}5 \\
1\end{array}$ & $\begin{array}{r}17 \\
3\end{array}$ & $\begin{array}{l}3 \\
0\end{array}$ & $\begin{array}{l}34 \\
29\end{array}$ \\
\hline Total & 34 & 6 & 20 & 3 & 63 \\
\hline
\end{tabular}




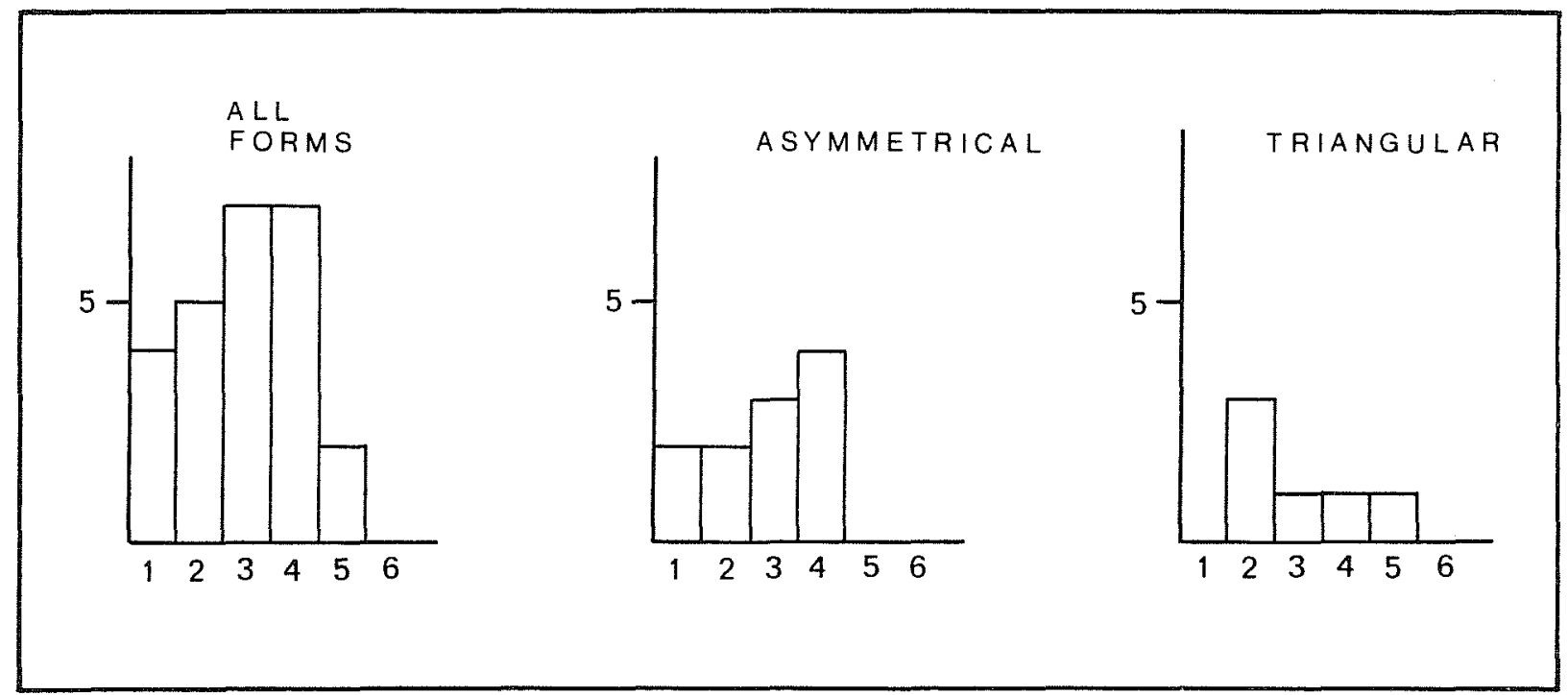

Figure 39. Vertical Distribution of Bifacial Intergrades in Area $A$ at 41 UV 48. 
Pointed ovate, triangular, and asymmetrical bifacial intergrades occurred in al1 areas of the site, and ovates and fragments were absent only from Area $D$. Notably, ovates, pointed ovates, and fragments were most common as surface finds, and over one-half of each of the forms occurred in Area $A$. The forms previously mentioned as being most common on the surface were also most frequently found outside of Area A.

\section{other Bifaces}

The other biface category, which consists of pointed fragments, medial and lateral fragments, and miscellaneous bifacial specimens, was the single largest artifactual category in the collection at 41 UV 48 . The distribution by area for the site is shown in Table 54. Two-thirds of the other bifaces are classified as pointed fragments (122 specimens), with 36 medial and lateral specimens, and 28 miscellaneous bifaces.

Within Area A excavations, all forms were most common in either Level 2 or Level 3 (Fig. 40). Over 70\% of the unit excavated specimens from Area $A$ are pointed fragments (85 specimens). There were four individual units within Area $A$ that contained unusually high numbers (seven to nine specimens in a leve1) of pointed fragments. The units were the three westermost units in Area $A(120-24,121-9$, and 121-10), and the high number of pointed specimens occurred in Level 2 or Level 3.

Within Area B, over half of the specimens were pointed fragments (nine of 16 specimens). Of the nine excavated specimens, there are three pointed fragments in Level 1, two pointed fragments in Level 2, and one pointed specimens in Level 3. There was one medial and lateral fragment each in Levels 2 and 3 . The only miscellaneous fragment was from Leve1 1 . 0ther bifaces occurred in all excavation units except Unit 499-12.

Within Area $C$, pointed fragments were the most common other biface form on and below the surface, as was the case with Areas $A$ and $B$. Of the seven

TABLE 54. OTHER BIFACE DISTRIBUTION AT 41 UV 48

\begin{tabular}{|c|c|c|c|c|c|}
\hline \multicolumn{6}{|c|}{ Site Area } \\
\hline & $A$ & B & C & $D$ & Total \\
\hline $\begin{array}{l}\text { Surface } \\
\text { Excavated }\end{array}$ & $\begin{array}{r}7 \\
133\end{array}$ & $\begin{array}{l}7 \\
9\end{array}$ & $\begin{array}{r}23 \\
7\end{array}$ & $\begin{array}{l}0 \\
0\end{array}$ & $\begin{array}{r}37 \\
149\end{array}$ \\
\hline Total & 140 & 16 & 30 & 0 & 186 \\
\hline
\end{tabular}




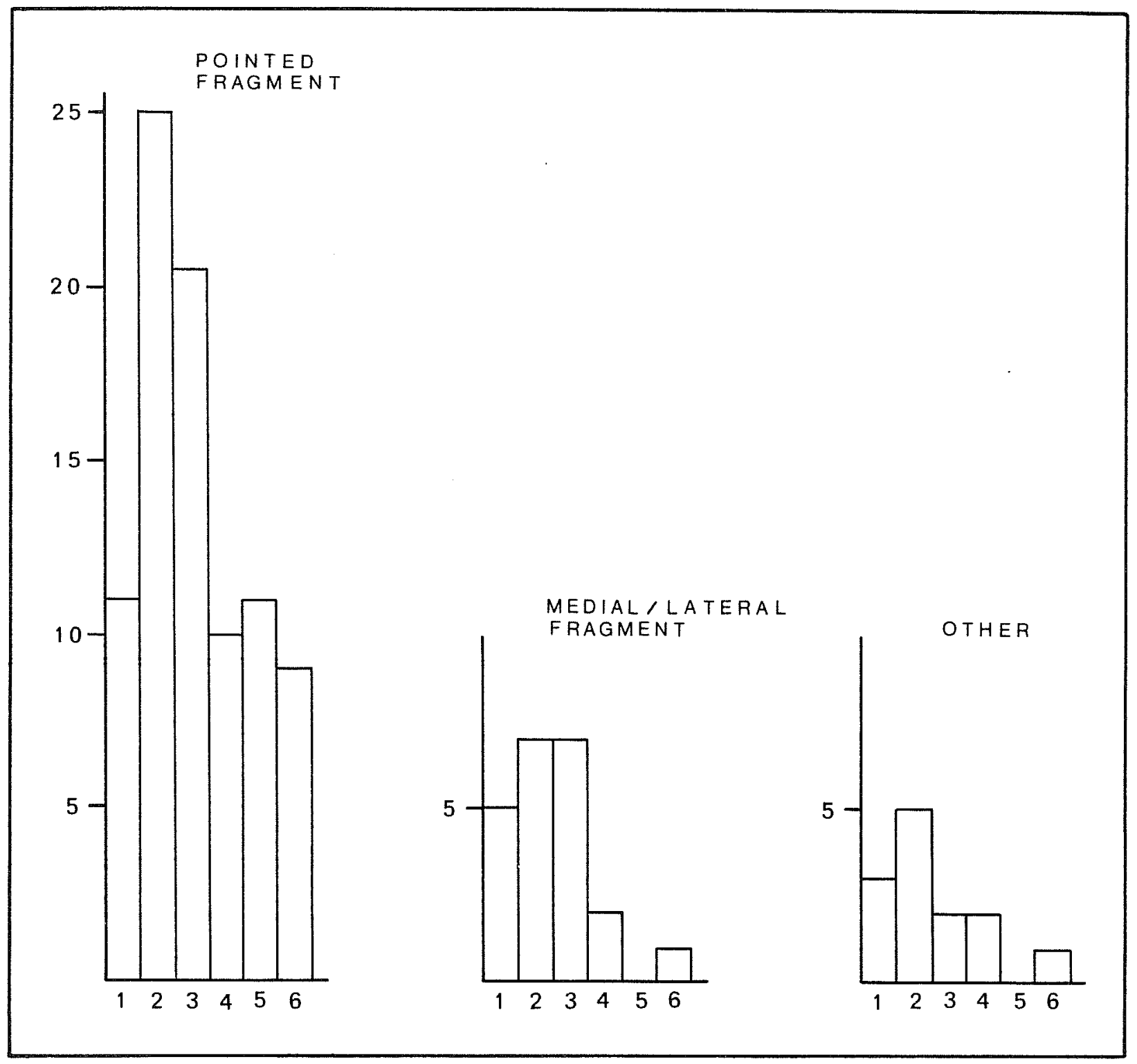

Figure 40. Vertical Distribution of Other Bifaces in Area A at 41 UV 48. 
excavated specimens, there were four from the excavation units; one specimen from Level 1 of each unit. They are three pointed fragments and one medial and lateral fragment. The other three specimens were from Backhoe Trench 1 (one pointed fragment and two medial and lateral fragments). No misce11 aneous bifaces were recovered from a subsurface context. Noted in the surface collection was an unusually high number of other biface forms within Area $C$, relative to the other site areas. No other biface forms were recovered from Area $D$.

\section{Unifaces}

A total of 36 unifaces was collected from 41 UV 48 . The unifaces are summarized by site area in Table 55. Miscellaneous specimens were the most common form with 14 specimens identified. Unifaces worked on one side are the next most common form (seven specimens), followed by five gravers, two specimens each of end, end and side, circumferential, and two-sided unifaces, and one specimen with a concave edge.

A11 forms except end and side specimens occurred within Area $A$. The surface finds within Area $A$ are a miscellaneous form and a graver. In the excavated sample from Area $A$, the vertical distributions indicated most specimens occurred within Levels 2 and 3. Two gravers occurred in Levels 2 and 4, and two gravers were from Level 3. Miscellaneous forms are the most common excavated unifacial artifacts from Area $A$, the six specimens occurred in every level except Level 6. One-sided or two-sided unifaces were present in Levels 1-4, with two examples in Levels 2 and 3, and one specimen in Level 1 and Level 4. Circumferential unifaces were recovered in Levels 1 and 3, and the single uniface with a concave edge is from Level 4. Finally, end scrapers, often recognized as a tool form associated with the Toyah phase (Prewitt 1981), occur as single specimens in Levels 1 and 4.

Within Area B, a concentration of four unifaces was noted near Unit 836-9. In and around that unit, a one-sided uniface was recovered from the surface,

TABLE 55. DISTRIBUTION OF UNIFACES AT 41 UV 48

Site Area

$\begin{array}{lllll}\text { A } & \text { B } & C & \text { D } & \text { Total }\end{array}$

Surface

Excavated

Total

24

$\begin{array}{rrrrr}2 & 2 & 3 & 1 & 8 \\ 22 & 4 & 2 & 0 & 28\end{array}$


and three miscellaneous unifaces were excavated from Level 1 of Unit 836-9. Close to Unit 211-3, one miscellaneous uniface was found on the surface, and a one-sided specimen was recorded in Level 1 of that unit. Thus, of the six unifaces recovered from Area $B$, they were only of two forms, one-sided and miscellaneous, and these were from two small locales within the area.

Within Area C, miscellaneous unifaces were widely scattered surface finds. The two excavated specimens are from Unit 800-1, Level 1 (one end and onesided uniface) and Unit 401-16, Level 2 (a one-sided uniface). The only specimen from Area $D$ was a surface-collected end and two-sided form.

of the nine forms of unifaces, five forms were found in Area A. The forms usually include only one or two examples each (end scraper, circumferential, two-sided, and concave-edged specimens). However, the gravers are represented by five examples, all confined to Area A. A single end and side uniface was recovered from in Area C. End and two-sided unifaces occurred in Areas $A$ and $D$ only. One-sided and miscellaneous forms were the most common unifacial artifact, and these occurred in Areas A, B, and C.

\section{Cores}

A total of 104 cores was recovered from 41 UV 48 . The distribution of the cores is.summarized by area in Table 56. Core nuclei were the most common type of core collected (37 specimens). Multidirectional, horizontal platform cores closely followed the core nuclei, with 32 specimens inventoried. Other cores from the site are 17 multidirectional cores with oblique platforms, 13 unidirectional, prepared platform cores, and two core tools.

Within Area $A$, all surface finds except for core tools were also present in the excavated sample. Bifacial cores were the only excavated core not represented on the surface. The most common core found on the surface was multidirectional horizontal platform cores (nine specimens), but core nuclei were most frequent in subsurface contexts. One-half of the excavated cores

TABLE 56. DISTRIBUTION OF CORES AT 41 UV 48

\section{Site Area}

$\begin{array}{lllll}\text { A } & \text { B } & \text { C } & \text { D } & \text { Total }\end{array}$

Surface

Excavated
17

57
5

3
10

5
7

0

39

65

Total

74

8

15

7

104 
are classified as nuclei (26 specimens). Additionally, half of the excavated core nuclei were confined to Level 2 of Area A. Core nuclei were the core type within Level 2 of Units 91-17 and 120-24. Of the other core forms in Area A, multidirectional, horizontal platform cores were the next most frequent (13 specimens); followed by multidirectional, oblique platform cores (11 specimens); unidirectional, prepared platform cores (six specimens); and bifacial cores (two specimens). The vertical distribution by level of the Area $A$ cores (except bifacial cores) is shown in Figure 41 . Within Area $A$, there were eight recorded cores. Multidirectional, horizontal platform cores and core nuclei were the only forms recognized within Area B. Each type was found in both surface and subsurface contexts, and each type comprises $50 \%$ of the area collection. The three excavated samples were from Unit 211-3, Level 1 (multidirectional, horizontal platform cores) and Unit 208-4, Levels 1 and 2 (core nuclei).

A total of 15 cores was recorded for Area $C$; 10 were surface finds. The surface finds are four specimens each of multidirectional cores with either horizontal or oblique platforms, and one specimen each of bifacial cores and core nuclei. Excavated specimens were from either Backhoe Trench 1 (four specimens) or Unit 525-5, Level 2 (one specimen). The specimen from Unit 525-5 was a unidirectional prepared platform core, a multidirectional, horizontal platform core, and two core nuclei.

In Area D, the seven cores recorded were surface finds. They are identified as three unidirectional, prepared platform cores; two nuclei; and one specimen each of multidirectional cores with horizontal or oblique platforms.

Of the six forms of cores, only one type, core tools, is 1imited to one area (Area A). Two core forms, multidirectional, horizontal platform cores and core nuclei (the most common core form), occurred in all site areas. Unidirectional, prepared platform cores and multidirectional, oblique platform cores occurred in Areas A, B, and D. Bifacial cores occurred in Areas $A$ and $C$. The most striking pattern revealed in the core distributions is the high frequency of cores within Area A, especially within Level 2.

\section{Modified Flakes}

A total of 13 modified flakes was recovered at 41 UV 48 . Modified flakes were recorded only from site Areas $A$ and $C$, from surface and subsurface contexts in both cases. Nine of the specimens were from Area $A$; three were from the surface collection of that area. All three of the surface finds are multiple facet platform flakes; two are interior flakes, and one retains cortex on the dorsal face of the specimen. The excavated sample comprises the six remaining modified flakes within Area $A$. Four of the excavated specimens are classified as chips (two corticate, two decorticate). The other two flakes are a cortex platform flake and a decorticate, single facet platform flake. The vertical distribution of the six flakes showed specimens were present in Levels 1-3, are most common in Level 1 and decreasing in amount each level thereafter.

Within Area $C$, all four of the recovered modified flakes are decorticate specimens. The two surface finds had either a multiple facet platform or was 


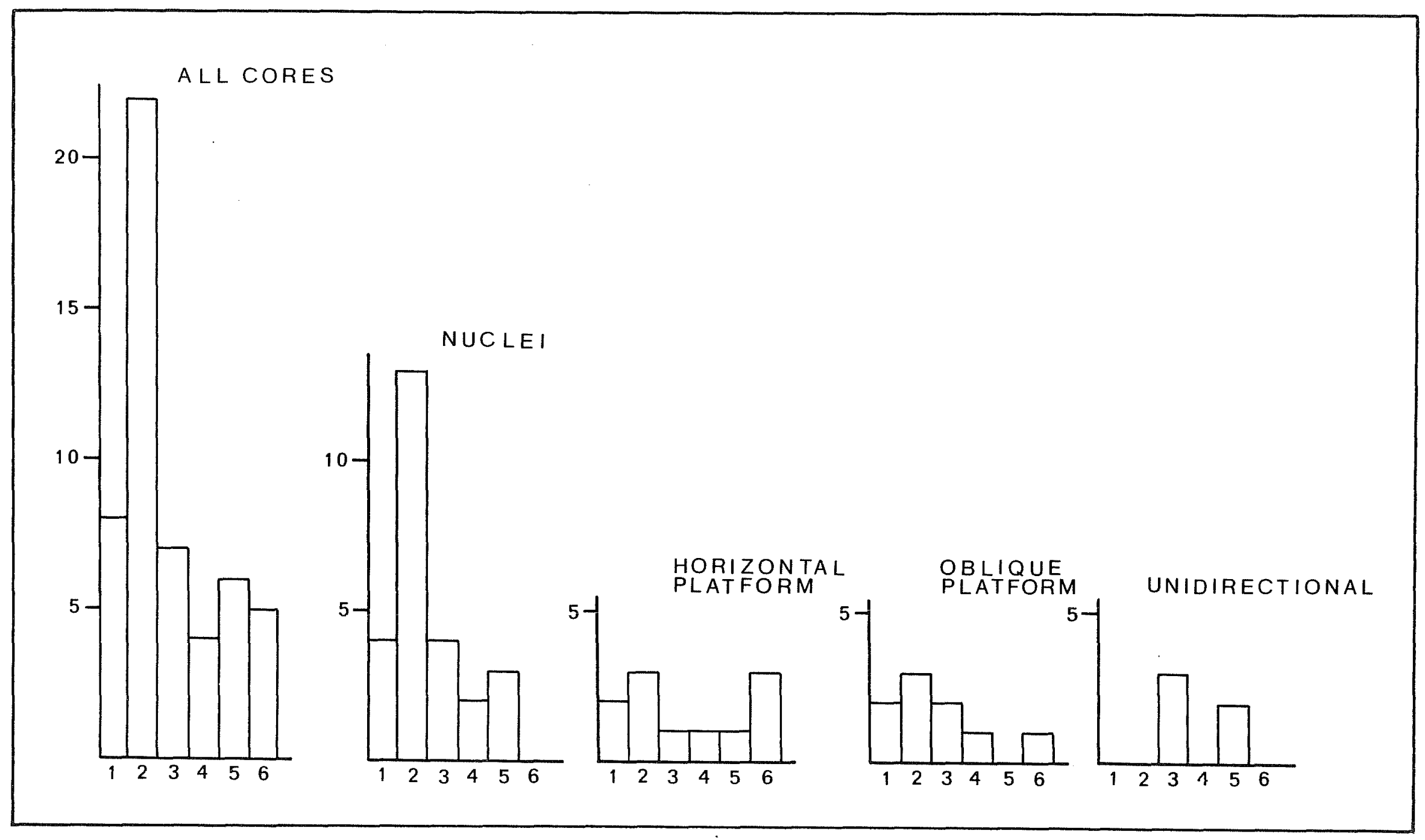

Figure 41. Vertical Distribution of Cores in Area A at 41 UV 48.

$\omega$
$\stackrel{5}{0}$
$\vec{E}$
$\vec{\infty}$ 
indeterminate (a chip). The two excavated examples, both from Level 4 of Unit 456-11, consisted of a single facet platform flake and a multiple facet platform flake.

Chips were most commonly classified as modified (six specimens), followed by multiple facet (four specimens), single facet (two specimens), and cortex platform (one specimen). Nine of the specimens are decorticate; four specimens retain some cortex.

\section{Other Lithics}

The other lithic category consists of hammerstones and ground stones. The three hammerstones collected from the site were a11 confined to the surface of Area A. Four ground stone specimens were recovered from the site. This includes two grinding slabs from Area $A$, one from the surface, another from Leve1 4 of Unit 61-21. The two specimens from Area $C$ are a handstone from the surface near the Leona River, and a grinding slab specimen from Area $C$ was found near Unit 525.

\section{Fired Clay}

Ceramics were found only in an excavated context from within Area A. of the 13 sherds excavated from Units 61-21, 91-18, or Backhoe Trench 2, two were from Leve1 1, eight were from Leve1 2, and three were from Leve1 3 . The 13 sherds probably represent two different vessels. Leon P1ain, Variety 3 was confined to Unit 91-18, Levels 1-3 (nine sherds) and Backhoe Trench 2 (one sherd). Leon Plain, Variety 4 was 1imited to Levels 2 and 3 of Unit 61-21 (three sherds). The only other example of a fired clay specimen was a specimen of impressed clay, suggested to be daub or a fragment of a pit lining. The specimen was recovered from Level 4 of Unit 120-24.

\section{Historic Materials}

Historic artifacts were not common at the site, and are 1 imited to small locales within Areas $A$ and $C$. Within Area $A$, there was a single surface find of an aquamarine glass bottle fragment. The excavated historic artifacts from Area A are two fence staples from Backhoe Trench 11 and some recent historic artifacts confined to Level 1 of Unit 121-9. Artifacts from Unit 121-9 consisted of two small clear glass fragments and a wood screw. The two historic artifacts from Area $C$ were plain white paste earthenware plate sherds collected from the surface near Unit 525-5.

\section{Debitage}

A review of the distribution of excavated debitage (flakes, chips, burned nonflaked chert, and chunks) within each area of the site is presented, and flake technology at the site in regards to flake platform types is discussed. Throughout the following discussion, only the excavated debitage from the $2-x$ 2-m units has been used for the analysis within Area $A$. In the 
site areas, all excavation units were considered. Note that all the levels considered in Area A and Unit 208-4 in Area B were excavated in 10-cm increments; the remaining units were excavated in $20-\mathrm{cm}$ levels (Fig. 42 ).

Within Area A, most of the debitage items were recovered from Levels 1-3. A total of 20 to $24 \%$ of the total recovery occurred within each of the first three levels (a collective total of 67\%). The overall debitage frequency decreased in each level thereafter. Two types of debitage "peak" in Leve1 2: burned nonflaked chert and decorticate chips. Both total $25 \%$ of their respective subgroupings in that level. Three types were most common below Level 3. These are primary flakes, most common in Level 4 (31\% of the cortex flakes); corticate chips, most common in Level 4 (31\% of the cortex chips), and chunks, most common in Level $5(28 \%)$. The primary flakes and corticate chips were most abundant for Level 4 within Units 120-24 and 121-9. Notably, while chunks were most common in Level 5 of Area $A$, an unusually Targe number are associated with Level 5 of Unit 91-17 (69\% of al1 the chunks from Level 5). Area-wide, the greatest amounts of debitage for are concentrated in Unit 120-24, Levels 2-4, and Unit 121-9, Levels 5 and 6, indicating that most of the chipping activity took place in the westernmost units of Area $A$. Considering the area as a whole, decorticate chips are the most common debitage item in Area $A$ at $54 \%$. Burned nonflaked chert specimens total $16 \%$ of the Area $A$ collection and reflect an unusually large amount of burned chert in comparison to other areas of the site. All other debitage items total 1ess than $10 \%$ each of the total Area A collection. Platformed flakes, to be further discussed later, comprise 19\% of the Area A collection.

Forty-four percent of the excavated Area B debitage occurred within Level 1. Horizontally, most of the debitage occurred in the excavation units nearest to Area A (Units 211-3 and 208-4). This distributional pattern is similar to that indicated by the surface collection. Subdivisions of the debitage material show that decorticate chips and interior flakes were the most common items (65\% and 18\%, respectively) of the total Area B debitage. The remaining categories total less than $10 \%$ each, and are distributed as follows: partially corticate chips and secondary flakes, $6 \%$ and $5 \%$, respectively; burned nonflaked material, $3 \%$; corticate chips, $1 \%$; chunks, $1 \%$; and a single cortex flake, less than 1\%. Flake to chip ratios approximated the distribution within Area A (Table 57). Twenty-four percent of the debitage collection for Area B consisted of platformed flakes. Other debitage items reflect a distribution similar to Area $A$, with the notable exception of burned chert, which was much more common in Area $A$.

Within Area $C$, all the excavated units contained an individual total of over 230 items. Area-wide, Level 1 contained the highest debitage inventories, although the unit-level totals did not drastically drop until after Level 3 (60 $\mathrm{cm}$ below the surface). Levels 4-6 showed a dramatic drop in the debitage count, averaging about four flakes per unit-1evel. In Unit 401-16, a bimodal vertical distributional pattern was noted. Within Unit 401-16, there was a decrease in the debitage count between Levels $1-3$. Level $3(40$ to $60 \mathrm{~cm}$ below the surface) contained Feature 1, a hearthlike burned rock feature.

Considering the overall distribution of debitage items, Area $C$ has similar patterns as in Areas $A$ and $B$. The ratio of flakes to chips is similar in all three areas, with the notable, recurring disproportional relationship of 


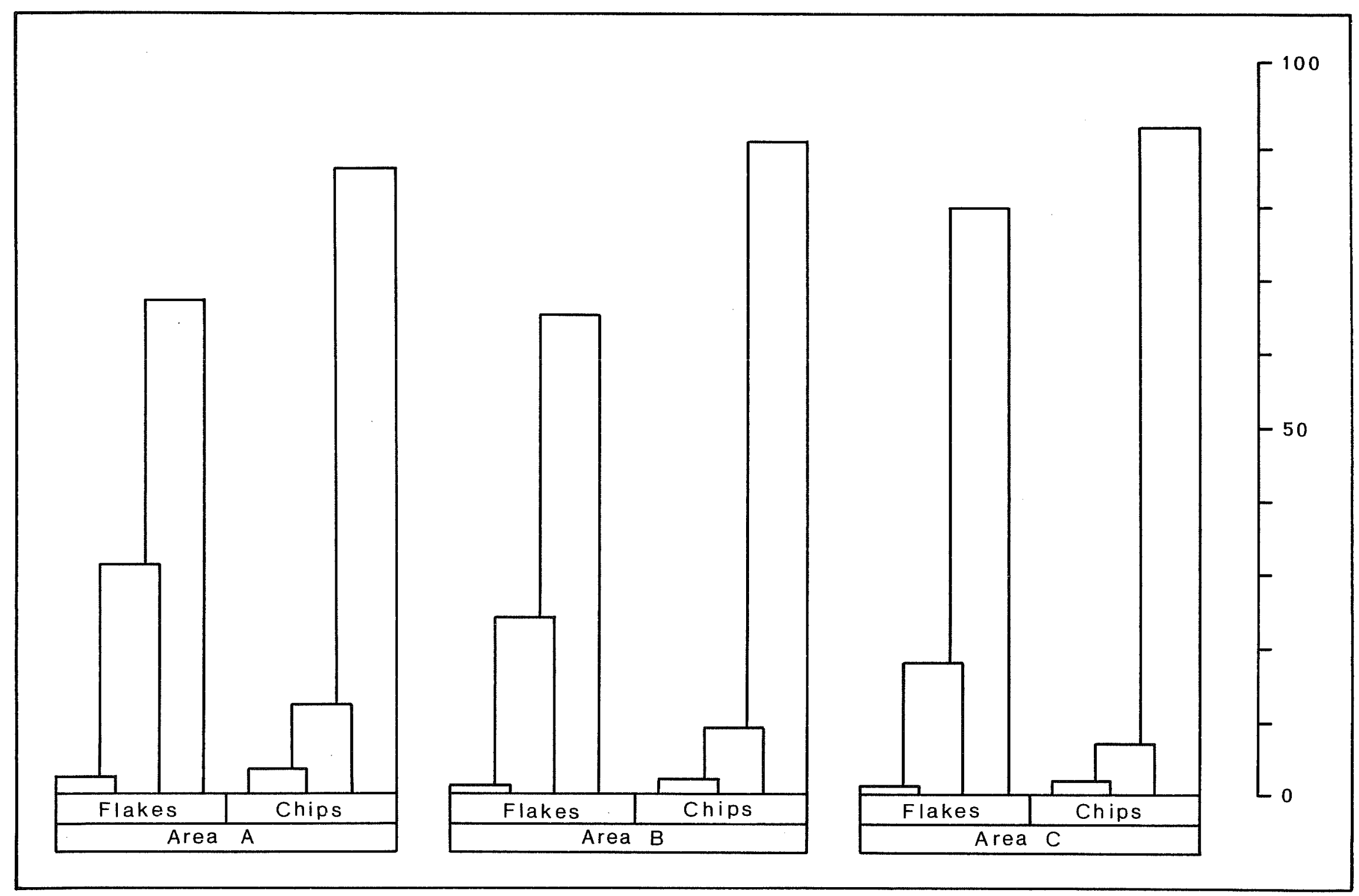

Figure 42. Comparison of Excavated Flakes and Chips by Area at 41 UV 48. 
TABLE 57. SUMMARY OF DEBITAGE CATEGORIES BY AREA FROM THE EXCAVATIONS AT 41 UV 48

Site Areas

Debitage

A

B

Total

Primary flakes

Secondary flakes

Interior flakes

Corticate chips

Partially corticate chips

Decorticate chips

Burned nonflaked material

Chunks

$\begin{array}{rrlrlr}80(0.4) & 1 & (0.2) & 3(0.2) & 84(0.4) \\ 1145(6) & 33(5) & 37(2) & 1215(6) \\ 2459(13) & 110(18) & 162(11) & 2731(13) \\ 377(2) & 9(1) & 20(1) & 406(2) \\ 1394(7) & 37(6) & 86(6) & 1517(7) \\ 10,088(54) & 388(65) & 1055(71) & 11,531(55) \\ 3041(16) & 19(3) & 122(8) & 3182(15) \\ 178(1) & 4(1) & 7 & (0.5) & 189(1)\end{array}$

Total
18,762

$(99.4)$
601

(99.2)
1493

$(99.7)$
20,855

$(99.4)$

Note: Number in parentheses represents percentage.

secondary flakes to partially corticate chips. The percentages of each subcategory within Area $C$ are also similar to that of Areas $A$ and $B$, except for the occurrence of burned nonflaked material, which is more frequent in Areas $A$ and $C$. No debitage was recovered from the backhoe trenches excavated within Area D.

In summary, Areas $A$ and $C$ show the highest debitage inventories. The percentages of each debitage item in the three areas with subsurface recovery were similar area-to-area, with the notable exception of the variation the burned nonflaked material showed. Burned nonflaked material was most common in Areas $A$ and $C$. Decorticate chips and interior flakes comprise well over half of the total debitage inventories in each of the three areas. Finally, while the ratio of flakes to chips is fairly consistent between site areas, a disproportionate relationship of partially corticate chips to secondary flakes was noted. Within any of the three site areas, secondary flakes are about three times more common within the flake category as partially corticate chips are within the chip category.

\section{Flake Platforms}

Six flake platform categories were recognized at site 41 UV 48 . The flake platforms are identified as cortex, single facet platform, large multiple facet platform, small multiple facet platform, lipped flakes, and other 
platforms. Utilizing the classification schemes of other researchers in south and central Texas (Hester 1978a; Montgomery 1978; Ha11, Black, and Graves 1982) two possible reduction technologies can be inferred from the platform types noted. Cortex platform, single facet platform, and large multiple facet platform flakes were probably struck from cores, whereas smal1 multiple facet platform and lipped flakes are suggested to have been created as a result of biface reduction activities. Table 58 summarizes the flake platform categories, grouped according to their suggested reduction technology. 0ther platform flakes, a miscellaneous catch-all category, comprise less than $1 \%$ of the flakes, and has been included arbitrarily with core reduction flakes. Of the 4030 flakes considered over half $(66 \%)$ fall into the core reduction group, and $34 \%$ are recorded as biface reduction $f 1$ akes. More specifically, $46 \%$ of the flake platforms are classified as single facet, the most common platform type at the site. Small multiple facet platform flakes were the next most common category at $32 \%$ of the collection. The remaining platform categories were much less common. Cortex platform flakes comprise $10 \%$ of the collection, large multiple facet platform $f 1$ akes $9 \%$, 7 ipped flakes $2 \%$, and other platform flakes less than $1 \%$.

Single facet platform flakes are the most common platform type associated with primary, secondary, and interior flakes (Table 58). Primary flakes were less frequently found with cortex platforms and other platforms. As noted previously, secondary flakes usually have single facet platforms, followed by cortex platforms; and less closely by small multiple facet, large multiple facet, and lipped flakes, in that order. More of the single facet platform interior flakes were noted than small multiple facet platform interior flakes. Much less common among the interior flakes were large multiple facet platforms, lipped flakes, and other platforms.

In summary, the large number of core reduction flakes would seem to indicate that core reduction activities resulted in the dominant flake production technology represented at the site. This suggestion can be supported in part by an examination of the bifacial categories recorded at the site. of the 187 bifaces categorized as overall retouch bifaces, bifacially retouched flakes, or bifacial intergrades, a substantial percentage (38\%) were classified a bifacially retouched flakes. One can argue that as such a large number of the three aforementioned artifacts were made on flakes, the flakes may have been produced from an established core reduction technology specifically oriented towards creating flakes suitable as bifacial blanks. Further support for a core reduction technology can be found in the core subcategory distributions. Of 104 cores recovered from the site, on 1 y $5 \%$ are classified as bifacial cores or core tools, while a significant number (12.5\%) are prepared platform unidirectional cores (which tend to produce single facet platform flakes, by definition). The other cores from the site (multidirectional, horizontal platform; multidirectional, oblique platform; and core nuclei) may have produced a much wider variety of platformed flakes. A further discussion of the lithic technologies present at the site is in the Intersite Comparisons section of this report. 
TABLE 58. SUMMARY OF PLATFORM CATEGORIES BY AREA FROM THE EXCAVATIONS AT 41 UV 48

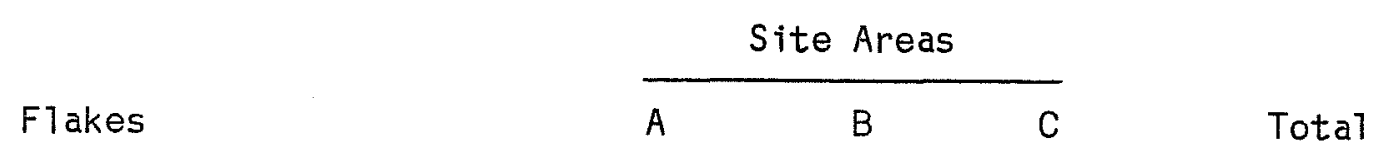

\section{Core Reduction Flakes}

Cortex Platform

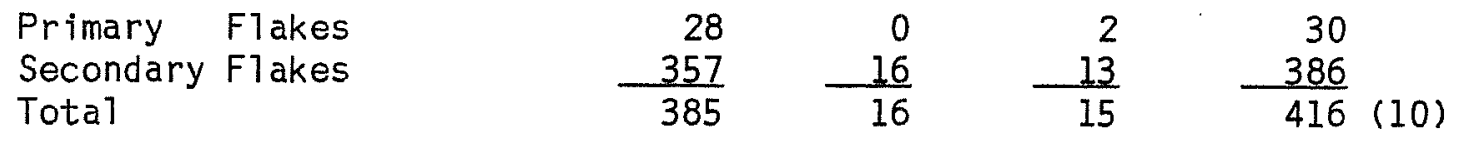

Single Facet Platform

Primary Flakes

Secondary Flakes

Interior Flakes

Total

$\begin{array}{rrrr}42 & 1 & 1 & 44 \\ 480 & 12 & 13 & 505 \\ 1214 & \frac{36}{173} & \frac{73}{87} & \frac{1323}{1872}(46)\end{array}$

Large Multiple Facet Platform

Secondary Flakes

Interior Flakes

Total

$\begin{array}{rrrr}111 & 4 & 4 & 119 \\ -227 & -6 & 10 & \frac{243}{338}\end{array}$

Other Platforms

Primary Flakes

Secondary Flakes

Interior Flakes

Total

\begin{tabular}{rrrr}
10 & 0 & 0 & 10 \\
0 & 0 & 0 & 0 \\
0 & 0 & $\frac{1}{1}$ & $\frac{1}{11}(0.3)$ \\
\hline 10 & 0 & 1 & $2661(65.3)$
\end{tabular}

\begin{tabular}{|c|c|c|c|c|}
\hline Total Core Reduction Flakes & 2469 & 75 & 117 & $2661(65.3)$ \\
\hline \multicolumn{5}{|l|}{ Biface Reduction Flakes } \\
\hline $\begin{array}{l}\text { Smal1 Multiple Facet Platform } \\
\text { Secondary Flakes } \\
\text { Interior Flakes } \\
\text { Total }\end{array}$ & $\begin{array}{r}192 \\
970 \\
1162\end{array}$ & $\begin{array}{r}1 \\
67 \\
68\end{array}$ & $\begin{array}{r}6 \\
72 \\
78\end{array}$ & $\begin{array}{r}199 \\
1109 \\
1308 \quad(32)\end{array}$ \\
\hline $\begin{array}{l}\text { Lipped Flakes } \\
\text { Secondary Flakes } \\
\text { Interior Flakes } \\
\text { Total }\end{array}$ & $\begin{array}{r}5 \\
48 \\
53\end{array}$ & $\begin{array}{l}0 \\
1 \\
1\end{array}$ & $\begin{array}{l}1 \\
6 \\
7\end{array}$ & $\begin{array}{r}6 \\
55 \\
61\end{array}$ \\
\hline Total Biface Reduction Flakes & 1215 & 69 & 85 & $1369(34)$ \\
\hline Grand Total & & & & $4030(99.3)$ \\
\hline
\end{tabular}

Note: Number in parentheses indicates percentage. 


\section{Burned Rock}

Burned rock was counted in the field and then discarded for all unit-levels except in Unit 121-10. Additionally, the burned rock in Area A from the $2 \times 2$ m excavation units was weighed with a kilogram scale. All of the burned rock was limestone, and generally consisted of fist-sized (ca. $8 \mathrm{~cm}$ ) or smaller stones.

The distribution of burned rock for Area $A$ is shown in Table 59. Vertically, the distribution for each unit reaches a maximum count or weight total in Levels 1-4. Area unit-level totals would indicate most of the burned rock occurred in Level 2, with considerable amounts also occurring in Levels 3 and 4. Horizontal distribution patterns indicate most of the burned rock was concentrated in the central area of the excavations (Units 91-17 and 91-18) and decreased on the edges of the midden. Unit 121-9 was an exception as it was on the edge of the midden area, but contained relatively high amounts of burned rock.

Unit 211-3 had the most burned rock in Area B (51\% of the excavated burned rocks) followed by Units 208-4, 499-12, and 836-9. Overall there was a tendency for the amounts of burned rocks to decrease as one moved to the northwest. Vertically, all of the burned rock from the individual unitlevels were more frequent in the first $20 \mathrm{~cm}$ (Level 1).

The burned rock in Area C was concentrated in Units 456-11 and 525-5, which were located within a lithic debitage concentration near the banks of the Leona River. Burned rock was most frequent vertically in the first $20 \mathrm{~cm}$ (Level 1), with the exception of Unit 401-16 where Feature 1 in Level 3 produced the largest number of rocks in that unit.

\section{PLANT AND ANIMAL REMAINS}

\section{Faunal Remains}

Verterate fauna were relatively common in many of the Area $A$ excavation units at 41 UV 48 (Table 60). A total of 7074 bone specimens was recorded from the site. From this total, 700 elements were identified as to genus or species and analyzed for their possible cultural and environmental implications. Additionally, distributional data were calculated for the unidentifiable fragments and burned bones. A small percentage of the bone was modified $(0.11 \%$, 8 specimens).

Faunal identifications were made by Robert F. Scott IV, with the aid of Danny Walker, formerly with the Department of Anthropology, University of Wyoming.

Most of the faunal remains were found in Area $A$ of the site, with all but 228 elements (about 3.2\%) not from Area A. Twelve mammals are represented, as are a small number of reptiles, fish, and a single bird element (Table 60). Desert cottontail rabbit (Sylvilagus auduboni i) and unspecified rodents (much of which may be rabbit), were the most common animals, each comprising about $29 \%$ of the identified collection. Black-tailed jackrabbit (Lepus 
TABLE 59. BURNED ROCK DATA AT 41 UV 48

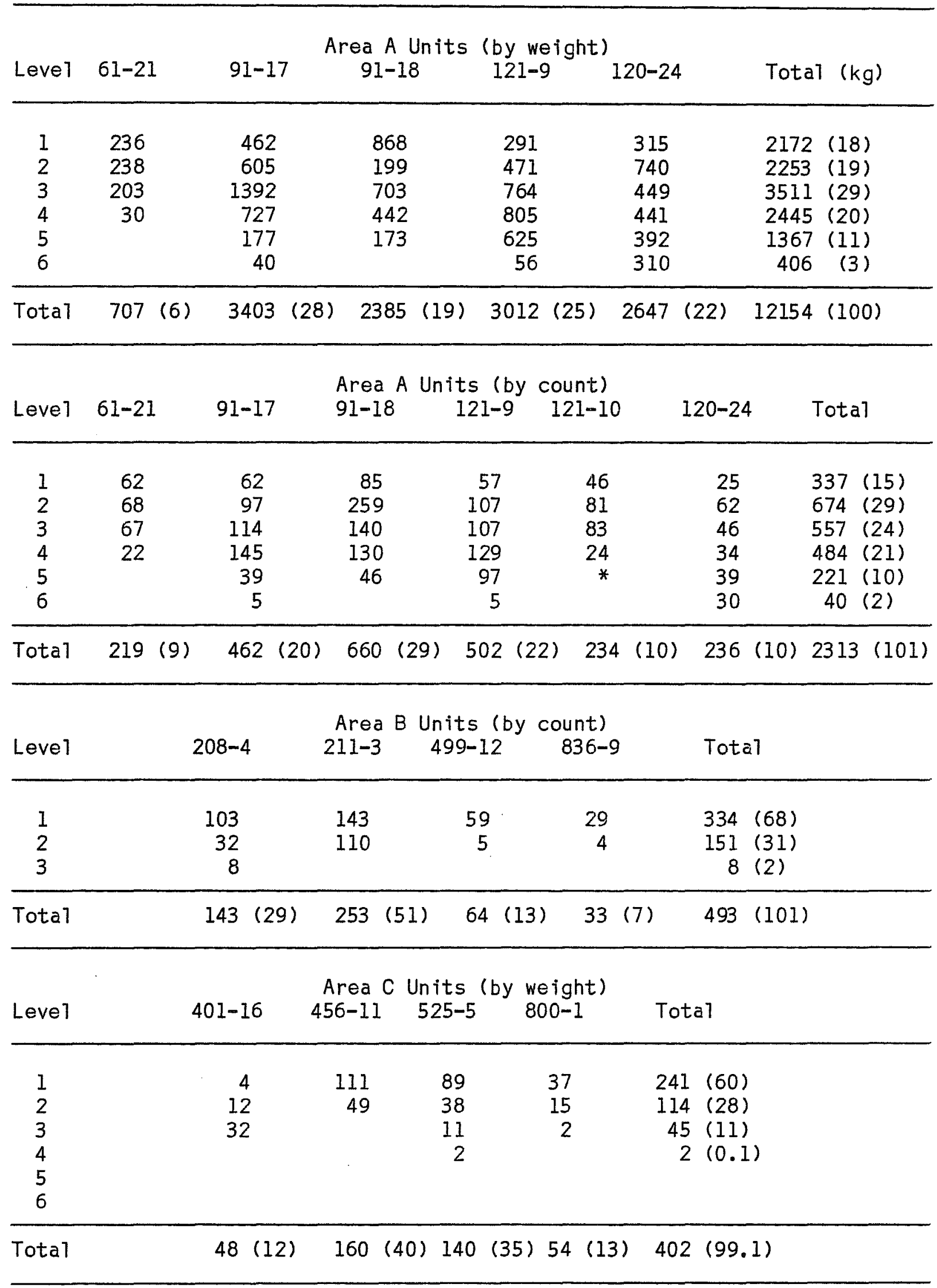


TABLE 60. FAUNAL REMAINS FROM 41 UV 48

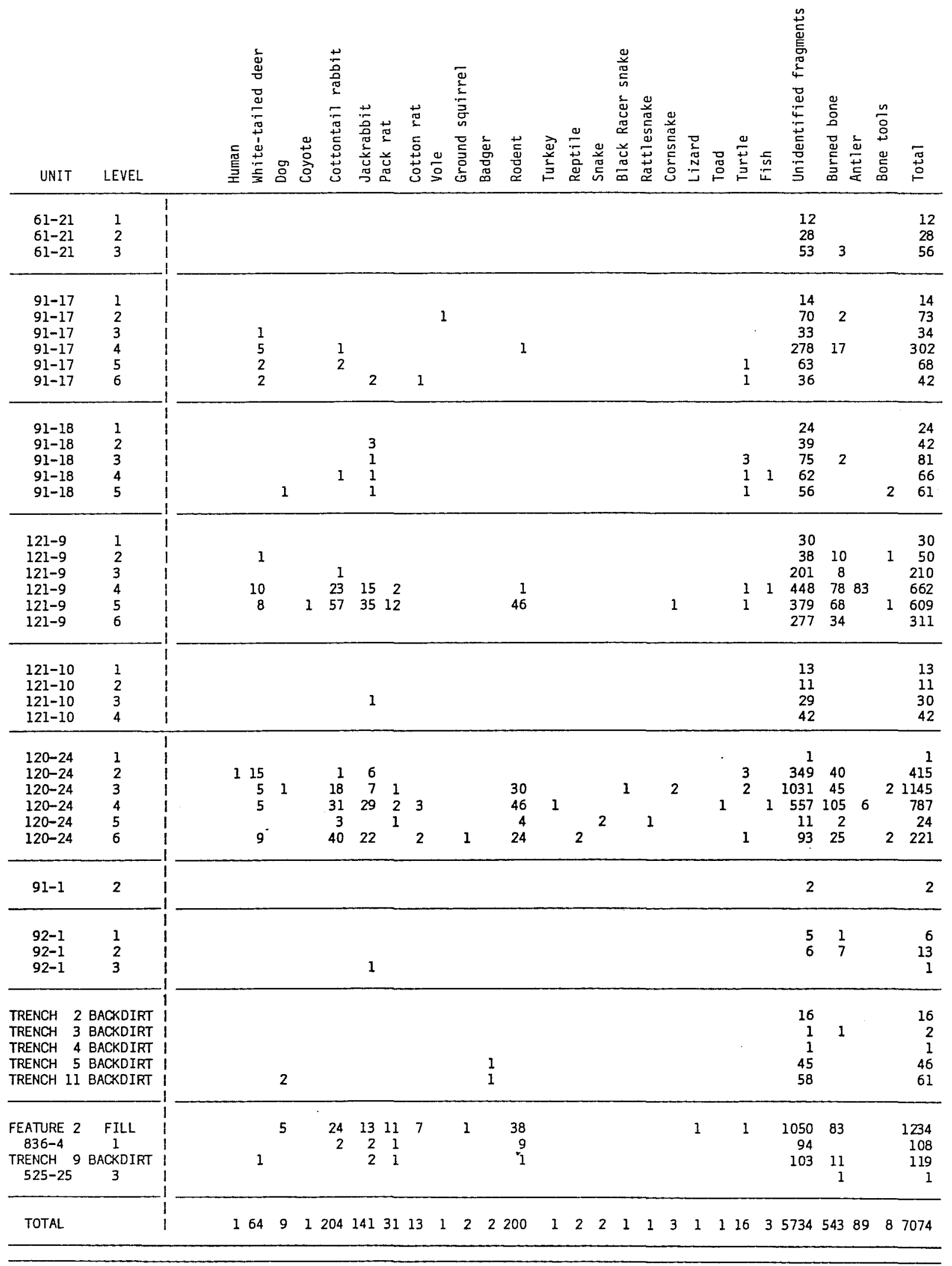


californicus) was also very common, representing $20 \%$ of the identified elements.

Less common were white-tailed deer (Odocoileus virginiana) at $9 \%$. of the following mammals, a 11 represent less than $5 \%$ each of the identified animal remains: pack rat (Neotoma sp.), cotton rat (Sigmodon hispidus), domestic dog (Canis domesticus), coyote (Canis latrans), badger (Taxidea taxus), ground squirrel (Spermophilus sp.), vole (Microtus sp.), and nine human teeth fragments. Reptiles included unidentified snake, lizard, toad (possibly Scaphiopus sp.), and turtle. Black racer snake (cf. Masticophis sp.), corn snake (Elaphe guttata), and rattlesnake (Crotalus sp.) were identified from the site. Three unidentified fish vertebrae were found at the site, and there was a single turkey element (Meleagris gallopavo) present.

Because of the relatively large numbers of cottontail rabbit, jackrabbit, and white-tailed deer, gross age estimates indicative of the probable population distribution are presented in Table 61. Most of the three species are represented by mature elements. The age distributions may indicate a selection preference for adult animals. Henderson (1978:245) indicated an approximate two-thirds adult to one-third subadult ratio could be expected for white-tailed deer populations. If this is true, then one could assume from the low percentage of subadult white-tailed deer represented in the collection ( $10 \%$ of the categorized elements), that there were few subadults available in the area or adult deer were the preferred game. The normal age distribution for a population of cottontail rabbit or jackrabbit was not determined, but Davis' $(1974: 238,242)$ discussions on cottontail rabbit (Sylvilagus audubonii) and jackrabbit (Lepus californicus) seem to indicate an average litter size of three. One could assume then a ratio of adults to subadults approximating two to three, an estimate essentially the reverse of that for white-tailed deer. Using this ratio, it would appear that there was a strong bias towards adult rabbits which comprise $82 \%$ or more of the rabbit elements.

A breakdown of the elements represented by the cottontail rabbit, jackrabbit, and white-tailed deer remains for the site is presented in Table 62. An examination of the elements representing cottontail rabbits and jackrabbits in Table 60 shows a probable minimum count of 16 cottontail rabbits, based

TABLE 61. AGE DISTRIBUTION OF IDENTIFIED COTTONTAIL RABBIT, JACKRABBIT, AND DEER ELEMENTS AT 41 UV 48

Mature Immature Unspecified Total

$\begin{array}{lrrrr}\text { Cottontail rabbit } & 167 & 3 & 34 & 204 \\ \text { Jackrabbit } & 139 & 2 & & 141 \\ \text { White-tailed deer } & 49 & 5 & 10 & 64\end{array}$


TABLE 62. IDENTIFIED ELEMENTS OF COTTONTAIL RABBIT, JACKRABBIT, AND WHITE-TAILED DEER AT 41 UV 48

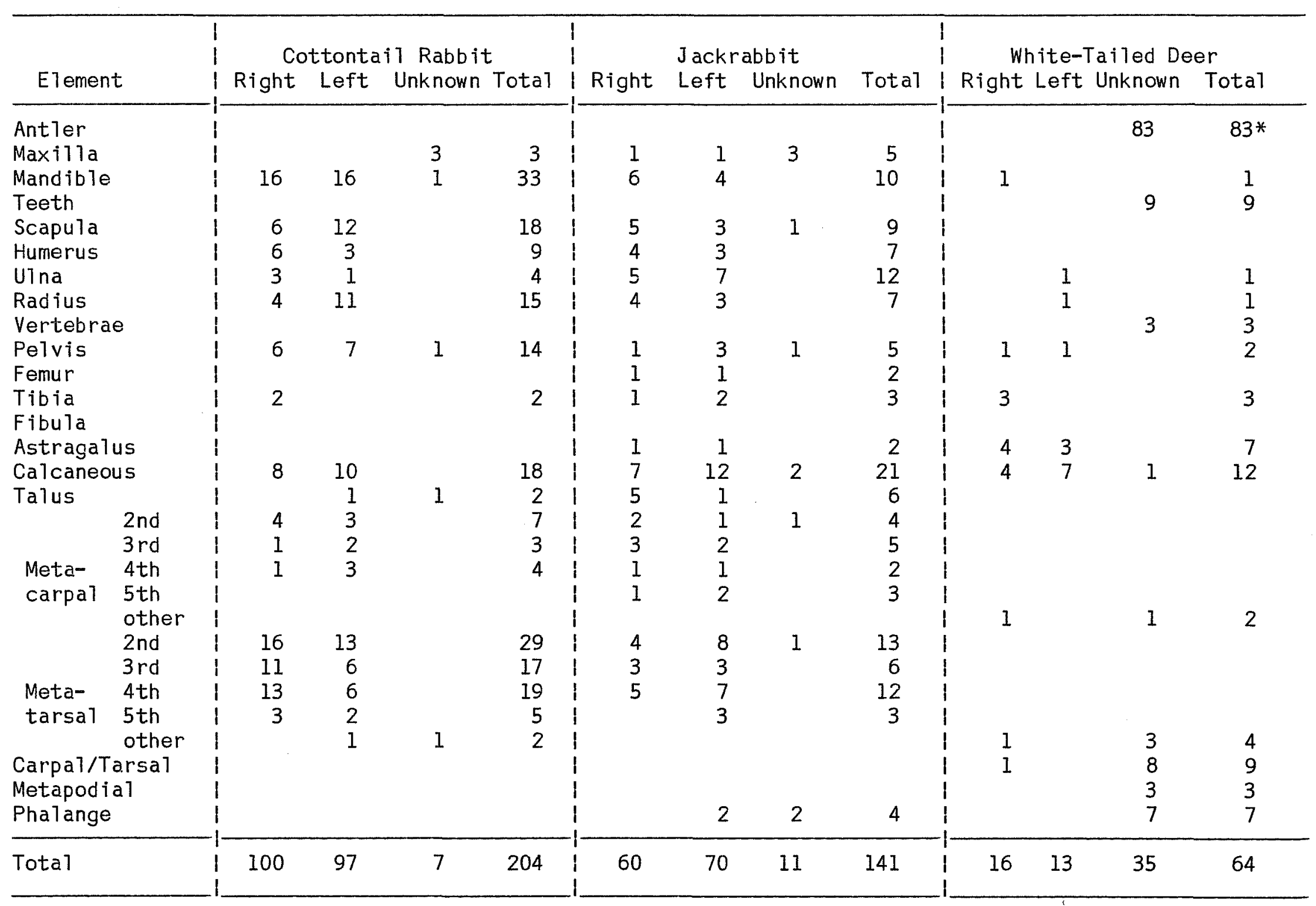

*Figure not used for column total. 
upon the number of mandibles. 0ther elements (cf. left scapulas and left radii) do not reflect as high a number. Jackrabbit elements are slightly more than half as frequent as the cottontail rabbit elements. The minimum count for cottontail rabbits and jackrabbits is 12 individuals based on left astragulus elements (Table 60). This number may also be partially supported by the frequency of right mandibles (six) or left ulnas (seven). Neither the right nor the left-sided elements dominated any of the three species. This probably suggests that whole quarters or carcasses were present in the camp. of note in the elements present for both jackrabbit and cottontail rabbits is the scarcity of hindquarter elements (femur, tibia, fibula), as compared to front quarter elements (scapula, humerus, ulna, radius). However, metatarsals, representing the back feet, out-number metacarpals for both cottontail rabbit and jackrabbit. This may suggest that whole carcasses were brought into the camp, and hindquarters were more completely utilized, thus, leaving less archaeological trace, while the remaining torso, feet, and skull were less fully exploited and, hence, more frequent in the archaeological record. Notably absent, however for both species of rabbit are ribs and vertebrae. Deer elements from the sku11, body, and legs are present, but in sparse numbers. This might suggest that whole carcasses were present in the camp. A minimum number of seven deer is estimated based on left calcanei present. The presence of a single shed antler base, which are usually dropped in white-tailed deer populations during December through February, is the only available faunal evidence that could be used to indicate seasonality. Whether or not the antler was imported to the site during any other time of year is unknown.

Al1 of the modified bone (11 specimens) came from two units in Area A, either Unit 121-9 (seven specimens) or Unit 120-24 (four specimens). A11 of the artifacts came from below Level 1. The tools include two positively identified white-tailed deer elements (a tibia and an ulna). There were five possible awls or awl fragments, one blunted ulna too, and four polished bones.

\section{Area A}

Most of the unidentifiable bone fragments and burned bone fragments from Area A came from Level 4 (Table 63). Burned bone usually comprised $15 \%$ of the level totals except for its notable absence in Level 1 , and its substantially lower percentage in Level 3. The bone from Feature 2 (not included in Table 63), comprised a very large percentage (18\%) of the unidentifiable bone excavated from the $2 \times 2-m$ units from Area A. The largest number of unidentifiable bone from a single unit-level (Unit 120-24, Level 3) also made up about $15 \%$ of the collection. The next largest number of unidentifiable bone was approximately half that amount (Unit 120-24, Level 5). The implications of the large number of faunal remains from Feature 2 will be discussed after a review of the horizontal and vertical distributions of the individual units in Area $A$.

An examination of Table 63 shows that the majority of identifiable and unidentifiable bone come from Units 121-9 and 120-24. Notably, there was only one identifiable faunal element from Unit 121-10 (a jackrabbit calcaneous), and no identifiable elements from Unit 61-21. Bone fragments 
TABLE 63. SUMMARY OF THE UNIDENTIFIED AND BURNED BONE IN AREA A AT 41 UV 48

\begin{tabular}{lrrrrrrr}
\hline Level & 1 & 2 & 3 & 4 & 5 & 6 & Total \\
\hline $\begin{array}{l}\text { Unidentified bone } \\
\text { Burned bone }\end{array}$ & 94 & $\begin{array}{r}535 \\
\text { 52 }\end{array}$ & $\begin{array}{r}1422 \\
58\end{array}$ & $\begin{array}{r}1387 \\
200\end{array}$ & $\begin{array}{r}509 \\
70\end{array}$ & $\begin{array}{r}406 \\
59\end{array}$ & $\begin{array}{r}4353 \\
439\end{array}$
\end{tabular}

from the two units were sparse, each about $2 \%$ of the collection as shown in Table 63. In Unit 91-17, white-tailed deer comprised half of the identified elements, with lesser traces of cottontail rabbit, jackrabbit, cotton rat, and the only identified vole element from the site. There was also a dramatic increase in the unidentifiable bone in Level 4. Unit 91-18, adjacent to Unit 91-17, did not have a corresponding increase of faunal material in Level 4. Jackrabbit and turtle were the most common elements identified in Unit 91-18, with single elements from domestic dog, cottontail rabbit, and fish also present. Unit 120-24 contained numerous amounts of faunal remains and the largest species inventory at the site, with 16 species represented. Cottontail rabbit and jackrabbit were most common, but deer was also well represented, especially in Level 2. Other animals represented were domestic dog, pack rat, cotton rat ground squirrel, corn snake, turtle, and fish. The faunal remains occurring only in Unit 120-24 were a human shovelshaped incisor, a spade foot toad (Scaphiopus sp.) vertebra, a black racer vertebra, a rattlesnake vertebra, and a tarsometatarsus of a turkey. In Unit 121-9, which contained Feature 2, numerous unidentifiable bone can be associated with the two unit-levels just above Feature 2. Identified elements from these unit-levels are dominated by cottontail rabbit and jackrabbit elements, and deer is also common. In Feature 2, there are only two turtle carapaces and single elements from coyote, corn snake, and fish occur. Additionally, and possibly significant towards the interpretation of Feature 2 is the occurrence of 12 pack rat elements in Level 5 , just above the feature. Faunal remains from Feature 2 are somewhat similar to those of the surrounding unit-levels in Unit 121-9. Species common to the unit-7evels and Feature 2 include cottontail rabbit, jackrabbit, turtle, and pack rat. Species occurring in Feature 2, but not present in the unit-levels of Unit 121-9 are domestic dog, cotton rat, ground squirrel, and lizard. Conversely, coyote, corn snake, and fish occur in the unit-levels of Unit 121-9, but not in Feature 2. The most notable species associated with the feature is pack rat. About $75 \%$ (23 of 31 ) of a11 the pack rat elements come from Unit 121-9, Leve 15 , or Feature 2. Hester and Hi11 (1980) described recent pack rat nests very similar to Feature 2 (cf. Feature Descriptions of 41 UV 48), and there seems to be some possibility that Feature 2 represents the remains of such a nest. 


\section{Ârea B}

Faunal remains for Area B came from only two proveniences, Unit 836-4, Level 1, and Backhoe Trench 9. A total of 157 bone fragments was from Area $B$, of which nine elements were identified, representing four species: cottontail rabbit, jackrabbit, pack rat, and white-tailed deer. Additionally 10 rodent bones were recorded from the area. Burned bone fragments were confined to Backhoe Trench 9.

\section{Area C}

There were only two unidentifiable bone fragments recovered in Area $C$, both from Unit 525-5, Level 2. One was burned, the other was not.

\section{Snail Shells}

A total of 9464 snail shells was recorded from the excavation units at 41 UV 48 (Table 64). Field sampling procedures involved collecting most or al1 of the whole she11 remains found while screening matrix through $1 / 4-$ inch screens. Four species were identified in the laboratory using CAR-UTSA type collection; a small number of snails (20 specimens) could not be identified. of the identified species three (Rabdotus sp., Polygyra sp., and Helicina sp.) are land snails adapted to sparse brushy woodlands or open fields (Allen and Cheatum 1961). The fourth species identified, Hel isoma sp., is a freshwater snail usually found associated with flowing water. The ecological implications of the above mentioned species habitats would suggest prehistoric environment at least somewhat close to present-day conditions. These snails, especially Rabdotus sp., may have been important culturally. Krieger (1956:53) relates ethnohistoric evidence of the use of snails as a food resource, and the presence of numerous Rabdotus sp. snail shells in archaeological sites throughout south and central Texas has been interpreted as the remains of an important food item (Allen and Cheatum 1961; Hester and Hi11 1975; Montgomery 1978:102).

Rabdotus sp. comprised $93 \%$ of the snails recovered at 41 UV 48 . Helicina sp. was the next most common species, but only represented $5 \%$ of the collection. Polygyra sp., Helisoma sp., and the unidentified snails were only little more than $2 \%$ of the collection.

The snail shel1 from the $2 \times 2-m$ units in Area A showed some indication of variation in horizontal and vertical distributions. Vertically, Rabdotus sp. and Helicina sp. appeared to co-vary. Helicina sp. is most common in the first three levels, Polygyra sp. in Levels 2 through 3, and Rabdotus sp. is most common in Levels 3-5 (Table 65). Gunn and Mahula (1977:104-106) showed a similar pattern at the Hop Hill site for these three snail species, and they suggested the possibility of a slightly moister environment where increases in Helicina sp. and Polygyra could occur. At 41 UV 48, Helisoma sp. and unidentified gastropods were not numerous, and their distribution appears erratic, therefore, they were not considered in the distributional studies. Horizontal studies show that $53 \%$ of the Helicina sp. occur in Unit 61-21, which is located well away from the central area of the midden. 0ther 
TABLE 64. SNAIL SHELL PROVENIENCE AT 41 UV 48

Unit Level Rabdotus Polygyra Helicina Helisoma Unidenti- fied Total $^{-}$

\begin{tabular}{|c|c|c|c|c|c|c|c|}
\hline $\begin{array}{l}61-21 \\
61-21 \\
61-21 \\
61-21 \\
\text { Subtota1 }\end{array}$ & $\begin{array}{l}1 \\
2 \\
3 \\
4\end{array}$ & $\begin{array}{r}65 \\
102 \\
166 \\
72 \\
405\end{array}$ & $\begin{array}{r}4 \\
5 \\
9 \\
2 \\
20\end{array}$ & $\begin{array}{r}77 \\
72 \\
94 \\
4 \\
247\end{array}$ & $\begin{array}{l}1 \\
3\end{array}$ & $\begin{array}{l}1 \\
1\end{array}$ & $\begin{array}{r}148 \\
179 \\
269 \\
80 \\
676\end{array}$ \\
\hline $\begin{array}{l}91-17 \\
91-17 \\
91-17 \\
91-17 \\
91-17 \\
91-17 \\
\text { Subtota1 }\end{array}$ & $\begin{array}{l}1 \\
2 \\
3 \\
4 \\
5 \\
6\end{array}$ & $\begin{array}{r}90 \\
207 \\
239 \\
379 \\
175 \\
69 \\
1159\end{array}$ & $\begin{array}{r}2 \\
10 \\
5 \\
7 \\
2 \\
\\
26\end{array}$ & $\begin{array}{r}12 \\
16 \\
5 \\
6 \\
1 \\
\\
40\end{array}$ & $\begin{array}{l}1 \\
2 \\
3\end{array}$ & 3 & $\begin{array}{r}105 \\
235 \\
252 \\
395 \\
178 \\
69 \\
1234\end{array}$ \\
\hline $\begin{array}{l}91-18 \\
91-18 \\
91-18 \\
91-18 \\
91-18 \\
\text { Subtota1 }\end{array}$ & $\begin{array}{l}1 \\
2 \\
3 \\
4 \\
5\end{array}$ & $\begin{array}{r}86 \\
257 \\
302 \\
207 \\
197 \\
1049\end{array}$ & $\begin{array}{r}2 \\
8 \\
6 \\
2 \\
4 \\
22\end{array}$ & $\begin{array}{r}18 \\
33 \\
6 \\
2 \\
3 \\
62\end{array}$ & $\begin{array}{l}7 \\
7\end{array}$ & $\begin{array}{l}3 \\
5\end{array}$ & $\begin{array}{r}106 \\
301 \\
319 \\
218 \\
204 \\
1148\end{array}$ \\
\hline $\begin{array}{l}121-9 \\
121-9 \\
121-9 \\
121-9 \\
121-9 \\
121-9 \\
\text { Subtota1 }\end{array}$ & $\begin{array}{l}1 \\
2 \\
3 \\
4 \\
5 \\
6\end{array}$ & $\begin{array}{r}90 \\
254 \\
575 \\
836 \\
778 \\
109 \\
2642\end{array}$ & $\begin{array}{r}8 \\
6 \\
13 \\
9 \\
1 \\
37\end{array}$ & $\begin{array}{r}27 \\
28 \\
10 \\
4 \\
2 \\
71\end{array}$ & 1 & $\begin{array}{l}2 \\
2\end{array}$ & $\begin{array}{r}117 \\
290 \\
593 \\
854 \\
789 \\
110 \\
2753\end{array}$ \\
\hline $\begin{array}{l}121 \mathrm{~m} 10 \\
121-10 \\
121-10 \\
121-10 \\
121-10 \\
\text { Subtota1 }\end{array}$ & $\begin{array}{l}1 \\
2 \\
3 \\
4 \\
5\end{array}$ & $\begin{array}{r}86 \\
178 \\
129 \\
150 \\
3 \\
546\end{array}$ & $\begin{array}{r}5 \\
4 \\
2 \\
11\end{array}$ & $\begin{array}{r}2 \\
16 \\
4 \\
4 \\
\\
26\end{array}$ & 1 & & $\begin{array}{r}88 \\
202 \\
137 \\
157 \\
3 \\
587\end{array}$ \\
\hline $\begin{array}{l}120-24 \\
120-24 \\
120-24 \\
120-24 \\
120-24 \\
120-24 \\
\text { Subtota1 }\end{array}$ & $\begin{array}{l}1 \\
2 \\
3 \\
4 \\
5 \\
6\end{array}$ & $\begin{array}{r}82 \\
416 \\
414 \\
534 \\
471 \\
259 \\
2176\end{array}$ & $\begin{array}{r}2 \\
8 \\
3 \\
\\
4 \\
17\end{array}$ & $\begin{array}{r}6 \\
4 \\
3 \\
1 \\
3 \\
1 \\
18\end{array}$ & $\begin{array}{l}1 \\
4\end{array}$ & $\begin{array}{l}2 \\
3\end{array}$ & $\begin{array}{r}89 \\
423 \\
427 \\
539 \\
477 \\
265 \\
2220\end{array}$ \\
\hline
\end{tabular}


TABLE 64. (continued)

Unit Level Rabdotus Polygyra Helicina Unidenti-

\begin{tabular}{|c|c|c|c|c|c|}
\hline $\begin{array}{l}91-1 \\
91-1 \\
91-1 \\
\text { Subtota1 }\end{array}$ & $\begin{array}{l}1 \\
2 \\
3\end{array}$ & $\begin{array}{r}8 \\
16 \\
2 \\
26\end{array}$ & & & $\begin{array}{r}8 \\
16 \\
2 \\
26\end{array}$ \\
\hline $\begin{array}{l}92-1 \\
92-1 \\
92-1 \\
\text { Subtota1 }\end{array}$ & $\begin{array}{l}1 \\
2 \\
3\end{array}$ & $\begin{array}{l}21 \\
54 \\
14 \\
89\end{array}$ & $\begin{array}{l}1 \\
1 \\
2\end{array}$ & & $\begin{array}{l}21 \\
55 \\
15 \\
91\end{array}$ \\
\hline $\begin{array}{l}150-5 \\
150-5 \\
150-5 \\
\text { Subtotal }\end{array}$ & $\begin{array}{l}1 \\
2 \\
3\end{array}$ & $\begin{array}{r}23 \\
5 \\
2 \\
30\end{array}$ & $\begin{array}{l}1 \\
2\end{array}$ & $\begin{array}{r}12 \\
2 \\
14\end{array}$ & $\begin{array}{r}36 \\
9 \\
2 \\
47\end{array}$ \\
\hline
\end{tabular}

Trench 2 Backdirt 14

\begin{tabular}{|c|c|c|c|c|c|}
\hline Feature 2 & Fill & 265 & 1 & 1 & 267 \\
\hline $\begin{array}{l}211-3 \\
211-3 \\
211-3 \\
\text { Subtota1 }\end{array}$ & $\begin{array}{l}1 \\
2 \\
3\end{array}$ & $\begin{array}{r}6 \\
67 \\
1 \\
74\end{array}$ & $\begin{array}{l}7 \\
7\end{array}$ & 1 & $\begin{array}{r}6 \\
75 \\
1 \\
82\end{array}$ \\
\hline $499-12$ & 1 & 7 & & & 7 \\
\hline $836-4$ & 1 & 5 & & & 5 \\
\hline $\begin{array}{l}208-4 \\
208-4 \\
208-4 \\
\text { Subtotal }\end{array}$ & $\begin{array}{l}1 \\
2 \\
3\end{array}$ & $\begin{array}{r}18 \\
5 \\
6 \\
29\end{array}$ & $\begin{array}{l}1 \\
8\end{array}$ & & $\begin{array}{r}25 \\
5 \\
7 \\
37\end{array}$ \\
\hline $\begin{array}{l}401-16 \\
401-16 \\
401-16 \\
\text { Subtota7 }\end{array}$ & $\begin{array}{l}1 \\
2 \\
3\end{array}$ & $\begin{array}{r}8 \\
5 \\
28 \\
41\end{array}$ & $\begin{array}{l}1 \\
1 \\
3 \\
5\end{array}$ & & $\begin{array}{r}9 \\
6 \\
31 \\
46\end{array}$ \\
\hline
\end{tabular}


TABLE 64. (continued)

\begin{tabular}{|c|c|c|c|c|c|c|c|}
\hline Unit & Leve1 & Rabdotus & Polygyra & Helicina & Hel isoma & $\begin{array}{l}\text { Unidenti- } \\
\text { fied }\end{array}$ & Total \\
\hline $\begin{array}{l}456-11 \\
456-11 \\
456-11 \\
\text { Subtota } 1\end{array}$ & $\begin{array}{l}1 \\
2 \\
3\end{array}$ & $\begin{array}{r}11 \\
16 \\
8 \\
35\end{array}$ & $\begin{array}{l}1 \\
2 \\
3\end{array}$ & & $\begin{array}{l}1 \\
1\end{array}$ & & $\begin{array}{r}13 \\
18 \\
8 \\
39\end{array}$ \\
\hline $\begin{array}{l}525-5 \\
525-5 \\
525-5 \\
525-5 \\
\text { Subtota1 }\end{array}$ & $\begin{array}{l}1 \\
2 \\
3 \\
4\end{array}$ & $\begin{array}{r}25 \\
32 \\
10 \\
3 \\
70\end{array}$ & $\begin{array}{l}4 \\
4 \\
8\end{array}$ & & & & $\begin{array}{r}29 \\
36 \\
10 \\
3 \\
78\end{array}$ \\
\hline $\begin{array}{l}800-1 \\
800-1 \\
800-1 \\
\text { Subtota1 }\end{array}$ & $\begin{array}{l}1 \\
2 \\
3\end{array}$ & $\begin{array}{r}8 \\
11 \\
2 \\
21\end{array}$ & $\begin{array}{l}1 \\
1\end{array}$ & & & $\begin{array}{l}1 \\
1\end{array}$ & $\begin{array}{r}10 \\
11 \\
2 \\
23\end{array}$ \\
\hline Trench 1 & Backdirt & 73 & 7 & 4 & & & .84 \\
\hline Total & & 8756 & 178 & 482 & 28 & 20 & 9464 \\
\hline
\end{tabular}


TABLE 65. VERTICAL DISTRIBUTION OF SNAIL SHELLS IN AREA A AT 41 UV 48

$$
\begin{array}{lllrlll}
\text { Levels } & & & \text { Total } \\
\text { (in percentages) }
\end{array}
$$

$\begin{array}{lrrrrrrr}\text { Rabdotus sp. } & 6 & 18 & 23 & 27 & 20 & 5 & 99 \\ \text { Polygyra sp. } & 12 & 27 & 34 & 19 & 8 & & 100 \\ \text { Helicina sp. } & 31 & 36 & 26 & 5 & 2 & >1 & 100 \\ \text { Helisoma sp. } & 16 & 24 & & 56 & & 4 & 100 \\ \text { unidentified } & 16 & 63 & 5 & 16 & & & 100\end{array}$

snails occur most frequently within the midden boundaries. Rabdotus sp. is most common in the units with the largest numbers of 1 ithic debitage and faunal remains, possibly an association that could imply the importance of snails as a food resource.

In Areas B and C, gastropods are much less common, but tend to be most frequent in Levels 1 and 2 of any unit. The single exception to this, occurred in Unit 401-16 where snails dramatically increased in Level 3 and can be associated with Feature 1.

\section{Freshwater Mussel Shel1}

Freshwater mussel she11 (Unio sp.) was recovered from all site areas, except Area $D$. The remains were most often fragmentary and present only in smal1 amounts. A total of eight umbos (Table 66) was the only available quantitative data. When complete she11s were available for inspection they were under $5 \mathrm{~cm}$ in length.

As Table 66 shows, mussel shell remains were most common in Area $A$, the locale with the densest quantity of occupational evidence. Hester and $\mathrm{Hill}$ (1975) have previously pointed out that mussel shell remains are often found in Late Prehistoric middens in southern Texas, and their presence is also common in central Texas sites. The presence of the shell remains probably represents a minor food resource, and the little distributional information available from the mussel shell remains indicates processing was most frequently carried out where the majority of other site activities took place, in Area $A$.

\section{Wood Species Identifications}

A 1 arge sample of wood charcoal from Area A of site 41 UV 48 was submitted for species identification to Donna Lannie of Mesquite, Texas. This section will review the distributional patterns of the analyzed charcoal specimens from the site. 
TABLE 66. MUSSEL SHELL REMAINS BY AREA FROM 41 UV 48

\begin{tabular}{|c|c|c|c|c|c|c|}
\hline & \multicolumn{6}{|c|}{ Level } \\
\hline & 1 & 2 & 3 & 4 & 5 & 6 \\
\hline $\begin{array}{c}\text { Area A } \\
61-21 \\
91-17 \\
91-18 \\
121-9 \\
121-10 \\
120-24 \\
91-1 \\
150-5\end{array}$ & $\begin{array}{l}X \\
X \\
X \\
X \\
\\
X \\
2\end{array}$ & $\begin{array}{l}X \\
X \\
X \\
X \\
X \\
X \\
X \\
X\end{array}$ & $\begin{array}{l}X \\
X \\
2 \\
1 \\
X \\
X \\
X\end{array}$ & $\begin{array}{l}X \\
X \\
X \\
X \\
X \\
X\end{array}$ & $\begin{array}{l}X \\
1 \\
X \\
X \\
X\end{array}$ & $X$ \\
\hline $\begin{array}{l}\text { Area B } \\
211-3 \\
208-4\end{array}$ & & $\begin{array}{l}X \\
X\end{array}$ & & & & \\
\hline $\begin{array}{l}\text { Area C } \\
401-6\end{array}$ & & $X$ & 2 & & & \\
\hline
\end{tabular}

$X=$ fragments present number $=$ umbo count

A total of $546.93 \mathrm{~g}$ of charcoal was analyzed and are tabulated by provenience in Table 67. Of the total amount, over $446 \mathrm{~g}$ were passed through a $3.35-\mathrm{mm}$ screen, and were then not considered for identification purposes. Of the remaining $100.45 \mathrm{~g}$ inspected for identification, $6.4 \mathrm{~g}$ were considered unidentifiable.

The most common identification made was for specimens of the Leguminosae family. Genera included in the Leguminosae family are Acacia, mesquite (Prosopis), common honey locust (Gleditsia triacanthos L.). Leguminosae, very common and characteristic of the Rio Grande Plain, comprise $52 \%$ of the identified specimens. Walnut (Juglans sp.) was the second most common category identified, comprising 16\% of the identifiable sample from the site. Persimmon (Diospyros texana), ash (Fraxinus sp.), and diffuse-porous specimens, each total $7 \%$ of the identified wood charcoal specimens. Present in lesser quantities (2-3\% of the identified sample) were Carya sp. (probably pecan), cottonwood (Populus deltoides), oak (Quercus sp.), and elm (UTmaceae family). Maple (Acer sp.) and juniper (Juniperus sp.) were each represented by a single identification at the site and total less than $1 \%$ of the identified collection. The overall distribution of the wood charcoal identifications indicates an environmental setting that is similar to 
TABLE 67. WOOD SPECIES IDENTIFICATIONS BY WEIGHT (GRAMS) AT 41 UV 48

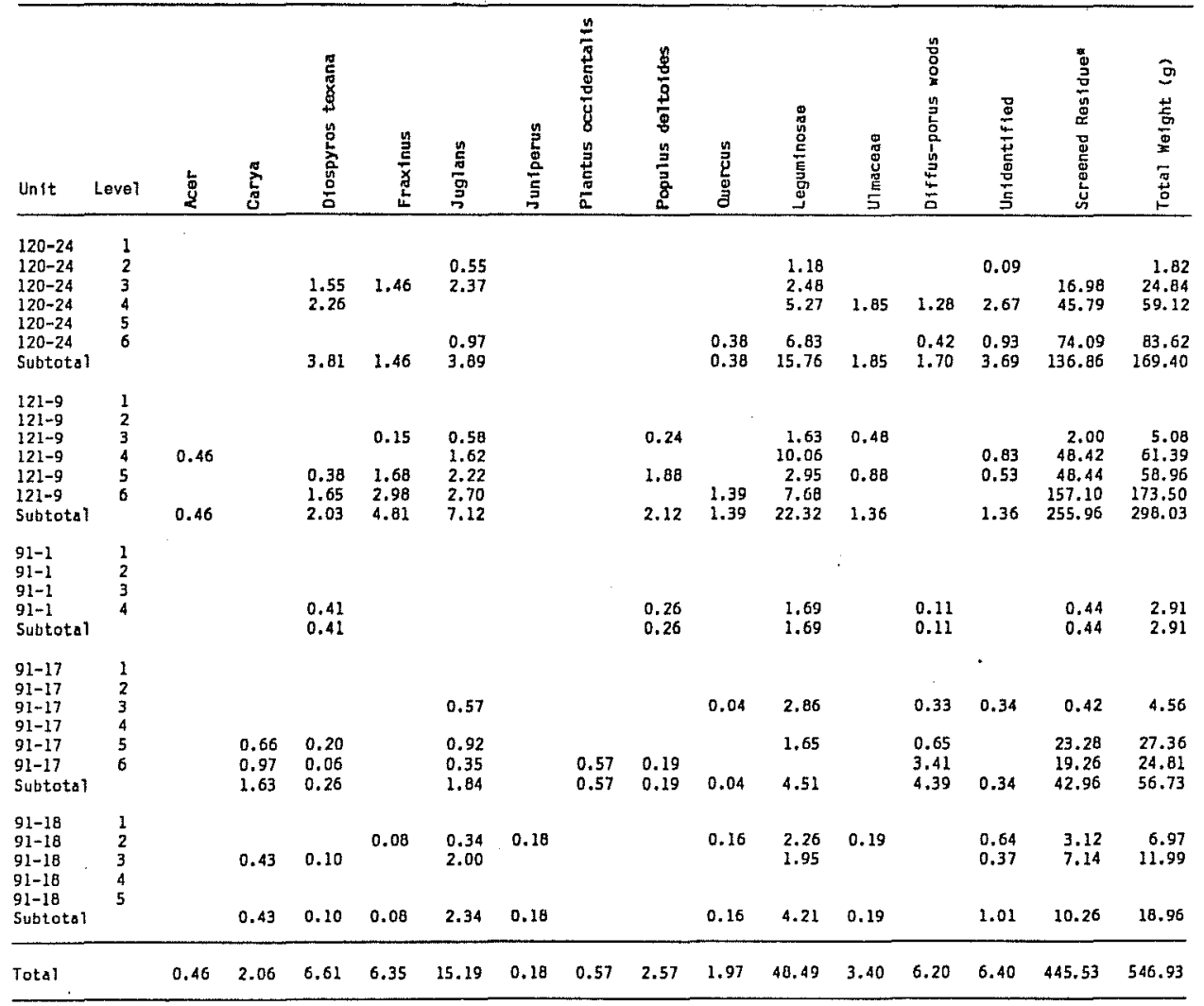

*Sample, unanalyzed portion whith fall through $3.35-\mathrm{mm}$ scroen.

TABLE 68. WOOD SPECIES IDENTIFICATIONS BY LEVEL AT 41 UV 48

\begin{tabular}{|c|c|c|c|c|c|}
\hline Wood Identification & 2 & 3 & $\begin{array}{c}\text { Level } \\
4\end{array}$ & 5 & 6 \\
\hline Acer & & & 2 & & \\
\hline Carya & & & 1 & 5 & 3 \\
\hline Diospyros texana & & 11 & 9 & 4 & 6 \\
\hline Fraxinus & 2 & 11 & & 12 & 10 \\
\hline Juglans & 18 & 24 & 12 & 22 & 13 \\
\hline Juniperus & 4 & & & & \\
\hline $\begin{array}{l}\text { Plantus occidental is } \\
\text { Populus deltoides }\end{array}$ & & 2 & 1 & 13 & 2 \\
\hline $\begin{array}{l}\text { Populus deltoides } \\
\text { Ouercus }\end{array}$ & 3 & * & 1 & 13 & 6 \\
\hline Leguminosae & 70 & 47 & 64 & 33 & 48 \\
\hline UTmaceae & 4 & 3 & 6 & 6 & \\
\hline Diffus-porus woods & & 2 & 5 & 5 & 13 \\
\hline Total percentage & 101 & 100 & 100 & 100 & 101 \\
\hline Total wefght $(g)$ & 4.94 & 14.74 & 29.75 & 14.07 & 30.55 \\
\hline
\end{tabular}

*Less than $0.5 \%$ 
present-day conditions. All of the plants identified are present in the Rio Grande Plain or the Edwards Plateau regions today (Gould 1975).

Vertical distribution studies by level (Tables 68) were prepared in order to investigate the possibility of any environmental trends or changes over time. In most cases the sample sizes for the various categories of wood charcoal were too small to allow any significant statement to be made concerning environmental changes, but it is interesting to note that there appears to be some tendency for particular plants to increase or decrease vertically. Elms tend to increase slightly with depth, while persimmon (Diospyros texana) and the Leguminosae show an overall tendency to decrease with depth. It is tempting to suggest that large trees, which prefer stream banks or moist woodlands (maple, pecan, ash, walnut, and $\mathrm{e} 1 \mathrm{~m}$ ), were more common in the past, and that the increase in the smaller persimmon and Leguminosae (more characteristic of the Rio Grande Plain environment), within the upper levels of the site, point to a drying creek bed or a drier environment. of possible importance also is the relative scarcity of both juniper and oak species within the sample. Both trees are very common in the project area today, and their scarcity in the site deposits could suggest a more varied mesic forest condition prevailed in the area in the past.

The presence of two nut-bearing genera in the collection may represent a food resource. Carya sp. identified from the wood charcoal analysis possibly represent pecan (Carya illinoensis) or black hickory Carya texana); and Juglans sp., present in the Edwards Plateau, includes black walnut ( $J$. nigra), little walnut (J. microcarpa), and Arizona walnut (J. major). Other food resources that may have been available in the past are represented by mesquite (included within the Leguminosae family), oaks (Quercus sp.), persimmon (Diospyros texana), and possibly hackberry (Celtis sp., included under the UTmaceae family). A few hackberry seeds, however, were the on $1 y$ direct evidence of seed collecting at the site.

\section{RADIOCARBON DATES}

Three charcoal samples were selected from the site for dating purposes. The samples were chosen in order to provide an absolute chronological sequence for Area A of the site. The Radiocarbon Laboratory, Balcones Research Center, The University of Texas at Austin, carried out the assays.

Table 69 shows the results of the radiocarbon assessments, given in the uncorrected B.P. dates and in MASCA corrected figures (Ralph, Michael, and Han 1973). Considering the ranges provided with each date, all of the samples overlap each other in time, giving a maximum range at the site from A.D. 1160 to A.D. 1390 (230 years). Using Prewitt's (1981:75) cultural chronological sequence based on radiocarbon dates for central Texas sites, the three radiocarbon dates fall into either the last 140 years of the Austin phase, or the first 90 years of the Toyah phase. A brief summary of each date and its associations at the site are presented next. 
TABLE 69. RADIOCARBON DATES FROM 41 UV 48

\begin{tabular}{cccc}
\hline Sample No. & Provenience & B.P. date & $\begin{array}{c}\text { MASCA } \\
\text { Date* }\end{array}$ \\
\hline TX-4429 & Unit 121-9, Leve1 3 & $600 \pm 40$ & A.D. 1350 \\
TX-4430 & Unit 91-17, Leve1 4 & $740 \pm 60$ & A.D. 1240 \\
TX-4431 & Unit 120-24, Level 2 & $760 \pm 70$ & A.D. 1230 \\
\hline
\end{tabular}

*Ra7ph, Michae1, and Han 1973

$\underline{T X-4429}(600 \pm 40$ B.P.)

The sample was taken from charcoal found throughout Unit 121-9, Level 3. The unit-level was vertically located in the approximate center of the midden zone in Area A. A Targe root disturbance occurred in the unit. There were four Perdiz arrow points and a single Frio dart point in the two levels preceding Level 3. In Level 3, the sample was associated with one Edwards, two Perdiz, one Scallorn corye11, one Scallorn eddy, one Sabinal, three arrow point preforms, and an unidentifiable dart point fragment. Additionally, there were 19 bifaces (among other artifacts) in the level. Level 3 also had the highest debitage count of the six levels in Unit 121-9. The sample provides the latest radiocarbon date for the site, even though it was from a deeper area below the surface than TX-4431 (with an earlier date) in Unit 120-24. While the date can serve as an indicator for the overall chronological positioning of the site, the disturbed nature of the unit and the wide variety of arrow points associated with the unit-level would caution against using it for a more specific interpretation of site chronology.

$\underline{\text { TX-4430 }}(740 \pm 60$ B.P.)

The sample was taken from charcoal found throughout Unit 91-17, Level 4. The level contained two Edwards, an arrow point preform, and arrow point blade fragment, and a Fairland dart point. There were five bifaces and a miscellaneous uniface also found in Level 4. The unit-level immediately above Level 4 contained an Edwards, Scallorn corye11, and a Zavala projectile point. No diagnostics were recovered from below Level 4 of Unit 91-17. The level lies close to the bottom of the midden soils and so may suggest a date reflecting a period of occupation not long after the midden began to accumulate. If the Edwards arrow points associated with the level represent forms from the initial occupations within the midden zone, then the Edwards type may have continued in use a longer time period than was reflected by the first series of radiocarbon dates provided for the type by Hester (1971:114115; TX-665, A.D.1080; TX-681, A.D. 1020; TX-685, A.D. 980) at the La Jita site in northeast Uvalde County. 
$\underline{T X-4431}(760 \pm 70$ B.P.)

The sample came from the upper levels of the midden zone in Unit 120-24, Level 2. It is associated with an Edwards, two Perdiz, and four Scallorn (Scallorn corye11, Scallorn sattler, and two Scallorn-like fragments) arrow points. Also associated with the sample is a arrow point preform, a miscellaneous arrow point form, 15 bifaces, two unifaces, and seven cores. The date is similar to that obtained by sample TX-4430, as both suggest use of the site during the last quarter of the Austin phase (Prewitt 1981:75). This date along with the date from TX-4430 may suggest that the Scal1orn and Edwards points co-existed over time at the site. The presence of Perdiz arrow points in the upper levels of Unit 120-24 might also suggest their introduction at this time.

\section{Summary of Radiocarbon Dates}

Three radiocarbon dates were obtained from the midden zone of site 41 UV 48 , Area A. The dates span from A.D. 1160 through A.D. 1390 and suggest that the midden is a Late Prehistoric component of the site utilized during a period of some 230 years. The dates from the midden fal1 into the later quarter of the Austin phase and the first quarter of the Toyah phase suggesting that it was a preferred campsite during the time immediately before and after a period of cultural change in central Texas (Prewitt 1981:84). Of additional significance, there is an indication in the radiocarbon dates of a continued use of the Edwards arrow point form beyond previously published dates, which have indicated Edwards to be a very early Late Prehistoric projectile point (Hester 1971:114-115; Gerstle, Kelly, and Assad 1978:253-254; Mitchel1 1978).

\section{SUMMARY}

Excavation and surface collections at 41 UV 48 have provided information on the nature and chronology of the site, and data reflecting the subsistence strategies of the prehistoric occupants. A review of the results of investigation at the site and an interpretation of the data are presented.

\section{Chronology}

A relatively well-established cultural chronology based upon projectile point sequences and supported by radiocarbon dates in central Texas can be used to determine the cultural stages represented at the site. of the 176 projectile points categorized, 107 can be used as cultural period time markers. Projectile points representative of all periods of the Archaic through the Late Prehistoric were recovered.

The Late Prehistoric period was the most visible component of the site, represented by $70 \%$ of the collection. The Late Prehistoric is further subdivided into at least two phases, the Toyah and Austin phases (Prewitt 1981), and possibly a third (the Turtle Creek phase, see Mitche11 1978). Of the three phases, 41 Austin phase diagnostics (Scallorn and Sabinal points) comprise $53 \%$ of the diagnostics attributable to the Late Prehistoric. Perdiz 
arrow points of the Toyah phase total $22 \%$ of the Late Prehistoric diagnostics. The proposed Turtle Creek phase (Mitchell 1978) is apparently represented by Edwards arrow point forms (18\% of the arrow points) In this report, Zavala dart point forms may be included in the Late Prehistoric assemblage, although their chronological positioning in relative chronologies is still in question (Montgomery 1978). The Late Prehistoric arrow point forms indicate utilization of the site occurred between A.D. 700 to as late as A.D. 1750.

Radiocarbon dates available from the Late Prehistoric midden in Area A suggest a more restricted time span than is implied by using the relative chronologies presented by Prewitt (1981). The radiocarbon dates suggest the site's Late Prehistoric component was deposited between A.D. 1160 to A.D. 1390. This would place the major use of the site in the first of the Toyah phase and the last of the Austin phase.

Archaic dart points comprise $30 \%$ of the projectile point collection. of the 35 diagnostic dart points $54 \%$ are assigned to the Transitional Archaic Twin Sisters phase, $11 \%$ to the Late Archaic San Marcos phase, 29\% to the Middle Archaic, and 6\% to the Early Archaic. However, no clearly definable Archaic subsurface components were encountered during the excavations. Feature 1 is suspected to represent an Archaic hearth, but a definite chronological placement for the feature was not possible.

\section{Site Nature and Extent}

Surface collections and subsurface excavations were utilized to determine the characteristics of the site's size and nature. In general, the surface concentrations of 1 ithics were met by similar subsurface distributions throughout the site. The site covers an area estimated at $125,100 \mathrm{~m}^{2}$. Much of the site surface had low debitage densities of less than 14 items per $10 \mathrm{~m}^{2}$. Area $A$ was shown through surface collections and excavations to be the most significant concentration within the site. Deposits at the site were general1y $60 \mathrm{~cm}$ or less in depth.

\section{Subsistence Strategies}

Hunting appears to be the most important subsistence strategy at the site. Faunal remains from the site were concentrated in the midden deposits of Area $A$, and reflect a wide range of food resources, primarily jackrabbit, cottontail rabbit, and deer. Other food resources, common at other Late Prehistoric sites in the region, include freshwater mussel and possibly Rabdotus sp. gastropods. Plant food processing is indicated by the presence of grinding stones and handstones. Charcoal wood species identifications show that seed and nut-bearing trees such as pecan, walnut, and hackberry occurred at the site, and these probably represented an important food supply; although the only seeds recovered from these trees were a few hackberry seeds. 


\section{ARTIFACTS RECOVERED}

The artifacts described in this section are arrow points, dart points, overall retouch bifaces, bifacially retouched flakes, cores, debitage, other lithics, fired clay, and historic artifacts. Further subdivisions of the major artifactual groupings are presented for descriptive purposes.

The following abbreviations are used to indicate the measurements of the specimens: $L=$ length, $W=$ width, $T=$ thickness, $S L=$ stem length, $S W=$ stem width, and $N W=$ neck width. All measurements are in millimeters unless otherwise noted. Numbers enclosed by parentheses indicate the measurements of incomplete or broken specimens. Additionally, the number enclosed in parentheses immediately following the abbreviations $L, W$, or $T$ indicates the actual number of specimens used is less than the total number of specimens in the category described. Using less than the total specimens in a given category was at times necessary in order to exclude damaged or otherwise unsuitable specimens that might not provide a size range that was representative of the overall dimensional characteristics of a group of artifacts. For example "L(5)" would indicate that the length of five specimens is included within the range that follows, but more than five specimens were present in the group described.

Finally, the number enclosed by parentheses and following the site numbers in the distribution statement indicates the quantity of that particular artifact form for each site. The specific provenience of individual specimens within each site can be found in the individual site reports in the main body of the text.

ARROU POINTS (191 specimens)

Arrow points are small (4 cm or less in length) bifacial projectile points that exhibit a distinct hafting element consisting of notches, expanding or contracting stems, etc., on the proximal end of the specimen.

Edwards (18 specimens; Fig. 43,a-r)

Description: Long narrow triangular form with straight blade edges, occasionally convex or serrated. Barbs may be slight to well formed. Narrow corner or side notches form the widely expanding stem. Neck widths may be broad to narrow. Stems flare outward, usually to equal the width of the blade, but may be much longer or shorter. The base is always concave, and this is considered to be a critical diagnostic attribute for this arrow point type. Specimens may be marginally retouched or overall retouched flakes.

Dimensions: $L(6): 23-31 ; W(12): \quad 13-17 ; \mathrm{T}: 2-5 ; \mathrm{NW}: \quad 6-10 ; \mathrm{SW}(7): 10-13$.

Distribution: 41 UV 45 (one), 41 UV 47 (three), 41 UV 48 (14).

Comments: The Edwards type has been defined by Sollberger (1978); Highley, Graves, and Judson (1978), Gerstle, Kelly, and Assad (1978), and Hester (1978b) also discuss the Edwards type. Hester (1971) and Mitchel1 (1978) 


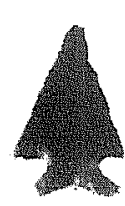

a

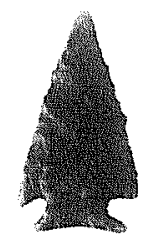

b

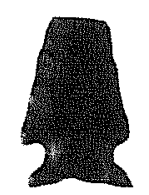

C

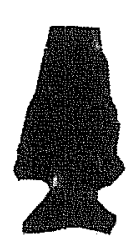

d

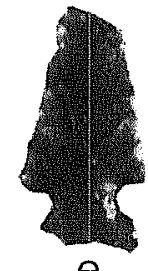

e

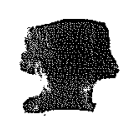

$f$
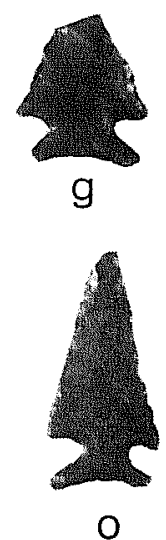

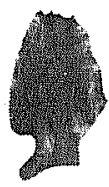

h

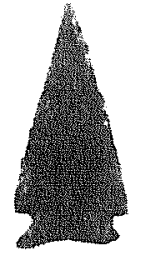

$p$
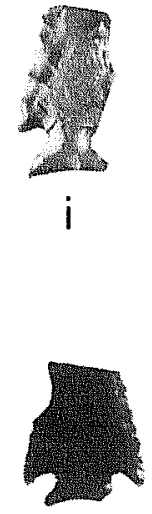

q

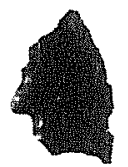

j

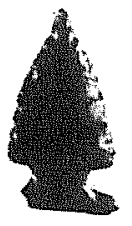

$r$

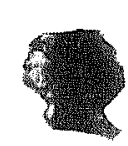

k

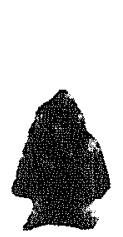

I

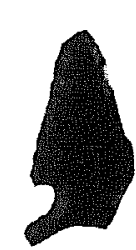

m

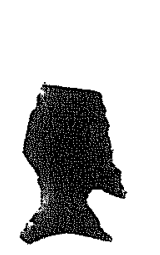

$n$

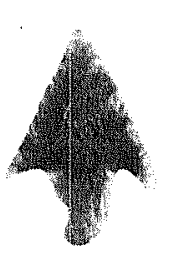

$\mathrm{S}$
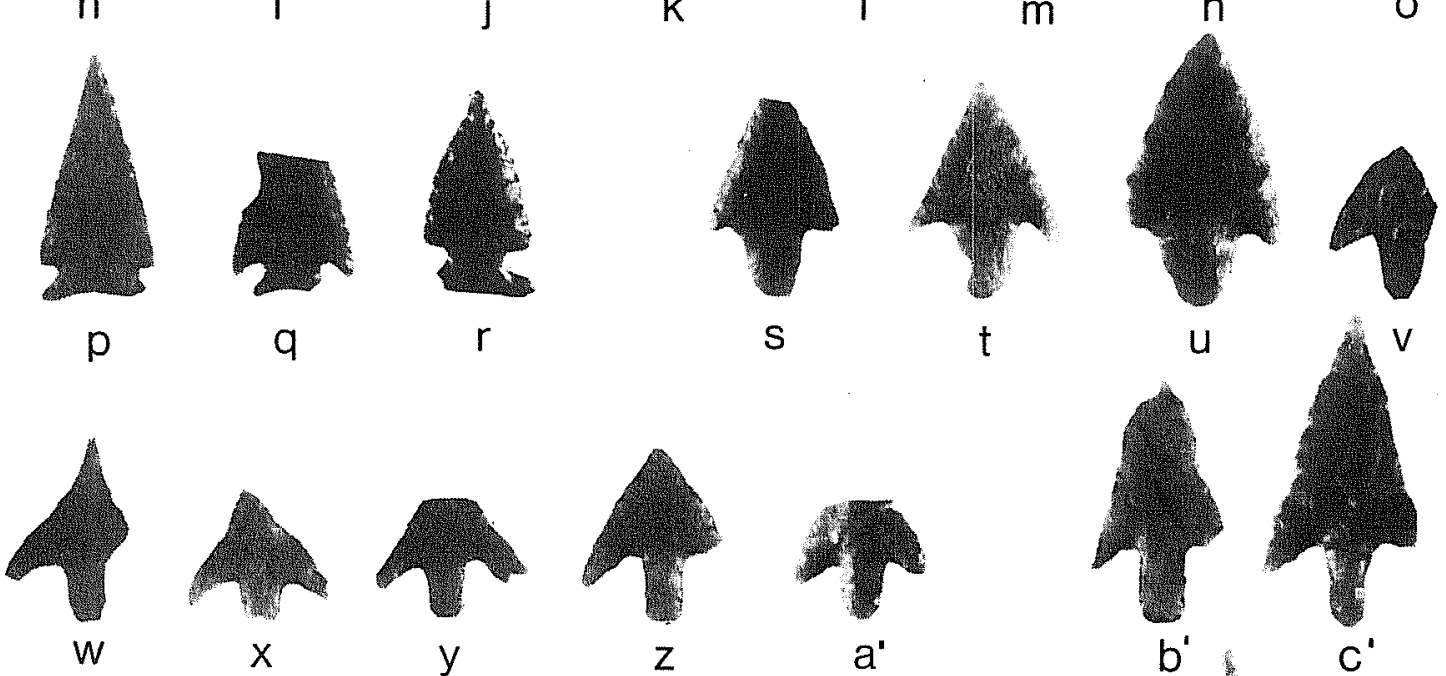

y

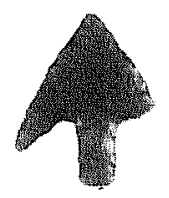

z

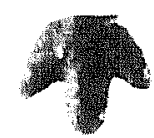

$a^{\prime}$

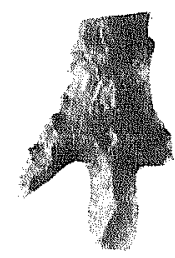

$f^{\prime}$

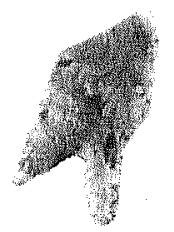

g'

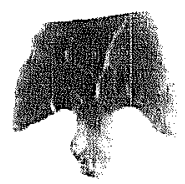

$h^{\prime}$
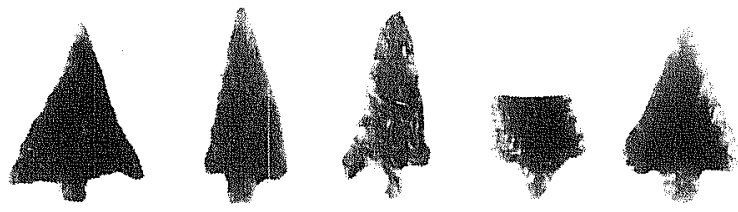

$k^{\prime}$

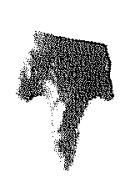

$n$
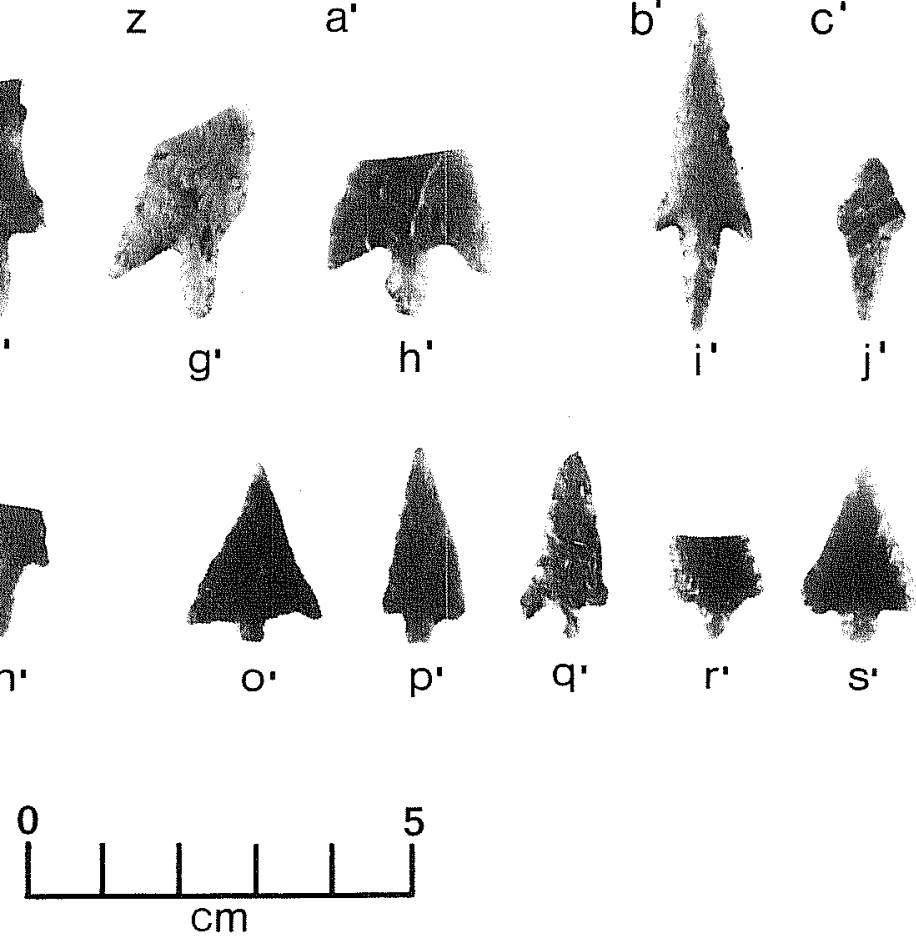

Figure 43. Arrow Points. a-r, Edwards; s-v, Perdiz morgan; w-a', Perdiz whitney, short blade; b'-h', Perdiz whitney, long blade; i'-n', Perdiz, pointed stem; o'-s', Perdiz, short stem. 
have suggested that the Edwards type is an early arrow point form in the Late Prehistoric period, a suggestion supported by the recent findings by Henderson (personal communication), who reports Edwards arrow points have been found in a distinct stratigraphic context below Perdiz and Scallorn arrow points. The Scallorn type is typologically similar to Edwards. I believe that Edwards arrow points may often be mistyped as Scallorn; e.g., see Montgomery (1978:P1ate 4, Fig. C).

\section{Perdiz (35 specimens)}

The general outline and stem characteristics of these 35 specimens conform to the traditional definition of the Perdiz type (Suhm and Jelks 1962). Several subdivisions within the type are presented following examples by Jelks (1962). The subdivisions are Perdiz morgan; Perdiz whitney, short blade; Perdiz whitney, long blade; Perdiz, pointed stem; Perdiz short stem; and miscellaneous Perdiz. Minor variations in stem or blade size and shape are evident for each subdivision. Each of the seven subdivisions is briefly described.

Perdiz morgan (four specimens; Fig. 43, s-v)

Description: Triangular blade with straight or slightly convex edges. Maximum stem width is generally one-third or more of the blade. The specimens have well defined, downward extending barbs. Bases are clearly rounded (convex). None of the specimens are serrated. Three of the specimens are bifacially retouched flakes.

Dimensions: $\quad \mathrm{L}(3): \quad 24-35 ; \mathrm{W}(2): \quad 17-19 ; \mathrm{T}: 2-5 ; \mathrm{SL}: 8-12 ; \mathrm{SW}: 8-10$.

Distribution: 41 UV 47 (one), 41 UV 48 (three).

Perdiz whitney, Short Blade (five specimens; Fig. 43,w-a')

Description: Small, broad triangular blades with recurved or slightly convex blade edges. Barbs are well formed and relatively long in relation to the blade length. The degree of contraction is slight to none, and overall stem length is always close to one-third of the total length of the specimen. Bases are slightly convex, sometimes almost straight.

Dimensions: $L(3): 17-24 ; W(3): 16-20 ; \mathrm{T}: 2-3 ; \mathrm{SL}: 5-8 ; \mathrm{SW}: 5-6$.

Distribution: 41 UV 47 (two), 41 UV 48 (three).

Perdiz whitney, Long Blade (eight specimens; Fig. $43, b^{\prime}-h^{\prime}$ )

Description: Long, narrow blades with straight or slightly recurved blade edges. Barbs are usually well formed and relatively long, extending down one-half the length of the base. Stems are sometimes slightly convex, creating an elongated bulbous outline (barrel shaped), but may also contract 
slightly or nearly parallel. Bases vary from being markedly convex to almost straight.

Dimensions: $L(1): 41 ; W(2): 20-22 ; \mathrm{T}: 3-5 ; \mathrm{SL}(7): 7-13 ; \mathrm{SW}: 5-7$.

Distribution: 41 UV 47 (four), 41 UV 48 (four).

Comments: As an overall assessment of the quality of flaking and the perceived degree of "finish" on the specimens, it seems likely that these specimens represent incompleted forms.

\section{Perdiz, Pointed Stem (six specimens; Fig. $43, i^{\prime}-n^{\prime}$ )}

Description: The blades on the two largest complete specimens are very narrow and long; blades on the smaller specimens are triangular. Blade edges are straight or concave and on the larger specimens, serrated. Barbs are well formed, but are relatively shorter than on the previously mentioned forms of Perdiz. Stems are one-third to one-half of the total length of the specimen. A11 contract to a very sharp, pointed base.

Dimensions: $L(3): \quad 19-42 ; W(3): \quad 12-15 ; \mathrm{T}: \quad 3-4 ; \mathrm{SL}: 8-13 ; \mathrm{SW}: 5-7$.

Distribution: 41 UV 47 (five), 41 UV 48 (one).

Comments: The distribution pattern emphasizes site 41 UV 47, where these forms are found exclusively within the excavated Area A midden.

Perdiz, Short Stem (six specimens; Fig. 43, $0^{\prime}-\mathrm{s}^{\prime}$ )

Description: Blades are roughly triangular, often with uneven or irregular blade edges. Blades are shouldered are weakly barbed, an unusual attribute for Perdiz forms. Stems are little more than protrusions in the base and rarely express the symmetry typical of Perdiz forms.

Dimensions: $L(4): 23-26 ; W: 11-18 ; T: 2-4$.

Distribution: 41 UV 47 (one), 41 UV 48 (five).

Comments: As with the Perdiz-pointed stem specimens, this grouping is almost exclusively limited to a single area of one site, in this case excavation Area $A$ of site 41 UV 48. The overall quality of retouching and the asymmetrical character of the forms seem to indicate these are Perdiz preforms or rejected, incomplete specimens.

Perdiz Preforms (two specimens; Fig. 44,a,b)

Description: One specimen is similar to the description for the cliffton type (Suhm and Jelks 1962). The other specimen appears to be a flake on which only the base of a Perdiz pointed stem form was completed; on one edge minute retouching is on what should be the blade area. 


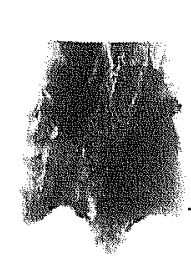

a

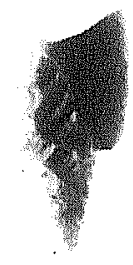

b

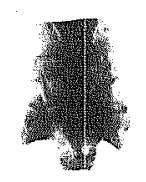

C

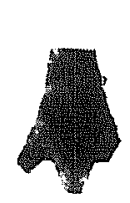

d

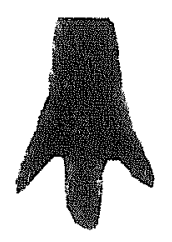

e

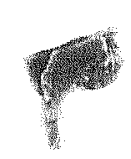

f

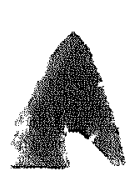

g

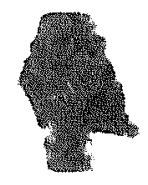

h

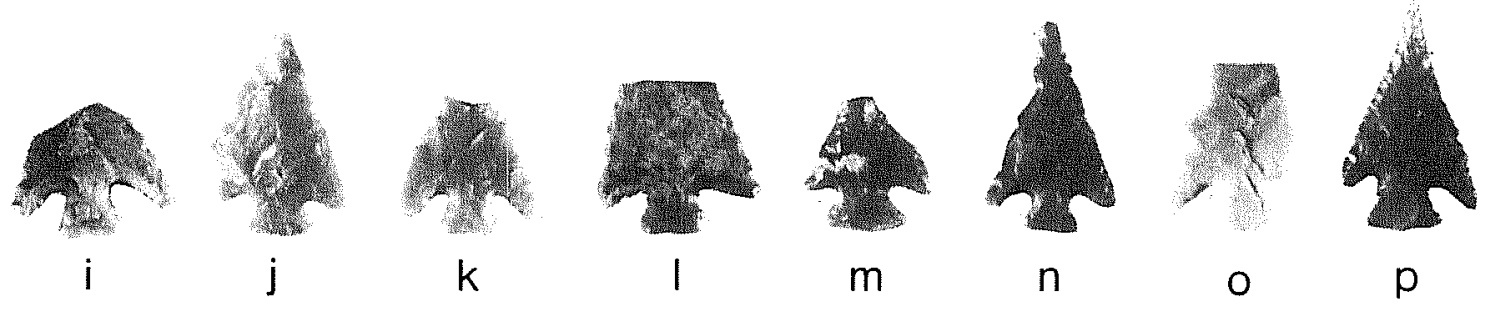

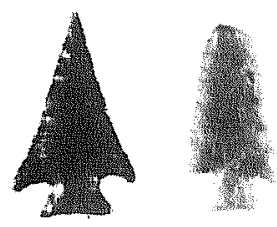

q

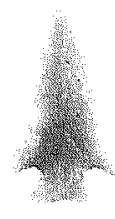

$\mathrm{S}$

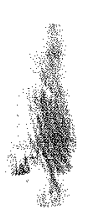

$t$

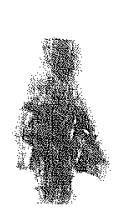

u

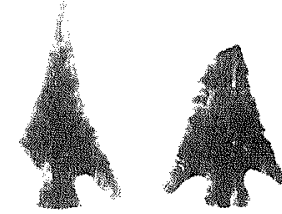

W
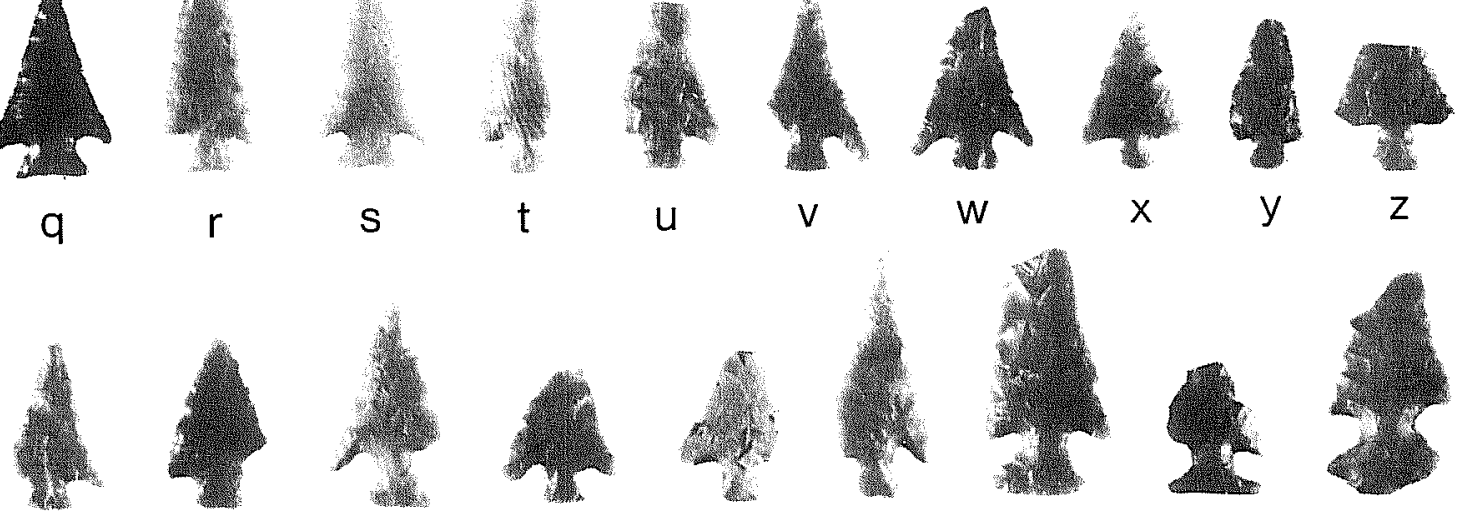

$g^{\prime}$
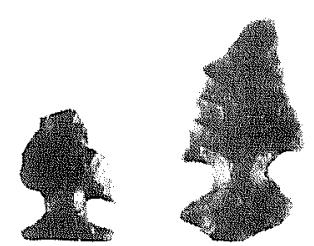

a'

$b^{\prime}$

$\mathrm{C}^{\prime}$

$d^{\prime}$

$e^{\prime}$

$f^{\prime}$

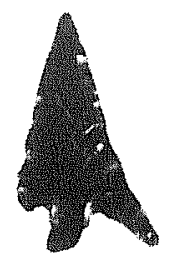

$h^{\prime}$
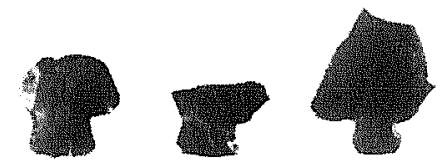

$j^{\prime}$

$k^{\prime}$

I"

m'

$n^{\prime}$

$\mathrm{O}^{\prime}$

$p^{\prime}$

$q^{\prime}$

$r$

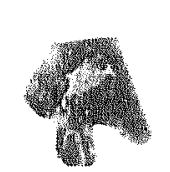

$\mathrm{S}^{\prime}$

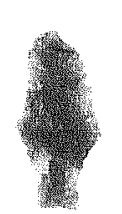

$t^{\prime}$

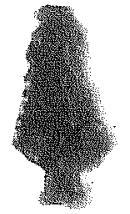

$u^{\prime}$

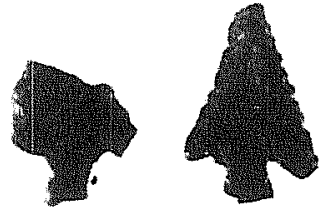

$W^{\prime}$

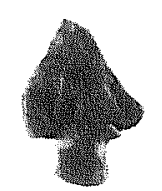

$X^{\prime}$

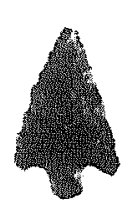

$y^{\prime}$

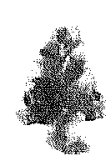

Z'

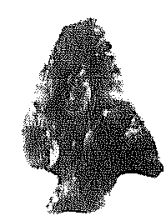

a"

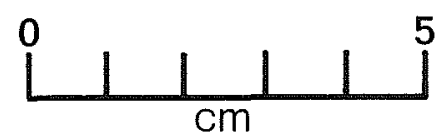

Figure 44. Arrow Points. a,b, Perdiz preforms; $c-f$, misce 11 aneous Perdiz; g-s, Scal1orn corye11; t-f', Scal1orn eddy; g'-1'; Scal1orn satt1er; m', misce 11 aneous Scal1 orn; $n^{\prime}-a^{\prime \prime}$, Scal 1 orn-1 ike fragments. 
Dimensions: L: (29)-(32); W: (16)-22; T: $3-4$.

Distribution: 41 UV 45 (one), 41 UV 47 (one).

Miscellaneous Perdiz (four specimens; Fig. 44,c-f)

Description: Perdiz-1ike forms too badly damaged to place in any other category. The base is snapped off on two specimens, and resharpened on another.

Dimensions: L: (17)-(27); W: (14)-(21); T: 2.5-3.

Distribution: 41 UV 45(one), 41 UV 47 (two), 41 UV 48 (one).

Scallorn (52 specimens)

Scallorn coryell, Scallorn eddy, and Scallorn sattler were recognized in the collection as previously defined by Jelks (1962). Other categories for this type are miscellaneous Scallorn and Scallorn-like fragments.

Scallorn coryel1 (13 specimens; Fig. 44,g-s)

Description: Blades are narrow to triangular. Blade edges vary from recurved or slightly concave to convex. Three specimens are serrated. Stems are expanding and are characterized by a broader, "sturdier" look than the Scallorn eddy. Bases are most often straight, but may be slightly concave or convex. It is possible to subdivide the Scallorn coryell of this collection into three groupings as follows: (1) six specimens with convex blades and essentially straight bases; (2) four specimens with convex blades and widely expanding stems and markedly convex bases; and (3) three specimens resembling Cunney-1ike forms (Hester 1981) with straight blades and slightly concave bases.

Dimensions: L(7): 27-31;W(9): 13-21; T: 2-4; SL: 4-7; SW: 7-10; NW: $5-7$.

Distribution: 41 UV 45 (one); 41 UV 47 (four); 41 UV 48 (eight).

Comments: All of the metric attributes are within the definition of the Scallorn coryell proposed by Jelks (1962).

Scallorn eddy (913 specimens; Fig. 44,t-f')

Description: Triangular blades with straight or slightly concave blade edges. Stems are expanding, but usually only slightly. Bases are straight or slightly convex. Barbs and stems are formed by deep, narrow basal notches. 
Dimensions: $\quad L(6): \quad 20-31 ; W(5): \quad 10-16 ; \mathrm{T}: 3-4 ; \mathrm{SL}: 4-7 ; \mathrm{SW}: 5-7$; NW: 46 .

Distribution: $\quad 41$ UV 45 (one), 41 UV 47 (six), 41 UV 48 (six).

Comments: Metric attributes are within the ranges given by Jelks (1962) for the Scallorn eddy types except for stem length; seven specimens (54\%) in this collection are below the given range of $5-7 \mathrm{~mm}$.

Scallorn sattler (seven specimens; Fig. $44, g^{\prime}-7^{\prime}$ )

Description: Triangular blades with straight or slightly convex edges. Stems are formed by narrow side notches. The depth of each side notch creates a proportionally narrow neck width on most of the specimens. Bases are straight on four of the specimens and convex on the remaining three.

Dimensions: L(3): 16-32; W: 13-17; T: 3-5; SL: 5-10; SW(5): 11-15; NW: $6-10$.

Distribution: 41 UV 47 (two), 41 UV 48 (five).

Miscellaneous Scallorn (one specimen; Fig. 44, $\mathrm{m}^{\prime}$ )

Description: "Bulbar stemmed" best characterizes this specimen. The blades are triangular with concave edges. The base is formed by wide basal notches, and the neck width equals just under one-half of the stem width.

Dimensions: L: 21; W: 19; T: 3; SL: 6; SW: 8; NW: 4 .

Distribution: 41 UV 48.

Comments: This specimen has some similarity to the Scallorn coryell variant. The "bulbar stem" label is persistently used in the regional literature (Hester 1980b) and probably reflects a true Scallorn variant found in southcentral Texas that was not well represented in the project area.

Scallorn-1ike Fragments (18 specimens; Fig. 44,n'-a")

Description: Damaged expanding stem arrow point fragments. These fragments may represent Scallorn coryell and Scallorn eddy variants; however, the extent of damage to the hafting elements precluded a more precise identification.

Dimensions: L(1): 38; W(1): 21; T: 3-7; SL(14): 3-7; SW(8): 7-10; NW(16): $4-7$.

Distribution: 41 UV 47 (five), 41 UV 48 (13). 
Sabinal (11 specimens; Fig. 45,a-1)

Description: The diagnostic elements of this form are the presence of strongly convex blade edges and long, outward flaring barbs. The barbs may be bulbous in appearance or finely chipped to sharp points. The stem is always expanding, but in varying degrees from moderately to almost paralle 1 sided. The base is straight or convex, although one specimen has had a single flake removed from the center of its base, producing a notchlike concavity.

Dimensions: $L(4): \quad 24-44 ; W(5): \quad 16-23 ; \mathrm{T}: 3-5 ; \mathrm{SL}: 3-6 ; \mathrm{SW}(10): 5-8$; NW: 4-7.

Distribution: 41 UV 47 (three), 41 UV 48 (eight).

Comments: The Sabinal arrow point was proposed by Hester (1971) as a new local type based on his findings at the La Jita site. More recently, Sabinal arrow points have been recovered from stratified Late Prehistoric deposits between Edwards and Perdiz arrow points (Henderson, personal communication). The overall dimensions and overlapping morphological attributes of the Sabinal arrow point indicate affinities with the Scallorn, especially the Scallorn eddy variant (Jelks 1962).

Corner-Notched Preforms (five specimens; Fig. 45,m-q)

Description: These rough subtriangular specimens have a variety of edges; the bases are straight or convex, and the stems are formed by 1 ittle more than shallow niches in the corners. Three of the specimens are bifacially retouched flakes.

Dimensions: L(4): 16-32; W: 17-22; T: 3-5; SL: 3-4; SW: 10-12.

Distribution: 41 UV 48 (five).

Basal-Notched Preforms (three specimens; Fig. 45,r-t)

Description: These triangular specimens have wide basal notches which form a relatively narrow rectangular stem.

Dimensions: L: 22-23; T: 3-4; SL: 3-4; SW: 5-6.

Distribution: 41 UV 47 (one), 41 UV 48 (two).

Crude Contracting Stemmed Preforms (six specimens; Fig. 45, u-z)

Description: The contracting stem is formed by wide corner notches. The specimens have straight, concave, or indeterminate blades.

Dimensions: L(2): 29-41; W(5): 18-29; T: 3-5; SL: 6-10; SW: 7-10. 


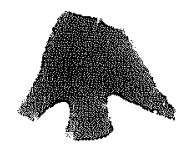

a

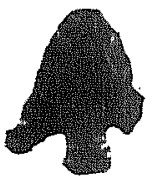

h

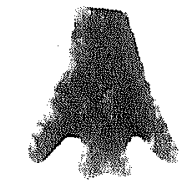

i

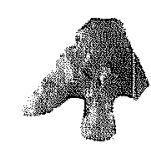

j

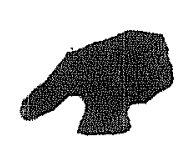

k

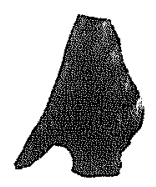

I

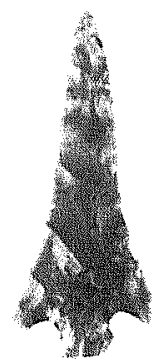

e

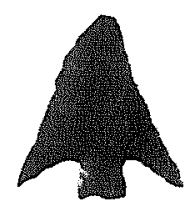

$f$

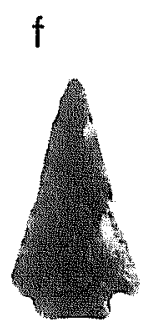

$\mathrm{n}$
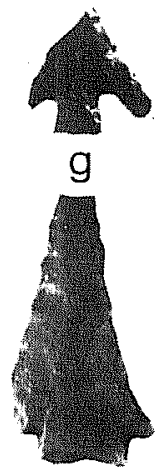

m

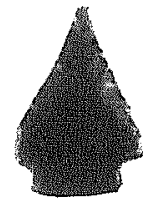

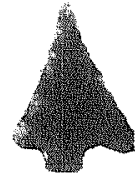

$\mathrm{S}$

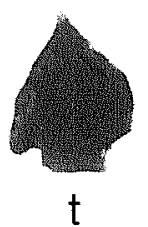

$r$
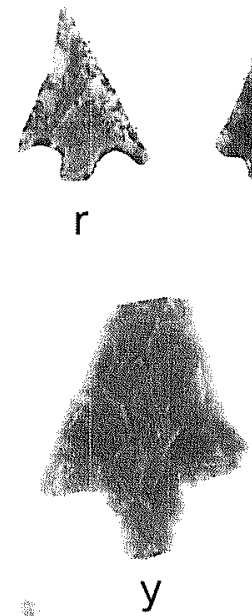

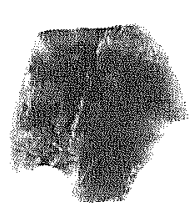

z

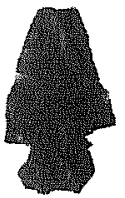

$h^{\prime}$

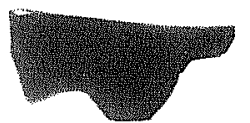

u
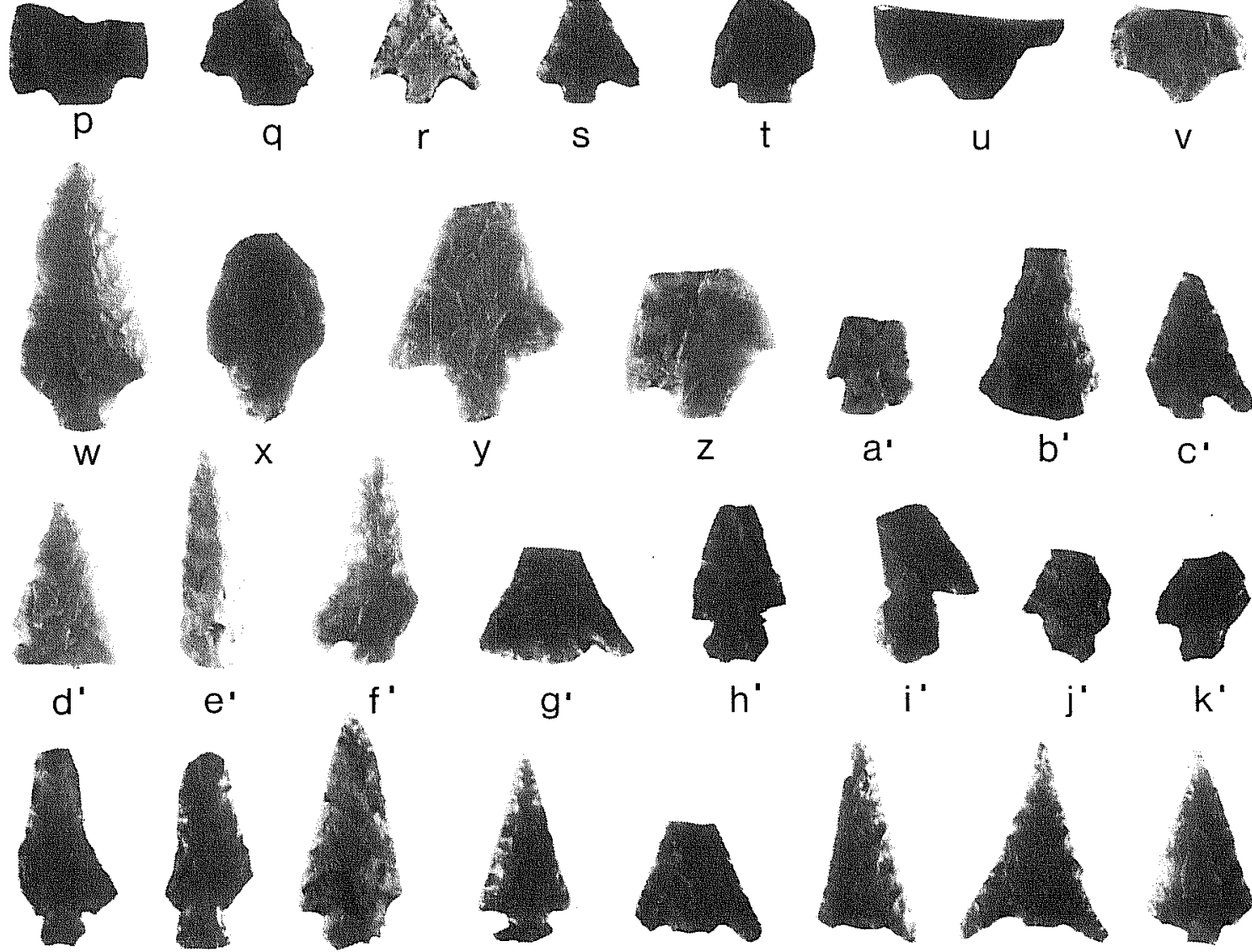

I'

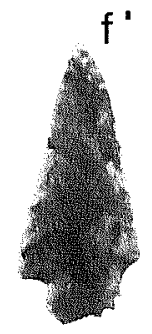

$n^{\prime}$.

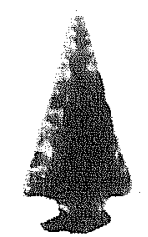

$0^{\prime}$

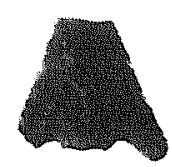

$p^{\prime}$

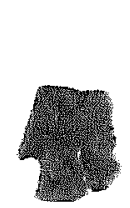

$a^{\prime}$

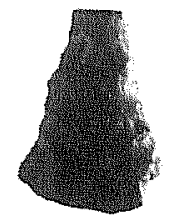

$b^{\prime}$

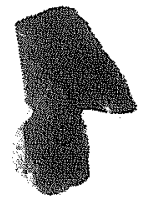

$i^{\prime}$

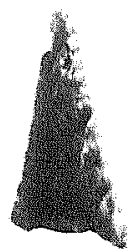

$q^{\prime}$

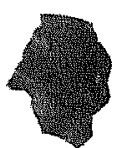

j"

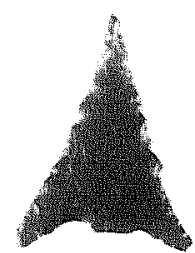

$r^{\prime}$

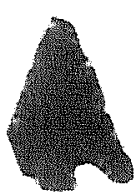

c'

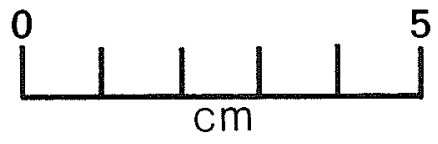

Figure 45. Arrow Points. a-1, Sabina 1; m-q, corner-notched preforms; $r-$ $t$, basal-notched preforms; $u-z$, crude contracting stemmed preforms; $a^{\prime}-$ $g^{\prime}$, single-notched preforms; $h^{\prime}-o^{\prime}$, miscel 1 aneous arrow points; $p^{\prime}-s^{\prime}$, arrow point blade fragments. 
Distribution: 41 UV 47 (two), 41 UV 48 (four).

Comments: Although these six specimens cannot be confidently classified as Perdiz preforms, they are reminiscent of the Perdiz point in general outline.

Single-Notched Preforms (eight specimens; Fig. 45, $\mathrm{a}^{\prime}-\mathrm{g}^{\prime}$ )

Description: Represented within this group are five triangular, one lanceolate, and one indeterminate form. Blade edges are concave or straight on the majority of the specimens (five), but recurved and convex edges also occur. Notches are intrusive from the base (three specimens), the corners (three specimens), and from the side (two specimens).

Dimensions: $L(5): 23-32 ; W(5): 14-24 ; \mathrm{T}: 3-6$.

Distribution: 41 UV 47 (three), 41 UV 48 (five).

Comments: The triangular forms closely resemble in outline the small triangulars in the overall retouch biface and bifacially retouched flake categories. Perhaps these bifacial categories represent final stage blanks for arrow points, or they were at least suitable for easy modification into hafted arrow forms.

Miscellaneous Arrow Points (10 specimens; Fig. 45, $\mathrm{h}^{\prime}-\mathrm{o}^{\prime}$ )

Description: Arrow point specimens with damaged hafting elements that prohibit satisfactory classification into any of the previous categories. Five specimens apparently had concave bases with side or corner notches and may be Edwards or Scallorn forms. The remaining forms are expanding stem fragments.

Dimensions: $L(2): 28-35 ; W(4): 14-16 ; T: 3-5 ; N W(8): 6-11$.

Distribution: 41 UV 47 (five), 41 UV 48 (five).

Arrow Point Blade Fragments (43 specimens; Fig. 45, $\mathrm{p}^{\prime}-\mathrm{s}^{\prime}$ )

Description: Blade fragments with indications of a snapped or damaged hafting element.

Dimensions: Minimum and maximum ranges for the length of these incomplete specimens are 10-42 $\mathrm{mm}$, respectively.

Distribution: 41 UV 45 (one), 41 UV 47 (12), 41 UV 48 (30).

DART POINTS (131 specimens)

Dart points are bifaces exhibiting overall retouch and deliberate modification of the proximal end of the specimen in order to form a hafting element 
in the form of notches or stems. The dart points were identified from the types presented by Suhm, Krieger, and Jelks (1954) and more recent, formally proposed types (Turner and Hester 1985). Additional dart point categories established for this collection are miscellaneous dart points and unidentifiable dart point fragments.

Bulverde (four specimens; Fig. 46,a-d)

Description: Blade edges are convex on two of the specimens; the other two specimens have indeterminate edge forms. The stems are long, parallel sided, or slightly contracting. The bases are concave or slightly convex. One specimen has been reworked at a distal break.

Dimensions: $\quad L(2): \quad(29)-61 ; W(2): \quad(29)-42 ; T(2): 6-7 ; S L(2): \quad 12-17$; SW(2): $16-19$.

Distribution: 41 UV 48 (four).

Castroville (seven specimens; Fig. 46, e-k)

Description: A broad-bladed triangular form with straight to slightly convex blade edges. The stems are formed by narrow, steeply upward-cutting corner notches, producing barbs that extend approximately one-half to three-fourths of the way down the length of the stem. The stems are expanding and wide in relationship to the blade width. The bases are straight to slightly convex.

Dimensions: L(2): $37-51 ; W(2): 33-39 ; \mathrm{T}: 5-8 ; \mathrm{SL}: \quad 6-14 ; \mathrm{SW}(6): 17-26$; NW: $14-24$.

Distribution: 41 UV 45 (two), 41 UV 47 (two), 41 UV 48 (three).

Comments: Two of the specimens from 41 UV 48 are distally reworked. One specimen from 41 UV 47 has a burin facet.

Early Corner Notched (two specimens; Fig. $46,1, \mathrm{~m}$ )

Description: These specimens have triangular blades with straight edges. The neck widths are comparatively narrow (approximately one-third of the total blade width), and the stems are widely expanding, formed by deep, narrow corner notches. Both bases are concave.

Dimensions: L: (39)-(42); W: (27)-(36); T: 6; SL: 9-11; SW: 16-21; NW: $12-15$.

Distribution: 41 UV 45 (one), 41 UV 47 (one).

Comments: See Hester (1971) and Sollberger and Hester (1972) for further typological characteristics. 

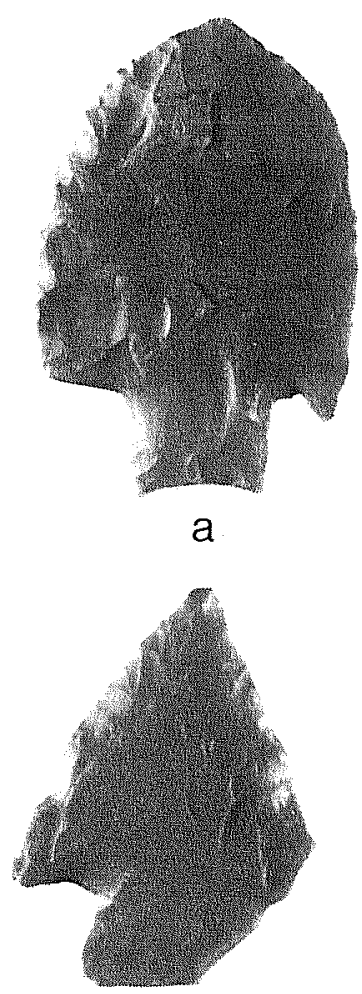

e

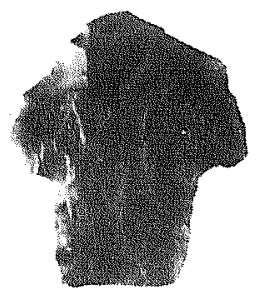

b

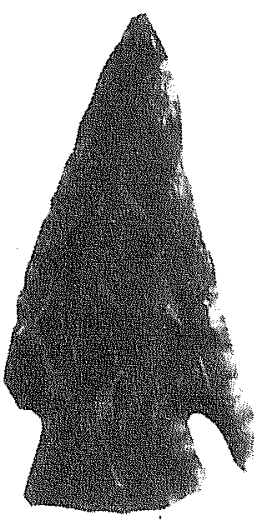

f

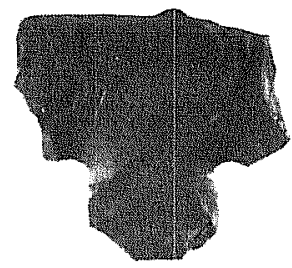

C

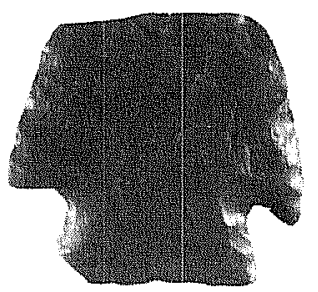

g

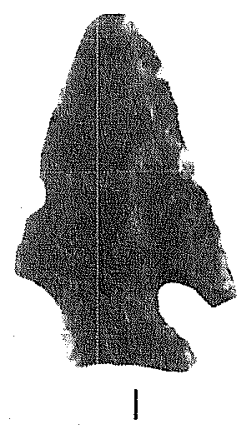

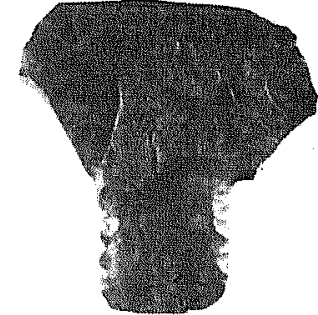

d

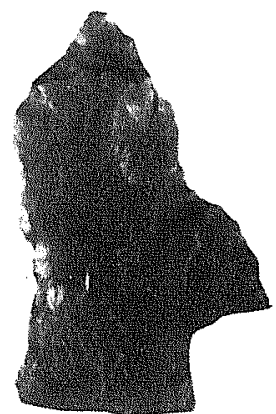

h

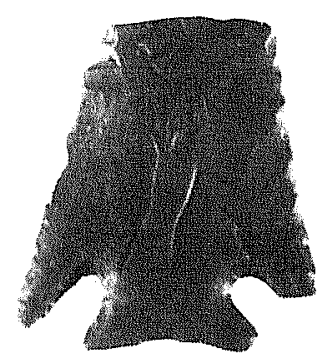

$m$

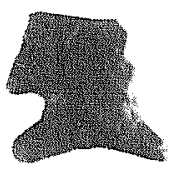

n

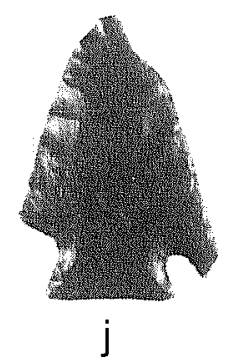

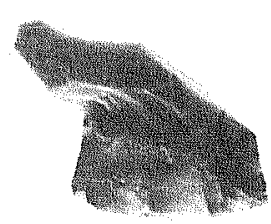

k

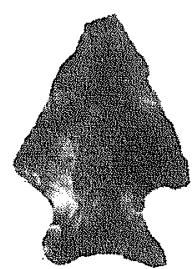

o

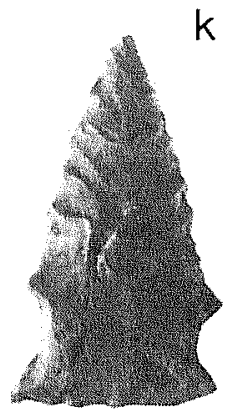

p

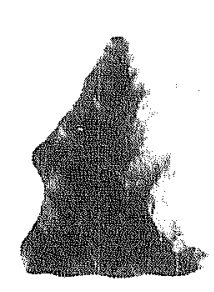

q

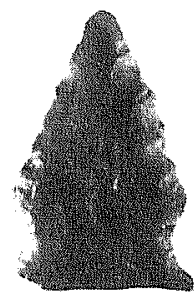

r

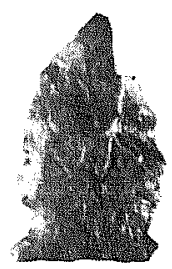

$\mathrm{s}$

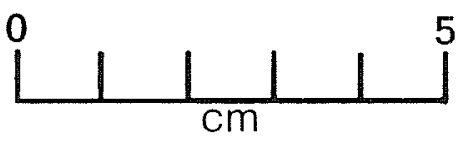

Figure 46. Dart Points. a-d, Bulverde; e-k, Castrovil1e; 1,m, Early Corner Notched; n,o, Edgewood; p-s, Ensor Variety 1. 
Edgewood (two specimens; Fig. $46, n, 0$ )

Description: One specimen has a short triangular blade, and the blade is broken on the other specimen. The expanding stems are formed by wide side notches, and the bases are concave.

Dimensions: L: (20)-(33); W: (12)-(23); T: 5-7; SW: (16)-27; NW: 11-12.

Distribution: 41 UV 48 (two).

Ensor Variety 1 (four specimens; Fig. 46,p-s)

Description: All five specimens have straight blades. One specimen has a beveled blade, and two specimens have serrated blades. The stems are wider than the blades and are formed by very shallow side notches. All of the bases are straight.

Dimensions: $L(3): \quad 29-45 ; \mathrm{W}: \quad 18-24 ; \mathrm{T}: 5-7 ; \mathrm{SW}(3):$ 18-25; NW: 14-19.

Distribution: 41 UV 45 (two), 41 UV 47 (two).

Ensor Variety 2 (four specimens; Fig. 47,a-e)

Description: Side notched, narrow triangular forms. The bases are all straight and, in contrast to Ensor Variety 1 the shoulders are well developed.

Dimensions: $L(1): 39 ; W(3): 21-22 ; \mathrm{T}: 5-7 ; \mathrm{SW}(1): 17$; NW: $13-16$.

Distribution: 41 UV 45 (one), 41 UV 47 (one), 41 UV 48 (three).

Fairland (nine specimens,:Fig. 47,f-n)

Description: A11 of these specimens have wide, shallow side notches and are morphologically similar to Ensor Variety 2 except in this collection the base of the Fairland dart point is almost always concave. A wide range of variation in the overall blade lengths and widths was noted. Two of the specimens are distally reworked.

Dimensions: $L(3): \quad 37-52 ; W(7): \quad 19-22 ; \mathrm{T}: 5-8 ; \mathrm{SW}(6): 15-21 ; \mathrm{NW}: 12-15$.

Distribution: 41 UV 47 (five), 41 UV 48 (four).

Frio (16 specimens; Fig. 47,0-w)

Description: The specimens a11 are side notched, ranging from shallow to deep cuts. The blade edges are usually straight, but a few are slightly convex. The bases may be formed by a deep, wide basal concavity, or by no more than a notch in the center of a straight or slightly convex base. Four 


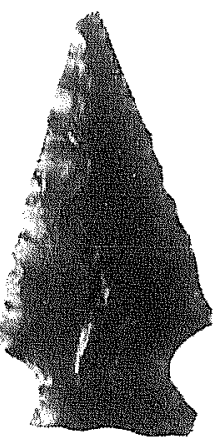

a

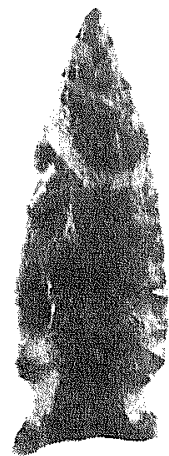

f

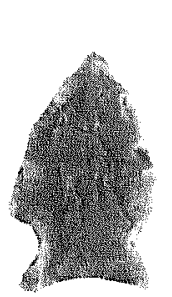

$\mathrm{m}$

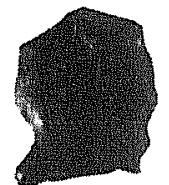

g

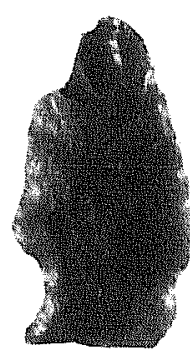

b

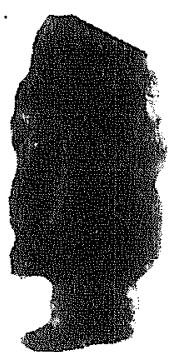

C

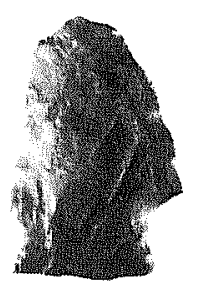

d

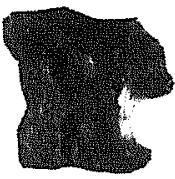

e

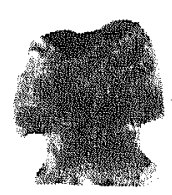

h

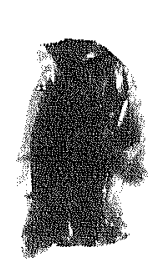

i
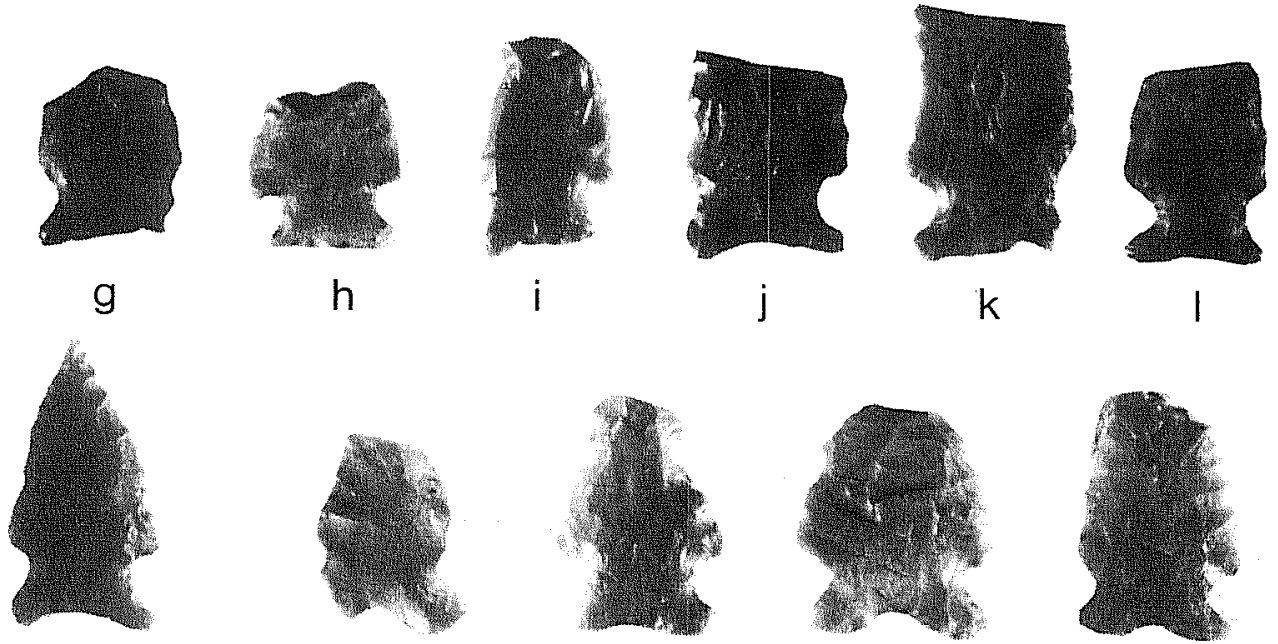

o

$p$

q

$r$

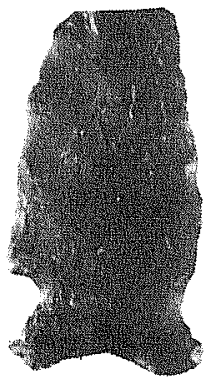

S

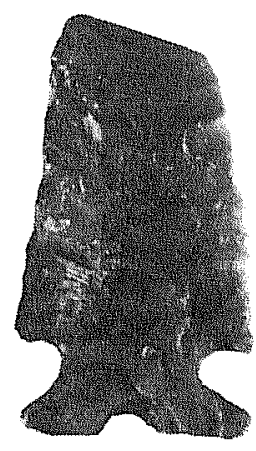

t

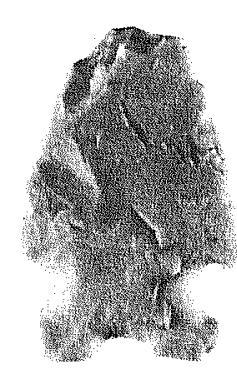

u

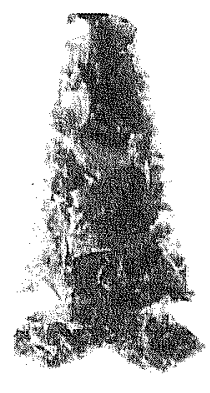

V
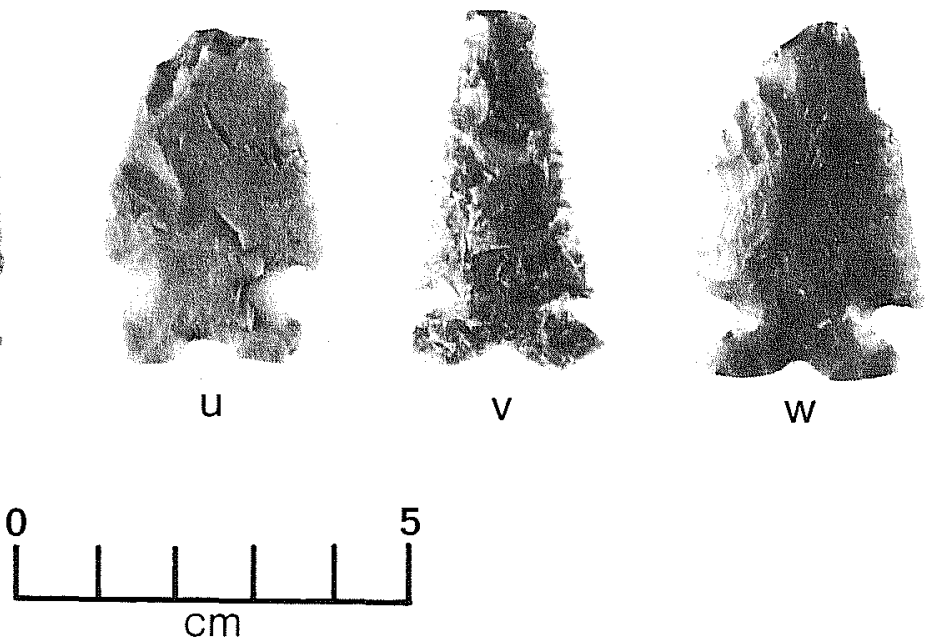

Figure 47. Dart Points. a-e, Ensor Variety 2; f-n, Fairland; $0-W$, Frio. 
of the specimens (three from 41 UV 48, one from 41 UV 47) have been reworked to varying degrees.

Dimensions: L: (21)-(55); W(11): 20-32; T: 5-8; SW(10): 21-31; NW: $15-$ 21.

Distribution: 41 UV 45 (four), 41 UV 47 (six), 41 UV 48 (six).

Gower (three specimens; Fig. 48,a-c)

Description: The specimens tend to be short, with well-developed shoulders formed against very wide, shallow side notches. The stems are nearly as long as the blade, and the bases are all deeply concave.

Dimensions: L: (34)-(39); W: (20)-(26); T: 6-8; SL: 13-18; SW: 17-20; NW: $15-16$.

Distribution: 41 UV 47 (two), 41 UV 48 (one).

Comments: See Shafer (1963) for the original type description, as well as further discussion in Turner and Hester (1985).

Kinney (three specimens; Fig. 48,d-f)

Description: A11 three specimens have convex blades with concave bases. Two specimens have corners at the blade, and the bases have been rounded off; but on the largest specimen the corners are pointed and sharply defined.

Dimensions: L: (22)-(90); W: (31)-(42); T: 7-10.

Distribution: 41 UV 45 (three).

Comments: Hester (1971) has suggested that the Kinney point is a minor type of the Middle Archaic period (4000-2600 B.C.). At the Anthon site in Uvalde County, Weir and Doran (1980), and Glen Goode (personal communication) report close associations of Pedernales and Kinney forms.

La Jita (two specimens; Fig. $48, \mathrm{~g}, \mathrm{~h}$ )

Description: Both specimens have expanded stems with slightly concave bases, and the corners of the stems are rounded. The blades would have probably been broad with straight or convex edges. The specimen from 41 UV 48 is distally reworked.

Dimensions: L: (38)-(48); W: 35-37; T: 8-9; SW: 29-30; NW: 26-28.

Distribution: 41 UV 45 (one), 41 UV 48 (one). 
Dart Points 221

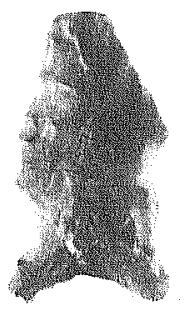

a

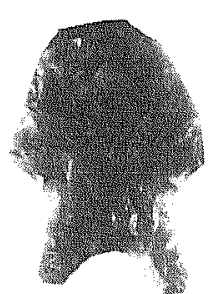

b

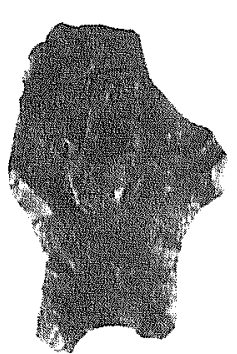

C

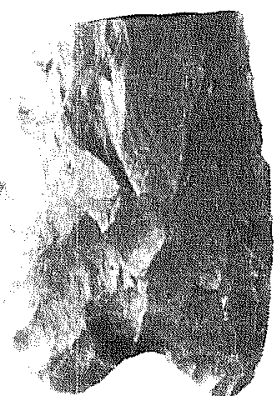

d

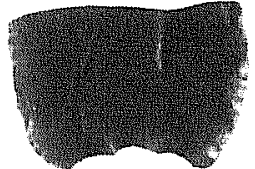

e

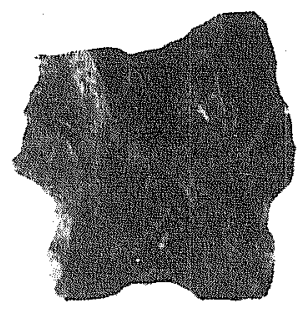

g

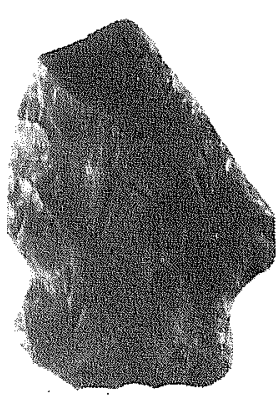

h
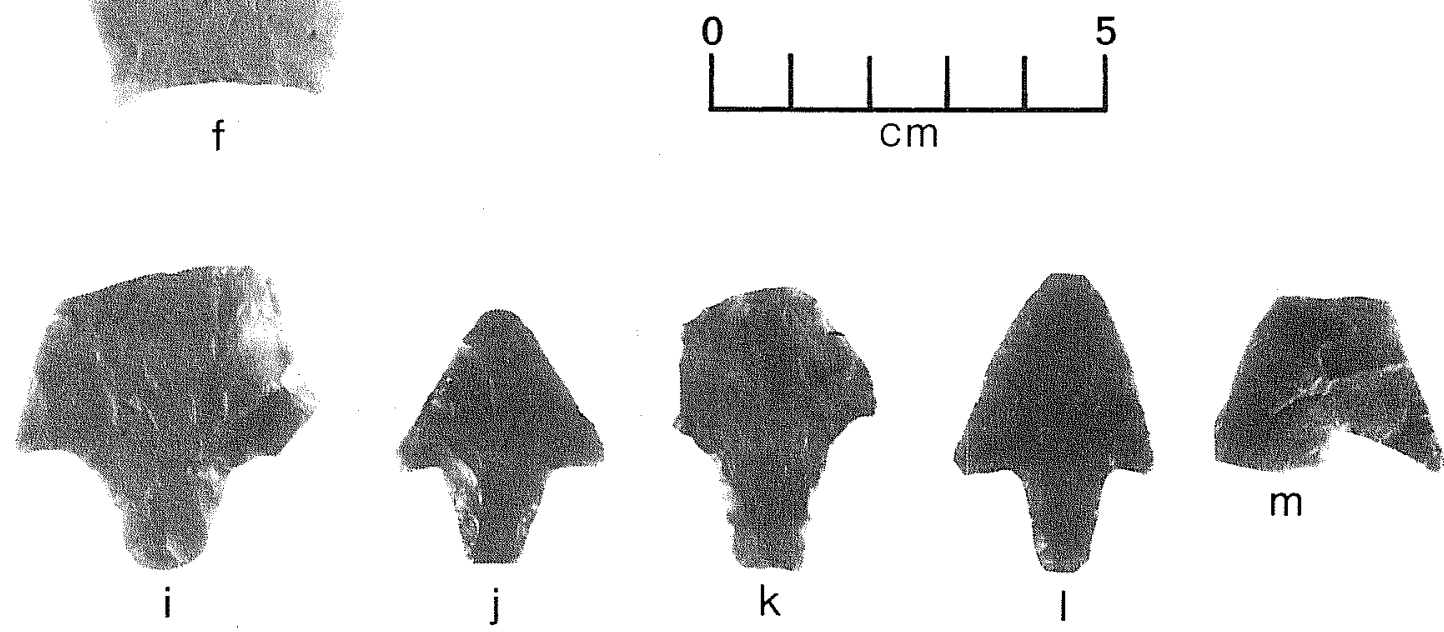

$\mathrm{m}$

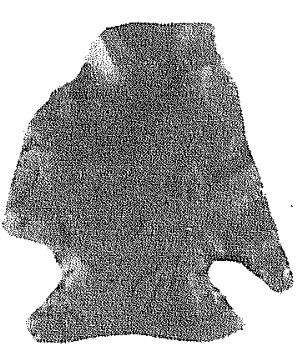

$\mathrm{n}$

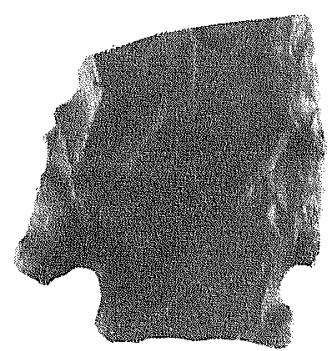

O

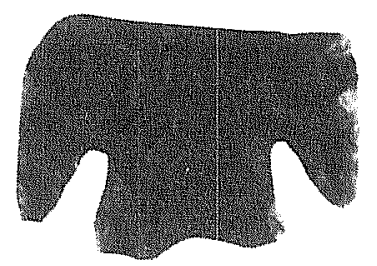

$\mathrm{p}$

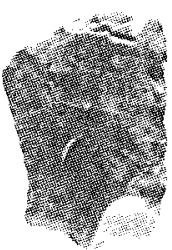

q

Figure 48. Dart Points. a-c, Gower; d-f, Kinney; g-h, La J ita; i-m, Langtry; $n-p$, Marcos; $q$, Matamoros. 
Comments: Hester (1971) noted beveling on specimens from the La Jita site, an attribute missing on the specimens presented in this report (see Turner and Hester 1985).

Langtry (five specimens; Fig. $48, i-m$ )

Description: These five specimens are characterized by broad triangular blades with straight edges. The stems on four specimens are contracting, and each equals almost half of the total length of the specimen. Two specimens have convex bases, and two have straight bases. One specimen is broken near the base. One specimen from 41 UV 47 is distally reworked.

Dimensions: L(2): 33-39; W(3): 26-40; T: 4-7; SL(4): 13-19.

Distribution: 41 UV 45 (one), 41 UV 47 (four).

Comments: These specimens have some similarities with the Shumla type, especially the two with the convex bases. However, none have the long, wellformed barbs common to the Shumla type, (e.g., see Suhm and Jelks [1962] and Johnson [1964]).

Marcos (three specimens; Fig. 48,n-p)

Description: All the specimens have broad blades with straight or convex blade edges. All the specimens are barbed, and the expanding stems are formed by narrow, sharply upward cutting corner notches. A11 the bases are concave.

Dimensions: L: (39)-(43); W: (36)-(40); T: 6-8; SW: 21-29; NW: 15-24.

Distribution: 41 UV 45 (one), 41 UV 47 (one), 41 UV 48 (one).

Marshal1 (two specimens; Fig. 49,a,b)

Description: The two small basal fragments have stems that are narrow in comparison to the blade widths, equalling about one-half to one-third of the total blade width. The stems are widely expanding and are formed by corner notches. The bases are convex. The overall impression is that these forms were simple-pointed ovates in outline prior to being notched.

Dimensions: L: (21)-(39); W: (31)-(33); T: 5-7; SW: 21-(21); NW: (11)15.

Distribution: 41 UV 45 (two).

Matamoros (one specimen; Fig. 48,q)

Description: This specimen is a triangular blade with right-handed bevels. The base is too irregular to identify its shape. 


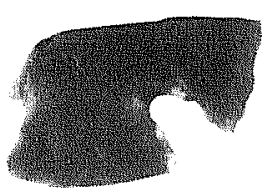

a
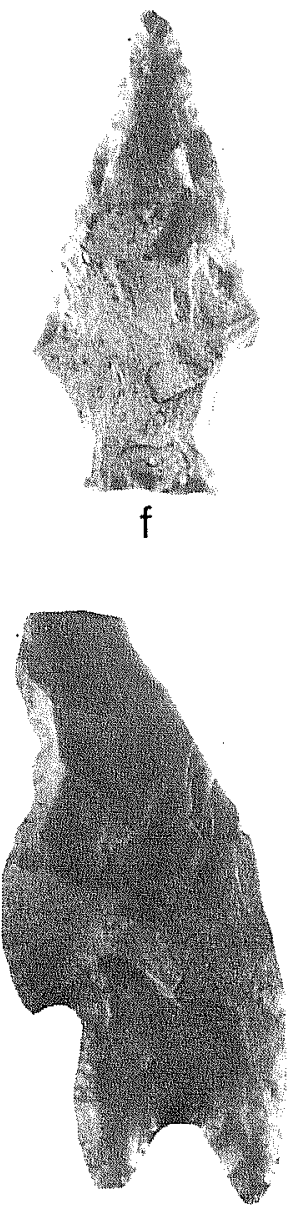

k

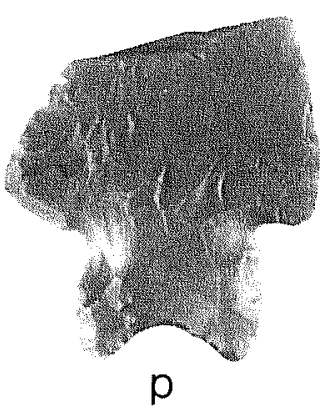

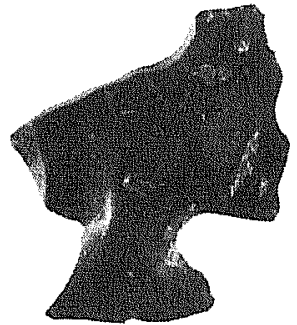

b

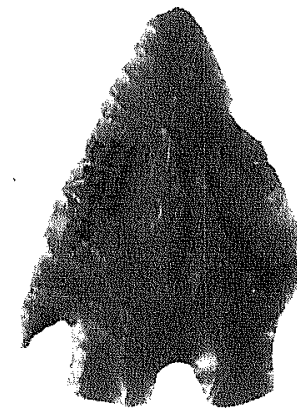

C

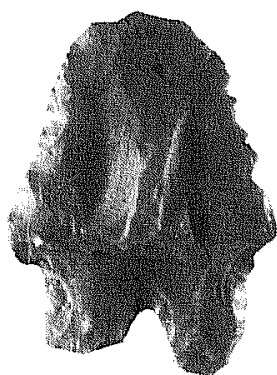

d

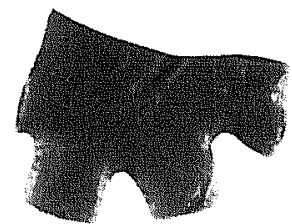

e

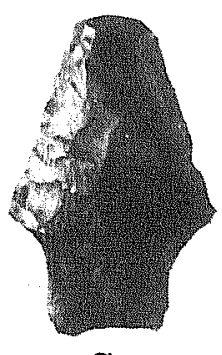

g

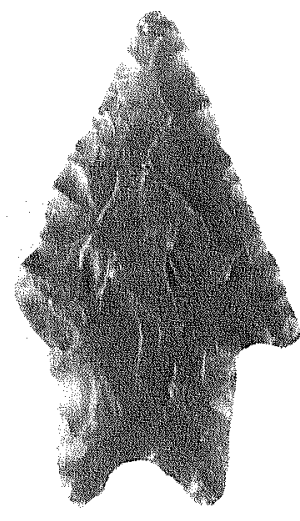

I

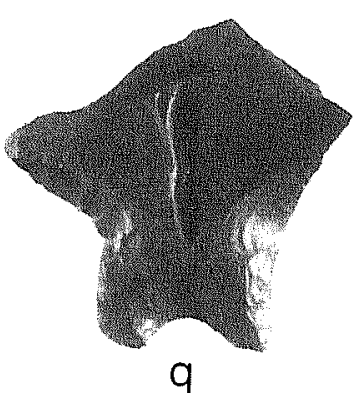

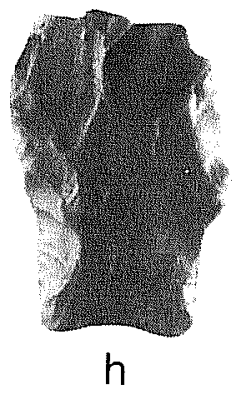
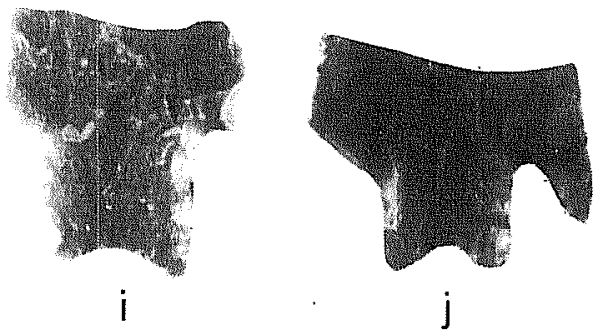

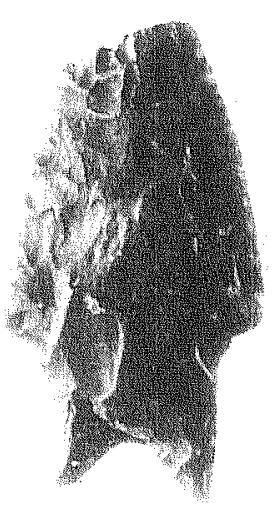

m

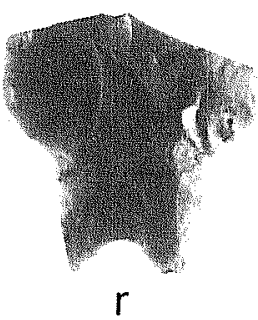

Figure 49. Dart Points. a,b, Marsha11; c-e, Monte11; f-h, Nolan; i$r$, Pedernales. 
Dimensions: L: 29; W: (25); T: 6 .

Distribution: 41 UV 45 (one).

Montell (four specimens, Fig. 49,c-e)

Description: Two of the specimens have blade edges that are straight or slightly convex. The hafting elements are characterized by a bifurcated stem, and the bases are convex.

Dimensions: L: (28)-51; W: (29)-(37); T: 5-8; SW(2): 26-27; NW: 22-26.

Distribution: 41 UV 45 (one), 41 UV 47 (three).

Nolan (three specimens; Fig. 49,f-h)

Description: The long, triangular blades have convex or straight edges. The stems equal about one quarter of the total length. The stem edges are characteristically alternately beveled; either from the right or left side. The bases are straight or concave.

Dimensions: L: (42)-62; W: (28)-29; T: 8-10; SW: 17-21; SL: 14-21.

Distribution: 41 UV 45 (one), 41 UV 47 (one), 41 UV 48 (one).

Pedernales (10 specimens; Fig. 49, $i-r$ )

Description: The specimens generally have relatively long, slender blades with straight or slightly convex edges. Some of the specimens have shoulders, and some have extended (1ong) barbs. The stems are usually onefourth to nearly one-third of the total length of the blade and have parallel-sided or slightly contracting stem edges. The bases are deeply concave.

Dimensions: L(3): 64-70; W(5): 30-39; T: 6-10; SW: 19-27; SL: 13-28.

Distribution: 41 UV 45 (three), 41 UV 47 (two), 41 UV 48 (five).

Uvalde (one specimen; Fig. 50,a)

Description: This specimen has a slender, triangular blade with convex edges. The stem is expanding, and the base is concave.

Dimensions: L: (59); W: (21); T: 7; SL: 11; SW: 18; NW: 14.

Distribution: 41 UV 48 (one). 


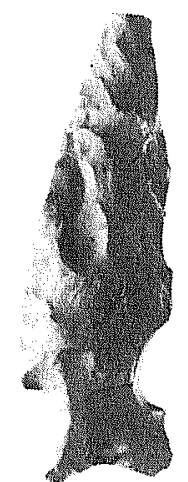

a

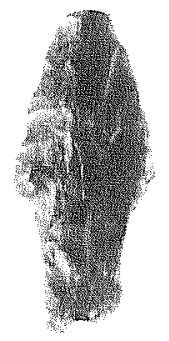

g

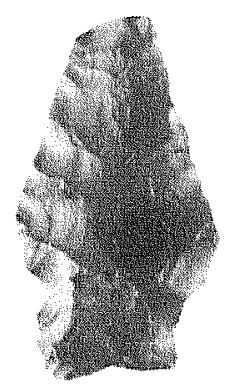

$m$

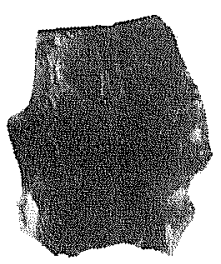

$\mathrm{S}$

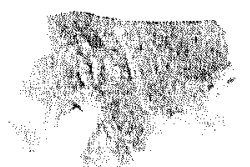

$\mathrm{h}$

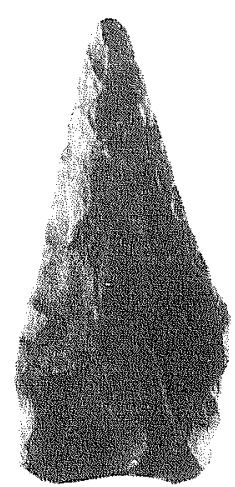

$n$

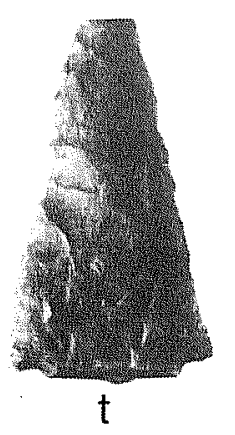

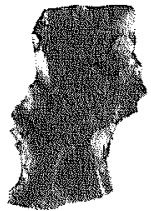

$\mathrm{C}$

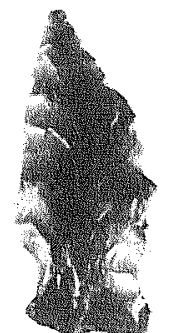

i

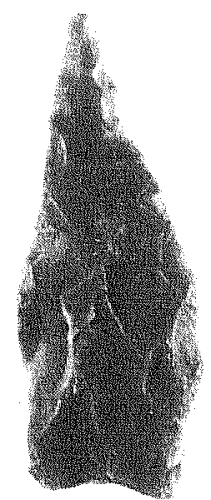

0

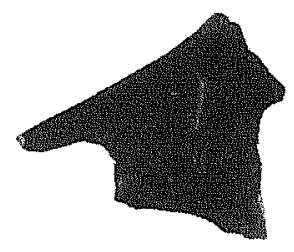

u

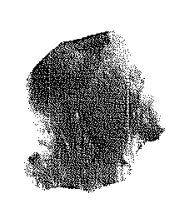

d
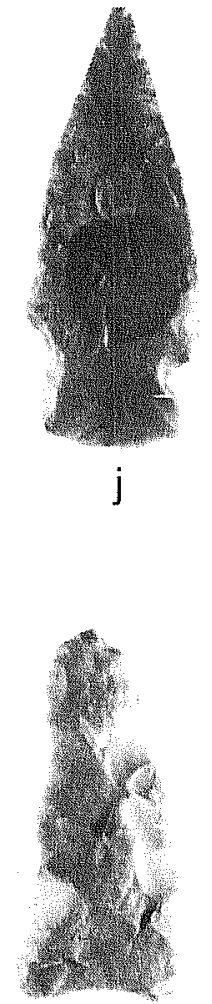

$\mathrm{p}$
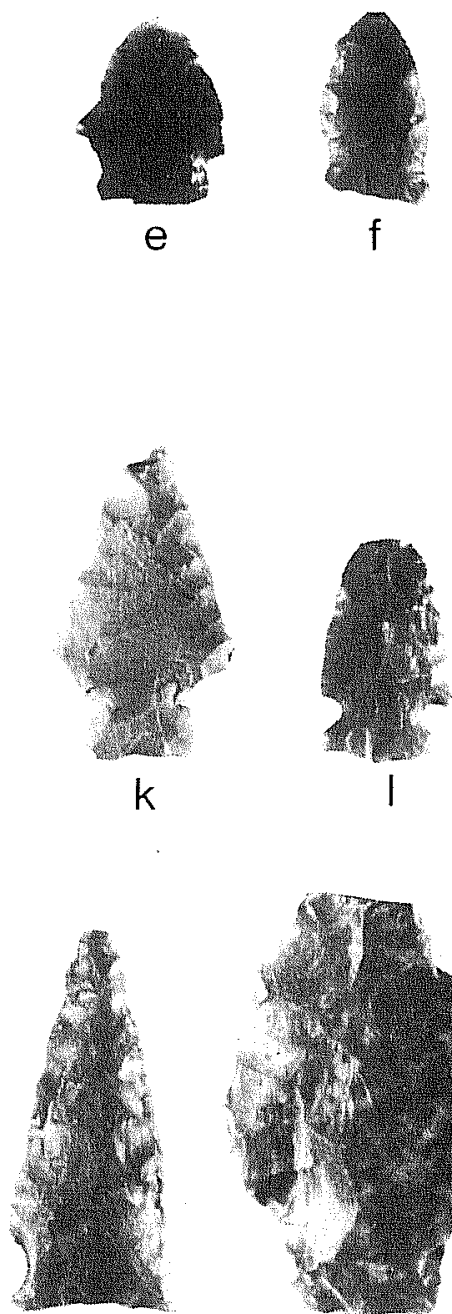

q

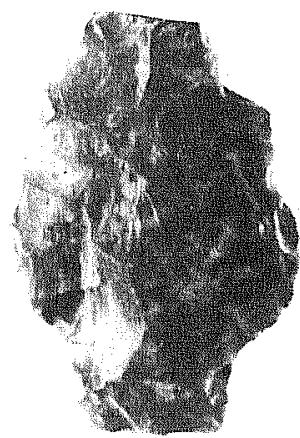

$r$

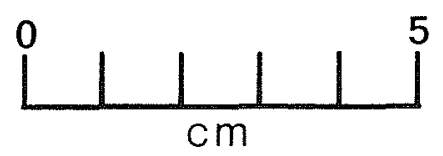

Figure 50. Dart Points. a, Uvalde; b-f, Zavala; miscellaneous dart points: g, Form 1 ; $h$, Form 2; $i$, Form 3; $j$, Form $4 ; k$, Form 5 ; 1 , Form 6; $m$, Form 7; $n, 0$, Form 8; , Form 9; q, Form 10; r, Form 11; s-w, unidentifiable fragments. 
Zavala (five specimens; Fig. 50,b-f)

Description: The five specimens are very short, broad-bladed specimens with irregular to triangular-shaped outlines. The specimens are not barbed, but are shallowly side notched. The bases are either convex or straight.

Dimensions: L: (20)-25; W: 15-20; T: 4-6; SW: 14-19; NW: 11-15.

Distribution: 41 UV 48 (five).

Comments: The Zavala dart point is generally considered by the author as a weak typological grouping, because it shows both arrow and dart point attributes (cf. Montgomery 1978:77; see also Turner and Hester 1985). In this report the placement within the dart point category is based upon arrow and dart point neck width comparisons within the project collection. Neck widths for dart points ranged from $10 \mathrm{~mm}$ (see Ensor Variety 2) to $28 \mathrm{~mm}$ (La Jita); arrow point neck widths ranged from $4 \mathrm{~mm}$ to $12 \mathrm{~mm}$ (corner-notched preforms), Montgomery (1978:77) designates the Zavala type as a Late Prehistoric and Late Archaic time marker.

\section{Misce1laneous Dart Points (12 specimens)}

Eleven forms are $\mathrm{placed}$ within a miscellaneous category; they represent aberrant or untyped dart points. Each form is briefly discussed.

Form 1 (one specimen; Fig. 50,g)

Description: A small, narrow triangular specimen that is shouldered with an extremely long base that expands slightly. The form is vaguely reminiscent of a Langtry dart point.

Dimensions: L: $41 ; \mathrm{W}: 19 ; \mathrm{T}: 7$.

Distribution: 41 UV 48.

Form 2 (one specimen; Fig. 50,h)

Description: This specimen is represented by the proximal section of what may be a small Marcos. Basal notches form an expanding stem with a straight base. The specimen is heavily patinated.

Dimensions: L: (21); W: (29); T: 4; NW: 10; SL: 8.

Distribution: 41 UV 47.

Form 3 (one specimen; Fig. $50, i$ )

Description: This specimen has side notches and an irregular base. 
Dimensions: L: 43; W: 19; T: 3; SL: 12; SW: 18; NW: 13.

Distribution: 41 UV 47.

Form 4 (one specimen; Fig. 50,j)

Description: This specimen has a long, narrow subtriangular outline with convex blade edges and base, and a broad slightly expanding stem.

Dimensions: L: 57;W: 23; T: 6; SL: 10; SW: 19; NW: 17.

Distribution: 41 UV 47.

Form 5 (one specimen; Fig. $50, \mathrm{k}$ )

Description: This specimen has a triangular outline with an expanded stem and a concave base.

Dimensions: L:(42); W:(24); T: 6; SL: 11; SW: 14; NW: 13.

Distribution: 41 UV 45.

Form 6 (one specimen; Fig. 50,1)

Description: This specimen is ovate to subtriangular with narrow and shallow side notches and an expanding stem with a convex base.

Dimensions: L: (29); W: (18); T: 6; SL: 12; SW: 15; NW: 11.

Distribution: 41 UV 48.

Form 7 (one specimen; Fig. $50, \mathrm{~m}$ )

Description: This triangular specimen has an irregularly shaped hafting element, and the base is concave.

Dimensions: L: (46); W: (22); T: 8; SL: 15; SW: 18; NW: 17.

Distribution: 41 UV 48.

Form 8 (two specimens; Fig. $50, n, 0$ )

Description: Both specimens have long, narrow, and "canted" triangular outlines, straight blade edges, and concave bases. Both show very slight alternate beveling on either expanding or parallel-sided stems.

Dimensions: L: 60-(61); W: 24-28; T: 6-8; SW: 21-26; NW: 21-26. 
Distribution: 41 UV 47 (one), 41 UV 48 (one).

Form 9 (one specimen; Fig. 50,p)

Description: This specimen with a triangular outline and a concave base is roughly worked with a relatively thick cross section.

Dimensions: L: $48 ; W: 22 ; T: 7$.

Distribution: 41 UV 45.

Form 10 (one specimen; Fig. 50,q)

Description: This specimen has a triangular outline; the blades are straight, and the base is concave. There is a single, shallow side notch on one side of the specimen.

Dimensions: L: $50 ; W: 22 ; \mathrm{T}: 8$.

Distribution: 41 UV 48.

Form 11 (one specimen; Fig. 50,r)

Description: This specimen with a broad ovate to subtriangular outline is shouldered, and the blade edges are convex. The stem is slightly contracting, and the base is straight. The specimen is heavily patinated.

Dimensions: L: (55); W: 38; T: 8; SL: 14; SW: 21.

Distribution: 41 UV 43.

Unidentifiable Dart Point Fragments (28 specimens; Fig. 50,s-w)

Unidentifiable dart point fragments are characterized as badly damaged or incomplete specimens that cannot be assigned to any of the other dart point categories. Of the 28 specimens, one may be a fragment of a reworked Nolan, four specimens may be Pedernales stems, and nine specimens were probably small expanding stem dart points that are reminiscent of Transitional Late Archaic types. Ten of the specimens have relatively larger expanding stem hafting elements than the others.

Dimensions: minimum to maximum extent: (19)-(49).

Distribution: 41 UV 43 (one), 41 UV 45 (eight), 41 UV 47 (seven), 41 UV 48 (12). 


\section{OVERALL RETOUCH BIFACES (104 specimens)}

Overall retouch bifaces are those bifacial specimens that have retouching to the extent that both faces are completely (or nearly so) altered by secondary retouch resulting in relatively smooth faces and even edges. These forms resemble the thin bifaces and formal bifaces described in regional site reports.

Distally Beveled Tools (seven specimens)

Artifacts with distally beveled bifacial or unifacial ends are often referred to as gouges. Three different forms are recognized in the collection. Two of the forms have been previously typed as Clear Fork (Hester, Gilbow, and Albee 1973) and Guadalupe tools (Hester and Kohnitz 1975).

Clear Fork Tools (three specimens; Fig. 51,a-c)

Description: The specimens have subtriangular to triangular outlines with strongly plano-convex cross sections. Two of the specimens are unifacial; one is bifacial. The working faces of the distal ends of the specimens are straight edged or may be slightly convex. The working edge of the tool, measured at the center of the distal end, is either $50^{\circ}$ (two specimens) or $60^{\circ}$ (one specimen).

Dimensions: L: (31)-(75); W(2): 45-51; T: 17-19.

Distribution: 41 UV 45 (one), 41 UV 47 (one), 41 UV 48 (one).

Guadalupe Tool (one specimen; Fig. $51, \mathrm{~g}$ )

Description: This is a roughly shaped specimen with secondary retouch only on the distal end. The cross section is roughly triangular. A small amount of cortex is present on the dorsal surface of the specimen. The working edge angle, taken at the center of the distal end working face, is $55^{\circ}$.

Dimensions: L: 127; W: 41; T: 35.

Distribution: 41 UV 43.

Miscel1 aneous Forms (three specimens; Fig. 51,d-f)

Description: Specimen 1 (Fig. $51, d$ ) is made on a 1 arge, single facet platform interior flake. Only the distal end of the flake has been retouched. It was fashioned bifacially to create a convex working edge beveled towards the ventral face of the flake. It is widest and thickest at the working end. The working edge angle is $40^{\circ}$. Specimen 2 (Fig. 51,e) is bifacial; the working face may have been fashioned on the snapped end of a distal fragment of a biface. The beveled edge is convex with a measured working edge angle of $55^{\circ}$. Specimen 3 (Fig. $51, f$ ) is also bifacial and has 


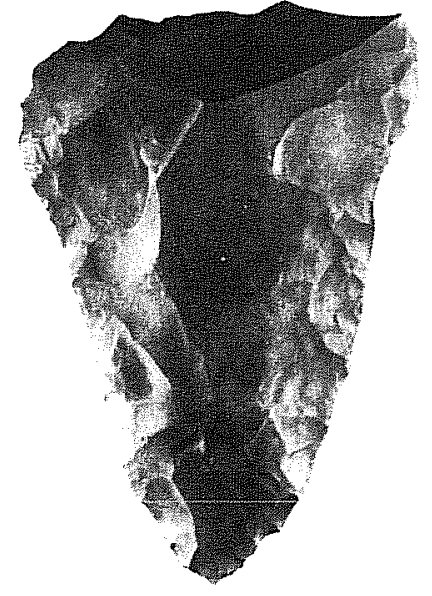

a

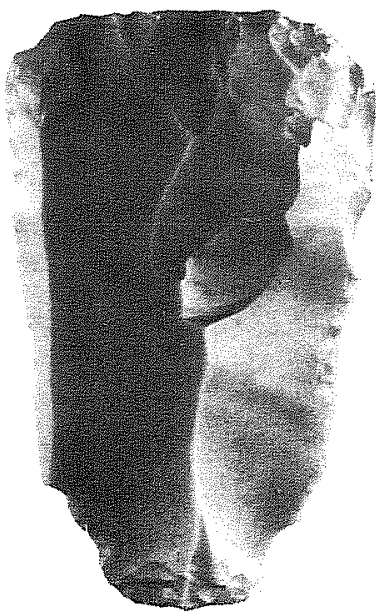

d
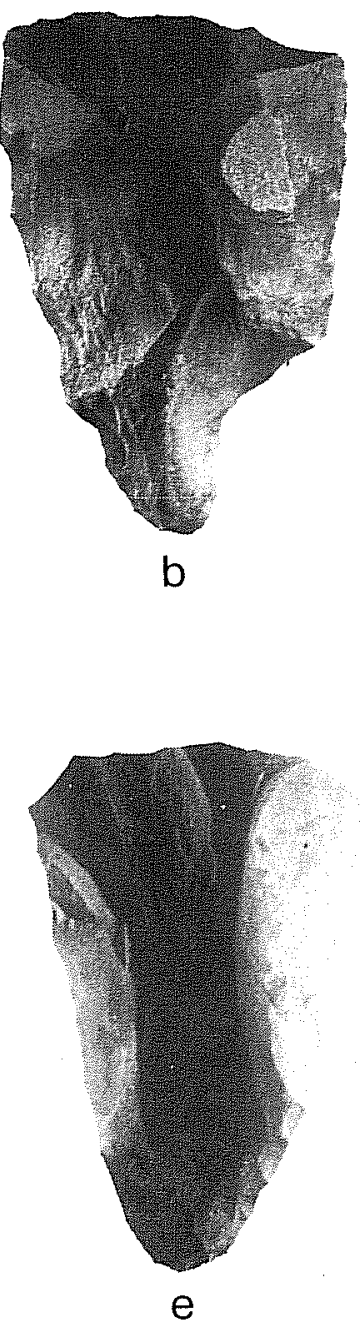

e

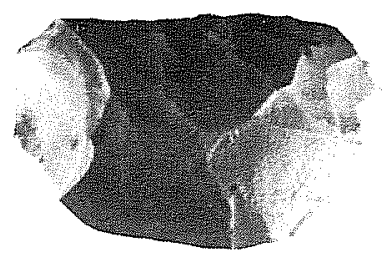

$\mathrm{C}$
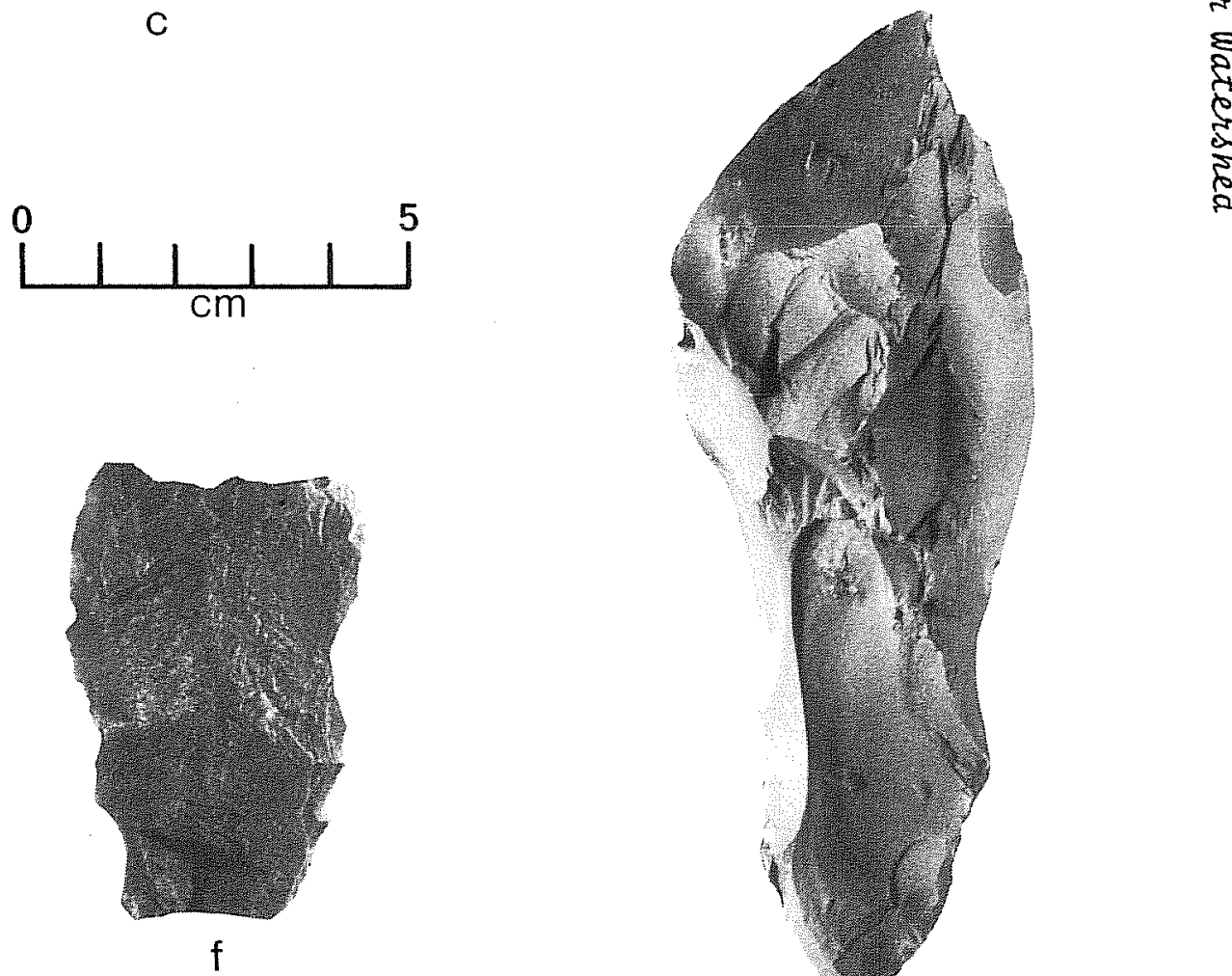

Figure 5l. Distal1y Beveled Tools. a-c, Clear Fork tools; d, miscellaneous form, Specimen 1; e, miscel1 aneous form. Specimen 2; f, miscellaneous form. Specimen 3; g, Guadalupe tool. 
a roughly rectangular outline, just slightly widest at the working end. The working face exhibits minute pronounced step fractures. The working edge angle was measured at $65^{\circ}$.

Dimensions: Specimen 1: L: 76; W: 48; T: 13. Specimen 2: L: 67; W: 44; T: 16. Specimen 3: L: 60;W: 51; T: 19.

Distribution: 41 UV 45 (Specimen 1), 41 UV 47 (Specimen 2 and 3).

Butted Bifaces (two specimens; Fig. 52, a,b)

Description: The specimens have subtriangular outlines and retain a cortex backed proximal end, intentionally providing a naturally shaped hand grip (Turner and Hester 1985). The blades are convex at the distal end. Specimen 1 is highly polished along both faces of the distal end, indicating extensive use as a cutting tool (Odel1 and Odel1-Vereeken 1980).

Dimensions: Specimen 1: L: 116; W: 78; T: 29. Specimen 2: L: 86; W: $72 ; \mathrm{T}: 22$.

Distribution: 41 UV 45 (Specimen 1), 41 UV 48 (Specimen 2).

Large, Pointed Ovates (six specimens; Fig. 52,c-h)

Description: The specimens have convex edges and pointed distal ends. A11 of the specimens show varying lengths of step fractures on some portion of the edge. The length of the individual specimens closely approximates twice the width. One specimen is plano-convex in cross section; the others are biconvex. Two of the surface finds from 41 UV 48 are patinated.

Dimensions: $L(5): 62-67 ; W(5): 29-37 ; \mathrm{T}: 9-12$.

Distribution: 41 UV 47 (one), 41 UV 48 (five).

\section{Large Triangulars (13 specimens)}

Large triangular specimens are subdivided according to basal edge shape: convex, straight, and concave.

Convex Base (four specimens; Fig. 53, a-d)

Description: Three of the specimens are broken near the distal end. The blades are straight and form distinct corners at the base. Blade length to width proportions indicate broad blades, ca. $70 \%$ to $90 \%$ of the total length of each artifact. Cross sections are biconvex in all but one specimen. One specimen is patinated.

Dimensions: L: (37)-(55); W: $30-48 ; \mathrm{T}: 8-10$. 

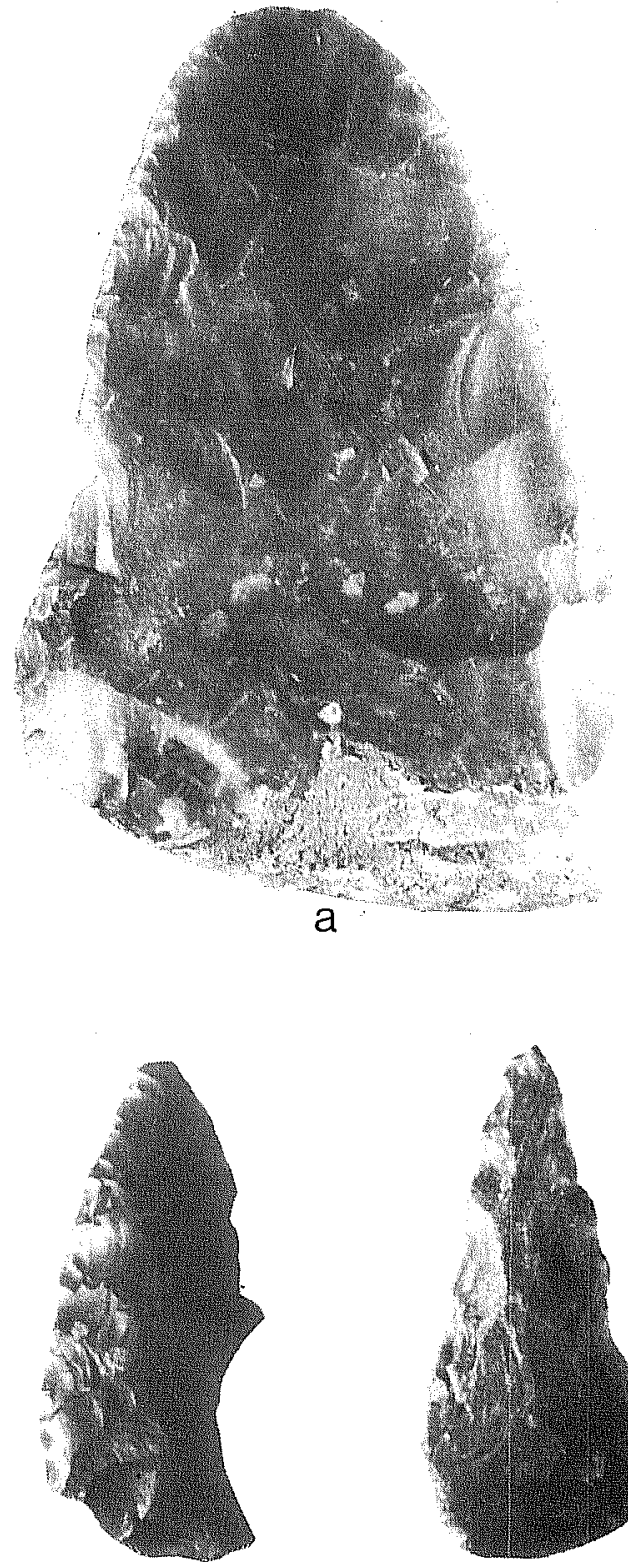

C

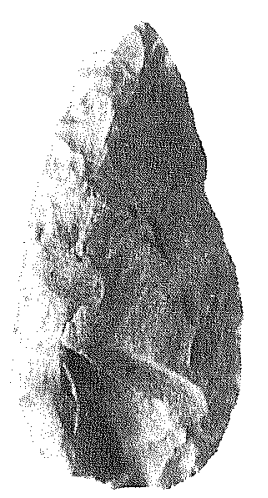

g

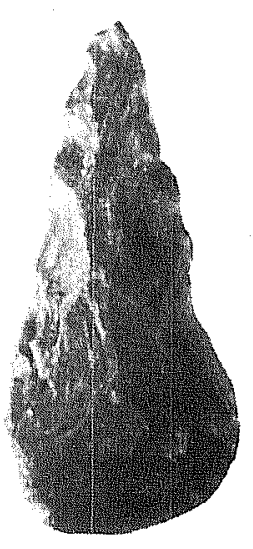

d

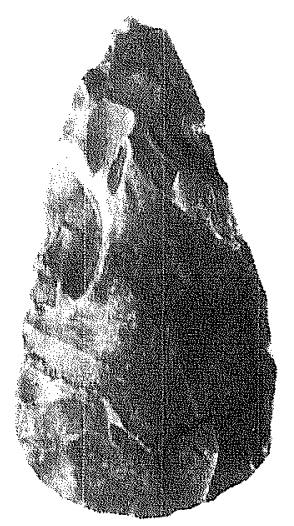

$\mathrm{h}$

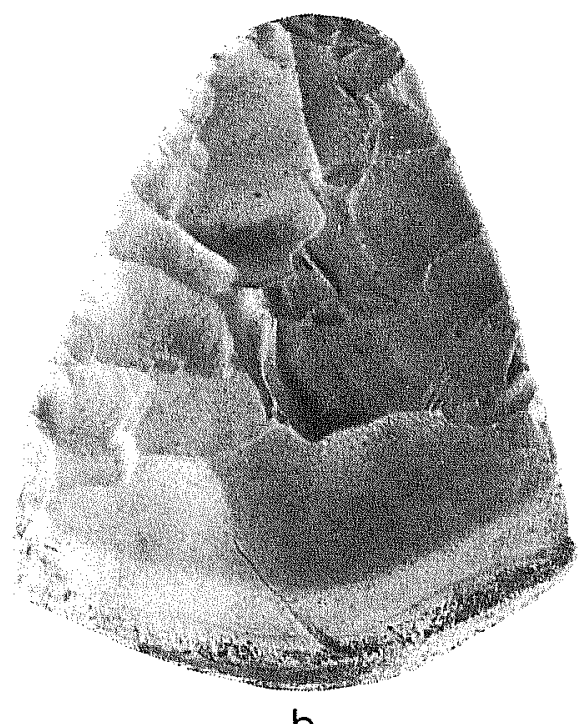

b

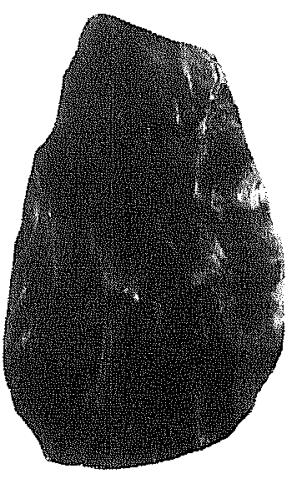

e
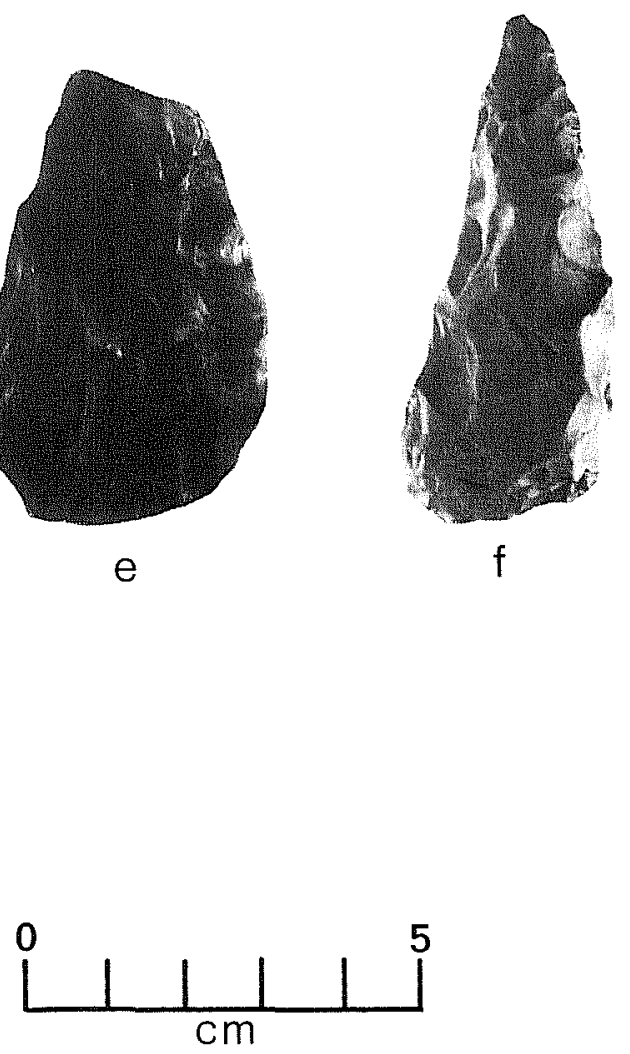

Figure 52. Overa11 Retouch Bifaces. a,b, butted bifaces; $c-h, 1$ large, pointed ovates. 


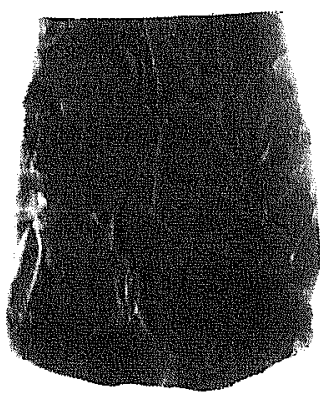

a

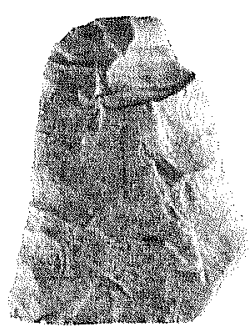

e

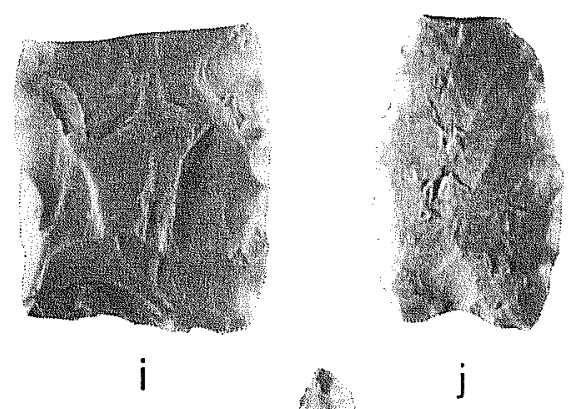

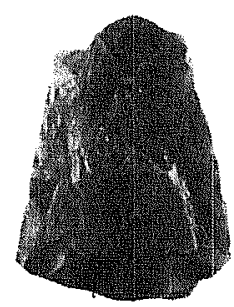

C

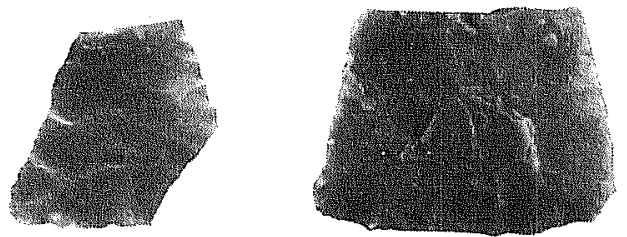

g
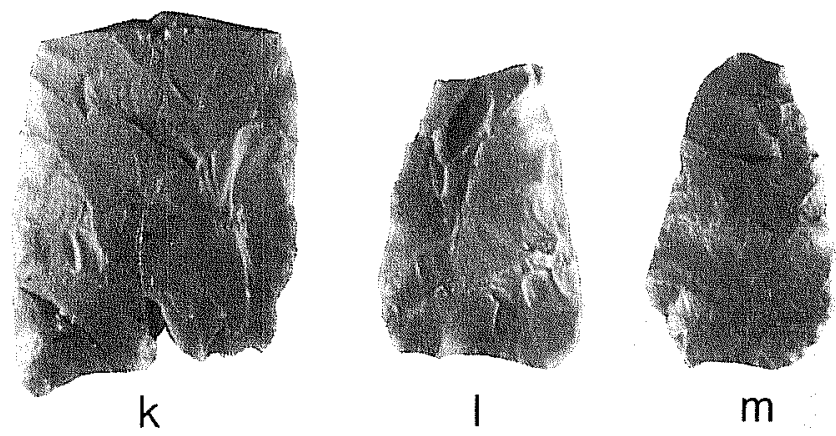

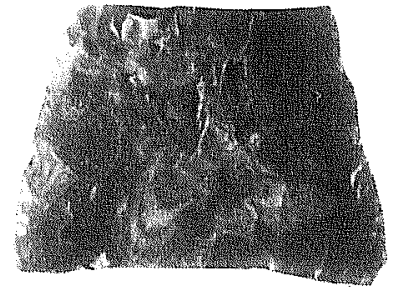

h d
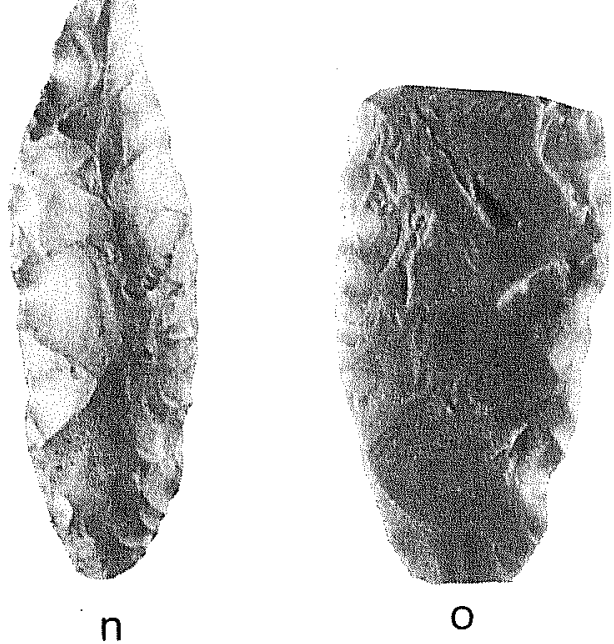

$\mathrm{n}$

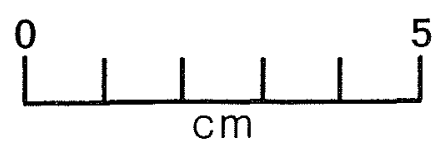

Figure 53. Overal1 Retouch Bifaces. Large Triangulars: a-d, convex based; e-g, straight based; h-m, concave based; Large Individual Forms: n. Form I; 0 , Form 2. 
Distribution: 41 UV 45 (one), 41 UV 48 (three).

Straight Base (three specimens; Fig. 53,e-g)

Description: All the specimens are distally snapped. All have simple triangular outlines with straight edges. The single specimen from 41 UV 48 has parallel flake scars on one face. One specimen from 41 UV 45 is patinated.

Dimensions: L: (28)-(40); W: (26)-39; T: 5-7.

Distribution: 41 UV 45 (two), 41 UV 48 (one).

Concave Base (six specimens; Fig. $53, \mathrm{~h}-\mathrm{m}$ )

Description: One specimen has straight blades; the remaining five specimens have convex blades. All of the specimens are distally broken and have biconvex cross sections. The bases are mildly convex. One specimen from 41 UV 45 is patinated.

Dimensions: L: (35)-(50); W: 25-48; T: 5-9.

Distribution: 41 UV 45 (two), 41 UV 47 (three), 41 UV 48 (one).

\section{Large Individual Forms (nine specimens)}

Nine individual forms were identified and are briefly described. They comprise approximately $9 \%$ of the overal1 retouch bifacial collection.

Form 1 (Fig. $53, n$ )

Description: This is a bipointed, leaf-shaped specimen with a pronounced plano-convex cross section.

Dimensions: L: 79; W: 24; T: 11.

Distribution: 41 UV 48.

Form 2 (Fig. 53,0)

Description: This is a distally broken specimen with pronounced convex blades and a small straight base.

Dimensions: L: (64); W: $35 ; \mathrm{T}: 8$.

Distribution: 41 UV 47. 
Form 3 (Fig. 54, a)

Description: The blades and base on this subtriangular specimen are slightly convex. There is a very small corner notch created by the removal of a single flake, but it is uncertain if the notch was intentional.

Dimensions: L: (36); W: $38 ; \mathrm{T}: 6$.

Distribution: 41 UV 47.

Form 4 (Fig. 54,b)

Description: This specimen has a long, narrow subtriangular outline, and the blades are slightly convex with well-formed corners. The base is straight and has been thinned. On the medial ridge of one side is an area of patinated flake scars that have been partially intruded upon by newer flake scars, indicating the specimen was reworked from an earlier, unidentified form.

Dimensions: L: $44 ; \mathrm{W}: 17 ; \mathrm{T}: 6$.

Distribution: 41 UV 47.

Form 5 (Fig. $54, \mathrm{C}$ )

Description: Form 5 has a subtriangular outline with slightly concave blades and rounded corners. The base is thinned and straight. The distal end is missing.

Dimensions: L: (44); W: $28 ; \mathrm{T}: 8$.

Distribution: 41 UV 48.

Form 6 (Fig. 54,d)

Description: The blades of this specimen are slightly convex towards the distal end (the distal end is missing). Near the base, the blades curve in sharply to form a convergent, pointed base.

Dimensions: L: (98); W: 74; T: 11.

Distribution: 41 UV 45.

Form 7 (Fig. 54,e)

Description: The specimen is complete with a nearly circular outline.

Dimensions: L: 46; W: $36 ; \mathrm{T}: 9$. 


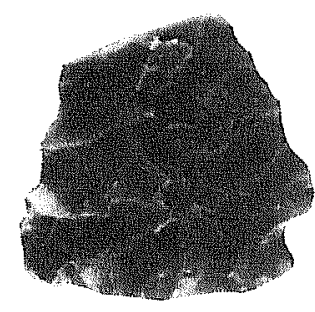

a
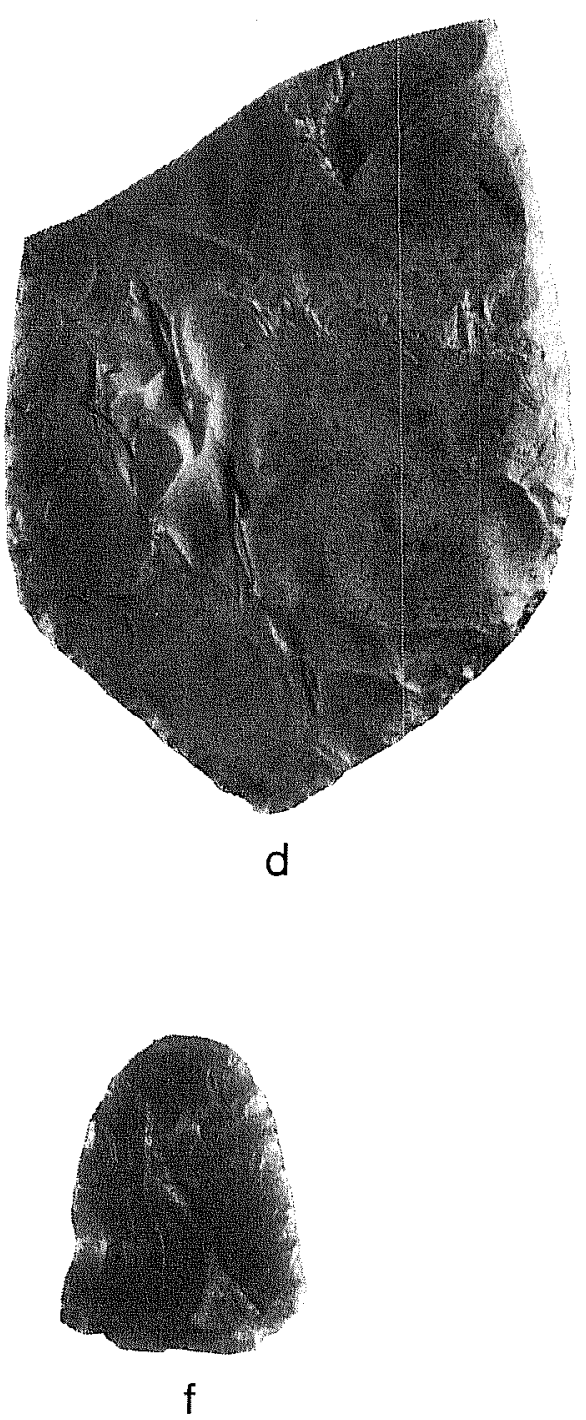

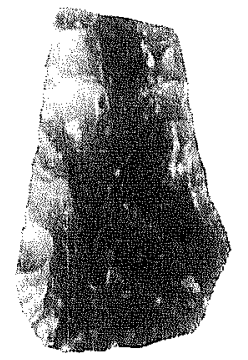

b

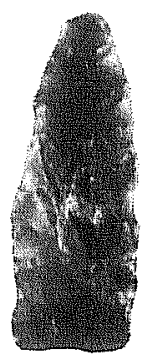

C
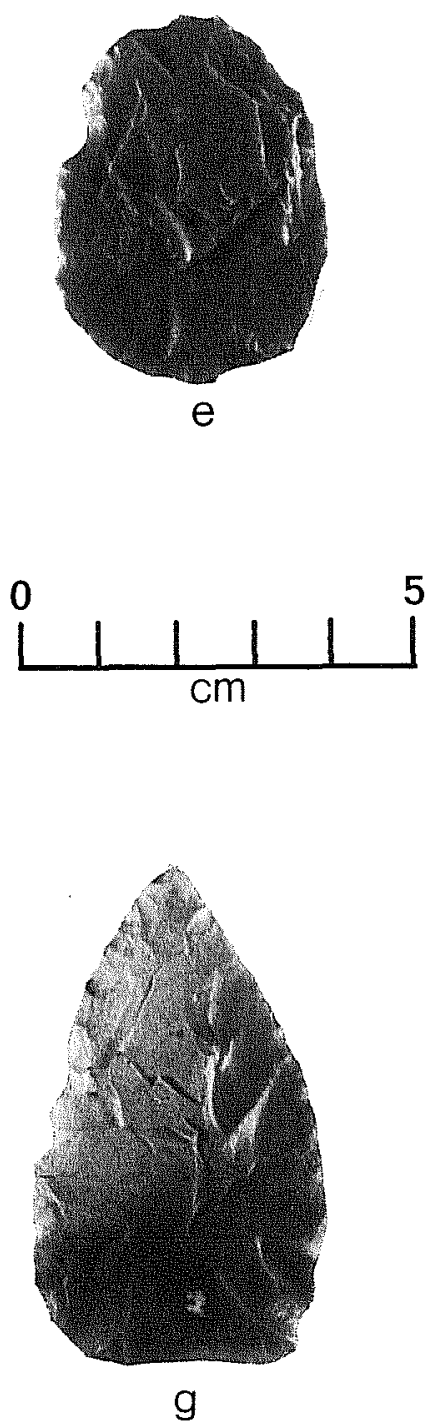

Figure 54. Overal1 Retouch Bifaces. Large Individual Forms: a, Form 3; b. Form 4; c, Form 5; d, Form 6; e, Form 7; f, Form 8; g, Form 9. 
Distribution: Surface collected from 41 UV 47.

Form 8 (Fig. 54,f)

Description: This specimen is apparently the distal end of a reworked artifact. The broken edge has been reworked to form a sinuous, irregular base. The distal end of the tool is convex and beveled by the removal of a series of small retouch flakes. The end is also noticeably dulled.

Dimensions: L: 41; W: $31 ; \mathrm{T}: 6$.

Distribution: 41 UV 48.

Form 9 (Fig. 54,g)

Description: The specimen has a broad, subtriangular outline with convex blades. The base is slightly ground and has a straight edge.

Dimensions: L: $64 ; \mathrm{W}: 38 ; \mathrm{T}: 7$.

Distribution: 41 UV 45.

Rounded Fragments (16 specimens; Fig. 55,a-h)

Description: Fragmentary, incomplete specimens that are convex bases or distal fragments of ovate or pointed ovate forms. Six of the specimens are complete enough in form to indicate they would have had elongated ovate outlines.

Dimensions: L: (29)-(72); W: (21)-(63); T: 5-11.

Distribution: 41 UV 45 (two), 41 UV 47 (five), 41 UV 48 (nine).

Large Miscellaneous Fragments (11 specimens; Fig. 55, $i-n$ )

Description: Amorphously or irregularly shaped specimens too fragmentary for further classification.

Dimensions: L: (32)-(95); W: 25-47; T: 5-12.

Distribution: 41 UV 43 (two), 41 UV 45 (three), 41 UV 47 (three), 41 UV 48 (three).

Sma11, Pointed 0vates (four specimens; Fig. 56,a-d)

Description: Three of the specimens have been shaped to form a fine, needlesharp point. The blade edges on the specimens are straight or convex. One of the specimens from 41 UV 47 has been reworked on both faces from an 


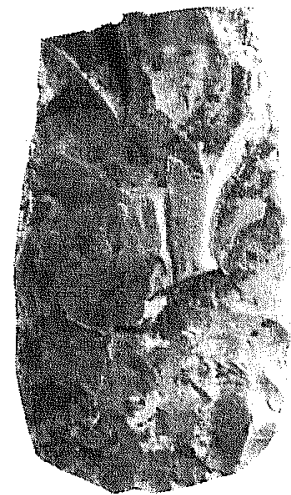

a
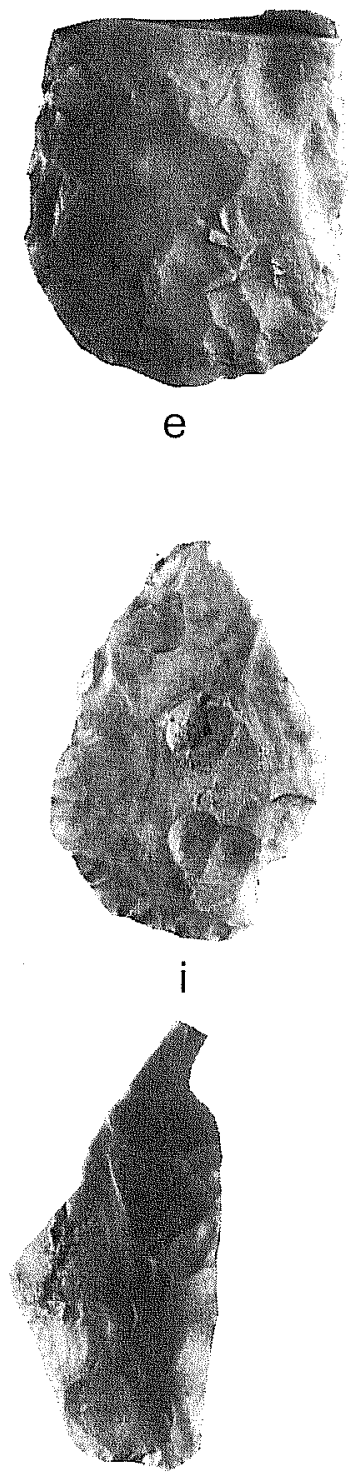

$\mathrm{m}$

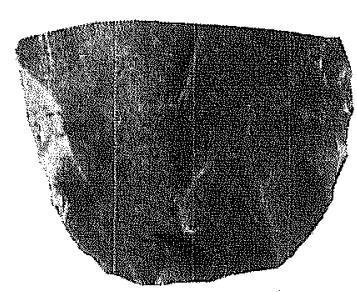

b
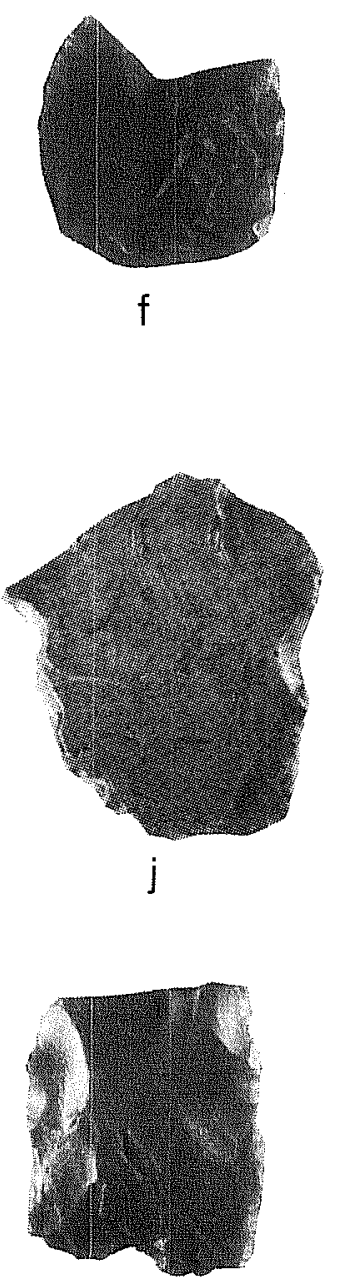

n

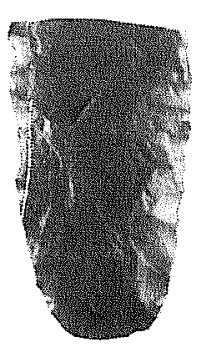

C
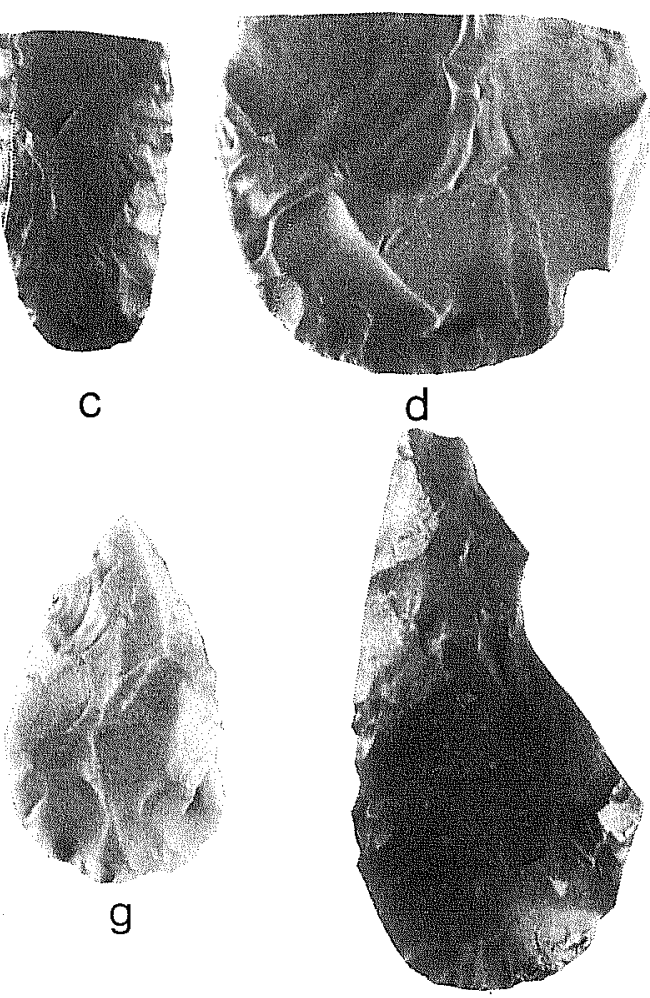

$\mathrm{h}$
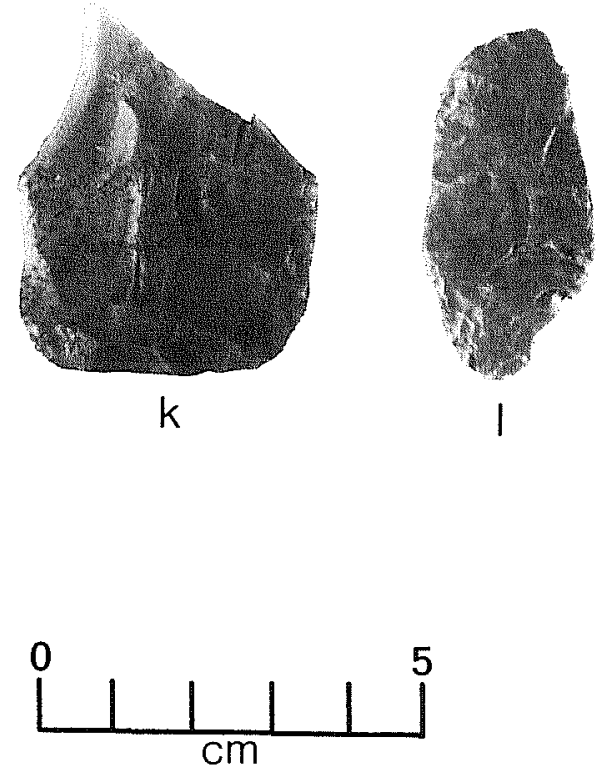

Figure 55. Overa11 Retouch Bifaces. a-h, rounded fragments; $i-n$, 1 arge misce 11 aneous fragments. 


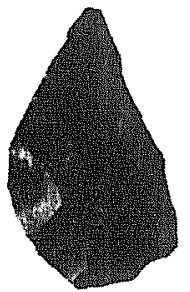

a

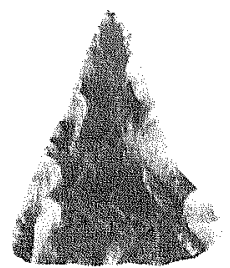

h

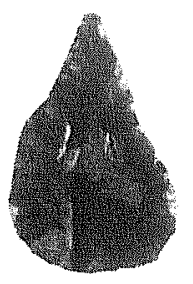

b

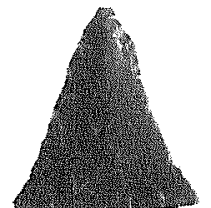

i

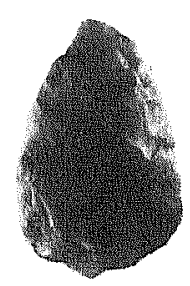

C

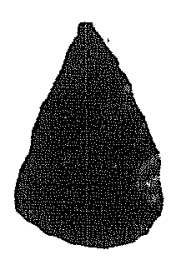

d

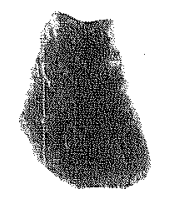

e

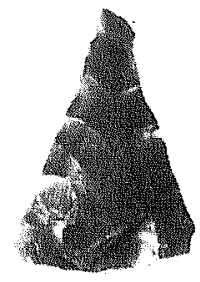

$f$

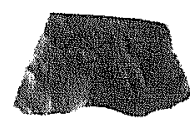

m

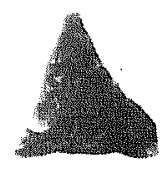

g

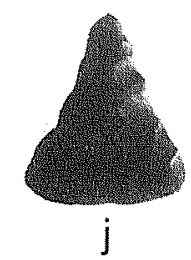

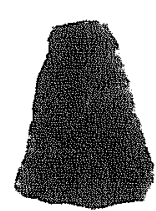

$\mathrm{k}$

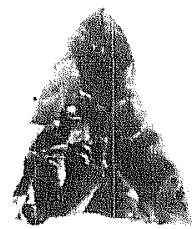

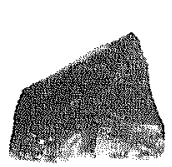

q

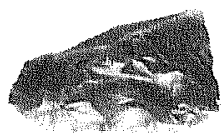

$\mathrm{x}$

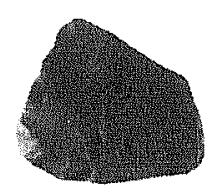

$r$

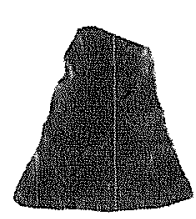

$\mathrm{S}$

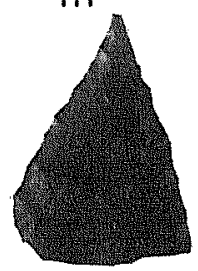

t

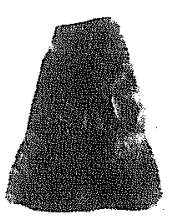

$a^{\prime}$

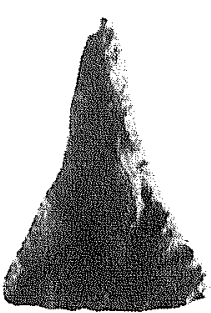

$n$

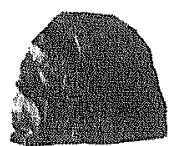

v

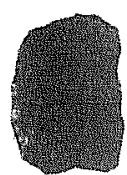

$C^{\prime}$

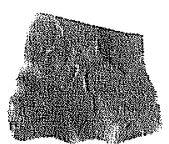

w

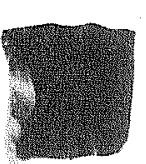

$d^{\prime}$

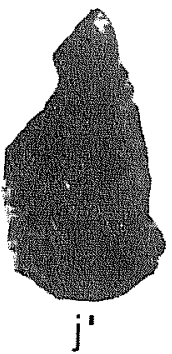

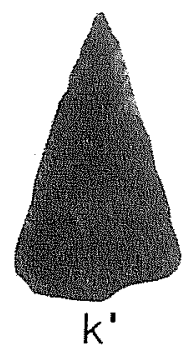

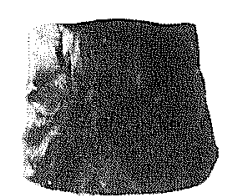

$e^{r}$
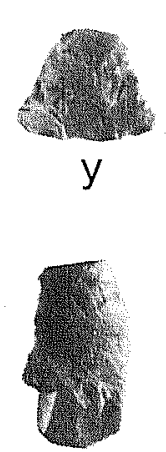

$f^{\prime}$

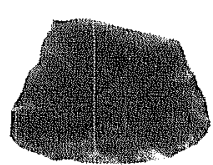

Z

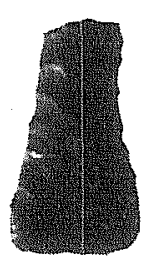

$g^{\prime \prime}$

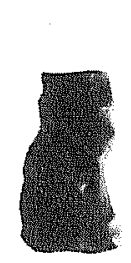

$h^{\prime}$

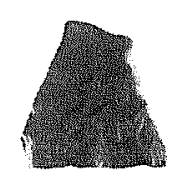

u
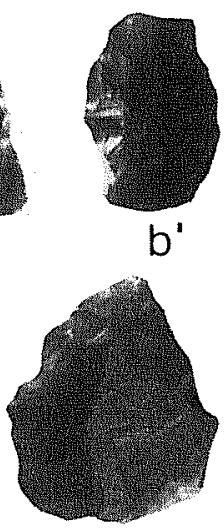

i'

Figure 56. Overal1 Retouch Bifaces. a-d, sma11, pointed ovates; e-b', sma11 triangulars; cl- 1 ', sma 11 misce 11 aneous forms. 
earlier patinated bifacial form. All specimens have a proportionally broader blade than do the large, pointed ovate forms described previousiy; the sma17pointed ovates have blade widths consistently approximating two-thirds the total blade length.

Dimensions: L: $30-36 ; \mathrm{W}: \quad 20-22 ; \mathrm{T}: 5-7$.

Distribution: 41 UV 47 (three), 41 UV 48 (one).

Small Triangulars (25 specimens; Fig. 56,e-b')

Description: The distinctive characteristic of these broad subtriangular forms is the basal element. The bases may be concave (33\% of all cases), straight, or very slightly convex. No hafting element is indicated, but all of the specimens flare outward at the broadest point along the blade, forming sharp, well-defined corners with the base. of 10 complete specimens measured, none of the blade widths were less than two-thirds the length, and on one specimen, the width exceeded the blade length. Blade edges are almost always recurved, but a few specimens have straight or slightly concave blade edges. Distal ends, when present, are always sharp. Cross sections may be plano-convex or biconvex.

Dimensions: $L(10): 20-38 ; W(22): 18-27 ; \mathrm{T}(26): 3-6$.

Distribution: 41 UV 45 (one), 41 UV 47 (six), 41 UV 48 (18).

Comments: The sma11, pointed ovates may represent knives, arrow point blanks, or perhaps finished arrow point forms. Based on a sample of 15 excavated specimens from Area A at site 41 UV 48, this form appears to stratigraphically predate the typed arrow point forms from the site, thus tending to argue against the hypothesis that they may be preforms for arrow points. Somewhat similar specimens noted at other sites are the triangular arrow point, Form 1 (Hester 1971); Granbury, bono variety from the Kyle site (Jelks 1962), and the Fresno type (Suhm, Krieger, and Jelks 1954). However, Hester's triangular arrow point, Form 1 seems to be too large (40-43 mm), and both the Granbury and Fresno types are narrower (ca. 10-20 mm) than the specimens described here.

Smal1 Miscellaneous Forms (11 specimens; Fig. $56, c^{\prime}-1^{\prime}$ )

Description: Fragmentary or irregular specimens without any substantial similarity in form. A variety of blade and basal edges occur. Seven bases are convex; two bases are straight, and one is concave.

Dimensions: L: (14)-38; W: (13)-28; T: 4-7.

Distribution: 41 UV 47 , (four), 41 UV 48 (seven). 


\section{BIFACIALLY RETOUCHED FLAKES (123 specimens)}

Bifacially retouched flakes have been marginally retouched on one or both faces in such a manner that the interior portion of at least one face remains relatively unaltered from its original form. The unaltered portion of the specimen has a flat, smooth surface that is easily recognized as the ventral surface of a flake, thus indicating the specimen was made from a flake detached from a core. The bifacially retouched flakes are divided into ten forms. A distinction is drawn between large and small specimens, the latter a) ways under $4 \mathrm{~cm}$ in length.

Large, Pointed Ovates (18 specimens; Fig. 57,a-m)

Description: A11 specimens have convex blade edges and bases. The maximum blade width is one-half to four-fifths of the blade length. The specimens are marginally retouched around the perimeter of the flake. Compression rings were noted, although no bulbs of percussion were seen. The cross section on all of the specimens is plano-convex. Several of the specimens were made on strongly curved flakes. Four specimens have some cortex remaining on the dorsal face.

Dimensions: $L(16): 41-70 ; W(16): 23-43 ; T: 5-15$.

Distribution: 41 UV 45 (three), 41 UV 47 (six), 41 UV 48 (nine).

Comments: Large, pointed ovates resemble roughly shaped blanks, or they may be expediency tools. The Cleborne type, defined by Jelks (1962), has similar measurements but the flake characteristics are not given.

Large Ovates (two specimens; Fig. $57, n, 0$ )

Description: Both specimens are marginally retouched around the perimeter, and percussion bulbs are absent. The largest specimen has cortex on its dorsal face, and more recent flake scars that cut into the patinated surfaces indicate it was reworked from an earlier form.

Dimensions: L: 53-63; W: 38-52; T: 9-18.

Distribution: 41 UV 47 (one), 41 UV 48 (one).

Large Triangulars (six specimens; Fig. 58,a-g)

Description: These specimens have rough triangular outlines with straight or very slightly convex blade edges, and the cross sections are plano-convex. A11 of the specimens are decorticate. Two specimens were reworked after they were patinated.

Dimensions: L: 42-64; W: 28-37; T: 6-14.

Distribution: 41 UV 45 (one), 41 UV 47 (one), 41 UV 48 (four). 


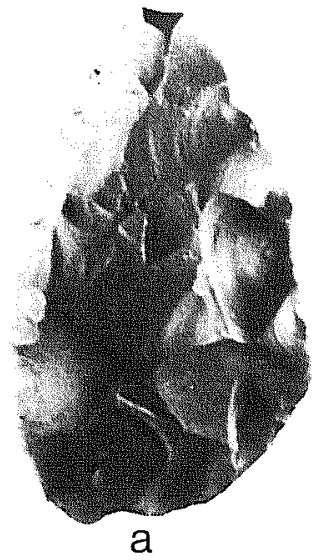

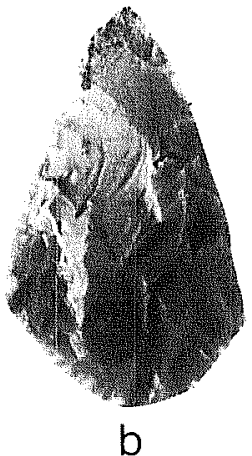

b

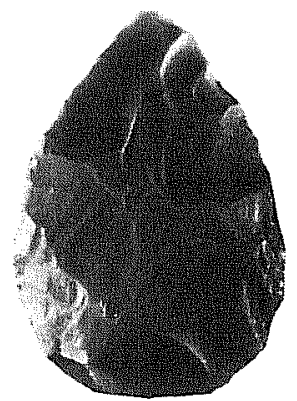

C

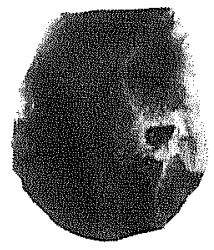

$\mathrm{h}$

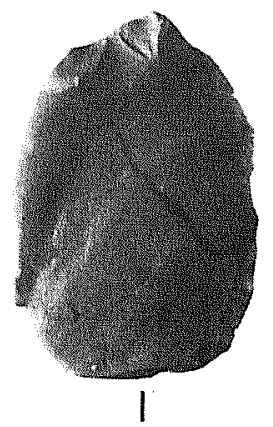

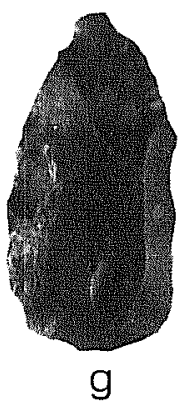
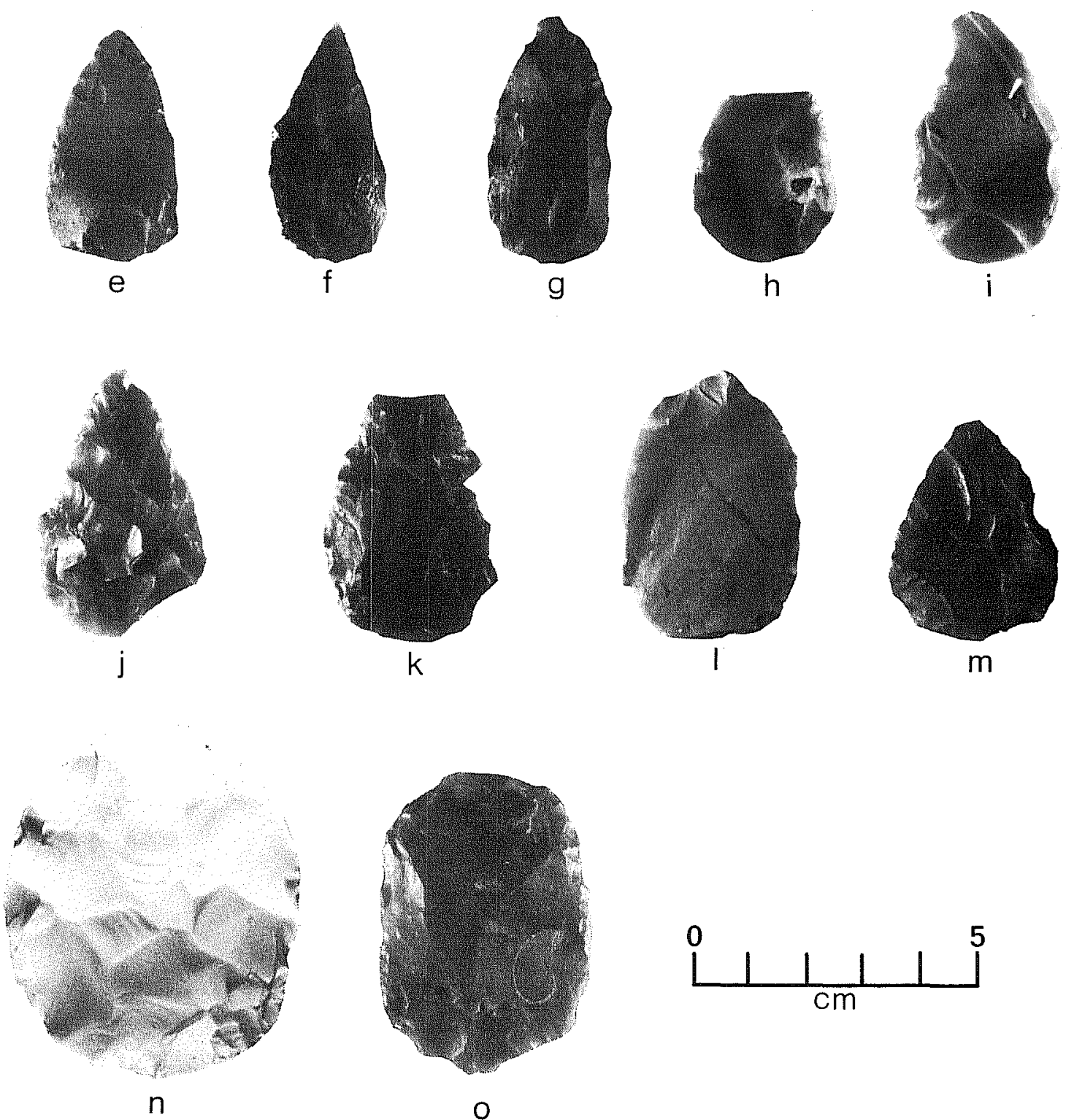

Figure 57. Bifacially Retouched Flakes. a-m, large, pointed ovates; n-o, 1 arge ovates. 


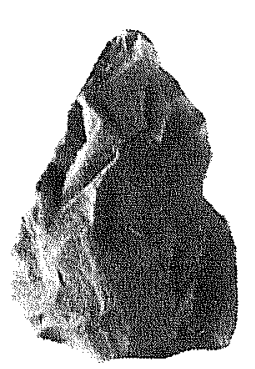

a
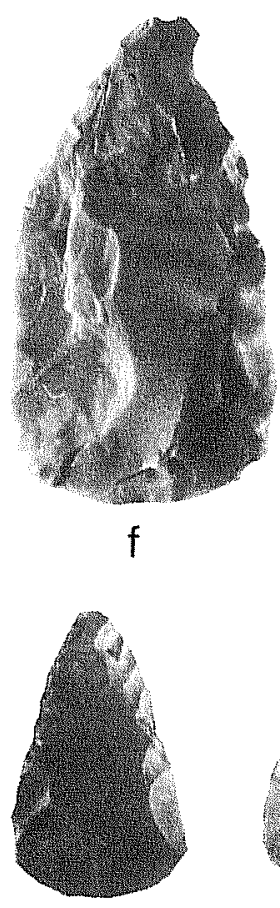

k

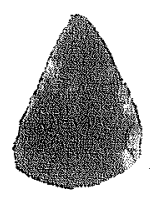

$r$

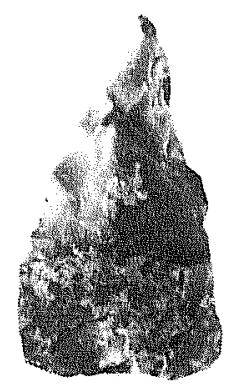

b

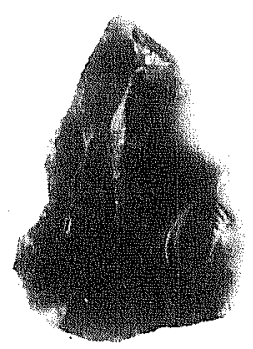

C

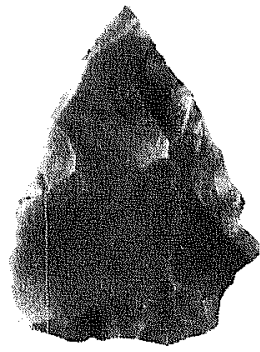

d

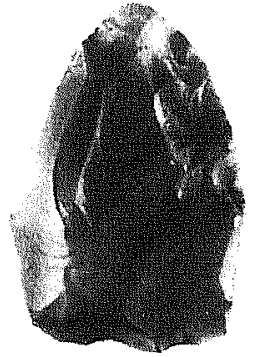

e

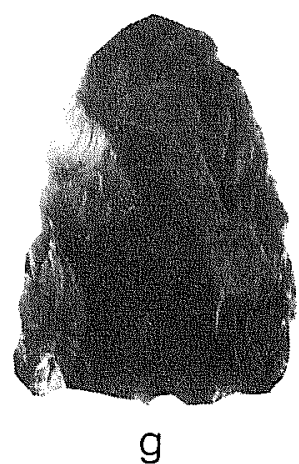

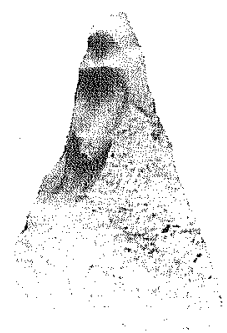

h
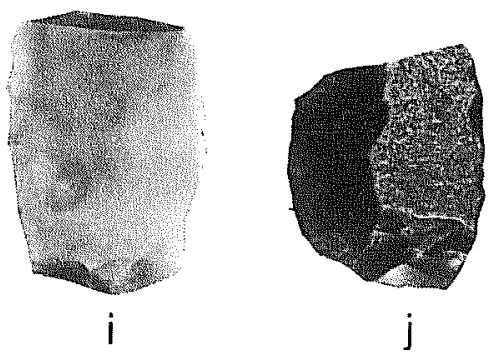

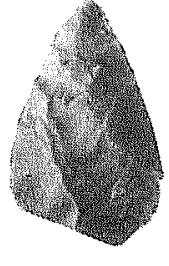

I

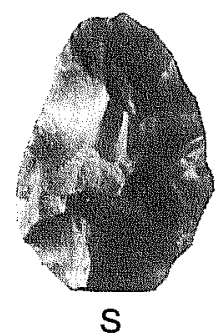

$\mathrm{S}$

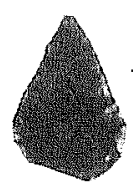

m

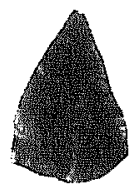

$\mathrm{n}$

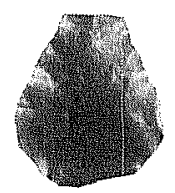

O

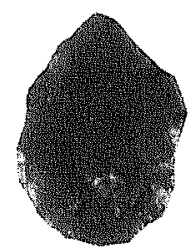

$\mathrm{p}$
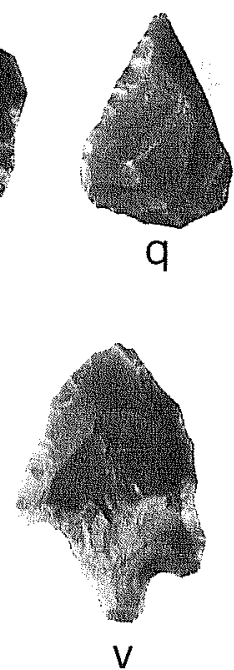
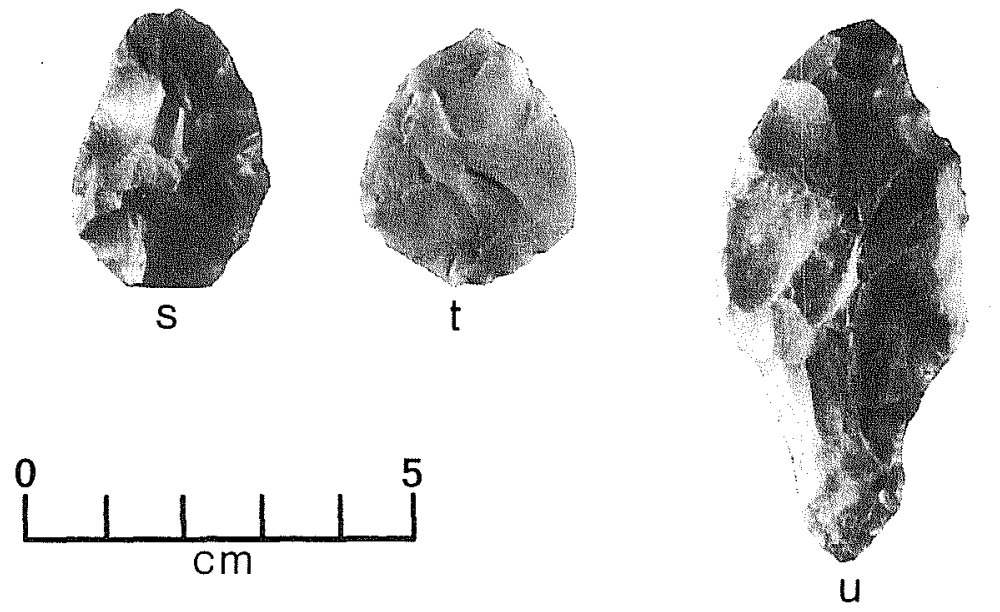

Figure 58. Bifacial1y Retouched Flakes. a-g, large triangulars; $h-j$, large fragments; $k-t$, smal 1 , pointed ovates; $u-v$, stemmed. 
Large Fragments (18 specimens; Fig. $58, h-j$ )

Description: Large fragments represent a variety of forms unsuitable for any other descriptive category. Placement in this category is partially based on the visual estimation of the original size. Six of the fragments exhibit dorsal face cortex.

Dimensions (to nearest $5 \mathrm{~mm}$ ): L: (15)-(65); W: 25-50; T: 7-24.

Distribution: 41 UV 45 (five), 41 UV 47 (six), 41 UV 48 (seven).

Sma11, Pointed Ovates (10 specimens; Fig. 58,k-t)

Description: All specimens have convex blade edges and bases. Maximum blade width is approximately three-fifths of the total length, and occurs at the point one-third or less from the base. All the specimens are marginally retouched to create even outlines with sharp distal ends. Six specimens are on curved flakes, and all have plano-convex cross sections. All are decorticate.

Dimensions: L: 21-37; W: 15-29; T: 2-10.

Distribution: 41 UV 47 (five), 41 UV 48 (five).

Comments: Sma11, pointed ovates are similar to the Young arrow point type description (Suhm and Jelks 1962), although the geographical distribution of Young seems to be east Texas. Jelks (1962:35) also reported similar specimens associated with the Austin focus at the kyle site, and a knife, Form III reported by Collins (1969:59) is similar.

Stemmed (two specimens; Fig. 58,u-v)

Description: The two specimens are crude contracting stem forms with convex edges. Both specimens are decorticate, and the larger specimen has been rechipped after it had patinated.

Dimensions: Specimen 1: L: $70 ; \mathrm{W}: 34 ; \mathrm{T}: 10$. Specimen 2: L: 36 ; W: $25 ; \mathrm{T}: 5$.

Distribution: 41 UV 48.

Small Triangulars (nine specimens; Fig. 59,a-i)

Description: Small triangulars have roughly triangular to subtriangular outlines with a variety of blade edge forms (convex, concave, straight). The bases are most commonly slightly convex (seven). Cortex is present on the dorsal face of three specimens.

Dimensions: $L(6): \quad 30-39 ; W: \quad 18-28 ; T: \quad 4-8$. 


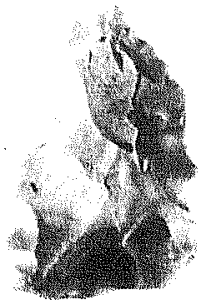

a

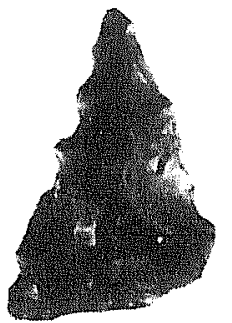

g

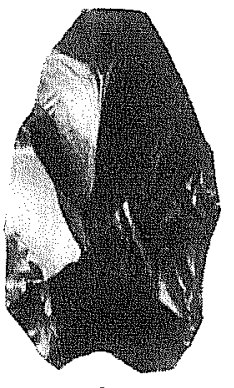

S

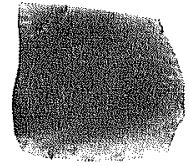

$n$

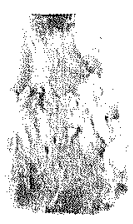

b

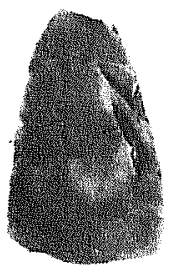

h

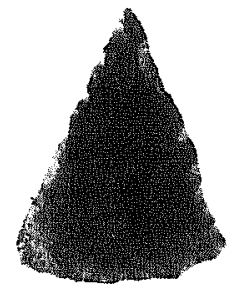

$\mathrm{C}$

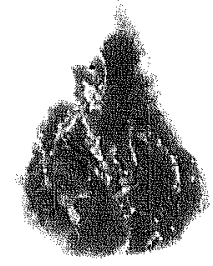

d
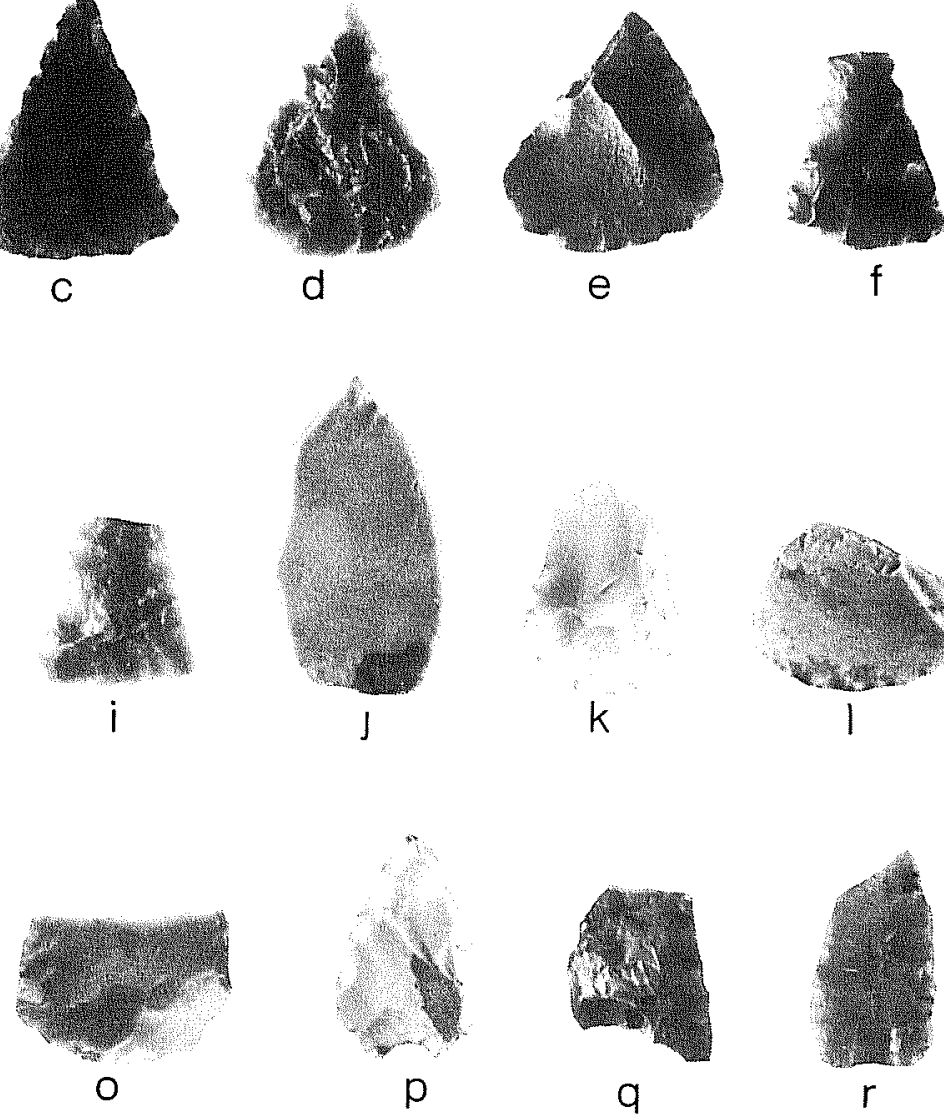

e
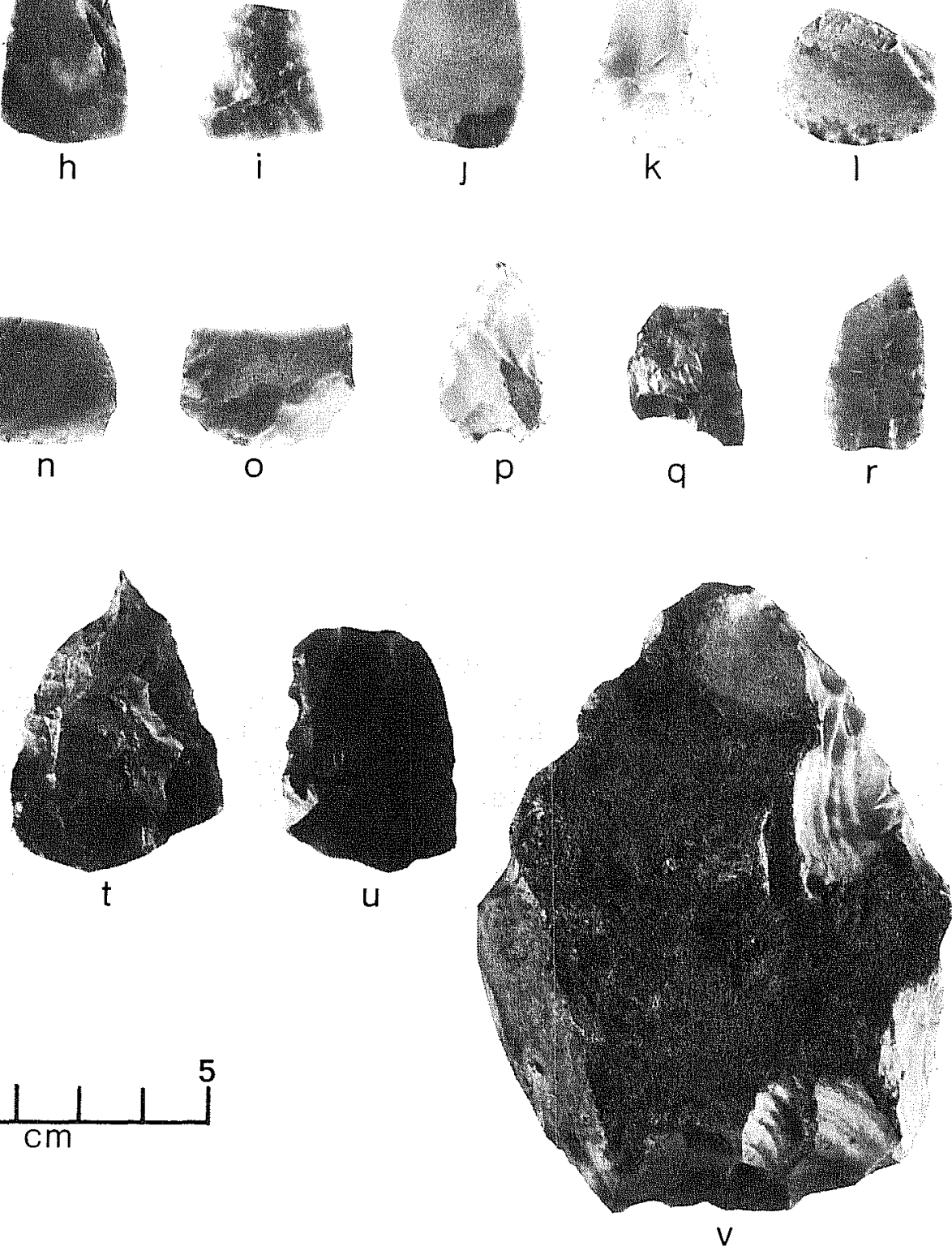

Figure 59. Bifacially Retouched Flakes. a-i, small triangulars; j-o, small fragments; $p-s$, concave based; $t-v$, amorphous. 
Distribution: 41 UV 45 (two), 41 UV 47 (two), 41 UV 48 (five).

Comments: The smal1 triangulars show considerable variation of form, and they do not appear to be flake specimens of the overall retouch biface category.

Sma11 Fragments (11 specimens; Fig. 59,j-0)

Description: Miscellaneous specimens too fragmentary to classify except by original size estimation and the presence of flake attributes. All of the specimens are decorticate.

Dimensions (to the nearest $5 \mathrm{~mm}$ ): L: (15)-(35); W: 20-30.

Distribution: 41 UV 45 (one), 41 UV 47 (two), 41 UV 48 (eight).

Concave Base (four specimens; Fig. 59,p-s)

Description: Three of the specimens are subovate in outline and have shallow, centrally placed notches on the base. The fourth specimen is a subtriangular form with straight blades and a broad concave base; this specimen somewhat resembles the Starr arrow point type. One specimen is corticate.

Dimensions: L: (21)-46; W: 17-27; T: 4-10.

Distribution: 41 UV 47 (two), 41 UV 48 (two).

Amorphous (43 specimens; Fig. 59,t-v)

Description: This category represents irregularly shaped, complete, or nearly complete forms. Some of the specimens have a single uniform edge suitable for use as a tool, but most exhibit little more than small areas of marginal bifacial retouch at discontinuous locations along the margins. Twenty-one percent of the specimens retain some portion of the striking platform; of these, seven are single facet platforms, two are small multifacet platforms, and one is a crushed platform. Forty-two percent retain some dorsal surface cortex. Six have patinated surfaces with more recent flake scars over the patination.

Dimensions (to nearest $5 \mathrm{~mm}$ ): L: 25-115; W: 20-80; T: 5-30.

Distribution: 41 UV 43 (two), 41 UV 45 (nine), 41 UV 47 (four), 41 UV 48 (28).

Comments: This category probably represents both expediency tool and manufacturing rejects. 
BIFACIAL INTERGRADES (208 specimens)

Bifacial intergrades are those bifaces formed by primary retouch only. Primary retouch is the initial series of percussion flake removals from an unshaped specimen; it is used to reduce or roughly shape the specimen and often leaves the piece with scalloped or extremely sinuous edges. Bifacial intergrades are similar to quarry blanks and thick bifaces described in other regional site reports.

Ovates (43 specimens; Fig. 60,a-d)

Description: The outline edge on bifacial intergrade ovates is often somewhat irregular because of the lack of secondary retouching. Cross sections vary from lenticular to biconvex; a few are plano-convex. The widest point of the specimens is most often near the middle of the long axis but may occur closer to one end. The largest individual specimens were recovered from 41 UV 43. Cortex is present on $23(53 \%)$ of the specimens.

Dimensions: L: 40-120; W: 30-70; T: 8-39.

Distribution: 41 UV 43 (20), 41 UV 45 (10), 41 UV 47 (six), 41 UV 48 (seven).

Pointed Ovates (34 specimens; Fig. 60,e-h)

Description: All the specimens have convex bases and pointed ends. Most of the blades have convex edges, but three specimens have colateral straight blades. Five specimens are widest at the midpoint and perpendicular to the long axis; the remaining specimens are widest near the base. Blade width is approximately one-half or more of the length. Fourteen specimens (41\%) are decorticate; $16(47 \%)$ specimens have cortex on one face or an edge, and one specimen, made on a cobble, has cortex on both faces. As was the case with ovate forms, the largest specimens were recovered from 41 UV 43.

Dimensions: L: 50-125; W: 26-75; T: 9-32.

Distribution: 41 UV 43 (14), 41 UV 45 (eight), 41 UV 47 (four), 41 UV 48 (eight).

Triangulars (20 specimens; Fig. 61,a-e)

Description: Roughly triangular specimens have blades generally one-half or more of their length. Eighty percent of the triangular specimens are decorticate, the highest percentage recorded for any of the bifacial intergrades. Also, the overall size range is smaller than in the other categories. Four of the specimens are patinated and have been rechipped after patination.

Dimensions: $L(19): 36-80 ; W: 22-44 ; T: 7-20$. 
248 Leona River Watershed
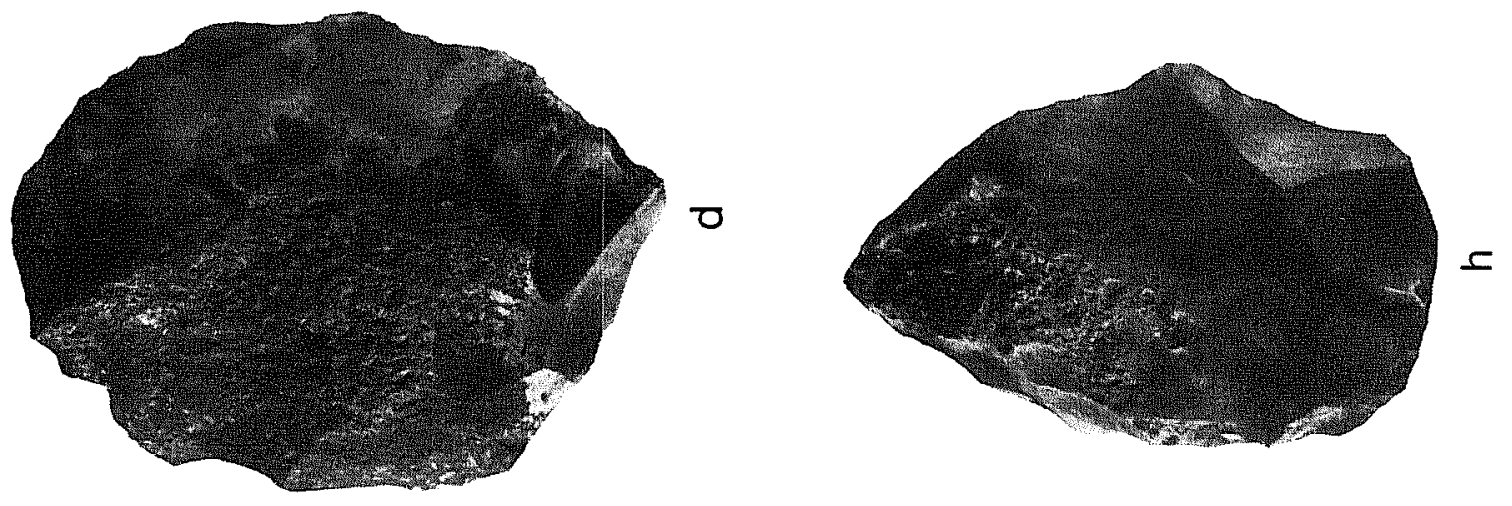

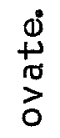

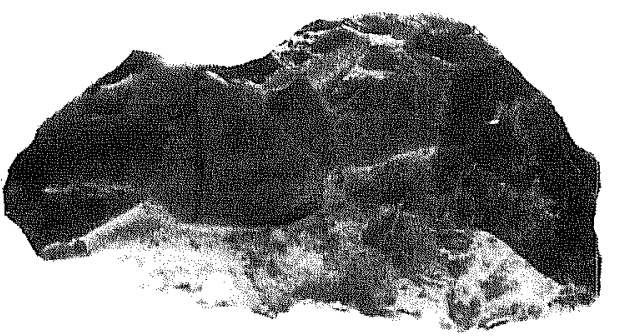

0

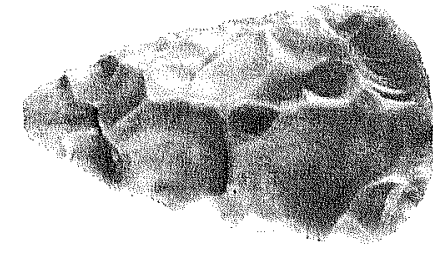

$\pi$
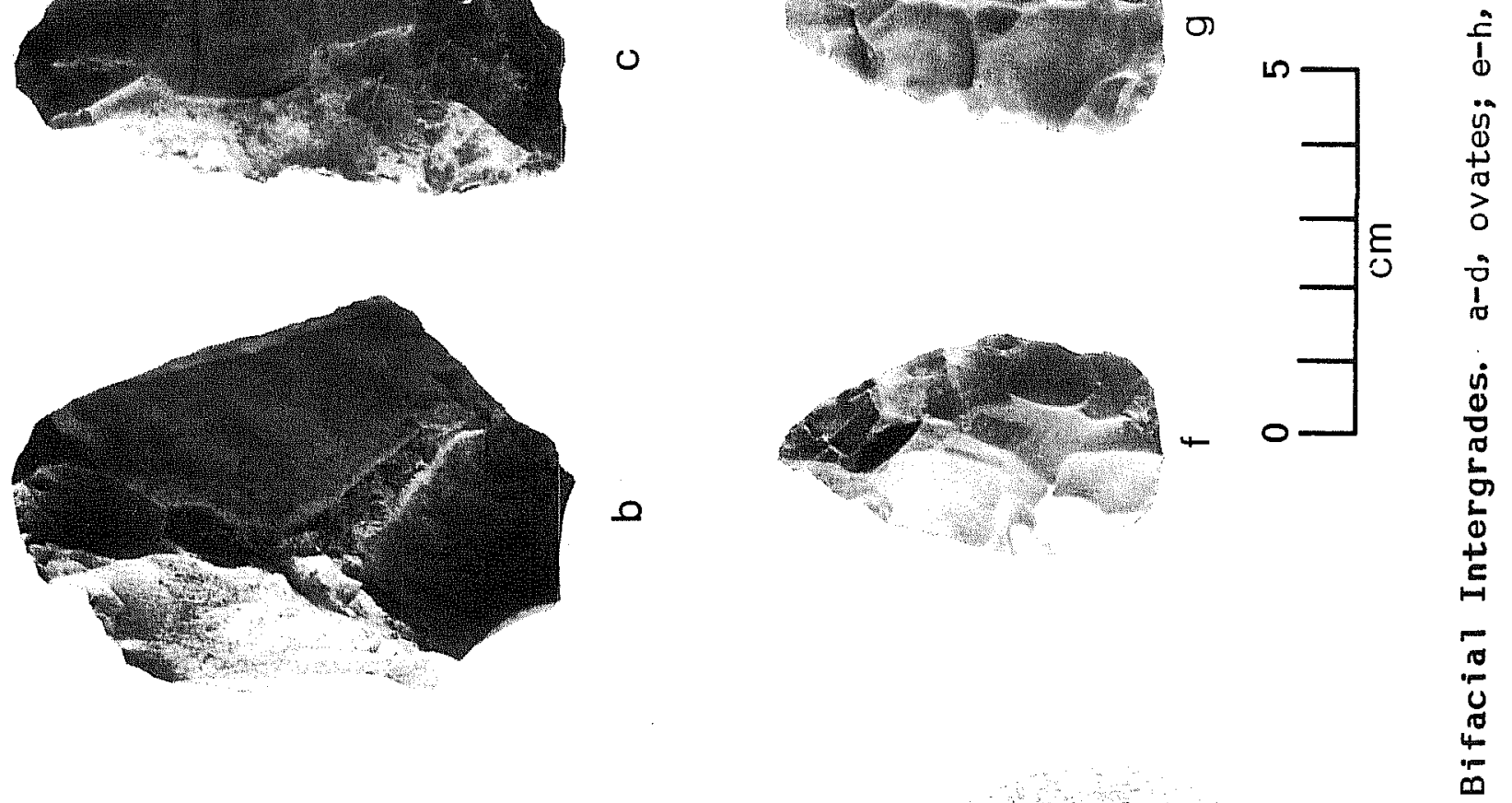

告
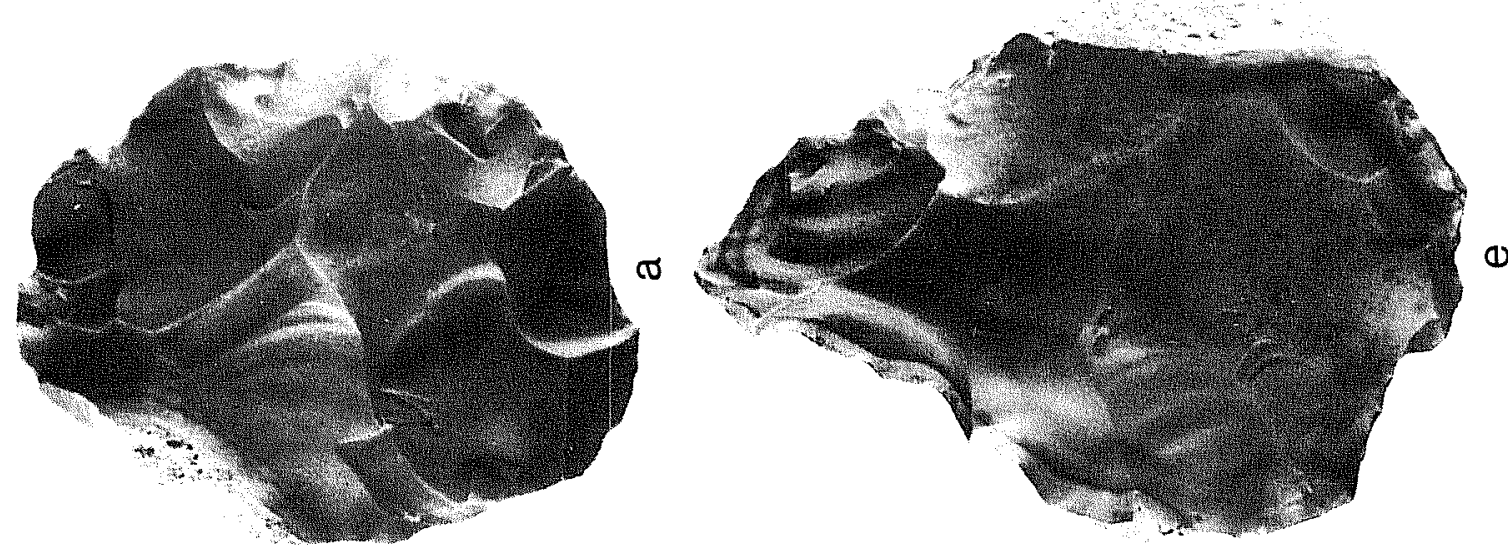

8

告 
arrow points of the Toyah phase total $22 \%$ of the Late Prehistoric diagnostics. The proposed Turtle Creek phase (Mitchel1 1978) is apparently represented by Edwards arrow point forms (18\% of the arrow points) In this report, Zavala dart point forms may be included in the Late Prehistoric assemblage, although their chronological positioning in relative chronologies is still in question (Montgomery 1978). The Late Prehistoric arrow point forms indicate utilization of the site occurred between A.D. 700 to as 7 ate as A.D. 1750.

Radiocarbon dates available from the Late Prehistoric midden in Area $A$ suggest a more restricted time span than is implied by using the relative chronologies presented by Prewitt (1981). The radiocarbon dates suggest the site's Late Prehistoric component was deposited between A.D. 1160 to A.D. 1390. This would place the major use of the site in the first of the Toyah phase and the last of the Austin phase.

Archaic dart points comprise $30 \%$ of the projectile point collection. of the 35 diagnostic dart points $54 \%$ are assigned to the Transitional Archaic Twin Sisters phase, $11 \%$ to the Late Archaic San Marcos phase, $29 \%$ to the Middle Archaic, and 6\% to the Early Archaic. However, no clearly definable Archaic subsurface components were encountered during the excavations. Feature 1 is suspected to represent an Archaic hearth, but a definite chronological placement for the feature was not possible.

\section{Site Nature and Extent}

Surface collections and subsurface excavations were utilized to determine the characteristics of the site's size and nature. In general, the surface concentrations of lithics were met by similar subsurface distributions throughout the site. The site covers an area estimated at $125,100 \mathrm{~m}^{2}$. Much of the site surface had low debitage densities of less than 14 items per $10 \mathrm{~m}^{2}$. Area $A$ was shown through surface collections and excavations to be the most significant concentration within the site. Deposits at the site were generally $60 \mathrm{~cm}$ or less in depth.

\section{Subsistence Strategies}

Hunting appears to be the most important subsistence strategy at the site. Faunal remains from the site were concentrated in the midden deposits of Area $A$, and reflect a wide range of food resources, primarily jackrabbit, cottontail rabbit, and deer. other food resources, common at other Late Prehistoric sites in the region, include freshwater mussel and possibly Rabdotus sp. gastropods. Plant food processing is indicated by the presence of grinding stones and handstones. Charcoal wood species identifications show that seed and nut-bearing trees such as pecan, walnut, and hackberry occurred at the site, and these probably represented an important food supply; although the only seeds recovered from these trees were a few hackberry seeds. 


\section{ARTIFACTS RECOVERED}

The artifacts described in this section are arrow points, dart points, overall retouch bifaces, bifacially retouched flakes, cores, debitage, other lithics, fired clay, and historic artifacts. Further subdivisions of the major artifactual groupings are presented for descriptive purposes.

The following abbreviations are used to indicate the measurements of the specimens: $L=$ length, $W=$ width,$T=$ thickness, $S L=$ stem length, $S W=$ stem width, and $N W=$ neck width. Al1 measurements are in millimeters unless otherwise noted. Numbers enclosed by parentheses indicate the measurements of incomplete or broken specimens. Additionally, the number enclosed in parentheses immediately following the abbreviations $L, W$, or $T$ indicates the actual number of specimens used is less than the total number of specimens in the category described. Using less than the total specimens in a given category was at times necessary in order to exclude damaged or otherwise unsuitable specimens that might not provide a size range that was representative of the overall dimensional characteristics of a group of artifacts. For example "L(5)" would indicate that the length of five specimens is included within the range that follows, but more than five specimens were present in the group described.

Finally, the number enclosed by parentheses and following the site numbers in the distribution statement indicates the quantity of that particular artifact form for each site. The specific provenience of individual specimens within each site can be found in the individual site reports in the main body of the text.

\section{ARROW POINTS (191 specimens)}

Arrow points are small (4 cm or less in length) bifacial projectile points that exhibit a distinct hafting element consisting of notches, expanding or contracting stems, etc., on the proximal end of the specimen.

Edwards (18 specimens; Fig. 43,a-r)

Description: Long narrow triangular form with straight blade edges, occasionally convex or serrated. Barbs may be slight to well formed. Narrow corner or side notches form the widely expanding stem. Neck widths may be broad to narrow. Stems flare outward, usually to equal the width of the blade, but may be much longer or shorter. The base is always concave, and this is considered to be a critical diagnostic attribute for this arrow point type. Specimens may be marginally retouched or overall retouched flakes.

Dimensions: $L(6): \quad 23-31 ; W(12):$ 13-17; T: 2-5; NW: 6-10; SW(7):10-13.

Distribution: 41 UV 45 (one), 41 UV 47 (three), 41 UV 48 (14).

Comments: The Edwards type has been defined by Sollberger (1978); Highley, Graves, and Judson (1978), Gerstle, Kelly, and Assad (1978), and Hester (1978b) also discuss the Edwards type. Hester (1971) and Mitchel1 (1978) 


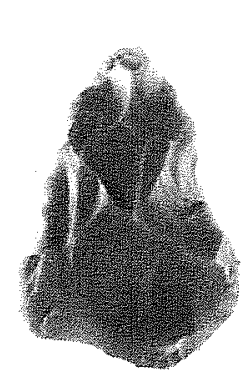

a
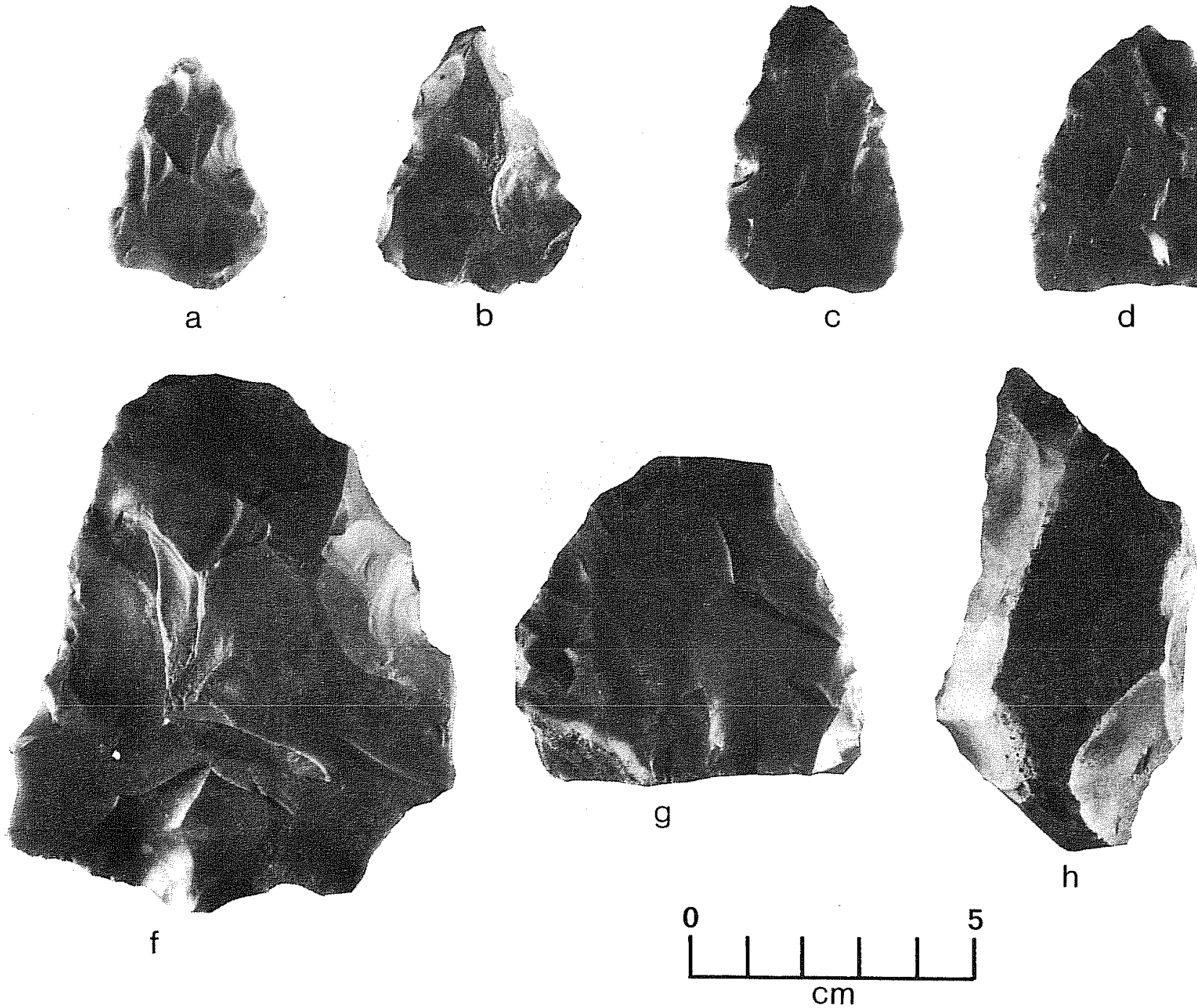

Figure 61. Bifacial Intergrades. a-e, triangulars; $f-i$, asymmetrical.
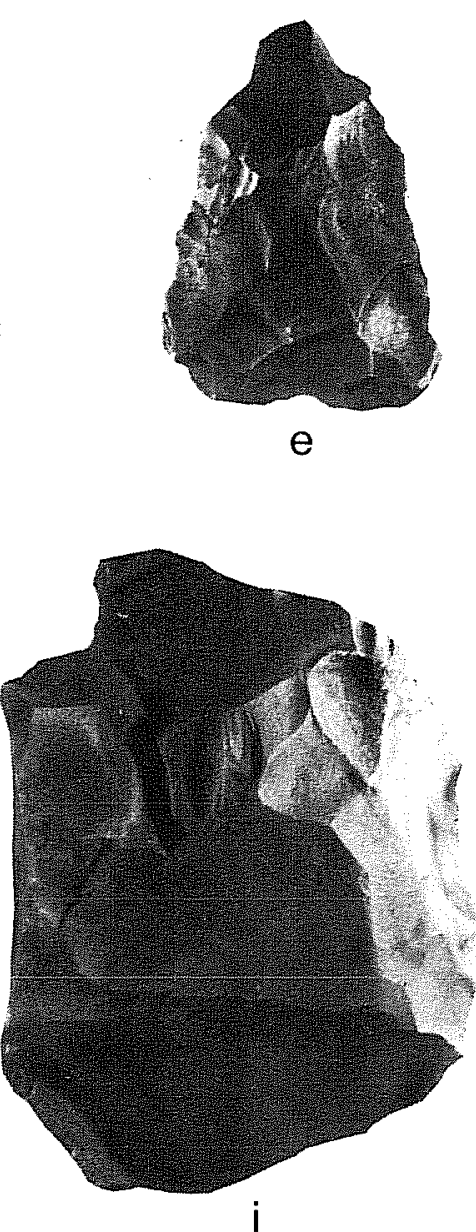

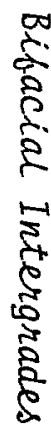

$\stackrel{N}{\oplus}$ 
Distribution: 41 UV 43 (two), 41 UV 45 (two), 41 UV 47 (six), 41 UV 48 (10).

Asymmetrical (60 specimens; Fig. $61, f-i$ )

Description: The specimens lack distinct outlines and constitute a loose typological subgrouping of the bifacial intergrade specimens. Twenty-four $(40 \%)$ of the specimens are decorticate (40\%). Of the remaining corticate specimens, three have cortex on both faces, indicating they were produced by cobble reduction.

Dimensions: L: 40-130; W: 25-75; T: 7-39.

Distribution: 41 UV 43 (15), 41 UV 45 (nine), 41 UV 47 (18), 41 UV 48 (18).

Fragments (51 specimens)

Description: All fragmentary specimens have been primarily retouched. Forty-one (79\%) specimens are decorticate; two specimens have cortex on both faces. Seven are patinated; of these, three were reworked after patination.

Dimensions: Maximum dimensions: 35-90.

Distribution: 41 UV 43 (seven), 41 UV 45 (nine), 41 UV 47 (16), 41 UV 48 (20).

\section{OTHER BIFACES (331 specimens)}

Specimens placed within the other biface category are divided into three subdivisions: pointed fragments, midsections and lateral fragments, and miscellaneous fragments. These specimens probably represent various fragments of the previously described projectile points or bifaces, but there was not enough of the specimen available for a confident assessment of the retouch and finish of the specimens.

\section{Pointed Fragments (202 specimens)}

Description: Pointed fragments are assumed to be distal fragments of bifaces. Forty-one (18\%) specimens appear to have been made on flakes.

Dimensions: L: (7)-(65); W: 6-65; T: 1-15.

Distribution: 41 UV 43 (one), 41 UV 45 (30), 41 UV 47 (49), 41 UV 48 (122).

\section{Midsections and Lateral Fragments (85 specimens)}

Description: These fragments represent the edges or midsections of bifaces. Eleven (13\%) specimens appear to have been made on flakes. 
Dimensions: L: (8)-(72); W: 9-47; T: 3-12.

Distribution: 41 UV 43 (one), 41 UV 45 (21), 41 UV 47 (27), 41 UV 48 (36).

Misce11aneous Fragments (44 specimens)

Description: These are complete and fragmentary specimens with amorphous or indeterminate outlines. Of the 43 specimens, five are probably made on flakes.

Dimensions: Minimum to maximum dimension: 13-60.

Distribution: 41 UV 43 (one), 41 UV 45 (nine), 41 UV 47 (six), 41 .UV 48 (28).

UNIFACES (118 specimens)

These specimens are retouched on one face only, most commoniy, but not always, the dorsal face of a flake. Retouch on the unifaces may be secondary or areal (unpatterned), and frequentiy occurs on one or more edges, leaving the remaining portions unmodified. There are nine subdivisions recognized within the uniface category.

End Scrapers on B1ades (17 specimens; Fig. 62,a-e)

Description: All specimens have a steeply convex working end formed at the distal end of a flake blade. The retouch is marginal and may extend down the lateral edges of the flake, usually not more than one-half the length of the long axis. The retouch is always located on the dorsal face of the flake. A11 the specimens are made on slightly curved flakes, so that when the ventral face of the flake rests on a plane only the ends contact the plane. of 11 specimens with an identifiable striking platform, eight have single facet platforms, and there is one example each of a large multifaceted platform, small multifacet platform, and a crushed platform. Fifty percent of the flakes are decorticate, and 12 specimens have a distinct medial ridge on the dorsal face.

Dimensions: $L(16): 49-99 ; W: 32-48 ; T: 10-23$.

Distribution: 41 UV 43 (one), 41 UV 45 (four), 41 UV 47 (10), 41 UV 48 (two).

Comments: Over half of the specimens were found in the southwest quadrant of site 41 UV 47 . Hester (1981) indicates these specimens are often associated with Late Prehistoric sites. 


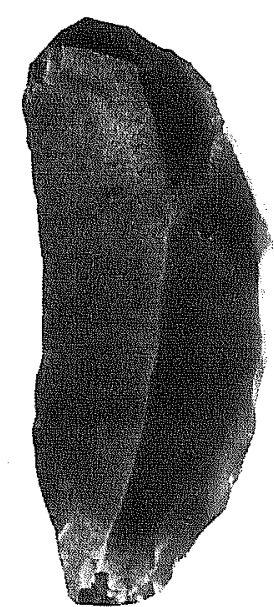

a

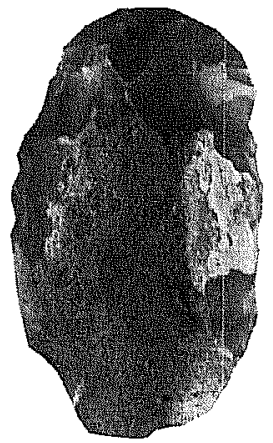

$\mathrm{b}$

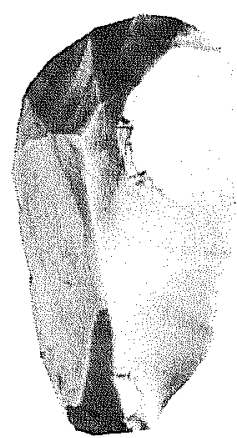

C

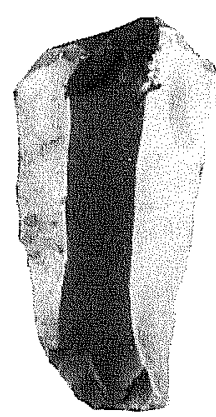

d

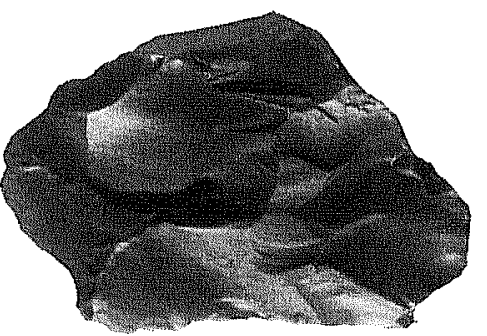

h

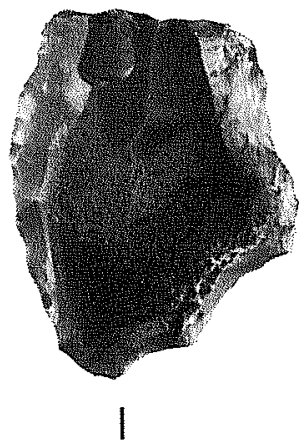

$\mathrm{k}$
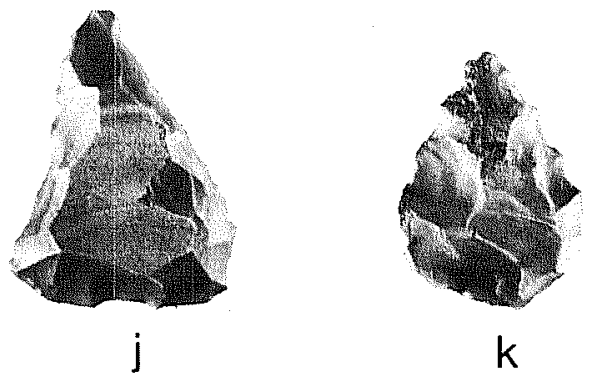

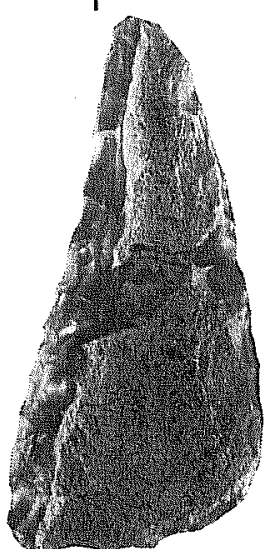

m

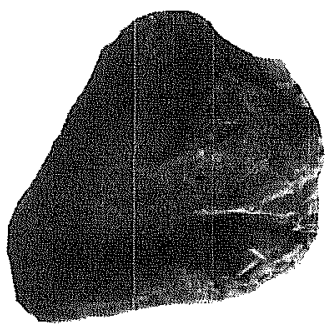

$n$

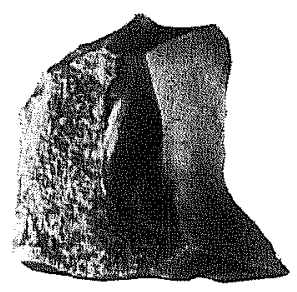

0

Figure 62. Unifaces. a-e, end scrapers on blades; $f-g$, end and one side; $h, i$, end and two sides; $j, k$, circumferentia $1 ; 1, m$, two sides; $n, 0$, one side. 
End and One Side (three specimens; Fig. 62,f,g)

Description: These specimens are marginally retouched on the dorsal face. Two specimens have single facet striking platforms, and the other specimen is a snapped flake with the platform missing.

Dimensions: L: 51-104; W: 51-74; T: 14-34.

Distribution: 41 UV 47 (two), 41 UV 48 (one).

End and Two Sides (seven specimens; Fig. 62,h,i)

Description: These unifaces have irregular to roughly ovate outlines. A11 of the specimens are marginally retouched on the dorsal face. Of the seven specimens, five have single-faceted platforms.

Dimensions: L: 48-102; W: 30-72; T: 10-36.

Distribution: 41 UV 43 (one), 41 UV 47 (four), 41 UV 48 (two).

Circumferential (four specimens; Fig. $62, \mathrm{j}, \mathrm{k}$ )

Description: These specimens have nongeometric outlines. Three specimens are marginally retouched on the dorsal face; the fourth specimen is worked on both faces of the flake but not in a manner that would produce the sinuous edge of a biface.

Dimensions: L: 44-54; W: 34-50.

Distribution: 41 UV 47 (two), 41 UV 48 (two).

Two Sides (nine specimens; Fig. 62,1,m)

Description: Marginally retouched specimens are worked on either the dorsal face only, or they may be worked on a ventral side with the opposite side worked on the dorsal face. Three of the specimens retain some cortex. The only identifiable striking platform is classifiable as a small multifaceted platform.

Dimensions: L: 29-120; W: 31-62; T: 5-23.

Distribution: 41 UV 43 (two), 41 UV 45 (one), 41 UV 47 (four), 41 UV 48 (two).

One Side (18 specimens; Fig. 62,n,0)

Description: Fifteen specimens are worked on the dorsal face; and three specimens are worked on the ventral face of the flake. The identifiable 
striking platforms are identified as three single-faceted platforms, one large and one small multifaceted platform, and two natural-faceted platforms.

Dimensions: L: 34-131; W: 31-84; T: 13-34.

Distribution: 41 UV 43 (three), 41 UV 45 (four), 41 UV 47 (four), 41 UV 48 (seven).

Concave Edge (five specimens; Fig. 63,a,b)

Description: The concave edges are pronounced, but when the depth of the concavity is compared with the length of the altered edge they must be considered shallow concavities. None of the specimens are shaped so as to be considered spokeshaves. A11 the specimens are worked on the dorsal face of the flake, and the only two striking platforms recognizable are a cortex platform and a large multifacet platform.

Dimensions: L: 40-81; W: 30-80; T: 11-32.

Distribution: 41 UV 45 (one), 41 UV 47 (three), 41 UV 48 (one).

Gravers (11 specimens; Fig. 63, C-e)

Description: The specimens all have a single-pointed protrusion that ranges from 1 to $5 \mathrm{~mm}$ in length. The only identifiable striking platform is a large multifacet platform.

Dimensions: L: 26-69; W: 16-62; T: 8-23.

Distribution: 41 UV 45 (one), 41 UV 47 (five), 41 UV 48 (five).

Miscellaneous (44 specimens; Fig. 63,f-h)

Description: Miscellaneous unifaces are nongeometric forms of flakes and chips with unpatterned areal retouch. of the seven identifiable striking platforms, four are single-faceted platforms, two are 1 arge multifaceted platforms, and one is a small multifaceted platform.

Dimensions: Minimum to maximum length: 28-80; Minimum to maximum thickness: 5-24.

Distribution: 41 UV 43 (nine), 41 UV 45 (seven), 41 UV 47 (14), 41 UV 48 (14).

\section{MODIFIED FLAKES AND CHIPS (64 specimens)}

Modified flakes and chips have minute retouch scars on either the dorsal or ventral face. of the 64 specimens, more than half (58\%) retain some cortex on the dorsal face. Twenty-seven (42\%) specimens are chips with 


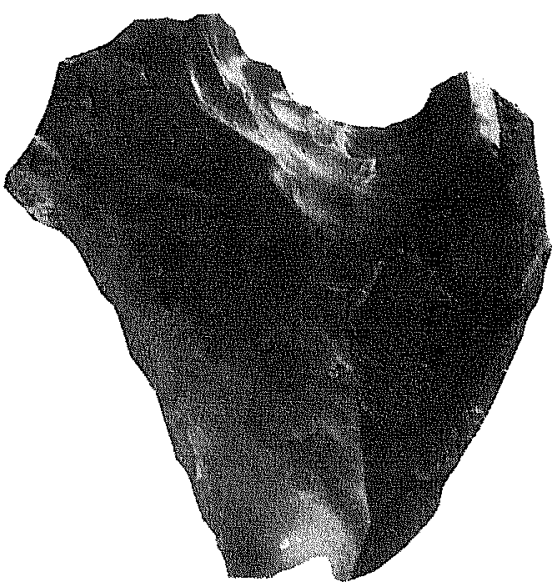

a

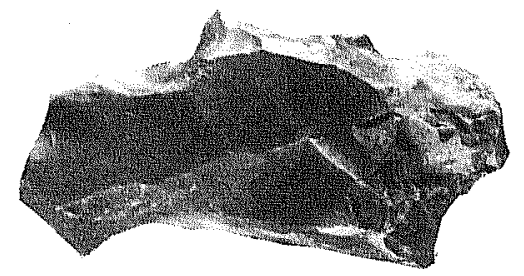

d

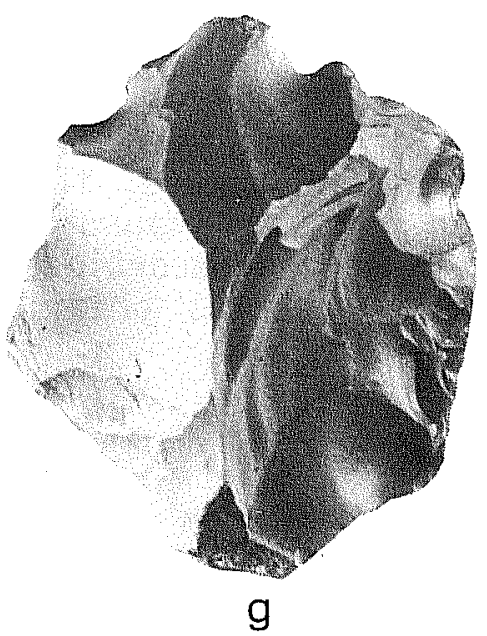

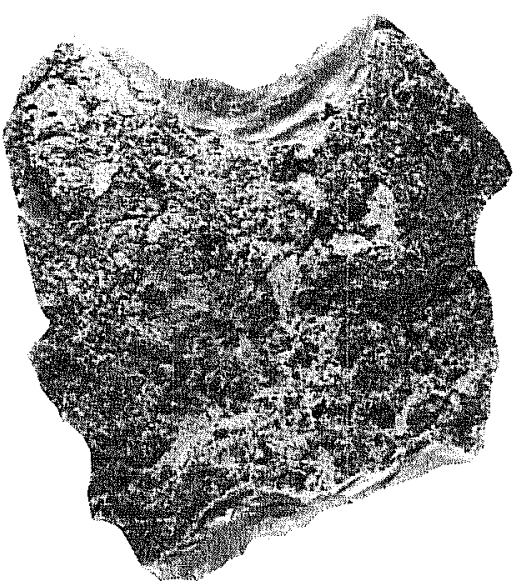

b

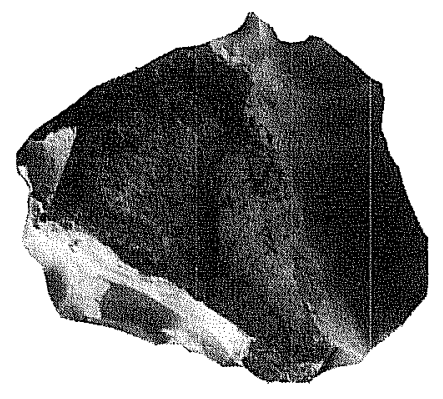

e

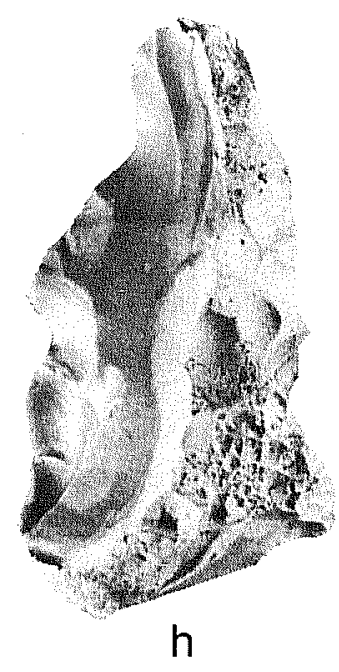

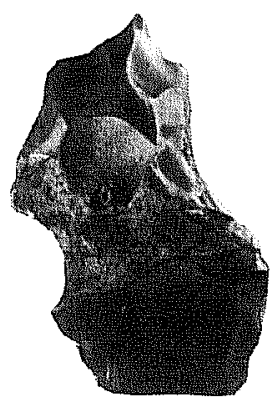

C

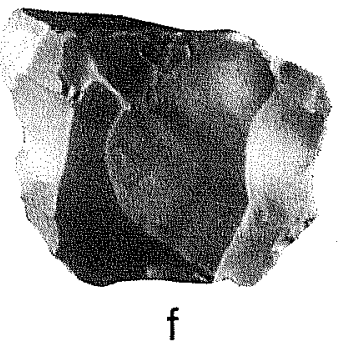

Figure 63. Unifaces. a-b, concave edge; c-e, gravers; $f-h$, miscell aneous. 
indeterminate striking platforms. Of those with identifiable platforms, 18 specimens have multifaceted platforms, 11 specimens have single facet platforms, and the remaining eight specimens have either crushed or naturalfaceted striking platforms.

Dimensions: Not measured.

Distribution: 41 UV 43 (seven), 41 UV 45 (11), 41 UV 47 (33), 41 UV 48 (13).

\section{CORES (451 specimens)}

Cores are chert nuclei that have had three or more flakes struck from them. Most cores were created from weathered chert cobbles, but it was not possible during the analysis to determine the original form of many of the cores because of the amount of reduction. Instead of core dimensions in the following descriptions, the total number of specimens is given for the following four ranges: small cores are smaller than $5 \mathrm{~cm}$ in minimum dimension, medium cores are between 4 and $7.5 \mathrm{~cm}$ in size, large cores are between 7.5 and $10 \mathrm{~cm}$ in size, and cores 1 arger than $10 \mathrm{~cm}$ in minimum dimension are classified as extra large.

\section{Unidirectional Prepared Platform (77 specimens; Fig. 64,a,b)}

Description: The defining characteristic for this form of core is the presence of a prepared striking platform created by the removal of one or more flakes (most commonly one); other flakes are then removed in a single direction along the perimeter of the prepared platform. Three variants can be described for the collection. Most of the cores have a single-prepared platform, but it is not uncommon to find a core that has more than one isolated platform from which flakes have been unidirectionally removed. When such cores occur, the platforms are formed at distinct, separate locations on the cobble. These cores thus form a variant where the core may have been flaked in more than a single direction relative to the two separate platforms, but the flakes struck from each isolated platform area are always removed unidirectional. The third variant is a polyhedral-like core; these have a single platform from which flakes have been removed around the complete perimeter of the platform. None of the specimens are decorticate, and the majority still retain the overall appearance of the cobbles' original shape.

Dimensions: Sma11:9; Medium: 43; Large: 23; Extra Large: two.

Distribution: 41 UV 43 (56), 41 UV 45 (three), 41 UV 47 (five), 41 UV 48 (13).

Multidirectional, Horizontal Platform (105 specimens; Fig. 64,c,d)

Description: This category consists of cores that have been struck on various prepared platforms, commonly both single faceted and multifaceted striking platforms, in more than one direction. The knapper apparently takes 


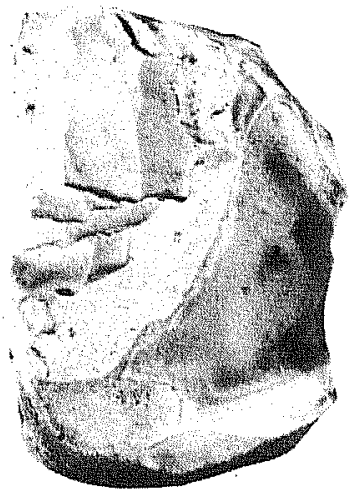

a

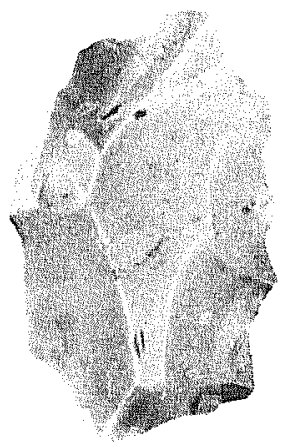

e

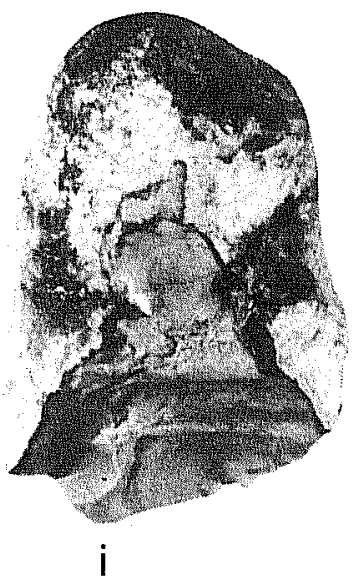

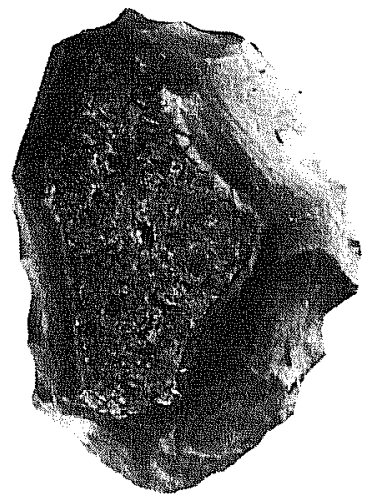
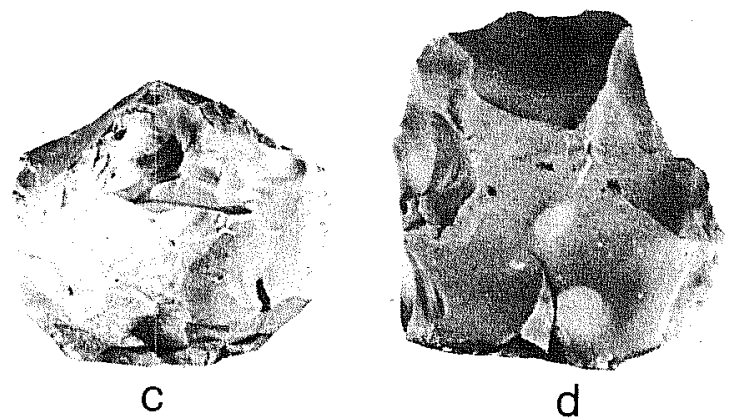

b
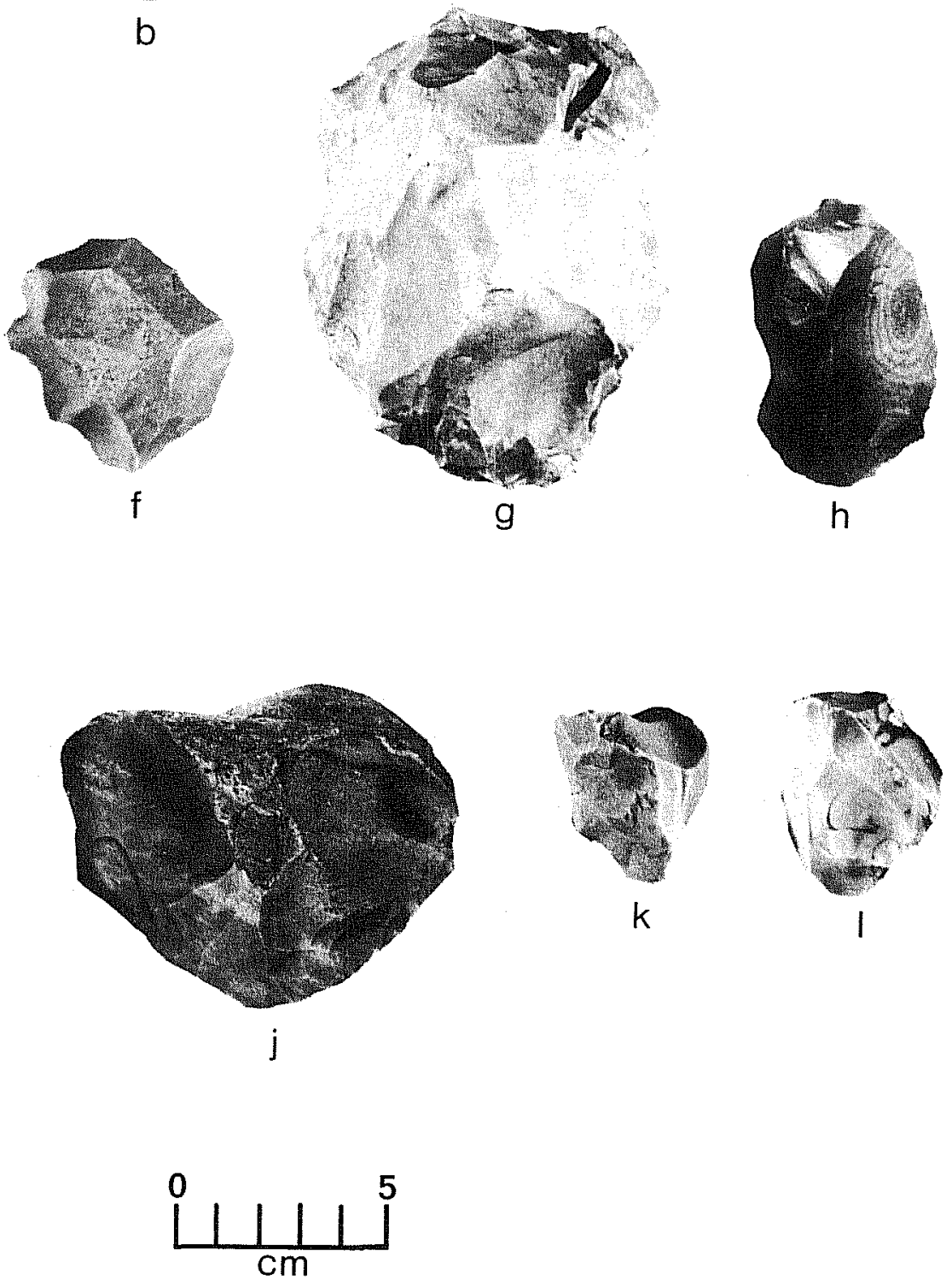

Figure 64. Cores. a,b, unidirectional prepared platform; c,d, mu1tidirectional, horizontal platform; e,f, multidirectional, oblique platform; $g, h$, bifacial; $i, j$, core tools; $k, 1$, nuclei. 
advantage of fortuitously (or planned) platforms that were created by earlier flake detachments. Characteristically, the angle formed by the platform and the flake scar is steep, measuring between $60^{\circ}$ and $90^{\circ}$. Thus, the cores have a randomly struck overall appearance with an irregular blocky form. Ninety percent of the cores are corticate

Dimensions: Sma11: 25; Medium: 62; Large: 18.

Distribution: 41 UV 43 (47), 41 UV 45 (16), 41 UV 47 (10), 41 UV 48 (32).

Multidirectiona1, 0blique Platform (71 specimens; Fig. 64,e,f)

Description: This subcategory is similar to multidirectional, horizontal platform cores, but the obvious difference is the angle created by the convergence of the striking platform and the flake scar. On oblique platform cores, the angle which is formed measures less than $60^{\circ}$, as opposed to cores with horizontal flaking patterns where the angles are greater than $60^{\circ}$. Some of the samples tend to approximate bifacially flaked cores, but the symmetry of flake removal combined with the continuous sinuous edges of the bifacial cores compared to the more random appearance of flake removal and overall outline of the multidirectional, oblique flaked specimens forms the distinction. Eighty-two percent of the specimens are corticate.

Dimensions: Sma11: 14; Medium: 47; Large: 10.

Distribution: 41 UV 43 (31), 41 UV 45 (14), 41 UV 47 (nine), 41 UV 48 (17).

Bifacial (34 specimens; Fig. $64, g, h$ )

Description: Bifacial cores have a continuous (or nearly so) flaked perimeter characterized by a rough, sinuous edge. The striking platforms indicate that single, multiple, and natural facet platform flakes would have been derived from the cores. Bifacial cores are distinguished from bifacial intergrades mainly in the relative thickness of the cross section of each in comparison to their length and width. The bifacial cores tend to be more spherical in form than the bifacial intergrades, which ordinarily lie distinctly on one of their two faces when placed on a plane. Of the 32 specimens, four are decorticate.

Dimensions: Sma11: 6; Medium: 19; Large: 8; Extra-Large: one.

Distribution: 41 UV 43 (26), 41 UV 45 (three), 41 UV 47 (two), 41 UV 48 (three).

Core Tools (27 specimens; Fig. $64, i, j$ )

Description: All of the specimens are stream-rolled cobbles that have been bifacially retouched to create a single, roughly sinuous flaked margin along approximately one-half of the tool. The remainder of the core is cortex and forms a suitable hand grip location if the specimens were to be used in a 
pounding or chopping motion. The specimens may also be considered choppers that are often recognized in other central and south Texas sites. Step fractures often occur on the flaked margins, but whether or not this results from use-wear or edge preparation/crushing is undertermined.

Dimensions: Sma11: 4; Medium: 16; Large: 4; Extra-Large: 3.

Distribution: 41 UV 43 (seven), 41 UV 45 (six), 41 UV 47 (12), 41 UV 48 (two).

\section{Natural Platform (27 specimens)}

Description: Natural platform cores exhibit more than two detached flakes, struck only from cortex platforms. Many of the cores are unidirectionally worked. While cortex platforms may occasionally occur in other core subcategories, this grouping forms a distinct type recognized only at the quarry site, 41 UV 43.

Dimensions: Medium: 15; Large: 8; Extra-Large: 4.

Distribution: 41 UV 43 (27).

Nuclei (71 specimens; Fig. 64,k,1)

Description: Nuclei are exhausted cores or core remnants. They are generally spherical, or more often angular, chert specimens so small that it would be difficult to detach useful flakes from them. Seventy-nine percent of the specimens retain some cortex.

Dimensions: Smal1: 70; Medium: one.

Distribution: 41 UV 43 (three), 41 UV 45 (13), 41 UV 47 (18), 41 UV 48 (37).

\section{Fragments (39 specimens)}

Description: Core fragments were only recovered from site 41 UV 43. Negative flake scars indicate the platform types are rare, if at all present, on the majority of the specimens. Four specimens appear to be core renovation flakes. Their inclusion under the subcategory of nuclei was deemed inappropriate for the specimens because of their relative size and the capability for them to be further reduced. All of the specimens retain some trace of cortex.

Dimensions: Sma11: 6; Medium: 28; Large: 5.

Distribution: 41 UV 43 (39). 


\section{DEBITAGE}

The chert debitage materials are sorted into four major divisions: platformed flakes, chips, burned nonflaked material, and chert chunks. The platformed flakes are further analyzed on the basis of two morphological criteria. The first is the amount of dorsal face cortex retained on each flake. The platformed flakes are deemed primary, secondary, or interior based upon the relative amount of remaining cortex. A second criteria is based on the striking platform characteristics. Six platform types are recognized: cortex platform, single facet platform, multifacet platform (either large or small), lipped flakes, and other platforms. Chips are divided into three subdivisions: corticate, partially corticate, and decorticate. Finally, the remaining miscellaneous specimens are separated into burned nonflaked chert specimens and chunks.

Chips are the most common debitage item, comprising $59.9 \%$ of the collection. Flakes are the second most common item at $24.4 \%$. Burned nonflaked chert specimens comprise $12.3 \%$, and chunks at $3.3 \%$ were the least frequent category.

Flakes $(14,684$ specimens $)$

Primary Flakes (325 specimens)

Description: The platform types are identified for the primary flakes: specimens with cortex covered striking platforms, 172; single facet platforms, 133; and other kinds of platforms, 20. Forty-five of the specimens are burned.

Distribution: 41 UV 43 (147), 41 UV 45 (14) 41 UV 47 (53), 41 UV 48 (111).

Secondary Flakes (4666 specimens)

Description: The six flake platforms identified for the secondary flakes and quantities associated with each are: cortex platforms, 1548; single facet platforms, 1893; small multifaceted platforms, 731; large multifaceted platforms, 416; 1 ipped flakes, 36; and other platforms, 42 . Approximately $16 \%$ of the secondary flakes are burned (749 flakes).

Distribution: 41 UV 43 (1273), 41 UV 45 (788), 41 UV 47 (1176), 41 UV 48 (1429).

Interior Flakes (9693 specimens)

Description: The inventory for flake platform types for the interior flakes are: single facet flakes, 4096; small multifacet flakes, 4574; large multifacet flakes, 729; 1ipped flakes, 270; and other platforms, 24. Burned specimens total 1228 flakes, about $12 \%$ of the interior flakes. 
Distribution: 41 UV 43 (200), 41 UV 45 (2577), 41 UV 47 (3617), 41 UV 48 (3299).

Chips $(36,197$ specimens)

Corticate Chips (1176 specimens)

Distribution: 89 specimens from 41 UV 43, 67 specimens from 41 UV 45, 538 specimens from 41 UV 47, and 482 specimens from 41 UV 48.

Partial1y Corticate Chips (4637 specimens)

Distribution: 637 specimens from 41 UV 43, 599 specimens from 41 UV 45, 1586 specimens from 41 UV 47, and 1815 specimens from 41 UV 48.

Decorticate Chips $(30,384$ specimens)

Distribution: 178 specimens from 41 UV 43,4324 specimens from 41 UV 45 , 12,671 specimens from 41 UV 47, and 13,211 specimens from 41 UV 48.

Burned Nonflaked Chert (7317 specimens)

Distribution: 571 specimens from 41 UV 43, 1550 specimens from 41 UV 45 , 1665 specimens from 41 UV 47, and 3531 specimens from 41 UV 48.

Chunks (1985 specimens)

Distribution: 1245 specimens from 41 UV 43, 54 specimens from 41 UV 45, 412 specimens from 41 UV 47, and 274 specimens from 41 UV 48.

\section{OTHER LITHICS}

Hammerstones and ground stone are included in this category. The types of ground stone recognized in this collection are: handstones, grinding slabs, and a single smoothed stone. Because of the small quantities recovered and the variable nature of the individual specimens, each are described separately. If the specimen is broken, the metric attributes are enclosed in parentheses.

Hammerstones (four specimens; Fig. 65,a,b)

One of the hammerstones is a chert cobble; the remaining specimens are limestone. Table 70 presents the location and dimensions of the specimens; individual descriptions follow. A11 hammerstones were surface finds. 
TABLE 70. HAMMERSTONES, PROVENIENCE AND DIMENSIONS

\begin{tabular}{clllll}
\hline Specimen & Site Provenience & $L$ & $W$ & $T$ \\
\hline 1 & 41 UV 47, Unit SW210-7 & $(78)$ & 87 & 79 \\
2 & 41 UV 48, Unit 120-11 & 101 & 71 & 58 \\
3 & 41 UV 48, Unit 91-12 & $(60)$ & 66 & 50 \\
4 & 41 UV 48, Unit 149 & $(97)$ & 101 & 63 \\
\hline
\end{tabular}

Specimen 1. This specimen is represented by one-half of a broken limestone cobble. A11 the wear (pounding/utilization) occurs on the leading edge directly opposite the broken end of the stone. The battered end is a rough band $60 \mathrm{~mm} \times 20 \mathrm{~mm}$ in size and extensively modified from its original shape.

Specimen 2: This specimen is a smooth, rounded, and water-worn chert cobble with a dark reddish cortex coloring. The specimen is roughly elliptical in shape with only very slight wear on one end.

Specimen 3: This specimen appears to be a roughly elliptical outline shape (estimated original form) and is made of burned limestone. There is extensive wear from pounding on the leading edge.

Specimen 4: This specimen is an irregularly shaped, orangish brown-colored hammerstone broken in half. Light pounding wear patterns occur on one edge of the specimen.

\section{Ground Stone (13 specimens)}

Four handstones, eight grinding slabs, and a smoothed stone are the ground stone types identified in this collection.

Handstones (four specimens)

A11 specimens are ovate in outline with a strongly biconvex cross section. Specimens 1 (Fig. 65,d), 3, and 4 (Fig. 65,c) clearly have two grinding facets. Specimen 1 has a small centrally located depression pecked into both grinding facets, and Specimen 3 has a similar depression on one grinding facet. These depressions characteristically occur on specimens called "nutting stones" (Turner and Hester 1985:254). The three longest specimens show some signs of pecking or battering use-wear on their edges. Table 71 presents the provenience and metric attributes of the handstones. 


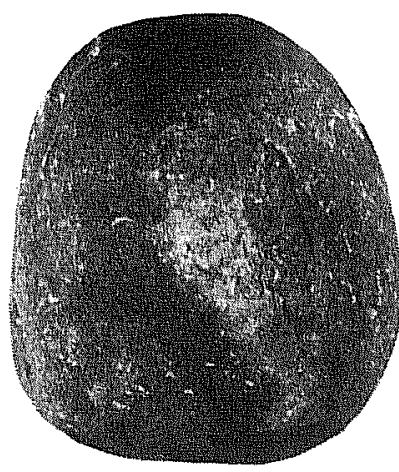

a

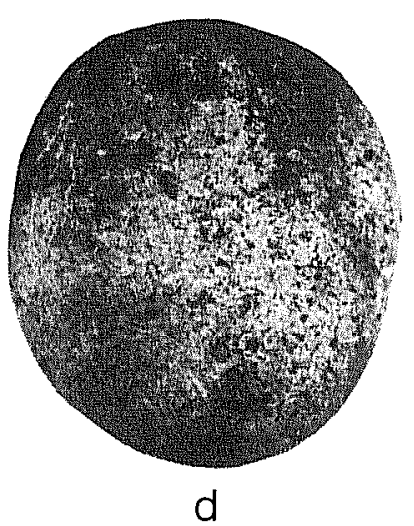

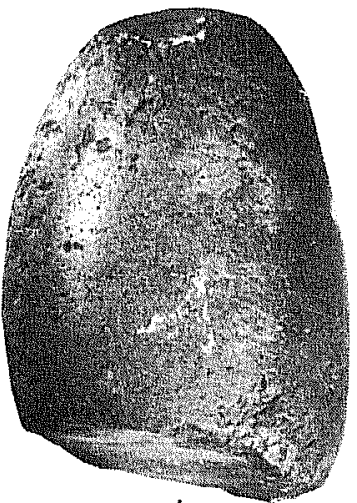

b

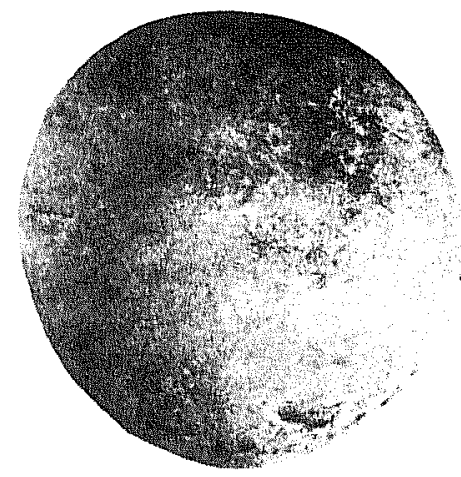

C

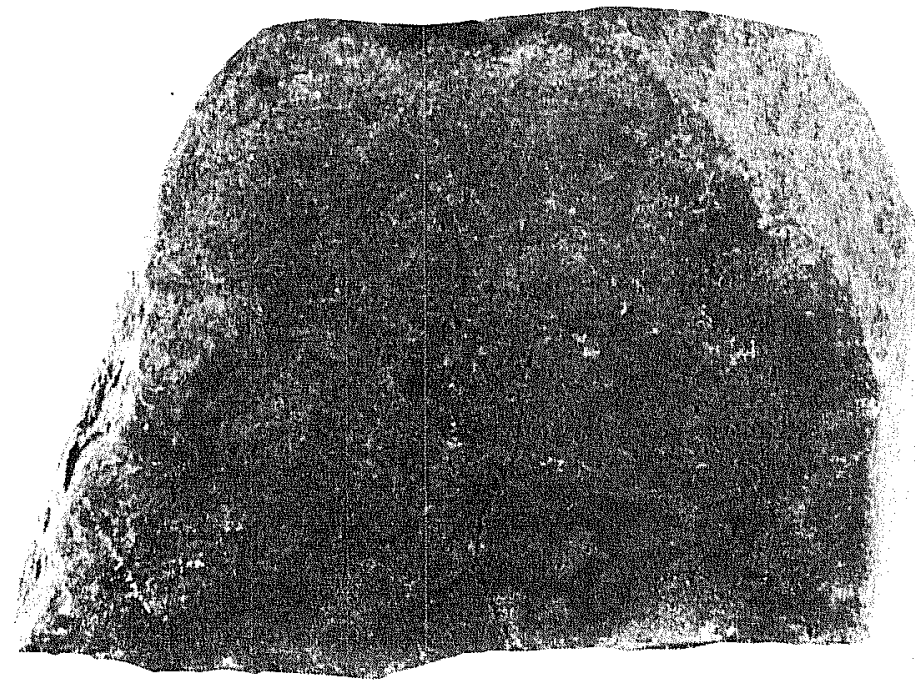

e
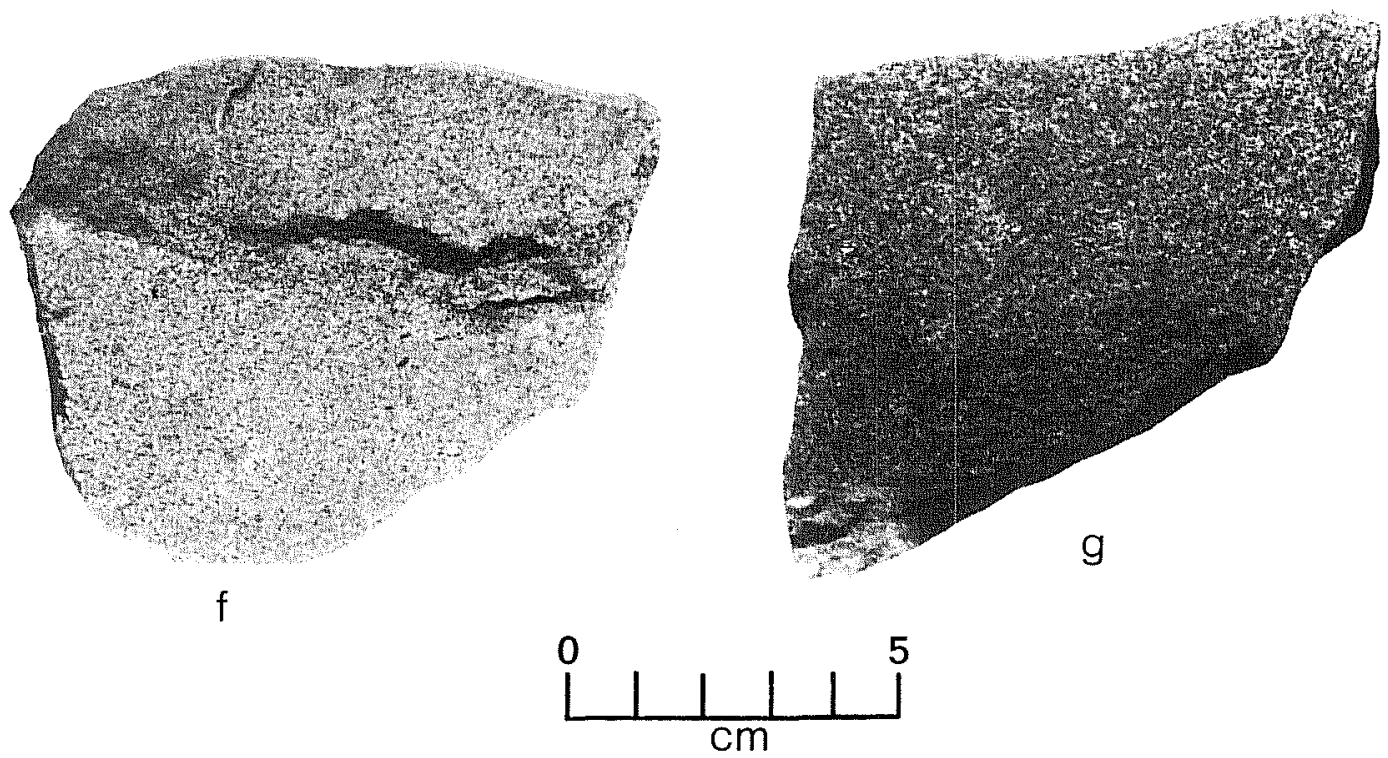

Figure 65. Hammerstones and Ground Stone. a,b, hammerstones; $c$, handstone Specimen 4; d, handstone Specimen 1; e, grinding $s 1 a b$, Specimen 3; f, grinding slab, Specimen 5; g, grinding $51 a b$, Specimen 2. 
TABLE 71. HANDSTONES, PROVENIENCE AND METRIC DATA

\begin{tabular}{ccccccc}
\hline \multirow{2}{*}{ Specimen } & Provenience & $\mathrm{L}$ & W & $\mathrm{T}$ \\
& & & & & \\
1 & 41 UV 47, Unit SE110-9, Leve1 3 & 90 & 79 & 46 \\
2 & 41 UV 47, Unit SE110-9, Leve1 3 & $(58)$ & 65 & 35 \\
3 & 41 UV 47, Backhoe Trench 7 & 79 & 70 & 44 \\
4 & 41 UV 48, Unit 604-7 & 95 & 87 & 77 \\
\hline
\end{tabular}

Grinding Slabs (eight specimens)

Specimen 1. This specimen is a thin, naturally formed rectangular slab of a granular, laminated, dark brown limestone. The specimen has been (presumably) broken in half. Both faces have been ground to form a slight oval-shaped depression that runs down the long axis of the specimen. Specimen 1 was recovered from site 41 UV 43, Unit (S)198-5. The dimensions are as follows: L: (126); W: 125; T: 22-23.

Specimen 2 (Fig. 65,g). This specimen is a small fragment of anapharitic, dark gray basalt, with only one face definitely ground. Specimen 2 is from site 4I UV 45, Unit (S)46-8. The metric attributes are as follows: L: (88); W: (77); T: $26-30$.

Specimen 3 (Fig. 65,e). Specimen 3 is similar in material and color to Specimen 2. The specimen appears to be approximately one-half of an oval, basin-shaped, single facet slab. Specimen 3 was recovered from 41 UV 45, Unit 47-22, Level 4. The metric attributes are as follows: L: (102); W: $125 ; \mathrm{T}: 39-51$.

Specimen 4. This specimen is a light brown limestone grinding slab fragment. The visible ground facet completely covers one face. Specimen 4 was recovered from 41 UV 47, Unit (S)NW61-14. The metric attributes are as follows: L: (68); W: (62); T: 44-50.

Specimen 5 (Fig. 65,f). This specimen is a fragment of dark gray basalt material ground on two facets. Specimen 5 was recovered from 41 UV 47, Unit (S)SW140. The metric attributes are as follows: L: (120); W: (71); $\mathrm{T}: 22$.

Specimen 6. This specimen is a reddish, burned limestone grinding slab which was reconstructed from several pieces. Not all of the grinding slab was found, but the overall outline indicates that the edges are irregular with no attempt being made to shape the artifact. The ground area is confined to the lowest lying areas of one face, but the overall extent or shape of the facet could not be determined. Specimen 6 was recovered from 41 UV 48, Unit 61-21, Leve1 4. The metric attributes are as follows: L: 350; W: 155; T: 44-98. 
Specimen 7. This specimen is a complete, single-faceted grinding slab. The grinding area, approximately $140 \mathrm{~mm}$ in diameter, appears as a very slight depression in the center of the one face. The material is a yellowish fossiliferous 1 imestone, readily available as a raw material in the Leona River near the site. Specimen 7 was recovered from 41 UV 48 , Unit (S) 459. The metric attributes are as follows: L: $430 ; \mathrm{W}: 400 ; \mathrm{T}: 52$.

Specimen 8. The slab is of the same material as specimen 7 . It has a centrally located shallow depression on one face, about $12 \mathrm{~cm}$ in diameter, that is ground. Most of the flat areas surrounding the depression are also ground. Specimen 8 was recovered from 41 UV 48, Unit (S) Area A. The metric attributes are as follows: L: 510; W: 430; T: 145.

Smoothed Stone (one specimen)

The specimen has a circular cross section and an elongated, parallel-sided ovate outline. The specimen is broken at one end. The unbroken end shows some light pounding use-wear. The sides of the specimens are smoothed all the way around the circumference. The specimen is made of limestone. It is $85 \mathrm{~mm}$ long and $50-55 \mathrm{~mm}$ in diameter. The specimen is from the surface of Unit SW165-7 at site 41 UV 47.

\section{FIRED CLAY}

\section{Ceramics (330 specimens)}

The analytical procedures to interpret the ceramic collection, i.e., surface treatment, temper, core, and paste descriptions, were derived from Bennet (1974) and Shepard (1976). Core and filler observations were examined with a 10X to 20X power binocular microscope. Clay colors were designated gray, red, orange, or tan based upon an arbitrary assessment of the overall variation within the collection.

A11 of the ceramics recovered during the project easily fit Suhm and Jelks (1962) type description for Leon Plain. Black (1982) has presented a detailed discussion on the variations of bone-tempered ceramics in the Choke Canyon Reservoir area similar to the Leon Plain (and other) type. Black (1982:453) suggests that formal type names associated with bone-tempered ceramics in Texas be discarded in favor of simple descriptive labels until a more thorough understanding of the "bone-tempered ceramic tradition of south and central Texas" is available. In this report, the type name Leon Plain is retained because of its long-standing use to describe a variety of bonetempered ceramics, even though the original definition by Suhm and Jelks (1962) stands in need of major revisions.

The five varieties of Leon Plain recognized in the collection are based essentially upon provenience data and bone temper variations. The varieties are not formal typological names, but instead are used to demonstrate the range of ceramics within the project area. 
The five varieties of Leon Plain were most easily recognized by bone temper treatments. Because much of the temper was bone, it was possible to subdivide treatments according to four colors. The four temper treatments and their corresponding colors are identified as ivory (unburned bone), black (charred bone), gray (moderately calcinated bone), and chalk (highly calcinated bone).

Leon Plain, Variety 1 (five specimens; Fig. 66,a,b)

Definition: Gray or tan surfaces and bone temper.

Number of Fragments: Four body sherds and one vessel handle.

Surface: Slight to no erosional damage or pitting. Both exterior and interior walls are well smoothed, with few visible brush marks remaining. The surfaces are dull.

Temper: The dominate filler consists of varying amounts of both burned and unburned bone, ranging in size from $1 \mathrm{~mm}$ to smaller. There is a minor filler of clear quartz grains averaging $0.3 \mathrm{~mm}$ in size.

Core: The core streak may be one-third to all of the interior. Color varies from dark gray to black with a blended to well-defined core streak.

Paste: Fine grained and compact.

Dimensions: Sherds have a maximum dimension of $15 \mathrm{~mm}$ to $35 \mathrm{~mm}$; walls are $6 \mathrm{~mm}$ to $7 \mathrm{~mm}$ thick.

Distribution: 41 UV 45 (one), 41 UV 47 (four).

Leon Plain, Variety 2 (306 specimens; Fig. 66,c-e)

Definition: Orange or red surfaces with a slight to moderate luster. The dominant filler is unburned bone with lesser amounts of moderately calcinated burned bone. Core streaks are absent or indistinct.

Number of Fragments: 304 body sherds, three rim sherds, and a neck sherd.

Surface: Little to no erosional damage, slight to moderate pitting. Partially smoothed brush marks are most common on the interior walls. Exterior walls are characteristically smoothed, with a slight to moderate luster. Color varies from orange to red. There are calcium carbonate encrustations on many of the specimens.

Temper: Mixed portions of burned and unburned bone. Unburned bones appear to be the dominant filler, although lesser amounts of moderately calcinated burned bone and charred bone occur (in that order).

Core: Core streaks are usually absent, but when streaks do occur, they are indistinct or blended and pale gray in color. 


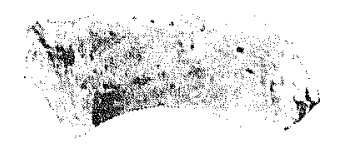

a

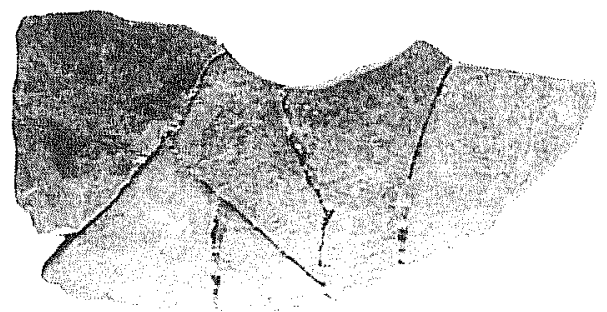

C
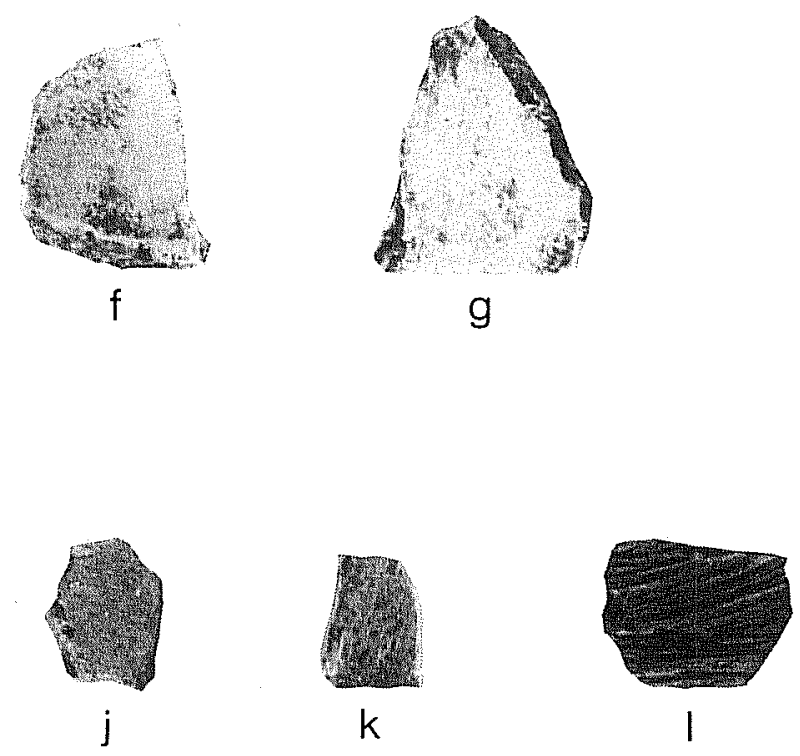

g

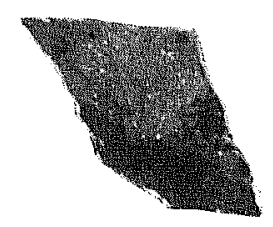

e
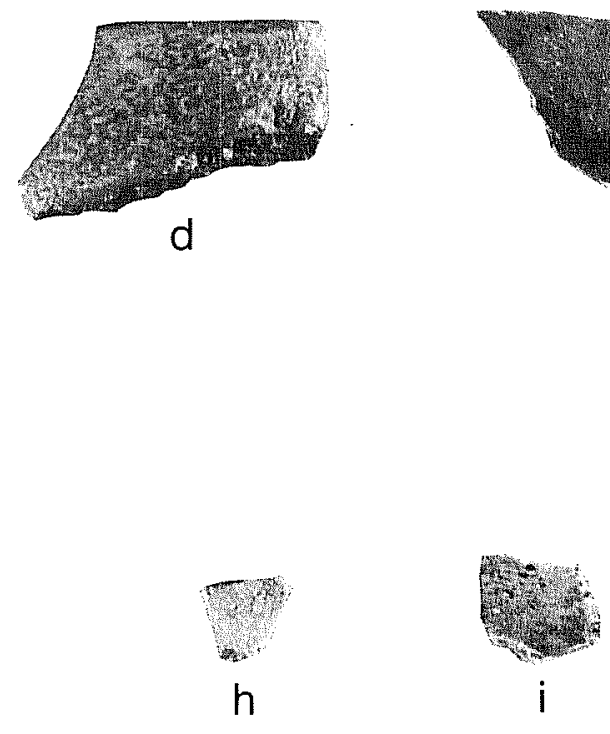

Figure 66. Leon Plain Ceramics and Impressed $\mathrm{Clay.} \mathrm{a,b,} \mathrm{Leon} \mathrm{Plain,}$ Variety 1 ; c-e, Leon P1ain, Variety 2; f,g, Leon P1ain, Variety 3; $h, i$, Leon Plain, Variety $4 ; j, k$, Leon Plain, Variety $5 ; 1$, impressed clay. 
Paste: Dense, fine-grained clay.

Dimensions: Sherds vary from $10 \mathrm{~mm}$ to $40 \mathrm{~mm}$ in maximum dimension. Vessel walls are $5 \mathrm{~mm}$ to $7 \mathrm{~mm}$ thick.

Distribution: 41 UV 45 (three), 41 UV 47 (305).

Leon Plain, Variety 3 (10 specimens; Fig. 66,f,g)

Definition: The temper is predominantly charred bone. Sherds are tan and smoothed with a dull surface.

Number of Fragments: Nine body sherds, one rim sherd.

Surface: Erosional damage is minimal, slight to no pitting occurs. The surface colors are tan. Surface texture is smooth, but traces of brush marks can sometimes be seen on the interior walls. Luster on the specimens is du11.

Temper: Almost a11 of the temper is charred bone, $1 \mathrm{~mm}$ or less in size.

Core: No core streaks were observed.

Paste: Dense, fine-grained clay.

Dimensions: $10 \mathrm{~mm}$ to $35 \mathrm{~mm}$ in maximum dimension. Sherd walls vary from $6 \mathrm{~mm}$ to $8 \mathrm{~mm}$ thick.

Distribution: 41 UV 48 (ten).

Leon Plain, Variety 4 (three specimens; Fig. $66, \mathrm{~h}, \mathrm{i}$ )

Definition: Unusually thin-walled sherds with smoothed, tan-colored surfaces. The dominant filler is very small fragments of unburned bone.

Number of Fragments: Three body sherds.

Surface: Erosional weathering is slight, pitting is minimal. The surfaces are well smoothed, and there is no evidence of brushing. Sherds are a uniform tan color. Calcium carbonate encrustations occur on some specimens.

Temper: Predominantly unburned bone. The temper inclusions are unusually small in comparison to the overall collection, averaging $0.3 \mathrm{~mm}$ in size.

Core: No core streaking occurs.

Paste: Dense, fine-grained clay.

Dimensions: $10 \mathrm{~mm}$ to $35 \mathrm{~mm}$ in maximum dimensions. Walls are $4 \mathrm{~mm}$ thick.

Distribution: 41 UV 48 (three). 
Comments: On one specimen edge fractures occur along two different coil lines, and two other coil lines are clearly visible on the interior wall of the specimen. These sherds look very similar to Variety 3 sherds, with the exception of temper colors and sizes. Both varieties were recovered from Area $A$ of site 41 UV 48, but from different locations within that area.

Leon Plain, Variety 5 (Fig. $66, \mathrm{j}, \mathrm{k}$ )

Definition: Surface color is orange. The filler consists of burned bone only, with highly calcinated bone predominating.

Fragments: Three body sherds.

Surface: Smoothed surfaces with dull luster. Erosional damage is slight, and pitting is minimal. Colors are uniform on both sides of the sherds. Calcium carbonate deposits occur.

Temper: Burned bone. Highly calcinated burned bone appears most common. The bone particles average $1 \mathrm{~mm}$ or smaller in size.

Core: Light gray blended cores.

Paste: Dense, fine-grained clay.

Dimensions: $10 \mathrm{~mm}$ to $15 \mathrm{~mm}$ in maximum dimension. Walls are $6 \mathrm{~mm}$ thick.

Distribution: 41 UV 47 (three).

Impressed Clay Specimen (Fig. 66,1)

A single specimen of red, compact, fine-grained fired clay was recovered from site 41 UV 48. A very few particles of unburned and charred bone were noted in the specimen. The artifact was impressed on one side with what must have been some kind of organic material such as grass, leaving roughly parallel molds running across the long axis of the specimen. The side opposite the impressions is an irregular, undulating surface. The specimen is $23 \mathrm{~mm}$ long. The specimen may be a daub fragment from a structure or pit 7 ining.

\section{MODIFIED BONE}

Modified bones are faunal remains that have been purposely altered from their original state by either use-wear (polishing and striations) and/or shaping (cutting, smoothing, or abrasion). Two types of modified bone are recognized in the collection: bone awls and an ulna tool. Robert F. Scott IV made the faunal identification for the modified bone. 
Bone Awls (eight specimens; Fig. 67,a-e)

One specimen is nearly complete, four specimens are lateral fragments, two specimens are midsection, and one specimen is a pointed fragment. A11, except the nearly complete specimen, are burned. All specimens show signs of polish and striations that tend to run parallel to the long axis and are most visible on the dorsal or exterior portion of the bone. The midsection specimen has an end that has been formed by cutting-and-snapping with the break unmodified (not smoothed). On the same specimen, at a point $5 \mathrm{~mm}$ down the long axis from the snapped end, is a deep cut mark perpendicular to the long axis, as if a second location for a cut-and-snap break had been prepared.

Two specimens are identified as to species and element. The first is a white-tailed deer metatarsal, identified from a burned midsection of an awl fragment. The other a single, nearly complete specimen is probably that of a white-tailed deer metapodial. Because of its uniqueness, a description follows.

The nearly complete awl was recovered from site 41 UV 48, Unit 120-24, Level 6 . The specimen is $131 \mathrm{~mm}$ long, $14 \mathrm{~mm}$ wide, and $5 \mathrm{~mm}$ thick. This aw fragment is the only specimen that has not been burned. This specimen is complete except for a small portion of the distal end. Both sides of the aw1 are polished, and there are parallel scratches on the distal one-third of the tool. The dorsal face is decorated with a lightly incised crosshatch design. The design is visible from a point about $30 \mathrm{~mm}$ from the distal end and terminates within $25 \mathrm{~mm}$ of the proximal end. The design has apparently been worn away by use-wear towards the distal end and along the medial ridge of the specimen. The parallel incised lines are spaced $5 \mathrm{~mm}$ or less apart and are placed in lines diagonal to the long axis. In addition to the crosshatch design, there are two incised lines, parallel to each other, located about $20 \mathrm{~mm}$ from the proximal end of the tool.

U1na Tool (two specimens; Fig. 67,f,g)

One specimen (Fig. 67,g) is made on the left ulna of a white-tailed deer. The proximal end of the tool is missing, and the distal end is blunted. The specimen is $62 \mathrm{~mm}$ long, $32 \mathrm{~mm}$ wide, and $18 \mathrm{~mm}$ thick. The ulna tool was recovered from site 41 UV 48, Unit 120-24, Leve1 3.

The second specimen (Fig. $67, f$ ) is made on the right ulna of a white-tailed deer. Both the proximal and distal ends are fragmentary. Lateral cut marks appear on the specimen towards the distal end of the specimen. The tool is $65 \mathrm{~mm}$ long, $28 \mathrm{~mm}$ wide, and $19 \mathrm{~mm}$ thick. The specimen was recovered from 41 UV 45, Unit 47-22, Level 4.

\section{HISTORIC ARTIFACTS}

The few historic artifacts recovered during the project have been divided into the following categories: ceramics, glass, mussel shell button, and metal artifacts. 


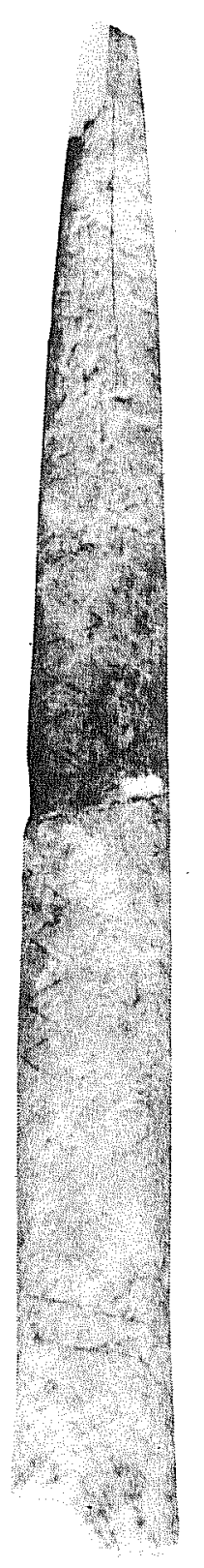

a
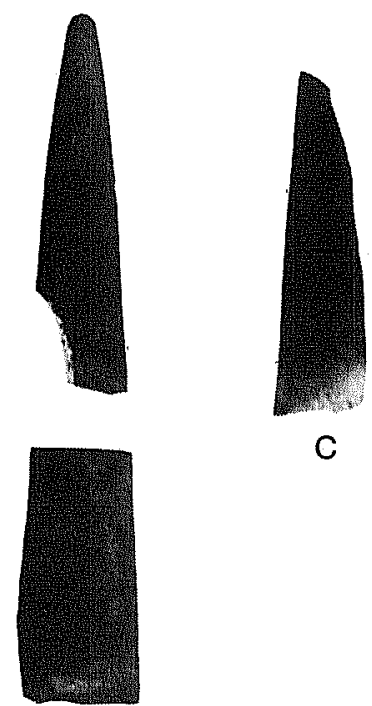

C

b
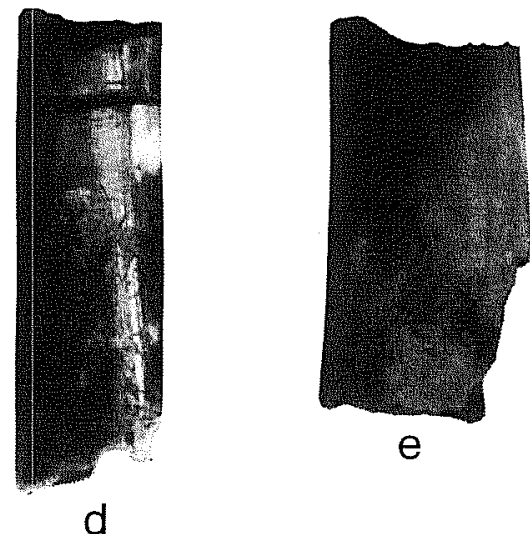

d
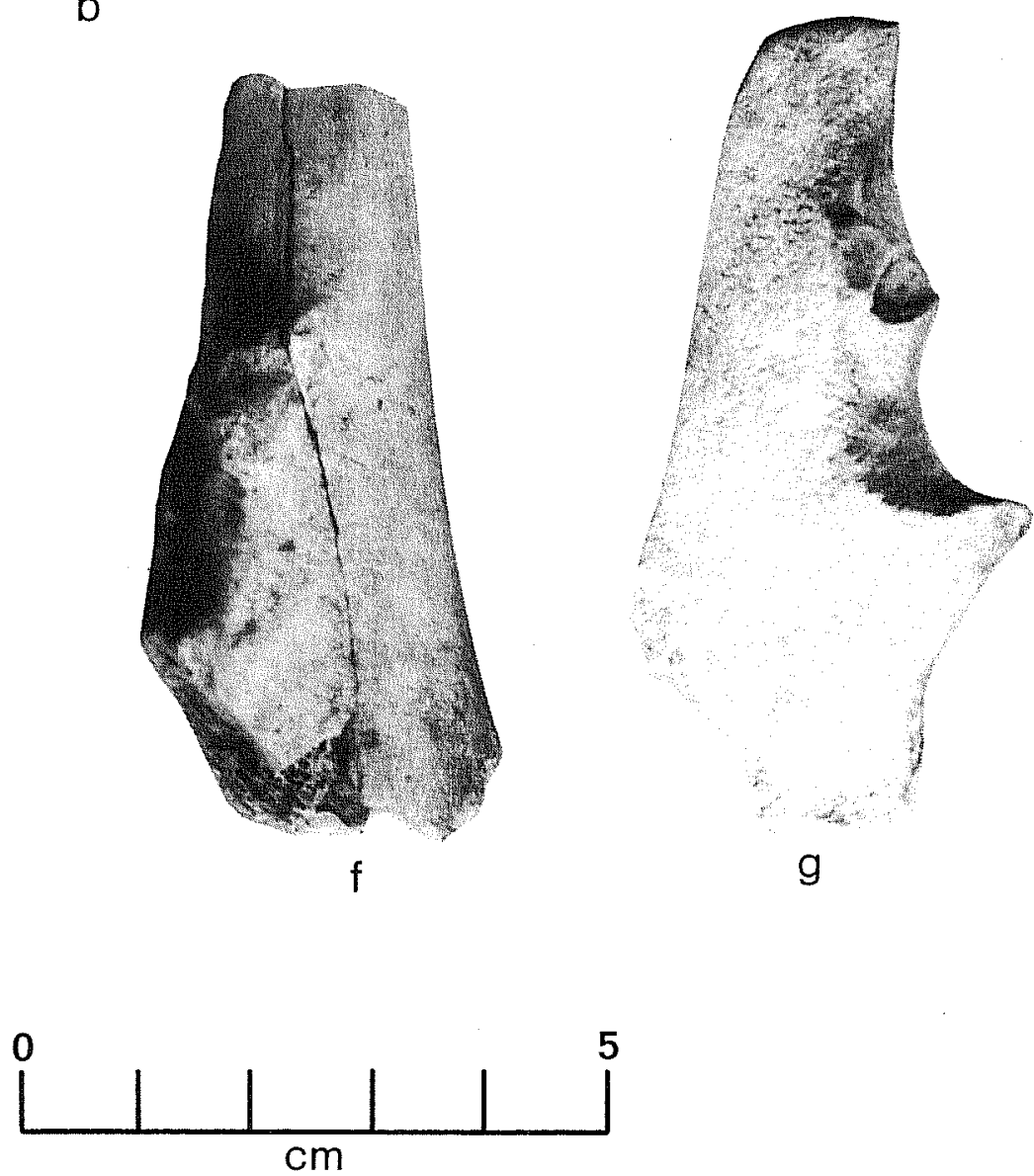

Figure 67. Modified Bone. a-e, bone aw 15; f,g, ulna tools. 
Ceramics (four specimens; Fig. 68,a,b)

Description: These specimens are plain white paste earthenware body sherds.

Dimensions: Specimens vary from $18 \mathrm{~mm}$ to $61 \mathrm{~mm}$.

Distribution: 41 UV 45 (one), 41 UV 47 (one), 41 UV 48 (two).

G1ass (19 specimens)

Nineteen glass fragments were recovered and are categorized according to color. Sizes vary from $11 \mathrm{~mm}$ to $61 \mathrm{~mm}$.

Clear Glass (five specimens)

Description: Four specimens appear to be body sherds from round bottles. Two of the sherds have raised, indeterminate designs on their exteriors. One specimen is heavily patinated and is from a squared bottle.

Distribution: 41 UV 45 (one), 41 UV 47 (two), 41 UV 48 (two).

Brown Glass (nine specimens; Fig. 68,c)

Description: Five specimens are body sherds of patinated, thick-walled bottles. Another body sherd appears to be from a recent beer bottle. The three remaining fragments may be from squared bitters bottles; one of these bears the raised lettering "R'S."

Distribution: 41 UV 45 (six), 41 UV 47 (three).

Purple Glass (one specimen; Fig. 68,d)

Description: This single fragment is a thin-walled jar or bottle with a raised floral and leaf design.

Distribution: 41 UV 45 (one).

Green Glass (two specimens; Fig. 68,e)

Description: The green glass fragments are one bottle sherd and one flat sherd bearing the raised lettering "MA."

Distribution: 41 UV 47 (two). 


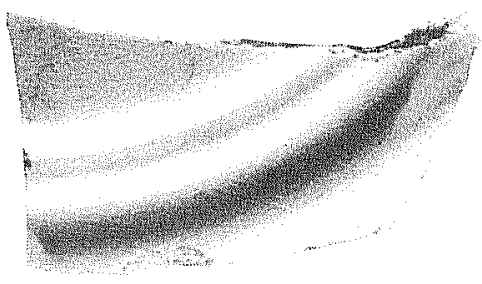

a
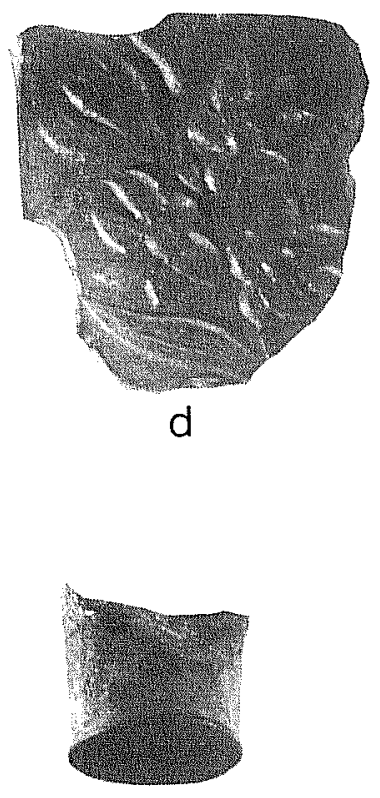

h

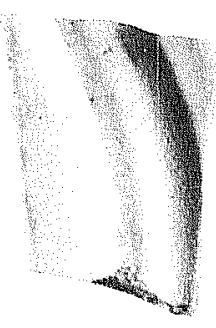

b

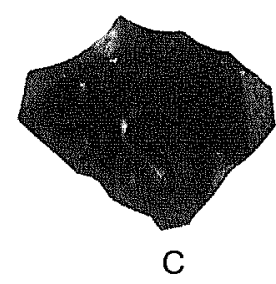

C
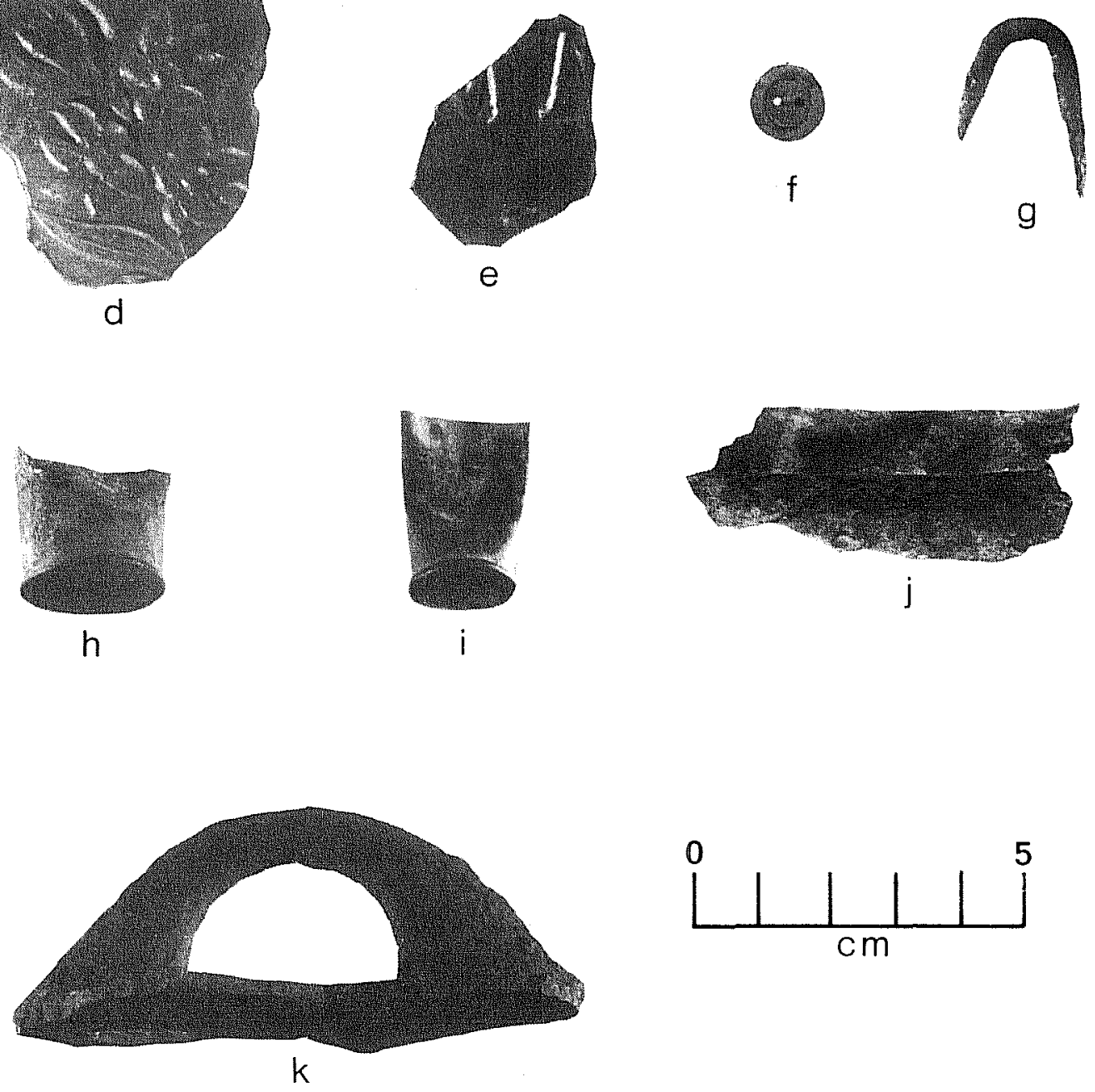

Figure 68. Historic Artifacts. a,b, ceramics; c, brown glass; d, purple glass; e, green $\mathrm{glass}$; $f$, mussel shell button; g, fence staple; h, shotgun shell casing; $i$, rimfire cartridge; $j$, rolled meta $1 ; k$, kett 1 e hand 1 e. 
Aquamarine G1ass (two specimens)

Description: Two aquamarine glass fragments are represented by one body and one neck fragment.

Distribution: 41 UV 45 (one), 41 UV 48 (one).

Mussel Shel1 Button (one specimen; Fig. 68,f) .

Description: The mussel shell button has two holes drilled into it, and one side has a raised circular area, $7 \mathrm{~mm}$ in diameter.

Dimensions: The diameter is $12 \mathrm{~mm}$, and the thickness is $1 \mathrm{~mm}$.

Distribution: 41 UV 45.

Metal Artifacts (10 specimens)

The few metal artifacts recovered during the project are briefly described.

Wood Screw (one specimen)

Description: The wood screw has a "Phi1lips" type head.

Dimensions: $16 \mathrm{~mm}$ long.

Distribution: 41 UV 48 (one).

Fence Staples (five specimens; Fig. 68,g)

Dimensions: $25-35 \mathrm{~mm}$ long with a spread of about $15-20 \mathrm{~mm}$.

Distribution: 41 UV 47 (three), 41 UV 48 (two).

Shotgun Shell Casing (one specimen; Fig. 68,h)

Description: 12-gauge nitro express shotgun shel1 casing.

Dimensions: $22 \mathrm{~mm}$ in diameter and $21 \mathrm{~mm}$ long.

Distribution: 41 UV 47 (one).

Rimfire Cartridge Casing (one specimen; Fig. 68,i)

Description: A .50 caliber shell casing. The distal end is crushed flat.

Dimensions: The specimen measures $16 \mathrm{~mm}$ in diameter and is $29 \mathrm{~mm}$ 1ong. 
Distribution: 41 UV 47 (one).

Rolled Metal (one specimen; Fig. 68,j)

Dimensions: The fragment is $61 \mathrm{~mm}$ long and about $1 \mathrm{~mm}$ thick with an edge folded over to create a border.

Distribution: 41 UV 45 (one).

Kettle Handle (one specimen; Fig. $68, \mathrm{k}$ )

Description: Cast iron kettle handle attached to a small portion of the kettle body. What appears to be a seam on the interior of the kettle runs perpendicular to the handle orientation.

Dimensions: The handle is $85 \mathrm{~mm}$ long and $34 \mathrm{~mm}$ high.

Distribution: 41 UV 45 (one).

\section{DISCUSSION AND PROJECT SUMMARY}

\section{INTERSITE COMPARISONS}

The individual site reports presented in this volume have provided the opportunity to examine a sampling of sites with similar excavation and analys is treatments. This section will briefly review the four sites investigated in this report, emphasizing intersite comparisons of chronology, tool assemblages, debitage, midden features, and environmental and subsistence data. An examination of other sites in or near Uvalde County is included, where comparative information is useful. Summary comments on settlement patterns and cultural change within the region are also included in this section, concluding with a summary of the project's mitigation efforts.

\section{Chronology}

Chronological data recovered from the four sites under investigation are based primarily on the recognition of historical typologies from the central Texas region. These diagnostics are composed mainly of projectile point forms, but a few other 1 ithic tool forms and ceramics were also considered. Radiocarbon dates from three of the sites were also used to evaluate the chronological setting within the project area.

Previous archaeological research in Uvalde County has shown that the central Texas cultural chronology presented by Suhm and Jelks (1962) and refined by later publications, such as Weir (1976) and Prewitt (1981) can be applied in the far southwestern edge of central Texas. A total of 18 radiocarbon dates from the La Jita site (Hester 1971) and the Anthon site (Weir and Doran 1980) associated with diagnostic points of the Archaic and Late Prehistoric periods 
indicates that the framework established for central Texas is applicable to Uvalde County. However, the dates recorded from Uvalde County show some discrepancies from the dates in other parts of central Texas. The Late Prehistoric period radiocarbon dates from the La Jita site (Hester 1971) indicated that a distinct arrow point type, Edwards, was the earliest arrow point form in the region. Mitchell (1978) has discussed the chronological placement of the Edwards type, showing evidence of its appearance prior to either Scallorn or Sabinal. However, the radiocarbon dates associated with the Late Prehistoric deposits from this project, in which the Edwards point was well represented, are all later than the range for the type (A.D. 930 to 1150) reported by Mitche 11 (1978). The six radiocarbon dates associated with Late Prehistoric deposits at 41 UV 47 and 41 UV 48 indicate a maximum date of A.D. 1210 (TX-4428, MASCA corrected) for the period.

A noteworthy discrepancy between the commonly accepted dates for the Middle Archaic period (3050 to 650 B.C.) and three of the five radiocarbon dates from Uvalde County was recognized during this project. Hester (1971) and Weir and Doran (1980) have reported radiocarbon dates associated with Middle Archaic diagnostics that were later than expected. Weir and Doran (1980) reported a date of 260 B.C. (uncorrected, TX-2380) from excavated Middle Archaic contexts at the Anthon site, and Hester reported a date of A.D. 160 (MASCA corrected, TX-692) from Middle Archaic contexts at the La Jita site. Both dates are much later than expected, falling within the Late Archaic period. Similarly, the radiocarbon date from 41 UV 45 (TX-4433, 100-10 B.C., MASCA corrected) was expected to fall within the current Middle Archaic parameters, but was also later than expected. The discrepancies of these three radiocarbon dates from different sites in Uvalde County are in conflict with the commonly assumed chronological time sequences for the region, and they suggest that there is a possibility that the Middle Archaic lasts substantially longer in this region than in other parts of central Texas. But, more radiocarbon dates from the area are needed to clarify the discrepancies with regional chronologies.

\section{Tool Assemblages}

Intersite comparisons within the project area show some significant differences in the cultural materials recovered from each site. These differences have implications for the chronological sequence and site functions in a most general sense, and are presented here as an aid in understanding the prehistoric systems under study. The tool assemblage suggests some indications of cultural change in 1 ithic technologies over time and also some functional differences in site use between chronological periods.

Project investigations showed that of the four sites studied, three were open campsites, and the other was a cobble quarry. All of the open campsites had both Late Prehistoric and Archaic components, but 41 UV 45 is predominantly a Middle to Late Archaic site, and sites 41 UV 47 and 41 UV 48 have predominantly Late Prehistoric components. The cobble quarry site 41 UV 43 is suspected to have been used from as early as the Early Archaic to the Late Prehistoric periods, although specific components could not be spatially isolated at this site. 
An examination of the excavated materials suggests that site function is reflected in the intersite distribution of the artifact groupings, and certain artifact types tend to be associated with different chronological periods. The summary of the major artifact categories is arbitrarily arranged so as to show their suggested chronological and functional differences (Table 72).

Table 72 shows that arrow points, small overall retouched bifaces, bifacially retouched flakes, and unifaces are more common at the two Late Prehistoric sites relative to the Archaic site. At the Archaic site, dart points, 1arge overall retouched bifaces, and bifacial intergrades are more common than the tool forms at the two Late Prehistoric sites. The intersite distribution of the projectile point forms is not surprising, as the two forms, arrow points and dart points, have been considered chronological diagnostics traditional1y. The predominance of the bifacially retouched flakes, small overall retouch bifaces, and unifaces at the Late Prehistoric sites, when contrasted with the relative percentage of large overall retouch bifaces and bifacial intergrades at the Archaic site suggests a difference in the 1ithic reduction technologies between the two chronological periods.

Forms that are most common at the Late Prehistoric sites are suggestive of a core flaking industry. Bifacially retouched flakes and unifaces are flake tools, and the small overall retouch bifaces at the Late Prehistoric sites are probably flake tools (also demonstrated by the similarity of some of the overall retouch bifaces and bifacially retouched flake typological groupings from those sites). At 41 UV 45, the artifacts exhibit attributes characteristic of a predominantly core tool industry. Many of the bifacial intergrades at 41 UV 45 retain cortex on at a least one side, and not infrequently two sides (as do the bifacial intergrades from all the sites in the study, although this form is predominant at 41 UV 45 and 41 UV 43), indicating they are worked cobbles (core tools). The 1 arge overall retouched bifaces from 41 UV 45 cannot definitely be identified as core or flake tools, but one suspects that the majority are core tools, given a cursory review of the size of the stream-rolled cobbles and flakes that were the source of the 7 ithic raw materials in the project area.

The differences between the quarry site 41 UV 43, and the three campsites is best exemplified in the distributions of cores and other bifaces (an artifact grouping representing biface fragments such as distal and medial fragments that could not be placed in any other artifact category). Table 72 shows that all of the excavated artifacts from the quarry were cores, but as the number of excavated artifacts was so low (two cores), the discrepancy between sites must be clarified with some discussion on the surface distribution of artifacts at 41 UV 43 to make the comparisons with the campsites more meaningful. The deposits at 41 UV 43 were shown to be primarily a surface manifestation, quite different from the buried deposits at the other three sites.

A brief summary of the surface artifacts collected from 41 UV 43 is as fol1 ows. Cores comprised $73 \%$ of the collection, bifacial intergrades $17 \%$, and the remaining $10 \%$ of the collection was of other artifact forms. Given the surface distributions at the quarry site, it is clear that the artifact types present at the three campsites are distinct compared to the quarry. 
TABLE 72. INTERSITE DISTRIBUTION OF SELECTED ARTIFACT GROUPS WITHIN THE LEONA RIVER WATERSHED PROJECT AREA IN PERCENTAGES

\begin{tabular}{|c|c|c|c|c|}
\hline & $\begin{array}{l}\text { Site } \\
41 \text { UV } 43\end{array}$ & $\begin{array}{l}\text { Site } \\
41 \text { UV } 45\end{array}$ & $\begin{array}{l}\text { Site } \\
41 \text { UV } 47\end{array}$ & $\begin{array}{c}\text { Site } \\
41 \text { UV } 48\end{array}$ \\
\hline $\begin{array}{l}\text { Late Prehistoric Association } \\
\text { Arrow points } \\
\text { Overall retouch bifaces (sma11) } \\
\text { Bifacially retouched bifaces } \\
\text { Unifaces } \\
\text { Subtotal }\end{array}$ & & $\begin{array}{r}4 \\
0 \\
8 \\
3 \\
15\end{array}$ & $\begin{array}{r}22 \\
4 \\
9 \\
6 \\
41\end{array}$ & $\begin{array}{r}22 \\
4 \\
11 \\
6 \\
43\end{array}$ \\
\hline $\begin{array}{l}\text { Archaic Association } \\
\text { Dart points } \\
\text { Overall retouch bifaces (large) } \\
\text { Bifacial intergrades } \\
\text { Subtotal }\end{array}$ & & $\begin{array}{r}15 \\
7 \\
12 \\
34\end{array}$ & $\begin{array}{r}6 \\
3 \\
8 \\
17\end{array}$ & $\begin{array}{r}5 \\
3 \\
5 \\
13\end{array}$ \\
\hline $\begin{array}{l}\text { Functional Association } \\
\text { Cores } \\
\text { Other bifaces } \\
\text { Subtotal }\end{array}$ & $\begin{array}{l}100 \\
100\end{array}$ & $\begin{array}{l}12 \\
32 \\
44\end{array}$ & $\begin{array}{r}6 \\
27 \\
33\end{array}$ & $\begin{array}{l}11 \\
28 \\
29\end{array}$ \\
\hline Totals & 100 & 93 & 91 & 95 \\
\hline
\end{tabular}

Note: Figures are percentages of excavated site collection. Ceramics from excavated context at 41 UV 47 excluded, and artifacts from backhoe trenches excluded. Totals from 41 UV 45,41 UV 47 , and 41 UV 48 are incomplete due to exclusion of certain artifact groupings (ground stone, hammerstones, historic artifacts).

The artifacts from 41 UV 43 are largely of two types, cores and bifacial intergrades, while a large variety of artifact types are well represented at the three campsites.

In light of the previous discussion the comparisons of other bifaces to cores shown in Table 72 is suggestive of functional differences between the quarry and the campsites. 0ther bifaces were the single largest 1 ithic artifact type recorded for excavated contexts at 41 UV 45,41 UV 47 , and 41 UV 48. The relatively consistent percentages of other bifaces present at the three campsites, and their high frequency, may be an indicator of the degree of final reduction sequences and maintenance activities performed at these sites. While the relative frequencies of cores at the campsites suggest that they are a significant part of the site collections, it is interesting 
to note that a large proportion (52\% of these cores were core nuclej (exhausted cores). The number of core nuclej at the campsites suggests that the cores were frequently used to produce lithics, possibly even curated, or at least repeatedly selected for within the camps over procurement of unused cobbles. Notably, at 41 UV 43 , core nuclei are very rare (1\%), and natura 1 platform cores, suggestive of infrequent use, are very common $(27 \%)$.

To summarize, the comparison of 41 UV 43 and the other three sites in the project area investigated shows that certain artifacts types are indicative of site function within the project area. The predominance of bifacial intergrades and cores at the quarry site indicated a $1 \mathrm{imited}$ and specific site function for raw material procurement.

The distribution of tool forms between the two Late Prehistoric sites (41 UV 47 and 41 UV 48) and the tools at the predominantly Archaic site (41 UV 45), suggests that change in the lithic reduction technology occurred over time. The two Late Prehistoric sites in the project area (41 UV 47 and 41 UV 48) had artifacts produced primarily from flakes, and the Archaic site had artifacts predominantly representing core tools. As is discussed next, the analysis of debitage and flake platforms within the project area strengthens the evidence for differing lithic reduction technologies between the Late Prehistoric and Archaic periods.

\section{Debitage}

The analysis of debitage from the project has shown significant differences in lithic technologies relevant to demonstrating changes over time. The intersite distributions of debitage indicate that the lithic technologies changed from a bifacing industry during the Archaic period to a core flaking technology during the Late Prehistoric. While several researchers in central Texas have generally discussed the change in lithic technologies over time (Weir 1976; Shafer 1977; Hester 1978a), there have been few monographs that deal with the topic (Gunn and Mahula 1977; Lynott 1979; Montgomery 1978). In addition to a review of the changes in lithic technologies within the project area through the analysis of debitage, site function is also considered. The intersite distribution of debitage described here supports the interpretation of site functions earlier suggested by the distribution of artifact forms.

A brief summary and comparison of site data from the four sites investigated are presented in Table 73. The table shows the percentages of the debitage categories analyzed in this report. Of particular interest is the relatively large percentage of primary and secondary flakes and corticate and partially corticate chips at site 41 UV 43 . These debitage categories dominate at 41 UV 43 and reflect the site's function as a 1 ithic quarry. Approximately $34 \%$ of the debitage is corticate or partially corticate flakes and chips; only about $16 \%$ is decorticate flakes and chips. In contrast, corticate and partially corticate flakes and chips comprise a maximum of $15 \%$ of the collection at any of the three open campsites, while decorticate specimens make up a minimum of about $69 \%$ of a site collection. In conjunction with the previously described artifact distribution at 41 UV 43 , the specialized function of the site as a quarry, and not a repeatedly used 
TABLE 73. INTERSITE DISTRIBUTION OF DEBITAGE WITHIN THE LEONA RIVER WATERSHED PROJECT AREA

$\begin{array}{cccc}\text { Site } & \text { Site } & \text { Site } & \text { Site } \\ 41 \text { UV } 43 & 41 \text { UV } 45 & 41 \text { UV } 47 & 41 \text { UV } 48\end{array}$

Primary flakes

Secondary flakes

Interior flakes

Corticate chips

Partially corticate chips

Decorticate chips

Burned chert

Chunks
1.7

12.2

4.9

1.7

17.9

10.6

44.7

6.5
0.1

6.8

25.1

0.8

6.0

44.5

16.2

0.4
0.2

3.9

13.7

2.9

7.3

62.6

8.2

1.2
$*$

5.8

13.1

1.9

7.3

55.4

15.2

0.9

Total

100.2

99.2

100.2

99.6

Note: Table shows all excavated data used in report sections, except trenches and test pits under one meter in size.

* = Less than $1 / 2 \%$.

campsite is clearly demonstrated. The significance of debitage and artifact distributions in identifying quarries in central Texas has also been demonstrated by other researchers (Kelly and Hester 1975; Assad 1978).

The analysis of flake platform types from each site was also useful in understanding the lithic technologies practiced at the four sites. Intersite comparisons point out the differences in lithic technologies between the Archaic (41 UV 45) and Late Prehistoric (41 UV 47 and 41 UV 48) components. There are also indications of site function revealed through the intersite comparisons between the open campsites and the quarry site.

The flake platform analysis from each of the sites utilized attributes characteristic of the striking platform on complete flakes that are interpreted as being indicative of two distinct flaking technologies. One of the flaking technologies is that of a bifacial reduction industry, and the other is a core flaking industry. The bifacial reduction industry is characterized by the production of flakes that have either small multifaceted platforms or 1ipped flakes. These flakes are the by-products of biface production. The core flaking industry tends to produce flakes with cortex platforms, single facet platforms, and large multiple platforms. The distribution of the various flake platform types from excavated contexts at each of the sites is summarized in Table 74 . The table shows the relative percentages of each platform type, and the relative percentages of the two lithic industries. 
TABLE 74. INTERSITE SUMMARY OF FLAKE PLATFORM TYPES WITHIN THE LEONA RIVER WATERSHED PROJECT AREA

$\begin{array}{cccc}\text { Site } & \text { Site } & \text { Site } & \text { Site } \\ 41 \text { UV } 43 & 41 \text { UV } 45 & 41 \text { UV } 47 & 41 \text { UV } 48\end{array}$

\begin{tabular}{lrrrr} 
Core Reduction & & & & \\
Cortex platform & 26 & 5.0 & 10.0 & 10.0 \\
Single facet platform & 52 & 24.0 & 45.5 & 46.0 \\
Large multiple facet platform & 13 & 8.0 & 4.5 & 9.0 \\
Other platform & 0.2 & 0.1 & 0.3 \\
\hline Total & 91 & 37.2 & 60.1 & 65.3 \\
\hline $\begin{array}{l}\text { Biface Reduction } \\
\text { Smal1 multiple facet platform }\end{array}$ & 4 & 61.0 & 34.9 & 32.0 \\
Lipped & 8 & 1.0 & 5.2 & 2.0 \\
\hline Total & & & & \\
\hline
\end{tabular}

Table 74 shows a very 1 arge percentage of the flakes from 41 UV 43 have cortex and single facet platforms (78\%); the high number is not surprising as the site has been identified as a cobble quarry, and the artifacts recovered from the site were predominantly cores. At the three other sites, identified as campsites where a wide range of subsistence activities took place, there appears to be a distinct difference in the reduction processes when comparing the predominantly Archaic site of 41 UV 45 to the Late Prehistoric components, at 41 UV 47 and 41 UV 48. Whi7e both industries are represented at all three sites, Table 74 shows that core reduction flakes are most common in the Late Prehistoric components, and bifacial reduction flakes predominate at the Archaic site. At 41 UV 45, flake platform types representative of a bifacial reduction technology are the most frequently recorded. At the site, $62 \%$ of the flakes were found to be bifacial reduction flakes, and the remaining $38 \%$ of the flakes were identified as core reduction by-products. The two Late Prehistoric sites had a distribution of flake types that were reversed from those recorded at the Archaic site. At 41 UV 47,60\% of the flakes were core reduction flakes, and $40 \%$ were bifacial reduction flakes. At 41 UV 48, the division of flake types was similar to that noted at 41 UV 47 ; about $65 \%$ of the flakes were core reduction by-products, and the remaining $34 \%$ of the flakes were bifacial reduction by-products.

The differential distribution of flake platforms at the four sites reinforces the suggestion of technological changes over time that have been forwarded by researchers in the region (Weir 1976; Shafer 1977; Hester 1978a). The 
distributions between core and bifacial reduction technologies at the Late Prehistoric sites studied here also help substantiate the similar analyses carried out by Montgomery (1978) in nearby Zavala County and in other studies from central Texas (Gunn and Mahula 1977).

\section{Midden Features}

The investigation of five midden features during the project, at the three sites 41 UV 45, 41 UV 47, and 41 UV 48, allows for intersite comparisons of these features. The two burned rock middens investigated at 41 UV 45 revealed significant differences between the northern and southern middens, and probably are reflections of the functions and activities carried out at different times at this multicomponent site. In the following paragraphs the two areas of the midden, the northern and southern areas, will be treated independently so that these differences can be demonstrated. At 41 UV 47, two distinct midden areas were investigated, one in the central portion of the site (Area A) and the other in the far eastern edge of the site (Area B). Both of the middens at 41 UV 47 were found to be Late Prehistoric features. The two middens investigated at 41 UV 48 were located at opposite ends of the site (Areas $A$ and $C$ ). Of the two middens, time limitations allowed for only minimal investigations of the Area $C$ feature through backhoe trench tests and profiles; it could not be confidently assigned to a chronological period, and information on its contents and constituency is severely limited. In the following discussions of midden features the Area C midden at 41 UV 48 wi11 not be considered.

In addition to the comparison of the midden features, the areas outside of the middens are also compared, relative to the middens. Areas away from the middens were investigated at every site. At 41 UV 45, the off-midden excavations were considered as a whole, while at 41 UV 47 and 41 UV 48 , several distinct off-midden areas were identified and treated independently during analysis. The off-midden areas at the two Late Prehistoric sites are in some cases associated with a nearby midden feature, or they are isolated activity areas.

The midden comparisons allow for a look at the relative distributions of four groups of data: tools, debitage, burned chert, and burned rocks. Because of varying unit sizes and amounts of excavation, volumetric estimates were necessary to make detailed comparisons within and between sites. The figures used in the comparison were obtained by totaling the inventory for an area or midden and dividing the inventory total by the metric volume excavated. The results obtained were then converted to percentages. Excavation units were used for the comparison, excluding only test pits and trenches.

The results of comparison are summarized in Table 75 . Table 75 allows for the intrasite comparison of midden and nonmidden areas between the three sites, and also provides information on intersite distributions. The following comments are based upon the table. 
TABLE 75. SUMMARY COMPARISON OF MIDDEN AND NONMIDDEN EXCAVATIONS AT 41 UV 45, 41 UV 47 , AND 41 UV 48 IN PERCENTAGES

\begin{tabular}{|c|c|c|c|c|c|}
\hline Sites/Area & Tools & Debitage & $\begin{array}{l}\text { Burned } \\
\text { Chert }\end{array}$ & $\begin{array}{l}\text { Count } \\
\text { Burned } \\
\text { Rock }\end{array}$ & $\begin{array}{l}\text { Weight } \\
\text { Burned } \\
\text { Rock }\end{array}$ \\
\hline \multicolumn{6}{|l|}{41 UV 45} \\
\hline North Midden & 55 & 34 & 38 & 45 & 42 \\
\hline South Midden & 19 & 24 & 38 & 48 & 53 \\
\hline Nonmidden & 26 & 42 & 23 & 7 & 5 \\
\hline Total & 100 & 100 & 99 & 100 & 100 \\
\hline Count & 31 & 1997 & 357 & 2966 & 700 \\
\hline \multicolumn{6}{|l|}{41 UV 47} \\
\hline Area A Midden & 39 & 52 & 39 & 12 & \\
\hline Area B Midden & 32 & 25 & 46 & 70 & \\
\hline Area B Nonmidden & 10 & 10 & 8 & 15 & \\
\hline Area C Nonmidden & 20 & 14 & 9 & 3 & \\
\hline Total & 101 & 101 & 102 & 100 & \\
\hline Count & $4 I$ & 3245 & 327 & 6009 & \\
\hline \multicolumn{6}{|l|}{41 UV 48} \\
\hline Area A Midden & 49 & 42 & 41 & 64 & 61 \\
\hline Area A Nonmidden & 32 & 39 & 51 & 20 & 40 \\
\hline Area B Nonmidden & 12 & 6 & 1 & 9 & \\
\hline Area C Nonmidden & 7 & 13 & 7 & 6 & \\
\hline Total & 100 & 100 & 100 & 99 & 101 \\
\hline Count & 82 & 3969 & 627 & 2177 & 351 \\
\hline
\end{tabular}




\section{Intersite Distributions}

At 41 UV 45 , comparisons of the midden features (to be referred to as the north and south middens) show some specific differences between the two. In the north midden the estimates for tools and debitage are substantially higher than they are in the south midden, while the percentages of burned chert and burned rock are about equally distributed between the two middens. The area off of both middens had the highest percentage of debitage at the site, and tools were found to be more common off-midden than in the south midden. Both burned chert and burned rock were less common in the nonmidden area. The intrasite distribution of these items may be related to the components found at the site; the north midden has been defined as an unstratified Late Prehistoric and Late Archaic feature, and the nonmidden areas contained only Late to Middle Archaic components. The south midden was not positively placed chronologically, as no projectile points or radiocarbon dates were recovered from it; however, comparisons of the south midden with those excavated at the La Jita site (and presented Tater in this section) lead one to strongly suspect that it is a Middle Archaic feature.

At site 41 UV 47, the two midden areas investigated show some differences when compared with each other. The Area A midden had very high percentages of tools and debitage compared to the Area B midden. The Area B midden contained a higher percentage of burned chert, and a much higher percentage of burned rock. The contrast between the two middens indicates that the function of each may be different. The kinds of items found in the Area $A$ midden suggest that the feature can be interpreted as a focus of a variety of activities, and can be considered a living area. The relatively high percentages of burned chert and burned rock in the Area B midden suggest the feature may have been primarily a cooking or roasting feature, although no direct evidence of its function was recorded (such as a central pit, burned seeds or bone). The Area B midden was identified as an Austin phase feature, based on a radiocarbon date and projectile point diagnostics recovered from Area B, and in this respect is especially interesting. The Area A midden is identified as a Late Prehistoric feature with both Austin and the 1ater Toyah phases represented. The unusual nature of the Area B midden when compared to the Area $A$ midden (and the midden at 41 UV 48) seems to suggest that there are at least two kinds of Late Prehistoric midden features in the region.

Nonmidden areas investigated at 41 UV 47 were in Area B, close to the Area B midden, and Area $C$, which contained a discrete activity area some distance from either midden. Both nonmidden areas had significantly lower percentages of artifacts and debitage, indicating that these areas were not the major focus of site activities.

Site 41 UV 48 had two midden features, however, only the midden in Area A was investigated adequately enough to be used in this discussion. Table 75 shows the intrasite distribution of tools, debitage, burned chert, and burned rock at the site. Area $A$ had the highest percentages of the items considered. When comparisons of the Area A midden and the Area A nonmidden unit are made, the debitage and burned chert categories appear to be fairly similarly distributed. The major differences within Area $A$ is the distribution of tools and burned rock, with both artifact types more common in the midden. Away from Area A, in the nonmidden Areas B and C of 41 UV 48, the percentages 
of all the artifact groupings are much lower relative to the Area A figures. The poor representation of artifact groupings outside of Area $A$ suggests that the majority of activities were concentrated within or immediately adjacent to the midden deposits at the site; a depositional pattern that is very similar to that found at 41 UV 47 , the other predominantly Late Prehistoric site considered in this study.

\section{Intersite Comparison of Middens}

Intersite comparisons reveal some common traits and differences between the three campsites. At the predominantly Late Prehistoric sites 41 UV 47 and 41 UV 48 , the middens investigated in Area $A$ of both sites were found to be very similar. Tools, debitage, and burned chert were most common at the Area A middens, emphasizing that the focus of occupational activities at the two sites were at the middens. Nonmidden areas were found to have lower overall concentrations of cultural debris reflecting more infrequent use of locations removed from the middens. The midden in Area B of 41 UV 47 is probably a distinct feature of the Austin phase, and may represent a plant or animal processing feature; it is not that similar to the other Late Prehistoric middens described previously, which should be considered refuse and living area accumulations.

The multicomponent site 41 UV 45 contained a strong Archaic component and a Late Prehistoric component, which was confined to the north midden. The north midden compares favorably with the Late Prehistoric features in Areas A of sites 41 UV 47 and 41 UV 48, suggesting a high degree of homogeneity for at least one type of midden feature within the period (the feature in Area $B$ of 41 UV 47 being currently the sole example of another kind of midden feature). Unfortunately, for the Archaic period, no other middens were investigated during the project except the south midden at 41 UV 45.

The south midden at 41 UV 45 is suspected to be an Archaic feature, and it is possible to make some comparisons of this feature to the Middle Archaic burned rock middens excavated at the La Jita site in northeast Uvalde County (Hester 1971). The La Jita site is the only other site besides 41 UV 45 excavated in Uvalde County with enough detailed descriptive data from an Archaic burned rock midden to allow for the following comments.

At the La Jita site (Hester 1971), analysis of intrasite distribution patterns focused on the dichotomy between Middle Archaic contexts within the middens (Areas $B$ and $F$ ) and the terrace deposits (Areas $A$ and $C$ ). In Hester's (1971) analysis, formed tools (projectile points, bifaces, unifaces, etc.) were found to be much more common in the terrace deposits associated with the Middle Archaic (155 tools) than in the Middle Archaic burned rock middens (52 tools). At the La Jita site, approximately $75 \%$ of the tools came from nonmidden contexts, the remainder from the middens. In comparing the La Jita site to the south midden at 41 UV 45 , Table 75 shows that tools at 41 UV 45 were more common in the nonmidden areas than in the south midden, but the difference is not as great as that of the La Jita data. The analysis of debitage at La Jita showed totals of 1430 and 1771 (for a total of $70 \%$ of the debitage) in the terrace deposits of Areas $A$ and $C$, respectively, while totals of 1264 and 82 (30\% of the collection) were 
recorded from the burned rock middens in Areas $B$ and $F$. The distribution of debitage at the site was used by Hester (1971) to suggest that the major activity areas were away from the burned rock middens. At 41 UV 45 , considering only the south midden (Archaic) and the nonmidden area, $36 \%$ of the debitage was recovered from the midden, and $64 \%$ was from nonmidden contexts. The distributions of debitage at 41 UV 45 and the La Jita site are similar, suggesting as Hester (1971) concluded, most of the Middle Archaic activity was focused off of the burned rock middens. Hester's (1971) summary of burned flakes from Middle Archaic contexts revealed approximately equal percentages between midden and terrace deposits (21 versus 24\%); comparisons with the burned chert recorded from the south midden and nonmidden areas of 41 UV 45 showed a significant dichotomy; $62 \%$ of the burned chert from 41 UV 45 was recovered from the south midden, and $36 \%$ was recovered from the nonmidden area. The differences in burned chert distributions between the two sites may be due to different classificatory schemes (Hester used burned flakes while this report used burned nonflake chert), but the discrepancy is so large as to suggest that the differences in the distribution of burned materials between the two sites are real, and expresses significant differences between the two sites that cannot be accounted for at present.

This brief comparison of site 41 UV 45 and the La Jita site is very suggestive in that the similarity of distributions of both tools and debitage at the sites supports Hester's (1971) contention that most of the activity took place away from the burned rock middens. However, the distribution of burned chert at 41 UV 45 and the burned flakes at La Jita is quite different, and explanations for the differences are lacking. It is possible that the difference is due to classificatory schemes, but it seems likely that the burning of flakes and nonflaked chert would tend to be co-variants, so although the extreme variation between the two sites is probably real, it remains unexplained.

\section{Summary of Midden Features}

In summary, this section has reviewed the intrasite and intersite distribution of tools, debitage, burned chert, and burned rock at three of the sites in the project area. Results of analysis of the Middle Archaic deposits from the La Jita site in northeastern Uvalde County were also included as part of this study.

Similarities between the middens associated with Late Prehistoric occupations in Area $A$ of 41 UV 47 and 41 UV 48 and the north midden of 41 UV 45 were noted, and one midden associated with the Austin phase of the Late Prehistoric was shown to be significantly different from the three aforementioned features. The only Archaic component burned rock midden investigated within the project area was compared to the excavated Middle Archaic components of the La Jita site (Hester 1971), and the similarities and differences were discussed. 


\section{SUBSISTENCE AND ENVIRONMENT}

A variety of the data recovered from the four sites in this study provides information related to the prehistoric environmental setting and subsistence patterns. Information relevant to understanding paleoenvironmental and subsistence patterns in the project area comes primarily from the recovery and analysis of faurial, snail shel1, and mussel shell remains, wood charcoal species identifications, and soil chemistry studies. While it is noted that subsistence patterns are necessarily bound to aspects of both environment and technology, this discussion will focus on the environmental aspects of subsistence. A review of the data groups at each of the sites in the project study provides intersite comparisons that evidence a paleoenvironmental setting similar to the present from the Middle Archaic period onward, although there are some indications of a change in the focus of resource procurement strategies over time.

\section{Faunal Remains}

Faunal remains were not well preserved at three of the four sites investigated during the project. The only site with significant quantities of bone was 41 UV 48, and there, virtually all of the bone was found in the Area A midden. There were 7074 bone fragments recovered at 41 UV 48; of the remaining three sites, 315 fragments were from 41 UV 47, 182 fragments were from 41 UV 45, and there was no recovery of bone from 41 UV 43 . Burned bone from the sites was distributed as follows: $6 \%$ of the collection from 41 UV $45,13 \%$ of the collection from 41 UV 47 , and $8 \%$ of the collection from 41 UV 48 . Identifiable bone was recognized at 41 UV 45 and 41 UV 47 (three elements each) and at 41 UV 48 (707 elements).

The species identified from 41 UV 45 were white-tailed deer, bison, cottontail rabbit, and fish (note that there are four species and only three elements; the deer identification comes from an ulna tool, and was not counted in the bone fragments inventory). White-tailed deer and cottontail rabbit were recorded at 41 UV 47 . At 41 UV 48 , fifteen species were identified. Cottontail rabbit, jackrabbit, and white-tailed deer dominated the bone inventory at 41 UV 48; pack rat, cotton rat, turtle, three species of snakes, domestic dog, coyote, vole, ground squirrel, badger, lizard, turkey, and toad were represented by lesser amounts of identifiable elements. While the diversity of species recorded from 41 UV 48 represents a wide range of potential food resources, it is important to note that together cottontail rabbit and jackrabbit elements comprised nearly one-half of all the bone identified. White-tailed deer elements totaled approximately $9 \%$ of the collection from the site, and the remaining species individually accounted for less than 5\% of the collection (and the majority of these 1 ess than $1 \%$ ).

The scarcity of faunal remains at 41 UV 45 and 41 UV 47 relative to the 1 arge amounts of bone recovered from 41 UV 48 may be due to prehistoric cultural patterns; however, it seems that differential preservation is more likely. At 41 UV 47 and 41 UV 48, where the bone remains were most common, phosphate assessments were on the average slightly higher than at 41 UV 45 and 41 UV 43 (spot test values of 4.3 versus 4.2 to 3.2 ). The average for $\mathrm{pH}$ readings was highest at 41 UV 43 and 41 UV 45 (an average of 8.4 at both 
sites) than at 41 UV 47 and 41 UV 48 (readings of 8.1 and 8.2 , respectively); the high pH readings at the first two sites would have the potential of increasing the rate of bone deterioration. It should also be remembered that the predominating cultural components of sites 41 UV 47 and 41 UV 48 are substantially younger (Late Prehistoric) than at 41 UV 45 . At the multicomponent site 41 UV 45 , over $85 \%$ of the bone recovered came from the Late Prehistoric and Late Archaic midden deposits.

Comparisons of the project collection with the La Jita site in northeast Uvalde County (Hester 1971) show significant differences between the faunal inventories. At the La Jita site, a total of 2078 specimens was examined. There were 167 identifiable elements in the La Jita collection, which included 10 species. White-tailed deer elements were the most common in the collection (71\%), followed by bison (17\%), and cottontail rabbit (5\%) and Canidae sp. (3\%); the remaining six species individually accounted for $1 \%$ or less of the total collection. Three species of turtles, cotton rat, raccoon, and antelope comprised the least frequently recorded elements from the $\mathrm{La}$ Jita site. The relatively common occurrence of deer and bison at La Jita differs significantly from the predominance of cottontail rabbit and jackrabbit within the Leona River project sample. The predominance of different species at the La Jita site and the Leona project may suggest prehistoric game preferences. However, La Jita site lies within the Balconian Biotic Province, and the Leona project area lies within the northern limits of the Tamaulipan Biotic Province, and the differences between the two collections may reflect differential species densities within adjacent environmental communities. Another factor causing the difference in the two collections may be chronological; the La Jita site is multicomponent with Archaic components most common while the only site in the Leona River project area with a significant sample of identified species is Late Prehistoric (41 UV 48). The percentage of burned bone from La Jita is comparable to the sites investigated in the Leona River project. Eleven percent of the bone collection from La Jita was burned, and a range of 6 to $13 \%$ of the bone from the four sites in the Leona River project was burned.

\section{Snail and Mussel She11}

Snail shells were recovered from all four of the sites investigated, and mussel she11 remains were found at every site except 41 UV 43 . Intersite distributions show some amount of variation between sites.

Slightly less than 15,000 snail shells were collected from the project excavations. The individual site analyses showed that Rabdotus sp. were the most common species recovered from each of the four sites. Rabdotus sp. are common in many prehistoric sites throughout south and central Texas, and may have been a food resource, especially during the Late Prehistoric (Hester and $\mathrm{Hill}$ 1975). The data from this project show that Rabdotus generally makes up about $90 \%$ of the collections from the two Late Prehistoric sites (41 UV 47 and 41 UV 48), while at the other two sites (41 UV 43 and 41 UV 45) Rabdotus sp. are a maximum of $75 \%$ of the collections. Rabdotus was most commonly found in the midden deposits of sites, except at 41 UV 43 , where there were no middens. 
Other snails identified in the project area were Polygyra sp., Helicina sp., Helisoma sp., and Succinea sp. Of these, Polygyra and Helicina are species often found in association with Rabdotus sp. Polygyra occurs infrequently in the collection (between 2 and $7 \%$ of the collection at any of the sites); Helicina is absent from 41 UV 43 , is relatively uncommon at 41 UV $47(5 \%)$ and 41 UV $48(2 \%)$, and is much more common at 41 UV $45(27 \%)$. The reason for the 1 arge percentage of Helicina sp. at 41 UV 45 is unknown but could possibly represent variation in the microenvironment of the site.

Two of the snails represented in the collection prefer a moist environment. Succinea sp., which was very rare and occurred only at 41 UV 47 , prefers moist woodlands. Helisoma sp., a freshwater snail, was present at three sites in the project. At 41 UV 47 and 41 UV 48, Heli soma was rare (less than $1 \%$ of the collection at each site), but at 41 UV 43 , the snail totaled $19 \%$ of the collection. As with the large percentage of Helicina at 41 UV 45 , the reason for the relative abundance of Helisoma at 41 UV 43 is unknown.

The species found in the project collection are all present in the region today, and the environmental implications are of a prehistoric setting similar to that of today. The most intriguing aspect of the intersite distributions is the large percentage of Rabdotus sp. in the midden deposits of the Late Prehistoric components at 41 UV 47 and 41 UV 48.

Mussel she11 (Unio sp.) remains were very infrequent at the sites. Fourteen umbos were found at 41 UV 47, and eight were found at 41 UV 48 . 0ther she11 parts were somewhat more common, and were recovered from most site areas, especially the midden deposits at 41 UV 47 and 41 UV 48 . No mussel shel1 remains were recorded from 41 UV 43. Complete (or nearly so) specimens ranged in maximum length from about 2 to $7 \mathrm{~cm}$. Their presence at the three campsites indicates that these sma11 unionids were a minor food resource.

\section{Wood Charcoal Species Identifications}

Wood charcoal species identifications from the project area revealed a range of different woody plants were present at the three campsites investigated (no samples of charcoal were recovered from the quarry site 41 UV 43). Of the 890 grams submitted for analysis, 218 grams (and a total of 788 pieces) were identified to species, genera, or family. The following is a discussion of the intersite distribution of the wood charcoal species at 41 UV 45, 41 UV 47 , and 41 UV 48.

Intrasite comparisons show that most of the wood charcoal identifications were common to all three of the sites. Identifications common to all the sites, in order of predominance by weight were Leguminosae, Diospyros texana, Juglans sp., Ulmaceae, Quercus sp., and Juniperus sp. Identifications common only to 41 UV 47 and 41 UV 48 were Carya sp. and Fraxinus sp. Populus deltoides was recovered only from sites 41 UV 45 and 41 UV 48. Identifications found only at a single site included Acer sp. and Plantus occidentalis from 41 UV 48 and Salix sp. from 41 UV 47. 
The identifications made from the collection are of plants present in the region today. Particularly common in the collection were Leguminosae, Diospyros texana, Juglans sp., and U1maceae. These were frequently recorded at all three sites with the following exceptions: Ulmaceae was relatively infrequent at 41 UV 47, Juglans sp. was infrequent at 41 UV 45, and Fraxinus sp. and Juniperus sp. were rare at 41 UV 48 . The remaining plants in the collection were from 41 UV 47 and 41 UV 48 (with the exception of a single identification of Populus deltoides from 41 UV 45).

The restriction of Acer sp., Carya sp., Fraxinus sp., Plantus occidentalis, and Salix sp. to sites 41 UV 47 and 41 UV 48 is suggestive. All of the plants identified prefer moist environments and are frequently found along stream banks, suggesting that the Leona River, or the Eightmile Waterhole provided a suitable environment for the growth of these plants that may not have been present at 41 UV 45 . Site 41 UV 45 is located on a intermittent tributary of the Leona River, Boon's Slough, and may not have supported the more diverse populations represented at 41 UV 47 and 41 UV 48 . However, differential preservation may have biased the record, as is noted later.

The individual site report discussions of wood charcoal identifications reveal two noteworthy facts beyond the identifications themselves. The first of these is the finding that the majority of the wood charcoal was recovered from midden contexts at all three sites. At 41 UV 45 , the majority of the samples was from either the north or the south middens (54 and $27 \%$, respectively); the remaining $19 \%$ was from a nonmidden context. At 41 UV 47 , about $91 \%$ of the samples was from the Area A midden, 5\% from the Area B midden, and the remainder from nonmidden contexts. Similarly, all of the wood charcoal samples from 41 UV 48 were from the Area A midden units. The second fact revealed by the intersite comparisons is the differential preservation of wood charcoal. The overwhelming majority of samples came from the Late Prehistoric components at 41 UV 48 (547 g) and 41 UV 47 (330 g), while only $17 \mathrm{~g}$ were available from 41 UV 45. Notably at 41 UV 45, most of the charcoal came from what were identified as the youngest deposits, those of the northern midden. The intrasite distribution of wood charcoal, as with other perishables from the sites such as shell and bone, reinforces the suggestion of differential preservation of these artifactual materials, and seriously affects the ability to make comparisons between the Archaic and Late Prehistoric components within the project. The overall indication is that there is little evidence for a significant change in the vegetation species present in the region since the Middle Archaic, although early historic reports have suggested that the vegetation distributions or patterns may have changed in favor of thorny brush during the early Historic period (Inglis 1964).

\section{Environmental and Subsistence Summary}

The intersite distribution of faunal, snail and mussel shell remains, and wood charcoal species identifications revealed similarities and differences between sites in the project area. The most significant similarities were the presence of species common to the region today, indicating an environmental setting not unlike the present. The differential preservation of the aforementioned perishable remains made extensive comparisons between 
components of the Archaic and Late Prehistoric unreasonable. However, subsistence and environmental resources were documented from each of the sites.

\section{SETTLEMENT PATTERNS}

A few observations and comments on the settlement patterns within Uvalde County and the Leona River watershed project area are presented. Limitations of time and available data prohibited intensive investigation of the settlement patterns, and the comments presented here must be considered preliminary observations at best. The following discussion is included to provide some impressionistic views that may be useful for future researchers to consider when working in the county.

\section{Site Type Diversity}

Sites 41 UV 47 and 41 UV 48 provide a tentative example of a Late Prehistoric base camp. At the two sites, the majority of site activities resulted in the accumulation of the sma11, discreet occupational middens (10-15 $\mathrm{m}$ in diameter and approximately $50 \mathrm{~cm}$ deep) in Area A of both sites. Although not quite as distinct, because of mixing with Late Archaic deposits, the north midden of 41 UV 45 is a similar example of a Late Prehistoric base camp. The lighter artifact distributions surrounding the midden deposits at 41 UV 47 and 41 UV 48 indicate that while some amount of activity took place away from the middens, it was limited. Interestingly, no Late Prehistoric hearth features were recorded outside of the middens. A Late Prehistoric feature different from the occupation middens noted previously was the midden in Area $B$ of 41 UV 47 . This midden is previously suggested to be a single phase feature (Austin phase) functioning as a resource processing station. The use of the quarry site 41 UV 43 during the Late Prehistoric was the only indication of a specialized activity site for this period.

The Archaic components investigated during the project indicate that there are at least three types of Archaic sites within the project area. Burned rock midden sites such as the one investigated at 41 UV 45 constitute the most commonly recognized Archaic site type in central Texas. The information recovered from 41 UV 45 and recorded from other sites in the region clearly suggest that these burned rock midden sites are primarily base camps. Where data is available, the intrasite structure indicates that the midden features are often associated with off-midden hearth features and occupation areas. Another Archaic site type recognized during excavations in the project area is evidenced by the recording of isolated hearth features associated with sparse cultural deposits below the Late Prehistoric occupation levels at 41 UV 47 and 41 UV 48. The occurrence of these isolated Archaic hearths within the project is interpreted as short-term use sites along drainage systems. Finally, as was the case in the Late Prehistoric, specialized function sites for 1 ithic resource procurement during the Archaic were documented in the use of the quarry site 41 UV 43, and is the third Archaic site type recognized in the project area. 
A cursory review of other sites in Uvalde County and nearby counties reflects a similar variety of site types as noted within the Leona River watershed project area. The two major excavation projects in the county, at the La Jita site (Hester 1971) and at the Anthon site (Weir and Doran 1980), were at multicomponent sites adjacent to streams. The La Jita site is a burned rock midden site in northeastern Uvalde County; Hester (1971) has demonstrated the Middle Archaic components of the site had a distinct intrasite patterning consisting of primary activity areas in the terrace deposits, and adjacent midden deposits with significantly lesser amounts of cultural materials, similar to the findings at 41 UV 45 . Hall (1974) has tested an Archaic burned rock midden site slightly east of 41 UV 47 on Taylor's Slough; his work on the margins of the midden feature revealed high densities of lithics, moderate amounts of burned rock, and ash stained soil in the area adjacent to the midden. Surface survey work and testing at sites in northeast Uvalde County along the Sabinal River by Hester (1971) identified several Archaic burned rock middens sites (41 UV 24, 41 UV 27 , 41 UV 28, and 41 UV 37) and multicomponent campsites without middens (41 UV 26 and 41 UV 29).

A preliminary report on the Anthon site (Weir and Doran 1980) in southwestern Uvalde County suggests that the Middle and Late Archaic components were characterized by a spatially patterned distribution of hearths. The distributional pattern of Archaic hearths expressed at the Anthon site differs from the Late Prehistoric components at the site, in that during the Late Prehistoric, the distribution of hearths becomes more spatially restricted. The restriction of the Late Prehistoric hearths at the Anthon site is interesting in that it may suggest how the occupational midiens of 41 UV 47 and 41 UV 48 were formed. In the Leona River project investigations, no Late Prehistoric hearths were recorded outside of the midden features, and the single excavated hearth from this period was found in the basal levels of the occupation midden at 41 UV 47 . Perhaps the repeated construction of hearths within restricted locations during the Late Prehistoric contributed to the kind of midden accumulations found at 41 UV 47 and 41 UV 48 . Hester (1971) has reported Late Prehistoric deposits of relatively dense amounts of cultural materials and burned rock (approximately $60 \mathrm{~cm}$ thick) within 41 UV 25, a long narrow site on the Sabinal River, that is reminiscent of the Late Prehistoric sites within the Leona River project.

Two distinct burned rock midden feature types, one type Late Prehistoric ("B" mounds), the other Archaic ("A" mounds), were reported by Huskey (1935) from his work in the Nueces Canyon within Uvalde, Real, and Edwards Counties. Huskey (1935) remarks that the "A" mounds were commonly found, but the "B" mounds were rarely found. While Huskey's (1935) report was written before temporal distinctions in the region were well defined the photographs in his report are very suggestive of the chronological position of the "B" mounds. The photographs show projectile points from the " $B$ " mounds are a 11 apparently Austin phase diagnostics, while the arrow points from his "kitchen middens" (occupational deposits?) include forms from both the Austin and the Toyah phases of the Late Prehistoric. Given the chronological placement of the two Late Prehistoric midden types presented in this report, future researchers in the region should be aware of the potential for recording more such features. 
In northern Zavala County, just south of Uvalde County, Montgomery (1978) has reported on the excavations at the Mariposa site. The Mariposa site is a Tong narrow site with at least two Late Prehistoric occupation areas, and the site is similar to other Late Prehistoric sites in south Texas in that the campsites tend to be very large and closely flank drainages (Montgomery 1978:21). Other Late Prehistoric site types in the area include workshops and short-term occupations. Short-term use sites (represented by single or multiple hearths) are also reported in northern Uvalde County and in the Leona River project area (Hester 1971; Ha11 1974).

As a final comment, rockshelters such as the Kincaid and Montell rockshelters, which are multicomponent sites, are an occupational site type that was utilized within the region, and the presence of shaft cave burial sites such as those reported by Benfer and Benfer (1981) and Huskey (1935) represent specialized activity sites.

\section{Physiographic Considerations}

Understanding and defining settlement patterns in the region are complicated by the effects of rapid changes in the physiographic setting as one moves north to south in the county, and by the lack of sufficient data bases to confidently interpret site functions in detail.

The fact that most of the sites discussed in this section are multicomponent sites (although many may have a dominating component), and virtually all are located along stream banks suggest extensive use of drainage systems through time. The diversity of site types and features recorded along the drainage systems also implies that a very large part of the subsistence requirements of the prehistoric groups was available within close proximity to the drainages.

In order to explain the variety of site types it is necessary to view them in respect to the resource distributions in the region. A general understanding of the environmental setting indicates that the most favorable location for a large number of both the plant and animal resources tends to be concentrated along the stream banks in the region. Topographical factors within Uvalde County are such that the distribution of streams and upland areas are homogeneously patterned, and a considerable range of subsistence needs can be met from a single base camp within any given area in the county (even within a small catchment area of $4 \mathrm{~km}$ ). The natural setting and the relative proximity of potential resources within a limited area may diminish the need for functionally specific short-term sites. However, the actual range or territory of particular groups is unknown and cannot currently be addressed without a more adequate data base; Hester's (1981) mode1 of south Texas subsistence patterns and Campbel1 and Campbe11's (1981) research on Historic Indian groups in the region would imply that the range or territory may be quite large. The total range of movement by the prehistoric groups is an important consideration in the region given the dramatic changes in the physiographic characteristics of this area.

Uvalde County is divided physiographically into two regions (Blair 1950; Gould 1975); the south half of the county lies in the South Texas Plains 
region (characteristically a thorny brushland environment), and the north half lies within the Edwards Plateau region (a scrub forest of juniper and oak). The Leona River project area lies within the northern limits of the South Texas Plains region, close to the Balcones Escarpment, which is the commonly recognized boundary between the two physiographic regions. The significant changes in the environmental setting and in the prehistoric site characteristics are recorded in the published research from the South Texas Plains of northern Zavala County (Hester 1978a; Montgomery 1978) and the Edwards Plateau in northeastern Uvalde County (Hester 1971). Both of these areas 1 ie less than $48 \mathrm{~km}$ north or south of the Leona River project area. Undoubtedly the environmental settings, as distinct and varied as those represented within Uvalde County provide different resource potentials that had significant effects on the settlement and subsistence patterns of prehistoric cultures utilizing the area. Examples of the importance of environmental factors in the region can be found in the survey work focusing on the distribution of Quercus sp. and Archaic burned rock middens (Creel 1978) and experimentations with the stone boiling of acorns (Jones 1981). The implications of these two very different studies suggest that the cooccurrence of Quercus sp. (acorn resources), and limestone rocks (for processing and neutralizing tannic acid in the acorns) may have provided the special circumstance that accounts for the limiting of the yet interpreted function of Archaic burned rock middens to the Edwards Plateau region and its southern transition zone.

The Late Prehistoric and Archaic sites just reviewed indicate that different site types exist within both cultural periods. These site types most commonly appear to represent base camps, less frequently recorded specialized activity sites for processing and procurement of different resources, and the occasional recording of rockshelters and burial sites. Admittedly, the range of activities carried out within the campsites is currently understood only at a basic level (artifact inventories and the recovery of perishable remains such as bones, seeds, and charcoal indicate the range of activities that took place, but the importance of specific resources and the function of many features remain in question), and the purpose of virtually all of the short-term sites is even less well understood. However, the presence of a variety of distinct site types is important to initiating settlement pattern studies.

\section{CULTURAL CHANGE}

Comparisons of the lithic technologies and intrasite patterns of the three sites (41 UV 45, 41 UV 47, and 41 UV 48) in the Leona River watershed project demonstrated that significant differences between the cultural periods of the Archaic and the Late Prehistoric can be documented. These changes imply that subsistence economies were altered over time.

Changes in the lithic tool forms and the lithic by-product distributions over time have been clearly demonstrated by this project. Tool forms from the predominantly Archaic site of 41 UV 45 have been shown to be primarily the artifact categories such as dart points, large overall retouch bifaces, and bifacial intergrades, while the artifacts from the two predominantly Late Prehistoric sites (4I UV 47 and 41 UV 48) are most commonly arrow points, 
small overall retouch bifaces, and bifacially retouched flakes. Tools from Archaic contexts tend to be larger than those from the Late Prehistoric components, while the Late Prehistoric artifacts are often recognizable as finished products made from flakes. The analysis of flake platforms in the project area revealed that the predominantly Archaic site of 41 UV 45 had a overall total of $62 \%$ bifacial reduction flakes, and $38 \%$ were core reduction flakes. At the Late Prehistoric sites of 41 UV 47 and 41 UV 48 , the distribution of platformed flake types was essentially reversed, with $63 \%$ of the collection being core reduction flakes and $37 \%$ bifacial reduction flakes. The apparent dichotomy between the Archaic and Late Prehistoric periods indicates that while there is certainly some overlap in the lithic technologies, a technological change over time has been described that characterizes the Archaic period as emphasizing a bifacial reduction technology, and the Late Prehistoric period as primarily utilizing a core reduction technology.

The investigation of intrasite composition within the project area revealed another distinct dichotomy between the Archaic and Late Prehistoric components. The Archaic midden investigated at 41 UV 45 (the southern midden) was found to be a relatively large and deep accumulation of burned rocks, containing comparatively lesser amounts of tools and debitage than were recorded in the Archaic deposits in the adjacent terrace soils. The mixed Late Prehistoric and Archaic components represented in the northern midden showed a quite different constituency than the rest of the site. Archaic features such as hearths were frequently found in the terrace deposits adjacent to the midden deposits and also as isolated features at other sites in the project area. In contrast, the three Late Prehistoric middens investigated at 41 UV 47 and 41 UV 48 were found to be of a consistent size and depth (10 to $15 \mathrm{~m}$ in diameter and about $50 \mathrm{~cm}$ deep), and commonly contained the majority of artifactual materials recovered from the investigations inside and outside the midden deposits. Two types of Late Prehistoric midden features were reported; one that appeared to be primarily occupational accumulations, and a single example of a food preparation feature, possibly similar in function (as an oven) to the sotol pits, or ring middens, found in west Texas. The intrasite distributions of cultural materials indicated that most of the activity took place within the middens; areas outside of the Late Prehistoric middens contained only minor evidence of use. It may be significant that the only Late Prehistoric hearth feature in the project area was found within a midden feature. To summarize, the analysis of midden features in the project area produced evidence of intrasite patterning that changed significantly between the Archaic and the Late Prehistoric.

Other Archaic and Late Prehistoric components in the region, such as the Anthon site (Weir and Doran 1980), the La Jita site (Hester 1971), and the Mariposa site (Montgomery 1978), show similar indications of cultural change extending into both the Edwards Plateau and South Texas Plains physiographic environments. In addition, studies from central Texas dealing with cultural changes between the Late Prehistoric and the Archaic (Skinner and Gallagher 1974; Gunn and Mahula 1977; Shafer 1977) seem to indicate the changes were effected over a large area. 
Interpreting the changes in lithic technologies and intrasite activity areas within the project area is difficult at best. Changes within the long lasting Archaic and the Late Prehistoric are apparent (Weir 1976; Jelks 1962), but need to be more thoroughly understood in details of the types and the rates of changes within the sequence before this problem can be approached. The data recovered during this project was not adequate to thoroughly investigate cultural change from a more detailed chronological perspective. The components from the Late Prehistoric and Archaic were in some instances mixed, or otherwise found to be too indistinct to allow for detailed examination of individual cultural phases. Also hindering interpretations is the differential preservation of perishables such as bone and plant remains that would provide information subsistence resources.

The dichotomy between the Archaic and the Late Prehistoric periods has been emphasized to demonstrate the occurrence of cultural change. There are indications that some of these changes, particularly 1 ithic technologies, began during the last phases of the Archaic (cf. Weir 1976; Shafer 1977). It may be that the cultural changes described in this report were less distinct than implied here, and with future research at suitable sites, it may be shown that the cultural changes between the Archaic and the Late Prehistoric were more gradual and evolved over some period of time.

\section{MITIGATION SUMMARY}

Construction plans for floodwater retarding structures within the Leona River watershed will have adverse effects on the archaeological resources within the project area. Sites will be periodically inundated by floodwater held behind the proposed dam structures, and construction activities associated with the building of the earthen dams will severely damage portions of two sites, 41 UV 43 and 41 UV 47. Mitigation of these two sites and sites 41 UV 45 and 41 UV 48 included investigations of both the surface and subsurface archaeological manifestations. These investigations were designed in response to the RFP and have been described in this report in such a manner as to allow future researchers a clear representation of the four sites' surface and subsurface characteristics. Detailed information on site content, depth of archaeological deposits, extent of site parameters, artifact densities and distributions within cultural zones, chronological documentation, and paleoenvironmental data were recorded from each of the sites investigated.

Mitigation measures within the sites included a $10 \%$ random sample from the surface and varying intensities of subsurface investigations. The excavated sample for each site was determined through a multistage strategy that incorporated field interpretations of the surface collections, followed by judgmental use of backhoe trenching and hand dug test excavations prior to determining locations for the final intensive excavations. The necessity of incorporating both exploratory and final excavation efforts within a single field session, along with time and funding limitations restricted the degree of intensive coverage at each site. The work carried out at the four sites has provided a data base useful to future research in the region. Previous archaeological research in Uvalde County is 1 imited, and at this point, gathering a substantial data base from excavations similar to those carried 
out during this project will continue to be valuable sources of information needed to answer more specifically problem oriented research.

\section{Future Research}

Mitigation efforts are often restricted from sufficiently detailed examinations of all the components in multicomponent sites (such as those considered in this report) undoubtedly due to the large areas that funding agencies must often consider when allocating available funds, and because of the perceptions of the responsible contractors to provide as broad and thorough coverage of endangered sites as is possible within RFP specifications. However, behavioral understanding of the prehistoric groups behind the relatively well agreed on chronological subdivisions is really just beginning. Pattern recognition searches and intracomponent studies such as those undertaken by Montgomery (1976) and Prewitt (1974) have been the result of non-federally funded research and are infrequent relative to mitigation measures of site inventorying and general documentation.

Federal agencies and researchers working within regions may find it useful to seek out and identify single component sites, or isolated components within multicomponent sites that can be more intensively focused on in order to provide greater spatial coverage of a particular cultural phase. Such sites are not often found within impacted areas covered by federal legislation, but when they can be identified prior to the final phases of mitigation measures, they should be given priority over those sites with components that are mixed. The Hinojosa site (BIack 1986) in south Texas is an excellent example of the kind of site that should be sought out for investigation. Whenever the ideal conditions for site selection can be met, the potential for a more thorough description of intrasite relationships can add greatly to an understanding of subsistence patterns and site functions.

\section{REFERENCES CITED}

Allen, D. C. and E. P. Cheatum

1961 Ecological Implications of Fresh-Water and Land Gastropods in Texas Archeological Sites. Bulletin of the Texas Archeological Society 31:291-316.

Assad, C.

1978 An Evaluation of Archaeological Sites in the Vicinity of Floodwater Retarding Structure No. 2, Dry Corral Creek, Comal County, Texas. Center for Archaeological Research, The University of Texas at San Antonio, Archaeological Survey Report 50. 
Barnes, V. E., project director

1974 Geologic Atlas of Texas. San Antonio Sheet. Robert Hamilton Cuyler Memorial Edition. Bureau of Economic Geology, University of Texas at Austin.

Benfer, A. and R. Benfer

1981 The Mason Ranch Burial Cave, Texas. La Tierra 8(3):16-27.

Bennet, M. A.

1974 Basic Ceramic Analysis. San Juan Valley Archaeological Project. Eastern New Mexico Contributions in Anthropology, Technical Series 1(6).

B1ack, S. L.

1982 Prehistoric Ceramic Artifacts. In Archaeological Investigations at Choke Canyon Reservoir, South Texas: The Phase I Findings, by G. D. Hall, S. L. Black, and C. Graves:390-453. Center for Archaeological Research, The University of Texas at San Antonio, Choke Canyon Series 5.

1986 The Clemente and Herminia Hinojosa Site, $41 \mathrm{JW}$ 8: A Toyah Horizon Campsite in Southern Texas. Center for Archaeological Research, The University of Texas at San Antonio, Special Report 18.

Black, S. L. and A. J. McGraw

1985 The Panther Springs Creek Site: Cultural Change and Continuity Within the Upper Salado Creek Watershed, SouthCentral Texas. Center for Archaeological Research, The University of Texas at San Antonio, Archaeological Survey Report 100.

Blair, W. E.

1950 The Biotic Provinces of Texas. The Texas Journal of Science 2(1):93-116.

Brown, D., P. Lukowski, T. R. Hester, and J. D. Eaton

1977 Archaeological Assessment of Two Sites in the Vicinity of Floodwater Retarding Structure No. 11, Salado Creek Watershed, Bexar County, Texas. Center for Archaeological Research, The University of Texas at San Antonio, Archaeological Survey Report 35. 
Bryant, V. M., Jr. and D. H. Riskind

1980 The Paleoenvironmental Record for Northeastern Mexico: A Review of the Pollen Evidence. In Papers on the Prehistory of Northeastern Mexico and Adjacent Texas, edited by J. F. Epstein, T. R. Hester, and C. Graves:7-32. Center for Archaeological Research, The University of Texas at San Antonio, Special Report 9.

Bryant, V. M., Jr. and H. J. Shafer

1977 The Late Quaternary Paleoenvironment of Texas: A Mode1 For the Archeologist. Bulletin of the Texas Archeological Society 48:1-26.

Campbe11, T. N.

1960 Texas Archeology: A Guide to the Literature. Bulletin of the Texas Archeological Society 29:117-254.

Campbe11, T. N. and T. J. Campbe11

1981 Historic Indian Groups of the Choke Canyon Reservoir and Surrounding Areas, Southern Texas. Center for Archaeological Research, The University of Texas at San Antonio, Choke Canyon Series 1 .

Clark, J. W., Jr.

1969 Implications of Land and Fresh-Water Gastropods in Archeological Sites. Arkansas Academy of Science Proceedings 23 .

Collins, M. B.

1969 Test Excavations at Amistad International Reservoir, Fa11, 1967. Papers of the Texas Archeological Salvage Project 16.

Cook, P.

1981 A Review of the History and Archaeology of Mission San Lorenzo, Real County, South Texas. La Tierra 8(3):3-15.

Cree1, D.

1978 An Archeological Survey in the South Concho River Area, West Central Texas. Bulletin of the Texas Archeological Society 49:241-308.

Davis, W. B.

1974 The Mammals of Texas. Texas Parks and Wild1ife, Bu1letin 41. Austin. 
Dering, P.

1978 Pollen Analysis of Soil Samples from 41 BX 36, 41 BX 377, and 41 BX 428. In The Fort Sam Houston Project: An Archaeological and Historical Assessment, by A. Gerstle, T. C. Kelly, and C. Assad:223-228. Center for Archaeological Research, The University of Texas at San Antonio, Archaeological Survey Report 40 .

1982 Analysis of Carbonized Botanical Remains from the Choke Canyon Reservoir Area. Appendix III in Archaeological Investigations at Choke Canyon Reservoir, South Texas: The Phase I Findings, by G. D. Ha11, S. L. Black, and C. Graves:518-530. Center for Archaeological Research, The University of Texas at San Antonio, Choke Canyon Series 5.

Dillehay, T. D.

1974 Late Quaternary Bison Population Changes on the Southern Plains. Plains Anthropologist 19(65):180-196.

Evans, G.

1947 Report on a cave at the Ray Miller Ranch, Uvalde County, Texas. Manuscript dated April 3, 1947. On file at the Center for Archaeological Research, The University of Texas at San Antonio.

Fisher, C. E.

1975 Mesquite and Modern Man in Southwestern North America. In Mesquite: Its Biology in Two Desert Ecosystems, edited by B. B. Simpson:176-188. Dowden, Hutchenson, and Ross, Inc., Stromberg, Pennsylvania.

Fox, D. E.

1979 Archaeological Investigations of Two Prehistoric Sites on the Coleto Creek Drainage, Goliad County, Texas. Center for Archaeological Research, The University of Texas at San Antonio, Archaeological Survey Report 69.

Gerstle, A., T. C. Kelly, and C. Assad

1978 The Fort Sam Houston Project: An Archaeological and Historical Assessment. Center for Archaeological Research, The University of Texas at San Antonio, Archaeological Survey Report 40 .

Gould, F. M.

1975 The Grasses of Texas. Texas A\&M Press, College Station, Texas. 
Graves, C.

ms. Archaeological Investigations at the Franks Site, Uvalde County, Texas. Manuscript on file at the Texas Archeological Research Laboratory, Austin, Texas.

Gunn, J. and R. A. Mahula

1977 Hop Hill: Culture and Climate Change in Central Texas. Center for Archaeological Research, The University of Texas at San Antonio, Special Report 5.

Ha11, G. D.

1974 Leona River Watershed, Uvalde County, Texas: An Archeological and Historical Survey of Areas Proposed for Modification. Texas Archeological Survey, The University of Texas at Austin, Research Report 37.

1981 Allens Creek: A Study in the Cultural Prehistory of the Lower Brazos River Valley, Texas. Texas Archeological Survey, The University of Texas at Austin, Research Report 61.

Hal1, G. D., S. L. Black, and C. Graves

1982 Archaeological Investigations at Choke Canyon Reservoir, South Texas: The Phase I Findings. Center for Archaeological Research, The University of Texas at San Antonio, Choke Canyon Series 5 .

Henderson, $\mathrm{J}$.

1978 Faunal Analys is of Site 41 BX 36, with Data Presented for 41 BX 377 and 41 BX 428. In The Fort Sam Houston Project: An Archaeological and Historical Assessment, by A. Gerstle, T. C. $\mathrm{Kelly}$, and C. Assad:223-228. Center for Archaeological Research, The University of Texas at San Antonio, Archaeological Survey Report 40.

Hester, T. R.

1970 Burned Rock Midden Sites on the Southwestern Edge of the Edwards Plateau, Texas. Plains Anthropologist 15(50), Part $1: 237-250$.

1971 Archeological Investigations at the La Jita Site, Uvalde County, Texas. Bulletin of the Texas Archeological Society $42: 51-148$.

1974 Bibliographic Guide to the Archaeology of Southern Texas. Journal of South Texas 1:18-36. 
Hester (continued)

1977a The Current Status of Paleoindian Studies in Southern Texas and Northeastern Mexico. In Paleoindian Lifeways, edited by E. Johnson. The Museum Journal 17:169-185.

1977b Observations on a Trip to Montell Rockshelter, October 1977. Notes on file at the Center for Archaeological Research, The University of Texas at San Antonio.

1978a Background to the Archaeology of Chaparrosa Ranch, Southern Texas. Center for Archaeological Research, The University of Texas at San Antonio, Special Report 61.

1978b Notes on the Edwards Arrow Point Type. La Tierra 5(4):21-22.

1980a A Chronological 0verview of Prehistoric Southern and SouthCentral Texas. In Papers on the Prehistory of Northeastern Mexico and Adjacent Texas, edited by J. F. Epstein, T. R. Hester, and C. Graves:119-138. Center for Archaeological Research, The University of Texas at San Antonio, Special Report 9.

1980b Digging Into South Texas Prehistory. Corona Publishing Company, San Antonio.

1981 Tradition and Diversity Among the Prehistoric Hunters and Gatherers of Southern Texas. Plains Anthropologist 26(92): 119-128.

Hester, T. R., F. Asaro, and F. Stross

1982 Results of Some Recent Studies by the Texas Obsidian Project. Houston Archaeological Society Journal 73:8-10.

Hester, T. R., D. Gilbow, and A. D. Albee

1973 A Functional Analysis of "Clear Fork" Artifacts from the Rio Grande Plain of Texas. American Antiquity 38(1):90-96.

Hester, T. R. and T. C. Hill, Jr.

1975 Some Aspects of Late Prehistoric and Protohistoric Archaeology in Southern Texas. Center for Archaeological Research, The University of Texas at San Antonio, Special Report 1.

1980 Transport of Cultural and Non-Cultural Materials by Texas Woodrats: Examples and Archeological Implications. Bulletin of the Texas Archeological Society 51:317-324. 
Hester, T. R. and H. Kohnitz

1975 The Chronological Placement of Guadalupe Tools. La Tierra 2(2):22-25.

Highley, L., C. Graves, and G. Judson

1978 Archaeological Investigations at Scorpion Cave (41 ME 7), Medina County, Texas. Bulletin of the Texas Archeological Society 49:139-194.

Huskey, V. W.

1935 Nueces Canyon Survey. Bulletin of the Texas Archeological Society 7:105-114.

Inglis, J. M.

1964 A History of Vegetation in the Rio Grande Plain of Texas. Texas Parks and Wildlife Bulletin 45:1-222.

Jackson, A. T.

1938 Picture Writing of Texas Indians. University of Texas Publication 3809.

JeTks, E. B.

1962 The Kyle Site: A Stratified Central Texas Aspect Site in Hill County, Texas. Department of Anthropology, The University of Texas at Austin, Archeological Series 5.

Johnson, C.

1978 Field Investigations at Loma Sandia, 41 LK 28. Paper presented at the Texas Archeological Society Annual Meeting, November 1978.

Johnson, L., Jr.

1964 The Devil's Mouth Site, A Stratified Campsite at Amistad Reservoir, Val Verde County, Texas. Department of Anthropology, The University of Texas at Austin, Archeological Series 6.

Johnson, L., Jr., D. A. Suhm, and C. D. Tunnel1

1962 Salvage Archaeology of Canyon Reservoir: The Wundertich, Footbridge and 0blate Sites. Texas Memorial Museum, Bulletin 5 . 
Jones, C. J.

1981 A Further Experiment in Stone Boiling: A Calcining Process for Acorns. La Tierra 8(2):31-39.

Kel1y, T. C. and T. R. Hester

1975 Archaeological Investigations at Four Sites in the Dry Comal Watershed, South Central Texas. Center for Archaeological Research, The University of Texas at San Antonio, Archaeological Survey Report 15.

Krieger, A. D.

1956 Food Habits of Texas Coastal Indians in the Early Sixteenth Century. Bulletin of the Texas Archeological Society 27:4758.

Lukowski, P. D.

1987 Archaeological Investigations at 41 BX 1, Bexar County, Texas. Center for Archaeological Research, The University of Texas at San Antonio, Archaeological Survey Report 126 (in preparation).

Lundelius, E. L., Jr.

1980 Late Pleistocene and Holocene Mammals from Northern Mexico and Their Implications for Archaeological Research. In Papers on the Prehistory of Northeastern Mexico and Adjacent Texas, edited by J. F. Epstein, T. R. Hester, and C. Graves:33-40. Center for Archaeological Research, The University of Texas at San Antonio, Special Report 9.

Lynott, M. J.

1979 An Archaeological Assessment of the Bear Creek Shelter, Lake Whitney, Texas. Archaeological Research Program, Department of Anthropology, Southern Methodist University, Archaeological Research Report 115.

McGraw, A. J. and F. Valdez, Jr.

197841 BX 68: A Prehistoric Quarry-Workshop in Northern Bexar County, Texas. Center for Archaeological Research, The University of Texas at San Antonio, Archaeological Survey Report 56.

Mitche11, J. L.

1974 Notes on Metal Projectile Points from Southern Texas. Journal of South Texas 1:47-51. 
Mitche11 (continued)

1978 The Turtle Creek Phase: An Initial Late Prehistoric Component in Southern Texas. La Tierra 5(4):32-43.

Montgomery, J.

1978 The Mariposa Site: A Late Prehistoric Site on the Rio Grande Plain of Texas. Center for Archaeological Research, The University of Texas at San Antonio, Special Report 6(2).

Netson, G.

1981 Preliminary Archaeological Survey and Testing at Fort Inge, Texas. Uvalde County Historical Commission.

Ode11, G. H. and F. Ode11-Vereeken

1980 Verifying the Reliability of Lithic Use-Wear Assessments by "BT ind Tests": the Low-Power Approach. Journal of Field Archaeology 7(1):87-120.

Patterson, L.W.

1975 A Quarry Site in Medina County, Texas. La Tierra 2(1):19-23.

1982 Some Prehistoric Sites on the Uvalde-Zavala County Line, Texas. La Tierra 9(1):11-14.

Prewitt, E. R.

1974 Archeological Investigations at the Loeve-Fox Site, Williamson County, Texas. Texas Archeological Survey, The University of Texas at Austin, Research Report 49.

1981 Cultural Chronology in Central Texas. Bulletin of the Texas Archeological Society 52:65-89.

Ralph, E. K., H. N. Michael, and M. C. Han

1973 Radiocarbon Dates and Reality. MASCA Newsletter 9(1):1-20.

Robinson, R. L.

1979 Biosilica and C1imatic Change at 41 GD 21 and 41 GD $21 \mathrm{~A}$. Appendix IV in Archaeological Investigations of Two Prehistoric Sites on the Coleto Creek Drainage, Goliad County, Texas, by D. E. Fox. Center for Archaeological Research, The University of Texas at San Antonio, Archaeological Survey Report 69. 
Robinson (continued)

1982 Biosilica Analysis of Three Prehistoric Archaeological Sites in the Choke Canyon Reservoir, Live Oak County, Texas: Preliminary Summary of Climatic Implications. Appendix VIII in Archaeological Investigations at Choke Canyon Reservoir, South Texas, The Phase I Findings, by G. D. Hal1, S. L. Black, and C. Graves:597-610. Center for Archaeological Research, The University of Texas at San Antonio, Choke Canyon Series 5.

Sellards, E. H.

1952 Early Man in America. Texas Memorial Museum Press, Austin.

Shafer, H. J.

1963 Test Excavations at the Youngsport Site: A Stratified Terrace Site in Bell County, Texas. Bulletin of the Texas Archeological Society 34:57-81.

1977 Late Prehistory of Central Texas, 500 B.C.- A.D. 1700. Bulletin of the South Plains Archaeological Society 3:18-27.

Shepard, A. 0 .

1976 Ceramics for the Archaeologist. Carnegie Institute of Washington, Publication 609.

Skinner, S. A. and T. Gallagher

1974 An Evaluation of the Archaeological Resources at Lake Whitney, Texas. Southern Methodist University, Contributions in Anthropology 14.

Sollberger, J. B.

1978 A New Type of Arrow Point With Speculations as to It's Origin. La Tierra 5(4):13-20.

Sollberger, J. B. and T. R. Hester

1972 The Strohacker Site: A Review of Pre-Archaic Manifestations in Texas. Plains Anthropologist 17:326-344.

Sorrow, W. M., H. J. Shafer, and R. E. Ross

1967 Excavations at Stillhouse Hollow Reservoir. Texas Archeological Salvage Project, The University of Texas at Austin, Papers 11. 
Stevens, J. N. and D. L. Richmond

1976 Soil Survey of Uvalde County, Texas. United States Department of Agriculture and the Texas Agricultural Experiment Station. Washington, D.C.

Suhm, D. A. and E. B. Jelks

1962 Handbook of Texas Archeology: Type Descriptions. Texas Archeological Society, Special Publication 1 and Texas Memorial Museum, Bulletin 4.

Suhm, D. A., A. D. Krieger, and E. B. Jelks

1954 An Introductory Handbook of Texas Archeology. Bulletin of the Texas Archeological Society 25.

Thoms, A. V., J. L. Montgomery, and A. W. Portnoy

1981 An Archaeological Survey of a Portion of the Choke Canyon Reservoir Area in McMullen and Live Oak Counties, Texas. Center for Archaeological Research, The University of Texas at San Antonio, Choke Canyon Series 3.

Tunne11, C. D. and W. W. Newcomb, Jr.

1969 A Lipan Apache Mission: San Lorenzo de la Cruz, 1762-1771. Texas Memorial Museum Bulletin 14.

Turner, E. S. and T. R. Hester

1985 A Field Guide to Stone Artifacts of Texas Indians. Texas Monthly Press, Austin.

Weir, F. A.

1976 The Central Texas Archaic. Ph.D. dissertation. Department of Anthropology, Washington State University, Pullman.

Weir, F. A. and G. H. Doran

1980 A Brief Report on the Anthon Site (41 UV 60). La Tierra 7(3): 17-23.

Wesolowsky, A. B.

n.d. The E. G. (Ernie) Garrison Collection. Notes on file at the Center for Archaeological Research, The University of Texas at San Antonio. 


\section{APPENDIX I}

\section{SOIL TEST DATA}

\section{INTRODUCTION}

Soil chemistry tests were conducted on selected soil samples especially collected from the sites. A total of 168 soil samples was collected during the project, comprised mainly of soils taken from profile columns or cultural features. Of the 168 samples collected in the field, $79(47 \%)$ were later subjected to chemical analyses. A summary of samples collected from each site and the total number actualiy tested are provided in Table 76.

Two different tests were used on each of the analyzed soil samples. The two tests were the phosphate field test and pH measurements. Both tests were selected as aids in identifying and isolating areas within each of the sites that could have had soils culturally altered significantly enough to be detected by the test results.

Consideration was given to both time and cost factors when deciding upon what tests to conduct on the selected soils. It was felt that applying only those tests that could be performed in the CAR laboratory would provide immediate access and a degree of control and monitoring that would not be available if the samples were sent to an agricultural testing laboratory. The desirability of performing the tests in our own laboratory would allow for alteration, fine adjustments, and crosschecking of the tests in order to insure optimal results for archaeological interpretations. Previous soil analysis tests performed on samples from other CAR projects, generally through the Texas A\&M University Soil Extension Service, have been of limited value due at least in part to the differences in the interpretive goals between archaeological research and the standard output of the extension lab (Gunn and Mahula 1977; Gerstle, Kelly, and Assad 1978). Tailoring the tests to our own needs was, in part, accomplished by pre-analysis experimentation with a view towards selecting the most suitable proportions of elements that would be required within each experiment, and the most appropriate time lengths necessary to complete each of the tests.

The tests were expected to provide specific data for interpretive purposes. The phosphate field test was selected for its use as a general indicator of human or animal activities. High phosphorus levels can help interpret, even in spot tests, the length and intensity of human occupations, isolate activity areas, especially in regards to bone and human wastes; and locate burials (Sanders 1977). Phosphate testing has proved to be of some significance at various sites in Texas (Gerstle, Kelly, and Assad 1978:220; Gunn and Mahula 1977:65, Burleigh 1980:163). While the spot test for phosphates performed on the Leona samples are qualitative, it was hoped that some indication of the land-use patterns within the site might be strongly enough indicated to suggest a more quantitative method of analysis such as phosphate fractionalization (Lewis 1978).

The possible cultural significance of $\mathrm{pH}$ levels may be used as a general indicator of cultural activity; it has been noted that alkalinity (low pH values) may be increased by the presence of wood ash and may cause 
TABLE 76. COLLECTION AND TESTING SUMMARY FOR PROCESSED SOIL SAMPLES FROM THE PROJECT AREA

41 UV $43 \quad 41$ UV $45 \quad 41$ UV $47 \quad 41$ UV $48 \quad$ TOTAL

Total number of samples collected

5

78

46

39

168

Total number of samples tested

4

37

18

20

79

encrustations on some objects (Dowman 1970:24). Readings that are more acidic (pH 5.6 or less) may allow more leaching out of the soils (Gerstle, Kelly, and Assad 1978:218) and so have a probable effect on organic preservation and phosphorus readings.

\section{METHODS}

The laboratory tests were carried out in the CAR-UTSA 1aboratory. A11 experiments were performed by Mike Woerner, CAR staff archaeologist. A11 work was carried out under the general supervision of the project consultant, Dr. Donald R. Lewis. The project archaeologist was responsible for selecting the kinds of tests to be run on the samples and on the execution of experiments.

Soil analysis for phosphates followed the procedures outlined in a CAR laboratory manual prepared by Dr. Lewis (1981a). The testing procedure and subsequent ranking system were adapted from Woods (1975) and Eidt (1977). A similar testing procedure and a more fully developed explanation are available in Burleigh (1980). The tests were performed by first placing a few grams of soil, not measured amounts but approximately of equal portions, in the center of a filter paper. An ammonia molybdate solution prepared according to the specifications in the laboratory manual was then dropped onto the soil sample, and after a set time an equal amount of ascorbic acid was added to the soil on the filter paper. The filter paper was then observed for two minutes. If phosphates were present, the filter paper around the soil would begin to show a blue color. The following observations were recorded for each sample as indicators of the amount of phosphate present: (1) length of time prior to first observation of color change; (2) percentage of sample surrounded by blue color; (3) the length of rays that extend away from the soil sample; and (4) the overall intensity of the color. Each observation was qualitatively ranked on a 1 to 5 scale using the criteria outlined by Woods (1975). To obtain a single figure for data summations, the rankings of the four observations taken for each test were averaged. Where samples were duplicated, the results were also averaged together to provide a single figure for data manipulations. 
Soil reaction was measured using a Corning Model $3 \mathrm{pH}$ Meter and following the instructions prepared by Lewis (1981b) on file at the CAR. Samples to be measured were mixed with distilled water and allowed to settle prior to insertion of the electrode. There was a consistent ratio of three parts water to one part soil for the process, and readings were taken two minutes after insertion of the electrode into the solution.

\section{RESULTS}

The results of the two tests are summarized in Table 77; individual site data are in Table 78. No significant variations in soil reaction or phosphate content were indicated by the test results, between or within the sites in the project area. Phosphates varied from a ranking of 2.4 to 5.5 (10w phosphate to concentrated phosphate readings). The average phosphate readings were approximately the same at 41 UV 45,41 UV 47 , and 41 UV 48 (about 4.2 to 4.3 ). The average phosphate reading at 41 UV 43 was slightly lower (3.2). The $\mathrm{pH}$ readings for all samples varied from 7.5 to 8.8 . On the average, 41 UV 47 and 41 UV 48 tended to have slightly lower values $(8.2$ and 8.1) than 41 UV 43 or 41 UV 45 (8.4). However, within the sites no patternings were evident vertically or horizontally. The following few paragraphs briefly summarize the test results by site.

At site 41 UV 43, phosphate readings ranged from 2.4 to 4.0 ; $\mathrm{pH}$ readings varied from 8.2 to 8.6 . The average phosphate reading was 3.2 , which is noticeably less than the other three sites in the project area (4.2-4.3). As phosphate presence is a likely indicator of human and animal occupation within a site, the lower average of the quarry is interesting; it would support other evidence from the quarry that its use as a camping or occupation site was very infrequent.

There was no clear patterning in the phosphate readings from 41 UV 45 . The range of readings from the midden area excavation units was slightly more restricted (3.8 to 4.6) than the readings from nonmidden area units (3.4 to 4.9). Readings from the trench samples fell within the above averages. Within the sample, Features 1 through 6 show the most restricted range, 3.9 to 4.5. The pH readings averaged 8.4, with a range of 8.1 to 8.8 .

Site 41 UV 48 showed indications of a slightly higher phosphate content in midden areas versus monmidden areas, with a range of 3.9 to 4.9 in the Area $A$ excavation units, and a range of 3.8 to 4.5 in the nonmidden areas exposed by Backhoe Trenches 1 and 9 . The pH readings at the site from 26 samples ranged from 8.0 to 8.4 with a single exception: a very low reading was obtained from the Feature 2 sample $(\mathrm{pH} 7.5)$. The reason for such a low reading is unknown but may be related to high wood ash amounts once present within the feature (Dowman 1970).

The combined tests for soil reaction and phosphate levels applied to the samples did not provide any clear evidence of intrasite patterning. In general, both tests produced rather variable readings from all contexts; some very slight suggestions of differences between midden and nonmidden, or terrace, deposits were seen by the phosphate levels, but much more testing would be necessary to make a meaningful interpretation. However, on an 
TABLE 77. SUMMARY OF SOIL TEST RESULTS, PHOSPHATE RANGES

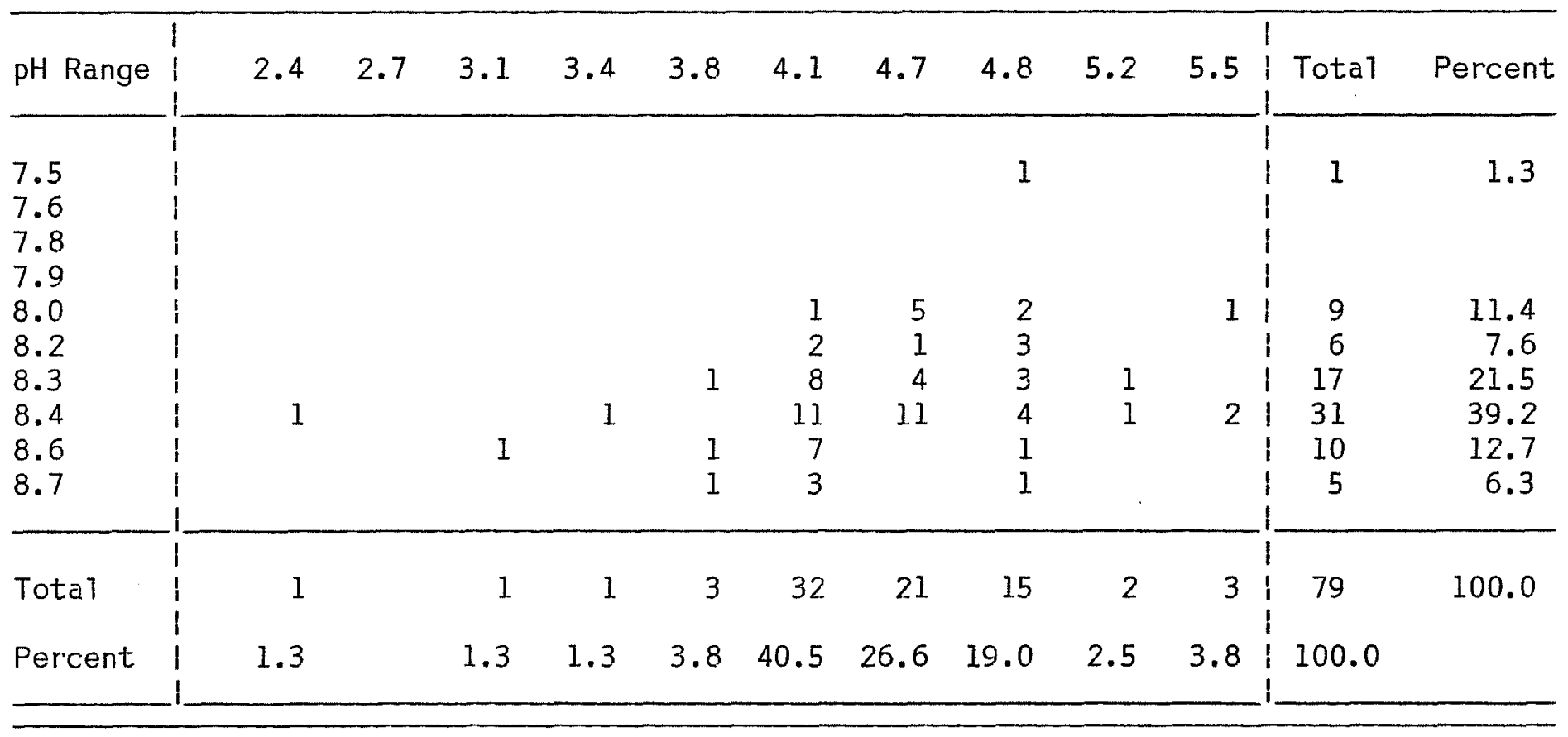


TABLE 78. RESULTS OF SOIL TESTS FROM THE PROJECT AREA

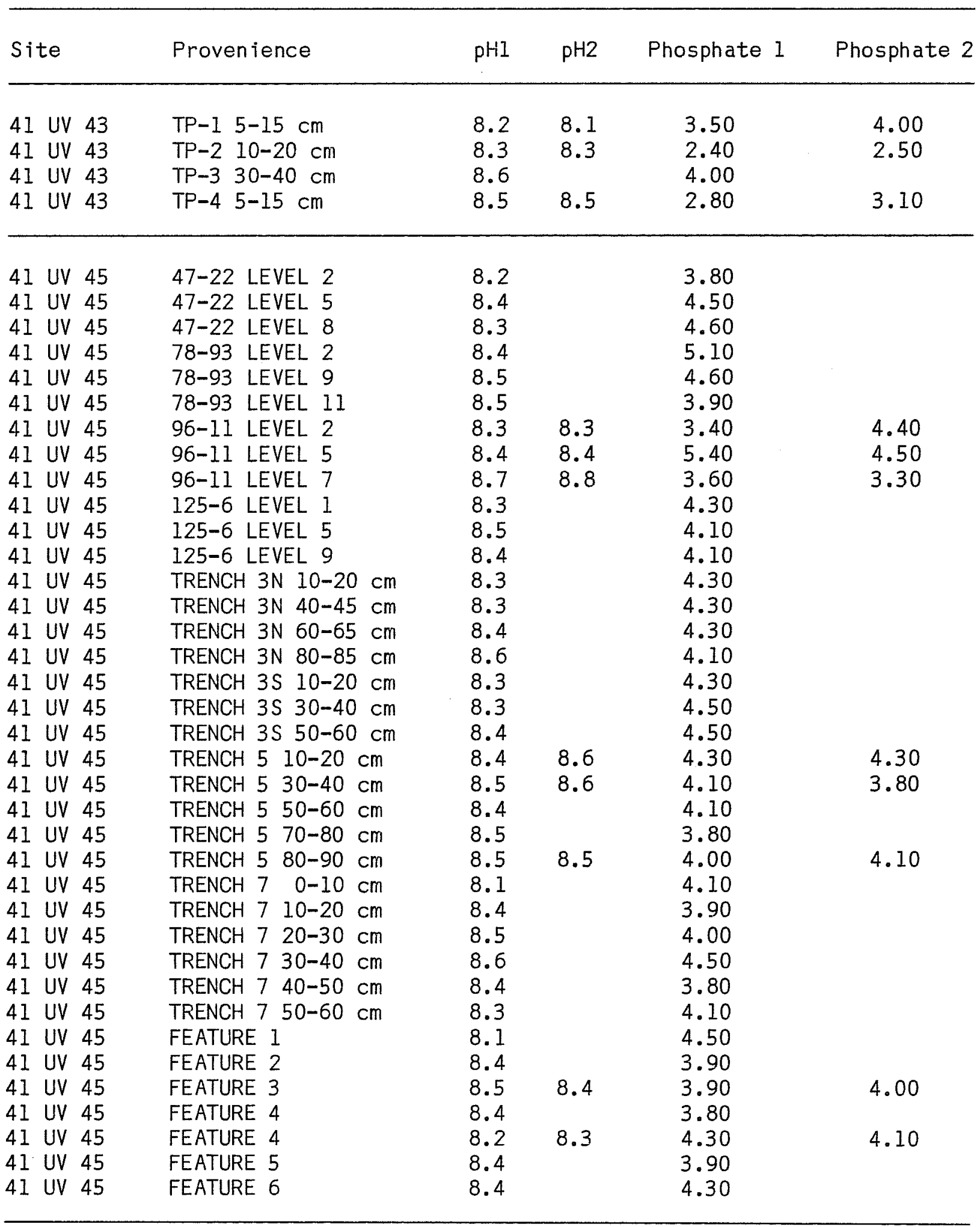


TABLE 78. (continued)

\begin{tabular}{|c|c|c|c|c|c|}
\hline Site & Provenience & $\mathrm{pHI}$ & $\mathrm{pH} 2$ & Phosphate 1 & Phosphate 2 \\
\hline $\begin{array}{lll}41 & \text { UV } & 47 \\
41 & \text { UV } & 47 \\
41 & \text { UV } & 47 \\
41 & \text { UV } & 47 \\
41 & \text { UV } & 47 \\
41 & \text { UV } & 47 \\
41 & \text { UV } & 47 \\
41 & \text { UV } & 47 \\
41 & \text { UV } & 47 \\
41 & \text { UV } & 47 \\
41 & \text { UV } & 47 \\
41 & \text { UV } & 47 \\
41 & \text { UV } & 47 \\
41 & \text { UV } & 47 \\
41 & \text { UV } & 47 \\
41 & \text { UV } & 47 \\
41 & \text { UV } & 47 \\
41 & \text { UV } & 47\end{array}$ & 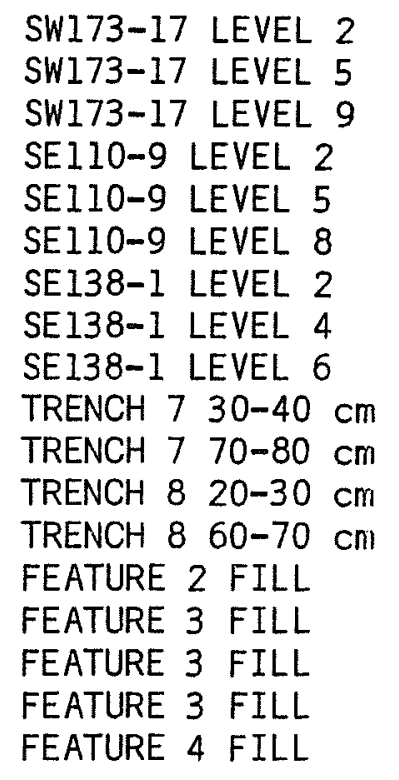 & $\begin{array}{l}7.9 \\
8.0 \\
8.2 \\
8.2 \\
8.4 \\
8.5 \\
8.1 \\
8.2 \\
8.2 \\
8.2 \\
8.3 \\
8.2 \\
8.2 \\
8.1 \\
7.9 \\
7.9 \\
7.9 \\
8.4\end{array}$ & $\begin{array}{l}8.2 \\
8.0 \\
7.9\end{array}$ & $\begin{array}{l}4.34 \\
4.80 \\
4.80 \\
4.10 \\
4.10 \\
3.50 \\
4.80 \\
4.00 \\
3.90 \\
4.30 \\
5.50 \\
4.40 \\
4.10 \\
4.40 \\
4.00 \\
4.30 \\
4.40 \\
4.40\end{array}$ & $\begin{array}{l}4.00 \\
4.10 \\
4.10 \\
4.60\end{array}$ \\
\hline $\begin{array}{lll}41 & \text { UV } & 48 \\
41 & \text { UV } & 48 \\
41 & \text { UV } & 48 \\
41 & \text { UV } 48 \\
41 & \text { UV } & 48 \\
41 & \text { UV } & 48 \\
41 & \text { UV } & 48 \\
41 & \text { UV } & 48 \\
41 & \text { UV } & 48 \\
41 & \text { UV } 48 \\
41 & \text { UV } & 48 \\
41 & \text { UV } 48 \\
41 & \text { UV } 48 \\
41 & \text { UV } 48 \\
41 & \text { UV } & 48 \\
41 & \text { UV } 48 \\
41 & \text { UV } 48 \\
41 & \text { UV } 48 \\
41 & \text { UV } 48 \\
41 & \text { UV } 48\end{array}$ & 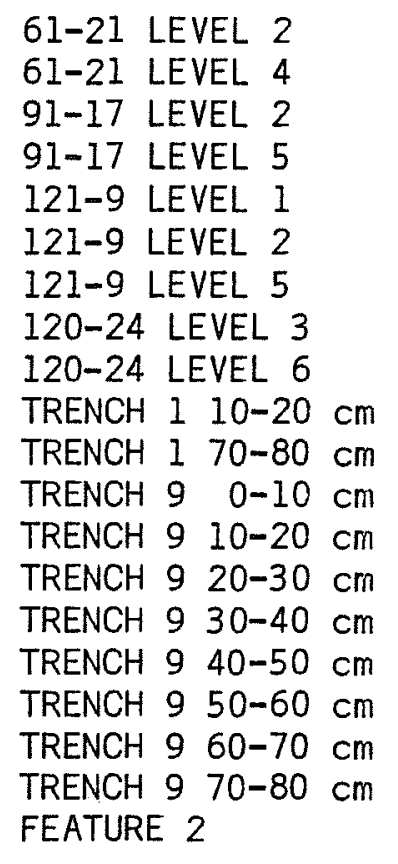 & $\begin{array}{l}8.2 \\
8.4 \\
8.0 \\
8.6 \\
8.2 \\
8.2 \\
8.0 \\
8.1 \\
8.2 \\
8.0 \\
8.0 \\
8.2 \\
8.1 \\
8.2 \\
8.3 \\
8.3 \\
8.3 \\
8.2 \\
8.3 \\
7.5\end{array}$ & $\begin{array}{l}7.9 \\
8.0 \\
8.1 \\
8.2\end{array}$ & $\begin{array}{l}4.90 \\
4.30 \\
5.50 \\
3.90 \\
4.40 \\
4.50 \\
4.40 \\
4.60 \\
4.50 \\
4.30 \\
4.50 \\
4.00 \\
4.00 \\
3.80 \\
4.30 \\
4.00 \\
4.30 \\
3.90 \\
4.10 \\
4.50\end{array}$ & $\begin{array}{l}3.80 \\
4.10 \\
4.50\end{array}$ \\
\hline
\end{tabular}


intersite basis, it is interesting to see that three of the sites interpreted as campsites ( 41 UV 45, 41 UV 47, and 41 UV 48) had relatively higher average phosphate readings $(4.2$ to 4.3 ), while the quarry site, 41 UV 43 (which showed very little evidence of use as an occupation site), had a relatively low phosphate average.

\section{REFERENCES CITED}

Burleigh, E.

1980 Chemical Analysis of Sediments. Appendix E in Archeological Investigations at the Thomas R. McKinney Homestead, Travis County, Texas: An Experiment in Historical Archeology, Part $\mathrm{I}: 162-163$, by M. McEachern and R. W. Ralph. Bulletin of the Texas Archeological Society 51.

Dowman, E. A.

1970 Conservation in Field Archeology. Methuen, London.

Eidt, R. C.

1977 Detection and Examination of Anthrosols by Phosphate Analysis. Science 797:1327-1333.

Gunn, J. and R. A. Mahula

1977 Hop Hill: Culture and Climatic Change in Central Texas. Center for Archaeological Research, The University of Texas at San Antonio, Special Report 5.

Gerstle, A., T. C. Kelly, and C. Assad

1978 The Fort Sam Houston Project: An Archaeological and Historical Assessment. Center for Archaeological Research, The University of Texas at San Antonio, Archaeological Survey Report 40.

Lewis, D. R.

1978 Use of Phosphate Analysis for Determining Land Use Patterns. Bulletin of the Texas Archeological Society 49:309-318.

1981a Spot Test for Phosphate Detection and Estimation. Procedural Checklist, on file at the Center for Archaeologial Research, The University of Texas at San Antonio.

1981b Use of the Corning Model $3 \mathrm{pH}$ Meter. Procedure Checklist, on file at the Center for Archaeological Research, The University of Texas at San Antonio. 
Sanders, L. E.

1977 Phosphate Spot Tests on Soil Samples from Mc-205 Waterfal1Gilford Creeks Watershed Project. In The Viper Marsh Site (Mc-205) McCurtian County, Oklahoma. Bulletin of the 0k1ahoma Anthropological Society 26:87-91.

Woods, W. I.

1975 The Analysis of Abandoned Settlements by a New Phosphate Field Test Method. The Chesopiean 13(1-2):1-45. 


\section{APPENDIX II \\ PROVENIENCE OF ARTIFACTS AND DEBITAGE BY SITE}

Appendix II consists of Tables 79-83 which provide the specific provenience of all materials recovered during the course of the project. Entries common to all of the tables are 1isted below. Separate tables are given for arrow points, dart points, bifaces, other artifacts (unifaces, modified flakes, cores, ground stone, hammerstones, prehistoric ceramics, and historic artifacts), and debitage. Listings are by site, ordered according to "site context," and then by the excavation units, test pits, backhoe trenches, features, and surface collections. Keys to artifact types are provided at the beginning of each table.

SITE Site number (Smithsonian trinomial system).

UNIT Horizontal provenience within the site. Provenience follows main body of text for Unit designations; TP = Test Pit at site 41 UV 45 . Also at 41 UV 45, the designation "155-16 SE" refers to the southeast quadrant of that unit, and "155-16" refers to the remaining quadrants.

LEVEL Vertical provenience within the site. Unit-levels follow text.

CTX Context of UNIT-LEVEL provenience. Refers to site Area. $A=$ Area $A, B=$ Area $B, C=$ Area $C, D=$ Area $D, S W=$ Southwest Quadrant, $N W=$ Northwest Quadrant, $S E=$ Southeast Quadrant, $N E=$ Northeast Quadrant, $M=$ Midden Zone, $T=$ Terrace Deposit. A blank entry indicates the context remains unassigned. 
TABLE 79. PROVENIENCE DATA FOR ARROW POINTS

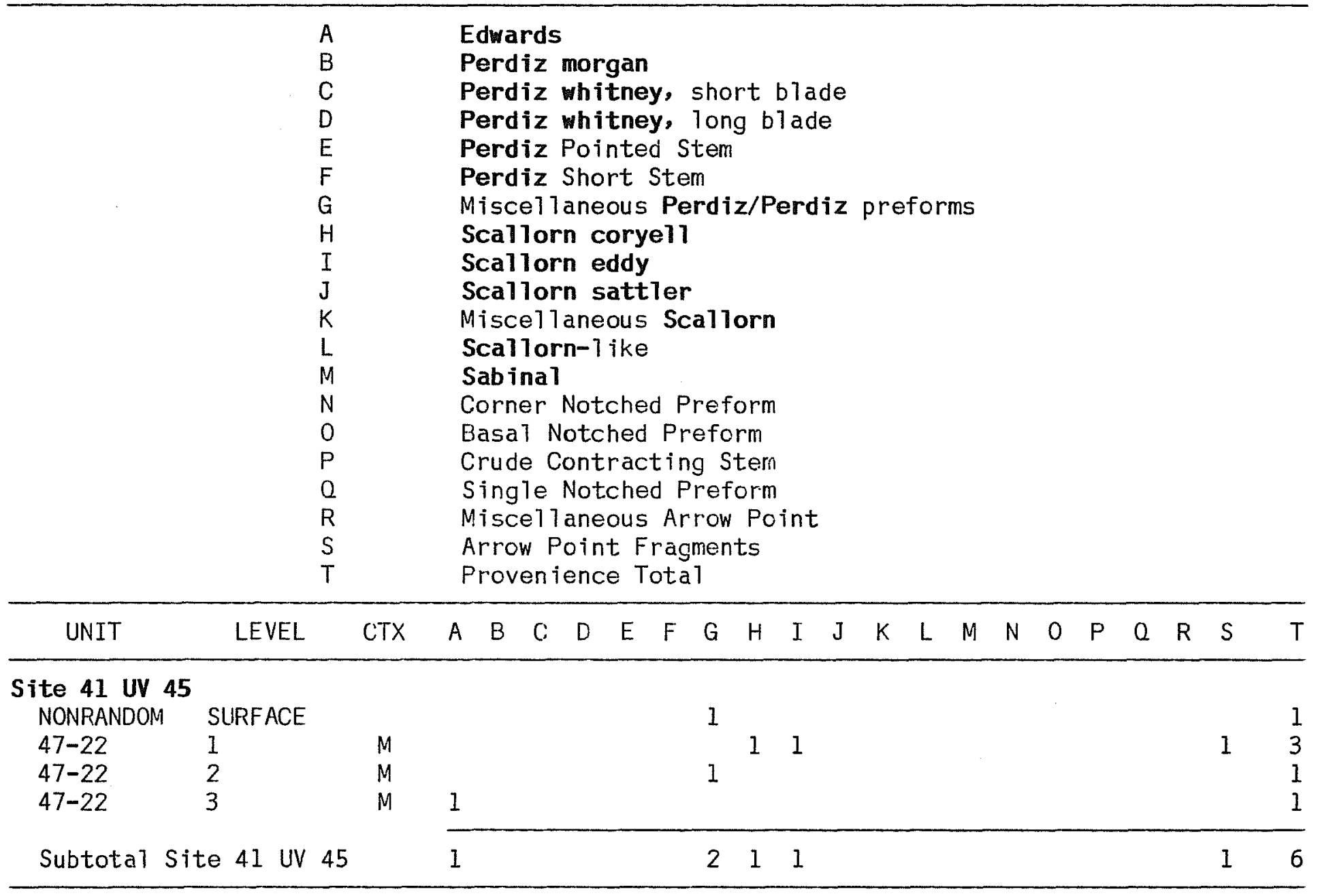

Site 41 UV 47

SWI73-11

SW173-12

SW173-13

SWI73-17

SW173-17

1
1
2
1
2

A
A
$A$
A
A

1

2

1

11

$\begin{array}{ccccc}1 & & & & 1 \\ & 2 & & 1 & 4 \\ & 1 & 1 & 2 & 7 \\ & & 1 & & 3\end{array}$


TABLE 79. (continued)

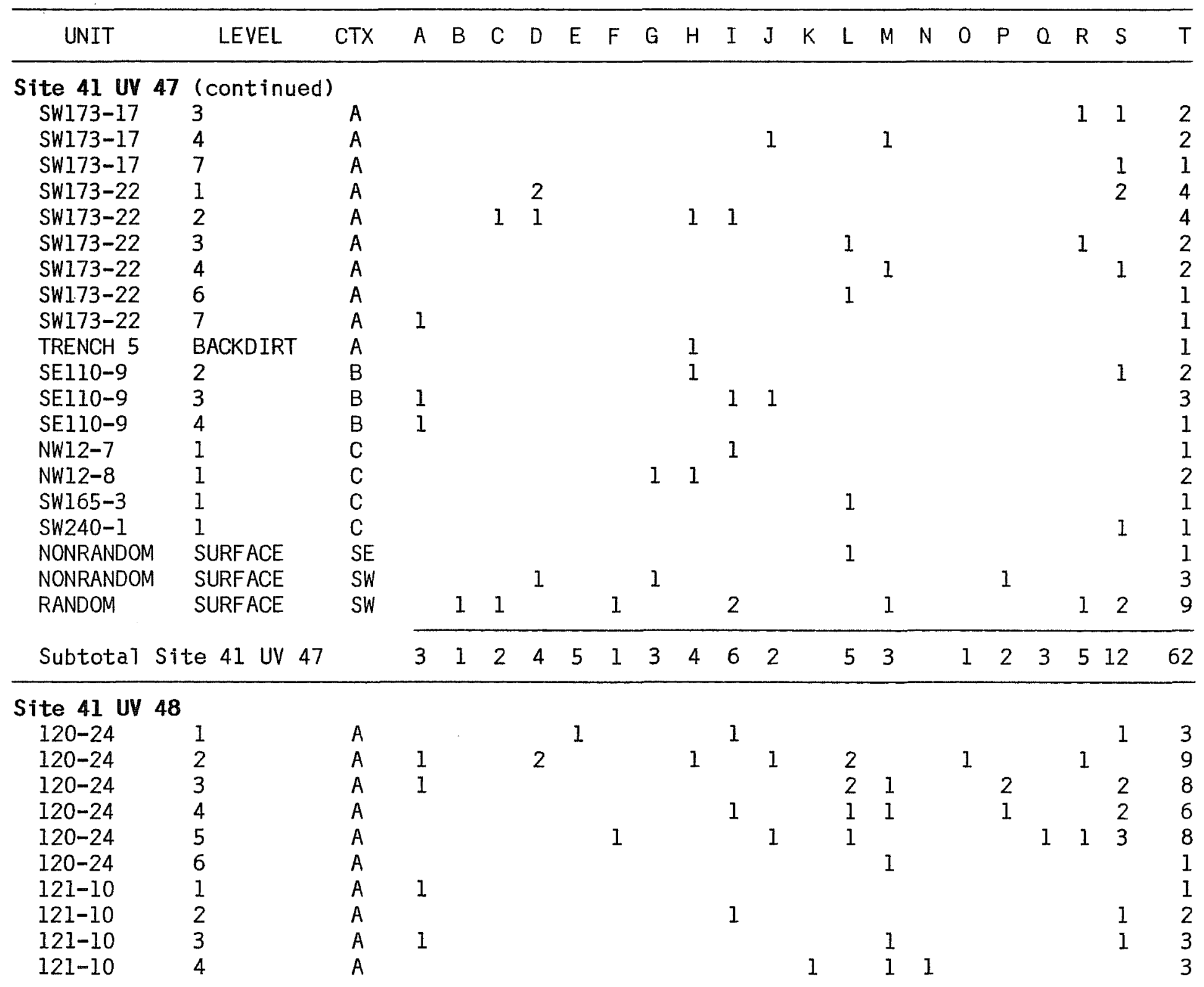


TABLE 79. (continued)

\begin{tabular}{|c|c|c|c|c|c|c|c|c|c|c|c|c|c|c|c|c|c|c|c|c|c|c|}
\hline UNIT & LEVEL & CTX & A & $B$ & $\mathrm{C}$ & D & $E$ & $\mathrm{~F}$ & G & $H$ & $\mathrm{~T}$ & $\mathrm{~J}$ & K & $\mathrm{L}$ & M & $\mathrm{N}$ & 0 & $P$ & 0 & $\mathrm{R}$ & $S$ & $\mathrm{~T}$ \\
\hline \multicolumn{23}{|c|}{ Site 41 UV 48 (continued) } \\
\hline $121-9$ & 1 & $A$ & & & 1 & & & & & & & & & & & & & & & & 1 & 2 \\
\hline $121-9$ & 2 & A & & & 2 & 1 & & & & & & & & & & 1 & & & & & 2 & 6 \\
\hline $121-9$ & 3 & A & 1 & 1 & & 1 & & & & 1 & 1 & & & & 1 & 2 & & & 1 & & & 9 \\
\hline $121-9$ & 5 & $A$ & & & & & & & & 1 & & & & 1 & & & & & 1 & & 2 & 5 \\
\hline $121-9$ & 6 & $A$ & & & & & & & 1 & & & & & 2 & & & & & & & & 3 \\
\hline $61-21$ & 1 & A & & 1 & & & & & & 1 & & & & & & & & & & & 1 & 3 \\
\hline $61-21$ & 2 & A & & 1 & & & & 1 & & & & & & & & & & & & & 2 & 4 \\
\hline $61-21$ & 3 & A & & & & & & & & & 1 & & & & & & & & & & & 1 \\
\hline $61-21$ & 4 & A & & & & & & & & & & & & & & & & & & 1 & & 1 \\
\hline $91-1$ & 1 & A & & & & & & 1 & & & & & & & & & & & & & 1 & 2 \\
\hline $91-17$ & 1 & A & $I$ & & & & & & & & & & & & & & & & & & & 1 \\
\hline $91-17$ & 2 & A & & & & & & & & & & & & & 1 & & & & & & & 1 \\
\hline $91-17$ & 3 & A & 1 & & & & & & & 1 & & & & & & & & & & & 1 & 3 \\
\hline $91-17$ & 4 & A & 2 & & & & & & & & & & & & & 1 & & & & & 1 & 4 \\
\hline $91-18$ & 1 & A & 1 & & & & & & & 1 & & & & & & & & & & & 1 & 3 \\
\hline $91-18$ & 2 & A & & & & & & & & 1 & & & & & & & & & 1 & & 1 & 3 \\
\hline $91-18$ & 3 & A & & & & & & 1 & & & & & & 1 & & & 1 & & & & & 3 \\
\hline $91-18$ & 4 & A & & & & & & & & & & & & & & & & & 1 & & 1 & 2 \\
\hline $91-18$ & 5 & A & & & & & & & & & & 1 & & & & & & & & & & 1 \\
\hline $92-1$ & 2 & A & & & & & & & & & & & & & 1 & & & & & & & 1 \\
\hline $92-1$ & 3 & A & & & & & & & & & & & & & & & & & & 1 & & 1 \\
\hline FEATURE 2 & FILL & A & & & & & & & & & 1 & & & 1 & & & & & & & 2 & 4 \\
\hline NONRANDOM & SURFACE & A & & & & & & & & 1 & & & & 2 & & & & & & 1 & & 4 \\
\hline RANDOM & SURFACE & A & & & & & & 1 & & & & & & & & & & & & & 1 & 2 \\
\hline TRENCH 2 & BACKDIRT & A & 1 & & & & & & & & & & & & & & & & & & & 1 \\
\hline NONRANDOM & SURFACE & $B$ & & & & & & & & & & 1 & & & & & & & & & 1 & 2 \\
\hline RANDOM & SURFACE & B & & & & & & & & & & & & & & & & 1 & & & & 1 \\
\hline $456-11$ & 2 & C & 1 & & & & & & & & & & & & & & & & & & & 1 \\
\hline $525-5$ & 1 & C & & & & & & & & & & 1 & & & & & & & & & & 1 \\
\hline NONRANDOM & SURFACE & C & 1 & & & & & & & & & & & & & & & & & & 2 & 3 \\
\hline RANDOM & SURFACE & C & 1 & & & & & & & & & & & & & & & & & & & 1 \\
\hline \multicolumn{3}{|c|}{ Subtotal Site 41 UV 48} & 14 & 3 & 3 & 4 & 1 & 5 & 1 & 8 & 6 & 5 & 1 & 13 & 8 & 5 & 2 & 4 & 5 & 53 & 30 & 123 \\
\hline
\end{tabular}


TABLE 80. PROVENIENCE DATA FOR DART POINTS

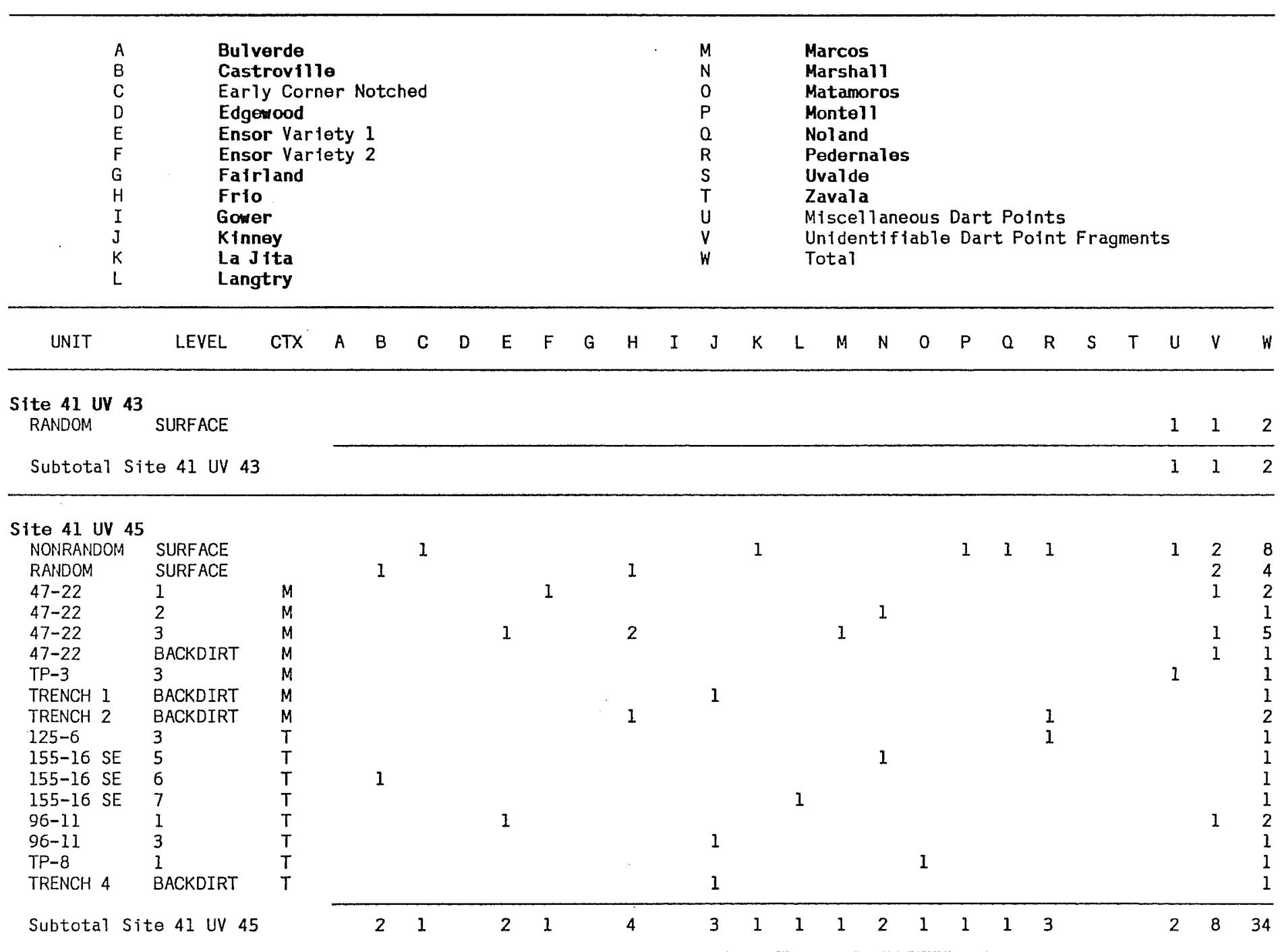


TABLE 80. (continued)

\begin{tabular}{|c|c|c|c|c|c|c|c|c|c|c|c|c|c|c|c|c|c|c|c|c|c|c|c|c|c|}
\hline UNIT & LEVEL & CTX & A & B & C & D & $E$ & $\mathbf{F}$ & G & $\mathrm{H}$ & $\mathrm{I}$ & $\mathbf{J}$ & K & $L$ & $M$ & $N$ & 0 & $\mathbf{P}$ & 0 & $\mathbf{R}$ & $\mathbf{S}$ & $T$ & U & v & $w$ \\
\hline \multicolumn{26}{|c|}{ Site 41 UV 47} \\
\hline UNPROVEN & SURFACE & & & & & & & & & & 1 & & & & & & & & & & & & 1 & & 2 \\
\hline SW173-I1 & 1 & A & & & & & & & & & & & & & & & & & & & & & & 1 & I \\
\hline $5 W 173-17$ & 3 & A & & & & & & & & & & & & & & & & 1 & & & & & & & $\overline{1}$ \\
\hline SW173-17 & 5 & A & & & & & & & & & & & & & & & & 1 & & & & & & & 1 \\
\hline SW173-17 & 7 & A & & & & & & & & & & & & & 1 & & & & & & & & & & $\mathrm{l}$ \\
\hline SW173-22 & 1 & A & & & & & & & 1 & & & & & & & & & & & & & & & & 1 \\
\hline SW173-22 & 4 & A & & & & & & & & & & & & & & & & & & & & & 1 & & 1 \\
\hline SW173-22 & 5 & A & & & & & & & & & & & & & & & & & & & & & & 1 & 1 \\
\hline SW173-22 & 6 & A & & 1 & & & & & & & & & & & & & & & & & & & & 1 & 2 \\
\hline SW173-22 & 7 & A & & & & & & & & & & & & & & & & & & & & & & 1 & 1 \\
\hline SE138-1 & 4 & B & & & & & 1 & & & & & & & & & & & & & & & & & & 1 \\
\hline$N W 12-8$ & 1 & $\mathrm{C}$ & & & & & & & & 1 & & & & & & & & & & & & & & & 1 \\
\hline RANDOM & SURFACE & $\mathrm{NE}$ & & & & & & & & & & & & & & & & & & & & & & 1 & 1 \\
\hline NONRANDOM & SURFACE & $\mathrm{NW}$ & & & & & & & & & & & & & & & & & & 1 & & & & & 1 \\
\hline RANDOM & SURFACE & $N W$ & & & & & & & & & & & & & & & & & & & & & & $I$ & 1 \\
\hline NONRANDOM & SURFACE & $\mathrm{SE}$ & & & 1 & & 1 & & & & 1 & & & & & & & & & & & & 1 & & 4 \\
\hline RANDOM & SURFACE & SE & & & & & & & & & & & & & & & & & 1 & & & & & & 1 \\
\hline NONRANDOM & SURFACE & $S W$ & & & & & & & 2 & 2 & & & & 3 & & & & & & 1 & & & & 1 & 9 \\
\hline RANDOM & SURFACE & SW & & 1 & & & & $I$ & 2 & 3 & & & & 1 & & & & 1 & & & & & 1 & & 10 \\
\hline \multicolumn{3}{|c|}{ Subtotal Site 41 UV 47} & & 2 & 1 & & 2 & 1 & 5 & 6 & 2 & & & 4 & 1 & & & 3 & 1 & 2 & & & 4 & 7 & 41 \\
\hline
\end{tabular}

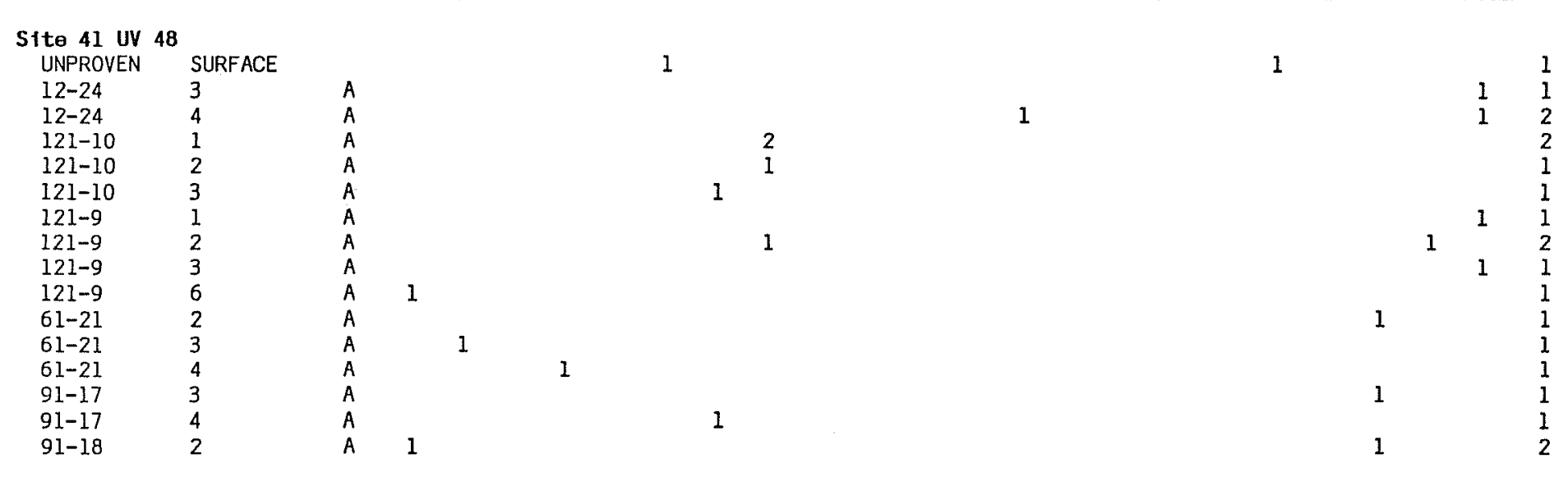


TABLE 80. (continued)

\begin{tabular}{|c|c|c|c|c|c|c|c|c|c|c|c|c|c|c|c|c|c|c|c|c|c|c|c|c|c|}
\hline UNIT & LEVEL & CTX & A & B & C & $\mathrm{D}$ & $\mathbf{E}$ & $\mathbf{F}$ & G & $H$ & I & $\mathbf{J}$ & $\mathrm{k}$ & $\mathrm{L}$ & M & $\mathrm{N}$ & 0 & $\mathbf{P}$ & 0 & $\mathbf{R}$ & $S$ & $T$ & $\mathrm{U}$ & $v$ & $w$ \\
\hline \multicolumn{26}{|c|}{ Site 41 UV 48 (continued) } \\
\hline $91-18$ & 3 & A & & & & & & 1 & & & & & & & & & & & & & & 1 & & & 2 \\
\hline $91-18$ & 4 & A & & & & & & & 1 & & & & & & & & & & & & & & & & 1 \\
\hline NONRANDOM & SURFACE & A & & & & & & & & & & & & & & & & & & & & 1 & & & 1 \\
\hline TRENCH 11 & BACKDIRT & A & & & & & & & & & & & & & & & & & & 1 & & & & & 1 \\
\hline TRENCH 2 & BACKDIRT & $A$ & & & & & & & & & & & & & & & & & & & & & 1 & & 1 \\
\hline TRENCH 5 & BACKDIRT & A & & & & & & 1 & & & & & & & & & & & & & & & 1 & & 2 \\
\hline $211-3$ & & B & & & & & & & & & & & & & & & & & & & & & & 1 & 1 \\
\hline $499-12$ & 1 & B & & 1 & & & & & & & & & & & & & & & & & & & & & 1 \\
\hline NONRANDOM & SURFACE & B & & & & & & & 1 & & & & & & & & & & & 1 & & & & 2 & 4 \\
\hline RANDOM & SURFACE & B & & & & & & & & 1 & & & & & & & & & & & & & & 1 & 2 \\
\hline TRENCH 9 & BACKDIRT & $B$ & 1 & & & & & & & & & & & & & & & & & & & & & & 1 \\
\hline $525-5$ & & c & & & & & & & & & & & & & & & & & & 1 & & & & & 1 \\
\hline NONRANDOM & SURFACE & $C$ & & 1 & & & & & & & 1 & & & & & & & & & & & & 2 & 1 & 5 \\
\hline RANDOM & SURFACE & C & & & & & & & & & & & 1 & & & & & & 1 & & & & & 1 & 3 \\
\hline TRENCH 1 & BACKDIRT & C & 1 & & & 1 & & & & & & & & & & & & & & 1 & & & & 1 & 4 \\
\hline NONRANDOM & SURFACE & D & & & & & & & & & & & & & & & & & & & 1 & & & 1 & 2 \\
\hline RANDOM & SURFACE & D & & & & & & & & 1 & & & & & & & & & & & & & & & 1 \\
\hline \multicolumn{3}{|l|}{ Subtotal } & 4 & 3 & & 2 & 0 & 3 & 4 & 6 & 1 & & 1 & & 1 & & & & 1 & 5 & 1 & 5 & 5 & 12 & 54 \\
\hline \multicolumn{3}{|l|}{ Grand Total } & 4 & 7 & 2 & 2 & 4 & 5 & 9 & 16 & 3 & 3 & 2 & 5 & 3 & 2 & 1 & 4 & 3 & 10 & 1 & 5 & 12 & 28 & 131 \\
\hline
\end{tabular}




\section{TABLE 81. PROVENIENCE DATA FOR BIFACES}

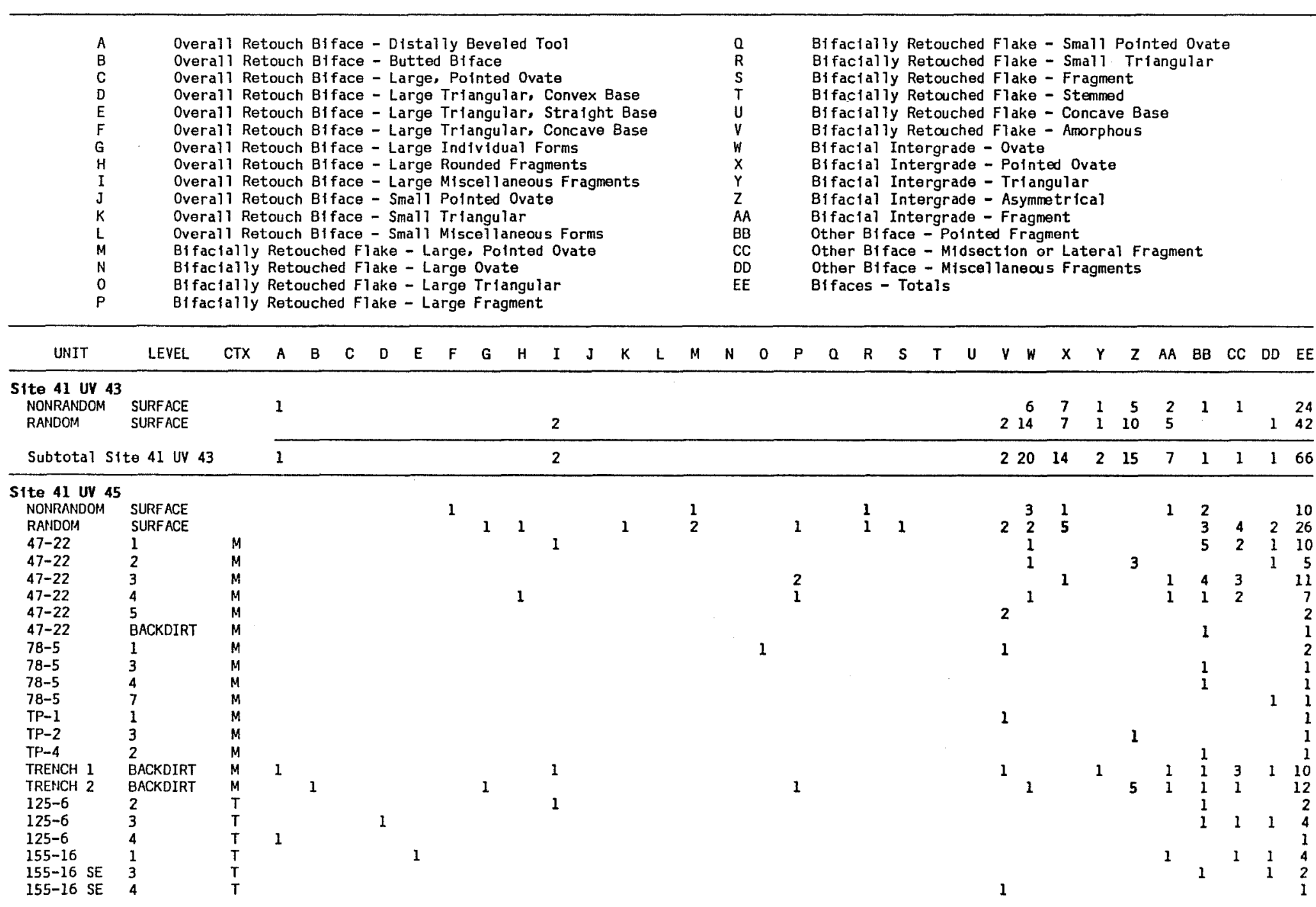


TABLE 81. (continued)

\begin{tabular}{|c|c|c|c|c|c|c|c|c|c|c|c|c|c|c|c|c|c|c|c|c|c|c|c|c|c|c|c|c|c|c|c|c|}
\hline UNIT & LEVEL & стX & A & B & $\mathrm{c}$ & $D$ & $E$ & $F$ & G & $\mathrm{H}$ & $\mathrm{I}$ & $\mathrm{J}$ & K & $L$ & M & N & 0 & $P$ & 0. & $\mathrm{R}$ & $s$ & $T$ & U & $V W$ & $x$ & $Y$ & $z$ & $A A$ & BB & $\mathrm{CC}$ & $D D$ & $\mathrm{EE}$ \\
\hline \multicolumn{33}{|c|}{ Site 41 uY 45 (continued) } \\
\hline $155-16 \mathrm{SE}$ & E 5 & $T$ & & & & & & & & & & & & & & & & & & & & & & & & & & & 1 & & & 1 \\
\hline $155-16$ SE & 8 & $T$ & & & & & & & & & & & & & & & & & & & & & & & & & & & $i$ & & & 1 \\
\hline $96-11$ & 1 & $T$ & & & & & & & & & & & & & & & & & & & & & & 1 & & & & 1 & & & & 2 \\
\hline $96-11$ & 2 & $T$ & & & & & & & & & & & & & & & & & & & & & & & 1 & & & 1 & 2 & 2 & & 6 \\
\hline $96-11$ & 3 & $\mathrm{~T}$ & & & & & & 1 & & & & & & & & & & & & & & & & & & & & & & & & I \\
\hline$T P-5$ & 2 & T & & & & & & & & & & & & & & & & & & & & & & & & & & & & 1 & & 1 \\
\hline$T P-8$ & I & $T$ & & & & & & & & & & & & & & & & & & & & & & 1 & & & & & & 2 & & 1 \\
\hline TRENCH 3 & BACKDIRT & T & & & & & 1 & & & & & & & & & & & & & & & & & & & 1 & & 1 & I & & & 4 \\
\hline TRENCH 6 & BACKDIRT & T & & & & & & & & & & & & & & & & & & & & & & & & & & & & 1 & & 1 \\
\hline TRENCH 8 & BACKDIRT & $\mathrm{T}$ & & & & & & & & & & & & & & & & & & & & & & & & & & & 1 & & & 1 \\
\hline \multicolumn{3}{|c|}{ Subtotal site 41 UV 45} & 2 & 1 & & 1 & 2 & 2 & 2 & 2 & 3 & & 1 & & 3 & & 1 & 5 & & 2 & 1 & & & 910 & 8 & 2 & 9 & 9 & 30 & 21 & 9 & 135 \\
\hline \multicolumn{33}{|c|}{ Site 41 UV 47} \\
\hline UNPROVEN & SURFACE & & 1 & & & & & & & & & & & & & & & & & & & & & & & 1 & & & & & & 2 \\
\hline SW173-11 & 2 & A & & & & & & & & & & & & & & & & & & & & & & & & & & & 1 & & & 1 \\
\hline SW173-11 & 4 & A & & & & & & & & & & & & & & & & & & & & & & & & & & & 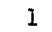 & & & 1 \\
\hline SW173-12 & 1 & A & & & & & & & & & & & & & & & & & & & & & & & & & & & $i$ & & & I \\
\hline SW173-12 & 2 & A & & & & & & & & & & & & 1 & & & & & & 1 & 1 & & & & & & & & & & & 3 \\
\hline SW173-13 & 1 & A & & & & & & & & & & & & & & & & & & & & & & & 1 & & & & & 1 & & 2 \\
\hline SW173-13 & 2 & A & & & & & & & & & & & & & & & & & & & & & & & 2 & 1 & 1 & & 3 & 2 & & 7 \\
\hline SW173-13 & 4 & A & & & & & & & & & & & & & & & & & & & & & & & & & & & 1 & 2 & & 3 \\
\hline SW173-13 & 5 & A & & & & & & & & & & & & & & & & & & & & & & & & & & & & 1 & & $i$ \\
\hline SW173-17 & I & A & & & & & & & & & & & & 1 & & & & & & & & & & & & & 1 & & 4 & & & 6 \\
\hline SW173-17 & 10 & A & & & & & & & 1 & & & & & & & & & & & & & & & & & & & & & & & I \\
\hline SW173-17 & 2 & A & & & & & & & & & & & & & & & & & & & 1 & & & & & 1 & & & 3 & 3 & & 8 \\
\hline SW173-17 & 3 & A & & & & & & & & & & & & & & & & & & & & & & & & & & & 1 & 2 & 1 & 4 \\
\hline SW173-17 & 4 & A & & & & & & 1 & & & & & & & 1 & & & & & & & & & 1 & & & 1 & & 1 & $i$ & & 6 \\
\hline SW173-17 & 6 & A & & & & & & & & & & & & & & & & & & & & & & & & & & & I & & & 1 \\
\hline SW173-17 & 7 & A & & & & & & & & & & & & & & & & & & & & & & & & & & & 1 & & & 1 \\
\hline SW173-17 & 9 & A & & & & & & & & & & & & & & & & & & & & & & & & & 1 & & & & & $\dot{I}$ \\
\hline SW173-22 & 1 & A & & & & & & & & & & & & & 1 & & 1 & 1 & & & & & & & & & 1 & & 4 & 1 & 1 & 10 \\
\hline SW173-22 & 2 & A & & & & & & & & & & & & 1 & & & & & 1 & & & & 1 & & & & & & 3 & & 1 & 7 \\
\hline SW173-22 & 3 & A & & & & & & & & & & & 1 & & & & & & 2 & & & & & & & & 1 & 1 & 1 & & & 6 \\
\hline SW173-22 & 4 & A & & & & & & & & & & & 2 & & & & & & & 1 & & & & 1 & & & & & 3 & & & 7 \\
\hline SW173-22 & 5 & A & & & & & & & & 1 & & & & & & & & & & & & & & & & & & & 1 & & & 2 \\
\hline SW173-22 & 6 & A & & & & & & & & & & & & & & & & & 1 & & & & & & & & & & 1 & & & 2 \\
\hline SW173-22 & 7 & A & & & & & & & & & & & & & & & & & & & & & & & & & & & & 1 & & $i$ \\
\hline SW173-22 & و & A & & & & & & & & & & & & & & & & & & & & & & & & 1 & & & & & & 1 \\
\hline SW210-25 & 4 & A & & & & & & 1 & & & & & & & & & & & & & & & & & & & & & & & & 1 \\
\hline TRENCH 5 & BACKDIRT & A & & & & & & & & & & & & & & & & & & & & & 1 & & & & & & & & & 1 \\
\hline SEI10-9 & 1 & B & & & & & & & & & & & & & & & & & & & & & & & & & 1 & & & & & 1 \\
\hline SE110-9 & 2 & $B$ & & & & & & & & & & 1 & & 1 & & & & & & & & & & & & & & & & & & 2 \\
\hline SEI10-9 & 3 & B & & & & & & & & & & & & & & & & & & & & & & & & & & & 1 & & & 1 \\
\hline SEI10-9 & 4 & B & & & & & & & & & & & & & & & & & & & & & & & 1 & & 1 & 1 & 1 & & & 4 \\
\hline SE110-9 & 6 & $B$ & & & & & & & & & & & & & & & & & & & & & & & & & & & 1 & & & 1 \\
\hline SE138-1 & 2 & $B$ & & & & & & & & & & & & & & & & & & & & & & & & & & & & 1 & & i \\
\hline SE138-1 & 3 & $B$ & & & 1 & & & & & & & & & & & & & & & & & & & & & & & & & & & 1 \\
\hline SE138-1 & 4 & B & & & & & & & & & & 1 & & & & & & & & & & & & & & & & & & & & 1 \\
\hline
\end{tabular}


TABLE 81. (continued)

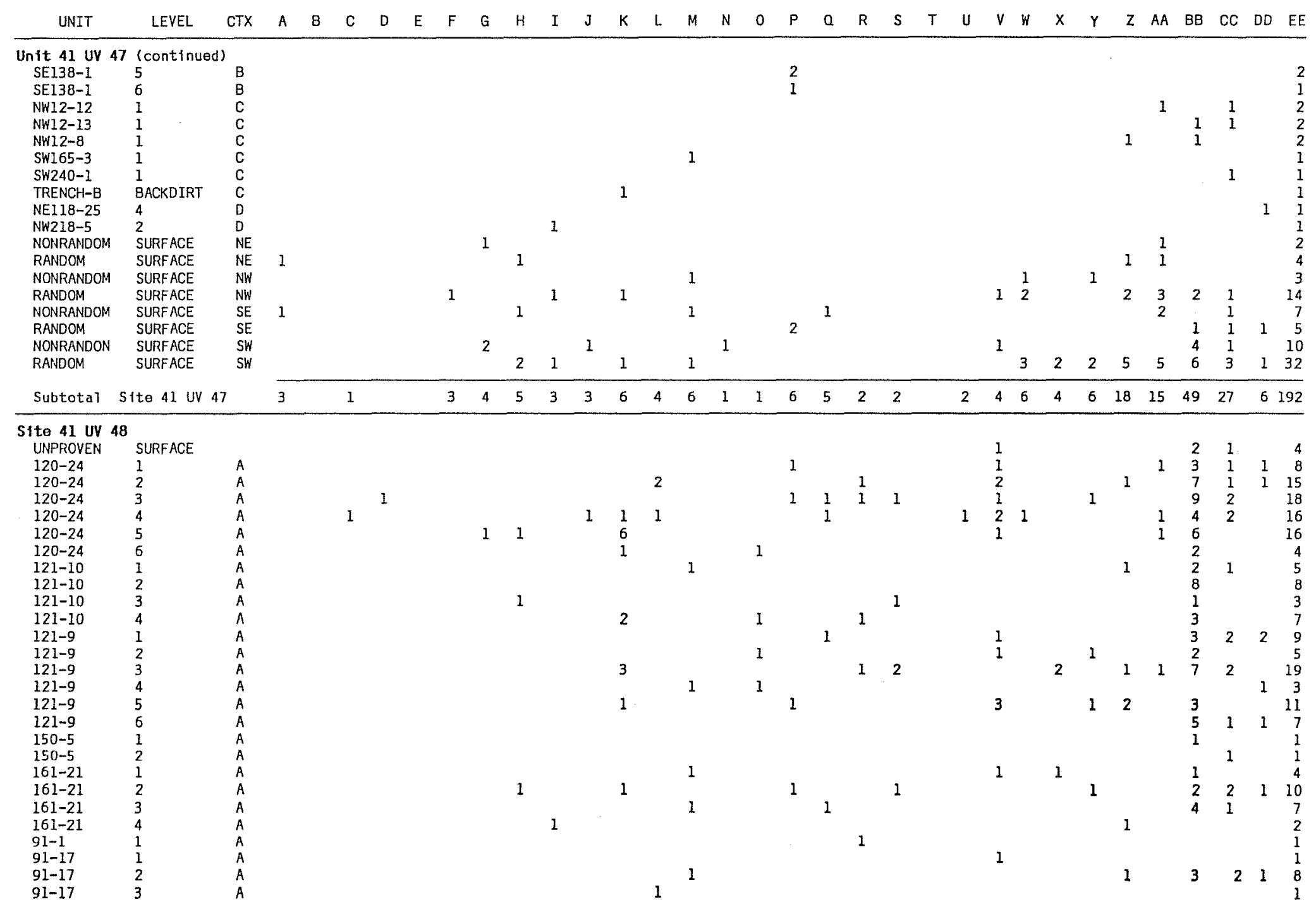


TABLE 81. (continued)

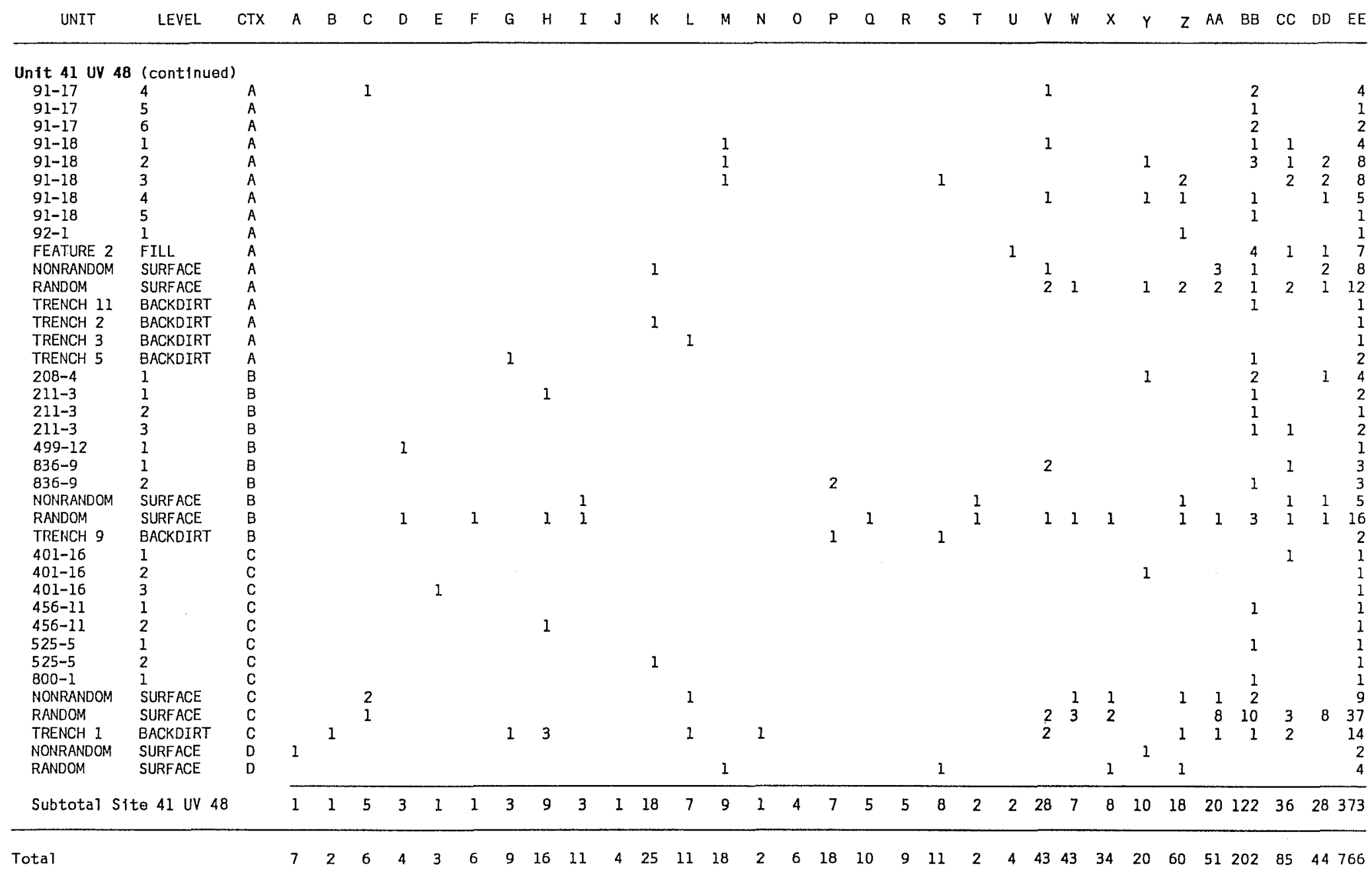


TABLE 82. PROVENIENCE DATA FOR UNIFACES, MODIF IED FLAKES, GROUND STONES, HAMMERSTONES, PREHISTORIC CERAMICS, AND HISTORIC ARTIFACTS

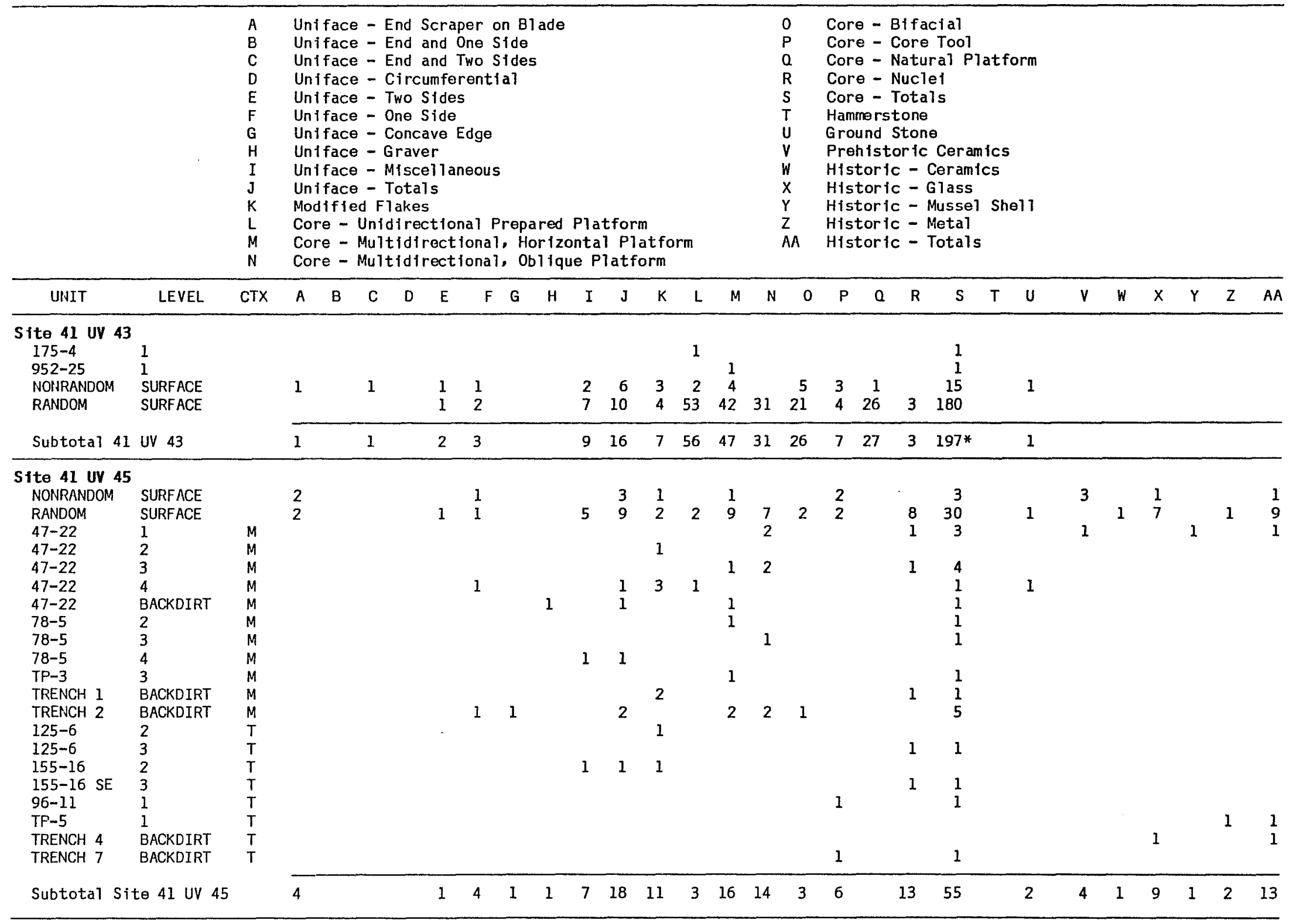


TABLE 82. (continued)

\begin{tabular}{|c|c|c|c|c|c|c|c|c|c|c|c|c|c|c|c|c|c|c|c|c|c|c|c|c|c|c|c|c|c|}
\hline UNIT & LEVEL & CTX & $A$ & $B$ & C & $\mathrm{D}$ & $E$ & $F$ & $G$ & $\mathrm{H}$ & I & $\mathrm{J}$ & $\mathrm{K}$ & $L$ & $M$ & $N$ & 0 & $\mathrm{P}$ & 0 & $\mathrm{R}$ & $S$ & $\mathrm{~T}$ & U & v & $W$ & $x$ & Y & $z$ & $A A$ \\
\hline \multicolumn{30}{|c|}{ Site 41 UV 47} \\
\hline UINPROVEN & SURFACE & & & 1 & & & & & & & & 1 & & & & & & & & & & & & & & & & & \\
\hline SW $173-12$ & 1 & A & & 1 & & & & & & & 1 & 2 & & & & & & & & & & & & & & & & & \\
\hline SW173-13 & 1 & A & & & & & & & & & & & 2 & & & & & & & & & & & & & & & 1 & 1 \\
\hline SWI73-13 & 2 & $A$ & & & & & & & & & & & & & & & & & & & & & & & & & & 2 & 2 \\
\hline SW173-13 & 3 & A & & & & & & & & & & & 1 & & & & & & & & & & & & & & & 1 & 1 \\
\hline SW $173-17$ & 1 & A & 1 & & & & & & & & 1 & 2 & & & & & & & & 1 & 1 & & & & & & & & \\
\hline SW173-17 & 2 & A & & & & & & & & & & & 1 & & & & & & & 1 & 1 & & & & & & & & \\
\hline SW $173-17$ & 3 & A & & & & & & & & & 1 & 1 & 2 & & & & & & & & & & & & & & & & \\
\hline SW173-17 & 4 & A & & & & & & & & & & & & & & & & & & 1 & 1 & & & & & & & & \\
\hline SW173-22 & I & A & & & & & & & & 1 & & 1 & 1 & & & & & 1 & & & 1 & & & 1 & & & & & \\
\hline SW $173-22$ & 2 & A & & & & & & & & & 1 & 1 & & & & & & & & & & & & & & & & & \\
\hline SW173-22 & 3 & A & & & $\cdot$ & 1 & & & & & & 1 & 2 & & & & & & & & & & & 2 & & & & & \\
\hline SW173-22 & 4 & $A$ & & & & & & & & 1 & & 1 & & & & & & & & 1 & 1 & & & & & & & & \\
\hline SW $173-22$ & 8 & A & & & & & & & & & & & 1 & & & & & & & & & & & & & & & & \\
\hline TRENCH 5 & BACKDIRT & A & & & & & & & & & 2 & 2 & & & & & & & & & & & & 1 & & & & & \\
\hline TRENCH 6 & BACKDIRT & A & & & & & & & & & & & & & & & & 1 & & & 1 & & & & & & & & \\
\hline SE110-9 & 1 & B & & & & & & & & & 1 & 1 & 1 & & 1 & & & & & 1 & 2 & & & & & & & & \\
\hline SE110-9 & 3 & B & & & & & & & & & & & & & & & & & & 1 & 1 & & 2 & & & & & & \\
\hline SE138-1 & 1 & B & & & & & & & & & & & & & & & 1 & & & 1 & 2 & & & & & & & & \\
\hline SE138-1 & 4 & $B$ & & & & & & & & & 1 & 1 & & & & & & & & & & & & & & & & & \\
\hline TRENCH 1 & BACKDIRT & B & & & & & & & & & & & & 1 & 1 & & & & & & 2 & & & & 1 & 6 & & & 7 \\
\hline NW12-12 & 1 & C & & & & & & & & & & & & & & & & & & 1 & 1 & & & 57 & & & & & \\
\hline NW12-13 & 1 & C & 1 & & & & & & & & & 1 & 1 & & & & & & & & & & & 143 & & & & & \\
\hline$N W 12-13$ & 2 & $\mathrm{C}$ & & & & & & & & & & & & & & & & & & & & & & 2 & & & & & \\
\hline NWII2-7 & 1 & $\mathrm{C}$ & & & & & & & & & & & & & & & & & & & & & & 16 & & & & & \\
\hline NW12-8 & 1 & C & & & & & & & & & & & & & & & & & & & & & & 80 & & & & & \\
\hline $5 W 240-1$ & 1 & C & & & & & & & & . & & & & & & & & & & & & & & 3 & & & & & \\
\hline SW350-25 & 1 & $\mathrm{C}$ & & & & & & & & & & & & & 1 & & & & & & 1 & & & & & & & & \\
\hline TRENCH 8 & BACKDIRT & $\mathrm{C}$ & & & & & & & & & 1 & 1 & & & & & & & & & & & & & & & & & \\
\hline NEIIZ-25 & 1 & D & & & & & & & & & & & & & 1 & & & & & & 1 & & & & & & & & \\
\hline NW218-5 & 2 & D & & & & & & & 1 & & & 1 & 1 & & & & & & & & & & & & & & & & \\
\hline NONRANDOM & SURFACE & $\mathrm{NE}$ & & & & & & & & & 1 & 1 & & & & & & & & & & & & & & & & & \\
\hline RANDOM & SURFACE & NE & & & & & & & & & & & 1 & & 1 & & & & & & 1 & & & & & & & & \\
\hline NONRANDOM & SURFACE & $\mathrm{NW}$ & & & & & 2 & & & & & 2 & & & & & & & & & & & & 5 & & & & & \\
\hline RANDOM & SURFACE & $N W$ & & & & & & & & & 1 & 1 & 2 & 1 & 2 & 1 & & 1 & & 2 & 7 & & 1 & & & 1 & & & $I$ \\
\hline RANDOM & SURFACE & SE & & & & & 1 & 1 & 1 & 1 & & 4 & 3 & $i$ & 1 & $i$ & & 4 & & $\bar{I}$ & 8 & & & & & & & & \\
\hline NONRANDOM & SURFACE & SW & 3 & & 1 & & & & & & 1 & 5 & 1 & & & & & & & & & 1 & 2 & & & & & 1 & 1 \\
\hline RANDOM & SURFACE & SW & 5 & & 3 & 1 & 1 & 3 & 1 & 2 & 2 & 18 & 13 & 2 & 2 & 7 & 1 & 5 & & 7 & 24 & & 1 & 2 & & & & & \\
\hline \multicolumn{3}{|c|}{ Subtotal Site 41 UV 47} & 10 & 2 & 4 & 2 & 4 & 4 & 3 & 5 & 14 & 48 & 33 & 5 & 10 & 9 & 2 & 12 & & 18 & 56 & 1 & 6 & 312 & 1 & 7 & & 5 & 13 \\
\hline \multicolumn{30}{|c|}{ Site 41 uV 48} \\
\hline $120-24$ & 1 & $A$ & 1 & & & & & & & & & 1 & 1 & & & 1 & & & & 2 & 3 & & & & & & & & \\
\hline $120-24$ & 2 & A & & & & & 1 & 1 & & & & 2 & & 1 & 2 & 2 & & & & 2 & 7 & & & & & & & & \\
\hline $120-24$ & 3 & A & & & & & 1 & & & 1 & & 2 & & & $\overline{1}$ & $\overline{1}$ & & & & $\overrightarrow{1}$ & 3 & & & & & & & & \\
\hline $120-24$ & 4 & A & 1 & & & & & 1 & & 1 & & 3 & & & 1 & & & & & & 1 & & & 1 & & & & & \\
\hline $120-24$ & 5 & A & & & & & & & & & 1 & 1 & & 1 & 1 & & & & & 1 & 3 & & & & & & & & \\
\hline $120-24$ & 6 & A & & & & & & & & & & & & & & 1 & & & & & 1 & & & & & & & & \\
\hline
\end{tabular}


TABLE 82. (continued)

\begin{tabular}{|c|c|c|c|c|c|c|c|c|c|c|c|c|c|c|c|c|c|c|c|c|c|c|c|c|c|c|c|c|c|}
\hline UNIT & LEVEL & CTX & A & $\mathrm{B}$ & C & D & $E$ & $F$ & G & H & $\mathrm{I}$ & $\mathbf{J}$ & K & L & M & $N$ & 0 & $P$ & 0 & $\mathrm{R}$ & $\mathbf{S}$ & $\mathrm{T}$ & U & $v$ & $W$ & $x$ & Y & z & $A A$ \\
\hline \multicolumn{30}{|c|}{ Site 41 UN 48 (continued) } \\
\hline $121-10$ & 1 & A & & & & & & & & & & & & & 1 & & & & & & 1 & & & & & & & & \\
\hline $121-10$ & 2 & $A$ & & & & & & & & & & & 1 & & & & & & & 3 & 3 & & & & & & & & \\
\hline $121-9$ & 1 & A & & & & 1 & & 1 & & & 1 & 3 & 1 & & & 1 & & & & 2 & 3 & & & & & 2 & & 1 & 3 \\
\hline $121-9$ & 2 & $A$ & & & & & & & & 1 & 1 & 2 & & & & & & & & 1 & 1 & & & & & & & & \\
\hline $121-9$ & 3 & $A$ & & & & 1 & & & 1 & & & 2 & 1 & & & & & & & 2 & 2 & & & & & & & & \\
\hline $121-9$ & 5 & A & & & & & & & & & 1 & 1 & & & & & & & & 2 & 2 & & & & & & & & \\
\hline $61-21$ & 2 & A & & & & & & 1 & & & & 1 & 1 & & 1 & 1 & & & & 1 & 3 & & & 2 & & & & & \\
\hline $61-21$ & 3 & A & & & & & & & & & & & & & & & & & & & & & & 1 & & & & & \\
\hline $61-21$ & 4 & $A$ & & & & & & & & & & & & & & & & & & 1 & 1 & & 1 & & & & & & \\
\hline $91-17$ & 2 & A & & & & & & & & & & & & 1 & & & & & & 4 & 5 & & & & & & & & \\
\hline $91-17$ & 4 & A & & & & & & & & & 1 & 1 & & & & & & & & & & & & & & & & & \\
\hline $91-17$ & $\sigma$ & A & & & & & & & & & & & & & 1 & & & & & & 1 & & & & & & & & \\
\hline $91-18$ & 1 & A & & & & & & & & & & & 1 & & 1 & & & & & & 1 & & & 2 & & & & & \\
\hline $91-18$ & 2 & A & & & & & & & & & & & & 1 & & & & & & 2 & 3 & & & 6 & & & & & \\
\hline $91-18$ & 3 & A & & & & & & & & 1 & 1 & 2 & & & & 1 & & & & 1 & 2 & & & 1 & & & & & \\
\hline $91-18$ & 4 & $A$ & & & & & & & & & & & & & & 1 & & & & 1 & $\overline{2}$ & & & & & & & & \\
\hline $91-18$ & 5 & $A$ & & & & & & & & & & & & 1 & & & & & & & 1 & & & & & & & & \\
\hline $92-1$ & 4 & A & & & $I$ & & & & & & & 1 & & & & & & & & & - & & & & & & & & \\
\hline FEATURE 2 & FILL & A & & & & & & & & & & & & & 2 & & 1 & & & & 3 & & & & & & & & \\
\hline NONRANDOM & SURFACE & $A$ & & & & & & & & & & & 1 & 1 & 3 & 1 & & 1 & & & 6 & 3 & 1 & & & 1 & & & 1 \\
\hline RANDOM & SURFACE & A & & & & & & & & 1 & 1 & 2 & 2 & 1 & 6 & 1 & & 1 & & 2 & 11 & & & & & & & & \\
\hline TRENCH 11 & BACKDIRT & A & & & & & & & & & & & & & 2 & & & & & & 2 & & & & & & & 2 & 2 \\
\hline TRENCH 2 & BACKDIRT & $A$ & & & & & & & & & & & & 1 & & 1 & & & & & 2 & & & 1 & & & & & \\
\hline TRENCH 4 & BACKDIRT & A & & & & & & & & & & & & & & & 1 & & & & 1 & & & & & & & & \\
\hline $208-4$ & 1 & $B$ & & & & & & & & & & & & & & & & & & 1 & $\overline{1}$ & & & & & & & & \\
\hline $208-4$ & 2 & B & & & & & & & & & & & & & & & & & & 1 & 1 & & & & & & & & \\
\hline $211-3$ & 1 & B & & & & & & 1 & & & & 1 & & & 1 & & & & & & 1 & & & & & & & & \\
\hline $836-9$ & 1 & B & & & & & & & & & 3 & 3 & & & & & & & & & & & & & & & & & \\
\hline NONRANDOM & SURFACE & B & & & & & & 1 & & & & 1 & & & 1 & & & & & & 1 & & & & & & & & \\
\hline RANDOM & SURFACE & B & & & & & & & & & 1 & 1 & & & 2 & & & & & 2 & 4 & & & & & & & & \\
\hline $401-16$ & 2 & C & & & & & & 1 & & & & 1 & & & & & & & & & & & & & & & & & \\
\hline $456-11$ & 4 & C & & & & & & & & & & & 2 & & & & & & & & & & & & & & & & \\
\hline $456-11$ & 6 & C & & & & & & & & & & & & & & & & & & & & & & & & & & & \\
\hline $525-5$ & 2 & C & & & & & & & & & & & & 1 & & & & & & & 1 & & & & & & & & \\
\hline $800-1$ & 1 & C & & 1 & & & & & & & & 1 & & & & & & & & & & & & & & & & & \\
\hline NONRANDOM & SURFACE & C & & & & & & & & & & & & & 3 & 1 & & & & & 4 & & 2 & & 2 & & & & 2 \\
\hline RANDOM & SURFACE & C & & & & & & & & & 3 & 3 & 2 & & 1 & 3 & 1 & & & 1 & 6 & & & & & & & & \\
\hline TRENCH 1 & BACKDIRT & $\mathrm{C}$ & & & & & & & & & & & & 1 & 1 & & & & & 2 & 4 & & 1 & & & & & & \\
\hline NONRANDOM & SURFACE & $D$ & & & & & & & & & & & & 1 & & & & & & & 1 & & & & & & & & \\
\hline RANDOM & SURFACE & D & & & 1 & & & & & & & 1 & & 2 & 1 & 1 & & & & 2 & 6 & & & & & & & & \\
\hline \multicolumn{3}{|c|}{ Subtotal Site 41 UV 48} & 2 & 1 & 2 & 2 & 2 & 7 & 1 & 5 & 14 & 36 & 13 & 13 & 32 & 17 & 3 & 2 & & 37 & 104 & 3 & 4 & 14 & 2 & 3 & & 3 & 8 \\
\hline \multicolumn{3}{|l|}{ Grand Total } & 17 & 3 & 7 & 4 & 9 & 18 & 5 & 11 & 44 & 118 & 64 & 77 & 105 & 71 & 34 & 27 & 27 & 71 & 412 & 4 & 13 & 330 & 4 & 19 & 1 & 10 & 34 \\
\hline
\end{tabular}

* I core fragment from the nonrandom collection and 38 core fragments from the random collection are excluded from this total. 


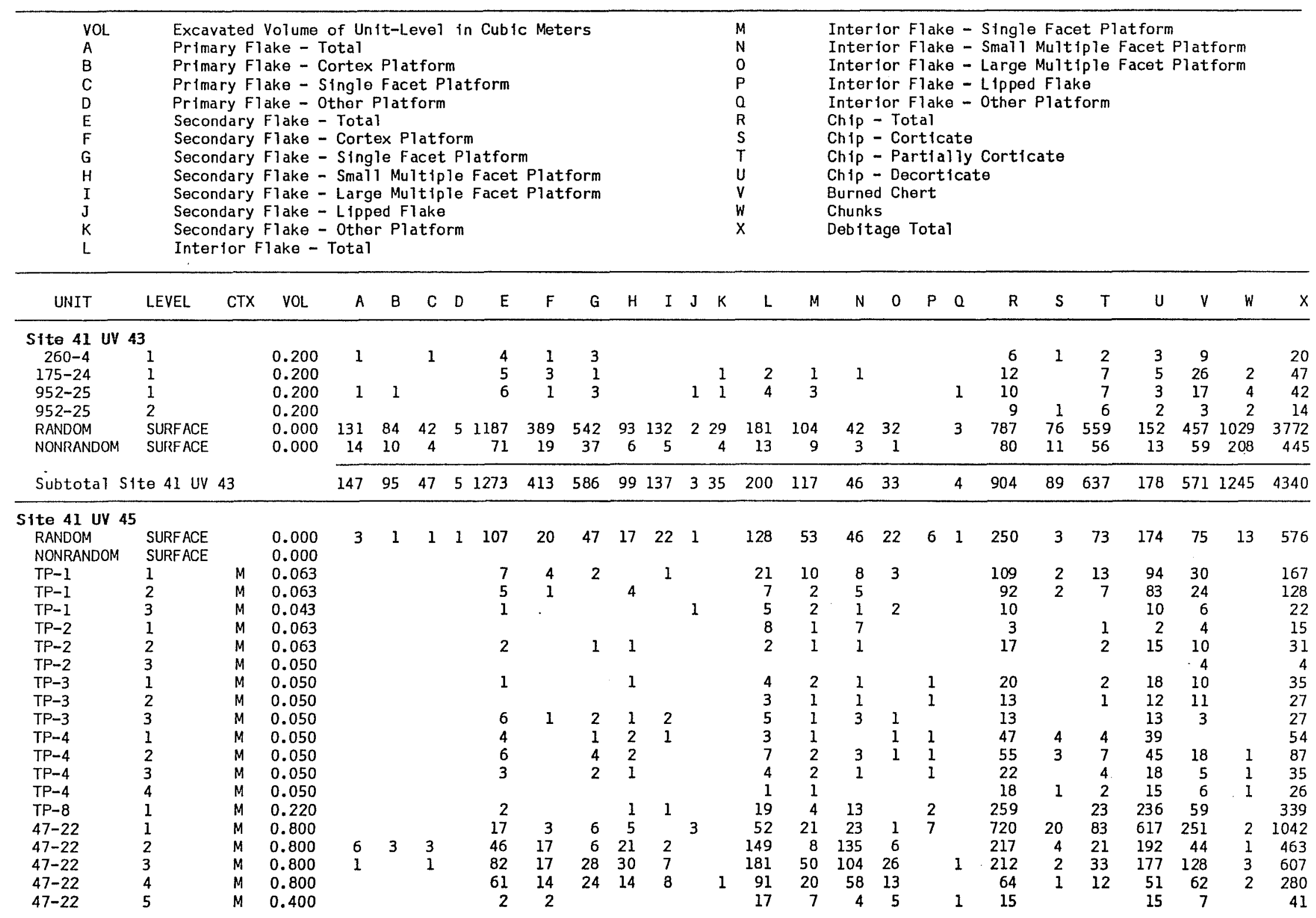


TABLE 83. (continued)

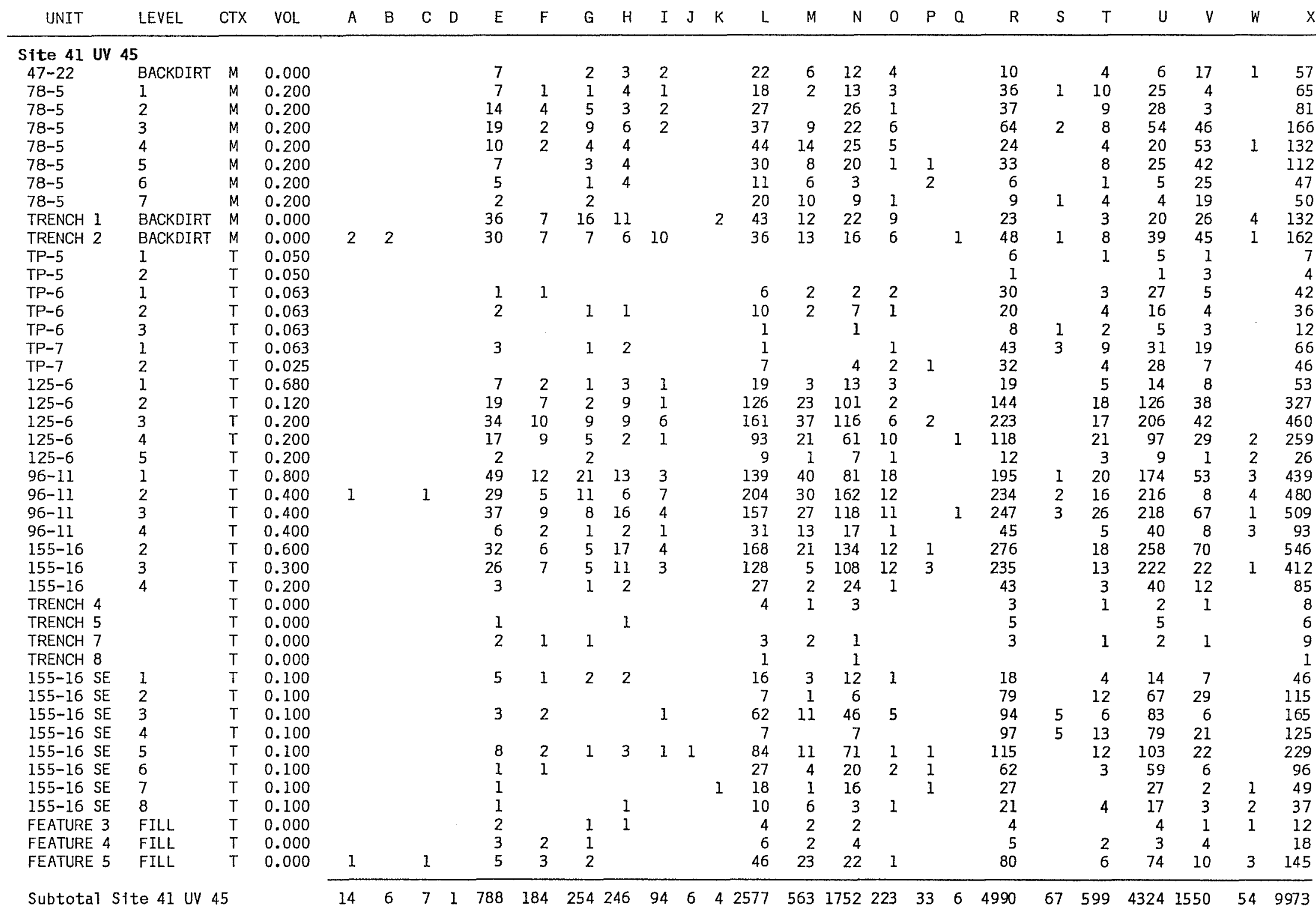


TABLE 83. (continued)

\begin{tabular}{|c|c|c|c|c|c|c|c|c|c|c|c|c|c|c|c|c|c|c|c|c|c|c|c|c|}
\hline UNIT & LEVEL & CTX & VOL & A & $B$ & $\mathrm{C}$ & $E$ & $F$ & G & $H$ & I & $\mathrm{J}$ & $L$ & $M$ & $\mathrm{~N}$ & 0 & $P$ & $\mathrm{R}$ & $s$ & $T$ & $U$ & V & $w$ & $x$ \\
\hline \multicolumn{25}{|c|}{ Site 41 UV 47} \\
\hline SW173-11 & 1 & A & 0.050 & & & & & & & & & & 6 & 2 & 3 & & 1 & 25 & 3 & 4 & 18 & 5 & 5 & 41 \\
\hline SW173-11 & 2 & A & 0.050 & & & & & & & & & & 3 & I & 2 & & & 15 & & 4 & 11 & 4 & & 22 \\
\hline SWI73-II & 3 & $A$ & 0.050 & & & & 2 & 2 & & & & & 7 & 2 & 5 & & & 15 & & 1 & 14 & & & 24 \\
\hline SW173-11 & 4 & A & 0.050 & & & & & & & & & & 1 & 1 & & & & 4 & & & 4 & 2 & & 7 \\
\hline SW173-12 & 1 & A & 0.400 & 3 & & 3 & 12 & 6 & 6 & & & & 85 & 49 & 24 & & 12 & 731 & 20 & 82 & 629 & 5 & 7 & 843 \\
\hline SW173-12 & 2 & A & 0.400 & & & & 7 & 1 & 4 & 2 & & & 47 & 27 & 5 & 9 & 6 & 336 & 15 & 26 & 295 & 8 & 3 & 401 \\
\hline SW173-12 & 3 & A & 0.400 & & & & 2 & 2 & & & & & 16 & 12 & 1 & & 3 & 206 & 8 & 6 & 192 & & 4 & 228 \\
\hline SW173-13 & 1 & A & 0.200 & & & & 3 & 2 & 1 & & & & 20 & 15 & 5 & & & 492 & 19 & 34 & 439 & 11 & 1 & 527 \\
\hline SWI73-13 & 2 & $A$ & 0.200 & 2 & 1 & 1 & 46 & 20 & 18 & 7 & 1 & & 141 & 70 & 62 & 8 & 1 & 499 & 15 & 47 & 437 & 92 & 13 & 793 \\
\hline SW173-13 & 3 & A & 0.200 & & & & 6 & 2 & 4 & & & & 19 & 7 & 9 & & 3 & 210 & 16 & 21 & 173 & 5 & 1 & 241 \\
\hline SW173-13 & 4 & A & 0.200 & & & & 23 & 14 & 5 & 4 & & & 68 & 33 & 33 & 2 & & 242 & & 40 & 202 & 16 & 4 & 353 \\
\hline SW173-13 & 5 & A & 0.200 & 1 & & 1 & 12 & 5 & 4 & & 2 & 1 & 34 & 19 & 13 & & 2 & 171 & & 17 & 154 & 12 & & 230 \\
\hline SW173-17 & 1 & A & 0.400 & & & & 48 & 24 & 19 & 5 & & & 135 & 61 & 70 & 4 & & 554 & 2 & 66 & 486 & 89 & 4 & 830 \\
\hline SW173-17 & 2 & A & 0.400 & 2 & & & 19 & 8 & 7 & 2 & 2 & & 119 & 50 & 47 & 12 & 10 & 903 & 52 & 65 & 786 & 101 & 33 & 1177 \\
\hline SW173-17 & 3 & A & 0.400 & & & & 17 & 7 & 5 & 5 & & & 78 & 44 & 25 & & 9 & 469 & 27 & 41 & 401 & 61 & 10 & 635 \\
\hline SW173-17 & 4 & A & 0.400 & & & & 39 & 17 & 15 & 7 & & & 100 & 47 & 48 & 5 & & 351 & & 41 & 310 & 59 & 6 & 555 \\
\hline SW173-17 & 5 & A & 0.400 & & & & 2 & 2 & & & & & 36 & 14 & 16 & 2 & 4 & 410 & 18 & 29 & 363 & 42 & 1 & 491 \\
\hline SW173-17 & 6 & A & 0.400 & 2 & 2 & & 9 & 4 & 3 & 2 & & & 89 & 51 & 10 & 2 & 26 & 346 & 24 & 42 & 280 & 51 & 5 & 502 \\
\hline SW173-17 & 7 & A & 0.400 & & & & 26 & 11 & 6 & 8 & 1 & & 62 & 23 & 33 & 5 & 1 & 158 & 2 & 14 & 142 & 19 & 1 & 266 \\
\hline SW173-17 & 8 & A & 0.400 & & & & & & & & & & 17 & 9 & 6 & & 2 & 69 & & 2 & 67 & 8 & 2 & 96 \\
\hline SW173-17 & 9 & A & 0.400 & & & & 1 & & 1 & & & & 10 & 8 & 1 & & 1 & 59 & 8 & 5 & 46 & 3 & 2 & 75 \\
\hline SW173-17 & 10 & A & 0.400 & 2 & 1 & & 1 & & 1 & & & & 5 & 3 & I & & 1 & 40 & 8 & 2 & 30 & 7 & 2 & 57 \\
\hline SW173-17 & 11 & A & 0.400 & 1 & 1 & & & & & & & & 1 & & & & 1 & 23 & 6 & 4 & 13 & 2 & & 27 \\
\hline $5 W 173-22$ & 1 & A & 0.400 & & & & 101 & 49 & 35 & 17 & & & 197 & 81 & 109 & 7 & & 758 & 17 & 124 & 617 & 47 & 11 & 1114 \\
\hline SW173-22 & 2 & A & 0.400 & 2 & 1 & 1 & 46 & 23 & 11 & 1 & & 11 & 194 & 124 & 58 & & 12 & 1085 & 41 & 85 & 959 & 169 & 17 & 1513 \\
\hline SW173-22 & 3 & A & 0.400 & & & & 22 & 9 & 10 & 2 & & 1 & 91 & 44 & 25 & 5 & 17 & 627 & 20 & 48 & 559 & 67 & 6 & 813 \\
\hline SWI73-22 & 4 & A & 0.400 & 4 & 3 & 1 & 68 & 33 & 20 & 7 & 7 & $i$ & 133 & 56 & 71 & 5 & 1 & 648 & 7 & 69 & 572 & 52 & 8 & 913 \\
\hline SW173-22 & 5 & A & 0.400 & 1 & & 1 & 11 & 8 & 2 & 1 & & & 76 & 32 & 33 & & 11 & 604 & 46 & 56 & 502 & 62 & & 754 \\
\hline SW173-22 & 6 & A & 0.400 & & & & 11 & 3 & 2 & 2 & & 4 & 57 & 12 & 33 & 12 & & 434 & 19 & 35 & 380 & 67 & 2 & 571 \\
\hline SW173-22 & 7 & A & 0.400 & & & & & & & & & & & & & & & & & & & & & \\
\hline SW173-22 & 8 & A & 0.400 & I & & 1 & 1 & & & 1 & & & 23 & 11 & 10 & 2 & & 60 & 1 & 3 & 56 & 7 & 1 & 93 \\
\hline SW173-22 & 9 & A & 0.400 & & & & 2 & 1 & & 1 & & & 13 & 6 & 5 & & 2 & 63 & 5 & 9 & 49 & 8 & & 86 \\
\hline SW173-25 & 1 & A & 0.050 & & & & 1 & 1 & & & & & 14 & 4 & 8 & & 2 & 65 & 1 & 8 & 56 & 16 & & 96 \\
\hline SW173-25 & 2 & A & 0.050 & & & & 6 & 2 & 4 & & & & I1 & 3 & 5 & 3 & & 40 & & 8 & 32 & 4 & 2 & 63 \\
\hline SW173-25 & 3 & A & 0.050 & & & & & & & & & & 3 & 2 & 1 & & & 15 & & 1 & 14 & 5 & & 23 \\
\hline SW $173-25$ & 4 & A & 0.050 & & & & 3 & 1 & 1 & & 1 & & 4 & 2 & 2 & & & 13 & 1 & 4 & 8 & 1 & & 21 \\
\hline SW210-25 & 1 & A & 0.050 & & & & 5 & 1 & 4 & & & & 3 & & 3 & & & 7 & & 1 & 6 & & & 15 \\
\hline SW210-25 & 2 & A & 0.050 & & & & & & & & & & 4 & 2 & 2 & & & 14 & 1 & & 13 & 1 & & 19 \\
\hline SW210-25 & 3 & A & 0.050 & & & & 1 & & & 1 & & & 3 & $\overrightarrow{1}$ & 2 & & & 11 & & & 11 & 3 & & 18 \\
\hline SW210-25 & 4 & A & 0.050 & & & & 3 & 2 & & 1 & & & 6 & 2 & 3 & 1 & & 44 & & 5 & 39 & & & 53 \\
\hline TRENCH 4 & BACKDIRT & A & 0.000 & & & & & & & & & & & & & & & & & & & & & \\
\hline TRENCH 5 & BACKDIRT & A & 0.000 & & & & 11 & 2 & 3 & 2 & 4 & & 21 & 9 & 2 & 10 & & 25 & & 10 & 15 & 5 & 3 & 65 \\
\hline TRENCH 6 & BACKDIRT & A & 0.000 & & & & 2 & 1 & 1 & & & & 8 & 2 & 4 & 2 & & 11 & & 4 & 7 & 4 & & 25 \\
\hline FEATURE 2 & FILL & A & 0.000 & & & & 2 & & 1 & & & & 15 & 9 & 4 & & 1 & 15 & & 1 & 14 & 9 & 3 & 44 \\
\hline FEATURE 3 & FILL & A & 0.000 & & & & 8 & 1 & 6 & 1 & & & 66 & 30 & 32 & 2 & & 26 & & 8 & 18 & 35 & & 135 \\
\hline FEATURE 4 & FILL & A & 0.000 & & & & 1 & 1 & & & & & 11 & 6 & 5 & & & 6 & & 1 & 5 & 3 & & 21 \\
\hline SE110-5 & 1 & B & 0.400 & 2 & & 2 & 6 & & 3 & 3 & & & 14 & 5 & 8 & 1 & & 128 & 14 & 10 & 104 & 34 & 5 & 189 \\
\hline SE110-5 & 2 & B & 0.400 & 3 & 2 & 1 & 8 & 3 & 5 & & & & 27 & 14 & 12 & & 1 & 269 & 19 & 26 & 224 & 58 & 18 & 383 \\
\hline SE110-5 & 3 & $B$ & 0.400 & & & & 13 & 4 & 3 & 6 & & & 47 & 18 & 23 & 5 & 1 & 287 & 1 & 57 & 229 & 88 & $I$ & 436 \\
\hline
\end{tabular}


TABLE 83. (continued)

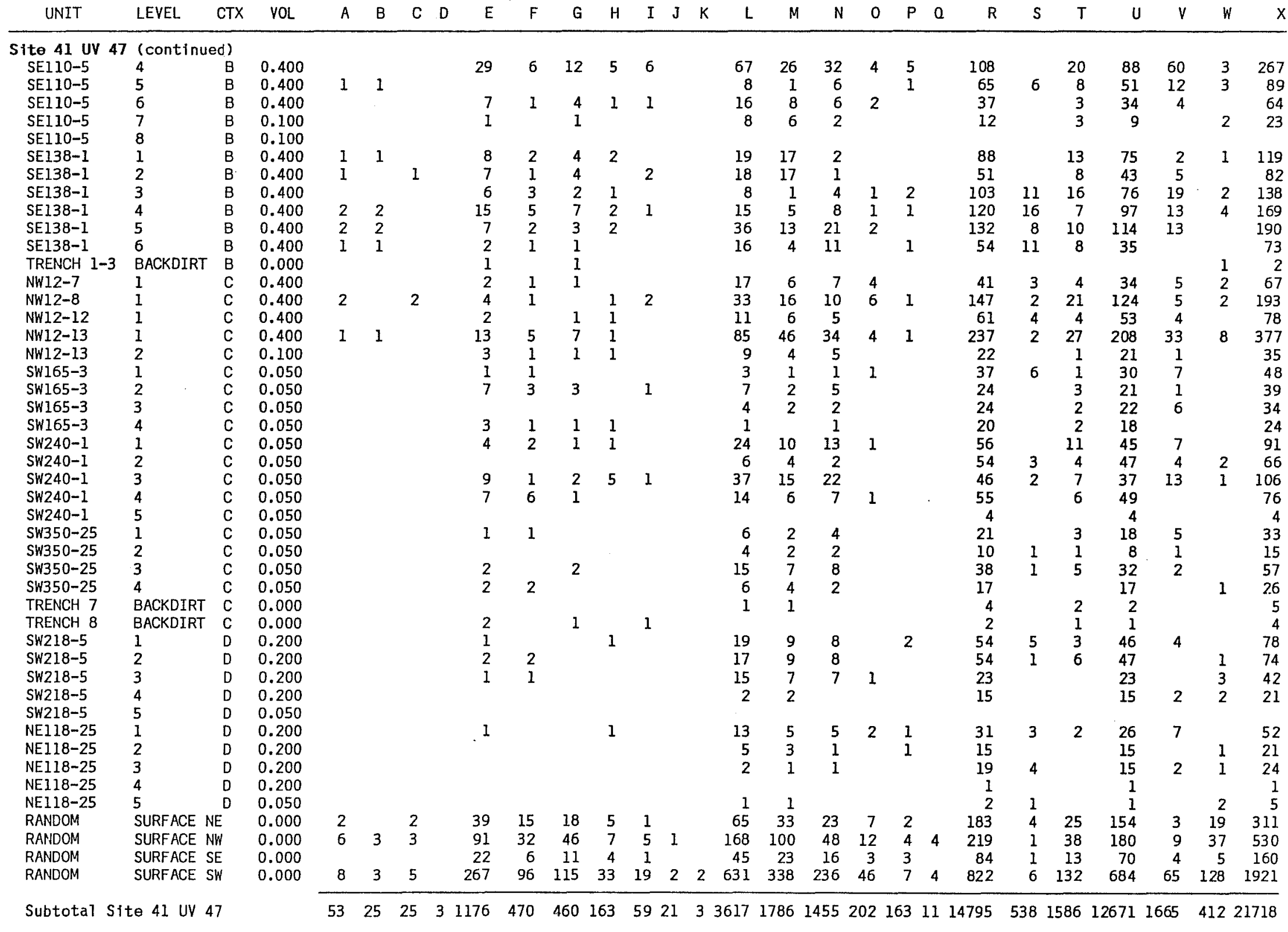


TABLE 83. (continued)

\begin{tabular}{|c|c|c|c|c|c|c|c|c|c|c|c|c|c|c|c|c|c|c|c|c|c|c|c|c|c|}
\hline UNIT & LEVEL & CTX & VOL & A & $B$ & $\mathrm{c}$ & $\mathrm{D}$ & $E$ & $F$ & G & $\mathrm{H}$ & I & $\mathrm{J}$ & K & M & $N$ & 0 & $P$ & 0 & $S$ & $T$ & $\mathrm{U}$ & v & $w$ & $x$ \\
\hline \multicolumn{26}{|c|}{ Site 41 UV 48} \\
\hline $91-1$ & & $A$ & 0.050 & & & & & 1 & 1 & & & & & 14 & 6 & 8 & & & 40 & 2 & 3 & 35 & 6 & & 61 \\
\hline $91-1$ & 2 & A & 0.050 & & & & & 3 & 1 & 2 & & & & 1 & 1 & & & & 54 & 2 & 3 & 49 & 2 & & 60 \\
\hline $91-1$ & 3 & A & 0.050 & & & & & & & & & & & 1 & 1 & & & & 5 & & & 5 & $\overline{1}$ & & 7 \\
\hline $91-1$ & 4 & A & 0.050 & & & & & & & & & & & & & & & & 4 & & 1 & 3 & & & 4 \\
\hline $92-1$ & 1 & A & 0.050 & 3 & 2 & 1 & & 5 & 3 & 2 & & & & 3 & 2 & 1 & & & 68 & 4 & 4 & 60 & & & 79 \\
\hline $92-1$ & 2 & A & 0.050 & & & & & 5 & 3 & 1 & 1 & & & 7 & 1 & 5 & & 1 & 87 & 4 & 7 & 76 & 13 & & 112 \\
\hline $92-I$ & 3 & A & 0.050 & & & & & 1 & & 1 & & & & 3 & 2 & 1 & & & 19 & 1 & 1 & 17 & 2 & & 25 \\
\hline $92-1$ & 4 & A & 0.050 & & & & & & & & & & & & & & & & & & & & & & \\
\hline $92-1$ & 5 & A & 0.050 & & & & & & & & & & & & & & & & 4 & & & 4 & & & 4 \\
\hline $121-9$ & 1 & A & 0.400 & 1 & 1 & & & 78 & 19 & 37 & 16 & 5 & 1 & 131 & 81 & 44 & 6 & & 451 & 6 & 84 & 361 & 90 & 13 & 764 \\
\hline $121-9$ & 2 & A & 0.400 & & & & & 62 & 20 & 27 & 11 & 4 & & 169 & 66 & 81 & 22 & & 416 & 2 & 83 & 331 & 115 & 6 & 768 \\
\hline $121-9$ & 3 & A & 0.400 & 1 & 1 & & & 120 & 27 & 67 & 18 & 5 & 3 & 242 & 155 & 71 & 13 & 3 & 470 & 2 & 74 & 394 & 117 & 12 & 962 \\
\hline $121-9$ & 4 & A & 0.400 & 5 & 1 & 4 & & 26 & 6 & 13 & 1 & 6 & & 66 & 46 & 17 & & 3 & 543 & 26 & 57 & 460 & 127 & 5 & 772 \\
\hline $121-9$ & 5 & A & 0.400 & 5 & 3 & 2 & & 30 & 17 & 8 & 1 & 4 & & 52 & 26 & 12 & 14 & & 639 & 41 & 69 & 529 & 122 & 5 & 853 \\
\hline $121-9$ & 6 & A & 0.400 & 3 & 1 & 2 & & 41 & 10 & 22 & 8 & 1 & & 109 & 70 & 34 & 4 & 1 & 194 & 2 & 46 & 146 & 38 & 12 & 397 \\
\hline $150-5$ & 1 & A & 0.200 & & & & & 13 & 5 & 8 & & & & 53 & 25 & 26 & 2 & & 247 & & 23 & 224 & 15 & 3 & 331 \\
\hline $150-5$ & 2 & A & 0.200 & & & & & 2 & & 1 & 1 & & & 5 & 4 & 1 & & & 47 & 1 & 4 & 42 & 3 & & 57 \\
\hline $150-5$ & 3 & A & 0.200 & & & & & & & & & & & 1 & & & 1 & & 8 & 2 & & 6 & & & 9 \\
\hline $150-5$ & 4 & A & 0.050 & & & & & & & & & & & & & & & & 1 & & 1 & & & & 1 \\
\hline $61-21$ & 1 & A & 0.400 & 2 & & 2 & & 27 & 10 & 8 & 5 & 4 & & 26 & 13 & 8 & 5 & & 440 & 17 & 22 & 401 & 161 & 4 & 660 \\
\hline $61-21$ & 2 & A & 0.400 & 9 & 4 & 5 & & 13 & 5 & 8 & & & & 31 & 12 & 15 & 3 & 1 & 630 & 18 & 30 & 582 & 183 & 6 & 872 \\
\hline $61-21$ & 3 & A & 0.400 & & & & & 58 & 18 & 17 & 16 & 6 & $I$ & 137 & 31 & 94 & 1.2 & & 424 & 8 & 94 & 322 & 138 & 2 & 759 \\
\hline $61-21$ & 4 & A & 0.400 & 1 & & & 1 & 15 & 9 & 2 & 3 & 1 & & 39 & 20 & 16 & & 3 & 80 & 9 & 4 & 67 & 26 & $I$ & 162 \\
\hline $91-17$ & 1 & A & 0.400 & 1 & & 1 & & 8 & 6 & 1 & 1 & & & 8 & 1 & 7 & & & $47 I$ & 9 & 25 & 437 & 85 & & 573 \\
\hline $91-17$ & 2 & A & 0.400 & 3 & 1 & 2 & & 17 & 10 & 6 & & 1 & & 49 & 30 & 15 & 4 & & 320 & 9 & 12 & 299 & 40 & & 429 \\
\hline $91-17$ & 3 & A & 0.400 & 1 & & 1 & & 27 & 8 & 11 & 5 & 3 & & 85 & 42 & 38 & 4 & 1 & 170 & & 30 & 140 & 75 & & 358 \\
\hline $91-17$ & 4 & A & 0.400 & 3 & & 3 & & 9 & 6 & & 1 & .2 & & 28 & 3 & 10 & 11 & 4 & 446 & 8 & 18 & 420 & 34 & 3 & 523 \\
\hline $91-17$ & 5 & A & 0.400 & 4 & 3 & 1 & & 7 & 5 & 1 & & 1 & & 26 & 15 & 3 & 6 & 2 & 93 & 1 & 3 & 89 & 3 & 34 & 167 \\
\hline $91-17$ & 6 & A & 0.200 & & & & & 6 & 3 & 2 & 1 & & & 14 & 7 & 6 & & 7 & 40 & & 7 & 33 & 9 & 1 & 70 \\
\hline $91-18$ & 1 & A & 0.400 & 3 & 1 & 2 & & 8 & 3 & & 5 & & & 23 & 9 & 10 & 2 & 2 & 244 & 6 & 26 & 212 & 81 & & 359 \\
\hline $91-18$ & 2 & A & 0.400 & 2 & & $I$ & 1 & 44 & 10 & 22 & 7 & 5 & & 120 & 83 & 20 & 16 & 1 & 341 & 1 & 58 & 282 & 42 & 18 & 567 \\
\hline $91-18$ & 3 & A & 0.400 & & & & & 54 & II & 33 & 7 & 3 & & 80 & 51 & 21 & 8 & & 197 & 5 & 43 & 149 & 38 & 8 & 377 \\
\hline $91-18$ & 4 & A & 0.400 & 2 & 1 & 1 & & 23 & 7 & 4 & 4 & 8 & & 19 & 10 & 1 & 7 & 1 & 290 & 19 & 4 & 228 & 101 & 3 & 438 \\
\hline $91-18$ & 5 & A & 0.400 & & & & & 2 & & & & 2 & & 28 & 13 & 14 & 1 & & 202 & 19 & 15 & 168 & 49 & 4 & 285 \\
\hline $120-24$ & 1 & A & 0.400 & & & & & 25 & 15 & 9 & 1 & & & 53 & 32 & 16 & 5 & & 537 & 18 & 50 & 469 & 141 & 2 & 758 \\
\hline $120-24$ & 2 & A & 0.400 & 1 & 1 & & & 93 & 29 & 42 & 15 & 7 & & 165 & 75 & 71 & 14 & 5 & 823 & 34 & 82 & 707 & 287 & 5 & 1374 \\
\hline $120-24$ & 3 & A & 0.400 & 2 & & 1 & 1 & 123 & 31 & 46 & 31 & 15 & & 240 & 84 & 142 & 10 & 4 & 702 & 4 & 124 & 574 & 223 & 6 & 1296 \\
\hline $120-24$ & 4 & A & 0.400 & 11 & 5 & 3 & 3 & 48 & 20 & 16 & 5 & 7 & & 155 & 72 & 52 & 23 & 8 & 632 & 33 & 63 & 536 & 180 & 5 & 1031 \\
\hline $120-24$ & 5 & A & 0.400 & $I$ & & & 1 & 95 & 20 & 47 & 20 & 8 & & 184 & 87 & 82 & 12 & 3 & 392 & 1 & 75 & 316 & 139 & 6 & 817 \\
\hline $120-24$ & 6 & A & 0.400 & 2 & 1 & & 1 & 13 & 7 & 3 & 2 & 1 & & 13 & 7 & 3 & 2 & 1 & 280 & 5 & 25 & 250 & 86 & 4 & 398 \\
\hline $121-10$ & 1 & A & 0.400 & 6 & 1 & 4 & 1 & 22 & 6 & 9 & 2 & 5 & & 32 & 11 & 12 & 9 & & 424 & 21 & 36 & 367 & 150 & 6 & 640 \\
\hline $121-10$ & 2 & A & 0.400 & 3 & 1 & 2 & & 24 & 8 & 12 & 1 & 3 & & 44 & 15 & 22 & 5 & 2 & 388 & 15 & 46 & 327 & 80 & 3 & 542 \\
\hline $121-10$ & 3 & A & 0.400 & 5 & 1 & 3 & 1 & 14 & 6 & 4 & 4 & & & 57 & 21 & 28 & 8 & & 349 & 17 & 25 & 307 & 48 & 3 & 476 \\
\hline $121-10$ & 4 & A & 0.400 & 3 & $i$ & 2 & & 12 & 4 & 3 & $i$ & 4 & & 33 & 25 & 5 & 1 & 2 & 208 & 20 & 24 & 164 & 31 & 1 & 288 \\
\hline $121-10$ & 5 & A & 0.200 & & & & & 1 & 1 & & & & & 1 & 1 & & & & 23 & 1 & $i$ & 21 & 2 & & 27 \\
\hline RANDOM & SURFACE & A & 0.000 & 1 & 1 & & & 48 & 16 & 27 & 5 & & & 97 & 64 & 30 & 2 & 1 & 207 & 7 & 38 & 162 & 53 & 25 & 431 \\
\hline TRENCH 2 & BACKDIRT & A & 0.000 & 4 & 1 & 2 & 1 & 27 & 6 & 8 & 10 & 3 & & 46 & 27 & 10 & 5 & 4 & 87 & 6 & 13 & 68 & 27 & 17 & 208 \\
\hline
\end{tabular}


TABLE 83. (continued)

\begin{tabular}{|c|c|c|c|c|c|c|c|c|c|c|c|c|c|c|c|c|c|c|c|c|c|c|c|c|c|}
\hline UNIT & LEVEL & CTX & VOL & $A$ & $\mathrm{~B}$ & $C \quad D$ & E & $\mathrm{F}$ & G & $H$ & I & $\mathrm{J}$ & K & M & $N$ & 0 & $P$ & 0 & $\mathrm{R}$ & $s$ & $T$ & $u$ & v & $w$ & $x$ \\
\hline \multicolumn{26}{|c|}{ Site 41 UV 48 (continued) } \\
\hline TRENCH 4 & BACKDIRT & $A$ & 0.000 & & & & 1 & & 1 & & & & 2 & & 2 & & & & & & & & & & 3 \\
\hline TRENCH 5 & BACKDIRT & A & 0.000 & & & & 5 & 3 & 1 & & 1 & & 8 & 4 & & 4 & & & 10 & 1 & 1 & 8 & 4 & & 27 \\
\hline FEATURE I & FILL & A & 0.000 & 2 & 2 & & 2 & 2 & & & & & 1 & 1 & & & & & 14 & $\bar{I}$ & 3 & 10 & 2 & 2 & 23 \\
\hline FEATURE 2 & FILL & A & 0.000 & 3 & & 3 & $2 \overline{2}$ & 14 & 5 & 2 & 1 & & 121 & 63 & 52 & 4 & & 2 & 430 & 16 & 39 & 375 & $10 \overline{1}$ & 4 & 681 \\
\hline $208-4$ & 1 & B & 0.100 & & & & 11 & 5 & 4 & & 2 & & 30 & 6 & 21 & 3 & & & 71 & & 6 & 65 & 5 & 2 & 119 \\
\hline $208-4$ & 2 & $\mathrm{~B}$ & 0.100 & & & & 4 & 1 & 2 & 1 & & & 8 & 2 & 5 & 1 & & & 20 & & 4 & 16 & 1 & & 33 \\
\hline $208-4$ & 3 & B & 0.100 & & & & 3 & 2 & 1 & & & & 9 & 2 & 7 & & & & 27 & & 3 & 24 & & 1 & 40 \\
\hline $208-5$ & 1 & B & 0.040 & & & & 2 & & 2 & & & & 10 & 3 & 6 & 1 & & & 12 & & 3 & 9 & 1 & & 25 \\
\hline $211-3$ & 1 & B & 0.200 & & & & 4 & 3 & & & 1 & & 9 & 3 & 6 & & & & 70 & 5 & 4 & 61 & & & 83 \\
\hline $211-3$ & 2 & B & 0.200 & $I$ & & 1 & 10 & 4 & 5 & & 1 & & 38 & 16 & 21 & 1 & & & 103 & 1 & 18 & 84 & 5 & 1 & 158 \\
\hline $211-3$ & 3 & B & 0.200 & & & & & & & & & & 1 & & & & 1 & & 20 & & & 20 & 4 & & 25 \\
\hline $836-9$ & 1 & B & 0.200 & & & & & & & & & & 4 & 2 & 2 & & & & 49 & 1 & & 48 & 2 & & 55 \\
\hline $836-9$ & 2 & B & 0.200 & & & & & & & & & & 5 & 3 & 2 & & & & 18 & 2 & 1 & 15 & 1 & & 24 \\
\hline $207-24$ & 1 & B & 0.040 & & & & 1 & & 1 & & & & 3 & & 3 & & & & 3 & & & 3 & 1 & & 8 \\
\hline $207-25$ & 1 & $B$ & 0.040 & & & & 3 & 1 & & 2 & & & 6 & 1 & 3 & 2 & & & 5 & & 2 & 3 & 3 & & 17 \\
\hline $499-12$ & 1 & B & 0.200 & & & & 1 & 1 & & & & & 2 & 1 & 1 & & & & 36 & & & 36 & & & 39 \\
\hline $499-12$ & 2 & B & 0.200 & & & & & & & & & & 3 & & 2 & 1 & & & 16 & & & 16 & & & 19 \\
\hline $499-12$ & 3 & B & 0.200 & & & & & & & & & & 1 & 1 & & & & & 4 & & 1 & 3 & 1 & & 6 \\
\hline RANDOM & SURFACE & B & 0.000 & 8 & 7 & 1 & 24 & 12 & 12 & & & & 66 & 41 & 18 & 3 & 4 & & 230 & 12 & 47 & 171 & 42 & 4 & 374 \\
\hline TRENCH 9 & BACKDIRT & B & 0.000 & & & & & & & & & & 5 & 3 & 1 & 1 & & & 2 & & 1 & 1 & & & 7 \\
\hline $525-5$ & 1 & C & 0.200 & 2 & 2 & & 3 & & 1 & & 2 & & 8 & 5 & 1 & 1 & 1 & & 178 & 5 & 10 & 163 & 39 & 2 & 232 \\
\hline $525-5$ & 2 & C & 0.200 & & & & 1 & 1 & & & & & 6 & & 5 & & $i$ & & 141 & 5 & 10 & 126 & 10 & & 158 \\
\hline $525-5$ & 3 & C & 0.200 & & & & 2 & & 1 & 1 & & & 12 & 5 & 6 & 1 & & & 65 & & 10 & 55 & 3 & & 82 \\
\hline $525-5$ & 4 & C & 0.200 & & & & 2 & 1 & & & & 1 & & & & & & & & & & & 2 & & 4 \\
\hline $800-1$ & 1 & C & 0.200 & & & & 6 & 3 & 2 & 1 & & & 21 & 10 & 9 & 2 & & & 110 & & 18 & 92 & 4 & & 141 \\
\hline $800-1$ & 2 & C & 0.200 & & & & 5 & 3 & 2 & & & & 13 & 2 & 11 & & & & 58 & & 4 & 54 & 3 & & 79 \\
\hline $800-1$ & 3 & $\mathrm{C}$ & 0.200 & & & & & & & & & & 3 & 1 & 2 & & & & 66 & 1 & 1 & 64 & 3 & & 72 \\
\hline $401-16$ & 1 & $\mathrm{C}$ & 0.200 & & & & 1 & & & & 1 & & 4 & 1 & 2 & 1 & & & 144 & 2 & 13 & 129 & 25 & 3 & 177 \\
\hline $401-16$ & 2 & $\mathrm{C}$ & 0.200 & & & & 1 & & 1 & & & & 11 & 3 & 7 & & 1 & & 112 & 3 & 5 & 104 & 10 & $I$ & 135 \\
\hline $401-16$ & 3 & C & 0.200 & & & & 9 & 2 & 5 & 2 & & & 53 & 35 & 15 & 3 & & & 107 & & 7 & 100 & 5 & & 174 \\
\hline $456-11$ & 1 & C & 0.200 & & & & 2 & 1 & 1 & & & & 11 & 6 & 4 & 1 & & & 44 & 1 & 2 & 41 & 5 & $I$ & 63 \\
\hline $456-11$ & 2 & C & 0.200 & I & & 1 & 5 & 2 & & 2 & 1 & & 13 & 3 & 6 & 1 & 3 & & 80 & 2 & 3 & 75 & 12 & & 111 \\
\hline $456-11$ & 3 & C & 0.200 & & & & & & & & & & 6 & 1 & 4 & & & 1 & 48 & & 3 & 45 & & & 54 \\
\hline $456-11$ & 4 & c & 0.200 & & & & & & & & & & & & & & & & 3 & & & 3 & & & 3 \\
\hline $456-11$ & 5 & $\mathrm{C}$ & 0.200 & & & & & & & & & & 1 & 1 & & & & & 3 & 1 & & 2 & & & 4 \\
\hline $456-11$ & 6 & C & 0.200 & & & & & & & & & & & & & & & & 2 & & & 2 & 1 & & 3 \\
\hline RANDOM & SURFACE & C & 0.000 & 4 & 2 & 2 & 42 & 24 & 13 & 3 & 2 & & 93 & 51 & 33 & 2 & 7 & & 412 & 12 & 94 & 306 & 68 & 26 & 645 \\
\hline TRENCH 7 & BACKDIRT & C & 0.000 & & & & & & & & & & & & & & & & & & & & & & \\
\hline RANDOM & SURFACE & D & 0.000 & 2 & 1 & 1 & 7 & 4 & 3 & & & & 22 & 7 & 12 & 1 & 2 & & 58 & 5 & 10 & 43 & 5 & 4 & 98 \\
\hline TRENCH 6 & BACKDIRT & D & 0.000 & & & & & & & & & & & & & & & & & & & & & & \\
\hline TRENCH 8 & BACKDIRT & D & 0.000 & & & & & & & & & & & & & & & & & & & & & & \\
\hline
\end{tabular}

Subtotal Site 41 UV 48

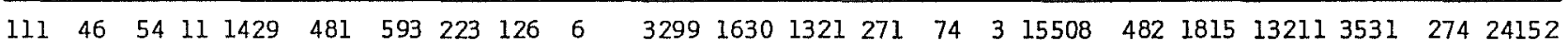


- 

